\author{
UNIVERSIDADE DE SÃO PAULO \\ Faculdade de Filosofia, Letras e Ciências Humanas \\ Programa de Pós-Graduação em História Econômica
}

FLÁVIO BENEDITO

\title{
ECONOMIA PETROLEIRA VENEZUELANA: O DILEMA ENTRE A SOBERANIA ECONÔMICA E A DEPENDÊNCIA ESTRUTURAL (1973-1998)
}

SÃO PAULO 
FLÁVIO BENEDITO

\section{ECONOMIA PETROLEIRA VENEZUELANA: O DILEMA ENTRE A SOBERANIA ECONÔMICA E A DEPENDÊNCIA ESTRUTURAL (1973-1998)}

Tese apresentada ao Programa de PósGraduação em História Econômica do Departamento de História da Faculdade de Filosofia, Letras e Ciências Humanas da Universidade de São Paulo, para a obtenção do título de Doutor em História Econômica

Orientador: Prof. Dr. Osvaldo Luis Angel Coggiola 
Autorizo a reprodução e divulgação total ou parcial deste trabalho, por qualquer meio convencional ou eletrônico, para fins de estudo e pesquisa, desde que citada a fonte.

\section{Catalogação na Publicação}

Serviço de Biblioteca e Documentação

Faculdade de Filosofia, Letras e Ciências Humanas da Universidade de São Paulo

B463e Benedito, Flávio

Economia petroleira venezuelana: o dilema entre a soberania econômica e a dependência estrutural (1973-1998) / Flávio Benedito; orientador Osvaldo Luis Angel Coggiola. - São Paulo, 2016. $327 \mathrm{f}$.

Tese (Doutorado) Faculdade de Filosofia, Letras e Ciências Humanas da Universidade de São Paulo. Departamento de História. Área de Concentração: História Econômica.

1. História econômica. 2. Economia petroleira. 3. Dependência estrutural. 4. Movimentos sociais. 5. Abertura petroleira. I. Coggiola, Osvaldo Luis Angel, orient. II. Título 
Para meu querido amigo Francisco.

Para minha esposa e minhas filhas.

Hat die Liebe überhaupt einen Plural? Ist sie nicht überall sich selbst gleich? Ludwig Feuerbach 


\section{AGRADECIMENTOS}

Ao professor Osvaldo Coggiola, com cuja competência intelectual pude contar na realização desta pesquisa. Sua solicitude nas dificuldades e contratempos que enfrentei - solicitude, diga-se, que foi além das incumbências de uma orientação acadêmica - me levou a contrair uma inestimável dívida de gratidão que desejo deixar aqui registrada.

Aos professores Rafael D. Villa e Lincoln Secco, membros da banca de qualificação, por suas observações e sugestões, que, tanto quanto me foi possível, incorporei ao texto final deste estudo. São ambos também credores do meu reconhecimento.

Ao professor Carlos Mendoza Pottellá, da Universidade Central da Venezuela, por sua gentileza em colocar à minha disposição cópias de seus trabalhos e de valioso material estatístico sobre a história econômica de seu país.

À professora Margarita López Maya, da Universidade Central da Venezuela, por sua amabilidade em permitir-me traduzir ao português um de seus estudos, o que, além de ter-me prestado um valioso apoio à compreensão dos problemas sociais da Venezuela de hoje, deu-me a oportunidade de contribuir para a difusão da história venezuelana em língua portuguesa.

Às amigas Rosana M. Schwartz e Maria Aparecida M. Pascal, e ao amigo Edson S. dos Santos, pelo constante apoio e incentivo ao longo desta pesquisa.

Aos professores e colegas do Programa de Pós-graduação em História Econômica da FFLCH-USP, pelas frutíferas discussões sobre questões de economia e política latino-americanas.

Ao CNPq, pelos recursos financeiros providos por uma bolsa de pesquisa, que tornaram possíveis as condições materiais deste trabalho.

A todos, enfim, que direta ou indiretamente me prestaram auxílio, deixo consignado meu sincero agradecimento, aproveitando para advertir, no entanto, que é apenas e inteiramente minha a responsabilidade pelas ideias aqui apresentadas, bem como pelas deficiências e incorreções que este estudo inevitavelmente encerra. 


\section{RESUMO}

A atividade petroleira constitui, desde as primeiras décadas do século $X X$, o cerne da vida econômica da Venezuela contemporânea. A importância que essa atividade veio adquirindo desde então foi tal que todas as principais decisões de política econômica nacional the dizem respeito, e representam inevitavelmente consequências de monta para o conjunto da sociedade venezuelana. Este estudo adota como ponto de partida uma reflexão crítica sobre a natureza e o alcance histórico das mudanças sociais e políticas que ocorrem atualmente no continente latino-americano, ou seja, sobretudo a ascensão dos governos progressistas (dentre eles, destacadamente, o bolivarianismo chavista), cujo maior desafio hoje encontra-se no confronto real entre as oportunidades de autonomização econômica (reconhecidas e proclamadas pelo discurso político progressista) e, em sentido contrário, as forças de perpetuação da dependência estrutural e do subdesenvolvimento, nas condições inerentes ao capitalismo dependente da região. Em seguida, o estudo detém-se em descrever o período da história venezuelana delimitado pelos anos de 1973 e 1998, interregno no qual uma questão essencial residiu no dilema entre a conquista da soberania econômica (condição necessária da democracia social) e a sujeição aos interesses imperialistas do grande capital estrangeiro, representados pelas empresas petrolíferas instaladas no país. As formas concretas que assumiu a nacionalização da indústria petroleira nos anos 1970, o modo de participação que daí resultou dessas empresas estrangeiras na exploração petrolífera durante as décadas de 1980 e 1990 - quando paulatinamente a política oficial foi-se orientando pelas prescrições do neoliberalismo (materializadas na assim chamada Abertura Petroleira) - e os desdobramentos sociais (sob a forma de conflitos de classe) dessas decisões econômicas compõem o cenário histórico venezuelano aqui estudado, o qual, ao final do século, expunha a crise do modelo rentista adotado e a dissolução das alianças políticas tradicionais - crise que, por fim, deu ensejo à vitória político-eleitoral do partido chavista, em dezembro de 1998, ponto inicial do progressismo de hoje.

Palavras-chave: Economia petroleira; dependência estrutural; subdesenvolvimento; abertura petroleira; movimentos sociais. 


\begin{abstract}
Oil activity constitutes, since the first decades of 20th century, the core of contemporary Venezuelan economy. The importance this activity has acquired since then was such that all the main decisions of the national economic policy concern it, and inevitably represent far-reaching consequences for the Venezuelan society. This study starts from a critical reflection on the nature and historical scope of social and political changes that occur in Latin America, i.e., the rise of progressive governments (among them, markedly, Chavist Bolivarianism), whose main challenge today is the actual confrontation between opportunities of economic autonomization (recognized and proclaimed by the progressist political discourse) and, conversely, forces of perpetuation of structural dependence and underdevelopment, in the inherent conditions in the region's dependent capitalism. Then, the study will describe the Venezuelan history from 1973 to 1998, interregnum in which an essential issue was in the dilemma between the achievement of economic sovereignty (social democracy necessary condition) and the subjection to imperialist interests of great foreign capital, represented by oil companies established in the country. The concrete forms the oil industry nationalization took form in the 1970s, the way of participation which resulted from those foreign companies in the oil exploration in the 1980s and 1990s - when gradually the official policy was guided by neoliberalism prescriptions (materialized in the Oil Opening Policy) - and the social unfoldings (in the form of class conflicts) of those economic decisions make up the Venezuelan historical setting studied here, which, at the end of the century, exposed the adopted rentist model crisis and the dissolution of traditional political alliances - a crisis which eventually gave opportunity to Chavist party political-electoral victory, in December 1998, point of departure of the present-day progressivism .
\end{abstract}

Keywords: Oil economy: structural dependence; underdevelopment; oil opening; social movements. 


\section{RESUMEN}

La actividad petrolera es, desde las primeras décadas del siglo XX, el centro de la vida económica contemporánea de Venezuela. La importancia que esta actividad ha adquirido desde entonces es tal que todas las decisiones más importantes de política económica nacional le conciernen y representan inevitablemente graves consecuencias para toda la sociedad venezolana. Este estudio toma como punto de partida una reflexión crítica sobre la naturaleza y el alcance históricos de los cambios sociales y políticos que ocurren actualmente en América Latina, es decir, principalmente el ascenso de gobiernos progresistas (entre ellos, en particular, el bolivarianismo chavista), cuyo mayor reto hoy en día consiste en el enfrentamiento entre las oportunidades de empoderamiento económico (reconocido y proclamado por el discurso político progresista) y, por el contrario, las fuerzas de perpetuación de la dependencia estructural y del subdesarrollo, en las condiciones inherentes al capitalismo dependiente de la región. A continuación, el estudio se centra en describir el período de la historia venezolana delimitada por los años 1973 y 1998, el interregno en el que una cuestión esencial residió en el dilema entre el logro de la soberanía económica (condición necesaria de la democracia social) y el sometimiento a los intereses imperialistas del gran capital extranjero, representados por las empresas petroleras que operan en el país. Las formas concretas que asumió la nacionalización de la industria petrolera en los años 70 , el modo de participación de esas empresas en la exploración de petróleo en las décadas de 80 y 90 cuando la política oficial fue poco a poco guiada por las recetas del neoliberalismo (materializadas en la así llamada Apertura Petrolera) - y los desdoblamientos sociales (en la forma de conflicto de clases) que resultaron de estas decisiones económicas son el contexto histórico venezolano aquí estudiado, que, al final del siglo, exponía la crisis del modelo rentista adoptado y la disolución de las alianzas políticas tradicionales - crisis que dio oportunidad a la victoria político-electoral del partido chavista, en diciembre de 1998, punto de partida del progresismo actual.

Palabras clave: economía del petróleo, dependencia estructural, subdesarrollo, apertura petrolera, movimientos sociales. 
Esta pesquisa é dedicada ao povo venezuelano, com o anelo de que ele seja hoje o verdadeiro protagonista de sua emancipação histórica e exemplo para os povos de toda a América Latina. Que suas vitórias traduzam a divisa de José Martí: Pátria é humanidade. E que seu empenho concretize o ideal do mesmo Martí: Buscamos a solidariedade não como um fim, mas como um meio voltado a conseguir que Nossa América cumpra sua missão universal. 


\section{REPÚBLICA BOLIVARIANA DA VENEZUELA}

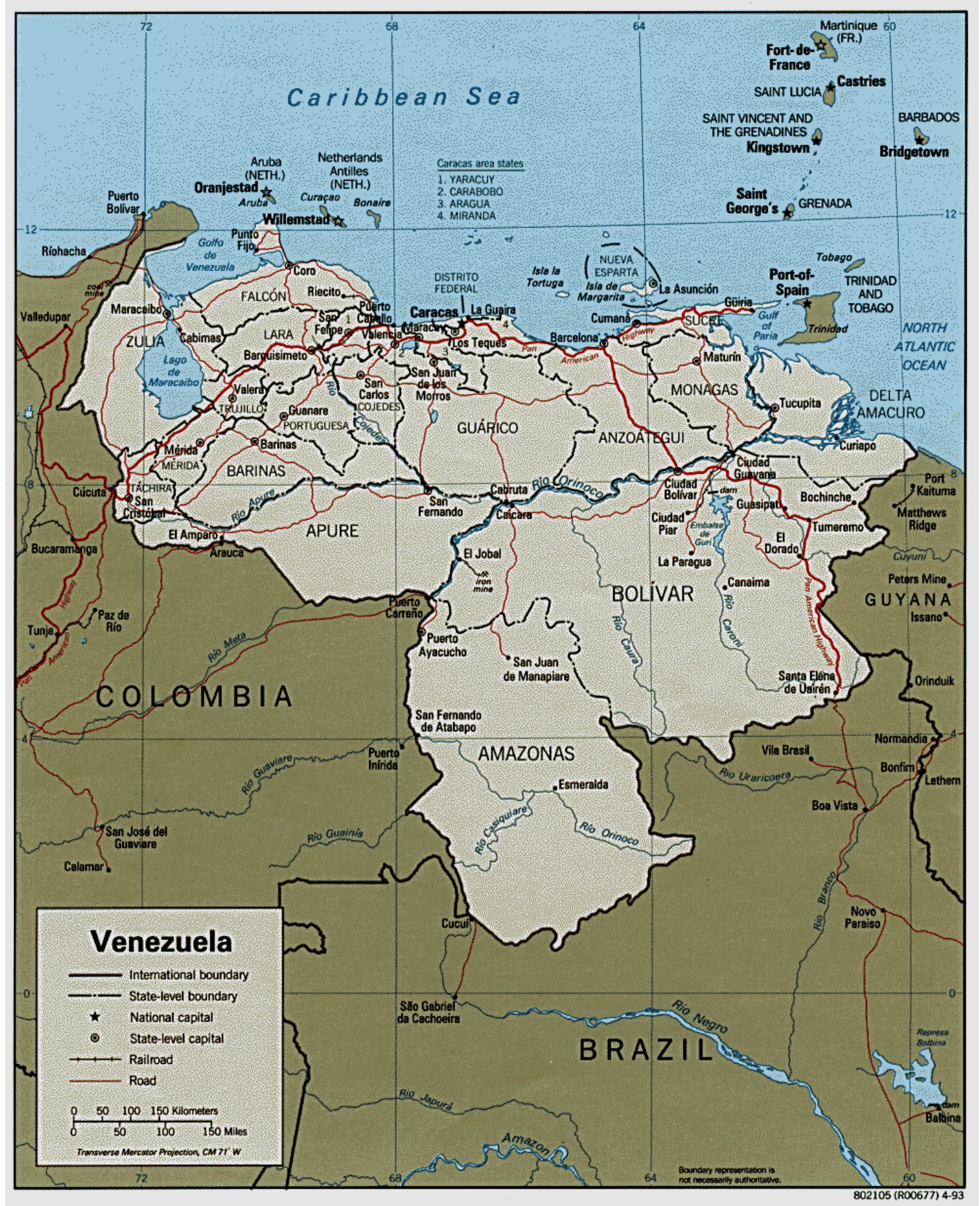

Nota: Caracas é hoje Distrito Capital da Venezuela. (Até 1999, era denominada Distrito Federal). 


\section{SUMÁRIO}

Introdução: A perpetuação da dependência e do subdesenvolvimento na América Latina 11

Parte I: A Venezuela Saudita: os anos da "euforia petroleira" e a questão da dependência estrutural (1973-1984) 83

Cap. 1: O "excepcionalismo" da Venezuela democrática 93

Cap. 2: Dependência e subdesenvolvimento: os limites do progresso nacional 114 Cap. 3: A nacionalização do setor petroleiro: uma experiência mutilada ..... 146

Cap. 4: A cooptação do movimento operário e a repressão à luta armada. 171

Parte II: 0 rentismo sob a "ofensiva neoliberal" e o aprofundamento do subdesenvolvimento (1984-1998) ..............................198

Cap. 5: Crise econômica e social. A Abertura Petroleira.....................................203

Cap. 6: O Caracaço e os levantes militares de 1992 …...................................227

Cap. 7: A crise final da democracia de Punto Fijo .........................................268

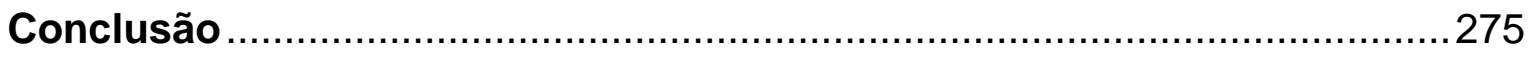

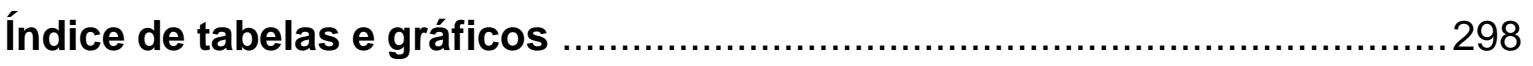

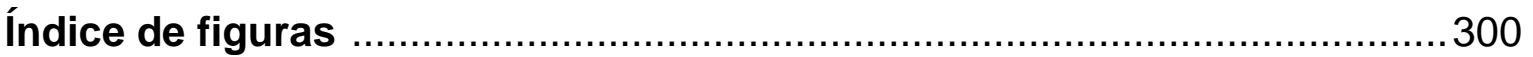

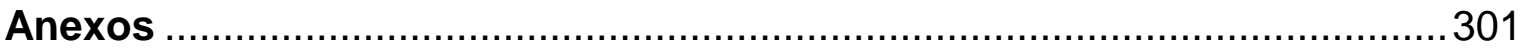

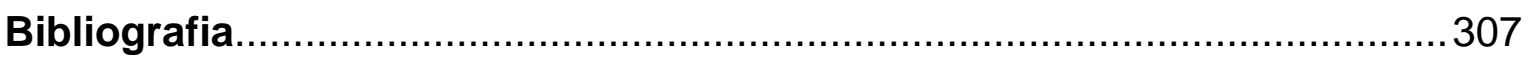


"(...) Se ou enquanto a sociedade subdesenvolvida não possuir requisitos estruturais e dinâmicos para engendrar processos de autonomização econômica, sociocultural e política, ao nível do padrão de integração, funcionamento e desenvolvimento da ordem social competitiva, ela ficará condenada ao destino histórico inerente ao capitalismo dependente (qualquer que seja a fórmula empregada para disfarçar esse destino) ou terá de procurar no socialismo (qualquer que seja a via pela qual ele se desencadeie historicamente) as soluções para os seus dilemas econômicos, sociais e políticos."

(Florestan Fernandes, Sociedade de classes e subdesenvolvimento, 1967)

"O pensamento revolucionário, e mesmo o reformista, já não pode ser liberal, mas sim socialista. O socialismo aparece em nossa história não por alguma razão do acaso, de imitação ou de moda - como supõem alguns espíritos superficiais - mas como uma fatalidade histórica."

(José Carlos Mariátegui, Siete ensayos de interpretación de la realidad peruana, 1928)

"(...) existe um liame dialético indestrutível entre ciência e emancipação, e, pois, igualmente entre emancipação e ciência, ao menos na sociedade de classes. As ciências sociais podem começar a desenvolver-se independentemente de qualquer projeto de emancipação. Mas, até aqui, somente o marxismo, unificando ciências sociais e projeto de emancipação, tem sido capaz de desenvolver uma ciência coerente, que põe radicalmente em questão todas as condições sociais desumanas, explicando suas origens, sua natureza profunda, sua evolução e as condições de seu declínio."

(Ernest Mandel, Emancipation, science et politique chez Karl Marx,1983) 


\section{Introdução: A perpetuação da dependência e do subdesenvolvimento na América Latina}

O mau êxito do modelo de desenvolvimento imposto às sociedades latinoamericanas por governos ditatoriais - a modernização autoritária das décadas de 1960-80 - e, igualmente, a tibieza do progresso econômico e social alcançado por governos neoliberais nos anos 1980-90 deram novo alento à discussão acerca da inviabilidade histórica, na América Latina, de se construírem sociedades democráticas sem que previamente seja rompido o sistema de relações de dependência que mantém subordinadas essas economias periféricas ao centro hegemônico do capitalismo mundial. E sobretudo hoje, quando, por praticamente todo o continente, vigoram regimes de esquerda ${ }^{1}$, considerados progressistas $^{2}$, a

\footnotetext{
${ }^{1}$ Entendendo-se esquerda em uma acepção lata, considera-se que inauguraram governos desse tipo Hugo Chávez na Venezuela (1998), Luís Inácio Lula da Silva no Brasil (2002), Néstor Kirchner na Argentina (2003) - e Cristina Kirchner (em 2007) - Tabaré Vásquez no Uruguai (2004), Evo Morales na Bolívia (2005), Michelle Bachelet no Chile (2006), Daniel Ortega na Nicarágua (2006), Rafael Correa no Equador (2006), Fernando Lugo no Paraguai (2008) - este deposto pelo "golpe branco" de junho de 2012 - e Carlos Mauricio Funes em El Salvador (2009). No México, as prováveis fraudes eleitorais impediram a vitória de Manuel López Obrador, em 2006. Em novembro de 2009, o antigo guerrilheiro José Mujica foi eleito presidente do Uruguai. No Peru, Ollanta Humala, considerado um dos principais líderes nacionalistas do país, venceu as eleições em 2011. Porém, no Chile, Sebastián Piñera, de centro-direita, foi eleito em 2010, e no mesmo ano, na Colômbia, o empresário conservador Juan Manoel Santos sucedeu ao direitista Álvaro Uribe, do qual fora Ministro da Defesa. A esquerda retornou ao poder no Chile, com a nova vitória de M. Bachelet, em dezembro de 2013. Em 5 de março de 2013, faleceu o presidente venezuelano Hugo Chávez, reeleito, havia poucos meses, para um quarto mandato. Na eleição presidencial que se seguiu, de 14 de abril, Nicolás Maduro (então vice-presidente) foi eleito por estreita margem de votos sobre o candidato oposicionista Henrique Capriles (50,78\% contra $48,95 \%$ - a menor diferença em disputas presidenciais ao longo destes 17 anos do chavismo no governo), o que reencetou o debate, na esquerda venezuelana, sobre o perigo de retrocesso nas conquistas da Revolução Bolivariana.

${ }^{2}$ Para muitos políticos e intelectuais de esquerda, o caráter progressista desses governos revelase em suas políticas de "integração regional" e de defesa dos "interesses nacionais e sociais", em oposição aos governos anteriores, receptivos à "globalização" e às políticas de privatização e de liberalização de mercados. Desse ponto de vista, tais governos progressistas teriam rompido com a política econômica vigente nas décadas precedentes e iniciado uma nova fase histórica. (Cf., por exemplo, SADER, Emir. "Posneoliberalismo en Brasil". In: ALAI (Agencia Latinoamericana de Información). América Latina: Las izquierdas en las transiciones políticas. Quito: ALAI, mayo de 2012, p. 5: "(...) Los nuevos gobiernos latinoamericanos, que se volvieron mayoritarios en el continente, deben ser considerados progresistas, porque desarrollan procesos regionales de integración autónomos respecto a la hegemonía norteamericana y, por otro lado, a contramano de los gobiernos neoliberales que los han precedido, priorizan políticas sociales y no ajustes fiscales, a la vez que desarrollan Estados que inducen el crecimiento económico y garantizan derechos sociales, en lugar de Estados mínimos".) Porém, a incapacidade que se vem patenteando de esses países superarem a profunda dependência em relação ao grande capital financeiro internacional e de implantarem políticas sociais que possam ir além do mero assistencialismo ou das "políticas compensatórias" (ou "focadas") - sempre insuficientes e efêmeras - torna a noção de "governos progressistas" um conceito, até certo ponto, impreciso e que não tem contado com
} 
pertinência de se indagar sobre as limitações do capitalismo dependente e as alternativas históricas que se lhe abrem acha-se, de uma perspectiva dialética, não só no valor teórico do assunto, mas também - e principalmente - na sua importância prática para as estratégias políticas que os movimentos sociais de base popular (e seus representantes políticos), reemergentes após décadas de refluxo e silêncio, devem traçar nas lutas por superar o quadro comum de subdesenvolvimento social, ao qual, ademais, se somam os riscos políticos das não infrequentes reações autoritárias das classes dominantes ao se sentirem ameaçadas. De fato, a tendência presente de esquerdização do cenário político latino-americano brotou, na passagem do século, em um clima geral de agudização dos conflitos sociais, de irrupção de rebeliões populares e de crises políticas em diversos países do continente ${ }^{3}$ - clima que conduziu à crise de representação da maioria dos partidos políticos tradicionais e ensejou a ascensão ao poder de Estado a novos grupos políticos, mas que não ficou incólume aos

aceitação unânime nos meios da esquerda latino-americana. Cf., também, ELÍAS, Antonio. (comp.). Los gobiernos progresistas en debate. Argentina, Brasil, Chile, Venezuela y Uruguay. Buenos Aires: CLACSO; Montevideo: PIT-CNT. Instituto Costa Duarte, 2006.

${ }_{3}^{3}$ Para uma análise de conjunto das rebeliões e movimentos populares e das crises políticas nos países latino-americanos, surgidas entre o fim do século passado e o princípio deste (p. ex., os piqueteros na Argentina, os trabalhadores sem terra no Brasil e no Paraguai, as revoltas indígenas nos países andinos, os zapatistas e o tequilaço no México, a reação popular ao golpe antichavista na Venezuela, as diversas paralisações operárias e protestos estudantis, etc., veja-se COGGIOLA, Osvaldo. América Latina siglo XXI: ¿una revolución en marcha?, 2006. A propósito do quadro atual de convulsão social e instabilidade política, assim como das limitações de sua perspectiva revolucionária na América Latina, observa esse historiador: "(...) Nuestro momento histórico se caracteriza por la contradicción extremadamente aguda entre la madurez de las condiciones objetivas - el agotamiento de las posibilidades históricas del capitalismo y la polarización de la sociedad entre explotados y explotadores - y el retraso del factor subjetivo. (...) Hay un vasto y profundo proceso de emergencia de los oprimidos y una intensificación de la lucha de clases, que ha abierto situaciones prerrevolucionarias en varios países, como en Colombia, Ecuador, Bolivia, Paraguay o Argentina, con levantamientos de rasgos insurreccionales como los de Ecuador y Bolivia, y múltiples manifestaciones de protestas y movilización social. El campesinado y las masas indígenas del continente protagonizan un vasto ascenso desde México a Chile, desde Colombia a Brasil, que ha fortalecido y renovado a poderosas organizaciones de masas, desde el MST brasileño a la CONAIE en Ecuador o la FNC en Paraguay. Hoy este proceso tiende a combinarse con luchas urbanas y obreras, como muestran Argentina y Bolivia. Vastos sectores populares participan de este proceso, desde pequeños productores amenazados por la ruina, sin techo, a capas medias que se movilizan tras reclamos democráticos. Diversas luchas estudiantiles, desde México a Chile, muestran la inquietud en sectores de las nuevas generaciones. (...) Un nuevo movimiento obrero comienza a dar sus primeros pasos al calor de los procesos de movilización social y crisis política, si bien la clase obrera no ha entrado aún en escena como fuerza social autónoma, es parte de este proceso. Desde Costa Rica y Colombia hasta Argentina y Uruguay se han registrado paros nacionales, así como centenares de huelgas, luchas de resistencia o movilizaciones parciales, mostrando las tendencias a su recuperación luego de años de duros golpes bajo la ofensiva capitalista".(pp. 5-7. Grifo nosso.) Cf., também, em uma perspectiva semelhante: KATZ, Claudio. Las encrucijadas del nacionalismo radical. 2007. Disponível em http://katz.lahaine.org. 
Putsche desfechados pelos setores conservadores das elites nacionais. ${ }^{4}$ Ainda assim, alguns desses regimes progressistas alcançam hoje uma razoável estabilidade, que - como nos casos do Movimento Quinta República, de Hugo Chávez na Venezuela (o MVR, reorganizado atualmente em torno do PSUV), do Partido dos Trabalhadores no Brasil e do justicialismo dos Kirchner na Argentina prolonga-se já por mais de uma década, mantendo consideráveis (embora oscilantes) níveis de aceitação popular, suficientes até agora ao menos para garantir a permanência desses partidos no poder sem que haja uma séria ruptura da institucionalidade política. ${ }^{5}$ Pouco comum para os padrões políticos autoritários latino-americanos, essa estabilidade vem sendo diversamente interpretada - seja, por um lado, como uma circunstância indicativa da vitória popular no longo processo de democratização levado a cabo pelos movimentos sociais ascendentes no continente em reação à grave crise social que se abateu sobre a região nas últimas décadas; seja, por outro lado, como expressão ou resultado da

\footnotetext{
${ }^{4}$ Considerem-se, por exemplo, os golpes de Estado, bem sucedidos ou não, dados nos últimos anos contra governos constitucionais na Venezuela, na Bolívia, em Honduras e, mais recentemente no Paraguai - bem como a reorganização dos partidos de centro e direita e suas vitórias eleitorais no Chile, Panamá, Honduras, México, Colômbia e Paraguai.

${ }^{5}$ Outro caso digno de nota é o da Bolívia, cujo partido MAS (Movimiento al Socialismo) - uma coligação de organizações populares - venceu a eleição de outubro de 2014 com expressiva vantagem em relação à principal oposição (61\% contra $24 \%$ ), e seu presidente Evo Morales deverá permanecer à testa do governo boliviano até 2020. No Brasil, o Partido dos Trabalhadores venceu, no mesmo mês, as eleições presidenciais, devendo governar até 2019. No mês seguinte, no Uruguai, Tabaré Vasquez foi reeleito, pela Frente Ampla, para um mandato até 2020.

* (N.B.) O caráter oscilante dessa aceitação mostrou-se claro quando, em 22/11/2015, Mauricio Macri venceu a eleição presidencial na Argentina, pondo fim a 12 anos ininterruptos de governo executivo dos Kirchner. $\mathrm{O}$ fato, não de todo surpreendente, representa para alguns analistas o primeiro ato do drama do malogro definitivo dos regimes progressistas contemporâneos latinoamericanos, vistos em geral como corruptos, autoritários e ineficientes. Para outros, contudo, constitui um sinal, em meio à crise mundial, da urgência de aprofundamento da orientação radicalprogressista e antineoliberal das políticas econômicas e sociais desses governos. É de notar que o novo presidente argentino terá de compor-se com um poder legislativo (Senado e Câmara dos Deputados) ainda de maioria kirchnerista. Por seu turno, na Venezuela, a aliança de partidos oposicionistas (MUD) alcançou ampla maioria parlamentar nas eleições legislativas de 05/12/2015, após 17 anos de domínio bolivariano do Parlamento, o que constituiu a maior derrota eleitoral do chavismo desde 1998. No entanto, nada parece indicar que a tentativa inconstitucional de depor o presidente Maduro ("la salida", planejada pela oposição venezuelana) ganhe força com a vitória nas urnas. Mais recentemente, no Brasil, a oposição ao governo petista conseguiu aprovar, em maio de 2016, a admissão do processo de impeachment da presidente Dilma Rousseff, em um indisfarçável golpe de Estado, que, todavia, não contradisse a vontade de grande parte da população, inclusive de antigos eleitores da presidente. Mas, apenas análises apressadas concluem pelo enfraquecimento e definhamento do Partido dos Trabalhadores no cenário brasileiro. Em qualquer desses casos, será preciso observar o desenrolar dos acontecimentos dos próximos anos para se apontar o rumo que tomará a vida político-social do continente. (Cf. AMÉRICA LATINA EN MOVIMIENTO. ¿ Fin del ciclo progresista? no 510, deciembre 2015, Año 39, $2^{2}$ época. Vejam-se também excelentes ponderações sobre o assunto em: KATZ, Claudio. Desenlaces del ciclo progresista. 25.ene.2016. Disponível em: http://katz.lahaine.org/?cat=1)
} 
mera substituição de antigos grupos políticos dominantes então decadentes por novos grupos - em geral, de extração social inferior e politicamente saídos das fileiras da oposição - que, cooptados afinal pelas classes dominantes de seus países, exercem hoje o poder institucional sob bandeiras de grandes transformações sociais, mas sem efetivamente pôr em xeque (antes, reassegurando-os) os tradicionais mecanismos de dominação política interna e externa. ${ }^{6}$ No primeiro caso, a ascensão ao poder dos grupos de esquerda estaria coroando um penoso período de lutas democráticas contra as ditaduras militares e seus epígonos civis, que haviam, nas décadas de 1970-90, reprimido e desarticulado violentamente os movimentos sociais, e sujeitado, como outrora, a vida política e econômica do continente aos interesses antipopulares das elites locais e dos grandes grupos empresariais estrangeiros. No segundo caso, a crise de representatividade dos maiores partidos tradicionais (sobretudo nos países da América do Sul), associada a uma conjuntura política de "normalidade democrática", teria aberto, em fins do século, espaços de ação a novos grupos, ansiosos por construir uma nova hegemonia política, mas reticentes ou débeis para transgredir os limites da democracia liberal. Em ambos os casos, contribuíra como uma circunstância externa importante o relativo enfraquecimento da supremacia mundial dos EUA, às voltas com a guerra ao terrorismo internacional e com o reaparecimento de novos adversários econômico-militares (Rússia e China, em especial), o que teria restringido o costumeiro poder de intromissão do Departamento de Estado norte-americano nas questões internas da vida política das nações latino-americanas. ${ }^{7}$ Nesse cenário, e procurando vencer os efeitos da crise de paradigmas teórico-ideológicos provocada pelo desaparecimento das experiências históricas do assim chamado socialismo real ${ }^{8}$, os projetos progressistas dos partidos ascendentes da esquerda latino-americana apresentaram-se, em sua raiz, como alternativas ao neoliberalismo e à

\footnotetext{
${ }^{6}$ Cf. uma importante discussão sobre os "paradoxos do desenvolvimento recente da América Latina" sob a condução da esquerda em PETRAS, James \& VELTMEYER, Henry. What's left in Latin America?: Regime change in new times. Farham: Ashgate, 2009.

${ }^{7}$ Contra essa interpretação da decadência do poderio econômico e militar-diplomático dos EUA (que, para alguns, ter-se-ia acentuado após os atentados terroristas de 11 de setembro de 2001), cf. FIORI, José L. et alii. O mito do colapso do poder americano. RJ-SP: Record, 2008. Cf., também, COGGIOLA, O. \& MARTINS, J. Dinâmica da globalização. Mercado mundial e ciclos econômicos (1970-2005). Santa Catarina: UFSC, 2006, (especialmente cap. 7 e 9).

${ }^{8}$ Cf. NETTO, José Paulo. Crise do socialismo e ofensiva neoliberal. São Paulo: Cortez, 1995.
} 
globalização ${ }^{9}$ - havendo gradativamente assumido em alguns casos uma feição predominantemente nacionalista ou neodesenvolvimentista (por ex., o kirchnerismo na Argentina e a Aliança PAIS no Equador); ou uma feição integradora multiclassista, baseada no pluralismo etnossocial (p. ex., o MAS boliviano); e ainda, uma feição de conteúdo transformador mais profundo, derivado de interpretações mais ou menos radicais de ideais anticolonialistas, de justiça social-popular e, mesmo, de pontos programáticos fundamentais do socialismo revolucionário (p. ex., o MVR venezuelano e o PT brasileiro) ${ }^{10}$. Outro

\footnotetext{
${ }^{9}$ Convém lembrar que, no final do século $\mathrm{XX}$, um amplo leque de movimentos sociais e de grupos políticos se organizou em torno do slogan "Um outro mundo é possível", em resposta aos efeitos catastróficos da globalização neoliberal e de seu pensamento único em todo o mundo. Esse autodenominado movimento altermundista (que, não obstante, não se proclamou absolutamente contra o capitalismo em si) projetou internacionalmente as realizações anuais do Fórum Social Mundial e deu uma inusitada evidência midiática aos diversos protestos contra as reuniões periódicas do FMI, da OMC e do G7.

${ }^{10}$ Os fundamentos ideológicos do Movimento V República (chamado, até 1997, de Movimento Bolivariano Revolucionário 200, quando então a sigla foi alterada para que Hugo Chávez concorresse à eleição presidencial como candidato da aliança Polo Patriótico) estão sintetizados na imagem figurada da "árvore das três raízes": 1) Simon Rodríguez, preceptor de Bolívar, que insistira na necessidade da educação popular e nas formas de organização social e política construídas pelo povo; 2) o próprio Simon Bolívar, com seus ideais de libertação anticolonial e de unidade dos povos libertados; e 3) Ezequiel Zamora, caudilho da Guerra Federal de 1859-1863, que exaltara mais radicalmente os princípios democrático-populares da luta contra a dominação oligárquica (Zamora tinha por lema "terras e homens livres, eleição popular e horror à oligarquia"). À interpretação popular-libertadora dada ao pensamento desses próceres nacionais acresceu-se, no ideário chavista, além de alguma confessa simpatia pelo marxismo, o princípio de conjunção dos interesses do povo com o sentimento nacionalista e democrático dos militares, a exemplo do que teria ocorrido no Peru do general Velasco Alvarado e no Panamá de Omar Torrijos, os quais exerceram, nos anos 1970-80, grande influência sobre o jovem militar Hugo Chávez. (Cf. ALCÂNTARA, Manuel \& FREIDENBERG, Flavia (coords.). Partidos políticos de América Latina. Países andinos. México: FCE, IFE, 2003 (Cap. Venezuela), pp. 487-606).

Por sua vez, o Partido dos Trabalhadores (PT), no Brasil, representou, em sua origem, uma das mais amplas e promissoras experiências de organização e representação política de movimentos populares, de trabalhadores urbanos e rurais, e de religiosos e intelectuais na luta contra o regime ditatorial brasileiro nascido do golpe de Estado de abril de 1964. Ideologicamente, o PT constituiu-se a partir da fusão ou justaposição de princípios de todos esses movimentos, embora definindo como sua concepção central de ação política a luta pela construção do socialismo. (Em 1989, fundamentando a candidatura presidencial de Lula, o partido sustentava: "(...) Contra o projeto das classes dominantes, o PT reafirma o seu caminho para resolver a crise do ponto de vista dos trabalhadores, que é a instauração de um governo democrático-popular, anti-imperialista, antimonopolista, contra o pagamento da dívida externa, que realize a reforma agrária e que promova o desenvolvimento sobre novas bases, e no qual os trabalhadores detenham a hegemonia e possam avançar em direção ao socialismo". O momento atual e as nossas tarefas). Ao longo de três décadas, porém, o partido - atravessando sucessivamente as etapas de oposição social, de oposição parlamentar e, ao fim, de partido de governo - foi paulatinamente abandonando seu projeto político de fundamentos socialistas e socialdemocratas para tornar-se não só um partido da ordem, lastimavelmente eivado dos vícios do pragmatismo político e da corrupção administrativa, mas também um verdadeiro "zumbi" político-ideológico (a expressão é de Mauro Luís lasi), aniquilando, por sua ação, o ideal de organização autêntica das classes trabalhadoras que ele próprio, a princípio, ajudou a construir fora do domínio dos tradicionais partidos trabalhistas brasileiros. Constituiu-se por isso em uma das mais deploráveis denegações dos ideais e ações da esquerda mundial. (Cf. duas valiosas interpretações críticas da
} 
elemento importante desse fundo ideológico comum da esquerda progressista chegada ao poder foi, caracteristicamente, o reconhecimento do protagonismo dos movimentos populares em sua luta contra a miséria social e a opressão política - reconhecimento que deveria, em alguns países, conduzir a mudanças no sistema de representação política e no ordenamento jurídico tradicional. ${ }^{11}$ Não obstante isso, em todos os exemplos desses projetos progressistas, o tom de radicalismo renovador (nacionalista ou revolucionário) dos discursos tendeu a reduzir-se drasticamente durante o período de composição das alianças partidárias (firmadas visando à disputa eleitoral) e quase silenciou por completo no período imediato ao triunfo nas urnas. ${ }^{12}$ É, pois, sumamente significativo que

evolução histórica do PT em: IASI, Mauro Luís. As metamorfoses da consciência de classe. O PT entre a negação e o consentimento. São Paulo: Expressão popular, 2006; e SECCO, Lincoln. História do PT 1978-2010. Cotia, SP: Ateliê Editorial, 2011.)

${ }^{11} \mathrm{Na}$ Venezuela, por exemplo, essas mudanças têm sido feitas em nome da assim denominada democracia participativa e protagônica, promovida pelo governo de Hugo Chávez (e substanciada, em grande medida, na Constituição da República Bolivariana da Venezuela, de 1999), em confronto com a democracia "oligárquica e partidocrática" dos governos anteriores. Cf. MAYA, Margarita López. Luta hegemônica na Venezuela. A crise do puntofijismo e a ascensão de Hugo Chávez, 2010 - sobretudo o cap. 15; e ARENAS, Nelly \& HENRíQUEZ, Haydée Ochoa. Venezuela: ¿más democracia o más populismo? Los consejos comunales y las disputas sobre la hegemonía democrática. Buenos Aires: Teseo, 2010. (Nesta última obra, debatem-se duas visões opostas sobre a "democracia participativa".) O princípio do protagonismo popular também vem sendo adotado pela oratória política dos governos atuais da Bolívia e do Equador. Na Venezuela, ademais, tem-se revelado cada vez mais clara a necessidade de associar a adoção do ideário socialista à promoção oficial de formas de ação popular que superem as limitações da democracia representativa. Para alguns, essa promoção expõe o travo populista do chavismo; para outros, ela constitui uma estratégia fundamental de construção da autêntica democracia popular - em que desempenham papel central os conselhos comunais. Nesta última perspectiva, pois, afirma-se: "É evidente que a participação cidadã é uma política do Estado venezuelano posta em prática desde o advento do governo de Hugo Chávez. É uma política estabelecida pela Constituição de 1999, mas que, na prática, vem sofrendo modificações em seu modelo, em um cenário de forte oposição ao projeto de transformação atual. Isso tem sido uma oportunidade para que se vá dando forma ao modelo, atrás do qual está a construção de uma democracia participativa e, ao mesmo tempo, a construção de uma sociedade de justiça social. Hoje, o modelo que se promove é o das comunas socialistas, que são espaços territoriais dirigidos pelo poder popular. Trata-se de um projeto que progride na prática, tendo-se consciência de que, mais do que decretá-lo, ele deve ser construído - diferentemente do que ocorria no passado recente, no qual importava mais a construção de políticas formais do que seu progresso na realidade prática". (HENRÍQUEZ, Haydée Ochoa. "A política de promoção da participação cidadã do governo de Hugo Chávez". In: BENEDITO, F. (org.). Venezuela: Temas contemporâneos, São Paulo, 2011, p. 130. Disponível em: http://pt.scribd.com/doc/65432081/ VENEZUELA-TEMAS-CONTEMPORANEOS)

${ }^{12} \mathrm{Na}$ Venezuela, o Polo Patriótico constituiu a aliança de forças políticas que respaldou a candidatura vitoriosa de Hugo Chávez em 1998. Nos anos seguintes, a insatisfação com a linha alegadamente "populista" do presidente Chávez levou ao desligamento de alguns partidos da aliança, como o Pátria para Todos e o Movimento ao Socialismo. No Brasil, em 2002, a vitória eleitoral do PT foi, em grande medida, fruto de sua aproximação com partidos mais à direita no espectro político brasileiro, como o Partido Liberal, o Partido da Mobilização Nacional, o Partido Progressista, o Partido Trabalhista Brasileiro e o Partido do Movimento Democrático Brasileiro. Para os setores mais radicais do PT, essa aproximação foi causa de desfiguração ideológica e de renúncia ao projeto socialista original, e provocou críticas e rupturas internas importantes. $\mathrm{Na}$ 
as pressões sofridas por esses novos regimes, exercidas por grupos de grandes investidores internacionais, pelas gigantescas corporações transnacionais estabelecidas nesses países, pela diplomacia estadunidense e por setores empresariais nacionais conservadores (integrantes ou não das coalizões vitoriosas) e, por outro lado, os compromissos assentados com os movimentos sociais de base popular, também indispensáveis ao bom êxito eleitoral, mas exigentes de mudanças estruturais efetivas para além das simples colusões políticas, geraram um conflito aberto de interesses opostos travado no âmbito do próprio Estado. Em consequência, no plano formal, esse conflito de classes foi sendo diferentemente manejado pelos novos grupos no poder - quer acentuandose progressivamente o "apelo revolucionário" do regime (como na Venezuela, na Bolívia e, em menor medida, no Equador, em torno de um difuso socialismo do século $X X I$ ); quer destacando-se a soberania nacional como meta principal (como na Argentina e na Nicarágua, nesta última com um forte acento anti-EUA), sem contudo adotar uma aberta postura "revolucionária"; quer ainda - no caso específico do Brasil, alçado ao nível de grande mercado emergente - abdicando completamente do programa de esquerda radical e substituindo-o incontinenti pelo velho programa liberal-autoritário, com sua surrada litania de integração e desenvolvimento econômico com democracia social, implementada esta última através de políticas assistencialistas de "combate à miséria e à exclusão social" ${ }^{13}$

\footnotetext{
Argentina, em 2003, a Frente para a Vitória organizou-se como uma aliança de centro-esquerda, que punha lado a lado peronistas, comunistas e socialistas, reunidos contra a candidatura de Carlos Menem. No Chile, entre 1990 e 2010, a Concertação de Partidos pela Democracia manteve-se no poder por quatro governos sucessivos, sendo os dois últimos de blocos de esquerda - Ricardo Lagos (PS-PPD) entre 2000 e 2006, e Michelle Bachelet entre 2006 e 2010. Sobre o caso chileno, em particular, no qual a herança opressiva do período militar é, sem dúvida, a mais pesada, observa um estudioso: "(...) En las elecciones parlamentarias, la Concertación triunfó durante todo el período, pero la presencia hasta 2005 de senadores designados, el sistema electoral binominal que le daba a la minoría de oposición el mismo número de escaños que a la mayoría, y la existencia de quórums especiales para los temas más significativos (todos ellos enclaves impuestos por la dictadura a través de la Constitución de 1980), en general consagraron un empate entre la coalición de gobierno y la de oposición de derecha". (GARRETÓN, Manuel Antonio. Neoliberalismo corregido y progresismo limitado: los gobiernos de la Concertación en Chile. 1990-2010. Santiago: CLACSO, 2012. Disponível em: http://bibliotecavirtual.clacso.org.ar/ clacso/coediciones/20121121122525/NeoliberalismoCorregido.pdf", p. 80)

${ }^{13} \mathrm{O}$ governo progressista de Dilma Rousseff não alterou absolutamente esse programa, delineado no governo anterior, de Lula da Silva. Sobre o Brasil enquanto potência econômica emergente e exemplo de governo progressista em sua projeção no conjunto do continente, nota acertadamente um estudioso: "Dans son nouveau rôle dominant le Brésil tente de jouer celui d'un sousimpérialisme. Bien que prétendant représenter les intérêts régionaux communs, ce rôle ne s'avérera pas moins défavorable pour les peuples que l'oppression traditionnelle exercée par les impérialismes américain ou européen. (...) Le terme «sous-impérialisme » pourrait suggérer - à
} 
Em vista dessas alternativas, um ceticismo justificável sugere hoje considerar que a continuidade desses governos progressistas dependerá do maior ou menor sucesso com que logrem manobrar a retórica de vanguarda e as políticas sociais de impacto imediato, de um lado, com a indisfarçável conservação in statu quo ante das estruturas econômico-sociais tradicionais, de outro.

Assentado isso, e qualquer que seja a interpretação que se adote, o certo é que veio ganhando consenso que a ênfase posta em aspectos cambiantes superficiais das práticas políticas e da ideologia não tem sido de molde a ocultar a timidez dos avanços promovidos por esses governos no campo econômico, ou seja, no antigo e pertinaz quadro de dependência estrutural que historicamente ainda aprisiona a existência desses países periféricos em sua relação subordinada com o capitalismo central. Por essa razão, como reflexo, tem-se arrefecido, em alguns casos, o entusiasmo popular por esses governos progressistas no que tange àquela que é a questão crucial inerente à condição de subdesenvolvimento - isto é, a do modo desigual e excludente com que as diversas classes sociais participam na produção e na distribuição da riqueza nacional - modo que, diga-se, não experimentou até o momento atual nenhuma alteração substantiva capaz de atestar que, nesses países, está-se plasmando um cenário de progresso real e sustentado em direção a uma verdadeira democracia social. Por isso, parece lícito presumir que o distanciamento cada vez mais dilatado entre as expressões formais (político-ideológicas) e os elementos essenciais (econômico-sociais) desse progressismo da esquerda no poder tem

tort - une délégation du pouvoir central à des serviteurs périphériques. Mais dans le cas du Brésil a toujours été souligné, au contraire, un processus de renforcement de l'autonomie des classes dominantes locales. L'application de ce concept à la région diffère, par exemple, de son emploi dans le cas d'Israël (qui agit avec le mandat du Pentagone) ou de puissances secondaires comme l'Australie ou le Canada, qui ont toujours adhéré à l'axe anglo-nordaméricain. Une analogie plus proche pourrait être faite entre le Brésil et le rôle joué par l'Afrique du Sud dans la région australe de l'Afrique. (...) Du fait de ces contradictions le Brésil adopte un comportement sous-impérial avant d'avoir atteint la puissance qu'avaient les principales économies centrales au XIXe et au XXe siècle. Cette asymétrie illustre les modalités actuelles du développement inégal et combiné." (KATZ, Claudio. "L'Amérique latine et la crise mondiale", In: KOWALEWSKI, Z. et alii. Amérique latine: Les "gouvernements progressistes " à la croisée des chemins. Bruxelles: Formation Léon Lesoil, Juillet 2011. Disponível em www.Icr-lagauche.be.) Veja-se também: LUCE, Mathias Seibel. O subimperialismo brasileiro revisitado: a política de integração regional do governo Lula (20032007). Dissertação de mestrado. Universidade Federal do Rio Grande do Sul, 2007. Com efeito, parece inelutável que os momentos de desenvolvimento das forças produtivas de uma nação periférica, enquanto estiverem condicionados pela incapacidade de superar o quadro de dependência, redundem internamente no agravamento da polarização entre classes dominantes e dominadas, e externamente em práticas próprias a um imperialismo reflexo - um subimperialismo - ainda que encobertas pelo ideal de promoção de integração regional. 
colocado em dúvida seu caráter histórico renovador, e acentuado seu conteúdo continuísta relativamente às formas contemporâneas do colonialismo latinoamericano. A confrontação necessária, que se poderia evidentemente esperar, entre os objetivos declarados de autonomia nacional desses projetos da esquerda e os tradicionais mecanismos imperialistas de sujeição política e exploração econômica na região, particularmente os exercidos pelos EUA, tem sido uma contingência cuidadosamente eludida por esses regimes progressistas, inaptos ainda para desafiar as potências hegemônicas do hemisfério norte. Isso constitui, certamente, um índice da estreiteza de seu radicalismo nacionalista, e denuncia antes a permanência, no âmbito do poder estatal, dos antigos vínculos de associação subordinada das burguesias periféricas com as das economias imperialistas. Esses vínculos, que não podem ser quebrados sem que haja de antemão uma alteração brusca e profunda tanto no quadro interno (nacional) das forças sociais em conflito quanto no cenário geopolítico internacional (entre as potências imperialistas e as economias dependentes), são hoje apenas "administrados" pelos governos de esquerda, todos eles confrontados com a exigência de "manterem-se as condições de governabilidade" - expressão que constitui um eufemismo de largo uso na grande imprensa liberal, e que dissimula as ameaças de reação golpista à ordem constitucional por parte de diversos grupos internos de direita e seus aliados externos. ${ }^{14}$ A presente conjuntura latinoamericana mostra-se, pois, como um desses momentos decisivos nos quais se joga a sorte das nações, havendo cada uma delas hoje de escolher entre, de um lado, o salto histórico para um padrão de desenvolvimento independente e, de outro, o estancamento irremissível em um nível de organização social, cultural e econômica persistentemente dependente e subdesenvolvido. $\mathrm{Na}$ periferia capitalista, vivendo-se sob o gravame permanente da exploração imperialista, essas alternativas se traduzem inexoravelmente, para as classes sociais em luta,

\footnotetext{
${ }^{14}$ Um exemplo eloquente da alegação, pela grande mídia, de "perda de condições de governabilidade" como pretexto para justificar-se um golpe de Estado é o da deposição (fracassada) de Hugo Chávez em abril de 2002. (Cf., entre outros, LEMOINE, Maurice. Venezuela's press power. How hate media incited the coup against the president. Le monde diplomatique. August 2002. Disponível em http://mondediplo.com/2002/08/10 venezuela.) Afirma a propósito esse articulista: "Never even in Latin American history has the media been so directly involved in a political coup. Venezuela's 'hate media' controls $95 \%$ of the airwaves and has a nearmonopoly over newsprint, and it played a major part in the failed attempt to overthrow the president Hugo Chávez, in April." Também o golpe de Estado que depôs Fernando Lugo, no Paraguai, em 2012, recorreu a um pretexto parecido, baseado na alegação de ingovernabilidade.
} 
em optar por uma revolução dentro da ordem ou por uma contra a ordem ${ }^{15}$ - isto é, na prática, por uma tolerante preservação das formas de dominação externa, que deixe inconcluso o processo efetivo de descolonização, permita uma participação tão-só de segunda ordem no processo de acumulação mundial capitalista e conduza, em consequência, a uma simples modernização contingente, mantendo, contudo, afastadas do exercício democrático do poder e do desfrute da renda e da propriedade os setores pobres e explorados da sociedade, ao mesmo tempo que reproduz continuamente essa mesma exclusão e exploração; - ou por uma subversão profunda das estruturas de poder e de produção material da sociedade, devendo as classes hoje expropriadas, tão logo tenham logrado certo grau de consciência revolucionária, recorrer a um programa anticapitalista como fundamento necessário de transformações radicais nas relações sociais de produção vigentes. Isso porque, nesta realidade da América Latina,

(...) as classes sociais não podem preencher suas funções sociais desintegradoras tanto quanto suas funções construtivas sob essa modalidade predatória de capitalismo selvagem. As classes puderam preencher tais funções nos modelos europeu e norte-americano de revolução burguesa, porque as classes sociais submetidas à expropriação e à espoliação conquistaram o direito de serem ouvidas, de usar meios institucionais de protesto ou de conflito, e de manipular controles sociais reativos, mais ou menos eficazes, regulando assim a sua participação social nos fluxos da renda e nas estruturas do poder. As classes sociais falham, nas situações latino-americanas, porque operam unilateralmente, no sentido de preservar e intensificar os privilégios de poucos e de excluir os demais. Elas não podem oferecer e canalizar socialmente "transições viáveis", porque a "revolução dentro da ordem" é bloqueada pelas classes possuidoras e privilegiadas, porque as massas despossuídas estão tentando aprender como realizar a "revolução contra a ordem", e porque o entendimento entre as classes tornou-se impossível, sem medidas concretas de descolonização acelerada (em relação a fatores externos $e$ internos dos velhos e novos colonialismos). Elas promovem mudanças e inovações, em geral descritas erroneamente (como se fossem produtos estáticos da mobilidade social, da urbanização, da industrialização e da educação), através das quais a crosta superficial da ordem social competitiva adquire a aparência dos modelos históricos originais. Como não vão além disso, engendrando uma consciência e ações de classe negadoras da dependência, do subdesenvolvimento, dos privilégios, da opressão institucionalizada, do desemprego em massa e da miséria generalizada, elas se

${ }^{15}$ Cf. FERNANDES, Florestan. Sociedade de classes e subdesenvolvimento. $4^{\mathrm{a}}$ ed. Rio de Janeiro: Zahar Editores, 1981, pp. 21-102. 
convertem em meios estruturais de perpetuação do capitalismo selvagem e de preservação do status quo. ${ }^{16}$

À luz dessas cogitações, afigura-se correto admitir que o fantasma que hoje assombra a esquerda progressista é o de ela transformar-se em fator de esvaziamento da revolução latino-americana - e isso lamentavelmente após décadas de lutas contra o obscurantismo de regimes militares e de governos civis neoliberais. A experiência histórica do continente, sobretudo nas últimas quatro décadas, comprova que o modo dependente de incorporação das economias latino-americanas ao mercado mundial impede, de fato, todo e qualquer desenvolvimento real que possa incluir, mesmo segundo critérios satisfatórios mínimos de integração social, as classes populares ao modelo de progresso regional conduzido por burguesias nacionais frágeis e subordinadas. À parte a venalidade política e ideológica dessas classes dominantes, um tal tipo de progresso esbarra no obstáculo central da sobreapropriação desigualmente repartida do excedente econômico nacional (sobreapropriação que, nessas economias dependentes, exerce-se objetivamente sob as formas da superexploração da força de trabalho local, do intercâmbio comercial desigual a partir de bens primários e recursos naturais, das ingentes remessas de lucros das empresas transnacionais para o exterior e da extorsiva remuneração aos capitais financeiros externos ${ }^{17}$ ), tanto quanto no obstáculo das limitações da produção

\footnotetext{
${ }^{16}$ FERNANDES, Florestan. Sociedade de classes e subdesenvolvimento, pp. 49-50.

${ }^{17}$ Um exemplo: estudando o impacto que os investimentos diretos estrangeiros têm provocado sobre o sistema produtivo dos países periféricos, Adriano Benayon conclui que os IDE constituem, na verdade, onerosos fatores de desestruturação econômica e tecnológica nesses países: a superproteção oficial dada aos IDE e, por extensão, às empresas transnacionais interessadas no país-objeto, combinou-se com a adoção de um programa de privatizações das grandes empresas estatais escandalosamente espúrio do ponto de vista dos interesses nacionais, de modo a, na realidade, entregar ao grande capital estrangeiro as empresas, os recursos minerais e as terras nacionais. Nesses termos, torna-se mesmo ingênuo falar em intercâmbio: "(...) A extração de recursos manifesta-se, mais do que na deterioração da relação de troca, na transformação desse conceito: não há troca alguma, e sim entrega unilateral do patrimônio e do valor do trabalho dos nacionais a oligarquias dos países sedes dos IDEs. A periferização e a dependência escapam ao conceito de relações internacionais: elas se dão nos âmbitos intraempresa e intraimpério. Subvertem, ademais, o conceito de comércio." (BENAYON, Adriano. Globalização versus desenvolvimento. São Paulo: Escrituras, 2005, p. 212.) No cap. 7 desse livro, o Autor enumera, para o caso brasileiro (que não é atípico), um conjunto de 15 recursos (diretos e indiretos) de que se valem as empresas transnacionais para transferir às matrizes os lucros de suas subsidiárias: 1) preços de transferência do comércio exterior (transfer pricing), 2) juros, 3) assistência técnica, 4) tecnologia, 5) uso de marcas, 6) consultoria e auditoria, 7) transportes, 8) seguros e resseguros, 9) despesas de câmbio e operações financeiras, 10) leasing, 11)
} 
agrária, da insuficiência tecnológica da produção industrial, da exiguidade do mercado consumidor interno e do endividamento externo público ${ }^{18}$, agravando a

despesas de comercialização, 12) comissões, 13) treinamento no exterior, 14) remuneração de executivos e técnicos, 15) remessa oficial de lucros. (Cf. pp. 245-247.)

${ }^{18}$ Particularmente sobre este problema crucial da dívida externa, as duas tabelas abaixo dão uma noção da correlação entre endividamento público nacional e porcentagens dos orçamentos destinados à educação e à saúde, bem como o número crescente de pessoas que vivem com rendas irrisórias em todo esse mundo subdesenvolvido endividado:

Tabela 1: PIB/Orçamentos destinados à educação, à saúde e ao serviço da dívida

Comparaison de la part du PIB et du budget allouée à l'éducation, à la santé et au service de la dette ${ }^{2}$

\begin{tabular}{|l|c|c|c|c|c|c|}
\hline $\begin{array}{l}\text { Chiffres } \\
2007\end{array}$ & $\begin{array}{c}\text { Service de la } \\
\text { dette } \\
\text { publique }\end{array}$ & $\begin{array}{c}\text { Dépenses } \\
\text { publiques } \\
\text { pour } \\
\text { l'éducation }\end{array}$ & $\begin{array}{c}\text { Dépenses } \\
\text { publiques } \\
\text { pour la } \\
\text { santé }\end{array}$ & $\begin{array}{c}\text { Service de la } \\
\text { dette } \\
\text { publique }\end{array}$ & $\begin{array}{c}\text { Dépenses } \\
\text { publiques } \\
\text { pour } \\
\text { l'éducation }\end{array}$ & $\begin{array}{c}\text { Dépenses } \\
\text { publiques } \\
\text { pour la } \\
\text { santén }\end{array}$ \\
\hline Argentine & 10,94 & 5,10 & 5,30 & 46,91 & 21,88 & 22,74 \\
\hline Brésil & 16,62 & 5,30 & 3,20 & 41,80 & 13,33 & 8,05 \\
\hline Chili & 3,13 & 3,20 & 3,60 & 16,82 & 17,18 & 19,32 \\
\hline Colombie & 10,44 & 4,60 & 2,40 & 33,57 & 14,80 & 7,72 \\
\hline Équateur & 14,20 & 2,62 & 1,26 & 59,90 & 18,40 & 8,87 \\
\hline Mexique & 8,78 & 5,20 & 3,10 & 40,03 & 23,71 & 14,14 \\
\hline Pérou & 7,63 & 3,40 & 1,20 & 43,66 & 19,45 & 6,86 \\
\hline
\end{tabular}

Tabela 2: Número de pessoas (em milhões) vivendo com menos de 1 dólar/dia e padecendo fome

\begin{tabular}{|l|c|c|c|}
\hline $\begin{array}{l}\text { Nombre de personnes vivant avec moins de 1\$ par jour (en } \\
\text { millions) }\end{array}$ & 1981 & 1990 & 2004 \\
\hline en Afrique subsaharienne & 214 & 299 & 391 \\
\hline en Amérique latine et Caraibes & 42 & 43 & 46 \\
\hline En Asie du Sud & 548 & 579 & 596 \\
\hline
\end{tabular}

\begin{tabular}{|l|c|c|c|c|}
\hline En millions & 2005 & 2007 & 2009 & 2010 \\
\hline Nombre de personnes souffrant de la faim & 848 & 923 & 1023 & 925 \\
\hline
\end{tabular}

Fonte (de ambas as tabelas): MILLET, Damien; MUNEVAR, Daniel \& TOUSSAINT, Éric. Les chiffres de la dette 2011 (CADTM).

Para se fazer ainda uma ideia aproximada, em uma referência rápida, do peso que continua a ter o endividamento público no conjunto, por exemplo, de uma economia das dimensões da brasileira, considerem-se as seguintes estimativas recentes: no Orçamento de 2013, projetou-se que "(...) quase a metade do orçamento federal do próximo ano, exatos $42 \%$, está destinada ao pagamento da dívida pública brasileira. Dos 2,14 trilhões de reais, 900 bilhões 
médio e longo prazo os problemas correlatos fundamentais da miséria e desigualdade social, da alienação política e cultural e - não menos importante hoje - da degradação ambiental. ${ }^{19}$ Por isso, os atuais governos progressistas latino-americanos somente podem reivindicar serem expressão política do avanço dos movimentos sociais populares - e não a denegação deles - se uma radicalização crescente ${ }^{20}$, em se realizando, coincidir com a implantação de reformas estruturais de conteúdo efetivamente socializante, tendentes a construir - sem protelações ${ }^{21}$ - um modelo autônomo de economia e de sociedade que reconheça nos lineamentos do socialismo científico e revolucionário a única fórmula autêntica de emancipação e progresso democráticos. ${ }^{22}$ A não ser assim,

serão gastos com o pagamento de juros e amortizações da dívida pública, enquanto estão previstos, por exemplo, 71,7 bilhões para educação, 87,7 bilhões para a saúde, ou 5 bilhões para a reforma agrária". (INSTITUTO HUMANITAS UNISINOS. Entrevista especial com Maria Lucia Fattorelli, 17/09/2012. Disponível em http://www.ihu.unisinos.br/entrevistas/513556-orcamentofederal-de-2013-42-vai-para-a-divida-publica-entrevista-especial-com-maria-lucia-fattorelli.)

${ }^{19} \mathrm{Cf}$., entre os estudos clássicos sobre o capitalismo dependente latino-americano, FERNANDES, Florestan. Capitalismo dependente e classes sociais na América Latina. São Paulo: Global, 2009 (1aㅡ ed. Zahar, 1973); MARINI, Rui Mauro. Dialéctica de la dependencia. 11ª reimpresión. México: Ediciones Era, 1991. (Disponível em: www.marini-escritos.unam.mx/ 004_dialectica_es. htm); MARINI, R. M. "O ciclo do capital na economia dependente", In: FERREIRA, Carla et alii (org.). Padrão de reprodução do capital. São Paulo: Boitempo, 2012, pp. 21-35; CARDOSO, F. H. \& FALETTO, Enzo. Dependência e desenvolvimento na América Latina. Ensaio de interpretação sociológica. 8aㅡ ed. Rio de Janeiro: Civilização Brasileira, 2004. (1ª ed.: Zahar Editores, 1970), FURTADO, Celso. A economia latino-americana. São Paulo: Companhia Editora Nacional, 1978; SANTOS, Theotônio dos. Imperialismo y dependencia. Caracas: Fund. Biblioteca Ayacucho, 2011 (1 ${ }^{\underline{a}}$ ed. México, Editorial Era, 1978); SANTOS, Th. dos. Imperialismo e corporações multinacionais. Rio de Janeiro: Paz e Terra, 1977; SANTOS, Th. dos. Democracia e socialismo no capitalismo dependente. Petrópolis: Vozes, 1991; e BAMBIRRA, Vânia. O capitalismo dependente latino-americano. Florianópolis: Insular, 2012 (1aㅡ ed., em espanhol: México: Siglo XXI, 1974).

${ }^{20}$ Radicalização crescente que parece ocorrer nos casos atuais da Venezuela, Bolívia e Equador. (Cf. BORÓN, Atilio. Socialismo siglo XXI: ¿Hay vida después del neoliberalismo? 1를 ed. Buenos Aires: Luxemburg, 2008.)

${ }^{21} \mathrm{~A}$ Revolução Cubana - cujo êxito, como é sabido, se deve à radicalização decidida e rápida em direção ao socialismo nos dois ou três anos imediatos à tomada do poder - continua a constituir nesta matéria o exemplo histórico par excellence na América Latina. Cf. FERNANDES, F. Da guerrilha ao socialismo: a revolução cubana. São Paulo: Ed. Expressão Popular, 2007, e MÁO Jr., José R. A revolução cubana e a questão nacional (1868-1963). São Paulo: Ed. do Autor, 2007.

${ }^{22}$ Assinala Ernest Mandel: "La force principale du socialisme scientifique réside dans le fait qu'il pose un but émancipateur - la libération du prolétariat, du travail et de l'humanité tout entière de toutes les conditions qui sont indignes de l'humanité - comme découlant du mouvement réel de la société et de l'histoire. Des contradictions internes du mode de production capitaliste, scientifiquement établies et attestées par deux siècles d'histoire, contradictions qu'aucun État, qu'aucune religion, qu'aucune terreur, qu'aucune "société de consommation " ne peuvent supprimer, il résulte, d'une part, une chaîne de crises de système successives dans le domaine économique, social, culturel, politique, militaire, moral, idéologique, ce qui se trouve totalement confirmé par le développement historique réel. Il en résulte, d'autre part, une tendance historique à l'organisation du travail salarié, un des présupposés les plus importants qui dérive de l'analyse marxiste de la société capitaliste en particulier". (MANDEL, Ernest. "Emancipation, science et politique chez Karl Marx" In: WORONOFF, Denis \& BROHM, Jean-Marie. Marx ... ou pas?: Reflexions sur un centenaire. Paris : Etudes et Documentation Internationale, 1986, p. 5.) 
uma nova onda "desenvolvimentista", que não altere em favor das maiorias pobres e exploradas as relações de produção e de propriedade, e que continue a transigir com as exigências de valorização do capital (nacional e internacional) em detrimento das necessidades sociais gerais básicas, apenas acarretará um outro tempo de estagnação e retrocesso das conquistas sociais populares e, além de tudo, não bastará nem mesmo para superar o caráter dependente do capitalismo da região. ${ }^{23}$ Nesse sentido, a obstinação hoje demonstrada pelos governos progressistas em privilegiar um modelo econômico de predominância de exportações de produtos primários (o que não deixou de acontecer mesmo em países "emergentes" como Brasil, Chile, México e Argentina), combinada à desindustrialização e à inércia oficial para impor restrições legais à imensa drenagem especulativa de capitais no setor propriamente financeiro, reforça as desconfianças quanto a se modificar efetivamente o multissecular quadro de atraso e de pobreza, e dá às críticas a esse modelo o mesmo destino desolador das palavras de Cassandra... É o que parece poder-se deduzir das proposições seguintes.

Uma contribuição teórica das mais importantes entre os estudos recentes sobre o capitalismo latino-americano encontra-se no reconhecimento da configuração de um novo padrão de reprodução do capital nas condições de

Semelhantemente, adverte outro estudioso: "[Diante da crise estrutural do capitalismo], o único programa realmente praticável - em agudo contraste com a praticabilidade contraproducente de medidas manipuladoras que apenas agravam a crise - é o programa marxiano de reestruturação radical "de cima para baixo", da totalidade das instituições sociais, das condições industriais, políticas e ideológicas da existência atual, de "toda a maneira de ser" de homens reprimidos pelas condições alienadas e reificadas da sociedade de mercado. Excetuada a realização de tal "impraticabilidade" não há saída para a crise cada vez mais profunda da existência humana". (MÉSZÁROS, István. A crise estrutural do capital. São Paulo: Boitempo, 2009, p. 72).

${ }^{23} \mathrm{Cf}$. as observações muito pertinentes sobre o impasse entre o "novo desenvolvimentismo" e a alternativa socialista em KATZ, Claudio. Socialismo o neodesarrollismo. 2006. Disponível em http://katz.lahaine.org. Diz esse pesquisador: "(...) Las formas retrógradas de acumulación que impuso la inserción dependiente en el mercado mundial han deformado históricamente el desarrollo regional. No hay carencia de ahorro local, sino exceso de transferencias hacia las economías centrales. El retraso agrario, la baja productividad industrial, la estrechez del poder adquisitivo han sido efectos de esta depredación imperialista. El principal drama latinoamericano no es la pobreza, sino la escandalosa desigualdad social, que el capitalismo recrea en todos los países. La hipótesis de la inmadurez económica está desmentida por la coyuntura actual, que ha creado un gran dilema en torno a quién se beneficiará del crecimiento en curso. Los neodesarrollistas buscan canalizar esta mejora a favor de los industriales y los neoliberales tratan de preservar las ventajas de los bancos. En oposición a ambas opciones, los socialistas deberían propugnar una redistribución radical de la riqueza, que mejore inmediatamente el nivel de vida de los oprimidos y erradique la primacía de la rentabilidad. Los recursos están disponibles. Hay un amplio margen para instrumentar programas populares y no solo condiciones para implementar cursos capitalistas." (pp. 4-5. Grifos nossos.) 
dependência estrutural do continente. Condicionado pelos elementos da crise estrutural do capitalismo ${ }^{24}$ (sobrevinda após quase três décadas de expansão da produção industrial mundial, no período pós-guerra ${ }^{25}$ ), um novo padrão exportador de especialização produtiva latino-americano ganhou forma a partir do início dos anos 1980, e tem-se distinguido por assinalar o fim e o fracasso do modelo industrial que se buscou implantar nas principais economias da região durante 0 período de 1940-1970. ${ }^{26}$ Resumidamente, os traços principais desse novo padrão são: $\left.1^{\circ}\right)$ o recuo industrial - a desindustrialização - atestado pelo peso crescente dos produtos agrícolas, mineiros e petrolíferos no total das exportações (embora esses produtos exportados apresentem hoje um grau muito maior de elaboração quando comparados aos do nível da antiga economia agro-petro-mineira exportadora das primeiras décadas do século $X X)$ - o que evidentemente levou à perda acentuada, em cada um desses países, da já diminuta autonomia econômica nacional; $2^{\circ}$ ) a sujeição, nos casos de países que possuem economias mais complexas (como Brasil e México), ao "projeto exportador", em que "(...) os eixos [industriais] exportadores constituem, em geral, segmentos de grandes cadeias produtivas globais sob a direção de empresas transnacionais" ${ }^{27}$; 3) a

${ }^{24}$ Vejam-se, entre outras obras, MANDEL, Ernest. A crise do capital. Os fatos e sua interpretação
marxista. São Paulo: Ensaio; Campinas, SP: Editora da Universidade Estadual de Campinas,
1990; BEINSTEIN, Jorge. Capitalismo senil. A grande crise da economia global. RJ-SP: Editora
Record, 2001; MÉSZÁROS, István. A crise estrutural do capital. São Paulo: Boitempo, 2009;
COGGIOLA, Osvaldo. A crise (2007-2012). Lineamentos para uma abordagem global. 2012 (texto
digital, disponível em www.apufpr.org.br/greve2012/images/stories/oc a crise 2007-2012.pdf); e,
em outra perspectiva teórica: STIGLITZ, Joseph E. O mundo em queda livre. Os Estados Unidos,
o mercado livre e o naufrágio da economia mundial. São Paulo: Companhia das Letras, 2010.
${ }^{25}$ Entre 1950 e 1973 - os "anos dourados" do capitalismo - o crescimento da produção mundial
atingiu uma média anual próxima de 5\%, algo até então sem precedentes.
${ }^{26}$ Cf. OSORIO, Jaime. "América Latina: o novo padrão exportador de especialização produtiva -
estudo de cinco economias da região", In: FERREIRA, Carla et alii (org.). Padrão de reprodução
do capital. São Paulo: Boitempo, 2012, pp. 103-133. (Os cinco países estudados são Argentina,
Brasil, Chile, Colômbia e México.)
${ }_{27}$ OSORIO, Jaime. Op. cit., p. 106. Nota esse pesquisador: "(...) Em 1999, as empresas
estrangeiras constituíam 41\% das duzentas maiores empresas exportadoras da região, com um
peso percentual similar no total das exportações e superior à participação das empresas privadas
nacionais e também das estatais". (p. 110) A tabela a seguir traz alguns dados percentuais para o ano de 2006, especialmente escolhido por ser um ano de expansão econômica na região:

Tabela 3: América Latina: as $\mathbf{5 0 0}$ maiores empresas locais e transnacionais por vendas e setores de atividade econômica (\%)

\begin{tabular}{|c|c|c|c|}
\hline & Privadas locais & Estatais & Transnacionais \\
\hline Primário & & & 30 \\
\hline Mineração & 19 & 51 & 10 \\
\hline Petróleo / gás & 10 & 80 & 0 \\
\hline
\end{tabular}


preponderância dos investimentos estrangeiros nos setores industriais, reforçando a tendência à segmentação em cadeias produtivas internacionais; e $4^{\circ}$ ) 0 agravamento da dependência dos setores mais dinâmicos nacionais em relação aos mercados exteriores - o que, contrastantemente, coexiste com um considerável mercado interno em expansão, no qual, porém, de fato "(...) participam os setores que vivem de mais-valia, renda ou salários elevados, seja no setor público, seja no privado. [Correspondem eles a] 10\% da população, que se apropriam, em quase todos os casos considerados, de mais de $40 \%$ dos rendimentos totais. [Este mercado local] demanda alguns dos bens-eixo do novo padrão e importações suntuárias que acompanham o processo". ${ }^{28}$ É, aliás, este último aspecto - o incremento da demanda interna de bens de consumo (em grande medida, suntuários) - o elemento superficial que confere ao conjunto da mudança econômica a falsa aura de modernização que reveste todo o processo. A realidade menos brilhante dessa "modernização", contudo, é a de que, em vez do dinamismo próprio de economias capazes de absorver positivamente os progressos tecnológicos e dirigi-los a uma expansão produtiva sustentada sobre os mercados interno e externo (expansão que, além disso, se fizesse acompanhar de uma distribuição mais equitativa da riqueza social), o que efetivamente se vê é, por exemplo, serem submetidos os avanços de produtividade do trabalho à sanha e ao empenho das classes proprietárias em ampliar, tanto quanto possível, o grau de exploração da força de trabalho - o mecanismo fundamental, como se sabe, da acumulação de capital - empurrando, por conseguinte, as massas trabalhadoras a condições de vida e de trabalho em que, amiúde, não podem ser satisfeitas nem mesmo as exigências ordinárias de manutenção e reprodução do

\begin{tabular}{|c|c|c|c|}
\hline & & & \\
\hline \multicolumn{4}{|l|}{ Manufatureiras } \\
\hline Automobilística/ peças & 7 & - & 93 \\
\hline Eletrônica & 23 & - & 77 \\
\hline Agroindústria/alimentos & 63 & - & 37 \\
\hline \multicolumn{4}{|l|}{ Serviços* ${ }^{*}$} \\
\hline Telecomunicações & 53 & 1 & 46 \\
\hline Energia elétrica & 21 & 53 & 26 \\
\hline Comércio & 70 & - & 30 \\
\hline
\end{tabular}

Fonte: Cepal, La inversión extranjera en América Latina y el Caribe 2007. Apud OSORIO, Jaime. Op. cit., p. 110. *Não estão incluídos os serviços financeiros, atividade em que o capital estrangeiro tem peso predominante.

${ }^{28}$ OSORIO, Jaime. Op. cit., p. 132. 
contingente de trabalhadores. ${ }^{29}$ Não surpreende, por isso, que o resultado final, para essas sociedades de capitalismo dependente, adquira a forma de um paradoxal e multifacetado quadro de agudização da miséria social ${ }^{30}$, da

\footnotetext{
${ }^{29}$ Neste ponto, em que se confrontam riqueza, tecnologia e miséria extrema, reside a expressão mais cabal da irracionalidade que impera nas relações sociais de produção sob as formas capitalistas. Não será ocioso lembrar que, por exemplo, a fome no mundo - que atualmente atinge cerca de um terço da humanidade, sendo 1 bilhão de pessoas vivendo sob condição de fome permanente - sempre teve, no passado, como causa principal as limitações naturais e técnicas dos grupos humanos na exploração da natureza para a produção de alimentos. Hoje, porém, é consensual que os recursos tecnológicos (de engenharia genética, de controle biológico de pragas, de fertilização de solos e dessalinização da água do mar, de acondicionamento e transporte de alimentos etc.), se racionalmente empregados, criariam as condições necessárias à alimentação adequada da população mundial. (Cf., por exemplo, o artigo de REVKIN, Andrew. Poverty and Lack of Research Block Path to a Well-Fed World. The New York Times. August 5, 2010.) Segundo Jean Ziegler, antigo relator da ONU sobre questão alimentar: "(...) No seu estado atual, a agricultura mundial poderia alimentar sem problemas doze bilhões de seres humanos, vale dizer, quase duas vezes a população atual." Compreende-se então o significado da sentença: "Uma criança que morre de fome é uma criança assassinada". Quanto a um problema correlato, o da disponibilidade mundial de água potável, esse mesmo estudo indica: "(...) Um em cada três homens já está condenado a beber água poluída. A cada dia, 9.000 crianças menores de dez anos morrem por causa da ingestão de água imprópria para consumo. Dos dois bilhões de casos de diarreia registrados anualmente no mundo, 2,2 milhões são mortais. As principais vítimas são crianças e bebês. A diarreia, porém, é tão somente uma dentre as inúmeras doenças transmitidas através da água de má qualidade; outras são o tracoma, a bilharzíase, o cólera, a febre tifoide, a disenteria, a hepatite, o paludismo etc. Grande número dessas doenças deve-se à presença de organismos patogênicos na água (bactérias, vírus e vermes). De acordo com a OMS, nos países em desenvolvimento, quase $80 \%$ das doenças e mais de um terço dos óbitos são devidos, ao menos parcialmente, ao consumo de água contaminada". (ZIEGLER, Jean. Destruição massiva. Geopolítica da fome. São Paulo: Cortez, 2012, pp. 11 e 187)

${ }^{30}$ Partindo-se dos dados do gráfico abaixo, sobre a evolução da pobreza e da indigência na América Latina, um prognóstico estatístico demonstraria, por exemplo: $\left.1^{\circ}\right)$ que seria necessário algo em torno de um século - 96 anos (!) - para que o ritmo médio de redução da pobreza no continente ao longo das últimas três décadas levasse, coeteris paribus, a um nível próximo ao dos países desenvolvidos da Tríade (aproximadamente 7 a $8 \%$, tendo por referência os dados de antes da crise econômica detonada em 2008); $2^{\circ}$ ) que, ao nos aproximarmos da metade do século XXI (por volta de 2044), e mantido o mesmo ritmo de redução - o qual permitisse esperar um percentual hipotético bastante otimista de aproximadamente $17 \%$ de pobres no total da população do continente - ainda haveria cerca de 135,3 milhões de pessoas pobres (e indigentes) na América Latina e Caribe, ou seja, em termos absolutos, quase o mesmo contingente de 1980. (Empregamos aqui as projeções para a população total da região apresentadas no Boletín demográfico América Latina e Caribe. Estimaciones y proyecciones de población. 1950-2050. CELADE, Cepal, 2004.) Embora esses números constituam apenas projeções, eles dizem muito acerca da natureza irrevogável do subdesenvolvimento sob as condições concretas do capitalismo dependente, e relativiza as crenças recentes na combinação neoliberal de capitalismo, progresso social e integração comercial. Quanto a essas crenças, cf., por exemplo, a coletânea SOLANA, F. (coord.) América Latina XXI: ¿Avanzará o retrocederá la pobreza? Parlamento Latinoamericano, Fondo de Cultura Económica, 2002, onde, entre outras coisas anódinas, lê-se: "(...) El capitalismo, el libre mercado, es el resultado de un proceso histórico y hasta hoy no existe otra institución o modelo económico que genere mayor riqueza ni que tenga mayor potencial para reducir la pobreza e incrementar de manera generalizada el estado del bienestar. (...) Que lograr la masa crítica de mercado y economías de escala en la producción de las empresas pequeñas, medianas y grandes a todo lo ancho y largo de los 34 países, generará una actividad económica muy dinámica que se traducirá en mejor y mayor producto interno bruto para cada uno de los países miembros, en mejor ingreso para sus habitantes y con ello podrá generarse un círculo virtuoso de mayor comercio, mayor riqueza, menor desempleo, menor pobreza." (p. 199) (!)
} 
concentração de riquezas $^{31}$, do desemprego e do subemprego ${ }^{32}$, da alienação cultural $^{\beta 3}$, da polarização socia/ ${ }^{34}$ e da destruição ecológica ${ }^{35}$ - quadro todavia

\section{Gráfico 1: América Latina: evolução da pobreza e da indigência - 1980-2012 (em \% e em milhões de pessoas)}

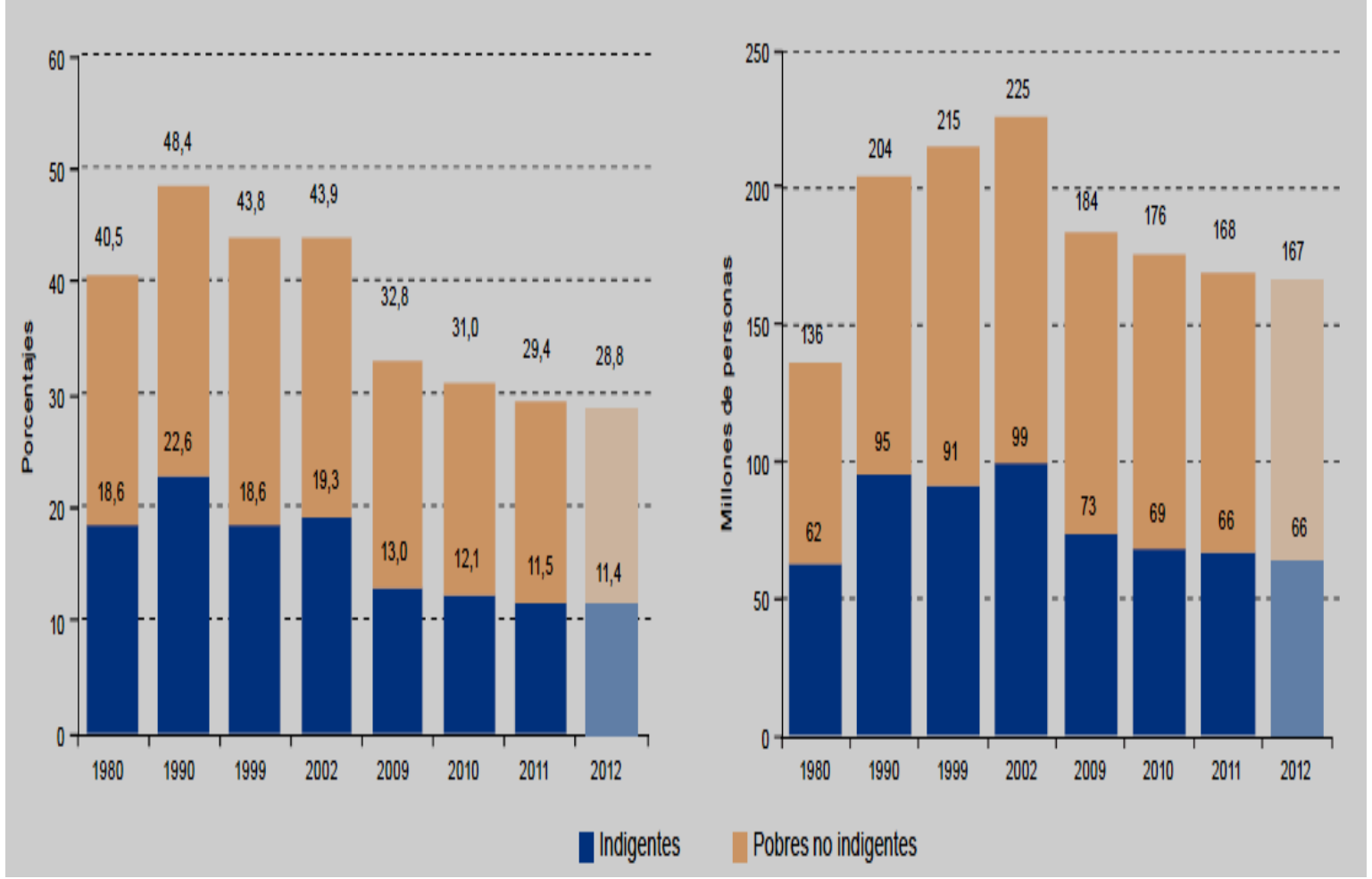

Fonte: Comisión Económica para América Latina y el Caribe (CEPAL), sobre la base de tabulaciones especiales de las encuestas de hogares de los respectivos países. Estimación correspondiente a 18 países de la región más Haití. Las cifras que figuran sobre las secciones superiores de las barras representan el porcentaje y el número total de personas pobres (indigentes más pobres no indigentes). Las cifras relativas a 2012 corresponden a una proyección. Apud: CEPAL, Panorama social de América Latina 2012, p. 19.

${ }^{31} \mathrm{~A}$ face mais execranda do subdesenvolvimento é, sem dúvida, o desequilíbrio na distribuição social da riqueza nacional. O gráfico abaixo mostra que, atualmente, na média latino-americana, os $10 \%$ mais ricos da população detêm $32 \%$ da renda total, enquanto os $40 \%$ mais pobres recebem apenas $15 \%$ dela. As maiores desigualdades se verificam no Brasil, Chile, Guatemala e Rep. Dominicana: 
Gráfico 2: América Latina (18 países): Participação na renda por grupos de decis (ano mais recente)

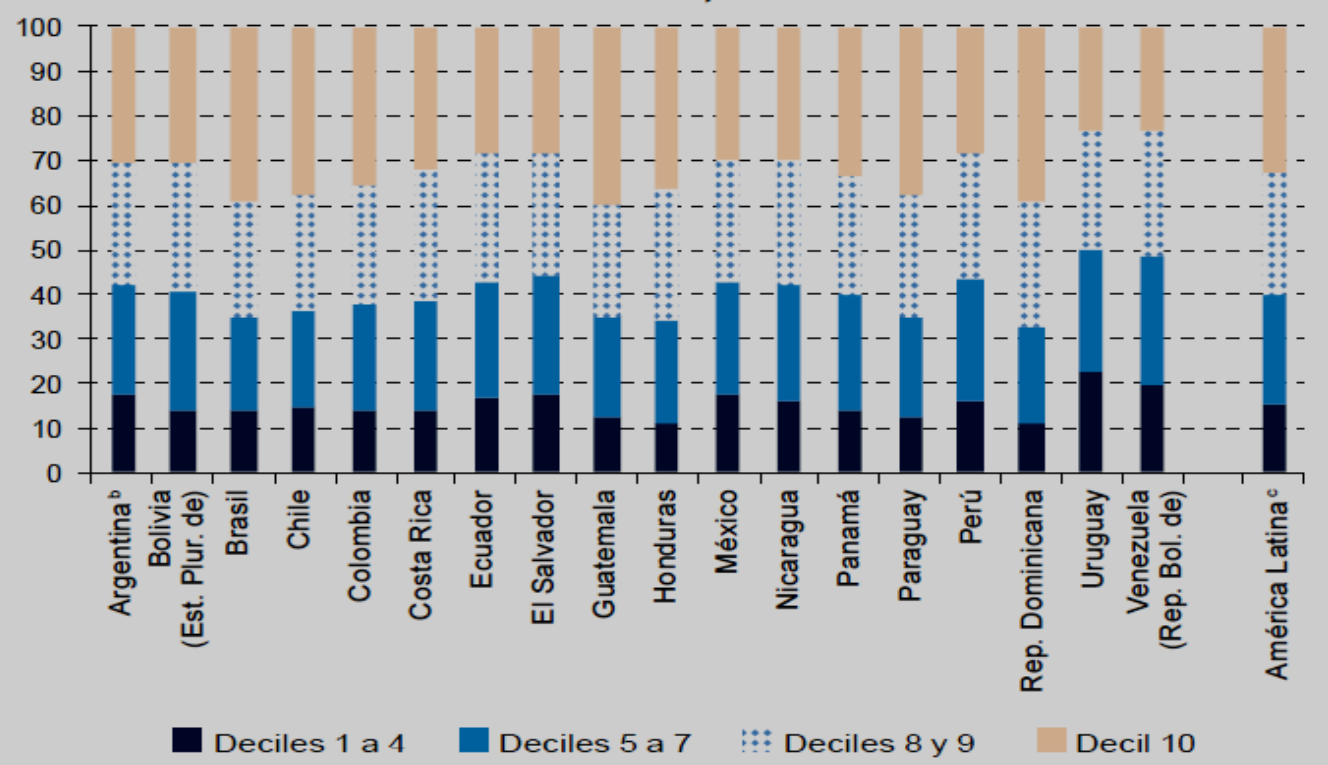

Fonte: CEPAL. Panorama social de América Latina 2012, p. 89.

Além disso, a América Latina detém ainda a deplorável condição de a região com a maior desigualdade social do mundo. Veja-se o coeficiente de Gini latino-americano - o pior quando comparado ao das outras regiões do mundo:

\section{Gráfico 3: Coeficiente de GINI (por grupo de países) Coeficiente de Gini}

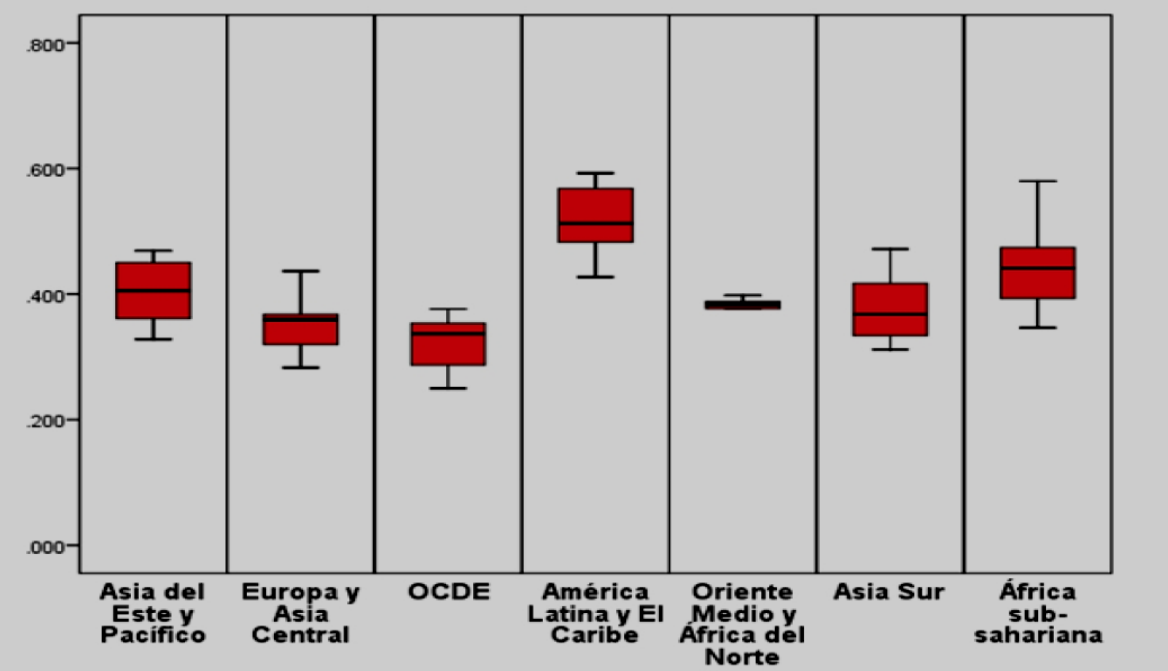

Fonte: CEPAL. La hora de la igualdad. Nações Unidas, 2010, p.13. 
${ }^{32}$ Segundo o relatório da OIT (Global Employment Trends 2013), o desemprego na América Latina atingiu, em 2011 e 2012, seus níveis mais baixos nos últimos 20 anos, o que é consequência da relativa recuperação econômica da região desde o início da crise, em setembro de 2008. Os números representam um percentual menos severo se comparado com os níveis de desemprego na Europa e nos EUA. O relatório também aponta uma tendência de declínio, a partir de 2003, do número de trabalhadores pobres, com a consequente ampliação da camada média. É preciso advertir, porém, que esta última tendência se deve, em boa medida, à facilitação de crédito para as famílias, com o qual se tem conseguido conter a queda da demanda interna, mas que não constitui um aumento real e duradouro dos salários. Ademais, o relatório aponta que, em termos mundiais, os mercados de trabalho voltaram a se deteriorar em 2012, atingindo mais duramente a parcela dos jovens (entre 15 e 24 anos), deixando então 73,8 milhões deles sem emprego. $\mathrm{Na}$ América Latina, eles representam a parte majoritária dos desempregados (em 2011, eram 13,4\% do total), com a tendência a ampliar-se a percentagem nos próximos anos - como efetivamente veio a se verificar em 2014 e 2015. A par disso, o aspecto mais contundente da precariedade do trabalho no continente está registrado pelos altos níveis de informalidade do emprego, que, na maioria dos países latino-americanos, se aproximam ou superam a metade (!) da força de trabalho nacional. Isso é um indicador importante da contradição, de projeção mundial, entre o movimento de busca de novos mercados consumidores em países periféricos empreendida pelas grandes empresas transnacionais e o movimento simultâneo de consolidação de uma economia de mão de obra barata global. (cf. CHOSSUDOVSKY, Michel. A globalização da pobreza. São Paulo: Moderna, 1999, em especial a Parte IV). Vejam-se a tabela e o gráfico seguintes:

Tabela 4: América Latina e Caribe: tendências e projeções do mercado de trabalho

\begin{tabular}{|c|c|c|c|c|c|c|c|c|c|c|}
\hline & & 2009 & 2010 & 2011 & 2012p & 2013p & $2014 p$ & $2015 p$ & $2016 p$ & 2017p \\
\hline \multicolumn{2}{|c|}{ Labour force participation rate (\%) } & 65.8 & 66.1 & 66.1 & 66.3 & 66.4 & 66.5 & 66.6 & 66.7 & 66.7 \\
\hline \multirow[t]{5}{*}{ Unemployment rate (\%) } & Total & 7.8 & 6.8 & 6.5 & 6.6 & 6.7 & 6.8 & 6.8 & 6.8 & 6.8 \\
\hline & Male & 6.5 & 5.8 & 5.6 & 5.6 & 5.7 & 5.7 & 5.7 & 5.7 & 5.7 \\
\hline & Female & 9.6 & 8.3 & 7.9 & 7.9 & 8.1 & 8.2 & 8.3 & 8.3 & 8.3 \\
\hline & Youth & 15.7 & 14.1 & 13.4 & 13.5 & 13.6 & 13.7 & 13.7 & 13.8 & 13.8 \\
\hline & Adult & 5.7 & 5.0 & 4.9 & 4.9 & 5.1 & 5.2 & 5.2 & 5.3 & 5.3 \\
\hline Employment growth (\% p.a.) & Total & 0.6 & 3.2 & 2.0 & 1.8 & 1.6 & 1.7 & 1.7 & 1.6 & 1.6 \\
\hline \multirow[t]{3}{*}{ Sectoral employment } & Agriculture & 16.4 & 16.2 & 15.8 & 15.7 & 15.3 & 15.0 & 14.6 & 14.3 & 13.9 \\
\hline & Industry & 22.0 & 21.8 & 21.7 & 21.7 & 21.9 & 22.0 & 22.1 & 22.3 & 22.4 \\
\hline & Services & 61.6 & 62.0 & 62.4 & 62.6 & 62.8 & 63.0 & 63.3 & 63.5 & 63.7 \\
\hline \multirow[t]{4}{*}{ Status and income } & $\begin{array}{l}\text { Wage and salary } \\
\text { earners }\end{array}$ & 63.5 & 63.5 & 63.8 & 63.8 & 63.9 & 63.9 & 63.9 & 64.0 & 64.0 \\
\hline & Self-employed & 25.9 & 26.2 & 26.1 & 26.1 & 26.2 & 26.3 & 26.3 & 26.4 & 26.4 \\
\hline & $\begin{array}{l}\text { Vulnerable } \\
\text { empoyment share }\end{array}$ & 31.9 & 31.9 & 31.5 & 31.5 & 31.4 & 31.3 & 31.2 & 31.1 & 31.0 \\
\hline & $\begin{array}{l}\text { Working poverty, } \\
\text { US } \$ 2 \text { a day (\%) }\end{array}$ & 8.7 & 7.9 & 7.6 & 7.4 & 7.1 & 6.7 & 6.4 & 6.1 & 5.8 \\
\hline
\end{tabular}

Fonte: ILO (International Labour Organization). Global Employment Trends 2013, p. 64. 


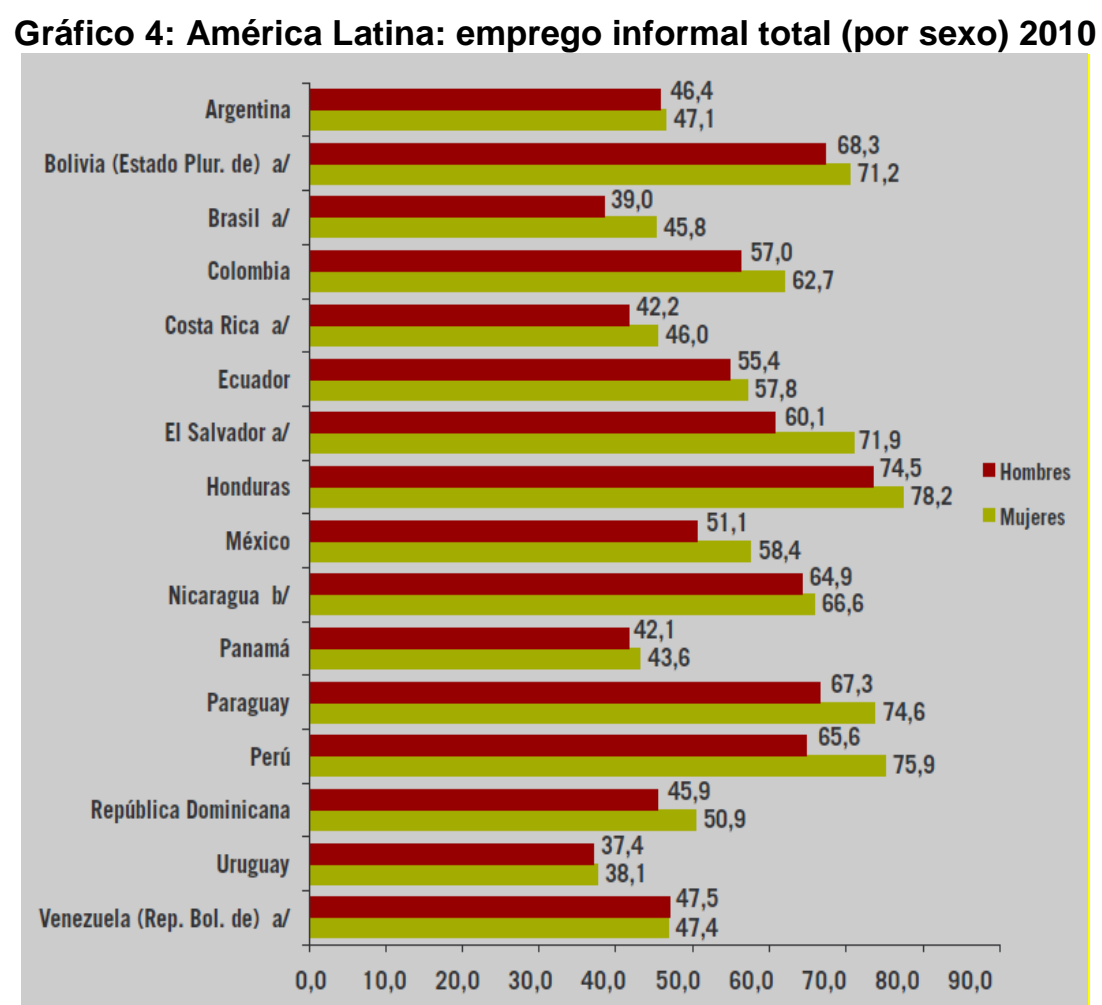

Fonte: OIT. Panorama Laboral 2011. América Latina y el Caribe, p. 70.

${ }^{33}$ Por seu "potencial mercadológico crescente" e seu papel ideológico estratégico, a Educação foi um alvo-chave das políticas privatizantes a partir dos anos de 1980, quando, sob força e orientação neoliberais, ganharam impulso e se aprofundaram os processos de mercantilização do ensino e de tecnicização do conhecimento. O primeiro processo representou o assedio vitorioso do capital privado sobre essa área fundamental das necessidades públicas básicas, e se singularizou por transformar os estudantes em autênticos consumidores, segundo uma visão empresarial definida por uma suposta qualidade total da mercadoria ensino. O segundo processo determinou a supressão quase completa do ideal da escola e da universidade como instituições responsáveis também por formação ético-filosófica e política, convertendo-as em meros centros de produção e/ou reprodução de conhecimento técnico ("centros de excelência"), de acordo com a lógica das necessidades de desenvolvimento da produção industrial e de especialização da força de trabalho. Tais processos ocorrem em escala mundial e têm sido tanto mais violentos quanto menor é o peso da tradição da educação institucional na vida social dos países atingidos. Em sociedades subdesenvolvidas, por sua parte, essa "sofisticada" educação promovida pelos "homens de negócio" convive indiferente com os alarmantes índices de analfabetismo e de alfabetismo funcional que vicejam nos segmentos mais pobres da população. Não sem razão, esse cenário continua a denunciar, no caso da América Latina, a persistente condição da educação formal como causa de fratura social. (Cf. GENTILI, Pablo A. A. \& SILVA, Tomaz T. da. Neoliberalismo, qualidade total e educação. Visões críticas. Petrópolis: Editora Vozes, 2002; e GENTILI, Pablo. (org.) Universidades na penumbra. Neoliberalismo e reestruturação universitária. São Paulo: Cortez, 2001.) Veja-se o gráfico abaixo, sobre as taxas de analfabetismo em países da América Latina. 


\section{Gráfico 5: Taxa de Analfabetismo da população com mais de 15 anos, por país. 2000-2008}

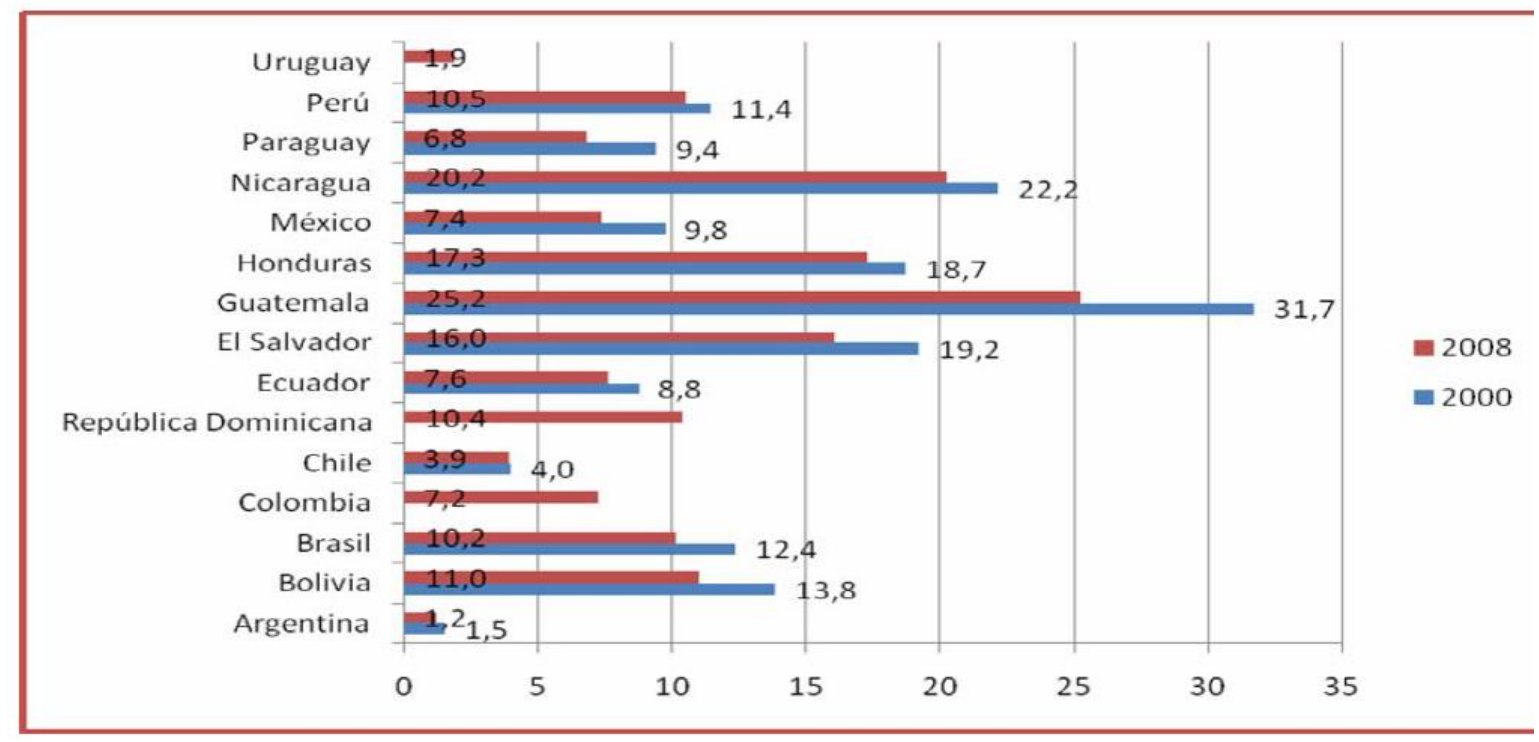

Fonte: SITEAL. El analfabetismo en América Latina, una deuda social. Dato destacado 18, $11 / 2010$, p. 2.

${ }^{34}$ A questão agrária representa hoje uma das principais manifestações da crescente polarização social nos países latino-americanos. Em praticamente todos esses países, os conflitos no campo tenderam recentemente ao agravamento como resultado imediato da adoção de políticas neoliberais, cujo escopo tem sido o de ampliar a propriedade e o controle da atividade agrícola pelas grandes corporações multinacionais e pelas oligarquias agrárias associadas. No centro da problemática agrária atual estão questões históricas antigas, que, contudo, se confrontam hoje com as novas formas de exploração e expropriação do campesinato ditadas pelo assim chamado agronegócio. Dentre essas questões se destacam: a persistência de formas de trabalho escravo, a expulsão dos pequenos agricultores de suas terras como resultado da expansão dos latifúndios de monoculturas de exportação (p. ex., a soja), a eliminação progressiva da agricultura familiar (e, por conseguinte, do tipo de produção voltada para os gêneros alimentícios básicos), as dificuldades de crédito bancário ao pequeno produtor, o controle oligopolista do comércio de sementes transgênicas, a apropriação dos recursos hídricos para prover as grandes plantações, e a concentração da propriedade fundiária (a despeito dos inúmeros programas de reforma agrária adotados oficialmente). No que tange aos governos progressistas da atualidade, a questão acima de todas crucial - da soberania alimentar define os limites de seu próprio progressismo diante do quadro mundial de aumento de preços dos alimentos e, por consequência, de crise alimentar. (Cf. FERNANDES, Bernardo Mançano (org.). Campesinato e agronegócio na América Latina: a questão agrária atual. São Paulo: Expressão Popular, 2008. Veja-se também o estudo clássico, notavelmente atual, de CASTRO, Josué de. Geografia da fome. 10ª ed. RJ: Antares, 1984. (A 1aㅡ edição é de 1956.))

${ }^{35}$ Aponta um informe do Banco Mundial, de 2010, sobre o impacto das mudanças climáticas sobre as perspectivas de desenvolvimento econômico de países pobres: "(...) El cambio climático amenaza al mundo entero, pero los países en desarrollo son los más vulnerables. Según las estimaciones, [os países em desenvolvimento] soportarán aproximadamente entre el $75 \%$ y el $80 \%$ del costo de los daños provocados por la variación del clima. Incluso un calentamiento de $2^{\circ} \mathrm{C}$ por encima de las temperaturas preindustriales - probablemente lo mínimo que padecerá el planeta- podría generar en África y Asia meridional una reducción permanente del producto interno bruto (PIB) de entre el $4 \%$ y el 5\%. La mayor parte de los países en desarrollo carecen de la capacidad financiera y técnica suficiente para manejar el creciente riesgo climático. Asimismo, dependen en forma más directa de recursos naturales sensibles al clima para generar sus ingresos y su bienestar. Además, la mayoría se ubica en regiones tropicales y subtropicales ya sujetas a un clima sumamente variable. Es improbable que el crecimiento económico por sí solo sea lo suficientemente rápido o equitativo para contrarrestar las amenazas derivadas del cambio climático, en particular si continúa el elevado nivel de intensidad del carbono y se acelera el 
emoldurado pelas linhas de uma pretensa "modernidade". Daí, portanto, a justeza da seguinte conclusão:

\begin{abstract}
Já não estamos diante de situações de pré-modernidade ou de insuficiência de capitalismo, como alguns tentaram alegar para explicar as barbaridades do século XIX ou do início do século XX. Essas mesmas barbaridades voltam a se repetir no fim do século $X X$ e início do XXI, após longas e profundas transformações e modernizações que estremeceram de cima para baixo as estruturas políticas e econômicas da região e que acabaram conformando o atual padrão exportador e as formas de governo que nos acompanham. ${ }^{36}$
\end{abstract}

A incongruência aparente entre progresso e pobreza ratifica, na verdade, a antinomia (esta sim, real) - intrínseca ao sistema de produção capitalista (tanto de economias avançadas como, e especialmente, de economias periféricas) - entre os aumentos da acumulação de capital e os aumentos da acumulação de miséria. Essa antinomia exprime, afinal, a própria lei absoluta geral da acumulação capitalista $^{37}$, que, nas condições do capitalismo dependente, isto é, nas condições

calentamiento mundial." (BANCO MUNDIAL. Desarrollo y cambio climático. Informe sobre desarrollo mundial 2010, pág. viii. Grifo nosso). Em outro estudo, Gerardo Honty enumera ao menos oito efeitos das alterações climáticas para os países subdesenvolvidos, nos quais as consequências ecologicamente danosas carregam em si um aspecto social inevitavelmente mais grave: 1) aumento dos fenômenos meteorológicos extremos: "(...) En los últimos 40 años se han registrado episodios inéditos como el fenómeno de "El Niño" en los años 1982-83 y 1997-98 o el huracán Catarina de 2004". Inundaciones y sequías se han incrementado 2,4 veces si se compara el período 1970-1999 con el período 2000-2005"; 2) aumento da temperatura média; 3) redução do volume de precipitações em algumas regiões (como no sul do Chile, sudeste da Argentina e sul do Peru) e aumento em outras (como no sul do Brasil, Paraguai, Uruguai, nordeste da Argentina, nordeste do Peru e Equador); 4) aumento de doenças como a dengue e a malária, e aumento dos índices de morbidade e mortalidade; 5) elevação do nível do mar (na área sul oriental da América do Sul, o nível médio do mar elevou-se entre 1 e $3 \mathrm{~mm}$ por ano nos últimos 20 anos); 6) redução média da massa glaciar; 7) avanço do processo de degradação do solo, da desertificação e redução da camada de floresta; 8 ) aumento do número de espécies em perigo de extinção. (HONTY, G. Cambio Climático: negociaciones y consecuencias para América Latina. Montevideo: CLAES, 2011, pp. 24-25.)

${ }^{36}$ OSORIO, Jaime. Op. cit., p.133.

${ }^{37}$ Diz K. Marx sobre a expansão da acumulação capitalista e seus efeitos sobre as condições de existência do exército industrial de trabalhadores: "Quanto maiores a riqueza social, o capital em funcionamento, o volume e a energia de seu crescimento, portanto também a grandeza absoluta do proletariado e a força produtiva de seu trabalho, tanto maior o exército industrial de reserva. $A$ força de trabalho disponível é desenvolvida pelas mesmas causas que a força expansiva do capital. A grandeza proporcional do exército industrial de reserva cresce, portanto, com as potências da riqueza. Mas quanto maior esse exército de reserva, em relação ao exército ativo de trabalhadores, tanto mais maciça a superpopulação consolidada, cuja miséria está em razão inversa do suplício de seu trabalho. Quanto maior, finalmente, a camada lazarenta da classe trabalhadora e o exército industrial de reserva, tanto maior o pauperismo oficial. Essa é a lei absoluta geral da acumulação capitalista. (...) Compreende-se a insanidade da sabedoria econômica, que prega aos trabalhadores que ajustem o seu número às necessidades de valorização do capital. O mecanismo da produção e acumulação capitalista ajusta constantemente 
de desenvolvimento histórico determinadas pelo padrão atual de dominação externa - o imperialismo tota ${ }^{\beta 8}$ - tem transformado em uma tosca "modernidade de segunda grandeza" todos os frágeis esforços de autonomização empreendidos pelos governos nacionalistas latino-americanos (de diversos matizes), quer hoje quer outrora (como foi também o caso do modelo chamado de substituição de importações, no período que se seguiu à II Guerra Mundial). Surge, pois, como uma lei de ferro do capitalismo, sobretudo em sua etapa monopolista ${ }^{39}$, o fato de que as épocas de progressos econômicos e tecnológicos na periferia - os quais somente in potentia constituem fatores de desenvolvimento sociopolítico-cultural representem tão-só reflexos de alterações na configuração do mercado mundial tendentes a reorganizar os mecanismos de transferência, para o centro, dos excedentes gerados nas economias dependentes. Tais alterações (provocadas, por vezes, pelas constantes disputas interimperialistas), embora apareçam para essas nações subdesenvolvidas como oportunidades de autonomização econômica, ocorrem concretamente apenas como novas adequações da produção e do consumo da periferia às necessidades de realização da acumulação ampliada capitalista mundial, segundo um movimento do capital que, ao mesmo tempo, inclui e exclui os países periféricos. Inclui porque os utiliza (ou os cria) como espaços econômicos desejáveis a empresas e capitais

esse número a essas necessidades de valorização. A primeira palavra desse ajustamento é a criação de uma superpopulação relativa, ou exército industrial de reserva; a última palavra, a miséria de camadas sempre crescente do exército ativo de trabalhadores e o peso morto do pauperismo. (...) A acumulação de riqueza num polo é, portanto, ao mesmo tempo, acumulação de miséria, tormento de trabalho, escravidão, ignorância, brutalização e degradação moral no polo oposto, isto é, do lado da classe que produz seu próprio produto como capital." (MARX, Karl. O capital: Crítica da economia política. $2^{\mathrm{a}}$ ed. São Paulo: Nova Cultural, 1985, v. I, t. 2, pp. 209-210).

${ }^{38}$ Vale lembrar: "(...) O traço específico do imperialismo total consiste no fato de que ele organiza a dominação externa a partir de dentro e em todos os níveis da ordem social, desde o controle da natalidade, a comunicação de massa e o consumo de massa, até a educação, a transplantação maciça de tecnologia ou de instituições sociais, a modernização da infra e da superestrutura, os expedientes financeiros ou do capital, o eixo vital da política nacional etc." (FERNANDES, Florestan. Capitalismo dependente e classes sociais na América Latina, p. 27).

${ }^{39} \mathrm{Cf}$. LENIN, V. I. Imperialismo, etapa superior do capitalismo. Lisboa/Moscovo: Editorial Avante Edições Progresso, 1984; HILFERDING, Rudolf. O capital financeiro. São Paulo: Nova Cultural, 1985; BROWN, Michael B. A economia política do imperialismo. Rio de Janeiro: Zahar Editores, 1978; MAGDOFF, Harry. A era do imperialismo. A economia da política externa dos Estados Unidos. São Paulo: HUCITEC, 1978; e HARVEY, David. O novo imperialismo. São Paulo; Edições Loyola, 2004. Para um estudo sintético das principais mudanças que o imperialismo pós-II Guerra sofreu (notadamente, a ausência de novos conflitos militares entre as potências imperialistas e a maior associação entre os grandes capitais de origens nacionais diversas - mudanças que a "globalização" neoliberal consolidou), e que sugerem uma atualização da teoria marxista clássica do imperialismo, veja-se o artigo de KATZ, Claudio. El imperialismo contemporáneo, 2011. Disponível em www.lahaine.org/katz. 
transnacionais - espaços que favorecem (sob guarida, em geral, dos Estados nacionais e em associação subordinante com o empresariado local) a produção e a transferência de excedentes econômicos, e que, ao mesmo tempo, absorvem agravadas - as contradições do polo hegemônico geradoras de pobreza social e de crises periódicas de produção. ${ }^{40}$ Exclui porque a dinâmica da concentração e centralização do capital financeiro, ao fazer refluir para as economias centrais a maior parte dos recursos gerados pela periferia, acaba por marginalizar dos fluxos mundiais de tecnologia e de investimentos amplas áreas periféricas ${ }^{41}$, delatando

${ }^{40}$ Cf. SAWAYA, Rubens R. Subordinação consentida. Capital multinacional no processo de acumulação da América Latina e Brasil. São Paulo: Annablume: Fapesp, 2006.

${ }_{41}$ "(...) Hoje em dia, muitos países, certas regiões dentro de países, e até áreas continentais inteiras (na África, na Ásia e mesmo na América Latina) não são mais alcançados pelo movimento de mundialização do capital, a não ser sob a forma contraditória de sua própria marginalização. Esta deve ser estritamente compreendida como mecanismo complementar e análogo ao da 'exclusão' da esfera de atividade produtiva, que atinge, dentro de cada país, uma parte da populacão, tanto nos países industrializados como nos países em desenvolvimento. (...) Esses processos, no entanto, acentuam os fatores de hierarquização entre os países, ao mesmo tempo em que redesenham sua configuração. $O$ abismo que separa os países participantes, mesmo que marginalmente, da dominação econômica e política do capital monetário rentista, daqueles que sofrem essa dominação, alargou-se ainda mais." (CHESNAIS, F. A mundialização do capital, p. 18. Grifo nosso). O autor apresenta o ritmo, nas últimas décadas, dos movimentos de concentração do capital e de polarização econômica, visível também na concentração dos fluxos tecnológicos e dos IED no interior da Tríade (EUA, Europa e Japão). Vejam-se os gráficos abaixo:

Gráfico 6: Concentração dos fluxos tecnológicos por grupos de países

Concentração dos fluxos tecnológicos (em porcentagem do total no perído 1980-1990)

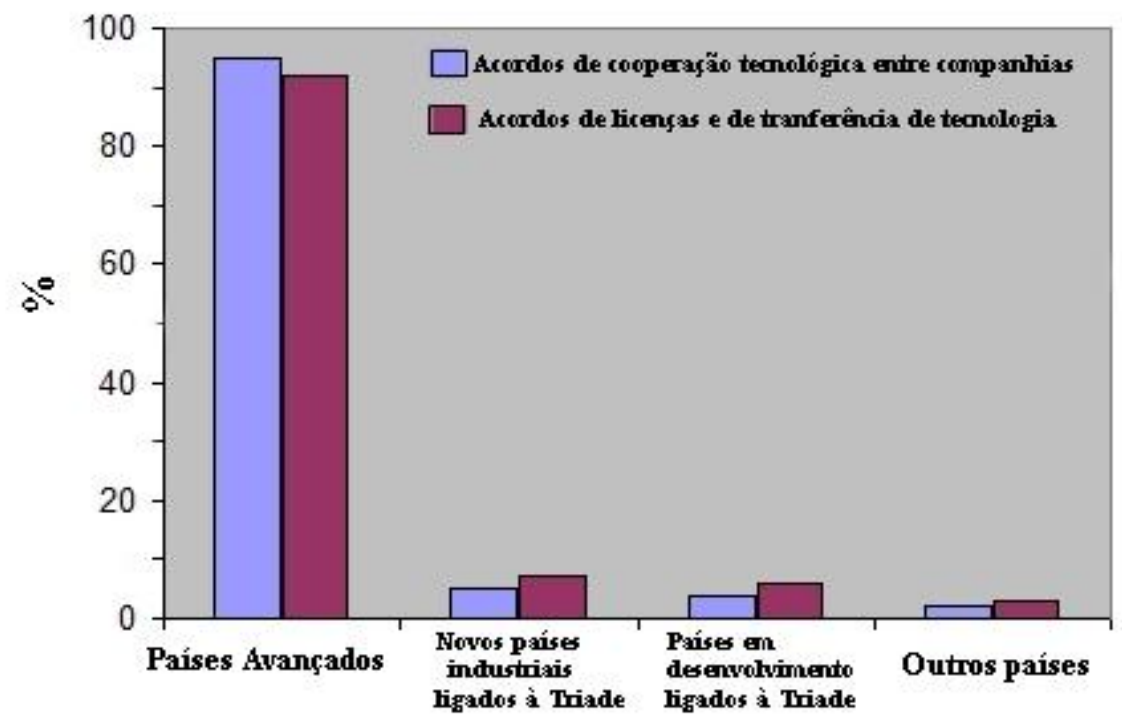

Fonte: C. Freeman e J. Hagedoom, in Woild development, vol. $22, n^{25}, 1994$, p. 576 
Gráfico 7: IED por grupos de países (1967-1989)

Países receptores dos investimentos diretos mundiais

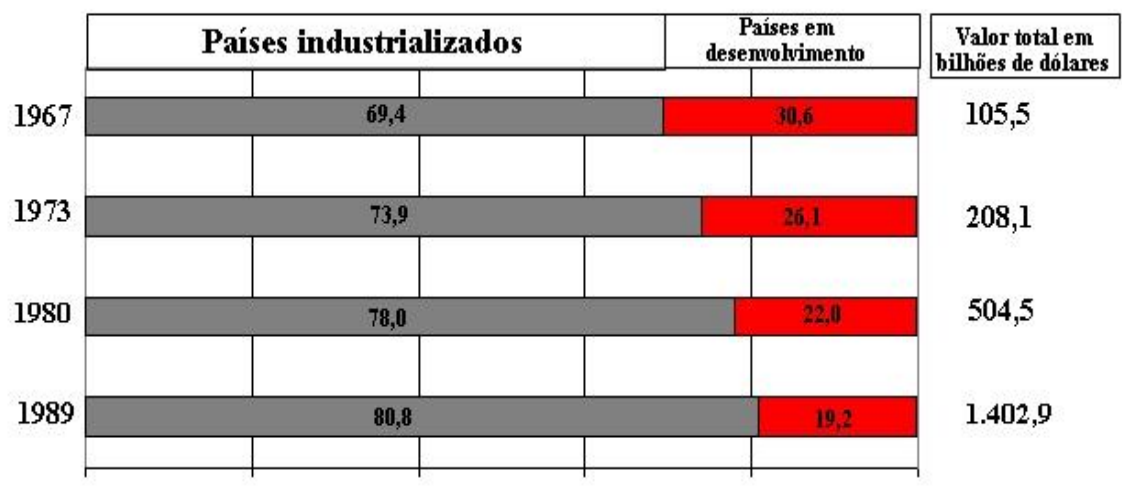

Fonte: Departamento de Comércio dos EUA, Serviço de Análise Econômica

Fonte: CHESNAIS, F. A mundialização do capital. Reproduzidos a partir dos gráficos 4 e 5 , às pp. 64 e 67.

Os dados acima se referem aos anos 1980 e começo dos 90. Com o correr da última década do século $X X$ e o início do novo século, a marginalização periférica não se alterou significativamente, embora tenha havido uma tendência ascendente de entrada de investimentos na América Latina acompanhando as fusões e aquisições de empresas estatais e privadas por parte de empresas transnacionais. Condizentemente, um estudo sobre Investimento e reformas econômicas, publicado em 2000, realizado por pesquisadores da Cepal, já chegava à seguinte conclusão: o quadro econômico geral da região apresenta grande instabilidade, após mais de uma década de reformas econômicas, em razão: $1^{\circ}$ ) da volatilidade dos fluxos financeiros internacionais e da fragilidade do sistema financeiro regional, que não favorecem um contexto macroeconômico para investimentos em expansão da capacidade produtiva dos setores nacionais; $2^{\circ}$ ) da menor rentabilidade e maiores riscos, com os investimentos concentrando-se em setores de alta rentabilidade e riscos reduzidos, em detrimento dos setores produtivos que perderam proteção e incentivo oficiais e tendem a ser vencidos pela concorrência internacional; $3^{3}$ ) do menor investimento público em infraestrutura: a privatização dos serviços públicos básicos acarreta maiores exigências de rentabilidade, incorporação do custo de risco e aversão à incerteza macro e microeconômica. Diz, em suma, o estudo: "(...) a la entrada del nuevo milenio nos encontramos en un contexto nuevo, donde se combinan incertidumbres macroeconómicas derivadas de la fragilidad resultante de la globalización financiera, con las incertidumbres microeconómicas relacionadas con el comportamiento de los agentes frente a nuevas reglas del juego en los mercados. Estos dos tipos de incertidumbres se retroalimentan, afectando el 'espíritu empresarial' y la propensión a invertir." (MOGUILLANSKY, G. \& BIELSCHOWSKY, R. Inversión y reformas económicas en América Latina. Santiago: Fondo de Cultura Económica - CEPAL, 2000, p. 169.)

Encerrada a primeira década do século XXI, outro estudo aponta concordantemente as linhas que seguiu a inversão estrangeira na região: "América Latina se ha convertido en la región más cotizada del mundo si se mide según las inversiones extranjeras directas que recibe. En los últimos años los 'negocios' que ofrece la región se han multiplicado como hongos. Este crecimiento se ha dado especialmente en el renglón de la minería, también en el agro, las finanzas y otras inversiones de carácter especulativo. El incremento es, en gran parte, resultado de la gran demanda de materias primas que realiza China en forma consistente durante los últimos tres lustros. (...) Entre 2002 y 2011, sin embargo, los pagos de los países latinoamericanos a empresas que hacen inversiones en la región se multiplicaron cinco veces (un 500 por ciento). Pasaron de 23 mil millones en 2002 a 115 mil millones dólares en 2011, según la CEPAL. La secretaria de la CEPAL, Alicia Bárcena, dijo que la rentabilidad seguirá elevada en los próximos años, favoreciendo las repatriaciones de divisas. La CEPAL recomienda a los gobiernos que impulsen políticas que vinculen el enorme flujo de inversiones con cambios estructurales de sus economías. 
assim quanto de trivial coonestação há nos argumentos liberais em favor do "escopo civilizatório" dos capitais estrangeiros e do imperativo de sua livre circulação. ${ }^{42}$ Também significa isso dizer (ou antes, reiterar) que, entre centro e periferia, não há analogias possíveis em seus desenvolvimentos históricos; não há entre ambos os polos do mundo capitalista uma proporção de escala, mas apenas oposição e exclusão. ${ }^{43}$ Nesses termos, portanto, a maneira como se deu (e se dá) a industrialização latino-americana resulta em, contraditoriamente, elevar o grau de dependência em relação ao grande capital internacional, o qual hoje, ademais, em meio a uma fase aguda da crise geral do sistema mundial (que é também uma crise de sua teorização apologética), não hesita, como foi dito acima, em fazer recuar o exíguo desenvolvimento da região. ${ }^{44}$

Si no se adoptan políticas adecuadas, pronto las exportaciones de rentas por las inversiones extranjeras superarán las entradas. Las recomendaciones de la CEPAL no son bien acogidas por la mayoría de los países, especialmente Panamá". (GANDÁSEGUI, Marco A. América Latina y las inversiones extranjeras. 30/05/2013. Disponível em http://alainet.org/active/64327. Grifos nossos.)

${ }^{42}$ A propósito disso assinala expressivamente Francisco de Oliveira: "(...) concorremos em busca desse capital fugidio, realizamos as privatizações, empenhamos os fundos públicos até a medula nos subsídios, praticando superávites fiscais suicidas, que são o lucro dos capitais especulativos, descuidando dos investimentos sociais e das políticas públicas, correndo permanentemente atrás dos prejuízos, e o capital brinca de gato e rato com nossos destinos nacionais". (OLIVEIRA, Francisco de. "Prefácio crítico". In: SAWAYA, Rubens R. Subordinação consentida, p. 12).

${ }^{43}$ Aos que acreditam ainda hoje que o problema do subdesenvolvimento se resolve pela mera absorção, nas economias dependentes, de padrões econômicos dos países capitalistas avançados, convém recordar o que dizia L. Trótski, no começo do século XX: "(...) Pour eux [para os que creem na "imitação"], I'histoire d'une nation capitaliste répète, avec des modifications plus ou moins importantes, I'histoire d'une autre. Ils n'aperçoivent pas le processus, unique de nos jours, du développement capitaliste mondial qui est le même pour tous les pays auxquels il s'étend et qui, par l'union de conditions locales avec les conditions générales, crée un amalgame social dont la nature ne peut être définie par la recherche de lieux communs historiques, mais seulement au moyen d'une analyse à base matérialiste. Entre l'Angleterre, d'une part, pionnier du développement capitaliste, laquelle, pendant une longue suite de siècles, a créé de nouvelles formes sociales et une puissante bourgeoisie qui en est l'expression et, d'autre part, les colonies d'aujourd'hui, auxquelles le capital européen apporte, sur des vaisseaux tout montés, des rails tout faits, des traverses, des boulons, des wagons-salons pour l'administration coloniale, et dont ensuite il persuade par la carabine et la baïonnette les indigènes de sortir de leur état primitif pour s'adapter à la civilisation capitaliste, il n'y a aucune analogie dans le développement historique, bien que l'on puisse découvrir un lien profond et intime entre des phénomènes si différents d'aspect". (TROTSKY, Leon. 1905. (edição francesa), p. 18. Grifo nosso.)

${ }^{44} \mathrm{O}$ cinismo de alguns pregoeiros do neoliberalismo revela um modo sutil de se reconhecer isso. Afirma um deles: "É equivocada a versão de que as multinacionais ignoram os países carentes. $O$ fato de evitarem alguns países pobres não surpreende. Elas são empreendimentos comerciais que sobrevivem à custa de lucros. Com efeito, nenhuma corporação jamais conseguiu promover o progresso sustentável acumulando prejuízos. Cabe ao país que queira atrair investimentos oferecer um ambiente atraente. Isso em geral implica na existência de uma estabilidade política $e$ de vantagens econômicas, como mão de obra barata e recursos naturais exploráveis. Por isso, no jogo para atrair investimentos, alguns países sairão perdedores simplesmente porque Ihes faltam tais atributos. (BHAGWATI, Jagdish. Em defesa da globalização: como a globalização está ajudando ricos e pobres. Rio de Janeiro: Elsevier, 2004, p. 181. (Grifos nossos.) 
As experiências progressistas da América Latina, no que possam abrigar de anseios de autonomização, deparam-se hoje com os óbices levantados pelos elementos de um cenário mundial marcado pela reestruturação dos mecanismos de exploração neocolonial, cujas forças - sob a denominação duvidosa de
"globalização" 45 - estabeleceram uma significativa alteração na antiga divisão
internacional do trabalho (tal como estava delineada ao fim da II Guerra Mundial). Na nova divisão surgida, a "ofensiva neoliberal" constituiu-se no ponto alto da

45 O termo globalização pretendeu designar, a princípio, um amplo e progressivo processo histórico (que se teria iniciado em fins dos anos 1970) de intensa transnacionalização da produção industrial e de internacionalização dos movimentos de mercadorias, tecnologia e capitais fenômenos que também seriam geradores de mudanças positivas (em escala mundial) nas culturas dos povos e na organização democrática dos diversos Estados nacionais. $\mathrm{O}$ emprego do termo, na literatura econômica burguesa conservadora, foi obviamente ideológico e deformador, e intentava denotar a ocorrência de um movimento histórico "impetuoso e irreversível", inclusive teleologicamente dirigido para um plano de evolução histórica que se caracterizaria pelo fim dos grandes antagonismos econômico-militares entre os Estados nacionais e pelo triunfo definitivo dos regimes liberais democráticos. Por sua vez, o pensamento econômico crítico (sobretudo de fundamento dialético-materialista) absorveu o termo e Ihe imprimiu uma denotação negativa por designar, em realidade, um novo momento de expansão das práticas imperialistas das nações capitalistas avançadas sobre as economias atrasadas - sobre seus mercados, seus recursos naturais e, especialmente, sobre sua mão de obra. (No caso dos trabalhadores dos países ricos, a globalização também representou um ataque bem sucedido contra os direitos trabalhistas, alcançados estes através de séculos de lutas proletárias - direitos, em parte, então cristalizados nos assim chamados Estados de Bem Estar Social - que, justamente por isso, se tornaram alvo do ataque das políticas neoliberais.) Em uma definição sintética, pode-se dizer, portanto, que "(...) globalização não é senão a expressão ideológica da internacionalização sem precedentes das forças produtivas, e de sua completa inadequação à sobrevivência dos Estados nacionais, insuperável para o capital e suas supostas 'instituições internacionais'". (COGGIOLA, O. (org.). Globalização e socialismo. São Paulo: Xamã, 1997, p. 138). Não será talvez supérfluo recordar um texto clássico, em que a "globalização" era já descrita, há mais de um século e meio, em sua verdadeira natureza e origem históricas: "A necessidade de mercados sempre crescentes para seus produtos impele a burguesia a conquistar todo o globo terrestre. Ela precisa estabelecer-se, explorar e criar vínculos em todos os lugares. Pela exploração do mercado mundial, a burguesia imprime um caráter cosmopolita à produção e ao consumo em todos os países. Para grande pesar dos reacionários, ela retirou a base nacional da indústria. As indústrias nacionais tradicionais foram, e ainda são, a cada dia destruídas. São substituídas por novas indústrias, cuja introdução se tornou essencial para todas as nações civilizadas. Essas indústrias não utilizam mais matériasprimas locais, mas matérias-primas provenientes das regiões mais distantes, e seus produtos não se destinam apenas ao mercado nacional, mas também a todos os cantos da Terra. Ao invés das necessidades antigas, satisfeitas por produtos do próprio país, temos novas demandas supridas por produtos dos países mais distantes, de climas os mais diversos. No lugar da tradicional autossuficiência e do isolamento das nações, surge uma circulação universal, uma interdependência geral entre os países. $E$ isso tanto na produção material quanto na intelectual. Os produtos intelectuais das nações passam a ser de domínio geral. A estreiteza e o isolamento nacionais tornam-se cada vez mais impossíveis, e das muitas literaturas nacionais e locais nasce uma literatura mundial". (MARX, K. \& ENGELS, F. Manifesto do Partido Comunista. Rio de Janeiro: Contraponto, 1998, p. 11-12). Em outra definição ainda, mais sucinta, mas cuja inopinada franqueza justifica sua referência, afirma-se que "(...) globalização não é um conceito sério. Nós, os norte-americanos, o inventamos para ocultar nossa política de entrada econômica nos outros países e para tornar respeitáveis os movimentos especulativos de capital, que sempre são causa de graves problemas". (“Entrevista com John K. Galbraith", Folha de São Paulo, Brasil, 11/1997, p. 2.) 
imposição às nações dependentes (imposição feita por economias centrais cada vez mais dilaceradas por dificuldades no processo de acumulação capitalista em escala mundial) de papéis econômicos diametralmente opostos ao ideal de desenvolvimento industrial autônomo e de luta contra a situação de subdesenvolvimento. Tais papéis, constrangidos ainda às condições ditadas pelo fenômeno presente de financeirização ${ }^{46}$ do sistema capitalista (fenômeno característico das etapas de crise aguda do sistema), apenas dão uma nova face à dependência estrutural da região e, ao contrário de gerar um ambiente interno de progresso e um externo de paz mundial (como prometiam inúmeros e "autorizados" prognósticos ${ }^{47}$ ), são hoje conducentes a uma situação geral

${ }^{46}$ Cf. ARRIGHI, Giovanni \& SILVER, Beverly J. Caos e governabilidade no moderno sistema mundial. Rio de Janeiro: Contraponto; Editora UFRJ, 2001, p. 214-215. O cenário socioeconômico mundial desta primeira década e meia do século XXI confirma as previsões dos autores quanto à "financeirização" progressiva da economia mundial e à polarização da riqueza dela resultante, indicativas da vigência da fase crítica do ciclo de acumulação capitalista. Da mesma maneira, a "globalização" do comércio internacional e dos fluxos mundiais de capital tem favorecido as classes dominantes relativamente à redução dos valores reais dos salários e à flexibilização do trabalho, de sua legislação e de sua demanda de trabalhadores nacionais. Cf., também, CHESNAIS, F. A mundialização do capital. São Paulo: Xamã, 1996, sobretudo pp. 69-88.

O gráfico seguinte mostra o crescimento do mercado financeiro mundial nos anos iniciais da globalização neoliberal.

Gráfico 8: Evolução do mercado financeiro mundial - 1985-1999

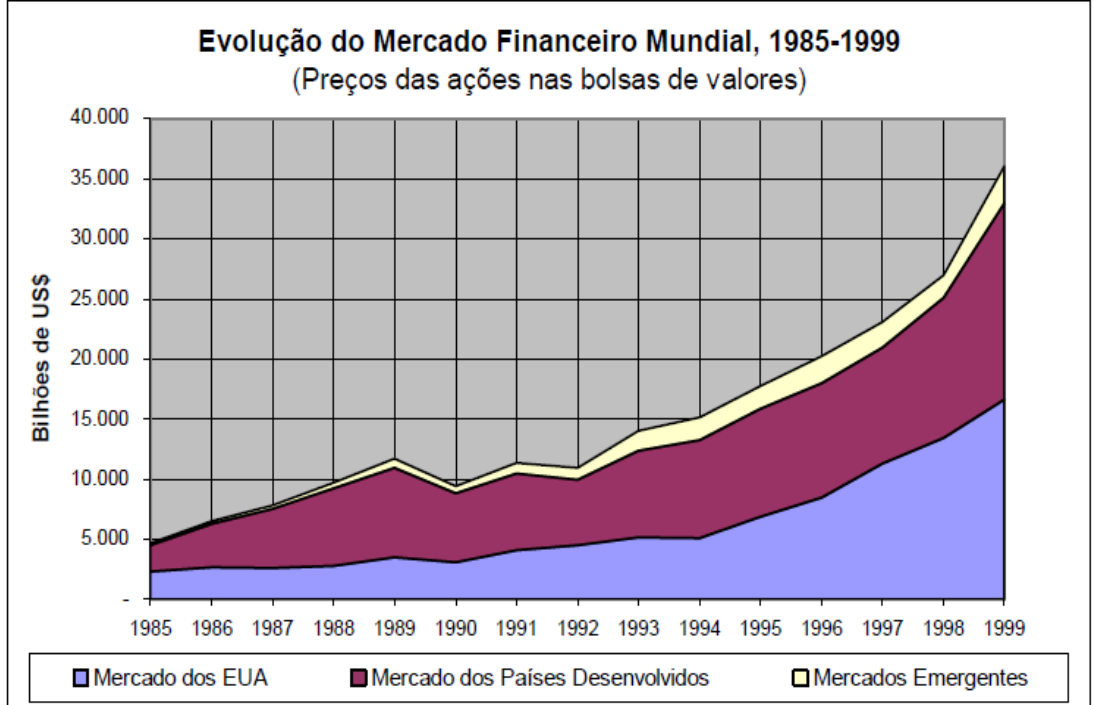

Fonte: A partir de dados do International Finance Corporation (IFC) Bloomberg, em COGGIOLA, O. "A crise estrutural do capital". Apud ESTENSSORO, L. Capitalismo, desigualdade e pobreza na América Latina, p. 19.

${ }^{47}$ Em meados da década de 1990, Jeffrey Sachs, um dos mais conhecidos propugnadores das políticas de abertura de mercados, diagnosticava, de sua cátedra em Harvard: "(...) open economies tend to converge, but closed economies do not. The lack of convergence in recent decades results from the fact that the poorer countries have been closed to the world. This is now changing with the spread of trade liberalization programs, so that presumably the tendencies toward convergence will be markedly strengthened. The power of trade to promote economic 
depressiva para o conjunto dessas economias ${ }^{48}$, cujo desempenho negativo, a médio e longo prazo, compõe o quadro daquilo que se denominou apropriadamente, para a periferia, de reversão colonial. De fato,

convergence is perhaps the most venerable tenet of classical and neoclassical economics, dating back to Adam Smith. As Smith's followers have stressed for generations, trade promotes growth, through a myriad channels: increased specialization, efficient resource allocation according to comparative advantage, diffusion of international knowledge through trade, and heightened domestic competition as a result of international competition. (...) It is tempting, at the end of the twentieth century, to believe that the birth of a global capitalist economy is inevitable. Some have proclaimed the 'end of history' following the collapse of communism. Similarly, in 1910, Norman Angell declared that European wars had come to an end because war was simply too costly for any rational European government. But our historical review should give us profound pause for thought. Yes, the late twentieth century has certain key advantages over 1910 for the preservation of emerging market institutions. There is the spread of sovereignty, so that imperial adventures no longer seem to threaten the global peace. There is the spread of an international rule of law, largely through institutions such as the World Trade Organization and the International Monetary Fund. There is the spread of democracy, which covered some 108 countries in 1994, according to the estimates of Freedom House". (SACHS, J. \& WARNER, A. Economic Reform and the Process of Global Integration. Brooking Papers in Economic Activity; 1995, p. 3 e 63. Grifo nosso).

Nesse sentido, também é digna de nota a expressiva mudança de atitude intelectual - no caso, uma atitude agora bem menos crítica - em relação às categorias teóricas fundamentais centro-periferia, imperialismo e "globalização" em uma obra clássica como Dependência e desenvolvimento na América Latina, de F. H. Cardoso e E. Faletto. Comparem-se, nesse sentido, a $1^{\underline{a}}$ edição (de 1970) e o Prefácio à nova edição revista (a 8ª , de 2004).

${ }^{48}$ Os efeitos calamitosos das reformas neoliberais revelaram-se clara e rapidamente já ao fim da primeira década do século XXI, quando a ilusão de estabilidade e prosperidade se desfizera por completo. Na América Latina, por exemplo, a variação do PIB e da demanda agregada dos países da região atingiu, em 2009, níveis negativos abaixo de imediatamente antes de 1990 - sendo os piores ao longo dos últimos 20 anos. Cf. o gráfico seguinte:

Gráfico 9: AL: Variação anual do PIB e da demanda agregada 1990-2009 (em \%) AMÉRICA LATINA (19 PAÍSES): VARIAÇÃO ANUAL DO PIB E DA DEMANDA AGREGADA, 1990-2009 (Em porcentagens)

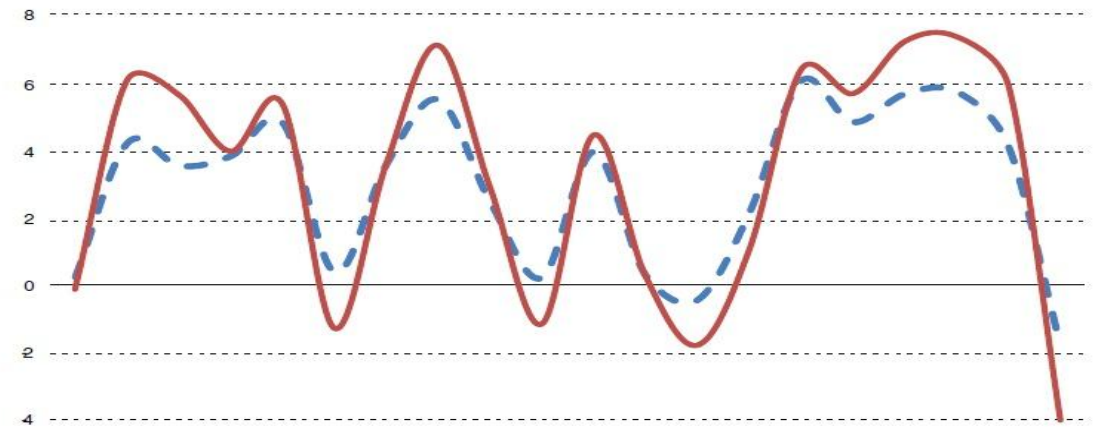

19901991199219931994199519961997199819992000200120022003200420052006200720082009

$$
\text { - - PIB }
$$$$
\text { -Demanda agregada }
$$

Fonte: Comissão Econômica para a América Latina e o Caribe (CEPAL), com base em cifras oficiais e R. Ffrench-Davis, Reformas para América Latina: después del fundamentalismo neoliberal, Buenos Aires, Comissão Econômica para a América Latina e o Caribe (CEPAL)/

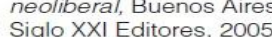

Fonte: CEPAL. A hora da igualdade. Brechas por selar, caminhos por abrir. abril/2010, p.12. 
(...) na ordem internacional emergente, o desenvolvimento nacional não está no horizonte de possibilidades dos países periféricos. A comunidade internacional reduziu tudo que estiver fora dos megablocos regionais a cobiçados mercados emergentes ou reles zonas de pobreza. Na nova divisão internacional do trabalho, cabem às economias periféricas fundamentalmente três papéis: franquear seu espaço econômico à penetração das grandes empresas transnacionais; coibir as correntes migratórias que possam causar instabilidade nos países centrais; e aceitar a triste e paradoxal função de pulmão e lixo da civilização ocidental. (...) Expostas à fúria da globalização e ao arbítrio dos países ricos, as sociedades latino-americanas ficaram sujeitas a mecanismos draconianos de neocolonização. ${ }^{49}$

Essa nova feição da dependência, ao lado do referido problema da desestruturação produtiva - que compele esses países de volta à função de feitorias modernas, destruidoras do próprio meio ambiente em proveito alheio ${ }^{50}$, como também de meros mercados de bens de consumo (ou, quando muito, de poucos bens de capital) do estrangeiro - traz consigo as agruras sociais associadas à dependência financeira agravada e, igualmente preocupante, à decomposição cultural. ${ }^{51}$ A primeira delas manifesta-se sob a forma, entre outras, da obrigação dos governos de se preocuparem, muito acima de qualquer problema social, com a implementação de políticas de liberalização comercial e financeira, bem como com a estabilidade monetária e o equilíbrio fiscal - todas elas condições técnicas exigidas pelas grandes instituições financeiras internacionais para que essas economias continuem consideradas "atraentes ao capital estrangeiro". Ora, romper essa imposição externa, que se funda em uma concepção de sociedade e de Estado claramente calcada em absoluto descompromisso entre o capital e os grupos humanos que o produzem ${ }^{52}$, constitui um dos principais desafios dos regimes progressistas, porquanto, sem isso, verse-á sucumbir qualquer pretensão de preservar ou de construir a função social e a

\footnotetext{
${ }^{49}$ SAMPAIO JR., Plínio de Arruda. "Globalização e reversão neocolonial: o impasse brasileiro. In: HOYOS VÁSQUEZ, Guillermo. Filosofía y teorías políticas entre la crítica y la utopía. Buenos Aires: CLACSO (Consejo Latinoamericano de Ciencias Sociales), 2007, p. 147. Disponível em: http://bibliotecavirtual.clacso.org.ar/ar/libros/grupos/hoyos/11Sampaio.pdf.

${ }^{50} \mathrm{Cf}$. GUDYNAS, Eduardo. Estado compensador y nuevos extractivismos. Las ambivalencias del progresismo sudamericano. Nueva Sociedad, nº 237, enero-febrero de 2012. Disponível em www.nuso.org.

${ }^{51}$ Cf. SAMPAIO JR., Plínio de Arruda. Op. cit., p. 148-149.

${ }^{52}$ Cf. SANTOS, Boaventura de Souza (org.). Democratizar a democracia. Os caminhos da democracia participativa. Rio de Janeiro: Civilização Brasileira, 2002 (ver: "Introdução geral", pp. 13-27).
} 
legitimidade democráticas dos atuais Estados nacionais latino-americanos. ${ }^{53}$ No que tange a estes, a persistência dessa discricionariedade externa (só possível, é preciso reconhecer, graças ao assentimento oficial, secundado pela benevolência conivente do empresariado nativo) deve servir para se recordar que, no passado recente da América Latina, a árdua transição dos truculentos regimes ditatoriais (militares e civis) para regimes de direito não representou (salvo poucas exceções - Cuba, Nicarágua) a consolidação de um autêntico Estado democrático (em rigor, nem mesmo de direito) porventura originário da vitória política dos movimentos populares contra o despotismo das elites dominantes, mas sim da derrota desses movimentos e de uma transição "segura" e consentida pelas classes governantes. Por essa razão, ao fim dessas ditaduras, as estruturas do poder institucional achavam-se ainda mais subservientes ao grande capital (nacional e internacional, associados) do que na efêmera fase anterior de prosperidade do pós-guerra, havendo sido alijadas da mais elementar representação política democrática as camadas majoritárias da população. Eis, pois, nesse sentido, o estigma de Estado policialesco e antipopular ${ }^{54}$ que permanece latente e intocado na história latino-americana, e que o progressismo de hoje precisa extinguir como prova de sua credibilidade de verdadeiros regimes de democracia. Afinal, a capitulação ideológica ante as promessas do neoliberalismo - capitulação a que nenhum dos governos progressistas ainda deu mostras de estar inteiramente imune - significa, para as frágeis democracias atuais do continente, suportar uma nova e perigosa involução, na medida em que, ocorrendo algo como uma bernsteinização dos princípios doutrinários fundamentais desses grandes partidos da esquerda latino-americana no poder, triunfe uma postura teórico-prática que abandona toda a fundamentação crítica da realidade socioeconômica e ignora a essência conflituosa (e, por conseguinte,

\footnotetext{
${ }^{53}$ Nota um pesquisador: "(...) [As] forças econômicas da globalização reduzem e até anulam a capacidade dos Estados Nacionais de se contraporem aos mercados em nome dos direitos sociais e do cidadão, criando o que se chamou de regimes globalitários, onde não se admite outra política econômica que não seja subordinada à razão competitiva e onde os mercados financeiros têm a direção das sociedades." (ESTENSSORO, Luís. Capitalismo, desigualdade e pobreza na América Latina. Tese de doutorado, FFLCH-USP, 2003, p. 19.)

${ }^{54} \mathrm{Cf}$. uma interpretação da origem e natureza do Estado-policial burguês em MANDEL, Ernest. La conception marxiste de l'Etat. Bruxelles, Documents Socialistes, 1965. (Documents socialistes: Numero special). Disponível em: http://www.ernestmandel.org/fr/ecrits/txt/1965/la _conception marxiste_de_etat.htm. Veja-se, em especial, a Terceira Parte, sobre a questão A classe operária tem necessidade de um Estado?
} 
perecível) da organização das sociedades sob o capitalismo. Ao mesmo tempo, esse recuo significa, no plano da práxis, contemporizar com a tradicional "política de conciliábulos" das elites e aceitar, por extensão, a concepção meramente formal de democracia - quer dizer, a de simulacro burguês dela. Em termos sucintos, tal capitulação implica, acima de tudo, renunciar a uma premissa fundamental do pensamento crítico-dialético - a que postula a força histórica transformadora das classes trabalhadoras da cidade e do campo - e adotar uma atitude que tem levado essa esquerda progressista a se resignar, em definitivo, ao desgastado dogma liberal da inexorabilidade dos fenômenos econômicos e da sua ascendência sobre toda capacidade político-social de controlá-los. Seria isso, enfim, o mesmo que confessar a naturalidade das situações socialmente iníquas, a ineficácia de qualquer Estado planejador, e, por cúmulo, a inevitabilidade do expediente autoritário de sempre "socializar as perdas", ou seja, de se atirarem sobre as camadas sociais exploradas as tribulações decorrentes das sucessivas crises econômicas. Intimamente relacionado a isso, o segundo problema (o da decomposição cultural) apresenta-se primeiramente na tendência demonstrada pelos segmentos sociais privilegiados de, cada vez mais, absorver os padrões de consumo e comportamento político-social próprios dos grupos sociais abastados dos países centrais. Em segundo lugar, na tendência à projeção de fortes ideais arrivistas (como enriquecimento pessoal, consumo de ostentação, competição e sucesso profissional individual a qualquer preço) sobre as classes média e baixa da sociedade, agravando por esse modo os efeitos terrivelmente desagregadores que hoje atingem os vínculos de solidariedade de classe e obstruem a conscientização política dos grupos explorados e/ou marginalizados. Quer essa absorção, quer essa projeção concorrem, como fatores de alienação, para uma anomia social por assim dizer hobbesiana ${ }^{55}$, ou seja, de hipertrofia do individualismo e da irracionalidade nas relações humanas, de dissolução dos valores morais e de busca implacável dos indivíduos por um hedonismo frívolo "de mercado" - o que resulta no confronto aberto entre os sujeitos sociais, caracterizando-se um estado de classes que torna inviável qualquer convivência minimamente pacífica entre as camadas sociais. Assim, dominantes e dominados

\footnotetext{
${ }^{55}$ Veja-se a concepção do estado natural (isto é, pré-social) hobbesiana (que empregamos aqui de forma apenas figurada) em HOBBES, Thomas. Leviatã, especialmente na Parte I, cap. XIII.
} 
tornam-se incapazes de enxergar ou admitir mesmo as formas mais agudas de exploração de classe, enquanto passam a tolerar, como naturalmente justificada, a coexistência social da mais aparatosa riqueza com a mais abjeta miséria. Desse bellum omnium contra omnes contemporâneo, cuja expressão política é a exclusão, à força, da multidão do povo das estruturas do poder estatal, derivam o caráter sempre potencialmente explosivo das relações sociais e, como resposta, a função violentamente repressora de seu Estado burguês (mesmo quando atua sob uma capa "democrática" ${ }^{56}$ ). Por último, a esses elementos desalentadores que abrem o século $\mathrm{XXI}$ na periferia capitalista, deve-se acrescentar o do perigo externo - ressurgido no coração de uma crise sistêmica sem precedentes na história - do recrudescimento das políticas belicistas e xenófobas dos centros imperialistas ${ }^{57}$, os quais, pretextando a necessidade de um humanismo militar intervencionista ${ }^{58}$, investem contra as sociedades de países pobres, culturalmente diferentes, mas possuidores de importantes recursos naturais - políticas essas de forte teor totalitário, como as que adotaram recentemente G. W. Bush, Tony Blair, J. M. Aznar e outros - de modo nenhum abandonadas por seus sucessores, e que têm conduzido as nações do mundo a um horizonte histórico muito diverso

\footnotetext{
${ }^{56}$ Cf. adiante o cap. 6, sobre o Caracaço.

${ }^{57} \mathrm{Cf}$. ROBINSON, William I. The crisis of global capitalism and the spectre of 21st century fascism. Disponível em: http://alainet.org/active/46914. Observa esse sociólogo que, nos EUA, o fantasma do fascismo do século XXI materializa-se sobretudo na fusão do grande capital transnacional com os fortes setores políticos conservadores do país: "(...) This fusion had been developing during the Bush years and would likely have deepened under a McCain-Palin White House. In the meantime, such neo-fascist movements as the Tea Party as well as neo-fascist legislation such as Arizona's anti-immigrant law, SB1070, have been broadly financed by corporate capital. Three sectors of transnational capital in particular stand out as prone to seek fascist political arrangements to facilitate accumulation: speculative financial capital, the military-industrial-security complex, and the extractive and energy (particularly petroleum) sector. (...) A 21st fascism would not look like 20th century fascism. Among other things, the ability of dominant groups to control and manipulate space and to exercise an unprecedented control over the mass media, the means of communication and the production of symbolic, images, and messages, means that repression can be more selective (as we see, for example, in Mexico or Colombia), and also organized juridically so that mass "legal" incarceration takes the place of concentration camps. Moreover, the ability of economic power to determine electoral outcomes allows for 21st century fascism to emerge without a necessary rupture in electoral cycles and a constitutional order". Vale assinalar sua conclusão: "(...) The counterweight to 21st century fascism must be a coordinated fight-back by the global working class. The only real solution to the crisis of global capitalism is a massive redistribution of wealth and power downward towards the poor majority of humanity. And the only way such redistribution can come about is through mass transnational struggle from below". (Grifo nosso.)

${ }^{58} \mathrm{Cf}$. ANDERSON, Perry. "A batalha das ideias na construção de alternativas" In: BORÓN, Atilio A. (org.). Nova hegemonia mundial. Buenos Aires: CLACSO, 2004. Veja-se também CECEÑA, Ana E. \& SADER, Emir. (coords.). La guerra infinita: Hegemonía y terror mundial. Buenos Aires: CLACSO, 2002.
} 
daquele que, há poucos anos, supunham vislumbrar alguns celebrados cientistas sociais. $^{59}$

Convém ainda, mesmo sob risco de uma prolixidade indevida, fazermos outra digressão e confrontar com esse panorama o sentido dos avanços recentes dos diversos movimentos populares, notáveis tanto nos grandes centros urbanos quanto nas zonas rurais do continente. Como se afirmou acima, esses avanços levam a América Latina a atravessar hoje um importante processo de mudança político-social que, apesar dos graus marcadamente desiguais de conscientização e de organização das classes populares, considerados segundo os diversos países e suas diferentes regiões (graus precaríssimos, em muitos casos!), apresenta traços análogos aos da época do avanço das lutas do proletariado europeu nas décadas que precederam à Primeira Guerra Mundial. A analogia, neste caso, é porventura pertinente: após sucederem-se fases de depressão e de expansão econômica (respectivamente, em 1873-1895 e 1895-1914), a progressiva tomada de consciência e o crescente poder de organização política dos trabalhadores, juntamente com o fortalecimento dos partidos socialistas e social-democratas, revelaram-se fatores decisivos para que se consumasse uma alteração substancial nas formas de dominação política da burguesia europeia frente às classes trabalhadoras. A violência repressiva aberta exercida contra as mobilizações reivindicatórias operárias; os abusos praticados por empresários

\footnotetext{
${ }^{59}$ Causa perplexidade reler hoje afirmações como as seguintes, ditas há algum tempo com uma singular euforia triunfalista: "(...) And yet, good news has come. The most remarkable development of the last quarter of the twentieth century has been the revelation of enormous weaknesses at the core of the world's seemingly strong dictatorships, whether they be of the military-authoritarian Right, or the communist-totalitarian Left. From Latin America to Eastern Europe, from the Soviet Union to the Middle East and Asia, strong governments have been failing over the last two decades. And while they have not given way in all cases to stable liberal democracies, liberal democracy remains the only coherent political aspiration that spans different regions and cultures around the globe. In addition, liberal principles in economics - the "free market" - have spread, and have succeeded in producing unprecedented levels of material prosperity, both in industrially developed countries and in countries that have been, at the close of World War II, part of the impoverished Third World. A liberal revolution in economic thinking sometimes preceded, sometimes followed, the move toward political freedom around the globe. (...) Liberal democracy replaces the irrational desire to be recognized as greater than others with a rational desire to be recognized as equal. A world made up of liberal democracies, then, should have much less incentive for war, since all nations would reciprocally recognize one another's legitimacy. And indeed, there is substantial empirical evidence from the past couple of hundred years that liberal democracies do not behave imperialistically toward one another, even if they are perfectly capable of going to war with states that are not democracies and do not share their fundamental values.(...) Today, by contrast, we have trouble imagining a world that is radically better than our own, or a future that is not essentially democratic and capitalist." (!) (FUKUYAMA, Francis. The End of History and the last Man. London: Penguin Books, 1992, pp. xiii-xiv e 46. Grifos nossos.)
} 
inescrupulosos (principalmente em relação ao trabalho infantil e feminino), tolerados ou ignorados pelo poder público; a perseguição oficial e o exílio movidos contra grupos políticos radicais; a privação imposta às classes trabalhadoras de meios de representação política institucional - tudo isso foi gradualmente substituído por um novo tipo de hegemonia político-social da classe burguesa, que se vira então obrigada a reconhecer direitos trabalhistas e civis às massas de trabalhadores, sem, contudo, Ihes ceder o poder do Estado. Esse processo de mudanças, é claro, teve ritmos e amplitudes diferentes conforme as condições específicas de cada país; mas, em sua linha geral, correspondeu à instalação da hegemonia de classe sob a forma da democracia burguesa - que se tornou, desse modo, fruto histórico da "(...) interação entre as conquistas arrancadas à burguesia pelos movimentos operários, socialistas e feministas e as reformas que a própria burguesia necessitava realizar em função das mudanças no processo de acumulação derivadas do surgimento da grande indústria". ${ }^{60}$ Dessa maneira, em meio às contendas de classes, emergiram mecanismos formais que principiaram a permitir uma relativa, mas importante, acomodação dos interesses de ambas as classes, e, conquanto a natureza antagônica das relações não desaparecesse (e mesmo recrudescesse nos períodos de crise), uma nova ordem jurídica e civil burguesa razoavelmente estável pôde-se impor, conjugada a políticas de melhorias do bem-estar geral das massas trabalhadoras. É de notar-se, porém, como um elemento explicativo de suma relevância desse fenômeno, que, nessas sociedades, o desenvolvimento econômico encontrou um impulso insubstituível no afluxo ininterrupto de riquezas oriundas da exploração imperialista de regiões coloniais e semicoloniais, o que dispôs às classes dominantes europeias volumes de excedentes que puderam ser, mesmo que em proporção mínima, distribuídos

\footnotetext{
${ }^{60}$ REGALADO, Roberto. La izquierda latinoamericana en el gobierno, p. 4. Disponível em http://www.rebelion.org/noticia.php?id=68635, 11/06/2008. Veja-se também, do mesmo autor, a obra mais extensa: ÁLVAREZ, R. Regalado. América Latina entre siglos. Cuba: Ocean Sur, 2006 (especialmente a Segunda Parte: Dominación, crisis, lucha social y alternativas políticas de la izquierda en América Latina). A comparação acima entre épocas históricas semelhantes, sugerida por este politógo cubano a partir do conceito gramsciano de hegemonia, deve, no entanto, levar em consideração, segundo ele, uma distinção importante, referente à ação do neoliberalismo na América Latina: "(...) la ideología hegemónica es el neoliberalismo, no como en el Viejo Continente, donde ese proceso estuvo influenciado por el liberalismo político emanado de la Revolución Francesa. (...) En las condiciones estudiadas por Gramsci, la hegemonía abría espacios de confrontación dentro de la democracia burguesa que los sectores populares podían aprovechar para arrancarle concesiones a la clase dominante, pero la hegemonía neoliberal abre espacios formales de gobierno con el objetivo de que no puedan ser utilizados para hacer una reforma progresista del capitalismo". (p. 4-5. Grifo nosso.)
} 
entre as classes dominadas, conciliando-as assim, em alguma medida, com a ordem vigente. A gravidade dos conflitos esteve, por isso, sempre em proporção inversa aos meios que a classe dominante proprietária encontrou de controlar as diversas formas de tensões sociais e de canalizá-las para uma solução ou apaziguamento no nível das esferas institucionais (jurídicas, parlamentares, sindicais) criadas pela própria ordem político-social burguesa. Em sentido oposto, a maior ou menor capacidade de organização e contestação política dos trabalhadores definiu historicamente o grau de exploração a que era submetida a força de trabalho, e a hegemonia política da burguesia passou a sofrer a contrapartida do crescimento da participação e representação dos partidos e organizações operários. ${ }^{61}$ Nesse cenário de oscilações, entre lutas revolucionárias e reformas burguesas, tais sociedades acabaram por conservar suas estruturas capitalistas ${ }^{62} \mathrm{e}$, principalmente na segunda metade do século

\footnotetext{
${ }^{61}$ Giovanni Arrighi (et alii) considera a existência de um padrão histórico repetitivo de círculos virtuosos e círculos viciosos que se alternam ao longo dos períodos de hegemonias do sistema capitalista mundial (hegemonias sucessivamente holandesa, britânica e norte-americana). Na base dos círculos virtuosos estariam os pactos sociais entre grupos dominantes e subordinados, que, nos momentos de expansão sistêmica do comércio e da produção, conduzem a épocas de relativa paz social. Esta, por sua vez, reforça a tendência à expansão produtiva. Nos momentos de transição hegemônica, em que os processos de reprodução do capital passam por uma "financeirização", a concorrência entre os Estados e entre as empresas capitalistas destrói aos poucos as condições concretas de manutenção desses pactos sociais e conduz a um estado de conflito social crescente, caracterizando daí em diante os círculos viciosos do processo. No que diz respeito às classes trabalhadoras do capitalismo fora do mundo europeu e norte-americano industrializado, o autor constata: "A consolidação de cada hegemonia mundial pressupôs 0 estabelecimento de novos 'compromissos históricos' capazes de controlar o conflito social. (...) [Nas] transições, contudo, a ampliação das bases sociais do bloco hegemônico foi acompanhada - a rigor, baseada - na exclusão da maioria da população mundial, de fato ou de direito, do acesso aos mesmos direitos e privilégios". (ARRIGHI, Giovanni \& SILVER, Beverly J. Caos e governabilidade no moderno sistema mundial. p. 162). Esta afirmação indica um aspecto histórico importante relativo à formação e evolução do capitalismo dependente latino-americano, dos tempos coloniais ao presente: a substituição de uma potência econômica hegemônica por outra (Portugal/Espanha, depois Holanda, Inglaterra, e finalmente EUA - ou outra que porventura venha a seguir-se a essas) não alterou, e não deve alterar, em essência, os mecanismos de controle externo das economias dependentes nem as formas de apropriação de seu excedente nacional, o que obriga a reconhecer, uma vez mais, que apenas um avanço real para um modelo de capitalismo autônomo, que seja capaz de realizar uma integração satisfatória das classes populares, ou, mais provavelmente, uma transformação profunda, de caráter socialista, poderá significar a autêntica superação da condição de dependência e de subdesenvolvimento.

${ }_{62} \mathrm{O}$ contundente revés dos movimentos operários europeus em 1848 consolidou o poder político da burguesia europeia, sobretudo da burguesia inglesa, que se tornou definitivamente hegemônica no cenário mundial de então. Com a derrota dos trabalhadores, abriu-se uma época de estabilidade política e expansão econômica na Europa, que perduraria até o início da crise econômica do final desse século e a crescente beligerância entre as nações, motivada por intenções imperialistas. Como a Comuna de Paris, também a Primeira Guerra Mundial, a Revolução Russa de 1917 e a Guerra Civil Espanhola expuseram, cada qual em grau superlativo, as contradições nacionais e internacionais do desenvolvimento capitalista e os conflitos sociais a ele inerentes. (Cf., entre outros, HOBSBAWM, E. Era dos extremos: O breve século XX (1914-
} 
passado, alcançaram certa estabilidade social (embora nunca absoluta nem permanente), de modo a manter a conflituosidade das relações de classes dentro de limites que apenas ocasionalmente deixaram entrever oportunidades reais de destruição e reconstrução revolucionárias de suas bases materiais. ${ }^{63} \mathrm{Em}$ uma escala considerável, portanto, essas nações capitalistas, em cuja base se constituíram economias autônomas, conseguiram integrar parcelas significativas das massas trabalhadoras nacionais ao jogo político e aos novos padrões de vida e de consumo, a ponto de enfraquecer o ímpeto revolucionário no meio operário e atrair para um projeto burguês de modernização econômica vários grupos políticos de origem proletária (como os socialdemocratas e os socialistas e comunistas "ortodoxos"). Após 1945, a maior participação política das massas populares no sistema representativo das democracias liberais, a conquista de direitos trabalhistas que asseguraram melhores condições de vida e de trabalho, e a absorção gradual de um padrão cultural no qual vigoram valores como o individualismo, a competitividade profissional e o apatismo político ${ }^{64}$, explicam em

1991). SP: Cia das Letras, 2003; e ARRIGHI, G. O longo século XX: Dinheiro, poder e as origens de nosso tempo. Rio de Janeiro: Contraponto; São Paulo: Unesp, 1996.)

${ }^{63} \mathrm{O}$ ano de 1968 assinalou, talvez, a mais importante dessas ocasiões revolucionárias da segunda metade do século XX. 1968 serviu de advertência para intelectuais e partidos de direita e de esquerda (como, entre estes, os PC francês e italiano) que haviam suposto ter o capitalismo europeu (e o norte-americano) atingido uma situação duradouramente estável. Também foi um aviso sobre as limitações históricas do mundo socialista, então em grande parte sob a influência poderosa da burocracia stalinista, ainda à testa do Estado soviético. ( $\mathrm{O}$ esmagamento da "Primavera de Praga", em agosto, deixou às claras ao mundo a traição aos ideais autenticamente libertários do socialismo revolucionário de 1917). As rebeliões populares que estouraram por toda a parte (Argentina, Japão, Brasil, Polônia, Espanha, México etc.) marcaram 1968 como o ponto alto de um período revolucionário de caráter mundial, no qual os movimentos estudantis projetaram-se em aliança estreita com as lutas da classe operária contra a exploração econômica e os modos de vida alienantes do capitalismo. Nos países capitalistas centrais, essa aliança materializou-se emblematicamente no Maio francês, mas conheceu manifestações importantes também na Alemanha, Itália e EUA, onde à revolta contra a ordem jurídica e cultural burguesa se somaram os protestos anti-imperialistas contra a guerra no Vietnã. O interregno revolucionário de 1968 foi, contudo, violentamente obturado pelo recurso à repressão, a qual os governos dessas democracias liberais não hesitaram em pôr em prática do modo mais agressivo e em absoluta contradição com os próprios preceitos do Estado de direito que elas propugnavam. Uma década depois, a derrota dos anseios revolucionários se confirmava nas eleições dos conservadores $M$. Thatcher e R. Reagan, com suas políticas econômicas de orientação neoliberal. Uma outra década mais, e a queda do socialismo real na URSS e no Leste europeu provocaria um novo descenso da pugnacidade das classes trabalhadoras em todo o mundo, ao passo que se espalhava nos meios políticos e intelectuais conservadores um triunfalismo cínico em torno das virtudes da democracia burguesa e das "leis de mercado".

${ }^{64}$ Sobre uma importante forma de manifestação recente desse apatismo entre a juventude europeia, adverte um historiador inglês: "(...) A destruição do passado - ou melhor, dos mecanismos sociais que vinculam nossa experiência pessoal à das gerações passadas - é um dos fenômenos mais característicos e lúgubres do final do século XX. Quase todos os jovens de 
parte o arrefecimento da aspiração revolucionária proletária nas sociedades desenvolvidas da Europa e Estados Unidos. Além disso, a implantação de políticas keynesianas no pós-guerra surtiu o efeito de represar os conflitos sociais, ao oferecer uma alternativa às políticas tradicionais do liberalismo econômico, alternativa que, ao mesmo tempo, "protegia" as classes trabalhadoras e a economia nacional e impedia que um eventual novo acirramento das lutas operárias levasse à sublevação e à reorganização da economia segundo, por exemplo, um modelo centralizado socialista, de tipo soviético. Por aproximadamente três décadas, os governos desses países conseguiram conjugar, de modo eficiente, a cooptação de parcelas superiores do operariado (e de seus representantes políticos) à repressão violenta dos segmentos mais bem organizados - como o exemplificam as práticas renhidamente anticomunistas do macarthismo e do gaullismo dos anos 1950 e 60 - dando assim ao Estado burguês um controle efetivo mais duradouro sobre as sociedades desenvolvidas controle que, ao construir certa "paz social", prometia mais ainda perpetuar-se quando, nos fins dos anos 80, principiaram a desmoronar as economias do bloco socialista. Não é necessário advertir, porém, que a integração social nessas sociedades de capitalismo avançado constitui um progresso histórico apenas relativo, visto que o sistema continua sendo intrinsecamente incapaz de manter, a longo prazo, os padrões de equidade e justiça social que correspondam aos princípios de isonomia jurídica e de liberdade política nos quais a ordem burguesa pretende fundar-se. ${ }^{65}$ Mas, por outro lado, seria errôneo não ver nessa integração, ainda que parcial e deficiente, uma força real de autopreservação de que se têm valido até hoje as elites das sociedades capitalistas desenvolvidas, e com a qual elas têm sabido erguer um forte obstáculo à construção da consciência proletária e ao avanço do socialismo revolucionário.

Estruturalmente diverso disso foi o processo de formação das sociedades de países coloniais e semicoloniais, nos quais, mesmo hoje, é evidente que o nível de forças no quadro de antagonismo das classes sociais não se equipara ao que se estabeleceu na Europa e nos EUA. Os fundamentos históricos dessa

hoje crescem numa espécie de presente contínuo, sem qualquer relação orgânica com o passado público da época em que vivem. " (HOBSBAWM, Eric. Era dos extremos, p. 13.)

${ }^{65}$ A ebulição social crescente na Europa e nos EUA, após a eclosão da crise econômica, em 2008, parece hoje apontar para essa relatividade do progresso histórico-social do capitalismo avançado. 
diferença formativa são relativamente claros, embora nem toda a sociologia os reconheça. Eles podem ser formulados, resumidamente, como se segue: ao longo da história do capitalismo, a batalha implacável travada, comercial e militarmente, entre as nações capitalistas pela hegemonia no controle da economia mundial conduziu ao aparecimento de padrões desiguais e combinados de constituição e desenvolvimento das diversas formações econômico-sociais que participam da divisão internacional capitalista do trabalho. ${ }^{66}$ Esses padrões se cristalizaram historicamente em um binômio centro-periferia, que exprime os vínculos de dominação/subordinação entre as economias mais poderosas e as que foram compelidas violentamente a integrar-se ao mercado mundial. Desse modo, como resultado da expansão desigual do capitalismo, constituíram-se dois modelos predominantes de estrutura econômica, em mútua relação dentro de um único e mesmo sistema: as economias que buscam o impulso ao seu desenvolvimento na exploração material de nações estrangeiras e as que são obrigadas a organizar seu sistema produtivo "nacional" em conformidade com as condições e imposições definidas de fora, por países hegemônicos. No centro das interações desses dois polos reside, como força determinadora sobre todo o conjunto, o próprio processo de acumulação ampliada do capital, a que, em escala mundial, prendem-se como peças intrínsecas os mecanismos, mencionados acima, de apropriação interna e externa dos excedentes econômicos produzidos nas nações periféricas. ${ }^{67}$ Por extensão, toda a superestrutura dessas formações periféricas

\footnotetext{
${ }^{66}$ Escrevendo contra Stálin, L. Trótski chamava a atenção (no Prefácio à edição francesa de $A$ revolução permanente, 1930) para a importância teórica de se considerarem as particularidades históricas nacionais das diversas formações: "(...) O marxismo procede da economia mundial, considerada não como simples adição de suas unidades nacionais, mas como uma poderosa realidade independente, criada pela divisão internacional do trabalho e pelo mercado mundial, que, em nossa época, domina do alto os mercados mundiais. (...) As particularidades econômicas dos diferentes países não têm uma importância secundária. Basta comparar a Inglaterra e a Índia, os Estados Unidos e o Brasil. Os traços específicos da economia nacional, por mais importantes que sejam, constituem em escala crescente, os elementos de uma unidade mais alta que se chama a economia mundial e que serve, afinal de contas, de base ao internacionalismo dos partidos comunistas". (TROTSKY, Leon. A revolução permanente, p. 39-42. Grifo nosso). Não é demais lembrar que essas asserções referem-se à concepção acerca do "desenvolvimento desigual do capitalismo" (ou, em sua expressão completa, a lei (ou teoria) do desenvolvimento desigual e combinado na história) - concepção fundamental, política e teoricamente, para a compreensão da formação moderna e da condição de atraso das sociedades coloniais e semicoloniais. (Cf., também, NOVACK, George. Uneven and combined Development in History. Edição digital disponível em www.marxists.org/archive/novack/works/history/ch05.htm.)

${ }^{67}$ De maneira mais ou menos esquemática, podem-se apontar três etapas sucessivas, na história latino-americana, do modo como ocorreu e ocorre o processo de acumulação mundial do capital levando-se em conta as relações estabelecidas entre as economias centrais e as periféricas: $1^{\text {at}}$ ) a
} 
(suas classes sociais, o nível de integração destas como nação, o modo de organização e distribuição do poder no Estado, o grau de consciência de classe e a viabilidade, mediada pelas lutas de classes, de se alcançar algum nível significativo de democracia social e autossuficiência cultural) não pode ser compreendida - no que elas comportam de dependentes e subdesenvolvidas fora do campo dessas condicionantes. É dessa perspectiva, portanto, que se deve interpretar o momento presente: se, efetivamente, na América Latina, as expressões mais brutais da dominação política burguesa (como foram os anos de chumbo das ditaduras militares e de alguns violentos governos civis posteriores) vão cedendo lugar, sob os governos progressistas, à abertura de espaços institucionais que os movimentos e grupos políticos de esquerda começam a ocupar nos quadros dessas democracias, isso, no entanto, sugere sérias reservas a qualquer observador, apesar de reconhecer-se o avanço. É verdade que se

etapa de expansão neocolonialista, de fins do século XIX e primeiras décadas do XX, na qual se reservou às áreas periféricas a função precípua de receptores de investimentos e consumidores de manufaturados, bem como provedores de matérias-primas e de mão de obra barata. Nesta etapa, os mercados consumidores latino-americanos atuaram predominantemente como lugares onde se dava a realização dos valores excedentes produzidos pela força de trabalho do centro; $2^{\mathrm{a}}$ ) a etapa da ampla internacionalização produtiva e financeira, nas décadas de 1940-1970, quando a maioria dos países dessa periferia impulsionou suas políticas anteriores de "substituição de importações", industrializando-se segundo uma orientação que abria as portas às empresas multinacionais, absorvia imensos volumes de investimentos em infraestrutura e ampliava extraordinariamente a demanda de bens de consumo através do crédito. Nesse período pósguerra, a hegemonia mundial desloca-se da Europa para os EUA, que impõem na América Latina sua dominação político-militar e comandam o impulso de desenvolvimento industrial dessas áreas atrasadas. Na década de 80 , porém, a "crise da dívida" dos países subdesenvolvidos marcou um momento crucial da falência desse modelo desenvolvimentista; $3^{\text {a }}$ ) a época mais recente, de mundialização do capital, de meados dos anos 1970 em diante, caracterizada pela imposição de políticas de liberalização plena dos mercados, sobretudo o financeiro, com a eliminação de restrições legais aos fluxos internacionais de capital monetário. Nesta etapa, um elemento-chave da acumulação encontra-se na reprodução, cada vez maior, do capital dentro do próprio meio financeiro, que, em detrimento do capital produtivo e recorrendo a mecanismos de rentabilidade fictícia, vem conduzindo ao quadro atual de domínio mundial do capital rentista especulativo e de suas grandes e inevitáveis crises financeiras. (Deixamos de lado a consideração sobre a etapa colonialista da expansão do capitalismo comercial, inaugurada pelas descobertas e conquistas ultramarinas dos séculos XV e XVI. Estritamente falando, essa etapa corresponde, para grandes áreas da América (como toda a América portuguesa), a um modo de produção colonial escravista - e não propriamente capitalista - em que predominam processos pré-capitalistas de formação do capitalismo e configuram uma época de acumulação originária do capital. Contudo, é obviamente nessa etapa colonial que se encontram as raízes mais remotas da dependência e do subdesenvolvimento, nascidos da pilhagem colonial. Cf., por exemplo, FURTADO, Celso. $A$ economia latino-americana (Primeira Parte: Da conquista à formação dos Estados nacionais). Apesar das distinções que devem ser apontadas de uma etapa a outra, os elementos que acompanham a acumulação mundial - ou seja, a concentração e a centralização do capital, a hegemonia dos oligopólios, o recurso a guerras imperialistas, entre outros - permanecem, em grande parte, inalterados. (Cf. o estudo de SAWAYA, Rubens. Subordinação consentida. São Paulo, Annablume-FAPESP, 2006. Veja-se também: FLORES, Consuelo S. \& CORTÉS, Claudio Lara (coords.). La crisis global y el capital ficticio. Editorial Arcis- Clacso, s/d. ) 
entrevê hoje ir adquirindo certa expressão concreta na realidade do continente o acima aludido princípio do protagonismo popular, se se considerarem, por exemplo, algumas importantes inovações legais consagradas em recentes reformas de constituições nacionais (como na Venezuela, na Bolívia e no Equador) que, entre suas novidades, passaram a prever, por exemplo, os direitos históricos de propriedade e de autonomia cultural a minorias étnicas, a criminalização do preconceito e da discriminação racial, sexual, religiosa e de gênero, a criminalização de práticas nocivas ao meio ambiente e, inusitadamente, o reconhecimento de uma dívida histórica, pelo Estado e pela sociedade, em relação a grupos e setores sociais historicamente marginalizados, como os imigrantes e os assim denominados afrodescendentes. Um passo à frente nessa democratização formal foi dado, ainda, pela incorporação do princípio de inclusão social, que, do ponto de vista oficial das políticas públicas, pôs-se a admitir a origem e causa socioestrutural do problema da pobreza e da marginalidade, recusando em princípio a justificativa de que ambas se deveriam a deficiências, carências ou desequilíbrios individuais, e lançando à competência do Estado a obrigação legal de dar-Ihes uma solução apropriada. ${ }^{68}$ No plano do exercício da cidadania, outras inovações jurídicas estabeleceram, por exemplo, o voto universal (a ser exercido em sua máxima extensão), a ampliação dos mecanismos de arbítrio popular sobre a condução dos cargos públicos (como os referendos consultivo e revogatório), a participação do povo na gestão pública ${ }^{69}$, e o reconhecimento da legalidade dos protestos sociais (com consequentes

\footnotetext{
${ }^{68}$ Essa nova noção de inclusão social, bastante presente nos discursos políticos atuais da esquerda latino-americana, remonta a uma mudança de perspectiva mundial que reconheceu (ao menos formalmente) os efeitos negativos da vigência prolongada de políticas econômicas neoliberais em todo o mundo. Cf., por exemplo, a noção elaborada pelo Programa das Nações Unidas para o Desenvolvimento (PNUD), que considera, por oposição, a exclusão social como a exclusão de direitos sociais, sendo, além disso, exclusão da própria condição humana enquanto membro da sociedade. Essa nova formulação do problema, que evidentemente não rompe com a visão burguesa de desenvolvimento, mas a atualiza, pode ser assim (oficialmente) sintetizada: "(...) Economic growth will not reduce poverty, improve equality and produce jobs unless it is inclusive. Inclusive growth is also essential for the achievement of the Millennium Development Goals (MDGs). The globalization process, when properly managed, becomes an important ingredient for inclusive growth. In this context, UNDP works to make real improvements in people's lives, opening up their choices and opportunities". (United Nations Development Programme) Disponível em http://www.undp.org/ content/undp/en/home.html.

${ }^{69}$ Por exemplo: 0 artigo 62 da Constituição da República Bolivariana da Venezuela diz: "A participação do povo na formação, execução e controle da gestão pública é o meio necessário para alcançar o protagonismo que garanta seu completo desenvolvimento, tanto individual como coletivo. É obrigação do Estado e dever da sociedade facilitar a geração das condições mais favoráveis à sua prática".
} 
restrições à ação repressiva violenta das autoridades policiais). 70 Concomitantemente, a criação recente de instituições como a ALBA, CELAC, UNASUL e Petrocaribe vem procurando revalorizar os ideais de soberania nacional e integração regional entre as nações latino-americanas, pretendendo, por esse meio, tanto superar o caráter simplesmente comercial dos blocos regionais (como o MERCOSUL e a CAN) - buscando substituí-lo pela cooperação e auxílio mútuo internacional - como levar para fora da órbita de influência político-militar dos EUA as decisões governamentais sobre as relações internacionais e sobre a condução de políticas autônomas de desenvolvimento no continente. $^{71}$

Não obstante, está-se ainda nos limites da democracia burguesa ${ }^{72}$, o que significa que todo esse avanço histórico se ressente de algo de superficial e ilusório (e por isso a comparação acima precisa ser relativizada). A modernização democrática na América Latina de hoje (com suas diligências por soberania, integração e protagonismo popular) difere em um aspecto crucial dos progressos que marcaram o contexto europeu de transição do século XIX ao XX: embora, lá

\footnotetext{
${ }^{70}$ A despeito dessas conquistas legais dos movimentos sociais latino-americanos, as fragilidades próprias da democracia burguesa permitiram que, em sentido contrário, o autoritarismo das elites e de seus sócios externos se impusesse sob outras modalidades, não menos poderosas e perniciosas. Estas são, principalmente, a militarização das relações sociais e a criminalização da pobreza - expedientes de que lançaram mão, por todo o continente, os governos de orientação neoliberal para conter a crescente conflituosidade e mobilização social. Um fator adicional ao quadro de militarização e criminalização social na América Latina (com o crescimento de formas repressivas paraestatais em diversos países - Paraguai, Colômbia, Guatemala) acha-se na receptividade desses governos à política externa norte-americana de "guerra infinita", implantada após os episódios de 11 de setembro de 2001. (Cf. SEOANE, José (comp.). Movimientos sociales y conflicto en América Latina. Buenos Aires: CLACSO, 2004; BUHL, Kathrin \& KOROL, Claudia (orgs.). Criminalización de la protesta y de los movimientos sociales. São Paulo: Instituto Rosa Luxembourg Stiftung, 2008; e CECEÑA, Ana Esther \& SADER, Emir. La guerra infinita. Hegemonía y terror mundial. Buenos Aires: CLACSO, 2002.)

${ }_{71}$ Uma vitória importante no sentido da soberania e da integração regional foi, como é notório, o repúdio das nações latino-americanas à implantação da ALCA (Área de Livre Comércio das Américas), pretendida sobretudo pelos EUA. A vitória, no entanto, não foi absoluta e vem sendo erodida pela estratégia norte-americana de firmar acordos comerciais bilaterais com os diversos países latino-americanos. A condição de dependência econômica da região para com os EUA é, certamente, o fator limitante principal à soberania, o que é evidente nos casos do México e dos países centro-americanos. (Cf. ESTAY, Jaime \& SÁNCHEZ, Germán (coord.). El ALCA y sus peligros para América Latina. Buenos Aires: CLACSO, 2005.)

${ }^{2}$ Cumpre não esquecer o que ela significa: "(...) O que é a democracia burguesa: como forma política da república democrática, uma ditadura de classe dissimulada com fundamento na representação, na divisão de poderes e nos direitos fundamentais dos cidadãos; como forma política dos regimes burgueses de exceção, uma ditadura de classe explícita, pela qual o poder real da minoria se organiza e se impõe sem o consentimento da maioria, garantindo pela força a eficácia da democracia restrita". (FERNANDES, Florestan. Brasil: em compasso de espera. Rio de Janeiro: Ed. UFRJ, 2011, p. 46.)
} 
como aqui, não se tivessem jamais rompido as linhas limítrofes da política burguesa e, em razão disso, as classes trabalhadoras europeias permanecessem sempre à mercê de bruscas reações conservadoras dos setores mais retrógados da burguesia (como o comprovaria, nos anos 1920-1930, a ascensão dos partidos nazifascistas) - aqui o quadro histórico está rigidamente condicionado pelo capitalismo dependente. Isso quer dizer que a lógica da dependência estrutural na qual a existência de alguns países é determinada pelo papel apenas ancilar que suas economias desempenham no sistema mundial, contentando-se com um progresso do qual compartilham tão-só reflexamente - reduz a limites estreitos as possibilidades reais de autonomização econômica e de modernização democrática contidas em projetos históricos que insistam em permanecer no âmbito das revoluções dentro da ordem. De fato, tais revoluções têm-se distinguido por serem resultado de relações circunstanciais de forças que surgem excepcionalmente em conjunturas de grande instabilidade política e econômica (nacional e mundial) e que, estimuladas, por vezes, pelo agravamento incidental de contendas entre as nações imperialistas, acabam por suscitar lutas hegemônicas internas entre grupos políticos antigos e novos. Contudo, visto que os grupos adventícios ao poder não alcançam romper o jugo externo de exploração econômica e sujeição político-ideológica, a "modernização" que por acaso venha a acompanhar os novos regimes acaba inevitavelmente por esbracejar-se na contradição entre a perspectiva nacionalista de progresso das forças produtivas internas (e, portanto, em tese, de redução da parcela externa na sobreapropriação da riqueza social do país, em contrapartida à ampliação da parcela nativa) e a impossibilidade real de eliminação, nos limites desse progresso, das condições de segregação social e política das grandes maiorias oprimidas e exploradas. Por isso, na história da América Latina, tem pesado como um fadário o fato de que as experiências de modernização, mesmo tendo criado condições excepcionais favoráveis ao avanço material e aos melhoramentos institucionais, desembocaram indefectivelmente no enrijecimento das distâncias sociais entre as maiorias pobres e as elites opulentas, fazendo com que fossem fugazes as melhorias de participação das classes populares na distribuição da riqueza nacional (o que explica que apenas esporadicamente essas melhorias tenham sido sancionadas em um corpo de leis que as garantisse como conquistas 
sociais permanentes) e que significassem somente ganhos momentâneos, concedidos segundo um assistencialismo social com forte sabor demagógico. ${ }^{73}$ Nesses casos, o Estado invariavelmente abdicou de sua linha progressista inicial para assumir - tão logo despontassem demandas populares mais exigentes - um viso repressor explícito, que ao fim o recoadunasse com a índole autoritária e os reclamos das elites nacionais e dos agentes estrangeiros da exploração econômica. $^{74}$

$\mathrm{Na}$ tradição marxista, a dinâmica histórica das nações capitalistas atrasadas e as implicações político-sociais de suas possibilidades concretas de desenvolvimento econômico autônomo encontram nos escritos de L. Trótski uma das formulações teóricas mais fecundas. Não por acaso, foi justamente a América Latina que, em especial, ocupou a atenção do revolucionário bolchevique em seus últimos trabalhos. Exilado no México desde 1937, ele pôde aí combinar suas reflexões (e ações) acerca do futuro do socialismo mundial à experiência imediata do exílio. O México de Lázaro Cárdenas (1934-1940) - um país ainda semicolonial, no qual se justapunham áreas urbanas, vivendo em torno da exploração mineral e petrolífera por empresas norte-americanas e europeias, e áreas rurais dominadas por latifundiários nativos e estrangeiros - ingressava em um período de reformas com clara orientação nacionalista, havendo o governo

\footnotetext{
${ }^{73}$ Os recentes programas assistencialistas (p. ex., Missão Mercal, Programa Bolsa Família, Cidadania Portenha, etc.) dos governos progressistas - alguns deles ditos Programas de Transferência de Renda (segundo a nomenclatura da ONU) e implementados invariavelmente em nome da "democratização do desenvolvimento" - encerram um nítido contrassenso ao declararem pretender priorizar as necessidades sociais em vez dos interesses do capital: a destinação de importantes recursos públicos ao financiamento de políticas sociais tem por resultado a redução promovida pelo próprio Estado - dos custos de reprodução da força de trabalho. No âmbito da produção social, essa diminuição dos gastos com o capital variável implica a ampliação do volume de mais-valia relativa apropriada pelo capitalista privado. Na prática, portanto, os regimes progressistas concorrem significativamente para a reprodução do capital privado com fundos públicos, o que não envolve nenhuma diferença expressiva se se comparar às políticas de desenvolvimento dos regimes militares passados. Ao mesmo tempo, no plano político, esses programas assistencialistas atrelam ao Estado as camadas mais pobres, cooptadas por essa verdadeira política de esmoler, que também não difere, em essência, das práticas clientelistas de outras épocas.

${ }^{74}$ Esse retrocesso do progressismo - se se permite a expressão - tem ocorrido claramente quando, nos momentos de crise social e diante do crescendo dos protestos populares, a resposta oficial se exerce sob a forma de violenta repressão policial e de recusa terminante em ceder às exigências de teor democrático das manifestações. Em nosso país, tivemos recentemente exemplos flagrantes disso: em junho de 2013, um milhão de pessoas participaram de protestos de rua contra a corrupção política e as condições precaríssimas dos serviços públicos. No ano seguinte, ano de Copa do Mundo de Futebol, sobrevieram novos protestos, embora de menor dimensão. Nos dois momentos, a força das manifestações suscitou uma resposta oficial "de violência à altura", revelando no desabrimento da postura governamental frente aos protestos todos os ressaibos do Estado ditatorial de nossa história de décadas recentes.
} 
mexicano, em 1937, nacionalizado o sistema de transporte ferroviário do país e, no ano seguinte, as empresas petrolíferas, de origem norte-americana e inglesa. As decisões do governo Cárdenas, que contrapunham um programa de desenvolvimento nacional independente aos interesses do imperialismo dos EUA e da Europa (com suas economias apenas se recuperando da grande depressão de 1929 e então às vésperas de uma nova conflagração mundial interimperialista) foram interpretadas por L. Trótski como representativas de um bonapartismo sui generis - isto é, um regime político burguês que, em sua "vertente de esquerda", incorporava a si as reivindicações de camponeses e operários e liderava-os em uma luta nacional de caráter revolucionário e democrático - na acepção que esses termos podiam ter ao se tratar de países semicoloniais (ou seja, no sentido de avanços para uma emancipação relativa frente aos centros imperialistas). ${ }^{75}$ Escrevia L. Trótski a propósito, em junho de 1938:

(...) O México semicolonial está lutando por sua independência nacional, política e econômica. Tal é o significado básico da revolução mexicana nesta etapa. Os magnatas do petróleo não são capitalistas de massas, não são burgueses comuns. Tendo-se apoderado das maiores riquezas naturais de um país estrangeiro, sustentados por seus bilhões e apoiados pelas forças militares e diplomáticas de suas metrópoles, fazem de tudo para estabelecer no país subjugado um regime de feudalismo imperialista, submetendo a si a legislação, a jurisprudência e a administração. Sob estas condições, a expropriação [das empresas petroleiras] é o único meio efetivo para salvaguardar a independência nacional e as condições elementares da democracia.

Qual direção tomará o posterior desenvolvimento econômico do México depende, decisivamente, de fatores de caráter internacional. Mas, isto é uma questão para o futuro. A revolução mexicana está agora realizando o mesmo trabalho que, por exemplo, realizaram os Estados Unidos da América ao longo de três quartos de século, principiando pela Guerra Revolucionária da Independência e terminando pela Guerra Civil, com a abolição da escravidão e com a unidade nacional. O governo britânico não só fez todo o possível, em fins do século XVIII, para manter os Estados Unidos sob a categoria de colônia, como também, mais tarde, durante os anos da Guerra Civil, apoiou os escravistas do sul contra os abolicionistas do norte, esforçando-se, em benefício de seus interesses

\footnotetext{
${ }^{75}$ Cf. CALELLO, Osvaldo. Trotsky y la revolución en América Latina. Ediciones de la Izquierda Nacional, 2009. Disponível em www.izquierdanacional.org. Embora o uso do conceito de bonapartismo sui generis seja mais ou menos elástico e pouco consensual na literatura marxista latino-americana, consideram-se também como exemplos, no passado, desse tipo de regime o de Domingo Perón na Argentina (1946-1955 - primeiro governo), o de Velasco Alvarado no Peru (1968-1975), o de Velasco Ibarra no Equador (sucessivos mandatos entre 1934 e 1972), o de Jacobo Arbenz na Guatemala (1951-1954) e, mesmo, o de Getúlio Vargas no Brasil (1930-1945) entre outros.
} 
imperialistas, por afogar a jovem república em um estado de atraso econômico e de desunião nacional. ${ }^{76}$

Para L. Trótski, a férrea sujeição das nações atrasadas semi-industriais ao poder do capital estrangeiro imprimia às burguesias nacionais desses países uma marca de debilidade diante de seu proletariado nacional, criando condições especiais à organização do poder do Estado, de modo tal que, em determinadas circunstâncias históricas, podia-se dizer que ele se estabelecia acima das classes sociais - como resultado de certo equilíbrio excepcional de forças existente entre a burguesia e o proletariado. Nesses momentos, o governo nacional "(...) oscila entre o capital estrangeiro e o nacional, entre a relativamente frágil burguesia nacional e o relativamente poderoso proletariado. (...) [Governa-se] ou convertendo-se em instrumento do capital estrangeiro e submetendo o proletariado às cadeias de uma ditadura policial, ou manobrando-se com o proletariado, chegando mesmo a fazer-Ihe concessões, alcançando deste modo a possibilidade de dispor de certa liberdade em relação aos capitalistas estrangeiros". ${ }^{77}$ Expressão propriamente desta segunda alternativa, o regime bonapartista semidemocrático (que, no caso mexicano, nasceu da radicalização das contradições sociais não resolvidas pela Revolução de 1910, entre campesinato, operariado, grandes terratenentes e empresas estrangeiras), ao fortalecer o poder central, passa a sustentar um autêntico capitalismo de Estado, que, no entanto, em economias semicoloniais, não pode prevalecer senão com o apoio das classes trabalhadoras (urbanas e rurais), capazes de servir como contrapesos às pressões imperialistas das empresas privadas estrangeiras e seus respectivos governos. As nacionalizações das indústrias básicas passam a contar com a participação mais ampla das organizações operárias na condução do processo produtivo, ainda que o Estado mantenha o controle sobre as empresas e sobre a produção. Acena-se, então, com alguns benefícios às classes populares: uma política de reforma agrária, mesmo diminuta, precisa ser adotada como meio de o governo encontrar apoio político nos camponeses; igualmente, uma relativa liberdade de organização política dos operários decorre do fato de os

\footnotetext{
76 TROTSKY, León. "México y el imperialismo británico". In: Escritos Latinoamericanos (compilación). Buenos Aires: CEIP León Trotsky, 2007, p. 92.

77 TROTSKY, León. "La industria nacionalizada y la administración obrera". In: Escritos Latinoamericanos (compilación). Buenos Aires: CEIP León Trotsky, 2007, p. 170.
} 
sindicatos aumentarem sua influência no âmbito da ação estatal, em consequência da política trabalhista. Atuando desse modo, esses governos latinoamericanos puderam representar oportunidades reais - conquanto incipientes de essas sociedades alçarem-se a um nível mais elevado de desenvolvimento histórico. Não obstante, neste cenário que L. Trótski descrevia como sendo de "oportunidades e perigos" para o proletariado, a inocultável origem burguêsnacional do regime levantava uma série de questões decisivas, a ser consideradas por intelectuais, trabalhadores e sindicatos: o conteúdo da revolução nacional-democrática, mesmo sendo manifestamente anti-imperialista, bastaria à superação da condição semicolonial, a ponto de garantir um desenvolvimento social que extinguisse o ambiente de miséria e de exploração das massas trabalhadoras? Até onde iria o radicalismo da burguesia na defesa da autonomia nacional, sobretudo quando confrontada com as exigências do proletariado contra os direitos da propriedade privada? Que posição prática esse proletariado deveria ocupar no processo revolucionário - empenhar-se presentemente na aliança com os setores burgueses nacionalistas para assegurar a etapa nacional do desenvolvimento capitalista como precondição à etapa socialista, ou radicalizar o processo no sentido de uma revolução socialista imediata, dirigida por ele e que, uma vez alcançando êxito em escala nacional, progredisse ao nível de um internacionalismo revolucionário?

A lucidez com que L. Trótski expôs as "grandes linhas de força" evolutivas das formações sociais capitalistas - particularmente as das atrasadas - lucidez, ademais, que outorga uma inegável atualidade e qualidade científica ao trotskismo $^{78}$ - mostra-se patente em suas teses sobre a revolução permanente. ${ }^{79}$ Capazes de dar resposta plena e concreta às interrogações acima, acham-se nessas teses (em oposição aos preceitos da concepção etapista, que, nas décadas de 1930-40 e nas seguintes, orientariam grande parte da conduta dos partidos comunistas) os lineamentos fundamentais para a compreensão e a ação política socialistas de que necessitam todas as classes trabalhadoras do mundo em sua luta de libertação histórica. Sinteticamente, esses lineamentos são: 1ํ) 0

${ }^{78}$ Cf. MANDEL, Ernest. Actualité du trotskysme. (1978). Disponível em: www.marxists.org /francais/mandel/works/1978/11/em10781100_pdf.zip.

${ }_{79}$ Vejam-se, em relação à discussão acima, especialmente as teses 8 a 12. (Cf. TROTSKY, Leon. A revolução permanente. São Paulo: Expressão Popular, 2007, pp. 208-209.) 
capitalismo, tendo criado a divisão mundial do trabalho, o mercado mundial e as forças produtivas mundiais, estabeleceu para o conjunto da economia de todo o planeta as condições para sua reconstrução socialista; $\left.2^{\circ}\right)$ o governo proletário revolucionário, uma vez instituído, precisará enfrentar as tarefas de supressão das formas do direito burguês de propriedade, para que a revolução democrática se transforme diretamente em revolução socialista; 3ํ) a revolução socialista só é possível se baseada na luta de classes em nível, progressivamente, nacional e internacional. Reside aí o caráter permanente da revolução, cuja luta deve travarse em cada país (avançado ou atrasado) internamente sob a forma de guerra civil, e externamente sob a forma de guerra revolucionária; $4^{\circ}$ ) a construção revolucionária do socialismo começa no terreno nacional, desenvolve-se na arena internacional e termina na arena mundial, e apenas alcança seu triunfo definitivo quando se realiza em todos os países do mundo; $5^{\circ}$ ) abdicar da conduta internacionalista é abrir as portas ao messianismo nacional, supondo erroneamente que um país possua qualidades históricas peculiares que impedem aos outros um mesmo papel revolucionário. Duas premissas, subjacentes às teses, completam as linhas de formulação da revolução permanente, quando aplicadas especialmente a países semicoloniais: primeiro, a de que a realização improvável de uma reforma agrária abrangente e radical e a incorporação subordinada dessas economias ao mercado mundial, dominado pelos monopólios industriais e financeiros das potências centrais, constituem impedimentos insolúveis ao desenvolvimento industrial autônomo buscado pelas revoluções democrático-burguesas; e, segundo, a de que a revolução, posta afinal sob o comando das classes trabalhadoras, não pode demorar-se em etapas democrático-burguesas, mas deverá saltar diretamente para as tarefas de construção socialista, tendo por tarefa prioritária a de socializar todos os meios de produção (as fábricas, a terra, os recursos naturais, o crédito, os meios de transporte e comunicação, a produção do conhecimento científico e tecnológico etc.) e pô-los a serviço das necessidades materiais básicas das massas populares.

Em sentido prático, as teses trotskistas sublinham o imperativo, durante eventualmente os episódios de nacionalismo progressista burguês, não do compromisso ou da colaboração de classes, mas do aproveitamento consciente, 
pelos movimentos operários mais avançados e seus grupos políticos representantes, das circunstâncias concretas favoráveis às tarefas precípuas de conscientização e de organização dos trabalhadores e das massas populares. Esta proposição de realismo prático é inteiramente diversa e divergente do desvirtuamento que padecem alguns dos grandes partidos de massa atualmente no poder na América Latina - os quais, premidos pelas necessidades de conservar o controle presente do Estado, optam pelo simples pragmatismo político ${ }^{80} \mathrm{com}$ as classes dominantes, enquanto buscam encontrar um equilíbrio de resto, impossível - entre a exploração externa imperialista, as pretensões nacionalistas de setores burgueses internos e as exigências radicais dos movimentos populares ascendentes. L. Trótski reconhecia que algumas oportunidades propícias reais surgiam ocasionadas por conflitos irrompidos excepcionalmente entre as burguesias nacionais e as imperialistas, e que, nesses momentos, constituiria um erro político dos trabalhadores abster-se do posicionamento de apoio crítico às medidas de conteúdo econômico nacionalista. ${ }^{81}$ Abster-se ou pôr-se neutro significaria infringir a lógica da luta proletária mundial contra as políticas imperialistas e abrir mão, quando menos, de um valioso recurso de formação da consciência proletária contra esse elemento central do capitalismo monopolista - o imperialismo - elemento, mais que qualquer outro, revelador da natureza defraudadora do sistema do capital em escala mundial. ${ }^{82}$ Daí a advertência:

\footnotetext{
${ }^{80}$ James Petras chama de "neoliberais pragmáticos" e de "esquerda pragmática" alguns dos governos latino-americanos, como (no primeiro caso) os recentes de Néstor Kirchner e de Lula da Silva, que preferiram pôr de lado as convicções ideológicas mais radicais em proveito do pragmatismo de alianças com partidos de centro e de direita, e prosseguiram com as políticas de privatização e liberalização típicas dos governos neoliberais anteriores; e (no segundo caso) os de Hugo Chávez e Evo Morales, que, a despeito do discurso socialista e anti-imperialista, não realizaram expropriações de capitais estrangeiros, não interromperam os pagamentos da dívida nacional nem romperam relações comerciais ou diplomáticas com os EUA. (Cf. PETRAS, James. América Latina: cuatro bloques de poder. La Jornada, 10/03/2007. Disponível em: http:// www.jornada.unam.mx/2007/03/10/index.php?section=politica\&article=030a1 pol.

${ }^{81} \mathrm{Em}$ um texto de 1850, Marx e Engels resumiam assim a questão do apoio crítico e da autonomia organizatória do partido proletário diante do nacionalismo burguês: "(...) A atitude do partido dos trabalhadores revolucionários, em face da democracia pequeno-burguesa, é esta: marchar com ela contra a fração cuja derrota é desejada pelo partido; marchar contra ela em todos os casos em que a democracia pequeno-burguesa queira fixar sua posição em proveito próprio". (MARX, K. \& ENGELS, F. "Mensagem do Comitê Central à Liga de março de 1850". In: História. São Paulo: Ática, 1984, pp. 223-224)

${ }^{82}$ Cf. MANDEL, Ernest. El pensamiento de Leon Trotsky. Edição digital. Disponível em www.revoltaglobal.net.
} 
Para os marxistas, não se trata de construir o socialismo com as mãos da burguesia, senão de utilizar as situações que se apresentam dentro do capitalismo de Estado e fazer avançar o movimento revolucionário dos trabalhadores. ${ }^{83}$

O reconhecimento lúcido do conteúdo progressista de certos governos burgueses nacionalistas representa, especialmente para o proletariado dos países atrasados, a reafirmação do internacionalismo da luta socialista, pois este ideal necessário nasce da constatação da própria tendência ordinária do capitalismo tanto à internacionalização de todas as forças produtivas e das lutas de classes como à escalada planetária dos conflitos militares travados entre as nações. ${ }^{84} \mathrm{Em}$ suma, a luta dos trabalhadores é uma luta inevitável, sob diversas maneiras e situações, contra toda a ordem mundial capitalista erigida pelo imperialismo. ${ }^{85}$ Não foi com outro sentido que declarara o líder revolucionário, em 1938, aos trabalhadores mexicanos:

\begin{abstract}
Sem sucumbir às ilusões nem temer as calúnias, os operários avancados apoiarão completamente o povo mexicano na luta contra os imperialistas. A expropriação do petróleo não é nem socialista nem comunista. É uma medida de defesa nacional altamente progressista. Evidentemente, Marx não considerou que Abraão Lincoln fosse um comunista; isto, todavia, não o impediu de manifestar a mais profunda simpatia pela luta que Lincoln dirigiu. A Primeira Internacional enviou ao presidente da Guerra Civil uma mensagem de felicitação, e Lincoln, em sua resposta, agradeceu imensamente este apoio moral. O proletariado internacional não tem nenhuma razão para identificar seu programa com o programa do governo mexicano. Os revolucionários não têm nenhuma necessidade de mudar de cor e de render devoção, ao modo da escola de cortesãos da GPU, que, em um momento de perigo,
\end{abstract}

\footnotetext{
${ }^{83}$ TROTSKY, Leon. "La industria nacionalizada y la administración obrera". In: Op. cit., p. 171.

${ }^{84} \mathrm{Cf}$. BUKHARIN, Nikolai I. A economia mundial e o imperialismo. Esboço econômico. SP: Abril Cultural, 1984, p. 120: "A sociedade capitalista é inconcebível sem armamentos da mesma forma que não pode ser concebida sem guerras. E assim como não são os preços baixos que engendram a concorrência, mas, ao contrário, é a concorrência que determina o aviltamento dos preços, tampouco é a existência dos exércitos a causa essencial e a força motriz das guerras (embora, na realidade, as guerras sejam impossíveis sem exércitos) - mas, muito ao contrário, é a inelutabilidade dos conflitos econômicos que condiciona a existência dos exércitos. Eis por que, nos dias de hoje, quando os conflitos econômicos atingem os mais altos níveis de tensão, assistimos à corrida armamentista. O domínio do capital financeiro pressupõe o imperialismo e 0 militarismo. Neste sentido, o militarismo é um fenômeno histórico tão típico quanto o capital financeiro". (O grifo é do original.)

${ }^{85} \mathrm{Na}$ Introdução (1929) de A revolução permanente, L. Trótski resumia: "(...) A revolução permanente, na concepção de Marx, significa uma revolução que não transige com nenhuma forma de dominação de classe, que não se detém no estágio democrático e, sim, passa para as medidas socialistas e a guerra contra a reação exterior, uma revolução na qual cada etapa está contida em germe na etapa precedente, e só termina com a liquidação total da sociedade de classes". (TROTSKY, Leon. A revolução permanente, p. 62)
} 
vendem e traem o mais fraco. Sem renunciar a sua própria identidade, todas as organizações honestas da classe operária no mundo inteiro, e principalmente na Grã-Bretanha, têm o dever de assumir uma posição irreconciliável contra os ladrões imperialistas, sua diplomacia, sua imprensa e seus áulicos fascistas. A causa do México, como a causa da Espanha, como a causa da China, é a causa da classe operária internacional. A luta pelo petróleo mexicano é somente uma das escaramuças de vanguarda das futuras batalhas entre os opressores $e$ os oprimidos. ${ }^{86}$

A vaga ascendente dos governos progressistas latino-americanos reacendeu discussões em torno do significado e alcance histórico das revoluções nacionais (ou, em termos sinônimos, das revoluções dentro da ordem) principalmente no que concerne àqueles países da região nos quais, como se mencionou acima, o "apelo revolucionário", de conteúdo formal anti-imperialista (e, por vezes, anticapitalista) é hoje um recurso de que lançam mão seus líderes para dar legitimidade a seus projetos históricos e estabelecer um ponto de ruptura com os regimes precedentes. Nessas discussões - embora as circunstâncias históricas presentes difiram, em muitos pontos importantes, das do passado - 0 conceito de bonapartismo sui generis continua a ter grande préstimo como categoria de análise teórica, além de, certamente, possuir um indiscutível valor político-programático posto à disposição das forças políticas e sociais comprometidas com as lutas socialistas. ${ }^{87}$ Mas, há aqui um ponto que se deve sublinhar, pois, esse valor programático revela-se ainda maior quando o que está em causa é o futuro imediato de sociedades que, se, por um lado, creem experimentar hoje um clima de "verdadeira construção democrática" ${ }^{88}$ -

\footnotetext{
${ }^{86}$ TROTSKY, Leon. "México y el imperialismo británico". Op. cit., pp. 94-95. Grifos nossos.

${ }^{87}$ Para um exemplo importante de interpretação do governo chavista e da Revolução Bolivariana segundo o conceito de bonapartismo sui generis, cf. DEMIER, Felipe. A natureza do governo Chávez: uma contribuição teórica para o debate. (10/04/2007). Disponível em: www.soberania.org. Crítico desse regime, afirma o estudioso brasileiro: "Nascido numa etapa na qual o imperialismo realiza uma ofensiva brutal sobre as economias semicoloniais, o regime "semibonapartista democrático" venezuelano não dispõe de condições suficientes que the permitam ir além de políticas sociais focalizadas. É por isso que, por exemplo, o pagamento da dívida externa é feito religiosamente pelo governo de Caracas, do mesmo modo que este último não deixa por um segundo sequer de vender petróleo à máquina de guerra estadunidense. Não obstante os lucros obtidos com o comércio petrolífero, não há dados que indiquem uma diminuição substancial da miséria do povo venezuelano e da desigualdade social no país. Nesse sentido, podemos dizer que - nacionalismo-burguês chavista, emerso da radicalização da luta de classes no país e em um contexto que praticamente reduz a zero a autonomia econômica dos países da América Latina, paga o preço de ser um nacionalismo-burguês tardio". Esta interpretação exprime, em suas linhas gerais, a posição política do PSTU brasileiro frente ao regime chavista.

${ }^{88} \mathrm{Cf}$. BORÓN, Atilio. Socialismo siglo XXI: ¿Hay vida después del neoliberalismo? $1^{\text {a }}$ ed. Buenos Aires: Luxemburg, 2008. Para esse sociólogo argentino, existem no cenário latino-americano atual
} 
destacadamente na Venezuela, Bolívia e Equador - por outro lado, e contraditoriamente, permanecem tendo por base material um modelo econômico arcaico, ainda tipicamente de enclave. ${ }^{89} \mathrm{E}$ particularmente digno de nota que as experiências progressistas, nesses três países em especial, enfrentem um óbvio descompasso entre o projeto de desenvolvimento democrático da sociedade e a condição, ainda quase intocada, de parasitismo externo que domina a organização de suas atividades produtivas. Como é notório, em economias desse tipo, os tradicionais problemas da dependência e do subdesenvolvimento são, por assim dizer, potenciados em um grau agudíssimo como consequência do modo peculiar de integração ao mercado mundial, ou seja - para dizer-se objetivamente - como economias que são quase um pouco mais apenas do que formas modernizadas de antigas estruturas coloniais da era mercantilista, visceralmente submetidas à exploração estrangeira de recursos naturais e expostas permanentemente, em virtude de seu caráter primário-exportador hiperespecializado, às perturbações provocadas pela profunda suscetibilidade interna às oscilações da demanda mundial. O peso dos enclaves - que, quanto a esses três países, envolvem quase completamente a exploração industrial de hidrocarbonetos - se faz sentir, acima de tudo, na extrema rigidez que caracteriza sua estrutura econômica - o que é patente (de maneira talvez ainda mais acentuada do que nas outras economias periféricas) no desenvolvimento desastrosamente acanhado das atividades produtivas nacionais dirigidas para 0 mercado interno, na deficiência e dependência tecnológico-científica que o setor dominante apresenta em relação às empresas estrangeiras no país, e na concentração dos investimentos externos em um único ramo de produção. Reflexamente, no plano social, essa condição se traduz na intensa concentração da renda e da propriedade - o que, ao atingir certo nível crítico, torna-se a causa

ao menos quatro democracias autênticas, sendo construídas através de processos revolucionários. São elas: Venezuela, Bolívia e Equador, além de Cuba, cujo processo é mais antigo.

${ }^{89}$ Cf. as clássicas análises das economias de enclave em: CARDOSO, F. H. \& FALETTO, Enzo. Dependência e desenvolvimento na América Latina. Ensaio de interpretação sociológica. 8르 ed. Rio de Janeiro: Civilização Brasileira, 2004. (1 $1^{\text {a }}$ ed.: Zahar Editores, 1970), pp. 64-69; e BAMBIRRA, Vânia. O capitalismo dependente latino-americano. Florianópolis: Insular, 2012 (1 ${ }^{\underline{a}}$ ed., em espanhol: México: Siglo XXI, 1974). V. também GUDYNAS, Eduardo. Estado compensador y nuevos extractivismos. Las ambivalencias del progresismo sudamericano. Nueva Sociedad, no 237, enero-febrero de 2012; e BRUCKMANN, Mônica. Recursos naturales y la geopolítica de la integración sudamericana. s/d. Disponível em: http://www.reggen.org.br/ reggen. 
principal da polarização e antagonismo crescentes entre as classes sociais. $O$ controle oligárquico do Estado por partidos políticos comandados pela plutocracia nacional associada aos agentes econômicos estrangeiros completa, com o autoritarismo político, o rijo quadro histórico que até recentemente esteve ligado a esse modelo de enclaves. Deveras por isso, sintomaticamente, não foi possível até o presente, quer na Venezuela, quer na Bolívia, quer no Equador, vencer de modo satisfatório quaisquer dos principais problemas relacionados a esse tipo de organização econômica, e é de assinalar-se que, como no caso venezuelano a ser aqui estudado, nem mesmo a nacionalização da indústria petroleira, realizada nos anos 1970, bastou a dar alguma autossuficiência considerável à economia do país. Ao contrário, como será discutido adiante (cap. 3), o modo como se realizou essa nacionalização acabou mesmo por agravar dois dos problemas correlatos ao modelo de enclave ${ }^{90}:$ o da hipertrofia burocrática do Estado nacional, sustentada pelos tributos cobrados da atividade extrativa, e o da elitização do segmento numericamente pequeno de trabalhadores especializados da indústria petroleira fenômeno que, ao exercer uma ação fragmentadora sobre todo o movimento operário nacional - ainda favoreceu a própria burocratização estatal. Passados quarenta anos da nacionalização, esses problemas não encontraram ainda, na Venezuela, uma solução razoável.

Disso tudo, enfim, decorre uma constatação principal, já enfatizada em relação ao conjunto dos países periféricos, mas que vale a pena repisar-se, pois ganha extraordinária pertinência no caso específico das economias de enclave: para as sociedades desses países, desenvolvimento só terá concretude social se tornar tangíveis transformações profundas em ao menos três elementos estruturais: 1) na estrutura de produção, de maneira a criar e consolidar os diversos setores do sistema produtivo de acordo com e em grau capaz de atender as necessidades de consumo essencial (não suntuário) da população, livrando-a tanto quanto possível do ônus, por exemplo, da importação de alimentos e de gêneros básicos; criar os setores industriais de produção de tecnologia e bens de capital para um consumo produtivo nacional autossuficiente, a partir principalmente de uma política efetiva de investimento estatal em ciência e

${ }^{90}$ Cf. CARDOSO, F. H. \& FALETTO, E. Dependência e desenvolvimento na América Latina, p. 66. 
tecnologia ${ }^{91}$; e absorver adequadamente contingentes mais amplos da mão de obra do país, em uma política de direção contrária à de minguados empregos de trabalhadores que oferece o regime de enclaves - causa primeira da emigração dos grupos mais pobres e menos qualificados de trabalhadores sem ocupação; 2) na estrutura fundiária, promovendo-se uma radical reforma do regime agrário, que proscreva sumariamente os latifúndios e sua orientação monoculturalexportadora, em favor de uma agricultura racionalmente planejada segundo as necessidades tanto do consumo popular quanto da preservação do equilíbrio ecológico; e 3) na estrutura administrativa, isto é, na gestão dos recursos naturais, devendo caber ao Estado a exclusividade da propriedade, da exploração econômica e da proteção legal dos bens naturais (solo, subsolo, recursos hídricos, biodiversidade etc.). (Além disso, a autossuficiência material que progressivamente essas mudanças propiciariam precisaria completar-se com o enriquecimento por assim dizer espiritual da sociedade, ao transformar-se também a consciência social predominante, no sentido da criação de um novo tipo humano, livre dos e infenso aos valores morais da ordem competitiva e mercantil capitalista. ${ }^{92}$ Um novo tipo humano que seja nascido de uma revolução cultural. ${ }^{93}$ ) Diante da pouco plausível hipótese de evoluírem gradualmente para níveis superiores próximos dos das sociedades desenvolvidas ${ }^{94}$, as sociedades

\footnotetext{
${ }^{91} \mathrm{O}$ caráter de perpetuidade que vimos assinalando relativamente ao subdesenvolvimento latinoamericano - e que tem no atraso técnico-científico um fator negativo crucial - encontra expressão na notável atualidade de considerações feitas há quase meio século em uma obra como Ciência e libertação (1969), de J. Leite Lopes: "(...) Para os países subdesenvolvidos, que se costuma chamar de nações em via de desenvolvimento, o dilema é inevitável e grave, pois envolve o futuro das aspirações de seus povos, o futuro de sua mocidade: ou uma ciência de segunda categoria e uma tecnologia obsoleta, com o que se conservaria e agravaria o seu estado de dependência econômica; ou uma ciência dinâmica e a procura de novas tecnologias, acompanhada de novas estruturas econômicas que traduzam e realizem as aspirações de bem-estar e cultura generalizados, de independência econômica e política, no sentido que o mundo contemporâneo ainda atribui a este termo". (LOPES, J. Leite. Ciência e libertação. $2^{\mathrm{a}}$ ed. Rio de Janeiro, Editora Paz e Terra, 1978, p. 41)

${ }^{92}$ Cf. GUEVARA, Ernesto Che. El socialismo y el hombre nuevo. $8^{\mathrm{a}}$ ed. México: Siglo Veintiuno, 1988. No Prólogo a esta obra, adverte José Aricó: "(...) El socialismo implica necesariamente, para ser definido como tal, la producción de 'cosas' e de 'conciencia'. Pero la conciencia sólo puede ser producida si, al decir de Marx, la revolución comunista va dirigida contra el carácter anterior de actividad, si es capaz de eliminar el trabajo como forma de actividad alienada y desintegradora de la personalidad humana, y de suprimir la dominación de todas las clases." (p. XIII).

93 "(...) a 'revolução cultural' é o máximo de esforço de conscientização possível que deve desenvolver o poder revolucionário, com o qual atinja a todos, não importa qual seja a sua tarefa a cumprir." (FREIRE, Paulo. Pedagogia do oprimido. 17ª ed. RJ: Paz e Terra, 1987, p. 156.

${ }^{94}$ Vânia Bambirra apontava, há já quatro décadas, essa tendência à estagnação estrutural latinoamericana: "Apenas para o Brasil, a Argentina e o México há, dentro do atual sistema de dominação, a alternativa da expansão do sistema em termos de subimperialismo. Para todos os
} 
assentadas em economias de enclave (mesmo quando impulsionadas por forças do radicalismo burguês) defrontam-se com o imperativo de os movimentos sociais populares ascenderem ao estágio correspondente às revoluções contra a ordem. $E$ isso não significa outra coisa senão a busca da soberania e da democracia através de um processo de mudanças substantivas de índole essencialmente socialista nas relações de produção e de propriedade da riqueza social, ainda que se reconheça o alcance inicialmente reduzido de tais mudanças em economias com tão grande submissão ao mercado mundial. A propósito disso, portanto, a nota de J. C. Mariátegui sobre o fatalismo histórico do socialismo revolucionário na América Latina, como precondição da autêntica independência, tem o valor de um verdadeiro programa de ação. Caso contrário, não se estranhará que a modernização empreendida pelos regimes progressistas estanque subitamente, diante de reações retrógradas vindas de fora, provocadas pelas potências imperialistas, e de dentro, por setores associados da grande burguesia nacional; nem surpreenderá que a luta das classes atinja um grau explosivo, desdobrandose em situações potenciais de desintegração social e de guerra civil, velada ou aberta; e que o possível malogro dessas experiências progressistas ressuscite as velhas formas autocráticas do Estado policial burguês. A história contemporânea da Venezuela - a cujas décadas que encerraram o século $X X$ este estudo volta sua atenção - é hoje um exemplo eloquente desse quadro indefinido e instável, que se encontra às vésperas talvez de um ou de outro desfecho.

Compreendida em seus traços gerais, a evolução da economia petroleira venezuelana pode ser descrita esquematicamente em uma linha histórica que, primeiro, parte da franca subordinação dos interesses nacionais aos ditames do imperialismo norte-americano e europeu, impostos pelas grandes empresas petrolíferas transnacionais que se instalaram no país no início do século $X X$; segundo, passa pelas lutas em torno da defesa e da nacionalização da indústria petroleira, sobretudo nos anos 1970, e pela severa crise que fez ruir, embora sem eliminar, o modelo rentista nos anos 1980-1990, quando as contradições sociais

demais países não há opção dentro desse sistema que não o destino de países capitalistas dependentes que, embora ainda possam atravessar períodos relativamente curtos de crescimento - estimulados em alguma medida por políticas reformistas e modernizadoras - tendem, cada vez mais, a uma situação básica de estagnação e crise, em cujo contexto as possibilidades de desenvolvimento das etapas mais avançadas da industrialização, através da montagem do setor de bens de produção, são remotas. (BAMBIRRA, Vânia. O capitalismo dependente latinoamericano, p. 221). 
geradas por esse modelo econômico explodiram com uma gravidade surpreendente; e, terceiro, atinge, por fim, na primeira década deste novo século, um momento crucial de sua trajetória, delineado pela reorientação nacionalista $e$ integradora da política petroleira do governo de Hugo Chávez - cujas linhas mestras seguem mantidas por seu sucessor. Neste enclave petroleiro, o dilema nacional tem-se demonstrado, acima de tudo, na luta que a sociedade venezuelana trava em torno do controle nacional sobre a exploração das jazidas de hidrocarbonetos - eixo central do sistema produtivo do país e fonte principal das divisas nacionais. Além disso, essa luta espelha as fraturas existentes no âmago da sociedade venezuelana, na qual os setores ricos parecem preferir como meio de consolidar (e mesmo ampliar) seu poder político e econômico - a preservação e o estreitamento dos laços de sujeição em relação aos agentes externos da exploração econômica, participando, assim, como um sócio menor, mas não ínfimo, dos mecanismos de apropriação privada da riqueza nacional. Conquanto possa parecer contraditório, na Venezuela (como alhures), essa sujeição ao agente explorador externo tem sido, para esses setores abastados, um recurso eficiente em assegurar a hegemonia na condução do Estado venezuelano, transformando-o no principal aglutinador dos interesses dos vários setores da burguesia nacional - os empresários privados, a numerosa burocracia estatal (formada, especialmente após a nacionalização do petróleo em 1976, pelo setor composto por altos executivos da empresa estatal petroleira - PDVSA), o setor importador privado e os latifundiários - harmonizando-os com os interesses do capital estrangeiro no país.

A hegemonia política desses setores burgueses exerceu-se, entre 1958 e 1998, através de um sistema de concertação construído pelos dois maiores partidos políticos nacionais da época (Ação Democrática e Cope ${ }^{95}$ ), conhecido

\footnotetext{
${ }^{95} \mathrm{Em} 31$ de outubro de 1958, tendo já sido derrubada a ditadura de M. Pérez Jiménez (que esteve no poder entre 1952 e 1958) pelo movimento cívico-militar de 23 de janeiro, foi assinado o Pacto de Punto Fijo (ou Puntofijo), que resultou, por instâncias de Rómulo Betancourt, em um acordo entre os partidos Ação Democrática (AD), Comitê de Organização Política Eleitoral Independente (Copei) e União Republicana Democrática (URD). Pretendeu-se com isso instaurar no país uma condição estável de institucionalidade e de equilíbrio político entre as diferentes forças participantes do movimento de 23 de janeiro. Contudo, a exclusão do Partido Comunista da Venezuela (PCV), considerado de diretriz política excessivamente radical pelos pactuantes, somada à posterior retirada da URD, tornou o pacto um meio de garantir de facto a hegemonia bipartidária de elite AD-Copei. O pacto que, por fim, consolidou-se entre os dois partidos pôde contar também com o apoio das Forças Armadas, dos dignitários da Igreja Católica, e - o que
} 
como puntofijismo - um sistema através do qual ambas as organizações partidárias se alternaram na direção política do país sem, no entanto, alterar em substância as linhas básicas tradicionais da economia nem pôr em questão a condição de subordinação econômico-política ao exterior. Contando em sua base com tal esquema bipartidário, o Estado venezuelano - formalmente democrático e atuando como canalizador da renda petroleira - funcionou como um centro distribuidor de riqueza e de privilégios para os setores ricos, repartindo para cada um dos grupos sociais uma parcela do que o Estado auferia da tributação sobre o petróleo: financiamento e proteção ao empresariado privado, distribuição de cargos e posições entre a burocracia e os partidos dominantes, e até mesmo, nos momentos em que uma maior bonança das rendas petroleiras enchia o erário nacional, o provimento mais amplo de serviços públicos (educação, saúde, moradia etc.) para a população pobre. ${ }^{96}$ Assim, dessa "função distributiva" resultou a formação de uma desmesurada rede clientelista a entremear-se no

constituiu um respaldo de importância decisiva - dos dirigentes da Confederação de Trabalhadores da Venezuela (CTV) e da Fedecámaras, que reunia (como ainda hoje reúne) grande parte do empresariado do país (Cf., adiante, Cap. 4). A ascensão de Hugo Chávez à presidência da República, em dezembro de 1998, significou o fim desse bipartidarismo de quatro décadas. Esse período histórico (1958-1998), com seu sistema de aliança e alternância no poder (ainda que não formalizadas) pelos dois partidos majoritários, recebe de vários historiadores venezuelanos a denominação de democracia puntofijista. Ambos os partidos mantiveram também certa proximidade ideológica: a AD professava o ideário social-democrata e o Copei o democratacristão.

${ }^{96}$ Também a elite agrária venezuelana não se viu esquecida pelo regime puntofijista. Embora, desde meados da década de 1920, a ascensão do petróleo à posição de principal produto da economia venezuelana tenha posto em segundo plano a produção agrícola de exportação (quase toda de café e cacau), essa mudança esteve longe de eclipsar o poder político da oligarquia agrária do país. Em 1960, o governo de Rómulo Betancourt (da AD) promoveu uma reforma agrária que, oficialmente, visava realizar uma distribuição mais equitativa da propriedade fundiária e aumentar a produtividade das atividades agrícolas. No entanto, na prática, essa reforma preservou e mesmo ampliou o regime de grande propriedade, enquanto a omissão ou ineficiência da ação legal do Estado acabou por dar azo, no meio rural, à difusão da prática do sicariato. Ao longo dos 40 anos da democracia puntofijista, a propriedade da terra tendeu a se concentrar em menos mãos e a expulsar para o meio urbano a maior parte da população rural, cuja permanência nas pequenas propriedades se tornara inviável, entre outras razões, pela falta de financiamento público aos pequenos produtores. Segundo dados oficiais, em 1998, apenas $5 \%$ de proprietários rurais detinham $75 \%$ das terras cultivadas do país, enquanto $95 \%$ de pequenos produtores possuíam os outros $25 \%$ de terras. No Informe Anual de 2001, o Provea estimava: "(...) La transferencia más importante de tierra en los últimos cuarenta años se dio hacia los productores de entre 50 y 1.000 hectáreas, quienes de poseer un 20,3\% de la tierra (6,4\% entre 50 has. y 200 has. $+13,9 \%$ entre 200 h. y 1000 h.), pasaron a poseer un $42,8 \%(14.1 \%+28.7 \%)$. Las producciones de más de 1000 has. aumentaron en número (...) pero disminuyeron su superficie relativa del $71,7 \%$ al $46,4 \%$ (...). El proceso de reforma agraria implementado a partir de 1961 transfirió enormes cantidades de tierras a quienes no eran sujetos de ella. Los pequeños propietarios hacia quienes supuestamente iba dirigida la reforma agraria sólo pasaron de poseer el $4,9 \%$ de la tierra, a poseer el 5,7\%". (PROVEA. Informe Anual 2001. Disponível em http://www.derechos.org.ve/informes-anuales/informe-anual-2001/). 
Estado venezuelano, o qual, sem precisar apelar a regimes de exceção, logrou impor sutilmente à sociedade um quadro de autoritarismo civil, mantendo-o todavia sob a capa do direito - o que levou muitos a reconhecer na situação venezuelana a particularidade de persistir como "uma sociedade que alcançara a liberdade sem alcançar o desenvolvimento social". ${ }^{97}$ Desse modo, na Venezuela, uma democracia peculiar existiu ininterruptamente por quatro décadas sob a forma do que se denominou - tendo em vista os mecanismos de sustentação social - de "populismo de conciliação" 98 , erguido e mantido pela renda do petróleo. Tal democracia, contudo, não foi capaz de impedir que o aparelho estatal operasse com altíssimos níveis de corrupção administrativa, nem que as políticas sociais "populares" fossem abandonadas tão logo surgissem momentos de redução nas receitas do Estado. ${ }^{99}$ Do mesmo passo, quando as circunstâncias o ditaram, este Estado liberal-democrático também não hesitou em atuar como um agente violentamente repressor dos movimentos populares e, em especial, do movimento operário. Desde o início do regime, em 1958, e a despeito do caráter pretensamente "nacional e revolucionário" do movimento político que pôs fim à ditadura de M. Pérez Jiménez, o meio pelo qual o Estado diligenciou dar solução ao problema do crescente enfrentamento social foi invariavelmente a brutal

\footnotetext{
${ }^{97}$ Cf. PERDOMO, R. P. Venezuela 1958-1999: el derecho en una democracia renqueante, p. 647. A propósito dessa contradição, observa esse autor: "(...) un Estado clientelar en el grado en que llegó a ser el venezolano es incompatible con el comportamiento conforme a normas que caracterizaría al Estado de derecho. Para que el Estado clientelar funcione, las reglas tienen que ser flexibilizadas - hasta el grado de su desnaturalización - cuando no simplemente ignoradas. Esto es necesario para que el sistema de favores y privilegios pueda actuar sin mayores obstáculos". (p. 648)

98 "El eje de la construcción del "populismo de conciliación" fue el logro de una forma de atenuar el conflicto político; así como la renta petrolera atenuaba el distributivo, el sistema de concertación entre elites permitía asignar distribuciones de esta renta por medio de negociaciones y diversas formas institucionalizadas de participación en la toma de decisiones. Ello se logra reconociendo a los partidos políticos, y especialmente a los dos de centro, AD y COPEI, el rol de mediadores casi exclusivos entre todos los actores sociopolíticos. $Y$ este rol es alcanzado por la alternancia en el ejercicio del gobierno, acompañado de coaliciones temporales y de acuerdos institucionales para el reparto de las posiciones claves. Al ser los intermediarios inescapables del proceso de distribución de la renta, fueron alcanzando un poder muy superior al que tienen los partidos en un sistema político moderno. Los partidos penetraron, cuando no crearon directamente, sindicatos y gremios, que regularmente escogían a sus directivas entre listas presentadas abiertamente por aquellos. Hasta instituciones normalmente autónomas como la lglesia, los gremios empresariales y las Fuerzas Armadas fueron penetradas, con mayor o menor éxito, por las orientaciones partidistas". (CALCAÑO, Luís Gómez \& ARENAS, Nelly. ¿Modernización autoritaria o actualización del populismo? La transición política en Venezuela, p. 66-67)

${ }^{99}$ Cf. PERDOMO, R. P. Op. cit., p. 649-650.
} 
repressão política ${ }^{100}$, com a ilegalização dos partidos de esquerda, o controle coercitivo sobre os sindicatos e a eliminação dos grupos de guerrilha urbana e rural. ${ }^{101}$ Os extremos a que a violência oficial dessa democracia burguesa podia chegar ficaram claros quando, em fevereiro-março de 1989, em resposta aos protestos populares que irromperam por todo o país contra o encarecimento do custo de vida, o governo venezuelano (então sob a presidência de Carlos Andrés Pérez, da $A D$ ) perpetrou um dos mais atrozes episódios de repressão popular da história do continente (episódio conhecido como o Caracaço), em que centenas ou talvez milhares (os números nunca foram estabelecidos definitivamente) - de pessoas do povo foram sumariamente assassinadas por forças policiais e militares, incumbidas pelo Executivo nacional de restaurar a ordem pública, de qualquer modo e a qualquer preço.

Um segundo aspecto relevante, nesse período, do dilema da dependência estrutural diz respeito a outro de seus desdobramentos sociais, a saber, o dos limites de organização e autonomia que a classe trabalhadora nacional foi capaz de alcançar em relação ao Estado e às outras forças sociais. Deve-se recordar que as economias de enclave (principalmente as de tipo minerador/petroleiro) apresentam, em geral, a particularidade de estruturar-se com elevada concentração de capital, mas com baixa taxa de utilização de mão de obra. $\mathrm{Na}$ Venezuela, essa peculiaridade favoreceu, em meio a um contingente de trabalhadores industriais já por si pequeno ${ }^{102}$, a formação de uma aristocracia operária, incrustada no setor petroleiro, e da qual proviriam os quadros - e, por

\footnotetext{
${ }^{100}$ Cf. LANDER, Edgardo. Izquierda y populismo: alternativas al neoliberalismo. Transnational Institute. Octubre de 2004. Sobre o caráter repressor do Estado venezuelano já nos anos imediatos ao fim da ditadura de Pérez Jiménez, diz esse estudioso: "En un clima de amplia conflictividad social, en poco tiempo se va agudizando la confrontación entre un régimen político excluyente con estrechos márgenes de tolerancia para la disidencia y una izquierda crecientemente radicalizada. En el año 1960 se suspenden las garantías constitucionales y se clausuran los periódicos de izquierda. Los dirigentes sindicales de ésta son pasados al tribunal disciplinario de la CTV. La suspensión de garantías se reafirma el mismo día de la aprobación de la nueva Constitución en el año 1961. Bajo la influencia de la Revolución Cubana se inicia la lucha armada. Son inhabilitados el Partido Comunista de Venezuela (PCV) y el Movimiento de Izquierda Revolucionaria (MIR), primer desprendimiento de Acción Democrática". (p. 1)

${ }_{101}^{101}$ Cf., adiante, Cap. 4.

${ }^{102}$ No início da década de 1970, a população economicamente ativa venezuelana era de cerca de 3,1 milhões de trabalhadores, estando $23,8 \%$ deles empregados no setor secundário (aproximadamente 737.800). A população do país atingia então cerca de 10,4 milhões de habitantes. Estima-se que o número de desempregados alcançava, em 1970, entre 700 mil e 800 mil pessoas, ou seja, cerca de $30 \%$ da população economicamente ativa. (Cf. FIGUEROA, Federico Brito. Historia económica y social de Venezuela: Una estructura para su estudio. Caracas: Universidad Central de Venezuela, Ediciones de la Biblioteca, 1996, t. III, cap. XX.)
} 
extensão, a própria mentalidade política - das lideranças sindicais, cuja cúpula e estratos médios foram, desde cedo, amplamente atraídos e cooptados pelo esquema puntofijista de partidos. ${ }^{103}$ Enredadas na teia do Estado clientelar e vivendo em função de suas benesses, as principais organizações sindicais do país foram afastando gradualmente de suas preocupações as necessidades reais de representação dos trabalhadores. Por conseguinte, o enfraquecimento do poder da classe operária - provocado organicamente pelas distorções e desvios históricos da ação de sua própria liderança oficial, enrijecida em uma burocracia sindical cada vez mais assimilada ao Estado e aos partidos das elites venezuelanas - esteve na raiz do processo de deterioração de toda a vida democrática nos anos 1980 e 1990. Ao longo dessas duas décadas, a cooptação da burocracia sindical, embora não fosse um fenômeno absoluto no conjunto do movimento operário venezuelano, atingiu tão profundamente a organização política dos trabalhadores, que não se pôde esperar algo diferente de um processo simultâneo tanto de declínio rápido e acentuado das condições de vida dessa classe como de decomposição das próprias instituições democráticas oficiais, paulatinamente deslegitimadas e postas a serviço de um poder central crescentemente discricionário, que, em meados dos anos 80 , já se revelava incapaz de impedir que se esvaísse por completo a "atmosfera de riqueza e liberdade" da então apelidada Venezuela Saudita. A formação de uma aristocracia operária $^{104}$, longe de ser um fenômeno exclusivo das sociedades desenvolvidas,

\footnotetext{
${ }^{103}$ Esta cooptação foi profunda e evidente em relação à Confederação de Trabalhadores da Venezuela (CTV), principal central do país a reunir sindicatos de trabalhadores. A CTV se manteve vinculada por todo o período posterior a 1958 ao partido Ação Democrática, e enfrentou, igualmente, um processo de desgaste e perda de representatividade política nos anos 80 e 90 . Em 1998, após a vitória eleitoral de Hugo Chávez, a CTV permaneceu aliada à Fedecámaras (a maior organização patronal da Venezuela) na oposição ao governo bolivariano, tendo inclusive participado do golpe de Estado de abril de 2002 e da paralisação-sabotagem de 2002-2003. Seu poder e influência, depois disso, entraram definitivamente em declínio. Cf., entre outros, ITURRASPE, Francisco. El movimiento sindical venezolano en la época de la mundialización: la transición del "puntofijismo" al "bolivarianismo". Clacso, 2001. Disponível em: http:/l bibliotecavirtual.clacso. org.ar/ar/libros/garza3/iturraspe.pdf.

${ }^{104} \mathrm{Cf}$. LENIN, V. I. O imperialismo, etapa superior do capitalismo. (Prefácio às edições francesa e alemã) Lisboa/Moscovo: Editorial Avante - Edições Progresso, 1984, e TROTSKY, Leão. Os Sindicatos na Época da Decadência Imperialista, 1940. Disponível em: http://www.marxists.org/ portugues/trotsky/1940/mes/sindicato.htm. Nota este último: "(...) Aos olhos da burocracia sindical, a tarefa principal é "liberar" o Estado de suas amarras capitalistas, de debilitar sua dependência dos monopólios e voltá-los a seu favor. Esta posição harmoniza-se perfeitamente com a posição social da aristocracia e da burocracia operárias, que lutam por obter algumas migalhas do sobrelucro do imperialismo capitalista. Os burocratas fazem todo o possível, em palavras e nos fatos, para demonstrar ao estado "democrático" até que ponto são indispensáveis e dignos de
} 
provoca em países atrasados efeitos debilitantes sobre a massa trabalhadora que talvez sejam menos sensíveis em um operariado com maior grau de mobilização política, como ocorre em países europeus. Seja como for, essa "camada de operários aburguesados" (cf. Lênin), no caso venezuelano, ao buscar absorver os modos de vida e de consumo burgueses e as expectativas de uma ascensão social que os eximisse da condição de assalariados, acabou por legitimar as formas agudas de exploração da força de trabalho nacional, difundindo pela massa de trabalhadores os "ideais" próprios de uma mentalidade dependente, expressa sob a forma da adesão passiva ao modelo rentista do capitalismo venezuelano e à política de "conciliação" com os setores burgueses nacionais e estrangeiros. Por isso, não seria difícil entrever que o papel dessa aristocracia operária, combinado com a força de uma burocracia sindical ideologicamente afim, representaria um importante freio às mobilizações operárias e populares nos anos de crise que se seguiram aos booms petroleiros dos anos 1970. Neste sentido, o receio manifestado por L. Trótski a respeito dos países atrasados de que os sindicatos cooptados viessem a constituir "(...) ferramentas secundárias do capitalismo imperialista, para subordinar e disciplinar os operários e impedir a revolução" 105 revelaria ser plenamente justificado se aplicado à Venezuela dessas décadas finais do século XX. Além disso, considerados em uma perspectiva mais ampla, o distanciamento do sindicalismo oficial venezuelano em relação aos movimentos operários do resto do continente na conturbada década de 1970 e, em outro plano, a manifestação de nacionalismo exaltado que invadiu o país no período da expansão petroleira - e do qual não ficou imune o meio sindical podem ser remontados a essa consciência dependente, que concorreu de modo

confiança em tempos de paz e, especialmente, em tempos de guerra. (...) Os países coloniais e semicoloniais não estão sob o domínio de um capitalismo nativo, mas do imperialismo estrangeiro. Mas este fato fortalece, em vez de debilitar, a necessidade de laços diretos, diários e práticos entre os magnatas do capitalismo e os governos que deles dependem, nos países coloniais e semicoloniais. À medida que o capitalismo imperialista cria nas colônias e semicolônias um estrato de aristocratas e burocratas operários, estes necessitam o apoio dos governos coloniais e semicoloniais, que desempenhem o papel de protetores, de patrocinadores e às vezes de árbitros. Esta é a base social mais importante do caráter bonapartista e semibonapartista dos governos das colônias e dos países atrasados em geral. Essa é também a base da dependência dos sindicatos reformistas em relação ao Estado". Na Venezuela, a vinculação entre o imperialismo (exercido pelas multinacionais petroleiras), o Estado clientelar e a burocracia sindical é um elemento-chave para a compreensão das condições de dependência estrutural e de subdesenvolvimento que imperaram ao longo de todo o século XX e marcam ainda hoje o caráter dos desafios históricos com que a sociedade venezuelana se defronta.

105 TROTSKY, Leão. Os Sindicatos na Época da Decadência Imperialista. (1940) 
ideologicamente retrógrado para que persistisse a condição de heteronomia estrutural. (Deve-se assinalar que essa consciência dependente é produto do longo e danoso estado de sujeição das estruturas econômica e sociopolítica nacionais a empresas e capitais e a padrões socioculturais estrangeiros, e constitui uma atitude mental coletiva inclinada a valorizar a própria condição de subordinação, vendo nela oportunidades de construir uma sociedade moderna e democrática sem, contudo, tocar nos fundamentos estruturais da dependência, nem, evidentemente, considerá-los como tais. Essa atitude ideológica tem sua origem na propaganda cavilosa de autopromoção que empresas e governos imperialistas realizam nos meios sociais que subjugam; com o passar do tempo, certos grupos sociais dominados vão, por assim dizer, sublimando os efeitos ruinosos da dominação e transformando-os em alguma forma de virtude ilusória. Ocorre, então, a interiorização ideológica da dependência por aqueles que, em princípio, deveriam combatê-la. Consuma-se assim, no plano das representações sociais, o equivalente da associação subordinada dos interesses políticoeconômicos das elites nacionais com os grupos monopolistas estrangeiros.) Uma das expressões desse tipo de consciência obnubilada, surgida na Venezuela dos anos da "euforia petroleira", foi a proposição do excepcionalismo venezuelano, o qual, elaborado teoricamente por estudiosos acadêmicos, exprimiu também um certo "espírito geral da sociedade venezuelana" (na verdade, de seus setores privilegiados), iludida pela crença em realizar "a harmonia social e o bem-estar geral", derivando-os da prodigalidade supostamente inexaurível do subsolo rico do país.

Porém, a realidade da dependência tinha uma face bem menos sedutora que isso. O "adequado funcionamento" do Estado democrático venezuelano, que, como se disse, as organizações operárias submissas ajudaram a construir em aliança com os partidos das elites nacionais, não impediu que fosse irrompendo, desde o início dos anos 1980, um agudíssimo processo de exclusão social da grande maioria da população. A partir desses anos, a miséria foi emergindo sem mais disfarces no cenário nacional, agravada pelos desequilíbrios financeiros do início da década e, subsequentemente, pelo peso crescente da dívida externa sobre as contas do Estado - ambos fatores que se refletiram, de imediato, no nível de emprego e no poder aquisitivo da população trabalhadora. Entre 1983 e 
1999 (com curtos lapsos de ínfima recuperação), o povo venezuelano se viu fustigado por uma cruel pauperização, acentuada pela sucessão de desastrosos programas de reforma econômica, entre os quais os de linha neoliberal (aplicados a partir de 1989), que coroariam o descalabro do modelo petroleiro rentista, capaz então apenas de aumentar a concentração de renda e a dependência tecnológica em relação ao exterior. Nesses anos, enquanto as elites políticas demoravam-se a discutir a necessidade de "reformar o Estado" ${ }^{106}$ (que elas passaram inopinadamente a reconhecer como corrupto e ineficiente), a sociedade se cindia cada vez mais em dois blocos desiguais e antagônicos. A polarização social, que fora mais ou menos escamoteada nos anos de expansão da economia, ganhava agora relevo e anunciava o início do desmoronamento do sistema político baseado no pacto das elites e dos grupos cooptados. A sociedade exibia, de um lado, a imensa parcela empobrecida do país, marginalizada das decisões políticas e a cada dia mais despojada de recursos elementares da existência material. Eis uma eloquente retratação dessa situação de penúria em sua fase mais avançada, ao final dos anos 1990:

Em junho de 1997, de um total de 4.740.250 lares, 2.122.016 achavam-se em situação de pobreza, e 895.542 deles em situação de pobreza extrema. Isto quer dizer que $44,76 \%$ dos lares venezuelanos não contavam com uma renda suficiente para satisfazer suas necessidades básicas, e 18,89\% não chegavam a satisfazer suas necessidades alimentícias. O Provea ${ }^{107}$ calculou, em relação ao ano de 1998, que $15 \%$ dos venezuelanos se encontravam em condição de pobreza atroz [!], entendendo-se por essa categoria a que abrange os que vivem ao relento e se acham excluídos de qualquer política social. Em termos de deterioração dos serviços

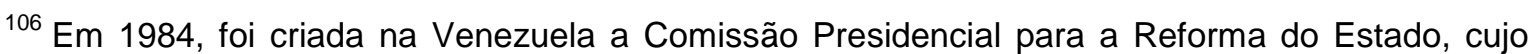
objetivo prioritário era a descentralização do poder, vista pelos próprios partidos hegemônicos como a forma ideal de sanar o problema da corrupção no aparelho do Estado e torná-lo mais democrático. Sobre as limitações reais dessa reforma, observou-se: "Em uma sociedade cada vez mais caracterizada pelo apartheid social - que assumia a forma de uma severa exclusão econômica, de fissuras culturais e de identidades individuais e coletivas diferenciadas - as reformas político-institucionais não podiam representar senão uma limitada e parcial contribuição à construção de um sistema político nacionalmente integrado. De um ponto de vista jurídico e institucional, eram necessários novos mecanismos efetivos de incorporação e participação. Além de medidas para descentralizar o Estado, essas reformas incluíam eleições diretas para prefeitos e governadores e promoveram o surgimento de novas lideranças locais e regionais, o que trouxe um ar renovado ao sistema político do país. (...) Não obstante, o processo de exclusão econômica e social provou ser muito mais poderoso do que o efeito democratizante dessas reformas políticas." (LANDER, E. "Venezuela: conflito social em um contexto global", In: BENEDITO, F. (org.). Venezuela: Temas contemporâneos. São Paulo, 2011)

107 Programa Venezolano de Educación-Acción en Derechos Humanos.
} 
públicos, como educação e saúde, $70 \%$ dos estudantes que ingressavam na educação primária não chegavam a concluir o nono ano, e 8 em cada 10 alunos que entravam na universidade provinham da educação privada. Nas áreas em que residia a população mais pobre, a taxa de mortalidade infantil era 2,5 vezes mais alta que as taxas nacionais. A esperança de vida ao nascer do estrato $V$ (o mais pobre) era 12 anos menor do que a dos estratos I e II. O Ministério da Saúde e Assistência Social estimou que, na época, $30 \%$ da população não tinham acesso aos serviços de saúde. Tudo isso revelava um quadro de profunda exclusão, assim como um cenário pouco propício para abrigarem-se expectativas de melhoria. $^{108}$

Do outro lado da sociedade, quedava-se a minoria abastada, senhora do aparelho estatal, e atada à associação com o capital imperialista forâneo. Conquanto o modo dessa associação permitisse à burguesia e aos estratos inferiores aliciados participar a contento da pilhagem da riqueza nacional gerada pela exploração do trabalho e da natureza, o caráter dependente de sua base material condicionou a configuração de uma sociedade estruturalmente imperfeita, cuja tendência à autodesagregação ia-se patenteando toda vez que o paroxismo das crises econômicas a inclinasse ao aniquilamento dos já frágeis vínculos entre as classes sociais. Eis de novo aqui a questão mais candente, visto que é justamente nesse caráter inconcluso da estrutura de classes que reside a mais grave expressão dos problemas relativos à condição de dependência dos países periféricos. Em poucas palavras, trata-se do problema de se as sociedades dependentes e subdesenvolvidas são ou não historicamente viáveis enquanto sociedades de classes. ${ }^{109}$ Considerando-se que nessas sociedades, as classes dominantes não puderam (como ainda não podem) completar motu proprio o ciclo de "construção da Nação" - no sentido de engendrar condições elementares aceitáveis de participação das classes trabalhadoras e das massas populares na condução do Estado, na posse de parcelas adequadas da renda e da riqueza nacional e no gozo dos mínimos direitos civis - aquelas se veem

\footnotetext{
${ }^{108}$ MAYA, Margarita López. Luta hegemônica na Venezuela. A crise do puntofijismo e a ascensão de Hugo Chávez, pp. 189-190. Considere-se, para uma melhor noção dessas porcentagens, que a população venezuelana era, em 1999, de aproximadamente 24 milhões de habitantes, estando cerca de $86 \%$ deles vivendo em cidades.

${ }_{109}$ Para a questão fundamental da viabilidade histórica das sociedades de classes em países subdesenvolvidos, cf. FERNANDES, Florestan. Sociedade de classes e subdesenvolvimento, pp. 21-102. Em uma perspectiva teórica próxima, consulte-se também SANTOS, Theotônio dos. Democracia e socialismo no capitalismo dependente. Petrópolis: Vozes, 1991.
} 
obrigadas a enfrentar as reações das classes excluídas através do entrincheiramento egoístico em um Estado que, literalmente, arma-se contra sua própria população nacional. É então razoável que esta, sob a pressão da miséria e da exclusão, não possua, em última análise, outro desígnio senão destruir per fas et nefas a organização da sociedade de classes, seus princípios normativos e a superestrutura política excludente. ${ }^{110}$ (Persiste sendo um reflexo dessa insanável clivagem social o fato de que, aos olhos das classes privilegiadas, toda a ação disruptiva dos grupos excluídos assuma sempre as formas impatrióticas da subversão, do terrorismo e/ou do vandalismo - e como tais, precisem ser energicamente reprimidas.) Por isso, o grau de consciência dessas maiorias exploradas e oprimidas dita os tipos de reação social e sua eficácia política - tipos que vão desde explosões espontâneas de fúria popular (quase sempre suscitadas por condições extremas de privação material; apresentam-se, em geral, desarticuladas entre si, e desencadeiam as formas mais selvagens de repressão oficial) até movimentos insurrecionais liderados por grupos ideologicamente mais bem preparados, que, não raro, contam com franco apoio popular. ${ }^{111}$ No caso específico da Venezuela, pois, cabe indagar: quais alternativas reais podem-se divisar para o dilema da dependência, cuja gravidade é acentuada pelo gênero de sistema produtivo de enclave? No esforço por construir-se uma sociedade democrática, pode o modelo de capitalismo venezuelano ser reformado ao ponto de criar-se no país algo semelhante a um novo tipo de Estado de bem-estar social, apoiado no controle estatal da exploração petrolífera nacional? Em caso negativo, possuem os grupos sociais expropriados e oprimidos da ordem burguesa os meios para assumir o papel de protagonistas em movimentos contra

\footnotetext{
110 Tratando do alcance possível da democracia liberal nos países dependentes, sobretudo quando comparada a dos países avançados, nos quais já se consumou a etapa das revoluções nacionais, assinala F. Fernandes: "(...) As maiorias oprimidas e descontentes não são contidas pela cultura política imperante, válida para as minorias privilegiadas e instrumentais para a defesa de uma determinação de classe rígida e dos interesses econômicos, culturais ou políticos externos. Essas minorias monopolizam por largo tempo privilégios antinacionais e, frequentemente, antissociais, desmoralizando o capitalismo, o Estado capitalista e os ideais democráticos puramente burgueses. (...) Nesse contexto, o Estado não podia ser, efetivamente, nem nacional nem democrático. Uma evolução nesse sentido significaria que os privilégios das minorias dominantes - urbanas, semiurbanas e rurais - se veriam ameaçados e, por sua vez, não poderiam continuar instrumentais para o sistema de poder do capitalismo mundial". (FERNANDES, Florestan. Brasil: em compasso de espera, p. 118-9.)

${ }_{111} \mathrm{Na}$ Venezuela, o Caracaço, de 1989, e os dois levantes militares de 1992 contra Carlos Andrés Pérez são exemplos, respectivamente, desses tipos de reação social. Veja-se, adiante, o Cap. 6.
} 
a ordem capitalista? Essas indagações, que, como se vê, nada têm de inéditas, voltaram a ser feitas com renovada veemência no fim do século $X X$.

De fato, na última década e meia, o quadro histórico nacional ganhou alguns contornos novos. A sociedade venezuelana tem conhecido, desde 1999, sob a condução política progressista de Hugo Chávez (e, hoje, de seus herdeiros bolivarianos), alguns avanços sociais e políticos importantes - inegáveis, por exemplo, na redução significativa dos níveis sociais de pobreza e de pobreza extrema, no aprimoramento dos mecanismos de representação e participação política das massas populares, e na difusão de ideais de organização e conscientização socialistas da sociedade. ${ }^{112}$ A economia, por sua vez, também experimenta certas mudanças positivas - marcadas, em especial, pelo maior controle estatal sobre a atividade petroleira (através da ampliação do controle governamental sobre a estatal PDVSA - Petróleos de Venezuela S.A.) e pela destinação de maiores volumes orçamentários a políticas sociais básicas. Isso tem despertado, por um lado, o entusiasmo das camadas sociais pobres quanto às possibilidades de aumentar sua participação na posse e fruição da riqueza social; e tem suscitado, por outro, o descontentamento das elites nacionais, há muito habituadas, juntamente com as grandes empresas estrangeiras, à cúpida partilha privada dessa riqueza proporcionada pelo petróleo. ${ }^{113}$ Neste cenário novo, tanto o entusiasmo de uns como o descontentamento de outros refletem-se no crescente consenso de que, ao nível regional presente (e afora Cuba), o governo bolivariano representa (principalmente após o golpe de Estado sofrido em abril de 2002, quando ficaram claras as restrições que a burguesia venezuelana e seus associados norte-americanos desejam impor ao projeto nacionalista-popular chavista, o que cobrou deste uma postura de maior definição ideológico-política) o mais prevalente regime de confrontação com as ideias e as

\footnotetext{
${ }^{112}$ Em janeiro de 2005, no V Fórum Mundial de Porto Alegre, Hugo Chávez declarou que seu governo doravante se nortearia pelo ideal de construção de um "socialismo do século XXI". O principal documento oficial em que se formularam publicamente as diretrizes político-econômicas de acordo com essa nova orientação são as Líneas Generales del Plan de Desarrollo Económico y Social de la Nación 2007-2013 (disponível em http://www.cenditel.gob.ve/node/343), editado em setembro de 2007.

${ }_{113}$ Veja-se uma excelente discussão sobre os ganhos sociais e políticos da Revolução Bolivariana, com ou sem Hugo Chávez, em ELLNER, Steve. Um chavismo sem Chávez é possivel? Le monde diplomatique Brasil. 02/09/2012. Disponível em: http:/l www.diplomatique.org.br /artigo.php?id=1258.
} 
práticas do neoliberalismo e do capitalismo selvagem. ${ }^{114}$ Para muitos estudiosos, o interesse da atual experiência venezuelana (como, semelhantemente, a experiência de Cuba no passado) reside justamente na perspectiva, primeiro, de que a Revolução Bolivariana constitua um caminho viável na luta contra o imperialismo e contra o avassalamento das economias periféricas ${ }^{115}$; e, segundo, de que o socialismo do século XXI, dela originado, conquanto ainda dúbio, possa transformar-se em um projeto histórico de verdadeira modernização democrática. Isso talvez explique por que não poucos intelectuais e políticos estrangeiros, ao passar pelo país, deixam-se convencer de que, de fato, respira-se hoje na Venezuela uma atmosfera auspiciosa de conquistas democráticas, que o governo bolivariano, aliás, tem sabido aproveitar politicamente com habilidade, e que as urnas - no que possam significar enquanto expressão legítima da vontade popular - têm sucessivamente ratificado. ${ }^{116}$

Mas, apesar dessas boas impressões, todo aquele que atente para a situação do país dificilmente não reconhecerá que a sociedade venezuelana encaminha-se para um novo período de turbação social. Vários estudiosos têm notado, com inquietação, a intensificada polarização que, ao longo dos últimos anos, vem crispando ainda mais as relações de classes, de modo tal que os protestos sociais e os índices crescentes de insegurança e violência urbanas passaram mesmo a servir de motivo recorrente nas críticas ao governo por parte dos grupos políticos de oposição. ${ }^{117}$ Diferentemente, porém, das alegações (feitas

\footnotetext{
${ }^{114}$ Essa é também a opinião expressa, por exemplo, em BORÓN, Atilio. Socialismo siglo XXI: ¿Hay vida después del neoliberalismo? Buenos Aires: Luxemburg, 2008; e em WOODS, Alan. La revolución bolivariana. Un análisis marxista. Madrid: Fundación Federico Engels, 2005.

115 Cf. o artigo PETRAS, James. Obama's War in the Western Hemisphere and Venezuela's National Liberation Struggle. Global Research, March 16th 2015. Disponível em: http:// venezuelanalysis.com/analysis/11274.

${ }^{116}$ A reeleição de Hugo Chávez, vitorioso contra Henrique Capriles (da MUD - Mesa da Unidade Democrática) na eleição presidencial de 8 de outubro de 2012, foi vista por seus aliados políticos (Cristina Kirchner, Evo Morales etc.) como um indicativo da força presente do ideal nacionalista ("dito anti-imperialista") na América Latina. Na conjuntura política incerta que se seguiu, a comoção provocada pelo doloroso passamento do presidente recém-eleito foi um ingrediente a mais no movimento que garantiu, a despeito da intensa propaganda oposicionista, a permanência do bolivarianismo chavista no poder. $\mathrm{Na}$ prática, a eleição de Nicolás Maduro estende $\mathrm{o}$ reconhecimento popular formal ao governo bolivariano até, pelo menos, 2019. Além disso, em 16 de dezembro de 2012, nas eleições para governos estaduais, o PSUV obtivera uma vitória esmagadora ao eleger representantes para 20 dos 23 Estados venezuelanos, e obter a maioria parlamentar em 22 dos 23 conselhos legislativos estaduais (poder legislativo estadual). (Cf. http://www.cne.gob.ve/ resultado_regional_2012/r/1/reg_000000.html).

${ }_{117}$ De fato, em 2012, por exemplo, houve um significativo aumento da taxa anual de assassinatos na Venezuela, que atingiu 73 mortes por cada 100 mil habitantes - uma das mais altas do mundo
} 
principalmente por setores sociais médios e altos) de que a desagregação social e a hostilidade entre as classes resultam da "demagogia incendiária e divisionista" dos chavistas, esse novo ciclo explosivo da história venezuelana constitui, na verdade, a culminância de contradições históricas que se avolumaram ao longo das últimas décadas - contradições, ressalte-se, geradas por um longevo padrão de estruturação socioeconômica monopolista, concentrador, excludente $e$ superexplorador. ${ }^{118}$ As iniquidades sociais assim acumuladas lançam hoje as massas populares - em uma conjuntura política reconhecidamente de menor repressão oficial, mas, ao mesmo tempo, de reação dos setores ricos (somandose ainda a circunstância do desapontamento popular diante das vacilações do regime chavista em aplicar os pontos mais radicais do programa dito socialista) para a contraviolência e para a rebelião contra a ordem social, estejam essas massas suficientemente organizadas ou não. De fato, o equilíbrio de forças sociais internas e externas é, no presente, tão instável que toda previsão sobre o desenrolar histórico da Revolução Bolivariana comporta, inevitavelmente, algo de temerário. O certo, apenas, é que, neste futuro imediato, as vitórias ou derrotas do povo venezuelano serão também vitórias e derrotas de toda a América Latina - e da viabilidade de sua democracia.

Por fim, para encerrar esta Introdução, uma consideração de ordem metodológica: todas essas questões teóricas e práticas nas quais até aqui nos demoramos - e que poderiam parecer, à primeira vista, dispensáveis ao tratarmos nosso objeto - foram discutidas com o fim não só de compor o pano de fundo histórico do assunto que passamos a estudar, mas também - e sobretudo - de atender aos quesitos vinculados à opção epistemológica e ideológica que fizemos e que deve fazer todo pesquisador trabalhando em sociedades subdesenvolvidas, condenadas ainda a viver em estado de flagrante injustiça social - ou seja, a opção pela proletarização de sua consciência social e profissional, de sua atitude

e o dobro da média latino-americana - e transformou esse ano no mais violento da história do país. Nas campanhas eleitorais para a presidência da República, em 2012 e 2013, o assunto se transformou em um dos mais evocados na propaganda oposicionista da MUD, e embora tenha claramente, nestes casos, servido apenas a propósitos eleiçoeiros, o problema da criminalidade social é um dos maiores desafios postos ao governo bolivariano, bem como um índice importante das limitações de que padece seu projeto oficial de transformações sociais. (Cf. CARLSON, C. Venezuela continues to search for solutions to high crime rate. Venezuelanalysis.com, 02/02/2013. Disponível em: http://venezuelanalysis.com/news/7668.)

${ }_{118}$ Cf. essa adjetivação para as sociedades dependentes em SANTOS, Theotônio dos. Democracia e socialismo no capitalismo dependente, p. 117. 
política e de seu trabalho intelectual, intentando dar ao conhecimento científico assim alcançado pela investigação teórica a função precípua de contribuir à formação da base cognitiva para a difícil mas necessária tarefa de construção da consciência crítica das classes exploradas e excluídas dessas sociedades relativamente às estruturas e mecanismos de perpetuação daquela injustiça. ${ }^{119}$ Com efeito, é preciso e desejável ver prevalecer como um postulado fundamental à verdadeira pesquisa acadêmica que, quanto mais agudas se revelarem as condições de miséria, opressão e alienação nas sociedades subdesenvolvidas, tanto maior seja a convicção com que o pesquisador atrele a orientação e os resultados de seu trabalho à causa democrática da luta e emancipação das classes populares frente às iniquidades sociais que as afligem. Essa atitude, ao contrário de pôr em risco a objetividade e o rigor científico da pesquisa, confere a ela uma função crítica que, de outro modo, a sujeitaria ao desatino da conivência e da alheação diante do dramático estado de coisas que permanece inseparável, em nosso continente, do capitalismo dependente. Cumpre à universidade, em especial, não voltar as costas à contradição em que se vive hoje entre os valores da ordem moral e ética própria da democracia (mesmo em sua limitada concepção liberal) e as insuficiências da organização da produção material da sociedade, provocadoras de graves injustiças sociais. Fazê-lo seria também fechar os olhos ao viso aristocrático de uma instituição que, na América Latina, ainda não se libertou totalmente da herança senhorial da cultura letrada para cá transplantada desde os tempos coloniais. Ademais, seria pueril esperar que, hoje, a superação do subdesenvolvimento se realize unicamente pela ação - cingida aos limites da institucionalidade vigente - dos grupos políticos progressistas se sobre eles não se exercerem a vigilância crítica e a pressão política por parte das classes trabalhadoras e populares, as quais, para isso, precisam achar-se razoavelmente instruídas e conscientes. Eis uma contribuição relevante a que a

\footnotetext{
${ }^{119}$ Cf. FERNANDES, F. A sociologia numa era de revolução social. Rio de Janeiro: Zahar, 1976. Florestan Fernandes definia assim um dos dilemas de consciência com que se deparavam, outrora como hoje, os cientistas sociais na América Latina: "(...) Continuaremos a produzir um conhecimento insensível aos aspectos mais profundos e dinâmicos do controle dos problemas sociais pelo homem - e então manteremos também o nosso conformismo diante dos inconvenientes da situação imperante. Ou produzimos o tipo de conhecimento exigido pela intervenção racional nos problemas sociais humanos - e então seremos levados a refletir criticamente sobre os fatores que perturbam o uso social construtivo dos conhecimentos sociológicos na sociedade em que vivemos". (p. 138)
} 
investigação acadêmica não deve furtar-se, sob pena de identificar os frutos de seu trabalho à apologia das arbitrariedades da ordem social presente. Nas últimas duas décadas, o assim denominado pensamento único deu à grande parte da produção acadêmica dos países avançados e atrasados um nocivo caráter asséptico, pretendendo despi-la de todo teor crítico que pudesse apontar as deficiências e as contradições do projeto histórico neoliberal. Nos dias que correm, contudo, o clamoroso malogro desse projeto e a soma de penúria e de sofrimento social que o acompanha nos países atrasados exigem do pesquisador, como sua obrigação social, esse exercício racional da crítica. Neste sentido, portanto, a sempre alegada neutralidade científica não obsta, de modo algum, ao engajamento no combater, onde ocorra, a falsificação da realidade histórica.

Com essas preocupações em vista, o presente trabalho procura estudar especificamente uma das fases da economia petroleira da Venezuela - a segunda fase das acima referidas - na qual o dilema entre a soberania e a dependência assomou a um ponto decisivo, e que desafortunadamente se resolveu em favor da segunda condição. Trata-se da fase que cobre, em primeiro lugar, os anos da euforia petroleira (1973-1984) - quando os booms do petróleo (em 1973 e 1979) e a nacionalização da indústria (em 1976) suscitaram uma atmosfera altamente promissora para o país, fazendo acreditar a muitos que a dependência e o subdesenvolvimento poderiam ser vencidos em definitivo através do controle nacional sobre a exploração dos hidrocarbonetos; e, em segundo, os anos de declínio (1984-1998), que comportaram uma série de crises financeiras, para as quais os sucessivos governos tentaram encontrar solução progressivamente na direção das prescrições neoliberais, que se lançavam avassaladoras então sobre todo o continente. A política de Abertura Petroleira desses anos correspondeu, no plano nacional, à tendência geral de dar-se prioridade à "livre empresa" e às "leis de mercado" como mecanismos de regulação da economia. Na realidade venezuelana, essa política - vista quase consensualmente como modernizadora - assestou, no entanto, ao país o golpe de um grave aprofundamento de seu atraso econômico, o que logo ficaria evidenciado em um dos mais desastrosos cenários de miséria e de desigualdade social do continente. Como referimos acima, quando, em 1989, o fundo sombrio desse cenário já se delineava, a exasperação das camadas pauperizadas 
assumiu a forma de uma vultosa rebelião popular, que foi impiedosamente debelada pela força repressiva do Estado. Este fato, mais que qualquer outro, iria tornar-se, em sua tragicidade dantesca, uma autêntica revelação do valor da "democracia" venezuelana. Nesse mesmo clima, em 1992, precipitaram-se nos meios militares dois movimentos conspiratórios (em fevereiro e novembro) contra o governo de Carlos Andrés Pérez, organizados respectivamente por oficiais de baixa e de alta patentes. Ambos fracassariam logo aos primeiros passos. Porém, a despeito do fracasso dos levantes militares e do anterior esmagamento da revolta popular, o ambiente de efervescência social permaneceu acirrado, indicando o início da ruína da "conciliação de classes" e da hegemonia política dos partidos tradicionais AD e Copei. Quando a eleição presidencial de dezembro de 1998 encerrou de vez a vigência do esquema puntofijista, o emergir de novas forças políticas assinalou o começo de um tempo com novas promessas, mas que tinha diante de si, em verdade, a reproposição do antigo dilema nacional autonomia/dependência. Seu desenlace, hoje ainda bastante incerto, acha-se talvez a meio caminho, e, como dissemos, alimenta certo otimismo justificável entre o grosso da sociedade. Daí sobejarem motivos - teóricos e práticos - para que sejam consideradas com atenção, na Venezuela do quartel final do século $\mathrm{XX}$, as condições históricas que ajudaram a conformar esse dilema. 


\title{
Parte I: A Venezuela Saudita: os anos da "euforia petroleira" e a questão da dependência estrutural (1973-1984)
}

\author{
"Nos próximos dois decênios a Venezuela poderá ter saltado a \\ barreira que separa subdesenvolvimento de desenvolvimento, \\ sendo quiçá o primeiro país da América Latina a realizar essa \\ façanha, ou terá perdido sua chance histórica."
}

(Celso Furtado, Notas sobre a economia venezuelana, 1974)

"(...) dentro do capitalismo, só existem saídas, na América Latina, para as minorias ricas, para as multinacionais, para as nações capitalistas hegemônicas e sua superpotência, os Estados Unidos".

(Florestan Fernandes, A sociologia no Brasil, 1977)

No pensamento econômico e sociológico do último meio século na América Latina, desenvo/vimento/subdesenvolvimento não constituiu uma concepção unânime ou unívoca. Esse binômio, derivado do pressuposto teórico da existência de níveis diferentes, mas inseparáveis e complementares, da evolução das formações econômico-sociais modernas, adquiriu significados diversos conforme seus inúmeros estudiosos, havendo a variação semântica obedecido sobretudo às divergências acerca das causas das dissimetrias entre os países e acerca dos meios de superação histórica do problema. Grosso modo essas divergências podem ser agrupadas segundo três grandes linhas de interpretação, que sucessivamente predominaram na produção científico-institucional do continente: a nacional-desenvolvimentista, de matriz cepalina; a dependentista, de inspiração marxista; e a neoliberal, de influência monetarista. ${ }^{120} \mathrm{~A}$ primeira, produto dos

\footnotetext{
${ }^{120}$ A descrição dessas três linhas é meramente esquemática e não leva em conta nem a rica diversidade interpretativa dentro de cada linha nem a existência concomitante de outras linhas interpretativas importantes (como o liberalismo tradicional ou o socialismo dos partidos comunistas e social-democratas), nas quais a questão do desenvolvimento/subdesenvolvimento também era discutida. Para estudos mais detalhados sobre o desenvolvimentismo da Cepal, a teoria da dependência e o neoliberalismo, cf., entre outros, COLISTETE, Renato Perim. $O$ desenvolvimentismo cepalino. Revista de Estudos Avançados. vol.15, oํ 41, São Paulo, Jan./Apr. 2001; BRESSER-PEREIRA, Luiz C. "Do ISEB e da CEPAL à teoria da dependência". In: TOLEDO, Caio N. (org.) Intelectuais e política no Brasil: A experiência do ISEB. Rio de Janeiro: Editora Revan, 2005, pp. 201-232; VALENCIA, Adrián. Teoria da dependência e desenvolvimento do capitalismo na América Latina. Londrina: Canal 6, 2008; MANTEGA, Guido. Teoria da dependência revisitada. EAESP/FGV/NPP - Núcleo de Pesquisas e Publicações, № 27/1997; VILLARREAL, René. A contrarrevolução monetarista. Teoria, política econômica e ideologia do neoliberalismo. RJ: Record, 1984; KATZ, Claudio \& COGGIOLA, Osvaldo. Neoliberalismo ou crise
} 
estudos empreendidos pela Comissão Econômica para a América Latina (CEPAL, criada pela ONU em 1948), teve seu apogeu nos anos 1950 e 1960, e ainda gozava de grande prestígio nos meios governamentais durante a década de 1970. A segunda, nascida em um cenário dominado por ferozes ditaduras militares de direita, foi elaborada, em grande parte, como resposta às insuficiências teóricas e práticas do desenvolvimentismo, e notabilizou-se por conferir importância decisiva ao estudo da dependência estrutural dos países periféricos, vista como um impedimento incontornável à superação do subdesenvolvimento se combatido apenas no âmbito da própria economia capitalista. A terceira corrente, muito menos acendrada enquanto formulação científica da realidade socioeconômica do que as duas precedentes ${ }^{121}$, experimentou, no entanto, uma impetuosa ofensiva a partir de meados dos anos 1980, quando foi então capaz de impor sua hegemonia tanto na definição da maioria das políticas econômicas oficiais da região, quanto na "reconstrução" do pensamento acadêmico em seguida à crise ideológica do fim do socialismo real. As três linhas de interpretação, hoje com relevâncias diferentes e apresentando traços de renovação teórica ${ }^{122}$, mantêm certo grau de

do capital? SP: Xamã, 1996; e SANTOS, Theotônio dos. Do terror à esperança: auge e declínio do neoliberalismo. SP: Ideias \& Letras, 2004.

${ }^{121}$ De fato, já se observou várias vezes que, no pensamento econômico burguês, o neoliberalismo ocupa antes um papel de simples "receituário" do que propriamente de um conjunto orgânico de proposições e ideias fundamentadas em um método científico (ou, ao menos, assim considerado). É, pois, patente sua inferioridade teórica (e ideológica) quando comparado ao liberalismo clássico: "(...) Não se trata mais, portanto, da ideologia como falsa consciência que marcou a natureza do liberalismo enquanto verdadeira doutrina social em sua primeira fase e que teve como nomes de destaque Locke e Mill. O que percebemos agora é o tom característico do sermão religioso, do discurso dogmático que exige rendição incondicional. (...) Muito mais incisivo, por isso, do que o liberalismo original, o neoliberalismo demonstra uma capacidade insuspeitada de ocupar todos os espaços, de não dar lugar ao dissenso. Confirmando sua natureza de puro receituário econômico destinado a recolocar o mercado no lugar que de direito the pertence, essa característica onipresente do neoliberalismo tem levado, no limite, a transformar o processo politicamente moderno de nossas sociedades em meros rituais vazios, sem nenhuma importância, processos que nada modificam o curso inexorável da marcha econômica". (PAULANI, Leda M. Modernidade e discurso econômico. São Paulo: Boitempo, 2005, p. 126.)

${ }^{122}$ Por exemplo: colhida pelo vórtice neoliberal dos anos 1990, a Cepal foi renunciando ao seu ideário nacional-industrialista, passando então a reconhecer a "inevitabilidade histórica da globalização" e aproximando-se, ainda que com alguma reserva, das formulações pragmáticas neoliberais. Veja-se como prova disso o documento Globalização e desenvolvimento (Brasília: CEPAL, 2002). Nele se afirma: "(...) A globalização oferece, sem dúvida, oportunidades para 0 desenvolvimento. Compreendemos que as estratégias nacionais devem ser desenhadas em função das possibilidades apresentadas, assim como os pré-requisitos para uma maior incorporação à economia mundial. Simultaneamente, este processo traz riscos originados de novas fontes de instabilidade (tanto comercial quanto, e em especial, financeira), riscos de exclusão para aqueles países não adequadamente preparados para as fortes demandas de competitividade próprias do mundo contemporâneo, e riscos de acentuação da heterogeneidade estrutural entre setores sociais e regiões dentro dos países que se integram, de maneira 
influência no âmbito político-intelectual da América Latina - destacadamente a terceira, que, a despeito de seu caráter de "recurso de crise" ${ }^{123}$ político-ideológico posto em uso pelas potências imperialistas, ainda dita grande parte das linhas de ação dos governos latino-americanos, progressistas ou não.

A teoria desenvolvimentista, surgida no pós-guerra, empregava o conceito de subdesenvolvimento para denotar um nível específico de evolução próprio dos países que compunham a periferia do capitalismo, cujas condições socioeconômicas eram contrapostas às do centro, desenvolvido e formado por economias modernas industrializadas. Um nível intermediário, resultante da formidável intensificação das inter-relações dos dois polos desde a Revolução Industrial (e especialmente a partir da segunda metade do século XIX), constituíase de nações que, à medida que iam erigindo núcleos industriais nacionais com crescente complexidade e autonomia (p. ex., Canadá, Nova Zelândia, Austrália etc.), tendiam a se aproximar do grau de progresso dos países centrais. Para os desenvolvimentistas, essa proposição de etapas sucessivas de desenvolvimento significava um recurso duplamente importante: por um lado, permitia conferir fundamento teórico à relação estreita - e determinante - entre a industrialização e o substancial desenvolvimento econômico e tecnológico (como também social, político e cultural) dos países centrais; e, por outro, indicava, em contraste, os desafios que os países atrasados deveriam enfrentar em sua marcha histórica. $\mathrm{Na}$ raiz do subdesenvolvimento, estava, para esses estudiosos, o fato de que as nações pobres, cujas origens modernas prendiam-se ao processo de expansão colonialista das potências europeias nos albores do capitalismo, não haviam conseguido eliminar (mesmo após a emancipação política) suas deficiências

segmentada e marginal, à economia mundial. Muitos destes riscos acompanham duas características preocupantes do atual processo de globalização. A primeira é o desvio que se observa na globalização dos mercados: junto com a mobilidade dos capitais, bens e serviços, existem fortes restrições à livre mobilidade da mão de obra. Isto se reflete no caráter assimétrico e incompleto da agenda internacional que acompanha a globalização, que não inclui, por exemplo, temas como a mencionada mobilidade de mão de obra, nem mecanismos que garantam a coerência global das políticas macroeconômicas das economias centrais - pautas internacionais para obter uma adequada tributação do capital e acordos de mobilização de recursos para compensar as tensões distributivas que a globalização gera, tanto entre os países como no interior deles" (p. 13-14. Grifo nosso.). Tais afirmações contrastam fortemente com o tom autonomista do discurso cepalino dos anos 1950-70.

123 "(...) O caráter disparatado das forças neoliberais torna evidente que não nos encontramos face a uma ofensiva política ordenada e coerente, mas diante de um recurso de crise aplicado pelo conjunto das forças (de qualquer orientação política ou cor ideológica) comprometido com o capital e com o imperialismo" (COGGIOLA, O. "Neoliberalismo: futuro do capitalismo?", in: KATZ, C. \& COGGIOLA, O. Neoliberalismo ou crise do capital?, p. 199) 
estruturais, mantendo-se, até ao presente, dependentes de capitais, de mercados e de tecnologia dos núcleos capitalistas avançados. No caso da América Latina, as economias tinham diante de si o entrave de estruturas produtivas pouco diversificadas e insuficientemente associadas aos setores primário-exportadores os quais, por sua vez, e a apesar de serem, em geral, os setores principais da economia nacional, permaneciam atados a sistemas produtivos arcaicos. Tal dissociação entre setores de produção era apontada como um fator-chave explicativo do baixo progresso técnico e do emprego precário de mão de obra, esta sempre em nível insuficiente para permitir um crescimento contínuo dos salários reais e a constituição de um mercado consumidor expressivo. ${ }^{124} \mathrm{Mas}$, em que pesasse à má herança da formação colonial, os desenvolvimentistas partiam do pressuposto fundamental (implícito, por exemplo, na própria obra inaugural de Raúl Prebisch, O desenvolvimento econômico da América Latina e alguns de seus principais problemas, de 1949) segundo o qual o atraso e a dependência na periferia eram, em essência, condições transitivas e, como tais, suscetíveis de serem superadas no âmbito do próprio sistema de produção capitalista - desde que um amplo planejamento estatal estabelecesse uma política efetiva de industrialização, de modernização tecnológica e de fomento do mercado interno, conjugada ainda à integração regional e ao desenvolvimento social, através dos quais se corrigissem também as dissimetrias entre as regiões de um mesmo país e os fortes desequilíbrios de renda e de propriedade entre suas classes sociais. ${ }^{125}$ Por conseguinte, o cerne da proposta cepalina de desenvolvimento jazia na combinação em substituir progressivamente 0 consumo de produtos manufaturados importados por produtos nacionais (incentivando-se para isso a industrialização autóctone), em procurar refrear a especialização econômica (visível na predominância maciça de exportações de produtos primários), em proteger o mercado interno e, por fim, em desenvolver uma demanda efetiva significativa e sustentada, que traduzisse, ao mesmo tempo, o crescimento real

\footnotetext{
${ }^{124}$ Cf., por exemplo, SUNKEL, Oswaldo. O marco histórico do processo desenvolvimento/ subdesenvolvimento. RJ: Unilivros, 1980, p. 7-12. (A 1a edição, em espanhol, do ILPES (Chile), é de 1967.)

${ }^{125}$ Cf. PREBISCH, Raúl. El desarrollo económico de la América Latina y algunos de sus principales problemas. (originalmente mimeografado: Santiago, CEPAL, 1949). Reedição em Desarrollo Económico, Vol. 26, No. 103. (Oct. - Dec., 1986), pp. 479-502. Disponível em: http://links.jstor.org/sici?sici=0046-001X\%28198610\%2F12\%2926\%3A103\%3C479\%3AEDEDLA \%3E2.0.CO\%3B2-P. (http://www.jstor.org; Thu Dec 28 10:23:33 2006).
} 
do poder de compra da maioria da população (com a consequente elevação dos seus padrões de vida) e a atenuação das disparidades nos níveis de distribuição social da renda nacional. Além disso, nessa perspectiva, os investimentos estrangeiros (especialmente diretos) constituiriam um valioso apoio à modernização tecnológica, submetendo-se essas inversões a uma estratégia de desenvolvimento impulsionada a partir da associação entre os Estados nacionais (como gestores dos recursos materiais e financeiros) e as empresas multinacionais (como difusoras do progresso técnico). Por esses meios, enfim, esperava-se reduzir o problema primordial da deterioração dos termos de intercâmbio, necessariamente desfavorável, a médio e longo prazo, às economias de base primário-exportadora. ${ }^{126}$

Discordantes dessa concepção gradualista de desenvolvimento, os teóricos dependentistas $^{127}$ preferiam considerar a dependência estrutural (e seu fenômeno correlato, o subdesenvolvimento) como uma especificidade histórica da periferia capitalista, a qual, em sua inserção subalterna na divisão internacional do trabalho, achava-se rigidamente condicionada tanto pelo modo de dominação e expansão do capitalismo central - em seu propósito de realizar a acumulação de capital em escala mundial - como pela natureza das alianças que as burguesias nacionais periféricas firmavam com o grande capital internacional para estabelecer as formas de sua associação e da partilha da riqueza material

${ }^{126}$ Cf., por exemplo, FURTADO, Celso. A economia latino-americana. $2^{\underline{a}}$ ed. São Paulo: Cia. Editora Nacional, 1978. Vejam-se, especialmente, os cap. XII a XVI. (A 1a edição é de 1969.)

${ }^{127} \mathrm{~A}$ "escola dependentista" esteve longe de constituir um grupo homogêneo de investigadores, ainda que, evidentemente, possa-se identificar nela um conjunto comum de conceitos e categorias básicas de análise. Bresser-Pereira (op. cit., pp. 219-226) considera a existência de três vertentes da teoria da dependência: a original, ortodoxamente marxista; a da dependência associada, cuja formulação básica está na obra de Fernando H. Cardoso e E. Faletto (Dependência e desenvolvimento na América Latina); e a nacional-dependente - na qual ele próprio, Bresser, se inclui. A distinção prática entre elas se encontra na diferença de premissas adotadas por cada uma quanto à existência ou não, nos países atrasados, de uma burguesia nacional capaz de realizar por si mesma uma "revolução democrática" e empreender um desenvolvimento autenticamente endógeno, em confronto aberto com o imperialismo dos países centrais. ( $\mathrm{Na}$ historiografia venezuelana, duas obras clássicas que adotam a perspectiva da dependência são: ZAVALA, D. F. Maza. Venezuela: una economía dependiente. (Instituto de Investigaciones Facultad de Economía, UCV, 1964; e FIGUEROA, Federico Brito. Historia económica y social de Venezuela. Una estructura para su estudio. Caracas: Venediciones, 1973.) Adicionalmente, é possível rejeitar a tese de que não existe uma teoria da dependência - como pretende demonstrar Luiz T. Machado, alegando que, nos países subdesenvolvidos latino-americanos, "[d]esde o início, a dependência está nas relações internacionais de domínio e submissão no sistema de interdependências. Não há, pois, mesmo teoricamente, como passar da teoria econômica do subdesenvolvimento para uma teoria da dependência, uma vez que a dependência antecede $o$ subdesenvolvimento". (MACHADO, Luiz Toledo. A teoria da dependência na América Latina. São Paulo: Estudos Avançados, 13 (35), 1999, p. 200.) 
produzida nessas sociedades. ${ }^{128}$ Tal partilha - em verdade, uma apropriação dual e desigual do excedente econômico ${ }^{129}$, da qual cabia, é claro, a parcela menor às burguesias periféricas - atuava internamente como uma força de inibição a qualquer iniciativa social criadora por parte das burguesias nacionais, o que as diferenciava de suas congêneres europeias e norte-americana, possuidoras, por exemplo, de melhores recursos de negociação com as classes sociais inferiores. Sintomático da força desse padrão de apropriação era o fato de que, na América Latina, a associação desigual redundasse inevitavelmente na permanência tanto das estruturas internas tradicionais de dominação de classe quanto das externas, de controle dos recursos financeiros e tecnológicos, o que, no plano concreto, fez frustrarem-se todos os projetos de emancipação econômica nacional onde eles surgiram (apesar de algumas experiências de industrialização e modernização relativas, como no Brasil, Argentina e México), e promoveu um rigoroso afastamento das elites periféricas em relação às classes dominadas de seus países, impondo irremediavelmente a essas sociedades uma eterna situação de instabilidade e de incompletude da integração social - o que inexistia, em grau tão elevado, nos países desenvolvidos. Um outro elemento fundamental da teoria da dependência atribuía ao imperialismo, praticado pelas potências centrais como uma força subjugadora combinadamente econômica e militar - e cujas "células" basilares são as corporações multinacionais ${ }^{130}$ - o papel de agente principal da imposição e preservação das condições de subordinação. Nesse sentido, a recorrente ingerência externa operaria como uma causa permanente de desestabilização política, levando, a intervalos curtos, ao rompimento da ordem institucional nessas sociedades subdesenvolvidas. A par desse problema político, o endividamento público crônico, associado aos déficits sucessivos da balança de

\footnotetext{
128 "O reconhecimento da historicidade da situação de subdesenvolvimento requer mais do que assinalar as características estruturais das economias subdesenvolvidas. Há que se assinalar, com efeito, como as economias subdesenvolvidas vincularam-se historicamente ao mercado mundial e a forma em que se constituíram os grupos sociais internos que conseguiram definir as relações orientadas para o exterior que o subdesenvolvimento supõe". (CARDOSO, F. H. \& FALETTO, Enzo. Dependência e desenvolvimento na América Latina. Rio de Janeiro: Civilização Brasileira, 2004, p. 39. (A 1a edição (de Zahar Editores) é de 1970.)) Há também um subdesenvolvimento do mundo socialista, que constituiu objeto de estudo secundário dos autores dependentistas latino-americanos.

${ }^{129}$ Cf. FERNANDES, Florestan. Capitalismo dependente e classes sociais na América Latina. A 1 ${ }^{\text {a }}$ edição é de 1973 (Zahar Editores).

${ }_{130}$ Cf. SANTOS, Theotônio dos. Imperialismo e corporações multinacionais. Rio de Janeiro: Paz e Terra, 1977.
} 
pagamentos, e a perda de divisas sob a forma de importações de tecnologia agravariam os desequilíbrios econômicos e repercutiriam nos níveis nacionais de desemprego e subemprego. O diagnóstico de amplitude estrutural assim feito levou os teóricos da dependência (em particular, os de maior convicção socialista) a reconhecer que a reprodução, em escala internacional, das relações sociais de exploração capitalistas e a formação dos fortes vínculos de subordinação e solidariedade de interesses das classes governantes periféricas com os centros de dominação imperialista conduziam à impossibilidade de superação da condição de atraso através de políticas de desenvolvimento gradual encerradas nos limites do modo capitalista de produção. Reconhecia-se, desse modo, que o problema do subdesenvolvimento não se limitava à "insuficiência de modernização", nem que era preciso "vencer uma etapa inferior" - como implicitamente admitiam as proposições cepalinas - porque os dinamismos de expansão em economias dependentes, quando ocorriam, acabavam por converter-se automaticamente em fontes de novo incremento dos volumes do excedente econômico nacional transferidos para as economias centrais. Por extensão, o subdesenvolvimento também envolvia necessariamente o conflito entre as classes sociais nacionais em torno da produção e da distribuição da riqueza social bem como do acesso ao controle do Estado. Derivava disso que a luta contra a dependência precisava travar-se em torno da construção de uma sociedade de democracia ampliada, que alcançasse satisfatoriamente o conjunto das classes trabalhadoras e as massas populares e, ao mesmo tempo e obrigatoriamente, se fundasse em uma economia autônoma. Era de esperar, por isso, que todo esse imperativo trouxesse a alternativa socialista revolucionária ao centro das discussões e a impusesse à consciência das classes dominadas (e a seus grupos políticos) como o único recurso possível ao rompimento efetivo da sujeição interna e externa, e, por conseguinte, do subdesenvolvimento.

As concepções desenvolvimentistas e dependentistas tiveram influência considerável sobre os rumos da política e da economia na América Latina nos anos 1950-1970. ${ }^{131} \mathrm{O}$ nacional-desenvolvimentismo representou a síntese, no plano teórico-científico, das crescentes reivindicações autonomistas dos países

\footnotetext{
${ }^{131}$ Ao neoliberalismo, a terceira linha mencionada, serão dedicadas algumas linhas no início da Parte II, adiante.
} 
periféricos frente aos problemas gerados por uma divisão internacional do trabalho que se reconfigurara no pós-guerra, mas não alterara substancialmente a condição de subalternidade dessas antigas formações coloniais. Representou, igualmente, a construção de uma "nova consciência latino-americana" ${ }^{132}$, e foi a suma mais bem elaborada do radicalismo burguês em seu curto elã emancipacionista no continente. ${ }^{133}$ A teoria da dependência, por sua vez, tendo sido impulsionada, a certa altura, pelos bons êxitos sociais da Revolução Cubana, vicejou em um contexto histórico de crescente conscientização revolucionária, no qual muitos já se haviam persuadido das limitações insolúveis do capitalismo dependente. Daí repontar a opção pela revolução socialista como uma ilação teórica e prática. Mas, ao final e apesar de tudo, tanto as teses dependentistas como as cepalinas acabariam sendo duramente obliteradas pela onda de regimes autoritários que varreu a região a partir de meados da década de 1960. Essa reação, obedecendo à férrea lógica imperialista, significou o revide das potências hegemônicas (especialmente os EUA) ao avanço do nacionalismo latinoamericano (sob qualquer de suas formas) e demonstrou, outrossim, a preferência da maior parte das elites nacionais da região por uma "modernização segura" de tipo autoritário e associado.

A partir do que foi exposto, será porventura instrutivo considerar como essas ideias de autonomia e desenvolvimento se comportaram em um ambiente no qual, em princípio, tudo se revelava infenso a elas, ou seja, a economia petroleira venezuelana, que, já na década de 1970, constituía um dos "casos extremos" ${ }^{134}$ de dependência externa e de atraso na América Latina, mas que, em contraste, se singularizava, naquele momento, pela institucionalidade não interrompida de sua vida política e, mesmo, por certa "euforia geral" em torno de

\footnotetext{
${ }^{132}$ FURTADO, Celso. Op. cit., p. 5.

${ }^{133}$ Não obstante isso, afirmava um importante crítico, em 1972: "(...) Com seus estereótipos de "desenvolvimento autossustentado", "internalização do centro de decisões", "integração nacional", "planejamento", "interesse nacional", a teoria do subdesenvolvimento sentou as bases do "desenvolvimentismo", que desviou a atenção teórica e a ação política do problema da luta de classes, justamente no período em que, com a transformação da economia de base agrária para industrial-urbana, as condições objetivas daquela se agravavam. A teoria do subdesenvolvimento foi, assim, a ideologia própria do chamado período populista; se ela hoje não cumpre esse papel é porque a hegemonia de uma classe se afirmou de tal modo que a face já não precisa de máscara." (OLIVEIRA, Francisco de. A economia brasileira: crítica à razão dualista. Estudos Cebrap (2), 1972. Disponível em: http://www.cebrap.org.br/v2/files/upload/biblioteca_virtual/ a economia_brasileira.pdf.) F. de Oliveira se refere aqui especificamente ao caso brasileiro.

${ }^{134}$ A expressão é de CARDOSO, F. H. \& FALETTO, Enzo. Op. cit., p. 39.
} 
possibilidades reais de progresso e enriquecimento social. Realmente, na Venezuela, o altíssimo grau de controle estrangeiro das decisões sobre a produção nacional e a proporção gigantesca da transferência ao exterior do excedente econômico interno foram responsáveis por delinear um cenário com todos os traços daquilo que expressivamente mutatis mutandis chamou-se de condição colonial permanente. ${ }^{135}$ Essa condição, alterável em seus elementos acidentais, mas intangível em sua estrutura e funcionamento essenciais, caracteriza-se não só pela longa e estéril inércia das políticas econômicas e sociais que o Estado e as elites governantes adotam diante do problema do subdesenvolvimento, mas também pela força dos mecanismos que, ao mesmo tempo, reproduzem indefinidamente o quadro de dependência e suprimem todas as tentativas de autonomização - em flagrante desacordo com os próprios ideais proclamados de modernização. Esses mecanismos são de ordem vária, e visto funcionarem, muitas vezes, sem interferência externa direta, apontam o compromisso, tácito ou não, que as elites nacionais possuem com as forças externas de perpetuação do atraso e da dependência. Alguns desses mecanismos, estatais ou privados, pertencem aos típicos aparelhos ideológicos e repressivos da sociedade capitalista, que, na periferia dependente, conjugam formas bem pouco sutis de manipulação ideológica e de bárbara opressão político-social. Em seu conjunto, esses aparelhos marcam, por um lado, o caráter deficiente das formas de pensamento e representação social da realidade histórica que as classes dominantes possuem e que elas se esforçam por impor a toda a sociedade; marcam, por outro, a limitação, como dissemos, que essas mesmas classes fixam à democracia e ao exercício dela pelas classes inferiores da sociedade. No que toca em particular às formas de pensamento e representação social, é lícito afirmar que, se a visão de mundo da burguesia constitui (em termos mannheimianos) uma ideologia (em oposição às utopias revolucionárias ${ }^{136}$ ) e, como tal, ressente-se de ser uma falsa consciência da realidade social que a gera e condiciona, constitui característica não incomum do capitalismo dependente a ocorrência de um rebaixamento ainda mais grave dessa

\footnotetext{
${ }^{135}$ FERNANDES, F. Sociedade de classes e subdesenvolvimento, p. 26.

${ }^{136} \mathrm{Cf}$. MANNHEIM, Karl. Idéologie et utopie. Une introduction à la sociologie de la connaissance. Paris: Librairie Marcel Rivière et Cie., 1956. (Tradução francesa). Disponível em: http://www.uqac.uquebec.ca/zone30/Classiques_des_sciences_sociales/index.html.
} 
consciência nas elites periféricas - um aviltamento mental no qual, amiúde, a consciência oscila confusamente entre o obscurecimento na compreensão lógica do real e o puro embuste com o qual pretendem essas elites, enquanto classe no poder, disfarçar as contradições e os conflitos da ordem social por elas construída. Na Venezuela dos anos 1970, um exemplo significativo desse tipo de consciência obtusa (que, em anos seguintes, chegaria a penetrar em alguns grupos acadêmicos) difundiu-se por toda a sociedade ao ponto de tornar-se parte do "senso comum" e, mesmo, de modelar certa "tradição teórica". Trata-se da concepção de que a aparente ausência de conflitos sociais graves, ao lado da suposta estabilidade política e do caudaloso afluxo de divisas do petróleo, outorgava à Venezuela a condição de uma democracia excepcional no conjunto da América Latina. Essa imagem, presumivelmente corroborada pela inexistência de radicalismos de esquerda e de direita, pretendia fazer crer que, após 1958, o "pacto da sociedade" em torno da democracia e da equidade social propiciadas pelo desenvolvimento nacional funcionaria como um lenitivo eficiente às divergências e diferenças sociais e raciais do país. Subjacentemente, no plano econômico, a conjugação da gerência da exploração petroleira pelo Estado com o recurso à atividade e à tecnologia das empresas estrangeiras era imaginada como o modo mais racional e mutuamente benéfico na relação do país com as grandes economias mundiais - sobretudo os EUA. Se, por um lado, essa última ideia acabou, na prática, por reduzir consideravelmente o influxo do conteúdo nacionalista das propostas desenvolvimentistas e dependentistas no cenário venezuelano, por outro, a crença em uma "democracia excepcional" exprimiu toda a força ideológica da condição de dependência. A esse último assunto é dedicado o primeiro capítulo. 


\section{Cap. 1: O "excepcionalismo" da Venezuela democrática}

Quase concomitante aos primeiros sinais da crise estrutural da economia capitalista mundial, a eclosão da crise energética no princípio dos anos 1970 trouxe o efeito de ampliar a importância geopolítica dos países exportadores de petróleo, ao mesmo tempo que, ao nível nacional, deu oportunidade a que ganhassem projeção os debates políticos em torno de maior controle estatal sobre a exploração de hidrocarbonetos. No cenário internacional da época, marcado por crescente demanda de petróleo ${ }^{137}$ e por conflitos militares nas regiões produtoras meso-orientais, os anos de 1973 e 1979 assinalaram a decisão dos países-membros da OPEP ${ }^{138}$ de adotar fortes e progressivos aumentos nos preços do barril exportado. Em 1974, o barril de petróleo passaria a custar mais do triplo do que ao início da década (de US\$ 3.42 subiria para US\$ 10.35) e atingiria quase US $\$ 20.00 \mathrm{em} 1979^{139}$, configurando-se assim, no comércio mundial, "(...) a mais radical transferência de riqueza jamais ocorrida sem guerra". ${ }^{140} \mathrm{Na}$ Venezuela, no auge da euforia provocada pelo dilúvio de

\footnotetext{
${ }^{137}$ Após a II Guerra, uma das razões que conduziram os EUA à hegemonia econômico-militar mundial foi ter o país conseguido impor a substituição do carvão pelo petróleo como base energética da grande indústria europeia. Além do impulso que isso deu às empresas petroleiras norte-americanas, lograva-se desarticular a bem organizada e contestadora classe dos trabalhadores do setor carbonífero. (Cf. MEZGER, Dorothea. "Crisis energética y nueva división internacional del trabajo. In: KAPLAN, M. (coord.). Petróleo y desarrollo en México y Venezuela. México, D.F.: Editorial Nueva Imagen, 1981, pp. 83-111.) Neste início de século XXI, os derivados de petróleo e o gás natural respondem ainda por cerca de $58 \%$ do consumo final mundial de energia, com crescente demanda relativa desse último. (Cf. IEA. World Energy Outlook 2009.) Veja-se também, adiante, o Cap. 3.

${ }^{138}$ A Organização dos Países Exportadores de Petróleo (OPEP) foi fundada em setembro de 1960, na Conferência de Bagdá. Sua criação correspondeu ao propósito desses países de contrabalançar a política de controle mundial de preços praticada pelo cartel das "sete irmãs", então as sete maiores empresas petrolíferas do mundo (Standard Oil of New Jersey, Standard Oil of New York, Standard Oil of California, Royal Dutch Shell, Anglo-Persian Oil Company, Texaco e Gulf Oil). Os membros fundadores da OPEP foram Irã, Iraque, Kuwait, Arábia Saudita e Venezuela, aos quais se juntaram depois Qatar (1961), Indonésia (1962), Líbia (1962), Emirados Árabes Unidos (1967); Argélia (1969), Nigéria (1971), Equador (1973), Gabão (1975) e Angola (2007). Hoje a OPEP possui 12 países membros (em negrito).

${ }^{139}$ A adoção dessa política de elevação de preços esteve relacionada, em 1973, ao embargo da produção para o Ocidente em razão do conflito árabe-israelense do Yom Kipur; em 1979, a Revolução Islâmica no Irã atingiu drasticamente a produção petrolífera desse país (então o $2^{\circ}$ maior exportador da OPEP); em seguida, o Irã enfrentaria uma longa guerra com o vizinho Iraque; em 1990, outra crise seria provocada pela invasão do Kuwait por Saddam Hussein e o consequente conflito com o Ocidente. Essa instabilidade política no Oriente conferiu à Venezuela, distante dos conflitos, uma grande importância estratégica no comércio petroleiro com os EUA e a Europa. (Cf. YERGIN, Daniel. La historia del petróleo. Buenos Aires: Javier Vergara Editor, 1992.) ${ }_{140}$ KARL, Terry Lynn. The Paradox of Plenty. Oil Booms and Petro-States. California: University of California Press, 1997, p. 3.
} 
"petrodólares", duas expressões antagônicas (emblemáticas ambas de noções diversas de desenvolvimento) espelhavam o ânimo do país: Carlos Andrés Pérez, então presidente da República, declarara exultante: "Um dia, vocês americanos vão dirigir carros cujos para-choques serão feitos com nossa bauxita, nosso alumínio e nosso trabalho. E então seremos um país desenvolvido como vocês". Opostamente, diante da bonança que se espalhava, Juan Pablo Pérez Alfonso, antigo ministro do petróleo durante o governo de Rómulo Betancourt (1959-1964) e fundador da OPEP, advertia: "Estamos afogando-nos nos excrementos do diabo". ${ }^{141} \mathrm{O}$ entusiasmo do presidente prevaleceria sobre a preocupação do ministro, e seria partilhado por muitos venezuelanos, que passaram a crer de boafé que a riqueza natural do país constituía uma fonte inesgotável de proventos para toda a sociedade. Significativamente, poucos se arriscavam a dizer que o frenesi nacional representava talvez não mais que uma visão exígua da noção de desenvolvimento que defendiam os setores da burguesia associada venezuelana, atuantes no Estado.

Foi, pois, nessas circunstâncias históricas que prosperou a crença de que a Venezuela ocupava uma posição privilegiada no cenário internacional - posição que the conferiria um caráter excepcional quando considerada contra o pano de fundo das ditaduras militares e da crise econômica geral na região. A visão de certa singularidade nacional difundiu-se, na conjuntura favorável do petróleo, estimulada por promessas e por anseios de prosperidade dos setores de classe média e alta, e foi ostensivamente promovida pelos governantes através dos

\footnotetext{
141 Ambas as declarações foram feitas em entrevistas concedidas a Terry Lynn Karl, respectivamente em 1979 e 1978, e reproduzidas em sua obra atrás citada. Uma terceira visão (mais antiga e da qual era bastante próxima a de Pérez Alfonso), que se tornou excepcionalmente recorrente nas discussões sobre o papel histórico do petróleo na Venezuela (e que persiste até os dias atuais) diz respeito à possibilidade de "semear o petróleo", ou seja, de aproveitar a riqueza transitória advinda do comércio do petróleo para lançar os fundamentos de uma industrialização diversificada e autônoma, bem como empreender a exploração racional da terra com vistas a prover as necessidades alimentares básicas do país. A expressão "sembrar el petróleo" foi cunhada por Arturo Úslar Pietri, em um artigo publicado em 1936, no qual exortava: "(...) Urge crear sólidamente en Venezuela una economía reproductiva y progresiva. Urge aprovechar la riqueza transitoria de la actual economía destructiva para crear las bases sanas y amplias y coordinadas de esa futura economía progresiva que será nuestra verdadera acta de independencia. Es menester sacar la mayor renta de las minas para invertirla totalmente en ayudas, facilidades y estímulos a la agricultura, la cría y las industrias nacionales. Que en lugar de ser el petróleo una maldición que haya de convertirnos en un pueblo parásito e inútil, sea la afortunada coyuntura que permita con su súbita riqueza acelerar y fortificar la evolución productora del pueblo venezolano en condiciones excepcionales." (PIETRI, A. U. Sembrar el petróleo. Ahora, 14/07/1936. Disponível em: http://www.analitica.com/bitblioteca/uslar/sembrar_el_petroleo.asp. Grifos nossos.)
} 
meios de comunicação e da propaganda dos órgãos oficiais (em especial, nos anos da presidência de C. A. Pérez). ${ }^{142}$ Mas, foi como uma formulação teóricosociológica, de certo sucesso dentro e fora do país, que essa percepção adquiriu status "científico", passando então a forjar internacionalmente a imagem de um país próspero e estável, e, ao mesmo tempo, reinterpretando em termos de excepcionalidade a história passada da Venezuela. Construía-se assim a tese do excepcionalismo venezuelano. ${ }^{143}$ Esta, segundo seus proponentes ${ }^{144}$, afirmava que a evolução histórica contemporânea da Venezuela transcorrera (principalmente após a instauração do novo regime político em $1958^{145}$ ) de um modo tal que propiciara a singularidade de - sem a necessidade da ocorrência tumultuosa de uma revolução social (do tipo, por exemplo, da cubana ${ }^{146}$, que

\footnotetext{
${ }^{142} \mathrm{Em}$ outro registro, rememorando suas impressões juvenis da época, dizia uma escritora venezuelana: "(...) me parecía que la promesa se estaba haciendo verdad ante mis ojos. ¿Qué veía? Pues veía que el número de universidades había crecido notablemente, y que en las aulas de la que yo estudiaba - una privada, la Universidad Católica Andrés Bello - se mezclaban las clases sociales, las procedencias y los géneros. Veía que lo que después supe se llamaba movilidad social era un hecho incontestable; veía que el país se podía cruzar por nuevas vías de comunicación y se inauguraban grandes obras de infraestructura; veía que los jóvenes nos divertíamos sin temor a la inseguridad y que se transformaban los rígidos códigos morales; veía que nacían instituciones culturales y podíamos disfrutar de cine y libros cosmopolitas. (...) A la par que veíamos los signos del progreso también era evidente que la pobreza arrastrada históricamente continuaba. Sin embargo, aquellas carencias, en aquel momento, parecían hechos superables, temas no resueltos, pero con esperanza de serlo en la promesa de Venezuela como un gran país, es decir, un país que cumpliría para todos porque marchaba en constante ascenso, y más todavía cuando, al cruzar la frontera de los años 70, se desató la lluvia petrolera." (TORRES, Ana T. Memorias de una venezolana de la democracia. Conferencia inaugural de la Cátedra Venezuela. Caracas: Universidad Metropolitana, 28/02/2008.)

${ }^{143}$ Ainda hoje essa ideia de excepcionalismo histórico reaparece de vez em quando na vida venezuelana, ocupando a mente de alguns intelectuais e publicistas, quer na forma de categoria sociológica (considerada ainda válida para explicar o passado recente do país), quer como recurso retórico (eficiente por ser seu significado imediatamente percebido e aceito pelo leitor comum venezuelano). Cf., por exemplo, os artigos Robert Kaufman: adiós al excepcionalismo venezolano, una mirada a América Latina, de Michael P. Becerra (Analítica.com, 01/07/1999), e El eterno excepcionalismo venezolano. Latinoamérica parece enrumbada a la estabilidad. ¿Será Venezuela la excepción?, de Francisco París (El Universal, 31/10/2006). Nos meios acadêmicos, no entanto, a teoria excepcionalista é hoje inexpressiva, e a ascensão do chavismo, ao revalorizar o papel das classes populares na história recente do país, tem favorecido o revisionismo das interpretações que se baseavam na tese excepcionalista. Um estudioso especialmente dedicado a esse revisionismo é Steve Ellner, da Universidade de Oriente.

${ }^{144}$ Veja-se a relação bibliográfica dos estudos que formularam a "tese excepcionalista", bem como dos recentes trabalhos que avaliam criticamente essa tendência teórica, em ELLNER, Steve \& SALAS, Miguel T. Venezuela: Hugo Chávez and the decline of an "exceptional democracy". Lanham: Rowman \& Littlefield Pub., 2007, sobretudo o Cap. 1.

${ }_{145}^{145}$ Veja-se a nota 95, supra.

${ }^{146}$ Quanto aos reflexos da Revolução Cubana na vida política venezuelana, nota um historiador: "Nunca un tema de política internacional ha creado mayores conflictos y movido mayores pasiones en la historia venezolana como el de Cuba revolucionaria, en la década de los años sesenta". (VELÁSQUEZ, Ramón J. et alii. Venezuela moderna: Medio siglo de historia. $2^{\mathrm{a}}$ ed. Barcelona: Editorial Ariel, 1979, p. 252). Embora esta afirmação se refira propriamente aos anos de 1960, seu
} 
vinha então inspirando movimentos radicais por todo o continente e, em consequência, convulsionando as relações entre as classes sociais), $e$ combinando-se a uma contínua expansão da capacidade produtiva do setor petroleiro - haverem-se alcançado as condições políticas e materiais para que se realizasse efetivamente o crescimento sustentado do país e, ao mesmo tempo, se implantasse uma política social capaz de abarcar satisfatoriamente todas as camadas sociais. Figurava evidente que, naqueles anos difíceis, nenhuma outra nação na América Latina gozava de um tal privilégio. Além disso, a orientação socialdemocrata do regime ${ }^{147}$, que paulatinamente se tornara hegemônica a partir dos sucessos de 1958, quando a vida nacional vira o fim dos sucessivos regimes autocráticos militares (J. Vicente Gómez, López Contreras, Medina Angarita, M. Pérez Jiménez) favorecera de modo decisivo o desenvolvimento socioeconômico ao outorgar ao Estado a tarefa de promover uma modernização de tipo democrático $^{148}$, diversa da que alhures vinha sendo implantada por governos ditatoriais. Um outro traço peculiar ao cenário venezuelano - prosseguiam os excepcionalistas - estava em encontrar-se o país livre de organizações políticas

conteúdo, em grande medida, continuaria verdadeiro para toda a década seguinte, quando os poucos movimentos revolucionários que então sobreviviam na Venezuela também buscavam alento e inspiração na vitória da revolução socialista em Cuba. Por outro lado, em 1974, em observância à linha socialdemocrata de Carlos Andrés Pérez e seu partido (AD), foram reatadas as relações diplomáticas com o país insular. Recentemente, a proximidade política e ideológica do governo bolivariano de Hugo Chávez e Nicolás Maduro com Cuba tem servido, mais uma vez, de Leitmotiv aos grupos de oposição em sua propaganda alarmista acerca do "perigo comunista" que ronda o Palácio de Miraflores.

${ }^{147}$ Vale lembrar que Carlos Andrés Pérez, que presidiu a Venezuela entre 1974 e 1979 (em seu primeiro mandato), foi nomeado vice-presidente da Internacional Socialista em janeiro de 1976 (permanecendo neste cargo até 1992). Seu partido, a Ação Democrática, era um dos poucos partidos latino-americanos a fazer parte dessa organização da socialdemocracia mundial. No contexto da Guerra Fria, a socialdemocracia venezuelana (sobretudo com o próprio Andrés Pérez) procurou manter uma política externa de relações estáveis tanto com Cuba e URSS, como com os EUA, principal país comprador da produção petroleira venezuelana.

${ }_{148}$ Edgardo Lander e Pablo Navarrete apontam um aspecto importante da função do Estado venezuelano, segundo lhe era atribuída pelo pensamento socialdemocrata dominante, quanto à mediação das relações entre as classes sociais e a política distributiva posta em execução: "Dentro del imaginario del desarrollo y la modernización, la incorporación clientelar y subordinada de los sectores populares y sus crecientes demandas no aparecía, a ojos de los sectores dominantes, como una amenaza a sus intereses. $Y$, lo que es vital, el gasto público con el cual se financiaba la educación, la salud y la infraestructura, no tenía su origen en un impuesto cobrado a los bienes e ingresos de los sectores más acaudalados. El consenso socialdemócrata estaba sustentado en un ingreso petrolero que se suponía iba a caracterizarse por su permanente expansión, y que por lo tanto permitía la distribución desigual de una torta siempre mayor. El reparto de la principal fuente de riqueza del país no tenía el carácter de un juego suma cero en el cual lo que se le daba a uno necesariamente se le tenía que quitar al otro". (LANDER, Edgardo \& NAVARRETE, Pablo. La política económica de la izquierda latinoamericana en el gobierno. Amsterdam: Havens Center - Rosa Luxemburg Stiftung, p. 8) 
extremistas, ao contrário do que ocorria nos países vizinhos, nos quais haviam-se radicalizado tanto a direita como a esquerda; e, além disso, em estarem suas classes dirigentes dispostas a não lançar mão das práticas discricionárias associadas a mal afamada ideologia de segurança nacional, que, na maior parte do continente, ia condicionando o desenvolvimento nacional à militarização abrupta das instituições do Estado. Nesse sentido, portanto, as linhas centrais da tese excepcionalista afirmavam: $1^{\circ}$ ) que a Venezuela possuía uma economia em surpreendente expansão, cuja renda nacional era ampla o bastante para dar sustentação ao desenvolvimento industrial e social, através tanto de políticas de investimentos em infraestrutura como de políticas sociais redistributivas das receitas petroleiras. Confiava-se em que a oferta mundial estável de petróleo creditaria ao país uma pujança que podia, por isso, "transbordar e cobrir toda a sociedade" - conforme uma imagem expressiva daqueles anos; $2^{\circ}$ ) que se podia contar com a existência de um sistema estável de partidos políticos, cuja solidez se alicerçava no equilíbrio de forças entre as organizações partidárias que formalmente haviam reconhecido a necessidade de "alternar e partilhar o poder" (ou seja, AD e Copei). ${ }^{149}$ Impedia-se assim a dominação exclusiva de qualquer uma delas, barrava-se o aparecimento de lideranças políticas personalistas e varria-se o extremismo revolucionário; $3^{\circ}$ ) que todo o funcionamento do sistema democrático venezuelano fundava-se na massiva participação eleitoral da população nos sucessivos pleitos, o que garantiria indiscutível legitimidade e representatividade às instituições políticas do país; $4^{\circ}$ ) que a normalidade democrática era favorecida pela circunstância também excepcional de as Forças Armadas nacionais estarem fortemente sujeitas ao controle do poder civil $^{150}$; e $5^{\circ}$ ) que um alto grau de concórdia social concretizara-se com o pacto democrático aceito pelas organizações de classes, sindicatos e partidos, de maneira a

\footnotetext{
${ }^{149}$ Com efeito, entre 1958 e 1998, foram escolhidos, em eleições presidenciais diretas, Rómulo Betancourt (AD, 1959-1964), Raúl Leoni (AD, 1964-1969), Rafael Caldera (Copei, 1969-1974), Carlos Andrés Pérez (AD, 1974-1979 e 1989-1993, sendo então destituído ao fim do processo de impeachment por malversação de fundos públicos), Herrera Campins (Copei, 1979-1984), Jaime Lusinchi (AD, 1984-1989). Em 1993, Rafael Caldera, que fora membro fundador do Copei, seria eleito para um segundo mandato (de 1994 a fevereiro de 1999) pelo partido Convergência, por ele fundado e que, embora não viesse a representar uma mudança expressiva de orientação em relação ao período anterior, foi a primeira ruptura formal no arranjo político puntofijista AD-Copei.

${ }^{150}$ Para um opúsculo crítico sobre a trajetória alegadamente democrática das Forças Armadas e o alcance da aliança cívico-militar desde os tempos de Rómulo Betancourt até os de Hugo Chávez, veja-se DECARLI, Humberto. El mito democrático de las Fuerzas Armadas Venezolanas. Caracas: Ediciones Comisión de Relaciones Anarquistas, 2006.
} 
empenharem-se em dirimir nas esferas jurídica e partidária as eventuais divergências ideológicas e sociais. ${ }^{151}$

Ora, ao operar como um fator de distorção ideológica, o "consenso teórico" que se firmou em torno da suposta concretude histórica desses traços tendeu a apresentar os anos da democracia de Punto Fijo como um período coeso e homogêneo, cujas características fundamentais teriam sido determinadas por condições políticas e econômicas relativamente duradouras e invariáveis (ou com variações não significativas). ${ }^{152}$ Para isso, as proposições excepcionalistas tomaram acriticamente como um pressuposto básico da realidade venezuelana da segunda metade do século XX uma pretensa longa constância tanto do equilíbrio político-partidário, como da estabilidade econômica, como da paz social. Sustentar, entretanto, essa posição teórica, exigiu de seus formuladores ignorar ou subestimar certos dados objetivos. Primeiro, que o alegado concerto entre AD e Copei ocultava importantes cisões no seio dos próprios partidos - cisões originadas de divergências em questões programáticas fundamentais, as quais, de fato, punham em dúvida a interpretação "consensual" que tinham esses

\footnotetext{
${ }^{151}$ Cabe acrescentar que a tese excepcionalista abrangia ainda outras dimensões da história pregressa da Venezuela, consideradas também "singularidades": a suposta ausência de racismo (mesmo entre as classes altas), explicável pela forte miscigenação da sociedade desde os tempos coloniais; a festejada superação do problema do caudilhismo, antigo fenômeno que marcara toda a política venezuelana no século XIX e que desaparecera com o movimento de 1958; o caráter democrático-popular do exército, que, desde as lutas da Independência, deixara de ser domínio das oligarquias; e o cosmopolitismo da cultura venezuelana, espontaneamente aberta às influências dos povos "modernos". Sobre isso notam Ellner e Salas: "This historical interpretation lent itself to exceptionalism thinking, which viewed modern Venezuela as following in the footsteps of developed nations, having left behind virtually all vestiges of its past. In this respect, exceptionalism was firmly rooted in concepts borrowed from nineteenth-century positivism. Latin American positivists extolled U.S. and European-style progress while disparaging and repudiating Latin America' cultural and political heritage, which they often equated with barbarism" (ELLNER, Steve \& SALAS, Miguel T. Op. cit., p. 7). Após a vitória eleitoral de Hugo Chávez e as subsequentes mobilizações populares de apoio a seu governo, reapareceram as alegações de "ressurgimento do caudilhismo venezuelano" (agora identificado como de "tipo chavista") feitas na grande imprensa liberal do país. Caracteristicamente, reapareceram também as declarações e manifestações públicas com conteúdo nitidamente racista, feitas por grupos opositores de classe média e classe alta em relação aos participantes populares das mobilizações. A própria origem "mestiça" do presidente Chávez (um "zambo" para os racistas venezuelanos) não passou despercebida pelo repúdio preconceituoso dos setores sociais ricos à nova reordenação política. No que respeita aos traços culturais dos integrantes dos protestos populares e às formas de sua percepção das motivações políticas dos movimentos de protesto nos primeiros anos do governo Chávez, veja-se um excelente trabalho em MAYA, Margarita López (coord.). Protesta y cultura en Venezuela: los marcos de acción colectiva en 1999. Buenos Aires: Clacso, 2002, e (da mesma autora) Luta hegemônica na Venezuela, 2010. Também são bastante elucidativos os informes anuais do PROVEA (Programa Venezolano de Educación - Acción en Derechos Humanos), disponíveis em www.derechos.org.ve.

${ }^{152}$ Cf. HERNÁNDEZ, Rossana. Aspectos problemáticos del excepcionalismo en Venezuela (19581989). Revista Venezolana de Ciencia Política, N. 9 / enero-junio 2006, pp. 153-167.
} 
partidos da realidade do país, de seus problemas e dos meios de sua solução. ${ }^{153}$ Segundo, que, quanto à expansão sustentada da economia no período, os anos, por exemplo, entre 1958 e 1963 foram de serí́ssimas dificuldades provocadas pela brusca diminuição das receitas petroleiras, e que, igualmente, os anos posteriores à Sexta-feira Negra (18 de fevereiro de 1983) ${ }^{154}$ amargaram a severa e longa crise que se estendeu até princípios do século XXI. ${ }^{155}$ Objetivamente, tendo-se em conta os anos entre 1959 e 1983, constatam-se, na verdade, duas fases de recessão (1959-1963 e 1979-1983), uma de lenta recuperação (19641973) e uma propriamente de expansão (1974-1978), o que significa, em resumo, que "(...) [e]m 24 anos, a economia esteve em auge apenas 4 anos, e entre recessão e recuperação moderada 20 anos". ${ }^{156}$ Certamente, tais números assim considerados não poderiam apoiar o argumento da prosperidade duradoura do após-Punto Fijo. E, terceiro, que, no tangente à ausência de perturbações sociais graves, alegadamente derivada do equilíbrio econômico e da estabilidade política, os anos que precederam e os que se seguiram ao boom petroleiro não deixaram

\footnotetext{
153 "(...) In both parties, left-leaning factions emerged but were the victims of heavy-handed treatment and violation of internal democratic rules on the part of party machines. The leaders of these factions articulated positions on social inequality, severance of dependency on foreign capital and technology, assertion of an independent foreign policy and internal democratization. They failed, however, to put forward an all-encompassing strategy to achieve these goals or to rally public support for them. Nevertheless, they raised issues, albeit timidly, that later were to become the focus point of the Chavista movement." (ELLNER, Steve. Rethinking Venezuelan Politics. February, 11th 2008. Venezuelanalysis. com.) O autor se refere especialmente às cisões internas que levaram à formação do MIR em 1960, o Grupo ARS em 1962 e o MEP em 1967, além de uma corrente "de esquerda" dentro da AD de seguidores de C. A. Pérez nos anos 70-80.

${ }^{154}$ Nessa data, o governo de Herrera Campins decidiu desvalorizar fortemente o bolívar em relação ao dólar e adotar o controle do câmbio. Encerrava-se aí a época do bolívar como moeda forte e estável. Recorda a propósito uma historiadora: "(...) Uma manchete de jornal daqueles dias resumiu o estado de ânimo de grande parte da população: $\underline{A}$ festa acabou! ". (MAYA, M. L. Luta hegemônica na Venezuela, 2010, p. 18.)

${ }^{155}$ Considerações como as apresentadas acima levaram R. Hernández a concluir: "(...) la evidencia muestra que no es tan válida esta suposición [do excepcionalismo]. En los comienzos de este periodo no hay evidencia que demuestre excepcionalismo venezolano. Todo lo contrario, el periodo 1958-1973 estuvo marcado por mucha volatilidad política. Igualmente, el periodo 19581966 también estuvo signado por problemas económicos comunes a los demás países de América Latina. Además, queda por examinar el papel controversial del sobrelapamiento de la volatilidad económica y la volatilidad política, pues no coinciden. Por lo tanto, no es muy productiva la aplicación del excepcionalismo a un proceso económico, por ejemplo, cuando, simultáneamente, hay un proceso político no marcado por un excepcionalismo. $Y$, por último, está el problema de la identificación de los límites del intervalo del periodo. Como se observó, el excepcionalismo no sólo empezó más tarde de lo supuesto, sino que terminó más temprano que lo éste presupone." (HERNÁNDEZ, Rossana. Aspectos problemáticos del excepcionalismo en Venezuela (1958-1989), p. 166.)

${ }^{156}$ ZAVALA, D.F.M. "Diagnóstico crítico de la economía venezolana en el período 1982-2007", In: Nueva Economía. Caracas: Academia Nacional de Ciencias Económicas, Año XVI, nํ28, octubre 2008, p. 23.
} 
de registrar graves e crescentes protestos populares, motivados diretamente por demandas socioeconômicas. Se os partidos que se consolidaram a partir de 1958 serviram inicialmente como canais de mediação e representação para as camadas populares - e, portanto, puderam funcionar como forças de contenção a manifestações sociais violentas - tão logo esses partidos se tornaram máquinas eleitorais a serviço das elites econômicas e políticas, empurraram as camadas excluídas da sociedade, progressivamente empobrecidas, para a luta à margem dessas organizações e diretamente através dos protestos de rua. ${ }^{157} \mathrm{~A}$ década de 1960, em especial, foi assinalada por claros lapsos de instabilidade política e social, evidenciáveis nas agitações decorrentes da ação dos movimentos guerrilheiros - os quais, apenas no fim da década de 60, seriam "pacificados". ${ }^{158}$ Desse ponto de vista, mostrou-se falsa a crença de que, em contraste com os outros países do continente, os mecanismos institucionais, a liberdade sindical e as práticas político-eleitorais da democracia de Punto Fijo se prestaram a impedir ou amenizar os conflitos de classes. ${ }^{159} \mathrm{~A}$ democracia venezuelana não foi então mais do que uma típica democracia latino-americana (das passadas e futuras), dominada por elites econômicas e da qual eram afastados aqueles grupos majoritários que lhe deviam dar base legítima. Por essa razão, adstrito a uma concepção funcional de democracia, o regime de Punto Fijo não se mostrou capaz de, em momentos de descenso econômico, dar solução satisfatória à insatisfação popular. Portanto, se os poucos anos mais favoráveis do petróleo explicam a atenuação da conflituosidade social, deve-se, todavia, reconhecer que se tratou apenas de "um breve período de trégua", e não de um aspecto histórico duradouro o bastante para distinguir uma época. Afinal, "(...) [a]s situações não

${ }^{157}$ MAYA, Margarita López (coord.). Protesta y cultura en Venezuela: los marcos de acción colectiva en 1999. Buenos Aires: Clacso, 2002.

${ }^{158}$ Afirma R. Hernández: "Hacia 1960 se inició un período de fuerte división política y fue en 1963, con la llamada "crisis de la ancha base", que se intentó la ampliación de la participación de otras organizaciones políticas en el proceso de consolidación y fortalecimiento de la democracia que comenzó a partir de 1958. Asimismo, El episodio de la guerrilla en Venezuela (1960), también marcó un periodo de inestabilidad política por el intento de desestabilizar el régimen democrático instaurado en Venezuela desde 1958. Por su parte, durante la presidencia de Raúl Leoni (19641969) persistieron los actos de violencia y la fuerte división política del período anterior. Se podría afirmar que hacia finales del 1967, Venezuela comienza un período de cierta estabilidad política en el momento en que los focos de la guerrilla se debilitan en los distintos enfrentamientos sostenidos con el gobierno. Fue a partir de 1969, cuando inició la presidencia de Rafael Caldera (1969-1974), que finalmente vino a materializarse el ansiado proceso de pacificación de la guerrilla". (HERNÁNDEZ, R. Op. cit., p. 159-160). Veja-se, adiante, cap. 4.

${ }^{159}$ Cf. ELLNER, Steve \& SALAS, Miguel T. "The Venezuelan Exceptionalism Thesis: Separating Myth from Reality" In: . Hugo Chávez and the decline of an "exceptional democracy", p. 5. 
resolvidas de exclusão social e cultural de caráter histórico, somadas à deterioração das condições de vida das maiorias - tão logo desapareceram os anos de bonança petroleira - foram construindo o cenário para a irrupção de um novo ciclo de conflitos e de luta política". ${ }^{160}$

Mas, a despeito do conteúdo simplificador, existiam frações de verdade na tese excepcionalista, as quais convém não omitir quando se levam em conta dados quantitativos do período. A bem dizer, também o excepcionalismo, afinal, partiu de um fato crucial da evolução contemporânea do país: o petróleo. Mesmo estudiosos que jamais partilharam daquelas ilusões enfatizaram o impulso colossal dado pela exploração petrolífera ao desenvolvimento venezuelano no século $X X^{161}$ - em especial entre os anos de 1970 e início de 1980. Por conseguinte, também eles se viram obrigados a admitir, em alguma medida, 0 efeito "democratizante" dessa riqueza nacional:

(...) a expansão experimentada pela economia venezuelana no período entre 1920 e 1980 não pode ser qualificada de outra coisa senão de simplesmente extraordinária. Assim, ela foi $75 \%$ mais alta que a do conjunto da América Latina e 45\% maior que a do mundo desenvolvido. Mais ainda, nos anos iniciais foi tão violento o efeito favorável disruptivo da exploração de petróleo, que, no prazo de uma década, a Venezuela já se emparelhava às outras economias latinoamericanas. A partir daí até fins dos anos 1950, ela se adiantará em relação a seus vizinhos, atingindo uma distância tal que seu produto por habitante chegou a ser algo mais que o dobro do desses outros países.

(...)

Entre 1936 e 1980, a Venezuela se torna um mundo urbano à velocidade astronômica de 5,7\% anual. Esta cifra representa, para se ter um adequado termo de cotejo, um terço maior que a correspondente do conjunto da América Latina. Quer dizer que enquanto a Venezuela duplicou sua população urbana em 14 anos, a América Latina o fez em 32 anos. $O$ acelerado crescimento populacional se fará acompanhar de uma expansão da massa de

\footnotetext{
${ }^{160}$ MAYA, M. L. Luta hegemônica na Venezuela, 2010, p. 94.

${ }^{161}$ Segundo um documento daqueles anos, do Banco Mundial, a transformação do país devida ao petróleo era assim descrita: "Gracias a la decisión adoptada en 1943 por el gobierno y las compañías petroleras de acelerar el desarrollo de los recursos petroleros, la rápida expansión económica produjo un cambio espectacular". [En efecto, se pasó] "de una pequeña economía agrícola (4 millones de personas con producto bruto inferior a 7 mil millones de Bs. (a precios de 1957), a una petrolera y manufacturera con más de 7 millones de habitantes y 26 mil millones de Bs. de producto total para 1959. En 1936, el petróleo creaba apenas un ingreso equivalente a un tercio del aporte agrícola. El crecimiento desde 1943 fue tan rápido que ya en 1948 contribuía con 20 por ciento al producto nacional, superando la contribución conjunta de la agricultura y la industria". (Citado por MIERES, Francisco. "Evolución socioeconómica de Venezuela". In: Problemas del Desarrollo. Revista Latinoamericana de Economía, Vol. 20, oํ 76, 1989, p. 170.
} 
bens e de serviços disponíveis aos habitantes que é igualmente espetacular. ${ }^{162}$

A grande expansão econômica venezuelana, secundada pela urbanização e pela relativa melhoria geral dos padrões de vida, não foi, entretanto, um fenômeno isolado, nem, em nenhum grau, excepcional. Para efeito de comparação, é preciso ter em mente a situação geral da América Latina: nas décadas de 1950-70, testemunhou-se um período de importante crescimento das economias da região só comparável (em termos absolutos e relativos) ao período que se seguiu à grande expansão comercial europeia de fins do século XIX, quando os países latino-americanos foram integrados definitivamente àquele comércio. Para os anos 1950, os seguintes números traçam as linhas desse desenvolvimento regional: uma taxa anual de aumento da produção industrial de $6,6 \%$, que, entre outros avanços, apresentou um crescimento anual da produção de aço de $13 \%$, de celulose e derivados de petróleo de $11 \%$ cada, e exportações de manufaturados de cerca de 7\%; no mesmo período, a participação dos produtos manufaturados no PIB ampliou-se de $18 \%$ para $21 \%$, e os investimentos internos na indústria cresceram anualmente a uma taxa de $7,8 \%$, enquanto o PIB regional mostrou um crescimento de $5,1 \%$. Tomando-se em consideração as três décadas conjuntamente (1950, 60 e 70), a região apresentou uma taxa média

${ }^{162}$ Cf. BAPTISTA, Asdrúbal. La economía venezolana entre siglos. Revista Nueva Economía. Vol. 28, Oct. 2008, p. 64 e 63. Contudo, segundo esse estudioso, a partir dos anos 80 uma curva descendente marcaria o nível de desenvolvimento, em uma longa deterioração geral que só com a primeira década do século XXI, pensou-se, começaria talvez a se reverter:

Gráfico 10: DESENVOLVIMENTO ECONÔMICO DA VENEZUELA 1830-2006.

NíVEIS DA ATIVIDADE ECONÔMICA (em preto) versus RENDA DO PETRÓLEO POR HABITANTE (em cinza)

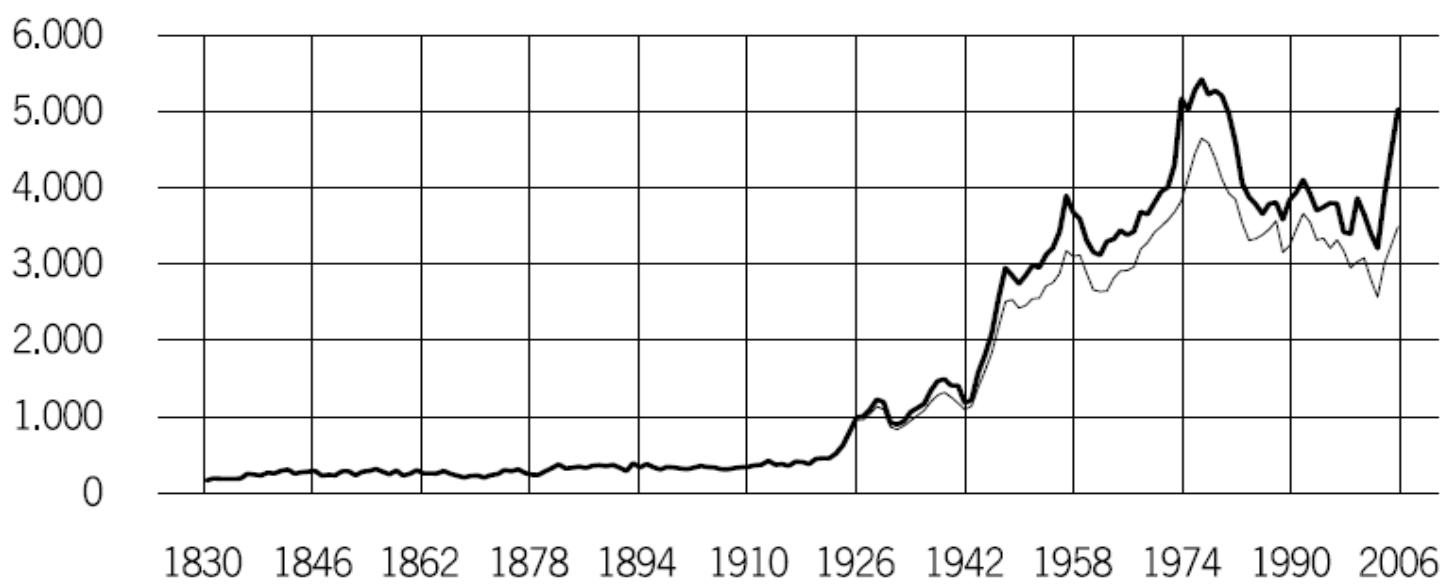

Fonte: BAPTISTA, Asdrúbal. La economía venezolana entre siglos, p. 60. 
anual de crescimento do PIB de 5,5\% e de produção per capita de 2,8\%, sendo particularmente digno de nota que a taxa de crescimento médio anual, durante esse período, foi um quarto maior do que a taxa de crescimento das chamadas economias de mercado desenvolvidas. Durante os anos entre 1960 e 1973, época em que as economias capitalistas tanto centrais como periféricas apresentaram seu maior dinamismo, os países latino-americanos exibiram números expressivos, como o aumento da produção industrial a uma taxa de 6,8\% anual, com sua participação no PIB subindo de $21 \%$ para $26 \%$; a ampliação dos investimentos internos de $9 \%$ ao ano, e o incremento do PIB a 5,9\% anual. ${ }^{163}$ Acompanhando essa expansão da industrialização, o processo de urbanização das principais áreas econômicas da América Latina refletia a atração que exerciam sobre as camadas pobres as oportunidades de ascensão social nas cidades, e era igualmente estimulado pela introdução definitiva, no campo, das relações capitalistas, que compeliam a massa de trabalhadores e pequenos proprietários a migrar e a compor parcelas cada vez maiores da força de trabalho redundante urbana. ${ }^{164}$ Em seguida, entre os anos de 1973 e 1981, as economias mundiais ver-se-iam convulsionadas pelas duas "crises do petróleo" (1973 e 1979), comumente consideradas como um dos fatores precipitantes do brusco fim desses anos prósperos e do início de uma longa fase de estagnação das economias capitalistas. Em que pese a essas crises, e concomitantemente à desaceleração do crescimento das economias centrais (cuja taxa se reduziu à metade), vários países da América Latina (mesmo os não produtores de petróleo) conseguiram manter, durante esses anos, o crescimento econômico em níveis semelhantes aos do período anterior, sobretudo aproveitando-se da grande oferta de capitais internacionais disponíveis, cujo fluxo passava então a se dirigir para a região em volume crescente. Ademais, um traço característico desse movimento financeiro era o de ser formado por capitais de baixo custo (que, durante esses

\footnotetext{
${ }^{163}$ Cf., para todos esses dados e análises, BETHELL, Leslie (Org.). A América Latina após 1930: Economia e sociedade. São Paulo: Editora da Universidade de São Paulo; Brasília, DF: Fundação Alexandre de Gusmão, 2005, v. 6, pp. 129-228.

${ }^{164}$ Nos grandes centros urbanos latino-americanos, a absorção dos contingentes de camponeses expulsos do meio rural compôs um fenômeno social que se estendeu por todo o século $X X$, e ao qual se associam problemas como a favelização das áreas periféricas, a precariedade das condições de alimentação e higiene dessa população, bem como a criminalidade e a desocupação de amplos contingentes dela. Na Venezuela, as áreas periféricas são conhecidas por barrios. Em torno de Caracas, por exemplo, é nesses barrios que se aloja grande parte do lumpemproletariado do país.
} 
anos, chegaram a ter taxas negativas de juros reais). Esses capitais abundantes, introduzidos na forma de empréstimos oficiais e privados, funcionaram como propiciadores de reservas liquidas de divisas a esses países, divisas necessárias para cobrir as importações de petróleo e de outros produtos (como bens de consumo e equipamento militar - este em particular nos países sob ditaduras militares). Foi somente a partir de meados de 1982, porém, quando os empréstimos externos se viram abruptamente interrompidos depois da declaração mexicana de moratória, é que as limitações e deficiências do processo de industrialização latino-americano iriam revelar-se com mais clareza, e os economistas mais entusiastas desse tipo de desenvolvimento se acharam forçados a admitir, com pesar, que os esteios que até então sustentaram o quadro de prosperidade da região começavam a ruir. ${ }^{165}$

Retornemos à Venezuela dos "bons anos". Um episódio emblemático do consenso quase unânime acerca de sua situação "afortunadamente singular" deuse com a visita ao país, a convite do então ministro do Planejamento Gumersindo Rodríguez, do economista Celso Furtado, à época professor em Cambridge e Sorbonne e um dos mais renomados representantes do pensamento desenvolvimentista na América Latina. Convidado pelo governo a opinar sobre as potencialidades do país para vencer os problemas do subdesenvolvimento, 0 visitante afirmaria, em setembro de 1974, em uma entrevista concedida ao jornal El Nacional de Caracas:

[A Venezuela] tem a possibilidade de intensificar consideravelmente a acumulação de capital sem exigir sacrifícios grandes do povo. $\mathrm{Na}$ Venezuela, aqui sim, é certo que se pode superar o subdesenvolvimento por métodos que não parecem muito complexos,

\footnotetext{
${ }^{165}$ Voltaremos a esse assunto, para o caso específico venezuelano, no capítulo seguinte. A título de ilustração, contudo, pode-se avaliar quantitativamente a interrupção, nos anos 1980, desse processo geral de crescimento (interrupção que atingiu seu ponto mais visível na eclosão da "crise da dívida") pelos seguintes dados: "(...) a região registrou uma taxa de aumento da produção de apenas 1,2 por cento ao ano, enquanto a renda per capita diminui quase na mesma proporção. Quase todos os indicadores refletem esse quadro global de estagnação e declínio. A produção industrial, por exemplo, que cresceu 6,5 por cento ao ano entre 1950 e 1981, subiu apenas 1,1 por cento entre 1981 e 1990. Os investimentos internos brutos per capita diminuíram de 500 dólares em 1980 para 310 dólares em 1990 (ambas as cifras medidas pelos preços de 1980). Mesmo assim, houve uma transferência de recursos para o exterior de 25 bilhões de dólares por ano entre 1982 e 1990 (221 bilhões de dólares no total); às vezes, as taxas de desemprego urbano chegaram, em diversos países, a mais de vinte por cento; muitos países, entre eles o Brasil, o México e a Argentina, experimentaram taxas de inflação de três, quatro e até cinco dígitos" (BETHELL, Leslie (Org.). Op. cit. p. 141).
} 
que não exigem grandes convulsões sociais, portanto muito mais fáceis de permanecer sob controle. Quando se fala em transformar mediante $o$ que chamamos de revolução... sabe-se perfeitamente que é fácil começar guerras, mas é difícil e incerto terminá-las. Ninguém sabe onde pode nos levar um processo revolucionário, portanto é muito difícil planejá-lo; especula-se vagamente. Mas, no caso da Venezuela, há condições reais para superar o subdesenvolvimento dentro de um processo totalmente controlado. É uma revolução, mas que se faz conscientemente, desejada e com base em um consenso, porque a verdade verdadeira é que o sacrifício que se exigiria da população seria mínimo ou nulo. (...) A Venezuela, como nação, como povo, tem enormes possibilidades. Eu diria que daqui a dez anos pode ser o primeiro país que, tendo sido tipicamente de economia subdesenvolvida, terá uma economia desenvolvida. ${ }^{166}$

Para o economista brasileiro, a Venezuela encerrava uma peculiaridade (o termo é do próprio C. Furtado), que, no quadro das economias latino-americanas, munia-a com especial vigor para empreender o salto ao desenvolvimento, a saber: o profuso fluxo de divisas - insuficiente nas outras nações - cuja grandeza podia servir de base a um impulso modernizador do conjunto do aparato produtivo nacional. Além disso, essa modernização dos diversos setores produtivos permitiria transformar o progresso econômico em desenvolvimento social, na medida em que esses setores promovessem a absorção, quantitativamente importante, da parcela da mão de obra nacional ainda mantida desocupada. Assim, o bom êxito na conjugação de ambos os fatores constituiria um terreno ideal para a superação das limitações próprias à estrutura de enclave. Somavamse a isso, ainda, na análise de Furtado, duas circunstâncias favoráveis: a de essas grossas divisas passarem obrigatoriamente pelas mãos do Estado e a de a conjuntura internacional indicar uma demanda mundial crescente de hidrocarbonetos (sem que, além disso, se avistasse alteração alguma, a curto ou médio prazo, da matriz energética das potências industriais). Nesse sentido, e de acordo com as categorias de análise desenvolvimentistas, C. Furtado ressaltava

\footnotetext{
${ }^{166}$ FURTADO, Celso. "O futuro se decide agora" (Entrevista a Lorenzo Batallán). In: Ensaios sobre a Venezuela. Subdesenvolvimento com abundância de divisas. RJ: Contraponto: Centro internacional Celso Furtado, 2008, p. 177-187. (Grifo nosso.) Celso Furtado já havia estado na Venezuela em 1957, quando era então pesquisador da Cepal e fora incumbido de preparar um estudo sobre a economia venezuelana naquela conjuntura ( $O$ desenvolvimento recente da economia venezuelana - exposição de alguns problemas, de agosto de 1957). Nesse estudo, tinham sido já delineados os dinamismos e os entraves da economia que estariam presentes quase sem alterações quando da nova visita, em 1974. Uma diferença, porém, a ser assinalada por Furtado era que antes, apesar da riqueza, parecia não haver por parte do Estado "um projeto orgânico, consistente, que desenvolvesse a economia" - o que depois passara a existir, acreditava ele.
} 
que, havendo o governo doravante adquirido a "clara consciência de que o país dispõe de recursos" e estabelecidas as prioridades sociais no emprego deles, cumpria ao Estado a primazia na consecução do projeto político de desenvolvimento. Esse imperativo, no raciocínio pragmático desenvolvimentista, obedeceria à seguinte lógica:

(...) Na sociedade capitalista, a acumulação de capital leva necessariamente à elevação de salários e, portanto, a uma repartição dos benefícios do desenvolvimento entre todas as classes sociais. Mas em alguns países, a Venezuela, por exemplo, isso não se faz espontaneamente, pois, mesmo com suas condições privilegiadas, 0 sistema cria muito pouco emprego, absorve muito pouca mão de obra; daí que, tendo uma tremenda abundância de capital, tenha também uma grande quantidade de subempregados e desempregados que, em termos relativos, é três, quatro vezes maior da que se admite num país desenvolvido. Portanto, o sistema não tende espontaneamente a solucionar esse problema. Ele só será solucionado por uma vontade política. A Venezuela tem uma possibilidade real de passar do subdesenvolvimento ao desenvolvimento, mas só por meio de um projeto político, não por meio da dinâmica espontânea do sistema econômico. ${ }^{167}$

Apesar do tom de franco otimismo que dominava essas declarações, C. Furtado se empenhou em alertar - e neste ponto desaparece qualquer possível semelhança que pareça haver com as ideias que viriam, nos anos seguintes, a servir de base à tese excepcionalista - que, contrariamente ao desejável, a alta abrupta e contínua dos preços das exportações de petróleo (mesmo que fosse mantida por um período longo), conquanto reforçasse extraordinariamente os excedentes de divisas nacionais, não conduziria automaticamente ao desenvolvimento. A ilusão, aliás, lembrava ele, era devida a uma compreensão errônea da noção de desenvolvimento, que, não obstante, vigorava ainda nos meios políticos venezuelanos. ${ }^{168}$ A principal distorção na utilização do grande

\footnotetext{
${ }^{167}$ FURTADO, Celso. "O futuro se decide agora", op. cit., p. 180.

${ }^{168} \mathrm{Em}$ um escrito (não publicado) do mesmo ano da entrevista (1974), Celso Furtado apontava: "Na Venezuela, mais que em qualquer outra parte, carecem de significado muitas das ideias convencionais sobre desenvolvimento e subdesenvolvimento econômico. Trata-se de uma realidade histórica sui generis que, como tal, deve ser compreendida e analisada. As teorias do desenvolvimento econômico têm como núcleo central um conjunto de hipóteses explicativas do processo de acumulação de capital, das relações desse processo com a assimilação de inovações técnicas e de seus efeitos sobre a estrutura do sistema de produção, a produtividade do fator trabalho, o incremento do fluxo de renda e a consequente diversificação da demanda final. Em suma: estuda-se o processo de acumulação para compreender o crescimento da renda e a diversificação do fluxo de bens finais. Na Venezuela nos confrontamos com uma situação quase
} 
excedente petroleiro - que inevitavelmente produzia a dependência de todo o sistema em relação a um bem não renovável - residia na tendência em impelir a economia para um estado de excesso de recursos financeiros e de capacidade de importação. Resultavam daí - concluía C. Furtado -, nas condições específicas venezuelanas, ao menos quatro consequências funestas para o conjunto da sociedade: primeira, a dissipação de grande parte do volume dessas divisas através da importação de bens supérfluos (inencontráveis na produção nacional), o que era favorecido ainda mais pela política de câmbio valorizado e que, ao mesmo tempo, inibia a diversificação produtiva interna; segunda, essa inibição estimulava apenas um mero "desenvolvimento para fora", ou seja, um crescimento incapaz de articular o setor petroleiro, de produtividade ampliada, ao desenvolvimento nacional de outros setores produtivos, reforçando assim especialmente em conjunturas mundiais favoráveis - o caráter monoprodutor da economia; terceira (e como decorrência direta da anterior), a impossibilidade de assimilar ao sistema as parcelas numerosas de trabalhadores desempregados e subempregados, cuja consequência era, necessária e contraditoriamente, o agravamento do problema da concentração social de renda em um cenário de abundância de divisas; e, quarta, a continuidade do estado de atraso tecnológico a que se sujeitava o setor de produção de bens de consumo e o de alimentos, sobretudo com a negligência em relação ao nível técnico da agricultura nacional, assaz precária e considerada "o calcanhar-de-aquiles do subdesenvolvimento venezuelano". ${ }^{169}$ Ao final, por causa da incúria do governo e dos setores sociais dominantes diante dessas questões, a grande expectativa de desenvolvimento desfar-se-ia rapidamente - demonstrando ser essa expectativa menos justificável

diametralmente oposta: um fluxo de bens finais em rápida expansão e diversificação constitui o motor das transformações econômicas no nível da produção e da acumulação. (...) Nas situações com que se depara correntemente a teoria do desenvolvimento, a expansão da demanda final reflete, em última instância, o incremento da produtividade física do trabalho; no caso venezuelano, o principal fator causante do crescimento da demanda é a utilização de um recurso não renovável. (...) Na Venezuela, a evolução da demanda final reflete primariamente a política seguida pelo Estado na apropriação e utilização do excedente petroleiro. (FURTADO, Celso. Notas sobre a economia venezuelana e suas perspectivas atuais. In: Ensaios sobre a Venezuela, p. 119-120. Grifos nossos)

${ }_{169}$ Nas notas não publicadas de 1974, Celso Furtado registrava: "(...) dadas as tendências estruturais do momento é de esperar que os traços principais do quadro herdado do passado se acentuem, agravando-se o excedente estrutural de mão de obra. Sendo assim, a maior riqueza trazida pelo boom petroleiro fará da Venezuela um país socialmente mais instável. Certo, um país rico, mas nem por isso menos subdesenvolvido. E também com maior dependência da importação de alimentos e das flutuações dos mercados internacionais". (FURTADO, Celso. Notas sobre a economia venezuelana e suas perspectivas atuais. Op. cit., p. 123). 
pelo estudo objetivo das condições históricas do país do que por um ufanismo inconsequente de suas classes governantes.

Todas essas ponderações de C. Furtado, ainda que precisas e valiosas, não constituíam, a rigor, novidade para alguns setores mais críticos do meio acadêmico venezuelano e, na realidade, faziam eco às concepções, por exemplo, do grupo de importantes intelectuais nacionais que, à mesma época, estudando os efeitos da dependência, já apontavam - destacando quase exatamente as mesmas causas - o traço negativo mais importante da evolução econômica da Venezuela contemporânea: o de um incontornável crescimento sem desenvolvimento. ${ }^{170}$ Por isso, é conveniente não exagerar aqui a "unanimidade" de então em torno do clima auspicioso que viria a servir de base à formulação da teoria excepcionalista. Ao dedicarmos-lhe um capítulo, e confrontando-a com algumas ideias desenvolvimentistas, desejamos apenas sublinhar o que a tese do excepcionalismo venezuelano possuiu de exemplar na vida de uma sociedade atrasada: ou seja, o de manifestar com meridiana clareza como, no plano políticoideológico, a condição de dependência e subdesenvolvimento se faz acompanhar - e, ao mesmo tempo, se nutre - de um tipo de consciência inepta da classe social que domina e dirige o evolver histórico dessa nação. É um fato que essa consciência distorcida e deformadora encontra eficácia na medida em que se apodera também das instituições de cultura (como a universidade e os meios chamados "formadores de opinião") e demonstra seu papel na construção da hegemonia de classe ao ditar os caminhos da ação do Estado respaldando-os em um consenso pretensamente espontâneo, que essa classe dominante se devota a construir no imaginário social. ${ }^{171}$ Tal consenso, nascido da sociedade civil, nem

\footnotetext{
${ }^{170}$ Cf. a obra coletiva (sob coordenação do economista D. F. Maza Zavala) Venezuela: crecimiento sin desarrollo. México: Editorial Nuestro Tiempo, 1974. Caracteristicamente, seus autores assinalavam desde o início, que "(...) Venezuela, con sus particularidades y complejidades, es un país esencialmente latinoamericano, y con destino ligado al común de América Latina." (p. 10). Ademais, um grande número de obras acadêmicas dos anos 1960 sublinhavam o caráter limitado e dependente do desenvolvimento venezuelano, preso às exportações de petróleo e à dominação estrangeira das empresas petroleiras multinacionais. Por exemplo: ZAVALA, D. F Maza. Venezuela: una economía dependiente. Caracas: UCV, 1964; MIERES, Francisco. El petróleo y la problemática estructural venezolana. Caracas: Instituto de Investigaciones, Universidad Central de Venezuela, 1969; ALFONSO, Juan Pablo Pérez. Petróleo y dependencia. Caracas: Síntesis dos mil, 1971.

${ }^{171}$ Essa situação venezuelana de "consenso espontâneo" se ajusta à descrição clássica do papel dos intelectuais orgânicos na organização da cultura segundo a proposição gramsciana. Vale lembrar, de acordo com A. Gramsci: "(...) Gli intellettuali sono $i$ "commessi» del gruppo dominante per l'esercizio delle funzioni subalterne dell'egemonia sociale e del governo politico, cioè: 1) del
} 
sempre representa apenas um simples ardil, deliberadamente manipulador. Também pode corresponder à própria concepção invertida da realidade da dependência, que os commessi da burguesia associada elaboram como expressão de seus anseios e de sua visão de mundo. Por isso, a despeito da efemeridade do excepcionalismo venezuelano (que praticamente desapareceria já ao final da década de $1980^{172}$ ), ele correspondeu à necessidade circunstancial que os setores dominantes manifestaram de emprestar "racionalidade e objetividade" - em uma palavra, legitimidade - às políticas de Estado. É de notar, aliás, que nisso se encerra a vinculação entre a natureza antidemocrática do domínio burguês e a tarefa de mistificação do real contida em seu projeto histórico conservador - cuja manifesta pretensão, em contraste, é justamente a de ser um projeto nacional e democrático. Nesses termos, portanto, tal necessidade explica por que pôde resultar daí uma formulação sociológica plausível à primeira vista, sustentada por intelectuais orgânicos que, no entanto, ao se identificarem com as estruturas de poder e com os desígnios da elite governante, transformaram 0 trabalho de investigação científica em mera manobra de propaganda e doutrinação. Evidentemente, o conhecimento assim empobrecido que daí resultou é desprovido de qualquer capacidade de representar a realidade como ela é. No fim das contas, essa "cientificidade" não chegou a ir além de uma precária reformulação retórica do senso comum e da aparência mais superficial das coisas, enquanto se esforçou por manter silêncio sobre os elementos contraditórios e antagônicos (internos e externos) da realidade venezuelana, os

consenso "spontaneo" dato dalle grandi masse della popolazione allindirizzo impresso alla vita sociale dal gruppo fondamentale dominante, consenso che nasce "storicamente» dal prestigio (e quindi dalla fiducia) derivante al gruppo dominante dalla sua posizione e dalla sua funzione nel mondo della produzione; 2) dell'apparato di coercizione statale che assicura «legalmente» la disciplina di quei gruppi che non "consentono" né attivamente né passivamente, ma è costituito per tutta la società in previsione dei momenti di crisi nel comando e nella direzione incui il consenso spontaneo vien meno." (GRAMSCI, Antonio. Gli intellettuali e l'organizzazione della cultura. 3. ed. Roma: Editori reuniti, 1996. Texto digital disponível em: http:// www.liberliber.it/biblioteca/licenze/.) Grifo nosso.

172 É de notar, contudo, que ecos dessa interpretação excepcionalista subsistiriam e podiam ser percebidos em alguns autores ainda nos anos 90, quando estes procuravam as causas da irrupção violenta das revoltas e protestos populares desses anos. Veja-se, por exemplo, ESPAÑA N., Luis Pedro. "Violence and the welfare state. The case of Venezuela as an oil country." In: RUPESINGHE, Kumar \& RUBIO C., Marcial (ed.) The culture of violence. Tokyo: United Nations University Press, 1994, cap. 7, pp. 178-197. Para esse estudioso, aliás, o regime democrático puntofijista permitiria enquadrar o exemplo venezuelano como o de um Estado de Bem-estar Social - algo, para ele, nitidamente excepcional na América Latina. 
quais, se devidamente elucidados, poriam talvez em risco aquelas mesmas estruturas de dominação.

Assim considerado, portanto, o excepcionalismo venezuelano vicejou e pôde agir, na prática, em vários sentidos: $\left.1^{\circ}\right)$ como um discurso de apologia do despotismo dos setores sociais dominantes, ao celebrar o puntofijismo e considerá-lo um momento definidor na construção da democracia no país, supostamente atestada pela longevidade das instituições de Estado; $2^{\circ}$ ) como um exame "científico" simplificador, ao assimilar certa "quietude" circunstancial das camadas populares a um cenário de paz e estabilidade social duradouro, expressão da democracia ${ }^{173} ; 3^{\circ}$ ) como uma teorização "ingênua", falseada pela associação mecânica entre abundância de receitas e desenvolvimento socioeconômico, e que absolutamente nada dizia sobre as condições adversas da exploração econômica externa, exercida sob a forma neocolonial imperialista; e $4^{\circ}$ ) finalmente, como um fator de negação da identidade histórica (sociocultural e econômica) latino-americana da Venezuela, pretendendo-se aproximá-la de uma "evolução histórica" alheia, supostamente própria de nações desenvolvidas. Em virtude disso, a democracia excepcional do país teve de, contra qualquer evidência, subtrair à vida nacional a grande massa miserável do povo e suas condições desumanas de existência material e de opressão política, pondo em seu lugar uma "Venezuela imaginária" - um mito que ganhou as dimensões do "(...) delírio coletivo da 'Grande Venezuela". ${ }^{174}$ Ademais, a força simbólica que esse falseamento exerceu fora do país ganhou uma expressão notável no tom de surpresa alarmada com que a grande imprensa internacional noticiou, mesmo vários anos depois, a irrupção dos violentos distúrbios populares que tomaram conta de Caracas e seus arredores em fevereiro/março de 1989. O assombro era explicável: afinal, havia duas décadas e meia que os venezuelanos não ouviam falar de suspensão de direitos constitucionais, de Estado de exceção e, menos ainda, de tensão social provocada por razões econômicas - impossível prima facie em meio a toda aquela riqueza petroleira. Expressivamente, a imagem do país no exterior persistia sendo, ao fim da década de 1980, a de uma nação pequena, mas rica e até certo ponto mergulhada numa enfadonha e marasmada

\footnotetext{
${ }^{173}$ Cf. MAYA, M. L. Luta hegemônica na Venezuela, 2010, cap. 4.

174 LANDER, Edgardo \& NAVARRETE, Pablo. Op. cit., p. 7.
} 
vida política e social. ${ }^{175}$ Porém, como se verá adiante, uma explosão popular com as proporções do Caracaço destruiria de vez essa ficção excepcionalista, daria a medida real da democracia "conquistada" e desnudaria a hipocrisia das elites governantes no tocante ao valor humano e aos direitos político-civis do que elas celebravam como povo venezuelano.

(Certamente o excepcionalismo não foi, à época, a expressão única da consciência dos grupos dominantes venezuelanos. Contra essa visão de classe (que, aliás, considerada retrospectivamente, hoje chega mesmo a parecer grosseira), puseram-se aqueles que, sem romper o campo do pensamento liberal, advertiam a insensatez do desvario nacional com o petróleo. Entre esses, o personagem mais célebre foi provavelmente o já citado Juan Pablo Pérez Alfonso. Em 1976, quando mal acabara de ser nacionalizada a exploração das jazidas de ferro e de petróleo na Venezuela, publicou-se sua obra Hundiéndonos en el excremento del diablo. ${ }^{176} \mathrm{Na}$ conferência aí incluída e apropriadamente intitulada Plano de Destruição Nacional (em alusão ao V Plano da Nação, de C. Andrés Pérez), o antigo ministro sublinhava, na contracorrente da euforia nacional, duas premissas sem as quais, segundo ele, nenhum pensamento de desenvolvimento teria algum valor prático relevante: primeira, a de que toda a riqueza nas mãos do Estado deveria ser concentrada no esforço de resgatar a sociedade da condição de abandono em que jazia a maioria do povo venezuelano, seus jovens e pais de família, o que só seria realizável se se Ihes provessem, antes de tudo, alimentação, saúde e educação; segunda, a de que a nacionalização do petróleo - "obra emérita da Ação Democrática", como ele reconhecia com satisfação pouco significaria em termos de soberania para o país se o governo se deixasse simplesmente ludibriar pelos ávidos "compradores de petróleo". Afirmava ele, a propósito dessas premissas, empregando um tom no qual transpareciam laivos de radicalismo nacionalista:

Nada nem ninguém fixará um caminho de esperanças para a Venezuela enquanto não se partir do ponto crítico em torno do qual

\footnotetext{
${ }^{175}$ Veja-se adiante o Cap. 6. Em 1976, o Financial Times de Londres ajudaria a construir essa imagem quimérica ao escrever sobre a Venezuela daqueles anos: "Pode considerar-se afortunado qualquer país que conte com enormes reservas de petróleo, um governo pluralista, um clima agradável e as mulheres mais bonitas do mundo"...

176 A edição original pertence à Colección Venezuela Contemporánea, Editorial Lisbona: Publicaciones Españolas, 1976.
} 
todo o restante gira. Nesta pobre-rica Venezuela, como em qualquer outra nação, o que conta é o seu povo. As sociedades humanas derivam sua significação e importância do que possam representar seus homens, mulheres e crianças. Os recursos naturais, renováveis ou não, oferecem possibilidades mais ou menos favoráveis à ação do homem, mas constituem fator secundário, como secundários são a extensão do território e a quantidade de sua população. (p. 21-22) (...)

A reforma agrária é o complemento imediato e direto da [situação] de emergência social. A política sobre essa matéria tem que ser consistente e firme. Não se pode falar de reforma agrária e fomentar ao mesmo tempo a propriedade privada no campo. Se a vontade geral dos venezuelanos se manifestou no sentido de que os camponeses e trabalhadores rurais fossem dotados de terra e munidos dos meios necessários para fazê-la produzir, ao passo que não manifestou nada sobre ajuda do Estado ao empresário rural e condenou o latifúndio, ela tornou evidente o caminho a seguir. Não se deve excluir de uma vez o empresário rural não latifundiário. Mas, ele irá tornando-se progressivamente limitado à proporção que avance o cumprimento do mandato constitucional de dotar de terras e meios para trabalhá-las aos camponeses e trabalhadores rurais. Resulta absolutamente incompatível com o conceito da reforma agrária a ajuda oficial ao empresário do campo que utilize camponeses e trabalhadores rurais assalariados. Semelhante empresário tem de valer-se de seus próprios recursos, ou de outras fontes privadas, mas não pode ser o próprio Estado aquele que desvie ou postergue a conversão dessa empresa privada assalariada em uma empresa camponesa de participação. Uma política eficaz deve propender a ampliar as margens de colaboração privada para uma intensificação da reforma no campo. (...)

A política sanitária, tanto preventiva como curativa, também reclama maior coesão para atender a uma população que precisa ser controlada para que possa ser servida com alguma eficácia. $\mathrm{Na}$ emergência, impõe-se com interesse prioritário a unificação dos serviços de saúde, ao mesmo tempo descentralizando sua administração. A preservação da saúde pública e a moral social impõem que todos os serviços assistenciais de que se disponha possam ser utilizados por aqueles que os necessitem, sem distinções econômicas ou de outro tipo. O custo desses serviços deve ser pago com os impostos, arrecadados, por sua vez, segundo a capacidade econômica dos contribuintes. Não se justifica a desigualdade entre assegurados e não assegurados. (...)

O sistema de educação formal deve ser revisto integralmente para que possa ir-se combinando ao trabalho produtivo. Aprende-se para trabalhar e produzir, e trabalhando e produzindo continua-se a aprender. $O$ resgate dos menores abandonados e uma qualidade melhor de vida para todos restariam inalcançáveis sem combinar o aprendizado ao trabalho. Maiores e menores, todos conseguiremos maior bem-estar e conhecimentos mais firmes aprendendo a ser e a fazer. (pp. 32-33) $)^{177}$

177 REVISTA BCV. Juan Pablo Pérez Alfonso, ¿profecías cumplidas?. (Suplemento de la Revista $\mathrm{BCV}$ ). Vol. XXII, № 1. Caracas, enero-junio, 2008. 
Sem fugir às implicações sociais da lógica liberal (que dominava o pensamento e a prática da socialdemocracia adeca), a austeridade desses juízos de Pérez Alfonso não condizia, porém, com o estado exaltado dos grupos governantes, e por isso ela esbarrou nos entendimentos surdos dos representantes de sua própria classe social. Essa classe, solidária com suas congêneres do resto do continente, não pôde nunca compreender o imperativo da vinculação entre desenvolvimento econômico e progresso social, nem quão insanavelmente curto era o fôlego desse "desenvolvimento" excessivamente ingênuo, empreendido sob as condições do capitalismo dependente. Por essa razão, alguns anos depois, quando o sonho de opulência já se desfizera, políticos e intelectuais enfim desiludidos preferiram ver nas palavras de Pérez Alfonso, não advertências da realidade periclitante, embora encoberta por uma aparência positiva, mas sim profecias que se iam infelizmente cumprindo... Tratava-se de mais um wishful thinking das elites venezuelanas, que teimavam em não recordar o que o ministro dissera, sem nenhum intento profético: "É impossível usar todo esse dinheiro de modo prudente".)

Como se procurará mostrar em capítulo adiante, essa cegueira de classe se repetiria nos anos 1990, quando a direção política do país passou a ser dominada por ideias e práticas do Consenso de Washington. A adoção de uma suposta nova estratégia modernizante - dita reajuste estrutural da economia - ao propor medidas que alegadamente visavam a combater os tradicionais problemas do rentismo petroleiro - mais uma vez em nome do desenvolvimento nacional empurrou o país a um novo desastre, dessa vez sob a forma de um retrocesso econômico, cuja significação profunda seria a de coroar um verdadeiro "(...) processo involutivo, que se manifestou na indústria petroleira venezuelana desde meados dos anos 70 até o presente: a desaceleração e queda de sua capacidade de geração de excedente" ${ }^{178}$ Assim, ao encerrarem-se os anos 1970, não mais se veriam (até pelo menos a primeira década do novo século) outros anos em que a abundância de divisas permitisse pensar em desenvolvimento e democracia.

\footnotetext{
178 POTELLÁ, Carlos Mendoza. "Presentación". In: REVISTA BCV. Juan Pablo Pérez Alfonso, ¿profecías cumplidas?. Vol. XXII, № 1. Caracas, enero-junio 2008, p. 11.
} 


\section{Cap. 2: Dependência e subdesenvolvimento: os limites do progresso nacional}

Desembaraçado das fantasias do excepcionalismo, o período que se inicia em 1973-1974 deve, não obstante, ser interpretado como uma época de importância especial na história contemporânea da Venezuela. Em fins de 1973, a coincidência do súbito e explosivo aumento dos preços internacionais do petróleo com a eufórica vitória eleitoral de Carlos Andrés Pérez à presidência da República ${ }^{179}$ propiciou um momento particularmente favorável ao funcionamento do esquema político puntofijista - auxiliado ainda, como referimos atrás, pela instalação de um clima de momentânea estabilidade social, devido, em parte, ao volume crescente de divisas petroleiras aplicadas em gastos sociais. Quando, no plano ideológico, começaram a ser traçadas as linhas do projeto oficial da Grande Venezuela, algumas circunstâncias justificavam essa boa expectativa. Afinal, no clímax de ingresso dos "petrodólares", alguns indicadores iriam, em pouco tempo, revelar avanços pontuais insólitos no país, como, por exemplo, o de a renda per capita nacional igualar-se à de países desenvolvidos, como a Alemanha Ocidental; ou o de, na América Latina, nenhum outro país experimentar um crescimento econômico da magnitude do venezuelano. Além do mais, o triunfo eleitoral de Andrés Pérez completava-se com a oportuna ampliação da representação parlamentar da Ação Democrática: na Câmara dos Deputados, de 66 cadeiras conquistadas nas eleições de 1968, a AD passava a 102 em 1973, em um total de 200 cadeiras; no Senado, de 19 passava a 28, em um total de 47 cadeiras. ${ }^{180}$ (O Copei, por sua vez, apresentou uma ampliação todavia mais tímida ou, então, viu reduzir-se sua representação em proveito da AD: de 59 deputados em 1968 subiu a 64 em 1973, e de 16 senadores caiu a 13.) Essa nova composição parlamentar produziu o efeito de reequilibrar o poder entre os

\footnotetext{
${ }^{179}$ C. Andrés Pérez elegeu-se ao final de entusiástica campanha cujo slogan "Democracia com energia" traduzia a renovada esperança de que o petróleo serviria de meio para elevar o país ao nível de progresso do "Primeiro Mundo". É digno de nota que a eleição de dezembro de 1973 contou com 96,5\% do eleitorado - a segunda eleição de maior participação de eleitores na história política venezuelana - e Andrés Pérez recebeu quase metade dos votos (48,7\%). (Cf. CONSEJO SUPREMO ELECTORAL. Elecciones presidenciales 1958-2000. Documento disponível em: http://www.cne.gob.ve/web/estadisticas/index_resultados_elecciones_anteriores.php)

${ }_{180}$ Cf. CONSEJO SUPREMO ELECTORAL. Elecciones presidenciales 1958-2000. Veja-se também KARL, Terry L. The Paradox of Plenty. p. 121.
} 
dois principais partidos, e, a par de lhes conferir o controle absoluto das decisões parlamentares - uma condição de hegemonia que só começaria a se alterar negativamente a partir das eleições de 1988 - a maioria adeca nas duas assembleias conformaria uma cômoda independência do Executivo em relação ao Congresso. ${ }^{181}$ Assim, de fato, a alta do petróleo e a normalidade dos pleitos eleitorais uniam surto de crescimento econômico e representatividade democrática em uma conjuntura nacional inusitadamente promissora. Se, para alguns, isso ia constituindo a culminância de um processo de modernização democrática construída ao longo de todo o século $X X^{182}$, para outros, representava o maior desafio ao modelo petroleiro, ao pôr à prova sua viabilidade como motor de progresso em um país cujos governantes sempre estiveram subordinados às transnacionais petroleiras, mas que agora enfatizavam 0 propósito de empreender um desenvolvimento de base nacional. ${ }^{183} \mathrm{~A}$ tabela seguinte permite fazer-se uma ideia inicial da dimensão do crescimento da economia, considerando-se a evolução de algumas variáveis nos primeiros anos da década de 1970:

Tabela 5: Indicadores econômicos 1972-1975 (em milhões de bolívares)

\begin{tabular}{|l|c|c|c|c|}
\hline & $\mathbf{1 9 7 2}$ & $\mathbf{1 9 7 3}$ & $\mathbf{1 9 7 4}$ & $\mathbf{1 9 7 5}$ \\
\hline Receita fiscal & 12.546 & 16.432 & 42.834 & 41.001 \\
\hline
\end{tabular}

${ }^{181}$ Nota a respeito T. L. Karl: "(...) the wide margin of Pérez's victory meant that neither coalitional constraints nor minority status in Congress could restrain presidential power; thus, virtually all political limitations on the office of presidency were removed. Since $A D$ maintained a majority in both houses, opposition parties could not influence Pérez by offering or withholding support for specific policies. Furthermore, because all of AD's members were constrained by party discipline, individual dissidents were bound to vote the official line. Given the structure of the state and its regime rules, only the regular holding of elections, the no-reelection clause in the Constitution, the influence wielded by the government party over its new leader, and Pérez's own character could act as checks on executive hegemony. With the exception of constitutional constraints, which would not become effective for five years, these other checks never became operative". (KARL, T. L. The Paradox of Plenty, p.121.)

${ }^{182}$ Acrescentando-se alguns números ao que ficou dito no capítulo anterior, observa-se que entre 1920 e 1980 - considerando-se a variável PIB/habitante - enquanto as economias mais industrializadas do mundo cresciam a uma taxa anual de 2,6\% e as economias latino-americanas a 2,2\%, a Venezuela alcançava $3,8 \%$ anuais. (Cf. BAPTISTA, Asdrúbal. La economía venezolana entre siglos. Revista Nueva Economía, p. 63. Cf., ainda, LANDER, Luis E. Petróleo y democracia en Venezuela: del fortalecimiento del Estado a la subversión soterrada y la insurrección abierta. Revista Galega de Economía, vol. 14, núm. 1-2 (2005), pp. 1-14. Disponível em: https://www.usc.es/econo/RGE/Vol14_1_2/Castelan/art9c.pdf.) Ambos estes autores, no entanto, concordam quanto ao malogro final dessa modernização venezuelana - grandiosa sim, mas "de pés de barro".

${ }^{183}$ Cf. o documento Acción de gobierno hacia la Gran Venezuela. NUEVA SOCIEDAD, no. 11-12 marzo-junio de 1974, pp. 121-136. 


\begin{tabular}{|l|c|c|c|c|}
\hline Despesas internas & 12.618 & 14.006 & 24.333 & 31.491 \\
\hline Liquidez & 17.205 & 21.284 & 28.047 & 41.406 \\
\hline PIB & 60.608 & 72.482 & 111.331 & 116.351 \\
\hline Demanda agregada & 58.303 & 65.211 & 83.086 & 104.976 \\
\hline Despesas de consumo & 40.597 & 43.935 & 56.391 & 70.492 \\
\hline Formação de capital & 15.783 & 18.616 & 20.984 & 30.598 \\
\hline
\end{tabular}

Fonte: KARL, T. L. The Paradoxy of Plenty, p. 120

O aumento vertiginoso dos valores (tanto relativos como absolutos) desses indicadores, ocorrido em um espaço de tempo notavelmente curto, redundou em um movimento de rápida e significativa ampliação da participação do capital público na economia. Tal ampliação, ao redefinir o papel do Estado na estratégia de desenvolvimento, tornou-se um dos traços históricos principais do período, e é por vezes apontado como a razão para se considerarem esses anos de 1970 (sobretudo a partir de 1973) como o início de uma nova etapa do desenvolvimento capitalista venezuelano. ${ }^{184}$ Segundo um estudo clássico sobre o assim chamado

\footnotetext{
${ }^{184} \mathrm{~A}$ propósito dessa questão central do papel do Estado venezuelano e do capital público, cf., entre outros, ARANDA, Sergio. La economía venezolana: Una interpretación de su modo de funcionamiento. Bogotá: Siglo Veintiuno Editores, 1977. Esse pesquisador vê o ano de 1973 como o início de uma época na qual perdeu força o ímpeto modernizador privado da burguesia venezuelana, que a partir de então teria cedido ao Estado a primazia na condução do desenvolvimento nacional. Um aspecto marcante desse enfraquecimento da iniciativa burguesa, quando comparada aos anos imediatamente após 1958, foi a dissolução progressiva das alianças dessa classe com os setores populares organizados, que haviam garantido o êxito das mudanças políticas no sentido da democracia representativa logo após o movimento de 23 de janeiro daquele ano. Quanto à evolução econômica da época, um outro estudioso - Asdrúbal Baptista -, descrevendo a trajetória do padrão de acumulação capitalista venezuelano no mesmo período, aponta o desequilíbrio crescente entre o capital público e o capital privado como o elemento fundamental do caráter rentístico da economia nacional, bem como de sua inviabilidade. 1973 tem novamente destaque: o gráfico seguinte demonstra como a tendência de desequilíbrio apontada pelo autor iniciou a curva ascendente por volta de 1958 (ano do Pacto de Puntofijo), tendo dado um salto significativo exatamente nos anos de 1973-1974:
} 
petro-Estado venezuelano (The Paradox of Plenty, de T. L. Karl), esse novo peso econômico do Estado - da ordem de 17,2\% em 1974 (calculado a partir do investimento financeiro do governo federal e das transferências de capital como porcentagem do PIB) era ainda mais surpreendente se comparado, por exemplo, ao do Estado brasileiro $(3,6 \%)$ e ao do mexicano $(1,8 \%)$ - em cujas economias reconhecidamente o setor estatal tinha um tradicional predomínio -, ou ainda se comparado aos anos anteriores a $1973(3,7 \%) .{ }^{185}$ Conquanto seja claro que desde os anos de 1920 a economia do país viesse progressivamente se sustentando nas exportações de petróleo - e, ao longo das décadas, o empenho do Estado tivesse sido justamente o de aumentar sua parcela nessas receitas ${ }^{186}$ foi nesta conjuntura dos anos 1970 que, dado o volume extraordinário das receitas e - não menos importante - a manifesta legitimação popular às instituições políticas, o Estado venezuelano passou a dispor dos meios concretos para empreender uma mudança qualitativa profunda na vida econômica e social do país. Em princípio, a conjunção de fatores externos e internos favoráveis teria podido lançar os alicerces de um processo estrutural efetivo de autonomização econômica, cuja oportunidade fora desconhecida em qualquer outro momento do passado histórico venezuelano. Se construtivamente aproveitados, esses fatores

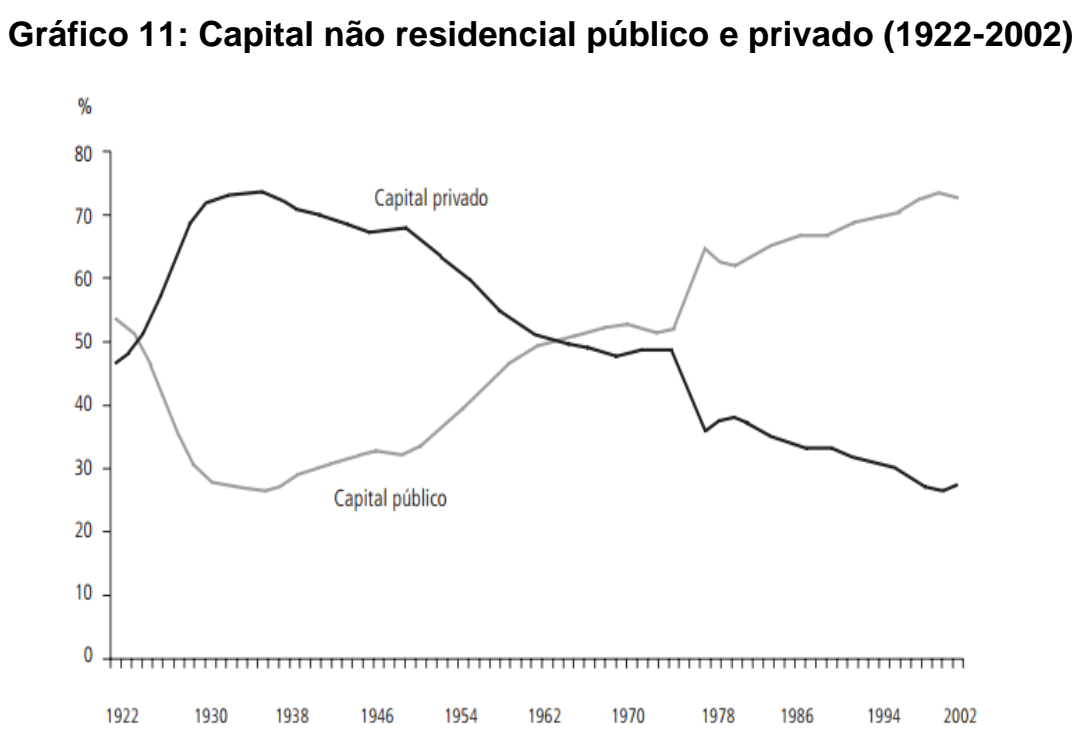

Fonte: BAPTISTA, Asdrúbal. El capitalismo rentístico, p. 108.

${ }^{185}$ Cf. KARL, T. L. The Paradox of Plenty, p. $120-121$.

${ }^{186} \mathrm{Um}$ detalhado histórico do papel do petróleo na evolução econômica venezuelana e dos sucessos em torno da participação estatal em suas receitas desde a década de 1920 até às vésperas da nacionalização de 1976 encontra-se em ARANDA, Sergio. La economía venezolana. Bogotá: Siglo Veintiuno Editores, 1977, sobretudo os cap. I a IV da Parte III. Veja-se também o Cap. 3, adiante. 
teriam permitido à Venezuela levar a cabo sua revolução nacional - ou seja, um conjunto de transformações estruturais, delimitadas por uma estratégia capitalista autonomista, que a burguesia venezuelana tinha de facto condições de executar e que, naquele momento, encontrava amparo na notavelmente expandida força do Estado. Essa estratégia continha em potência os recursos para alçar o país ao plano de uma economia soberana e de uma ordem social democrática, o que representaria alcançar níveis superiores tanto das forças de produção nacionais como, e principalmente, da integração social das classes trabalhadoras e, em geral, das massas populares - em um quadro de normalidade institucional. $\underline{\mathrm{O}}$ sentido autonomista dessa mudança estaria, ao fim, em que, ao aprofundar um processo de restrições relativas ao grande capital imperialista, cresceria, de modo substantivo e duradouro, a participação das diferentes classes tanto na divisão social da riqueza nacional quanto nas estruturas do poder político. ${ }^{187}$ Seria razoável presumir, inclusive, que padrões mais elevados de atuação política das classes trabalhadoras (e das massas populares), facilitados pela própria institucionalidade liberal, constituiriam uma conquista valiosa como fundamento para maior grau de conscientização política sobre as condições de exploração do trabalho e de exclusão social. Nesse sentido, portanto, teriam uma oportunidade real as funções sociais desintegradoras e (subsequentemente) construtivas exercidas pelas classes trabalhadoras e as massas populares, ainda que difíceis nas condições do capitalismo selvagem latino-americano (cf. Florestan Fernandes). Os primeiros passos na autonomização significariam garantir as condições elementares da democracia, nas quais se veria favorecido o próprio trabalho de conscientização proletária (cf. L. Trótski). Essa situação venezuelana,

\footnotetext{
${ }^{187}$ Fazer essa afirmação não significa nem pressupor uma excepcionalidade do caso venezuelano no cenário da América Latina, nem, muito menos, concordar com os velhos argumentos da interpretação etapista do desenvolvimento dos países coloniais e semicoloniais - interpretação que L. Trótski criticou abertamente aos comunistas ao se referir à premissa - errônea - deles de reconhecer e aceitar a capacidade das burguesias nacionais em alcançar as conquistas democráticas da "revolução antifeudal" como um pré-requisito da revolução socialista. Neste caso venezuelano, o que desejamos aqui é apenas ressaltar a potencialidade histórica (notada também, como vimos, por Celso Furtado, embora ele a considerasse em termos diferentes - cf. a citação acima à p. 104-5) de, naquela conjuntura dos anos 1970, o dilema soberania/dependência encontrar uma solução positiva inicialmente dentro dos limites da própria economia capitalista dependente. A importância teórica dessa constatação reside em que a renúncia em aproveitar a oportunidade de autonomização econômica é a prova mais flagrante do peso histórico da condição de associação subordinada das elites proprietárias venezuelanas (a exemplo das demais latinoamericanas) às empresas monopolistas estrangeiras, o que tem mantido atadas essas elites a uma formulação autoritária do ideal de desenvolvimento e a uma concepção egoística e desintegradora das relações sociais.
} 
aliás, acentuaria o contraste com os retrocessos de níveis de organização e conscientização proletárias provocados pelas contrarrevoluções que então se desenrolavam no resto do continente - contrarrevoluções que, em alguns países (Brasil, Argentina, Chile), aniquilariam brutalmente as experiências de ampliação da democracia aí esboçadas em décadas anteriores.

$\mathrm{Na}$ conjuntura venezuelana, entre os fatores favoráveis mencionados, ao menos três merecem ser descritos, mesmo que sucintamente. Em primeiro lugar, a valorização do petróleo à época não tinha, a rigor, um simples caráter circunstancial: a alta espetacular de 1973, embora adviesse do conflito militar no Oriente Médio (como também, anos mais tarde, o novo boom ocorreria em seguida à deflagração da Revolução Islâmica e da guerra Irã-Iraque), inseria-se em um contexto maior, de alterações graduais importantes nas relações da periferia capitalista com os países hegemônicos após a II Guerra Mundial. ${ }^{188}$ Os países atrasados, convencidos da fragilidade de sua industrialização pela via da substituição de importações (ainda mais difícil em economias de enclave), passaram, desde os anos 1950, a considerar a necessidade de ampliar a parcela nacional nos benefícios provenientes de seus recursos naturais. A nacionalização da indústria petroleira (e mineira) tornou-se então uma das principais tônicas dos programas partidários em países periféricos. Na Venezuela, a redefinição de sua inserção no mercado mundial ${ }^{189}$ materializou-se formalmente, entre outras, na Lei de Reversão Petroleira, de 1971, que determinava a transferência ao Estado, em breve período e sem compensação, de todo o controle, funções, instalações e bens da indústria petroleira estabelecida no território do país. Nesse cenário, criaram-se, pois, condições potenciais para que o montante das receitas nacionais se sustentasse em um fluxo fiscal relativamente volumoso e estável, e assim tornasse segura a definição das políticas oficiais de investimentos produtivos e de gastos públicos. Uma conquista dessas seria possível através da defesa dos preços internacionais do petróleo - providência absolutamente factível na medida em que se adotasse uma postura firme da OPEP. ${ }^{190}$ Comprovaria,

\footnotetext{
${ }^{188}$ Veja-se, adiante, o início do Capítulo 3 , em que é apresentada com mais detalhes essa importante mudança histórica da ordem petroleira mundial, valiosa para a compreensão da viabilidade de projetos autonomistas em economias petroleiras da periferia capitalista.

${ }_{189}$ Cf. ARANDA, Sergio. La economía venezolana, p. 283.

${ }^{190}$ Vale lembrar, ainda, que, anterior à fundação da OPEP, a efêmera mas vigorosa experiência nacionalista iraniana de M. Mossadegh (1951-1953) constituiu um exemplo que poderia indicar o
} 
ainda, no caso da Venezuela, a transcendência dessa possível estabilidade a ser alcançada no balanço nacional o fato de, embora irromper à época um período de crise mundial, todo o decênio que se seguiu a 1973 ter sido de aumento da demanda mundial do petróleo venezuelano. ${ }^{191}$

Em segundo lugar, o expressivo crescimento demográfico venezuelano ocorrido desde os anos 1950-60, combinado ao movimento migratório para as cidades (sobretudo para Caracas) e às mudanças de hábitos de consumo daí decorrentes, oferecia as condições para concretizar-se o processo de ampliação do mercado nacional, quer pela via de uma mais equitativa distribuição social das receitas petroleiras - capaz de incrementar a capacidade aquisitiva geral -, quer pela via da expansão dos gastos sociais do Estado. Essa ampliação do consumo, em se realizando, resultaria numa significativa alteração nos padrões então vigentes de acumulação de capital, permitindo à burguesia nacional conduzir o reordenamento estrutural da produção através, primeiro, do aproveitamento - em um nível muito mais alto - da substituição de importações (destacadamente as de bens duráveis); segundo, do aproveitamento produtivo ampliado das matérias primas nacionais (cuja exploração, aliás, como a do ferro e alumínio, ia-se também nacionalizando) e dos investimentos públicos em produção de energia elétrica, produção de alimentos e infraestrutura urbana; e, terceiro, da canalização de parcelas dos grandes volumes fiscais nas mãos do Estado para inversões no desenvolvimento de bens de capital e, em especial, de tecnologia. ${ }^{192}$ Também, o imenso potencial agrícola do país - áreas extensas e férteis - aguardava aperfeiçoamentos técnicos e subsídios, a fim de ampliar sua produtividade e conter o êxodo de trabalhadores e pequenos proprietários sem recursos. Por seu turno, o aumento gradual da população universitária, então observável, justificaria a expectativa positiva na formação de técnicos e pesquisadores nacionais. Em suma, era exequível combinar (como, aliás, prescreviam então os estudos da

grau de dificuldade, como também de viabilidade, das medidas e práticas autonomistas das nações subdesenvolvidas exportadoras de petróleo.

${ }^{191}$ Apenas após 1985 é que o valor das exportações de petróleo venezuelano regrediu para abaixo do de 1973 - embora se acusasse uma diminuição relativa já a partir de 1981. Cf. os valores a seguir:

Valor das exportações venezuelanas de petróleo (preços constantes de 1985, em bilhões de bolívares): 1973: 90,7 // 1974: 152,7 // 1975: 121,4 // 1976: 121,7 // 1977: 117,4 // 1978: 105,9 // 1979: 136,1 // 1980: 145,8 // 1981: 135,3 // 1982: 109,5 // 1983: 92,0 // 1984: 93,0. (Dados extraídos de KARL, T. L. The Paradox of Plenty, Tab. A-I3.)

${ }^{192}$ Cf. BAPTISTA, Asdrúbal. El capitalismo rentístico, p. 106. 
CEPAL) o incremento do consumo nacional com a tão reclamada diversificação produtiva, adicionalmente estimulada por investimentos em ciência e tecnologia autóctones - uma decisão previsivelmente bem dotada para suplantar o caráter meramente rentístico da vida econômica e, principalmente, a instabilidade condicionada pelas fortes oscilações do mercado internacional de petróleo. ${ }^{193}$

Em terceiro lugar, uma mais ampla intervenção do Estado no processo produtivo, como parte da perspectiva de alargamento de sua função social, traria a consequência fundamental de conduzir amplos setores populares a padrões superiores de bem-estar material, e isso sem que os setores burgueses se vissem "subtraídos" de sua parcela na apropriação privada da riqueza provida pelo petróleo. Dito em outras palavras, a orientação social-democrática do governo adeco harmonizava-se com o duplo intento de prover melhores condições materiais de existência ao grosso da população (com gastos ampliados em saúde, educação, moradia, etc.) e de garantir a acumulação privada de capital, aí realizada através de um bem que era, em princípio, propriedade de toda a sociedade. O primeiro propósito serviria à construção das bases populares de sustentação da estrutura política, ao mesmo tempo que permitiria materializar algum grau satisfatório de integração social - ainda que ao custo da formação de uma rede clientelista do Estado. Nisso, vale lembrar, consistia um dos traços essenciais do populismo de conciliação, cujo efeito esperado no plano social era o de diluir os questionamentos populares à ordem vigente. O segundo propósito visava, ante o abrandamento dos riscos de animosidade social (em um momento no qual já haviam sido eliminados os grupos mais radicais e sido cooptados os setores operários mais ativos ${ }^{194}$ ) a fortalecer os setores burgueses hegemônicos nacionais (sobretudo o empresariado industrial, em detrimento parcialmente dos setores agrário-exportador e comercial-importador). Caberia, assim, ao Estado contrabalançar o poder das grandes empresas petroleiras estrangeiras e impulsionar os projetos das bases da industrialização nacional, atenuando as consequências mais agudas da especialização produtiva no mercado mundial e concedendo aos setores da burguesia nacional prerrogativas mais condizentes

\footnotetext{
${ }^{193}$ Cf. ARANDA, S. Op. cit., p. 237. Veja-se também MATA, Héctor Malavé. Venezuela: la economía en el período 1974-1980. México: Comercio Exterior, vol. 32, núm. 1, enero de 1982, pp. 99-104. Disponível em: http://revistas.bancomext.gob.mx/rce/magazines/655/10/RCE10.pdf.

${ }^{194}$ Veja-se adiante o Cap. 4.
} 
com a nova projeção internacional da Venezuela. Pretendeu-se denominar isso de capitalismo de Estado - que representava o outro lado da moeda do populismo de conciliação. Ao delegar ao Estado as funções de promotor e gestor das bases da industrialização, o empresariado venezuelano poderia seguir um caminho de autonomização que contaria com a garantia estatal à acumulação privada, com o empenho oficial em impor restrições à depleção de recursos provocada pelas empresas estrangeiras, e, adicionalmente, com a atuação governamental no controle político das classes subalternas. Como bem assinalou Sergio Aranda a propósito desse caminho virtualmente aberto ao empresariado venezuelano:

(...) a burguesia de todos os países subdesenvolvidos da América Latina e, provavelmente de muitos outros, em outras regiões atrasadas do mundo, tem atribuído ao Estado importantes funções na direção operativa de projetos de base. Apenas os setores burgueses mais recalcitrantemente conservadores têm combatido este novo papel do Estado; os outros, mais sagazes e realistas, não encontram nenhum antagonismo fundamental entre seus interesses de classe $e$ a relevância dada ao Estado na gestão direta de ramos completos da economia interna. Pelo contrário, a experiência de mais de 30 anos demonstra que estes últimos tiveram e têm razão. Em todos os países nos quais o Estado administra gigantescos projetos industriais, energéticos, de transporte etc., os ganhos não se produzem, em definitivo, para essas mesmas empresas, mas sim elas os transferem para a burguesia através de diversos artifícios, sendo o mais conhecido deles o fornecimento, ao setor privado, dos bens produzidos a preços próximos aos de custo de produção, ou mesmo abaixo deles. A diferença na tarefa atribuída agora ao Estado em relação à situação que prevalecia antes de 1974 é que os projetos industriais de que ele estará encarregado não são apenas projetos para a criação de infraestrutura e para pôr à disposição da burguesia os produtos intermediários de uso mais geral, como ferro, aço, alumínio, ou matérias primas de origem química, mas sim que o Estado porá ombros a uma vasta gama de iniciativas que incluem a produção de bens de consumo e bens de capital. Trata-se, conforme as palavras do Presidente da República, de criar um poderoso capitalismo de Estado. ${ }^{195}$

A síntese de todas essas potencialidades históricas encontrou expressão no projeto da Grande Venezuela, cujo programa incorporava prescrições então em voga em praticamente toda a América Latina: combater a pobreza social e promover o desenvolvimento do país tendo por alavanca a expansão e a nacionalização das indústrias de base (sobretudo petroquímica e siderúrgica) e a diversificação das indústrias de transformação; substituir importações, criar

$\overline{{ }^{195} \text { Cf. ARANDA, S. Op. cit., p. } 239 .}$ 
empregos, ampliar o mercado interno e aprimorar a oferta de serviços sociais públicos; favorecer investimentos nacionais e estrangeiros em infraestrutura e tecnologia - tudo isso, ainda, podendo contar a Venezuela com a ventura de uma natureza pródiga (minérios, combustíveis, eletricidade) e uma geografia que a situava próximo do grande mercado consumidor norte-americano. ${ }^{196}$ Nesse cenário, a estratégia oficial do início da década de 70 foi, pois, impulsionar com maior vigor medidas de desenvolvimento já tomadas em governos anteriores. Por exemplo, a partir de 1974, segundo dados oficiais, a SIDOR (Siderúrgica do Orinoco) elevaria sua capacidade de produção para quase 5 milhões de toneladas anuais de aço ${ }^{197}$ - nível que, indiscutivelmente, daria ao país a autossuficiência no setor; além disso, no ano seguinte, toda a exploração industrial de minério de ferro seria nacionalizada. Por sua vez, a indústria petroleira - pedra angular do impulso à industrialização (cf. T. L. Karl) - embora tivesse sua capacidade extrativa gradualmente reduzida em razão do desestímulo às empresas estrangeiras desde o anúncio da decisão de nacionalização, passara a operar com projeções e estimativas de quantidades fabulosas a serem exploradas, ao mesmo tempo que era animada pela previsão - que, todavia, se mostraria depois falsa - de ampliação longa e progressiva da demanda mundial de hidrocarbonetos. ${ }^{198}$ (Deve-se ainda acrescentar como um outro fator favorável da época, segundo se mencionou no capítulo anterior, a conjuntura de facilidade de

\footnotetext{
${ }^{196}$ Cf. KARL, T. L. Op. cit., p. 124.

${ }^{197}$ A Siderúrgica do Orinoco, inaugurada oficialmente em 1962, foi um dos mais importantes projetos industriais do período posterior a 1958. Situa-se no sul do país, em uma região pouco habitada, mas que se aproveita de um imenso potencial hidroelétrico. Desde os anos 1960, Cidade Guayana constituiu um polo de atração de trabalhadores nacionais e ali se formou um importante centro de mobilização e organização operária. (Cf. MAYA, M. L. Luta hegemônica na Venezuela, 2010, cap. 6 et seq.). A expansão da produção siderúrgica alcançaria grande êxito com o Plano IV de Sidor, posto em execução durante o primeiro mandato de Andrés Pérez. A empresa tornar-se-ia, nos anos 1970, uma das maiores estatais siderúrgicas da América Latina, mas passou a enfrentar dificuldades a partir de 1983, quando estourou a crise financeira na Venezuela. Em 1988 possuía ainda 18.000 empregados, número que se iria reduzindo drasticamente após sua privatização em 1997, no bojo do processo de reajuste estrutural neoliberal. Em 2008, foi reestatizada (sob a denominação de Planta Siderúrgica del Orinoco "Alfredo Maneiro"), havendo atingido no ano anterior o recorde de produção (ao longo de um período de mais de vinte anos) de 4,3 milhões de toneladas de aço. Contudo, desencadeada a crise econômica mundial em 2008, sua produção decaiu a menos da metade (1,5 milhão de toneladas, em 2013). (Cf. artigo SUTHERLAND, Manuel. Nacionalización de SIDOR, éxitos de la clase trabajadora, retos, y deberes fundamentales para el desarrollo socialista venezolano. 01/05/2008. Disponível em http:// www.nodo50.org/ceprid/spip.php?article102\&id_document $=1$ \#documents_portfolio.

${ }^{198}$ Veja-se, atrás, a nota 187.
} 
crédito internacional a juros baixos.) Acerca da indústria petroleira nesses anos de boas promessas, observou Terry L. Karl:

Uma expectativa de largo prazo residia na Faixa Petrolífera do Orinoco, a maior reserva mundial de petróleo não convencional, que foi conservadoramente estimada em 1,8 trilhão de barris. Mas, antes que esse depósito pudesse ser explorado, bilhões de dólares teriam de ser investidos em tecnologia para que se pudesse livrar o óleo pesado de seu alto conteúdo de metal e enxofre. Assim, a fim de começar a desenvolver esse "gigante adormecido", o general Alfonzo Ravard, presidente da Petróleos da Venezuela (PETROVEN) estimava que os investimentos na indústria petrolífera teriam de crescer de 1,2 bilhão de bolívares previstos para 1976 a impressionantes 7 bilhões de bolívares em 1980. (...) Desse modo, o primeiro emprego dos petrodólares seria o de garantir a vida da indústria nos anos vindouros. ${ }^{199}$

Ao aproveitar-se o boom do petróleo, conjugado ao aumento extraordinário dos investimentos estatais em infraestrutura (dirigidos também, com especial atenção, para a produção de energia elétrica), a parcela do PIB que cabia ao setor público saltou de 8,278 bilhões de bolívares (em valores correntes) em 1970-1972 para 64,086 bilhões em 1978. ${ }^{200}$ A par disso, o jorro de divisas permitiu ao governo de Andrés Pérez realizar, ainda na primeira metade da década, uma política social com alguns avanços comparativamente expressivos conforme mostram a tabela seguinte (matrícula escolar) e o conjunto de outras medidas sociais, determinadas pelo presidente (cf. também o grupo de gráficos com outros indicadores sociais, adiante, à p. 143):

Tabela 6: Matrícula escolar (1973-1974 e 1974-1975, em milhares de alunos)

\begin{tabular}{|c|c|c|c|c|c|c|}
\hline & $\begin{array}{c}\text { total } \\
(1973-74)\end{array}$ & oficial & privado & $\begin{array}{c}\text { total } \\
(1974-75)\end{array}$ & oficial & privado \\
\hline $\begin{array}{c}\text { nível de } \\
\text { ensino }\end{array}$ & $2.760,5$ & $2.382,7$ & 377,8 & $3.370,8$ & $2.873,1$ & 427,0 \\
\hline $\begin{array}{c}\text { pré- } \\
\text { escolar }\end{array}$ & 93,1 & 56,9 & 36,2 & 152,2 & 108,5 & 43,7 \\
\hline primário & $1.924,0$ & $1.704,7$ & 219,3 & $2.168,5$ & $1.930,1$ & 238,4 \\
\hline
\end{tabular}

${ }_{199}$ KARL, T. L. The Paradox of Plenty, p. 124-5.

200 Cf. BANCO CENTRAL DA VENEZUELA. Informe Económico, 1974, 1977, 1978. Apud. KARL, T. L. Op. cit., p. 142. 


\begin{tabular}{|c|c|c|c|c|c|c|}
\hline médio & 584,2 & 477,2 & 107,0 & 766,8 & 642,1 & 124,7 \\
\hline superior & 159,2 & 143,9 & 15,3 & 212,6 & 192,4 & 20,2 \\
\hline
\end{tabular}

Fonte: Ministerio de Educación, Oficina de Planificación del Sector Universitario. Apud: ARANDA, S. Op. cit., p. 248.

A esses progressos na área da Educação - cujos números apontavam um aumento notável de $22,1 \%$ no número total de alunos de um ano letivo para o seguinte - se somariam outros, de implicação direta no mercado de trabalho e no financeiro, fixados por decretos e destinados a "(...) provocar uma discreta redistribuição da renda entre os setores mais pobres da população e atenuar os problemas do desemprego". ${ }^{201}$ Para tanto, em abril de 1974, o Congresso concedeu ao presidente poderes extraordinários para governar por decretos, inclusive na área econômica:

Medidas de impacto que se somam à ampliação dos gastos públicos com fins sociais:

a) Decreto 122 de 31/05/1974: Fixação do salário mínimo nacional em 15 bolívares diários.

b) Decreto 123 de 31/05/1974: Aumento geral de ordenados e salários até uma porcentagem máxima de $25 \%$ para ordenados e salários até 1.000 bolívares mensais; aumento que decresce progressivamente segundo escalas maiores de renda até $5 \%$ para os compreendidos entre 4.000 e 5.000 bolívares.

c) Decreto 124 de 31/05/1974 e Decretos 858 e 563 de 15/04/1975: Recursos e regulamentações como direitos adquiridos da indenização por antiguidade no trabalho e por auxílio de desemprego.

d) Decreto 563 de 19/11/1974: regulamenta Lei contra demissões injustificadas.

e) Aumento de pessoal não menor que $5 \%$ do pessoal com atividade nas empresas

f) Controle do tipo de juros para os créditos ao consumidor.

A concepção de desenvolvimento contida no discurso político de Andrés Pérez, e na qual se fiava a estratégia oficial venezuelana, correspondia, à

${ }^{201}$ ARANDA, S. Op. cit., p. 249. Como apontou esse autor, todos esses programas de conteúdo social se refletiram nos aumentos anuais dos gastos correntes do Governo Federal, que entre 1972 e 1975 ascenderam de 8,7 bilhões de bolívares para 15 bilhões. 
primeira vista, às linhas gerais daquilo que os estudiosos da CEPAL propunham como fórmula ideal para todo o continente. Com o expandir-se da ação planejada do Estado seguindo um programa de desenvolvimento econômico e social e com aproveitamento dos recursos naturais nacionalizados, o caminho traçado parecia adequado e realizável ao definirem-se por metas prioritárias a industrialização nacional autônoma e o bem-estar social. Na prática, e no que tangia à acumulação de capital, a criação do Fundo de Investimentos da Venezuela (Decreto $\mathrm{N}^{\circ} 151$ de 11/06/74), inserida no programa, visava a transferir aos grupos empresariais privados venezuelanos parcelas significativas da renda nacional por meio do financiamento de grandes projetos industriais (inicialmente até 1977 - estavam previstos cerca de 20 bilhões de bolívares para esses projetos, e eles chegariam, em 1980, a 36 bilhões!). Com o mesmo propósito foram implementados o Fundo de Crédito Industrial (2 bilhões de bolívares para concessão de crédito industrial de médio e longo prazo) e a Corporação de Desenvolvimento da Pequena e Média Indústria (400 milhões de bolívares); além de reativada a Corporação Venezuelana de Fomento. Em 1ํ de janeiro de 1976, nacionalizou-se integralmente a indústria petroleira, e a cerimônia de hasteamento da bandeira nacional em Zumaque I, em Mene Grande (Estado de Zúlia), pretendeu ter a força simbólica de uma vitória definitiva na luta pela autonomia nacional. ${ }^{202} \mathrm{Em}$ termos estatísticos, e considerados em conjunto, os anos entre 1974 e 1980 apresentaram um crescimento da produção nacional (em valores correntes) de $127 \%$ - o que perfez uma taxa de crescimento anual de 18\% - algo claramente surpreendente, mas que já em 1979 acusaria um primeiro estancamento e em 1980 uma primeira regressão. Eram os primeiros sinais de que o projeto desenvolvimentista do discurso oficial esbarrava nas injunções da rígida realidade de dependência externa, visto que o desempenho geral da economia oscilou estritamente condicionado pela variação internacional do preço do petróleo. Nesse sentido, pois, os números da tabela seguinte, que apresenta com maiores detalhes alguns elementos do desempenho econômico nos anos dos booms petroleiros, demonstram que a estagnação do setor primário no final da década (rubricas petróleo, gás natural e mineração) foi acompanhada da

202 Cf. SALAS, Miguel Tinker. The Enduring Legacy. Oil, Culture and Society in Venezuela. Durham and London: Duke University Press, 2009, cap. 7. 
desaceleração brusca ou da interrupção completa de crescimento tanto no setor secundário (especialmente indústria manufatureira - quase estagnada nos últimos três anos) quanto no setor terciário (destacadamente rubrica comércio, que regrediu sensivelmente):

Tabela 7: Venezuela - Produto Territorial Bruto $^{203}$ (milhões de bolívares a preços de 1968)

\begin{tabular}{|c|c|c|c|c|c|c|c|}
\hline PTB & 1974 & 1975 & 1976 & 1977 & 1978 & 1979 & 1980 \\
\hline Total & 60.978 & 64.590 & 70.015 & 74.796 & 77.161 & 77.829 & 76.906 \\
\hline Setor primário & 12.112 & 10.830 & 10.420 & 10.480 & 10.593 & 11.378 & 11.067 \\
\hline Agricultura & 3.958 & 4.236 & 4.083 & 4.403 & 4.682 & 4.854 & 4.993 \\
\hline $\begin{array}{l}\text { Petróleo e } \\
\text { gás natural }\end{array}$ & 7.302 & 5.770 & 5.655 & 5.505 & 5.330 & 5.897 & 5.437 \\
\hline Mineração & 852 & 824 & 682 & 572 & 581 & 627 & 637 \\
\hline $\begin{array}{c}\text { Setor } \\
\text { secundário }\end{array}$ & 14.547 & 15.778 & 17.921 & 19.530 & 20.767 & 20.926 & 20.794 \\
\hline $\begin{array}{c}\text { Indústria } \\
\text { manufatureira }\end{array}$ & 8.333 & 9.286 & 10.392 & 10.839 & 11.368 & 11.945 & 12.404 \\
\hline $\begin{array}{c}\text { Refinação de } \\
\text { petróleo }\end{array}$ & 1.845 & 1.348 & 1.523 & 1.492 & 1.511 & 1.473 & 1.417 \\
\hline Construção & 3.103 & 3.661 & 4.431 & 5.510 & 6.115 & 5.519 & 4.674 \\
\hline $\begin{array}{c}\text { Eletricidade e } \\
\text { água }\end{array}$ & 1.266 & 1.483 & 1.575 & 1.689 & 1.773 & 1.989 & 2.299 \\
\hline Setor terciário & 34.319 & 37.982 & 41.674 & 44.786 & 45.801 & 45.525 & 45.045 \\
\hline Comércio & 6.391 & 7.364 & 8.295 & 8.655 & 8.670 & 8.210 & 6.936 \\
\hline $\begin{array}{l}\text { Transporte e } \\
\text { comunicações }\end{array}$ & 6.961 & 7.664 & 8.404 & 9.439 & 10.128 & 9.683 & 9.639 \\
\hline Serviços & 12.321 & 13.203 & 14.403 & 15.303 & 15.813 & 15.351 & 15.574 \\
\hline
\end{tabular}

${ }^{203}$ PTB, segundo a terminologia do BCV. Há, nesta tabela, algumas pequenas diferenças com relação à tabela 5 , apresentada acima. 


\begin{tabular}{|c|c|c|c|c|c|c|c|}
\hline Governo geral & 7.177 & 7.850 & 8.622 & 9.281 & 9.486 & 9.883 & 10.219 \\
\hline $\begin{array}{c}\text { Direitos de } \\
\text { importação }\end{array}$ & 1.469 & 1.901 & 1.950 & 2.108 & 1.704 & 2.398 & 2.677 \\
\hline
\end{tabular}

Fonte: BCV. Informe Econômico, 1979, 1980. Apud: MATA, Héctor Malavé. Op. cit., p. 101.

A principal inferência a se fazer da evolução desses números, quando analisados à luz da estagnação econômica que se desenhava já com nitidez no início dos anos 1980, é, segundo H. Malavé Mata, a de que houve pouco equilíbrio e articulação entre as atividades produtivas nacionais e as propriamente extrativas de exportação. Embora, efetivamente, o petróleo (secundado pelo ferro) continuasse a ser a principal fonte de recursos de investimentos, sua expansão conjuntural encontrou entraves estruturais que minaram as chances de progresso sustentado do conjunto da economia. A contradição entre a expansão e os entraves verificou-se, por exemplo - ainda de acordo com M. Mata - na exiguidade e rigidez relativas da base produtiva material - o que determinava um insanável desperdício de recursos financeiros, por serem eles parcialmente inaplicáveis em setores fundamentais e, por conseguinte, serem desviados para atividades improdutivas:

(...) a economia do país, sem projetos de investimentos realizáveis em breve lapso, não tinha capacidade real de absorver - visando a uma ampla formação bruta de capital - os ingentes recursos disponíveis. Era óbvio que as receitas petroleiras adicionais proporcionaram um volume de recursos extraordinários, que superava sobejamente a imediata capacidade de absorção de seu aparato produtivo. Isso ocorria porque, em termos gerais, a política de investimentos dos setores público e privado não havia proposto até então senão realizações que, em sua maior parte, se esgotavam em curto tempo. Como evidenciavam os próprios resultados, essa política não se havia ajustado a uma estratégia de formação de capital segundo padrões que harmonizassem a longo prazo a destinação de recursos e as crescentes necessidades nacionais. ${ }^{204}$

A tais percalços juntou-se ainda um somatório de outros obstáculos, inevitáveis em uma economia moldada por longo passado de rentismo e desprovida, mesmo agora em circunstâncias favoráveis, de uma estratégia coerente de desenvolvimento que fosse implementada no curto e médio prazo e

${ }^{204}$ MATA, Héctor Malavé. Op. cit., p. 99-100. 
aproveitasse racional e eficientemente a abundância de receitas. Em primeiro lugar, a baixa produtividade da indústria de transformação - já per si pouco diversificada - e a escassez de mão de obra especializada, que tornava aquela deficiente, eram ambas confrontadas com a circunstância da facilidade de crédito ao consumidor, de maneira que se manteve demasiado alta a parcela do comércio exterior na oferta de bens de consumo, em detrimento da parcela de produção nativa. ${ }^{205} \mathrm{O}$ saldo do comércio exterior de manufaturados - negativo em 1973 - teria esse seu déficit multiplicado por quatro em 1980 (cf. a tabela 9, Comércio exterior de produtos manufaturados, à p. 138). Essa combinação desastrosa, como era de prever, entravou drasticamente o plano de fomento industrial por substituição de importações. Do mesmo modo, o aumento de apenas 26,1\% da produção agrícola entre 1974 e 1980 denunciava o quase nenhum apreço que o governo dedicava à agricultura voltada ao consumo interno, talhando-se assim uma situação na qual cerca de $80 \%$ dos alimentos, destinados a uma população crescentemente urbana, precisavam ser importados. Em segundo lugar, a pletora financeira causada pela abundância fiscal sem absorção na produção e estimulada pelo afã geral de consumo de produtos importados provocou um quadro crônico de forte inflação de preços. Foi, pois, nesse cenário de ampla oferta creditícia e de grande liquidez monetária (liquidez que havia crescido quase duas vezes e meia entre 1972 e 1975 - veja-se a tabela 5, à p. 115), sem a contraparte necessária do incremento e diversificação produtivos, que enfim se frustraram também as metas oficiais de pleno emprego e de cruzada contra a pobreza - havendo os ganhos reais de salários sido, em pouco tempo, devorados pelo aumento do custo de vida. ${ }^{206}$ (Cf. também a coluna remunerações da tabela 10: Participação do setor manufatureiro no PIB não petroleiro, emprego

\footnotetext{
${ }^{205}$ Recordem-se as advertências que C. Furtado fizera pouco tempo antes, em sua visita ao país, acerca dessas dificuldades econômicas (cf. cap. 1).

${ }^{206}$ Sintetizando seu acurado diagnóstico do período, de que fizemos largo uso acima, conclui $\mathrm{H}$. M. Mata: "El congestionamiento financiero de la economía, que operaba contra los mandamientos de la estabilidad monetaria, significó una desmedida efusión de dinero, sin restricciones que frenaran el envilecimiento de su poder adquisitivo, sin medidas que impidieran convertir las inversiones productivas en inversiones especulativas, sin control ni vigilancia que evitaran la fuga del financiamiento crediticio desde los sectores de la producción material hacia las actividades altamente lucrativas del sector terciario. Eso ocasionó que la economía, bajo los auspicios de aquel auge pernicioso, determinara su comportamiento entre una producción deficitaria y una profusión financiera que no mostraban perspectivas de equilibrio a corto plazo, creando las causas y condiciones de un estancamiento agravado por persistentes presiones inflacionarias". (MATA, Héctor Malavé. Op. cit., p. 103.)
} 
e remunerações, à p. 139.) Demais disso, um exemplo claro do mencionado desequilíbrio e desarticulação entre setores econômicos pode ser visto na queda, em participação no PTB, do importante segmento da construção (setor secundário) como também do segmento de transporte e comunicações (setor terciário): no primeiro, importante pelo número de empregados absorvidos, a redução entre 1978 e 1980 foi de 23,6\%, enquanto que, no segundo, em proporção relativa, o crescimento, que fora entre 1974 e 1976 de expressivos 20,7\%, rebaixara-se entre 1978 e 1980 a -4,9\%. É de assinalar-se que a evolução de ambos os segmentos acompanhou de perto a trajetória ascendente (19741978) e descendente (1979-1980) das atividades extrativas de exportação, indicando serem incapazes aqueles segmentos de se sustentar sem estas atividades. Em resumo, dadas tantas insuficiências e contradições, em fins dos anos 1970 já se faziam sentir os indícios de "(...) esgotamento do modelo petroleiro de desenvolvimento" 207 adotado pelos governos venezuelanos. (De passagem, deve-se mencionar que ao fracasso desse "milagre" venezuelano seguiram-se alterações, ainda que não profundas, na composição política do governo: em março de 1979, assumiu a presidência do país Herrera Campins, do Copei, vencendo Luis M. Piñerúa Ordaz, da AD. Um dos motes de sua campanha havia sido justamente o de denunciar o desperdício irresponsável de divisas do governo adeco. Não obstante, e apesar dos tropeços na economia - que persistiriam e se agravariam na nova administração - os dois partidos ainda reuniam os votos de $90 \%$ do eleitorado.)

Em 1980, sobreveio um segundo boom do petróleo, decorrente da instabilidade política em que se precipitaram países exportadores (Irã e Iraque). Os preços internacionais saltaram para 28,67 dólares/barril (estavam em 12,7 dólares/barril em 1978), e atingiram 33,47 dólares/barril em 1982. Reacendeu-se por um momento a crença no petróleo caro como saída para os problemas do país. Em pouco tempo, porém, os preços começaram a decair novamente, chegando a 13,08 dólares/barril em 1986; e assim permaneceriam por um longo tempo. Em contraste com o decênio anterior, os anos entre 1980 e 1988 viram as exportações de petróleo venezuelano recuar em torno de 52\% - situação tão mais grave quando se nota que o pico de preços de 1982 não foi inteiramente positivo

${ }^{207}$ MATA, Héctor Malavé. Op. cit., p. 99. 
para a Venezuela, visto que, nesse ano, as receitas totais do governo reduziramse $15,4 \%$ em relação ao ano anterior. ${ }^{208}$ Concomitante a todo esse descenso geral, que o comportamento das variáveis econômicas (sobretudo o índice de inflação) evidenciava como preocupante e que se manifestava, no plano social, sob a forma de progressiva desvalorização dos salários e de concentração de renda - invertendo, assim, o sentido da momentânea distribuição positiva da renda nacional - a Venezuela ingressava em um período marcado por outro sério problema: o endividamento externo. De fato, como os programas de investimentos oficiais tinham por premissa a expectativa de se manterem altos os preços internacionais do petróleo, quando estes recuaram bruscamente (entre setembro de 1976 e janeiro de 1979, e depois de 1981), foi preciso ao governo recorrer a empréstimos em bancos internacionais para dar continuidade aos gastos previstos (como os dos projetos industriais do V Plano Nacional) - ao custo, todavia, de adotar-se uma política financeira cujo resultado era contrário ao esperável em uma conjuntura de recente abundância fiscal. Por isso, os benefícios da abundância rapidamente se anularam em virtude das obrigações de pagamento externo: ao longo dos mandatos presidenciais de $\mathrm{H}$. Campins e J. Lusinchi (Copei e AD), a dívida externa venezuelana (calculando-se em moeda norte-americana) passou de 12 bilhões em 1979 para o maximum de 32,7 bilhões em 1986, colocando o país entre os mais endividados do continente. A tabela abaixo mostra o movimento ascendente da dívida pública (em moeda venezuelana), cujo ritmo acelerado após 1977 deve ser considerado em comparação com a forte desaceleração dos investimentos, destacadamente após 1981.

Tabela 8: Gastos do Governo/ Investimentos/ Dívida Pública 1970 - 1984 (em milhões de bolívares)

\begin{tabular}{|c|c|c|c|c|}
\hline Ano & Gastos totais & Gastos correntes & Investimentos & Dívida pública \\
\hline 1970 & 10295 & 7159 & 2959 & 177 \\
\hline 1971 & 11915 & 8057 & 3141 & 717 \\
\hline 1972 & 12842 & 8924 & 3489 & 429 \\
\hline
\end{tabular}

${ }^{208}$ Cf. KARL, T. L. Op. cit., Tabelas A-1 e A-2, p. 246-7. 


\begin{tabular}{|c|c|c|c|c|}
\hline 1973 & 15042 & 10087 & 4485 & 470 \\
\hline 1974 & 40059 & 15368 & 24103 & 588 \\
\hline 1975 & 40370 & 19339 & 20676 & 355 \\
\hline 1976 & 39468 & 21250 & 17615 & 603 \\
\hline 1977 & 52041 & 25638 & 24256 & 2147 \\
\hline 1978 & 49905 & 26745 & 20956 & 2564 \\
\hline 1979 & 47569 & 32157 & 10945 & 4467 \\
\hline 1980 & 68551 & 41209 & 21987 & 5955 \\
\hline 1981 & 92182 & 54616 & 32753 & 4813 \\
\hline 1982 & 88942 & 54440 & 27438 & 7064 \\
\hline 1983 & 80134 & 54042 & 20399 & 5693 \\
\hline 1984 & 99706 & 68797 & 19461 & 11448 \\
\hline
\end{tabular}

Fonte: BCV. Informe económico (diversos anos). Apud: KARL, T. L. Op. cit., p. 165 (modificado).

Em fins dos anos 1980, a CEPAL preparou um estudo interno (A Poupança na Venezuela) sobre o quadro econômico venezuelano dos dois decênios anteriores, no qual sublinhava as severas limitações às possibilidades de crescimento "(...) independentemente de quão bem sucedidas pudessem ser as políticas internas que o país se decidisse a implementar". ${ }^{209} \mathrm{O}$ estudo permitia quantificar a disparidade crescente entre os diversos setores da economia (petroleiro e não petroleiros) e os índices de inflação, e ressaltava como sendo o aspecto mais crítico daquelas limitações a gigantesca sangria que o país passara a sofrer em virtude dos serviços da dívida contraída. Afirmava o estudo:

Como resultado dos fatores analisados, os pagamentos a título do serviço da dívida externa venezuelana aumentaram consideravelmente, passando de \$121 milhões em 1970 para 4,107 bilhões em 1987. Durante o período 1982-87, a transferência liquida de recursos do exterior para a Venezuela foi negativa da ordem de 3 bilhões anuais e, por essa razão, a partir de 1982, as transações vinculadas com a dívida subtraíram recursos da poupança interna ao invés de complementá-la. O país utilizou proporções significativas de suas receitas de exportacões para dar cumprimento aos compromissos derivados de suas obrigacõos externas, não obstante o qual seu nível de endividamento global não se reduziu.

${ }^{209}$ Cf. CEPAL. El ahorro en Venezuela. (1970-1988). Trabajo preparado por Cristina Rodríguez. Distribución interna. 13/11/1989. Disponível em: http://repositorio.cepal.org/handle/11362/33324. 
No que se refere à dívida pública, de acordo com cifras do Fundo Monetário Internacional (IMF, World Debt Tables, 1988-1989), a dívida externa de longo prazo contraída pelo setor público, que em 1970 ascendia a \$ 728 milhões, alcançou um montante de 25,245 bilhões em 1987. Esse crescimento acumulado significou uma mudança na relação da dívida com o PIB, de $7 \%$ para $65 \%$, e proporções de $26 \%$ e $197 \%$ em comparação com as exportações de bens e serviços. Do mesmo modo, as relações do serviço dessa dívida no tocante ao PIB passaram de $0,7 \%$ para $7,4 \%$, e, em comparação com as exportações de bens e serviços, a relação aumentou de $3 \%$ para $22 \% .{ }^{210}$

As acentuadas mudanças nessas relações - ou seja, no concernente ao volume da dívida, ao montante de seu serviço e à queda não contida do PTB a até pelo menos 1984 (vejam-se os gráficos 12 e 13, em seguida) - somadas à perda progressiva do valor real do bolívar, transformaram o projeto de desenvolvimento venezuelano em um pesadelo de inflação, alto custo de vida e endividamento externo, a que os sucessivos governos tentaram contrapor uma série de pacotes de ajustes macroeconômicos. Em fevereiro de 1983, diante do quadro de estagnação da atividade econômica (a qual teve variações do PTB interanuais negativas em 1980, 81, e 83), o presidente Herrera Campins tomou a decisão de desvalorizar fortemente a moeda venezuelana (Sexta-Feira Negra) e adotar um sistema de câmbio diferencial. Em fevereiro de 1984, o recémempossado Jaime Lusinchi também procurou corrigir os desequilíbrios econômicos, buscando sobretudo refinanciar a dívida externa do país. Para isso, adotou uma nova desvalorização do bolívar, a concessão de bônus para trabalhadores de menor renda, a ampliação do controle oficial de preços, aumentos no preço interno da gasolina e derivados de petróleo e a promessa de reduzir os gastos do Estado. ${ }^{211}$ Nenhum dos dois pacotes surtiu os efeitos desejados e esse período se fechou em 1984 com o triplo indicativo de produção nacional em baixa e de inflação e dívida externa em alta. Entretanto, a crise assim instalada seria ainda mais aprofundada nos anos seguintes, quando às deficiências internas do modelo exportador juntaram-se algumas mudanças importantes do mercado internacional de petróleo: a) a adoção, nos países industrializados, de medidas para substituir parcialmente os combustíveis fósseis por formas alternativas de energia; b) as descobertas de grandes jazidas em

\footnotetext{
${ }^{210}$ CEPAL, El ahorro en Venezuela. (1970-1988), p. 12-13. (Os valores estão em dólares norteamericanos. Grifo nosso.)

${ }^{211}$ Cf. MAYA, Margarita López. Luta hegemônica na Venezuela. 2010, p. 17-25.
} 
países não pertencentes à OPEP; e c) as dificuldades de uma ação coesa entre os países-membros dessa organização para atuar como um cartel de facto.

Gráfico 12: PTB e Taxa de inflação

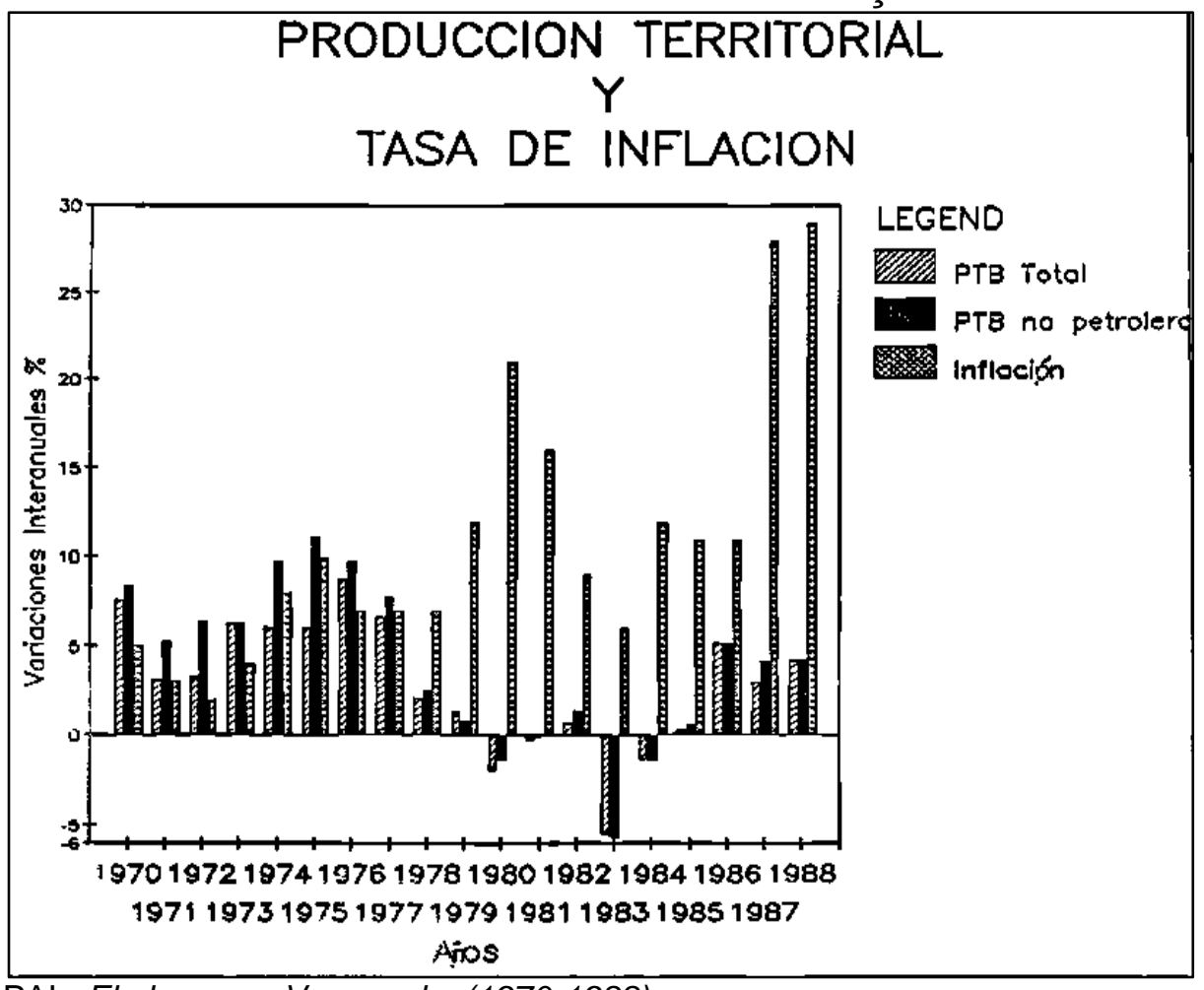

Fonte: CEPAL. El ahorro en Venezuela. (1970-1988).

Gráfico 13: Transferências externas vinculadas ao endividamento TRANSFERENCIAS EXTERNAS VINCULADAS AL ENDEUDAMIENTO

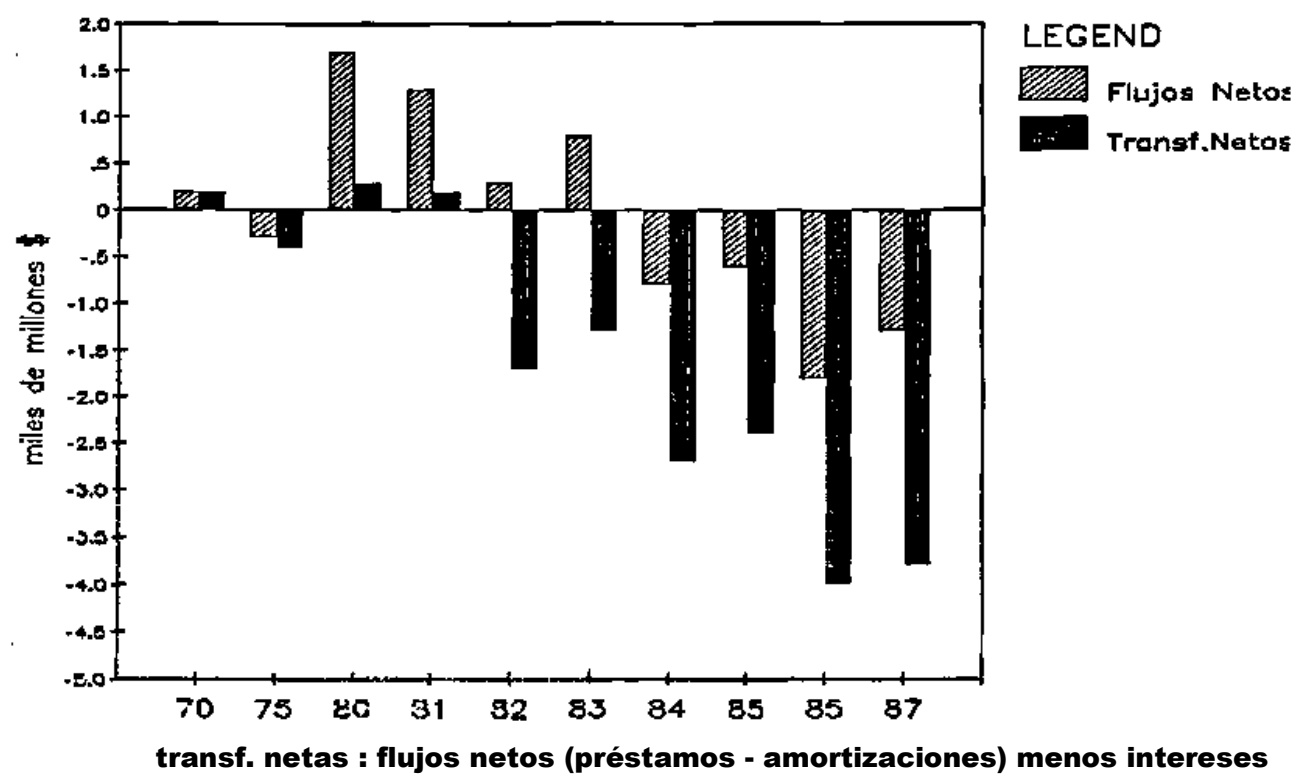

Fonte: CEPAL. El ahorro en Venezuela. (1970-1988). 
Em um balanço sintético do período 1973-1984 pode-se, pois, afirmar: que, em linhas gerais, todos os segmentos da economia venezuelana foram, nos primeiros cinco anos, positivamente impulsionados pelo afluxo maior de receitas provenientes do comércio externo petroleiro; que, no entanto, o quinquênio seguinte experimentou um estancamento ou retrocesso em praticamente todos os mesmos segmentos; que os investimentos nos segmentos não petroleiros repetiram a oscilação de alta e baixa do setor petroleiro; que, analogamente, houve de início uma melhoria substancial nos padrões gerais de vida e de consumo das populações sobretudo urbanas, seguida, todavia, de uma depauperação contínua, especialmente dos grupos sociais assalariados; que a depauperação tornar-se-ia particularmente aguda na segunda metade da década de 80 , ocasionando uma situação de descontentamento e agitação social contrastante com a situação da década anterior; que os gastos públicos (gastos correntes) tenderam a um aumento contínuo por todo o período, mas para o qual foi necessário ao Estado recorrer progressivamente a empréstimos internos e externos, apesar da abundância fiscal; que, ao final do período, a economia havia-se tornado ainda mais dependente das receitas petroleiras para custear as despesas do Estado, estimular a demanda dos outros setores, e amortizar e pagar empréstimos externos; que, em conclusão, ao maior crescimento econômico nacional do século XX seguiu-se um período visto como um dos mais críticos da história contemporânea da Venezuela, mergulhada daí em diante em inflação, endividamento e instabilidade política e social. ${ }^{212}$ Pouca discordância há de que o definhamento da Grande Venezuela se deveu ao pesado ônus da condição de dependência estrutural do país - sua intocada essência primáriomonoexportadora, a carência de tecnologia e a profunda suscetibilidade às variações externas - problemas que, não obstante, bem cedo foram apontados por observadores que viam com manifesta reserva o lema presidencial Democracia com energia - desconfiados, inclusive, da real significação progressista da nacionalização do petróleo. De fato, ao fim do período, reconhecia-se: aquilo que, de qualquer perspectiva racional, deveria constituir um

${ }^{212}$ Cf. SALAZAR-CARRILLO, Jorge \& WEST, Bernadette. Oil and Development in Venezuela during the 20th Century. Westport, Connecticut: Praeger, 2004, 214-215. 
meio de impulso ao desenvolvimento - a riqueza do subsolo -, destinada a alimentar transitoriamente o progresso econômico e social (fora sempre esse, afinal, o significado de "semear o petróleo"), acabou por tornar-se, como outrora, um fim em si, tendente a estimular a burocratização do Estado (especialmente em torno dos recursos da gigantesca estatal petroleira - PDVSA) e a corrupção político-administrativa, florescente nesse meio opulento (embora ela seja, infelizmente, um fenômeno difícil de ser quantificado para um estudo econômico), bem como tendente também a gerar um grau agudo de desigualdade na distribuição social da riqueza. Assim, quando, poucos anos depois (1993), o próprio presidente Andrés Pérez se viu envolvido por essa mesma corrupção, a ponto de ser destituído, já a fé no sistema democrático, nos grandes partidos e no petróleo como "riqueza nacional" deixara de ser um sentimento popular.

No que concerne especificamente à indústria manufatureira não petroleira, se a sensação ao fim do período não era ainda, a rigor, de frustração, uns poucos anos mais bastariam também para evidenciar a fragilidade inata do setor. Nos anos de prosperidade do petróleo, observou-se realmente um impulso concomitante na expansão dos níveis da produção industrial, em certa diversificação setorial e em um relativo aperfeiçoamento tecnológico - processos esses que, embora em ritmo mais lento, vinham-se desenrolando desde 1958. ${ }^{213}$ Tal impulso claramente acontecia, como foi dito acima, à proporção que a indústria nacional se valia tanto da conjuntura de dilatação do mercado interno como do apoio financeiro do Estado. Ao irromper, porém, a crise após 1981 (marcada por preços do petróleo e investimentos em queda em 1982, e por desvalorização do bolívar em 1983), a trajetória até então progressiva da industrialização começaria a sofrer, após três décadas, soluções de continuidade. Estas, por fim, seriam agravadas quando até mesmo os poucos mecanismos de defesa da produção manufatureira nacional (proteção alfandegária e cotas de importação) foram sendo aos poucos abandonados pelo governo. ${ }^{214} \mathrm{Em}$ vista

\footnotetext{
${ }^{213}$ Veja-se TORO, Héctor Valecillos. "Reajuste estructural de la economía y desindustrialización en Venezuela". In: TORO, Héctor Valecillos \& RODRíGUEZ, Omar Bello (comps.). La economía contemporánea de Venezuela. 1990-1999. Ensayos escogidos. Tomo I. Caracas: Departamento de Publicaciones BCV, 2001, pp. 101-140. Disponível em: http:/www.bcv.org.ve.

${ }^{214}$ Apontando as principais deficiências do processo de industrialização venezuelano dos anos 1960-80, resume H. Valecillos Toro: "(...) el sector industrial no logró generar recursos suficientes para financiar su crecimiento, debiéndose apoyar en el ahorro público y dependiendo de una protección elevada para su funcionamiento y de un esquema de precios
} 
disso, ao encerrarem-se os anos 1980, a porcentagem do setor manufatureiro no PIB - porcentagem que viera crescendo ininterruptamente desde 1970 e que, sendo ainda ascendente entre 1984 e 1986, "(...) parecia evidenciar a presença de forças de expansão desse setor econômico" ${ }^{215}$ - principiou, no entanto, a reduzir-se sensivelmente, e a trazer junto nessa queda os níveis de emprego e de remuneração dos trabalhadores. $O$ alento que a indústria fabril recebera do petróleo não the garantira nem autossuficiência nem maturidade. As tabelas abaixo (que incluem anos que ultrapassam o período aqui estudado) ilustram como a resultante do processo de industrialização, visto tão entusiasticamente nos anos 1970-80, terminou por assumir sua feição mais desoladora: a da desindustrialização. Ao observar-se o comportamento do comércio exterior de produtos manufaturados (Tabela 9), destaca-se o saldo exportações/importações quase sempre negativo entre 1970-1992. Isso se deu, em geral, por causa ou da incapacidade de atender a demanda interna em crescimento, ou da fragilidade na concorrência com produtos importados, especialmente em momentos de valorização cambial da moeda venezuelana - ou, ainda, pela combinação de ambas as coisas. Assim, enquanto o volume das exportações regredia para um nível de 8 anos antes (1992 comparado a 1984), as importações explodiam atingindo seu maior nível histórico. Condizentemente, a oscilação dos níveis de remuneração (Tabela 10), de óbvio impacto na qualidade de vida da maioria da população urbana e, também, no grau de agitação social, apresentou, junto com os níveis de emprego - considerando-se 1992 novamente como referência final a particularidade de haver regredido a valores semelhantes ou inferiores a de vinte anos antes. Mesmo a pequena e momentânea diminuição no saldo comercial que o reajuste estrutural neoliberal trouxe nos anos 1989 e 1990 não foi capaz de sustar a regressão; ao contrário, provocando o que se chamou de uma internacionalização passiva da política econômica nacional, o reajuste conduziu a

relativo que lo favoreció claramente en detrimento del sector agropecuario. La protección excesiva y prolongada dio lugar a una industria poco competitiva, con productos frecuentemente de baja calidad y precios elevados en términos internacionales, que no satisfacían eficazmente las necesidades de los consumidores nacionales y eran prácticamente no exportables. Además, y en líneas generales, los tamaños de plantas se mostraron inadecuados, conllevando una sobrecapitalización del sector, la cual fue favorecida por la sobrevaluación externa de la moneda nacional. La industria registró (y continúa haciéndolo) una alta concentración regional, sectorial y social, con un impacto reducido en la distribución del ingreso, pues se favoreció más el uso de tecnologías intensivas en capital que en mano de obra". (TORO, Héctor Valecillos. Op. cit., p. 107) ${ }^{215}$ TORO, Héctor Valecillos. Op. cit., p. 110. 
que "(...) o intento de enfrentar o endividamento externo nos termos ditados pelo Fundo Monetário Internacional soldou a gestão monetária do país, de maneira subordinada, ao mercado financeiro internacional, dolarizando a economia e vinculando perversamente o tipo de câmbio e as taxas de juros domésticas". ${ }^{216}$ Isto significou a imediata redução da demanda interna e do volume de investimentos, e emprestou às medidas do reajuste estrutural um nítido viés antiindustrial. Por isso, o "modelo petroleiro" recobraria força relativa sob as políticas neoliberais - ou seja, não por um impulso próprio, mas pela gradual falência dos setores que lhe deveriam ser complementares no conjunto da economia.

Tabela 9: Comércio exterior de produtos manufaturados (milhões de dólares)

\begin{tabular}{cccc}
\hline Años & Exportaciones' & Importaciones & Saldo \\
\hline 1970 & 42 & 1.538 & -1.496 \\
1973 & 59 & 2.251 & -2.192 \\
1980 & 700 & 9.292 & -8.592 \\
1981 & 815 & 10.049 & -9.234 \\
1982 & 662 & 10.215 & -9.553 \\
1983 & 782 & 5.672 & -4.890 \\
1984 & 1.036 & 6.084 & -5.048 \\
1985 & 1.299 & 6.619 & -5.320 \\
1986 & 1.258 & 7.301 & -6.043 \\
1987 & 1.430 & 8.162 & -6.732 \\
1988 & 1.987 & 10.525 & -8.538 \\
1999 & 1.340 & 6.911 & -5.571 \\
1990 & 1.337 & 6.558 & 5.221 \\
1991 & 1.131 & 9.852 & -8.721 \\
1992 & 1.066 & 12.062 & -10.996 \\
\hline
\end{tabular}

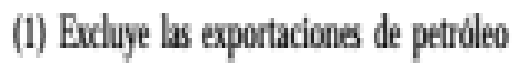

Fonte: BCV. Apud TORO, Héctor Valecillos. "Reajuste estructural de la economía y desindustrialización en Venezuela", p. 120.

${ }^{216}$ TORO, Héctor Valecillos. Op. cit., p. 105. 
Tabela 10: Participação do setor manufatureiro no PIB não petroleiro, emprego e remunerações

\begin{tabular}{cccc}
\hline & \multicolumn{3}{c}{ \% DEL SECTOR INDUSTRIAL NO PETROLERO } \\
\cline { 2 - 4 } Años & En el PIB $^{1}$ & En el empleo $^{\mathbf{2}}$ & En las remun. $^{\mathbf{3}}$ \\
\hline & & & \\
1970 & 15,3 & 9,75 & 15,3 \\
1973 & 15,8 & 10,52 & 15,0 \\
1980 & 15,8 & 12,28 & 14,1 \\
1981 & 15,1 & 11,22 & 13,5 \\
1982 & 15,6 & 11,04 & 14,2 \\
1983 & 15,9 & 10,86 & 14,5 \\
1984 & 18,4 & 10,66 & 16,7 \\
1985 & 21,1 & 10,14 & 20,4 \\
1986 & 22,3 & 9,68 & 19,1 \\
1987 & 20,5 & 9,71 & 18,8 \\
1988 & 20,3 & 9,51 & 18,6 \\
1989 & 20,5 & 8,68 & 20,5 \\
1990 & 20,5 & 8,17 & 16,6 \\
1991 & 19,8 & 8,40 & 16,1 \\
1992 & 17,7 & 7,99 & 15,8 \\
\hline
\end{tabular}

1. Se excluye refinación

2. Empleo en áreas urbanas

3. Total de remuneraciones pagadas a los trabajadores en el año

Fonte: BCV. Apud TORO, Héctor Valecillos. "Reajuste estructural de la economía y desindustrialización en Venezuela", p. 110

No plano das necessidades sociais, a melhora de vários indicadores durante os anos de boom não bastou para iludir aqueles que tinham por premissa que o sistema capitalista (principalmente em seu padrão dependente) mostra-se sempre intrinsecamente incapaz de promover estados duradouros de equidade e de bem-estar geral. Tal convicção, aliás, completava-se com duas outras, distintas mas inter-relacionadas: a do caráter necessariamente ideológico, e portanto, ilusório, das análises econômicas burguesas, e a da natureza antissocial da concepção capitalista-dependente de desenvolvimento. Com essa perspectiva teórica, em 1976, publicou-se em Caracas, o estudo de Michel Chossudovsky La miseria en Venezuela -, que procurava explicar como, em um meio de fartos recursos econômicos, vigoravam contraditoriamente altos níveis de pobreza e de marginalização social - consequências de uma distribuição sui generis da riqueza social, o petróleo, aí "(...) convertido em riqueza privada de uma minoria que, ao 
enriquecer, adquir[ia] o poder de converter seus privilégios em direitos". ${ }^{217}$ Segundo denunciava o estudo, os argumentos pretensamente científicos adotados pelos economistas liberais tendiam a distorcer a realidade social das maiorias populares por privilegiarem dados puramente econômicos dos períodos de prosperidade - os "milagres" latino-americanos (como, por exemplo, o brasileiro, que, por sua "excelência", devia servir de espelho ao venezuelano). Quando, porém, fora desse campo teórico, investigavam-se objetivamente as condições concretas de vida das camadas majoritárias dessas sociedades de classes, o quadro se revelava profundamente diverso do descrito pelo otimismo burguês. Desse modo, na riquíssima Venezuela, que, havia pouco, nacionalizara sua maior riqueza e a promovia como caminho ao desenvolvimento:

(...) $16 \%$ da força de trabalho (de acordo com estatísticas oficiais) estão sem emprego, e mais de uma terça parte dela percebe "rendas" abaixo do salário mínimo oficial. Nos últimos anos, paradoxal e precisamente durante os anos favoráveis da "bonança financeira", ampliou-se o desemprego, e a capacidade de absorção de mão de obra por parte do setor industrial vem diminuindo. Isto (...) não é uma circunstância fortuita nem um desvio das normas da planificação governamental, mas parte de um processo social coeso no qual a destinação e utilização do excedente, que é resultado da "privilegiada situação financeira da Venezuela", contribuiu tanto para incrementar a concentração industrial como para produzir um processo de centralização da propriedade e do capital industrial. Vale dizer, a classe empresária é a beneficiária da nacionalização da indústria petroleira. A "nova ordem institucional", as disposições creditícias e os subsídios e incentivos diretos ao setor fabril, etc. constituem a mecânica que permite à classe capitalista nacional dispor dos recursos financeiros do Estado. Além disso, a fórmula de "empresas mistas" em petroquímica e siderurgia, ou o que alguns observadores denominam de "a pentagonização", permite às empresas multinacionais "participar" em condições muito favoráveis, sendo o Estado aquele que assume o "fator risco" e provê a maior parte do financiamento. Ao passo que os indicadores financeiros, o consumo de champanhe e das melhores marcas de uísque importado, a compra de automóveis Mercedes Benz e aviões privados (sem mencionar as viagens de fim de semana a Miami) mostram uma indubitável tendência ascendente que bate "novos recordes" e são característicos de um "saudável" processo de crescimento e de um "dinâmico" mercado consumidor, a mortalidade infantil e a frequência de desnutrição também exibem um movimento ascendente, indicativo presumivelmente do fato de que a "saúde da economia" não se consegue "sem custo". A taxa de mortalidade infantil em 1973 (53.7 por 1.000) era mais alta que

${ }^{217}$ CHOSSUDOVSKY, Michel. La miseria en Venezuela. $2^{\text {a }}$ ed. Caracas: Vadell Hermanos Edit., 1977. O excerto acima é da Presentación de Héctor Silva Michelena. 
a registrada no período imediatamente posterior à derrubada de Pérez Jiménez e da restauração do "governo democrático".218

De fato, ao considerarem-se índices como desnutrição e subalimentação, educação, saúde, pobreza habitacional, emprego e distribuição de renda (cap. II a VI do estudo), o panorama venezuelano não deixava margem a dúvidas quanto a, ao menos, duas verdades, essencialmente conflitantes. Primeiro, a da efetividade dos meios materiais, em uma nação de recursos fartos, para se superar, de uma vez por todas, o subdesenvolvimento social. (Como vários outros autores já referidos, também $M$. Chossudovsky acreditava que a Venezuela, com o petróleo valorizado, possuía meios concretos bastantes para erradicar satisfatória e definitivamente a pobreza social.) Segundo, e desafortunadamente, a do inelutável revés dessas tentativas de superação em virtude de serem empreendidas por elites políticas aferradas à crença de que deviam sempre prevalecer os interesses privados na destinação dos recursos públicos. Essa crença estaria na base de um estilo de progresso do qual o capitalismo dependente não se podia eximir e que encarava as carências e injustiças sociais como fatalidades a serem toleradas em favor do desenvolvimento nacional. ${ }^{219}$ Demais, um aspecto particular do problema do desenvolvimento venezuelano que esse estudo apontava com ênfase maior do que outros publicados à época referia-se aos mecanismos institucionais e à sua orientação privatista no definir a destinação oficial dos excedentes financeiros de origem petroleira. Afirmava M. Chossudovsky:

(...) observaremos, em primeiro lugar, que as instituições financeiras do Estado operam de maneira bastante integrada com o setor financeiro e

\footnotetext{
${ }^{218}$ CHOSSUDOVSKY, Michel. La miseria en Venezuela, s/p.

${ }^{219}$ Quanto a isso, o estudo ainda acrescentava: "(...) Más del 70 por ciento de los venezolanos y la casi totalidad de la población agrícola vive en condiciones de subalimentación. La hipoalimentación afecta a casi la mitad de la población venezolana, y más de la mitad de los niños del país presentan algún grado de desnutrición. Un venezolano de cada tres, en edad de trabajar, está o desempleado o sub-empleado. Dos de cada tres venezolanos ocupados en actividades no agrícolas y la casi totalidad de los ocupados en actividades agrícolas, perciben ingresos mensuales inferiores al salario mínimo de subsistencia. Casi una cuarta parte de los venezolanos son analfabetos y más de un niño de cada cinco está marginado del sistema de educación. Uno de cada tres niños alcanza a terminar la educación primaria, mientras que en el medio rural más de la mitad de los niños no se inscriben en el primer grado y apenas uno o dos en cien terminan la primaria. La mitad de la población del país vive o en un rancho o no dispone en el interior de la vivienda de agua y de la estructura sanitaria adecuada. Casi una de cada cuatro familias no disponen de electricidad en su vivienda." (CHOSSUDOVSKY, M. Op. cit., s/p.)
} 
bancário privado. Desse modo, os excedentes financeiros do Estado são canalizados para projetos específicos de investimentos no setor real da economia através do sistema financeiro e bancário privado, e presumivelmente de acordo com critérios de destinação correntemente utilizados pelo setor privado. Nesse sentido, o setor financeiro e bancário privado desempenha um papel-chave no processo de destinação do excedente econômico do Estado, já que pode determinar, na etapa inicial de avaliação, se um projeto de investimento é aceitável ou não. Uma vez que o crédito tenha sido outorgado, a instituição creditícia estatal transfere os fundos correspondentes a uma instituição bancária privada para que esta os administre. Assim, por não ter uma relação contratual direta com o receptor do crédito, o fundo do Estado passa a depender, em grande medida, da entidade financeira privada, não só na etapa de avaliação do projeto, mas também na etapa de sua implementação. ${ }^{220}$

O que daí decorria era algo decisivo: se o raciocínio que definia a função e a atuação das instituições de crédito do Estado era, em tese, o da rentabilidade social - ou seja, aquela a se materializar através do crédito predominantemente à produção agrícola, à produção industrial básica e à infraestrutura urbana, cujo significado urgia exprimir um real progresso social - ao imporem-se as exigências da rentabilidade financeira, ditadas pelos interesses privados (nacionais e estrangeiros), estes, na prática, acabavam por condicionar as decisões quanto aos critérios de destinação dos excedentes financeiros. Provocava-se assim uma clara contradição entre o imperativo da valorização do capital privado e a necessidade de aplicações sociais dos excedentes - contradição que, em razão da dinâmica própria do sistema, seria resolvida em prejuízo da segunda. Portanto, - concluía o estudo - ou destruía-se radicalmente essa dinâmica, substituindo-a por outra de orientação socialista, ou reconhecia-se que o desenvolvimento nacional não passava de mais uma falácia burguesa de economistas liberais.

Os gráficos a seguir apresentam o comportamento de algumas variáveis sociais, e demonstram como, em um período de aproximadamente quinze anos a contar do primeiro boom econômico (1973-4), realmente os níveis de qualidade de vida da sociedade venezuelana foram decaindo (paralelamente aos níveis de salário) para atingir patamares de crise aguda em fins dos anos 80 , após haverem

${ }^{220}$ CHOSSUDOVSKY, M. Op. cit., s/p. 
chegado - vale lembrar - aos melhores níveis da América Latina apenas uma década antes. ${ }^{221}$

Grupo de gráficos: Evolução de indicadores sociais (anos 1970-80)
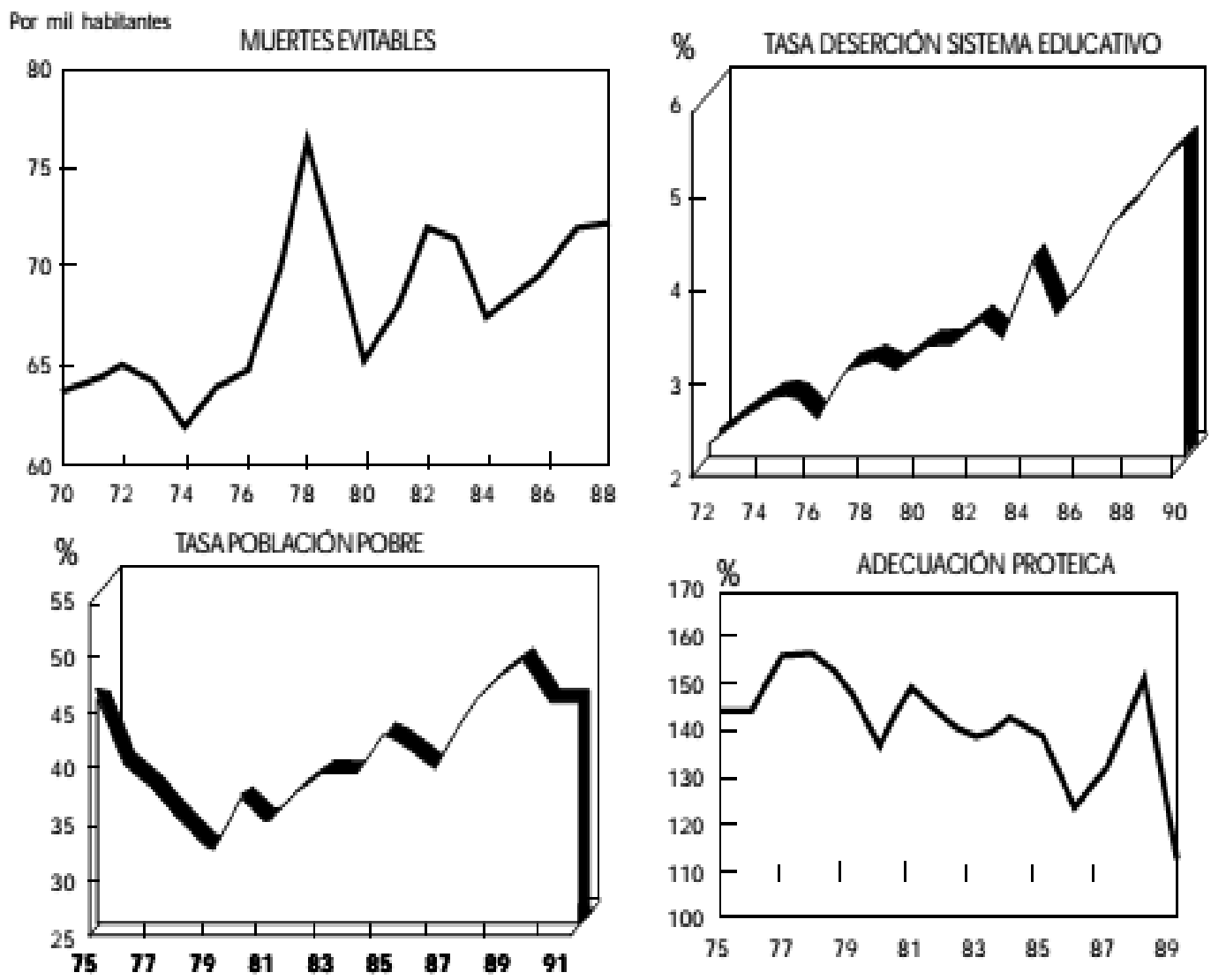

Fonte: VIVANCOS, Francisco. "Salarios, ingresos y estabilización en Venezuela", p. 79.

Por fim, uma rápida observação, de ordem teórica: todo esse drama venezuelano de contradições, a exemplo do que ocorreu a outros países subdesenvolvidos igualmente dotados de grandes recursos naturais, configura um quadro histórico descrito por alguns estudiosos como um paradoxo da abundância. ${ }^{222}$ Trata-se da situação de economias que, ocasionalmente, experimentam anos sucessivos de grandes receitas e altos produtos agregados, mas que permanecem, a médio e longo prazo, apresentando taxas modestas de

${ }^{221}$ Cf. VIVANCOS, Francisco. "Salarios, ingresos y estabilización en Venezuela". In: TORO, Héctor Valecillos \& RODRíGUEZ, Omar Bello (comps.). La economía contemporánea de Venezuela. 1990-1999. Ensayos escogidos. Tomo I. Caracas: Departamento de Publicaciones BCV, 2001, pp. 65-100. Disponível em: http:/www.bcv.org.ve.

${ }_{222}$ A expressão foi originalmente usada por Terry Lynn Karl, em sua obra mais conhecida The Paradox of Plenty, acima referida. 
crescimento econômico, reduzidos padrões médios de bem-estar social e persistente instabilidade política. Esses países são, por isso, caracteristicamente compreendidos como países pobres precisamente porque são ricos. ${ }^{223}$ Segundo essa interpretação, a lógica econômica que neles impera tende a levá-los a situações "patológicas" de subdesenvolvimento, entre as quais tem destaque a assim chamada enfermidade holandesa: conjunturas de receitas inopinadamente abundantes em seguida a um boom de exportação primária, consequente sobrevalorização cambial, perda de competitividade do setor secundário nacional e, ao fim, deslocamento de recursos financeiros de volta para o setor primário, resultando em regressão na produção industrial, nos níveis de emprego e de tecnologia. Dessa perspectiva teórica, pois, a Venezuela aparece como um exemplo cabal desse paradoxo e dessa enfermidade, e, de fato, tem sido por vezes assim tratada. ${ }^{224}$ Com efeito, praticamente todas as deformações $e$ patologias apontadas por essa teoria verificaram-se na realidade da Venezuela contemporânea: deterioração tendencial dos termos de troca, elevação (também tendencial) das taxas de juro, queda progressiva do produto no mercado mundial, volatilidade dos preços internacionais das commodities, ampliação da dívida externa em virtude da contração de empréstimos em volumes superdimensionados durante a euforia de exportação, afã consumista gerado pela facilitação de crédito, tendência à concentração social de renda e de riqueza, ampliação da influência das grandes empresas transnacionais nas esferas político-institucionais em detrimento tanto dos grupos empresarias interessados em investir em setores de produtos de maior valor agregado quanto de grupos políticos de orientação nacional-popular, difusão de uma "mentalidade exportadora", etc. - em suma, quase todos os componentes do modelo baldado que procuramos descrever neste capítulo. A força elucidativa dessa teoria do paradoxo da abundância está em haver ela combinado coerentemente elementos de várias outras teorias sobre subdesenvolvimento, reunidos com o objetivo de

\footnotetext{
${ }^{223}$ Além da obra anteriormente citada, veja-se SALAS, Miguel Tinker. The Enduring Legacy. Oil, Culture and Society in Venezuela. Durham and London: Duke University Press, 2009; também o artigo de SCHULDT, Jürgen. Somos pobres porque somos ricos. 28/07/2004. Disponível em: www.rebelion.org/noticia_pdf.php?id=2579; e SCHULDT, J. \& ACOSTA. Alberto. Petróleo, rentismo y subdesarrollo. ¿una maldición sin solución? Revista Nueva Sociedad, no 204, pp. 7189. Disponível em: http://nuso.org/articulo/petroleo-rentismo-y-subdesarrollo-una-maldicion-sinsolucion/.

${ }^{224}$ Cf. SCHULDT, J. \& ACOSTA. A. Op. cit., pp. 73-81.
} 
estudar a realidade desses países em contraste com a história de outros - como Canadá, Finlândia, Noruega, Nova Zelândia e Suécia - os quais, sendo também ricos em bens naturais e havendo-os explorado amplamente, alcançaram, no entanto, níveis muito superiores de desenvolvimento social e econômico. $O$ esforço teórico assim realizado foi, é claro, bem sucedido. Contudo, desejaríamos sublinhar que, no que tange ao tema da autonomização econômica (e suas oportunidades), um aspecto que porventura mereceu uma atenção menor dessa explicação, ao menos no caso particular da Venezuela, refere-se ao modo anômalo, por assim dizer, como se desenrolou o longo processo de nacionalização da indústria petroleira. A anomalia, que, como se verá, permitiu que o exemplo venezuelano fosse até mesmo caracterizado como uma nacionalização transnacionalizada, comprometeu decisivamente o bom êxito do desenvolvimento nacional e transformou a possível solução do dilema soberania/dependência em uma mera reacomodação das relações de dominação da economia rentista às injunções do imperialismo. Desse ponto de vista, o fracasso venezuelano revelou a feição, talvez, mais de um corolário previsível do que realmente de um paradoxo. Tendo isso em vista, o capítulo seguinte procura apresentar alguns dos traços próprios mais relevantes da nacionalização petroleira na Venezuela, levando-se em conta sua inserção no contexto internacional da época e os desdobramentos para a história interna do país. 


\section{Cap. 3: A nacionalização do setor petroleiro: uma experiência mutilada}

Em fins dos anos de 1960, a ordem petroleira mundial sofreu uma importante mudança quando os governos dos principais países exportadores foram paulatinamente impondo alterações nas formas de relação com as companhias petroleiras instaladas em seu território. A mera participação no negócio do petróleo - a qual constituíra a relação típica desde o século anterior e se caracterizara pela outorga ao Estado de uma porcentagem da exploração dos hidrocarbonetos, então extraídos sob concessão às companhias ${ }^{225}$ - se viu confrontada por exigências feitas por grupos políticos nacionais, que, em nome da soberania nacional, reivindicavam agora o controle e a nacionalização da exploração de seus recursos naturais. ${ }^{226}$ Episódios de nacionalização radical, como da Rússia bolchevique e do México de Cárdenas, bem como a experiência nacionalista iraniana de M. Mossadegh (1951-1953), já haviam demonstrado a exequibilidade da medida. Também a criação da OPEP, em 1960 - ainda que seus idealizadores não defendessem absolutamente a estatização - fora inspirada por ideais autonomistas, constituindo, como vimos, um primeiro passo no sentido de reequilibrar mundialmente os interesses em jogo (embora deva-se recordar que a organização permaneceu mais ou menos inócua até os últimos anos da década, quando então o quadro começou a se alterar). De fato, uma série de circunstâncias novas tornara o cenário internacional suscetível à mudança, ao permitir aos países exportadores opor-se com algum êxito à antiga

\footnotetext{
${ }^{225} \mathrm{Na}$ Venezuela, já nos primeiros anos do século XX, quando se iniciou a exploração do petróleo, - Estado garantiu-se juridicamente como o único proprietário do subsolo nacional e de seus recursos, e, portanto, o único com direito a autorizar concessões. Estas, por seu turno, atendiam ao interesse oficial de cobrar das empresas concessionárias uma taxa pela exploração, procurando-se auferir a maior renda possível e, alegadamente, investi-la no desenvolvimento nacional. Nesse sentido, rentismo e nacionalismo petroleiro nasceram juntos como ideais nacionais desde os tempos de Juan Vicente Gómez. Não obstante, compromissos escusos entre o ditador e concessionárias inglesas e norte-americanas mantiveram esses ideais mais como retórica do que como objetivos reais. As concessões tinham, na prática, o efeito de um contrato entre um arrendador e um arrendatário, cabendo a este último uma parcela imensamente mais vantajosa do negócio, enquanto o primeiro tinha pouco controle contábil e tributário sobre o volume produzido. A ditadura gomezista, aliás, celebrizou-se pela venalidade dos responsáveis das concessões e pelo entreguismo na política de exploração dos recursos - política defendida, todavia, com a recorrente justificativa de "estímulo aos investimentos estrangeiros".

${ }^{226}$ Cf. MOMMER, Bernard. Petróleo global y Estado Nacional. Abril de 2003. Edição digital disponível em: https://pt.scribd.com/doc/80004891/2003-Petroleo-global-y-Estado-nacionalBernard-Mommer\#scribd, (sobretudo capítulos 5 e 6 ).
} 
dominação das gigantes petroleiras. Primeiramente, a demanda mundial de petróleo - sobretudo a parcela tocante aos países industrializados, e destacadamente aos EUA - vinha ascendendo a níveis muito próximos dos da oferta, levando a que se reduzissem a quase nada os volumes excedentes acumulados em décadas anteriores. Já mencionamos o fato de que o grande desenvolvimento industrial dos anos pós-guerra - encabeçado pela produção norte-americana - teve o petróleo por nova matriz energética, de maneira que o consequente reequilíbrio demanda/oferta acabaria por provocar um aumento da dependência dessas economias industrializadas relativamente aos países exportadores - em especial aos do Oriente Médio e da África. ${ }^{227} \mathrm{Em}$ termos quantitativos, o quadro passaria a ser o seguinte:

\begin{abstract}
(...) A demanda de petróleo do mundo livre cresceu de 19 milhões de barris por dia em 1960 para mais de 44 milhões de barris por dia em 1972. O consumo de petróleo criou uma grande expectativa em todo o mundo, visto que cada vez mais eram utilizadas maiores quantidades de produtos derivados de petróleo nas fábricas, em usinas de energia, nos automóveis e nos lares. Na América do Norte, o uso da gasolina aumentou não só porque as pessoas dirigiam os automóveis por distâncias mais longas, mas também porque estes se tornavam cada vez maiores e melhores, com novos acessórios, como o ar condicionado. O baixo preço do petróleo da década de 1960 e princípio da de 70 significou que não havia nenhum incentivo para a fabricação de carros de baixo consumo. (...) Com um consumo que continuava aumentando, os EUA tiveram que recorrer ao mercado petroleiro mundial para satisfazer sua demanda. As cotas originalmente estabelecidas por Eisenhower foram abandonadas, as importações liquidas aumentaram rapidamente, de 2,2 milhões de barris diários em 1967 para 6 milhões de barris por dia em 1973. As importações como participação no consumo total durante esses anos aumentaram de 19\% para $36 \% .{ }^{228}$
\end{abstract}

Segundo, à diminuição da autossuficiência energética das grandes economias somou-se outro elemento, nascido no próprio interior delas: as exigências políticas de preservação do equilíbrio ambiental, ameaçado pelos novos hábitos mundiais de produção e de consumo. Particularmente nos países industrializados, principiou a formar-se uma consciência econômico-ecológica do desenvolvimento capitalista - consciência cuja expressão materializou-se, por

\footnotetext{
${ }^{227}$ Cf. YERGIN, Daniel. La historia del petróleo. Buenos Aires: Javier Vergara Editor, 1992 (sobretudo capítulos 28 e 29).

${ }^{228}$ YERGIN, D. Op. cit., p. 750-751.
} 
exemplo, na configuração de novas políticas públicas tendentes, nesses países, a restringir a liberalidade com que as empresas petroleiras costumavam tratar os problemas ambientais decorrentes de suas atividades. Isso motivou as empresas a preferir instalar-se predominantemente em países com leis ambientais menos severas ou inexistentes. Como bem observa o estudo clássico de Daniel Yergin sobre o problema ecológico:

Não havia nada que refletisse com tanta precisão a nova consciência sobre o meio ambiente como a ampla e intensa resposta pública a The Limits to Growth: a Report for the Club of Rome's Project on "The Predicament of Mankind. Publicado em 1972, o livro afirmava que se várias tendências básicas mundiais - quanto a população, industrialização, contaminação, produção de alimentos, consumo de energia, esgotamento de recursos (incluindo o gás natural e o petróleo) - continuassem sem diminuição, a civilização industrial contemporânea se tornaria insustentável, e "os limites do desenvolvimento deste planeta poderiam ser atingidos em algum momento dos cem anos seguintes". $O$ estudo alertou não apenas para o esgotamento dos recursos, mas também para as consequências, quanto ao meio ambiente, da queima de hidrocarbonetos, do aumento do dióxido de carbono na atmosfera e de uma nova preocupação sobre o calor no mundo. Era uma preocupação geral: o momento das futuras crises era totalmente desconhecido. ${ }^{229}$

Acresce-se que essas mudanças - ampliação da demanda nas economias centrais, redução dos excedentes, dependência das exportações meso-orientais e africanas, pressões dos ecologistas - todas elas de considerável alcance, inscreveram-se em um contexto mundial pós-guerra assinalado pela irrupção, na periferia do capitalismo, de movimentos políticos de descolonização e de nacionalismo revolucionário, destinados a redesenhar a geopolítica da época. Expressão disso, uma década após o fim da II Guerra os países reunidos em Bandung (1955) puseram-se a invocar o direito ao desenvolvimento, e o lema da autodeterminação dos povos foi proclamado como um legítimo anseio de autonomização das economias dependentes. Peculiarmente, em muitos dos antigos enclaves e ex-colônias exportadores de petróleo, suas elites governantes (por vezes compelidas ou ameaçadas por grupos nacionalistas) deram-se conta de que o petróleo que possuíam não só representava um símbolo de independência nacional, mas também oferecia oportunidade, muito claramente à

${ }^{229}$ YERGIN, D. Op. cit., p. 752-753. 
mão, de ampliar significativamente a parcela da qual se apropriavam no conjunto da riqueza nacional. Absorvidos pela atmosfera das lutas anti-imperialistas, às quais não podiam afinal ficar inteiramente indiferentes, os grupos governantes desses países petroleiros passaram a considerar a possibilidade, quanto ao petróleo, de não mais serem apenas simples coletores de impostos de concessionárias, mas serem também partícipes diretos no comércio mundial. ${ }^{230}$ Ainda assim, a decisão de nacionalizar - que acabaria por impor-se universalmente apenas a médio prazo - assumiu formas diversas em sua discussão e aplicação imediata. No que tangia a contratos já firmados com as empresas petroleiras, alguns governos optaram por adotar mudanças graduais, orientadas principalmente para a ampliação dos royalties - cuja porcentagem, além disso, seria doravante determinada pelos próprios governos, objetivando superar, tanto quanto possível, o velho esquema fifty-fifty. Foram estes, por exemplo, os casos da Arábia Saudita e do Irã. Outros regimes, porém - como o de M. Kadafi na Líbia (1969), o de H. Boumédiène na Argélia (1970), e o de Rafael Caldera na Venezuela (1971) - preferiram adotar a nacionalização plena e em breve lapso, seguida ou não de compensação às empresas petroleiras estrangeiras. $^{231}$

Graduais ou imediatas, as medidas causaram, realmente, importante impacto na geopolítica pós-guerra, graças ao novo papel estratégico do petróleo frente às necessidades mundiais. Não obstante isso, seria incorreto presumir que, mesmo em cenário favorável a um maior acometimento fiscal de Estados rentistas, as grandes empresas petroleiras privadas tenham sido deslocadas para um plano secundário. Também seria errôneo crer que a onda de nacionalizações

${ }^{230} \mathrm{O}$ alcance histórico dessa mudança de perspectiva pode ser assim avaliado: "(...) The nationalization of transnational tenants was the most important attack against private enterprise outside the communist countries, launched not by a revolutionary proletariat or communist parties, but by a handful of Third World landlord states. This would not have been possible without the isolation of these foreign companies. On the one hand, national interests were clearly identified with ground-rent; on the other hand, the tenant interests were unequivocally perceived as foreign interests. National entrepreneurs, and more generally citizens, firms, and households, were linked to the oil sector, almost exclusively, through the public spending of rent and thus resolutely supported a rent-maximizing policy, and finally nationalization. It is important to note that private national capital was never involved in a significant manner in oil. This almost absolute exclusion was not only due to historical accidents, but also to a deliberate policy of the landlord states. An examination of the Venezuelan experience (...) illustrate[s] the point." (MOMMER, Bernard. The Political Role of National Oil Companies in Exporting Countries: The Venezuelan Case. Oxford Institute for Energy Studies. September 1994. Disponível em: http://citeseerx.ist.psu.edu/viewdoc/ download?doi=10.1.1.392.8448\&rep=rep1\&type =pdf, p. 11. Grifo nosso.)

${ }^{231}$ YERGIN, D. Op. cit., p. 771-777. 
- adotadas, afinal de contas, por elites de países pertencentes à periferia dependente, em processos que não contaram com a participação ativa e organizada das classes trabalhadoras e populares - tenha constituído um instrumento efetivo capaz de propiciar a tão propalada soberania nacional. Ambas as questões apontaram, desde logo, a estreiteza concreta das mudanças - e vimos no capítulo anterior quão limitada foi essa soberania, em termos de industrialização nacional e progresso social quando baldou-se afinal o projeto da Grande Venezuela - comandado pelo Estado e sustentado pelo petróleo nacionalizado. Quanto à primeira questão, as empresas petroleiras souberam, em escala mundial, preservar seus lucros (quando não aumentá-los) através do controle sobre as etapas superiores de elaboração do petróleo - mesmo quando a OPEP, alguns anos depois das nacionalizações, logrou atuar de modo mais incisivo na definição dos preços internacionais do barril. A nova estratégia das petroleiras privadas tratava de incitar a concorrência entre os Estados petroleiros e, ao mesmo tempo, concentrava esforço em açambarcar mundialmente o transporte, a comercialização e a tecnologia dos produtos refinados:

O efeito dos aumentos do petróleo bruto da OPEP sobre os principais países [compradores] foi determinado essencialmente pelo que ocorreu nos preços dos produtos refinados. Do petróleo obtido dos países da OPEP, as transnacionais petroliferas venderam relativamente pouco na forma bruta. A maior parte é transferida a suas próprias refinarias, e vai ao mercado petroleiro depois de ter sido transformado em produtos refinados. Qualquer incremento no custo do petróleo bruto, da matéria prima, incidiria de maneira adversa nos lucros das companhias apenas e exclusivamente se os preços dos produtos refinados não subissem, o que de fato as empresas se encarregam de fazer. Ou seja, o incremento dos preços dos insumos se faz acompanhar de acentuados aumentos, mais do que proporcionais, dos preços dos produtos refinados. ${ }^{232}$

Quanto à segunda questão, a herança de atraso do passado neocolonial, o incipiente desenvolvimento econômico-tecnológico nacional, a longa sujeição ao capital externo e a tradição oligárquico-autoritária de controle do Estado burguês (ou pré-burguês) condicionaram em todos esses países uma conformação sui generis das noções de democracia e soberania. Onde quer que projetos autonomistas se esboçaram, eles foram frustrados por forças internas e externas,

\footnotetext{
${ }^{232}$ BLAIR, John. "The Control of Oil". Apud KAPLAN, M. (coord.). Petróleo y desarrollo en México y Venezuela. México, D.F.: Editorial Nueva Imagen, 1981, p. 134.
} 
interessadas antes de tudo em assegurar o desenvolvimento capitalista (mesmo dependente) a salvo das contradições internas das lutas de classes, como também em salvaguardar a acumulação de capital em nível mundial, por parte das economias imperialistas. A história de defesa e por fim nacionalização do petróleo venezuelano - esta apenas ideada nos anos que se seguiram à ditadura gomezista (1908-1935), decidida com maior resolução em fins da década de $60^{233}$, e levada a termo somente em janeiro de 1976 - percorreu um caminho traçado por todas essas condicionantes históricas, as quais, ao final, definiram a nacionalização venezuelana como uma experiência mutilada. É o que se infere da análise dos dois episódios centrais dessa malfadada experiência, apresentados a seguir.

Em 1943, o Congresso Nacional da Venezuela promulgou a Lei de Hidrocarbonetos, considerada a mais importante reforma das relações Estadoconcessionárias antecedente à nacionalização e, também, pioneira na própria definição jurídica de concessão. ${ }^{234}$ Com a Lei de 1943, o Estado reafirmava seu papel de único proprietário do recurso natural, cumprindo à concessionária a função específica de "(...) operador, que se encarrega - em nome da sociedade de extrair e comercializar tal recurso". ${ }^{235}$ Além disso, as concessões passavam a ser regidas pelo princípio da soberania tributária da Nação, segundo o qual esta reservava a si o poder de unilateralmente estabelecer a taxa de imposto sobre a exploração. Acrescia-se à faculdade tributária exclusiva do Estado - tornada geral e automática - a uniformização jurídica de todas as concessões então existentes,

\footnotetext{
${ }^{233}$ Ao longo dos anos de 1960, uma defesa da nacionalização completa do petróleo esbarrava ainda, mesmo para os nacionalistas mais resolutos, na constatação de que faltavam ao país recursos técnicos e humanos necessários a uma política de produção e comercialização totalmente independente das concessionárias. Por isso, o nacionalismo petroleiro não radical insistia na necessidade de defender os interesses nacionais segundo um esquema que combinasse, por um lado, participação fiscal justa do Estado, controle sobre volumes a serem explorados com vistas à defesa dos preços nacionais e internacionais, preservação das áreas a serem exploradas, coparticipação operativa e comercial, e, por outro lado, investimentos e tecnologia das empresas estrangeiras concessionárias, responsáveis diretas pela exploração. Além do mais, defender os interesses nacionais do petróleo deveria representar o meio para "libertar o país da excessiva dependência de um único recurso, não renovável". (Veja-se a respeito dos fundamentos dessa defesa em El Pentágono Petrolero, de J. P. Pérez Alfonso, que, em 1967, preceituava: 1) participação razoável 2) Comissão Coordenadora da Conservação e Comércio dos Hidrocarbonetos; 3)Corporação Venezuelana do Petróleo; 4) "Não mais concessões", e 5) Organização de Países Exportadores de Petróleo (OPEP)).

${ }^{234}$ Cf. FRONJOSA L., Ernesto. La ley de hidrocarburos de Venezuela del año 1943: Un complejo proceso de negociación en el ámbito global. Academia Nacional de la Ingeniería y el Hábitat. Boletín No 25. Mayo de 2013. pp. 176- 210.

${ }^{235}$ FRONJOSA L., Ernesto. Op. cit., p. 6.
} 
visto que muitas delas obedeciam a regimes legais específicos, que dificultavam o controle oficial sobre os volumes produzidos a serem taxados. Ainda, a Lei elevava a um mínimo de 16,6\% a taxa de royalty (que fora até então, em média, de $9 \%$ ), permitia ao Estado supervisionar as etapas técnicas da produção, e promovia o princípio de realizar a refinação do óleo cru no próprio país. ${ }^{236}$ No que tocava ao efeito reformador mais importante da Lei, a concessão passava a definir-se como uma divisão dos benefícios em partes iguais entre proprietário e operador - divisão que, apoiando-se na Lei de Imposto sobre a Renda (aprovada em janeiro daquele mesmo ano), equivalia ao princípio fifty-fifty, ou seja, o de que os diversos impostos que gravavam a produção deveriam perfazer, em prol do Estado, um montante aproximadamente igual à renda líquida auferida pelas companhias. ${ }^{237}$ A Lei, por fim, prorrogava por um período de 40 anos (a expirar, portanto, em 1983) todas as concessões feitas, qualquer que fosse o prazo original anteriormente fixado. Esta última medida, ademais, contou com o apoio internacional de governos (como o de F. D. Roosevelt) que, estando envolvidos direta ou indiretamente no conflito mundial, então em seu auge, alertavam para a necessidade de manter estável o fornecimento de petróleo por uma nação que se encontrava distante e a salvo das batalhas. Bem consideradas, todas essas disposições de 1943 significavam que a ampliação do poder de negociação da Venezuela nas circunstâncias internacionais da época não só garantia ao país que, ao término do prazo das concessões, seriam mantidas as operações de produção (daí em diante sob comando do Estado e sem a necessidade de indenizações), como consolidava irreversivelmente a própria concepção jurídica de divisão equitativa de benefícios entre Estado e empresas, tornando-a, aliás, "(...) o ponto de referência das reivindicações nacionalistas do restante dos países

\footnotetext{
${ }^{236}$ Cf. FRONJOSA L., Ernesto. Op. cit., p. 4.

${ }^{237}$ Cf. FRONJOSA L., Ernesto. Op. cit. Enfatizando esse aspecto central da Lei de 1943, afirma o estudioso: "(...) La fijación de la tasa del impuesto sobre la renta por parte del Estado permitió que de allí en adelante Venezuela pudiera tomar otra serie de decisiones relacionadas con su participación en el negocio petrolero. Todas las modificaciones posteriores a la Ley del Impuesto sobre la Renta se fundamentaron en esta idea. Igualmente la eventual fijación unilateral de los valores de referencia a los fines del mencionado impuesto sobre la renta el 17 de diciembre de 1970 (...) tuvo el mismo fundamento. Finalmente, el concepto jurídico de reversión que aparecería años más tarde se basó en la misma noción. Todas estas acciones no hubieran sido posibles bajo el concepto de concesión prevaleciente antes de 1943." (p. 7)
} 
petroleiros". ${ }^{238}$ Ainda, como parte das negociações internacionais do governo venezuelano, a Stardard Oil of New Jersey e a Royal Dutch-Shell assumiram o compromisso de construção de duas refinarias no país, tão logo terminasse o conflito mundial. ${ }^{239}$

A reforma petroleira de 1943, embora, a rigor, não se referisse nunca a nacionalização, é tema que tem suscitado pontos de vista teóricos diversos acerca do alcance nacionalista e dos desdobramentos autonomistas de suas medidas. Vista retrospectivamente, e considerando-se o panorama internacional fortemente determinado pelas contingências da guerra, a reforma tem sido geralmente interpretada, primeiro, em função dessas mesmas contingências e, em seguida, em confronto com dois episódios históricos correlatos, entre os quais ela está inserida: a nacionalização mexicana de 1938 e a iraniana de 1951. Um estudioso como Bernard Mommer, por exemplo, observa que o movimento político por soberania iniciado em 1943 representou a mola que impulsionou a conformação definitiva do Estado venezuelano como um verdadeiro Estado petroleiro (ou seja, capitalista rentista), em torno de cujas políticas de gastos públicos as classes dominantes se organizaram, sem assumirem, em nenhum momento, um papel de protagonistas à margem da ação estatal. Essa conformação somente se concretizou historicamente na medida em que os grupos políticos governantes (liderados pelo próprio presidente Isaías Medina Angarita, cuja política econômica foi-se apartando do entreguismo franco dos gomezistas mais renhidos) souberam contrabalançar a avidez das companhias estrangeiras com medidas de caráter impositivo soberanas, sem serem, todavia, anti-imperialistas, nem tampouco democráticas. E, as condições imprescindíveis para isso foram engendradas, em última análise, pelo papel estratégico oportunamente assumido pela produção venezuelana como fonte indispensável de combustível à máquina de guerra aliada. (Nos anos seguintes à guerra, quando a $A D$ se alçou ao poder, essa política petroleira não sofreu nenhuma alteração expressiva em suas linhas principais.) Assim, a convicção da importância desse papel estratégico ampliou a força de negociação internacional

${ }^{238}$ FRONJOSA L., Ernesto. Op. cit., p. 8. Não obstante a importância histórica da Lei de 1943, é de notar que uma limitação significativa em sua aplicação concreta estava na dificuldade persistente de controle contábil oficial sobre os volumes produzidos sujeitos à tributação, sempre escamoteáveis pelas empresas - e hoje difíceis de ser estimados pelos estudiosos do assunto.

${ }^{239}$ MOMMER, Bernard. Petróleo global y Estado Nacional. Abril de 2003, pp. 116-122. 
dos grupos governantes, cimentou a proeminência da Venezuela no mercado petroleiro mundial, e fortaleceu os laços dos setores burgueses nacionais - via Estado - com o capitalismo avançado. Adicionalmente, tal como ocorrera à política petroleira norte-americana, a política venezuelana distinguiu-se por também consolidar um Estado soberano em matéria jurídico-patrimonial e tributária. Foi esse, para vários estudiosos, o grande fruto de 1943. Segundo B. Mommer, de fato,

[a] reforma foi um êxito rotundo, que pode ser resumido nas seguintes poucas palavras: o Estado venezuelano, como soberano e proprietário do recurso natural, equiparou-se, quanto aos seus direitos e obrigações, ao Estado norte-americano no que se referia às terras federais; e o mesmo se podia dizer mutatis mutandis em relação às companhias. ${ }^{240}$

Demais disso, a reforma teria permitido à Venezuela poupar-se às desinteligências políticas e às dificuldades econômicas que poderiam decorrer de medidas de maior radicalismo nacionalista - como havia ocorrido ao México, cuja produção petroleira decaíra drasticamente em razão do boicote das empresas estrangeiras após 1938; e como ocorreria mais tarde ao Irã, cuja experiência de nacionalização petroleira, vivida pelo país em um cenário de forte sentimento anticolonialista (antibritânico) e, ao mesmo tempo, de aproximação à orbita soviética, teve por desfecho a deposição do primeiro-ministro Mossadegh em 1953, vítima de um golpe de Estado no qual foi copartícipe o governo dos EUA. Comparativamente, o alinhamento da Venezuela às democracias liberais, durante e após a II Guerra, teria conferido ao Estado venezuelano tanto o apoio político-

\footnotetext{
${ }^{240}$ MOMMER, Bernard. Op. cit., p. 118. Em sentido semelhante, afirma em outro texto o mesmo Autor: "(...) El Estado venezolano como soberano, desde 1943, independientemente de la duración del contrato, estaba facultado, en principio, para transformar en cualquier momento toda ganancia extraordinaria en renta del suelo, mediante el impuesto sobre la renta. Al respecto se encontraba limitado no jurídicamente, sino sólo por las relaciones de fuerza reales, políticas y económicas, determinadas tanto nacional como internacionalmente. Empero, éstas eran tales que todavía en 1966 el intento del Gobierno venezolano de crear un impuesto sobre la renta selectivo, ligado a la tasa de ganancia, naufragó en el Congreso Nacional. La posible renovación de los contratos no carecía así de significación especial. En todo caso, la reversión de las concesiones ofrecía al propietario la oportunidad de apropiarse, sin indemnización alguna, del capital de su arrendatario y, con ello, la mejor posibilidad para abrirse paso en la producción. Ello tenía que ejercer una influencia importante sobre la correlación de fuerzas en general entre el capital internacional y la propiedad nacional estatal. De ahí que, efectivamente, las discusiones sobre la reversión de las concesiones, prevista para 1983 en adelante, ya se iniciara en 1959, es decir, antes de que hubiera transcurrido siquiera la mitad de la duración de los contratos firmados entre 1943 y 1945. (MOMMER, B. La cuestión petrolera. 1988. Edição digital disponível em: https://pt.scribd.com/doc/ 216844901/La-Cuestion-Petrolera-Bernard-Mommer-1988-Corregida-050111, p. 137. Grifo nosso.)
} 
diplomático desses países (em especial dos EUA), como um maior poder de barganha, suficiente para reequilibrar a seu favor o despotismo das petroleiras estrangeiras. Tratou-se, como assinala um estudioso, de uma negociação integradora, que resultou em poder exercer-se certo grau considerável de soberania nacional combinado à aprovação de medidas legais e fiscais irreversíveis, mas apresentadas às multinacionais em termos aceitáveis para elas - e só sancionadas nesses termos. ${ }^{241}$

Porém, há que enfatizar-se que essa soberania não prevaleceu sem ceder em muitos e valiosos pontos, de que resultaram efeitos lesivos à sociedade venezuelana. É o que sublinha Carlos Mendoza Pottellá, segundo um juízo crítico da reforma de 1943 que se empenha justamente em denunciar o privilegiamento dos interesses das petroleiras em detrimento dos direitos nacionais e a ausência de nexo lógico real entre o discurso oficial de defesa destes e a conivência escusa com o favorecimento daqueles:

A Lei de Hidrocarbonetos de 1943 teve a virtude de converter-se na
expressão acabada do regime concessionário. Significou a cristalização
de algum nível da correlação de forças [entre grupos nacionalistas,
governo venezuelano e companhias estrangeiras] que vimos
considerando, condicionada, desde logo, por uma circunstância
internacional- a Segunda Guerra Mundial - porém, mantendo o signo
predominante dessa correlação, ou seja, o predomínio dos interesses
estrangeiros, apesar da evolução formal quando comparada ao caos da
época gomezista. Nesse sentido, a figura da "conversão" deu nova vida
- 40 anos - a concessões em vias de expirarem, concessões que
poderiam ter sido negociadas em muito melhores condições, como por
exemplo, os milhôes de hectares da concessão Valladares,
irregularmente usufruídos pela Shell. Mas essa conversão, de altíssimo
custo para a Naçâo, constituiuse também em um processo de
homogeneização, ao criar um único padrão normativo dos vínculos
Estado-concessionárias, colocando sob seu império concessões

\footnotetext{
${ }^{241}$ Cf. FRONJOSA L., Ernesto. Op. cit., p. 32. Para este Autor, que entende a reforma de 1943 como uma negociação cujos resultados foram equitativos entre as partes envolvidas, 0 pragmatismo dos negociadores nacionais resultou benéfico para a Venezuela. Afinal, "[el] intercambio de valor es siempre importante en cualquier negociación por compleja que sea. Cuando tópicos tales como el interés nacional, la soberanía o la integridad territorial aparecen en los conflictos existe una tendencia muy fuerte a migrar hacia un estilo de negociación de tipo marcadamente distributivo. Esta postura suele justificarse afirmando que "en esos temas no se puede ceder". No es necesario hacerlo. Lo que hace falta es realizar el arduo trabajo que significa identificar los mencionados contrastes de valoración con aspectos de interés para las demás partes que permitan conducir la negociación a un plano integrador. Este enfoque, a pesar de lo arduo del proceso que conduce a él, lo que logra es precisamente preservar aquello que es verdaderamente importante para las partes. Por el contrario, no enfrentar el conflicto bajo esa perspectiva y tomar posiciones intransigentes suele resultar en graves perjuicios para todas las partes particularmente en aquellos puntos que más aprecian". (p. 34)
} 
outorgadas em termos muito dissímeis. Esta circunstância permitiria assentar as bases de uma fiscalização mais efetiva das atividades das concessionárias. (...)

Porventura o aspecto mais criticado do pacto entre [o presidente] Medina e as concessionárias, por suas evidentes e imediatas implicações negativas, foi o "total saneamento" outorgado às concessões eivadas de ilegalidade, viciadas de nulidade e em vias de caducidade (...) [como indicavam] as conclusões da Comissão do Congresso que realizara a investigação a instâncias do próprio Medina. O saneamento e a nova vida de quarenta anos eram parte do preço da conversão, pela qual todas as concessões se submetiam ao império da nova Lei e seus mecanismos reguladores. Todavia, uma outra parte do leão do pacto restou à vista de todos quando se cumpriu o que Lieuwen qualifica de "o maior programa de entrega de concessões na história do país (...) seis milhões e quinhentos mil hectares, superfície maior do que a que já era possuída pelas companhias. ${ }^{242}$

Aduzindo um rol de importantes autores venezuelanos, que anteriormente já haviam ressaltado o caráter dúbio da modernização promovida em 1943, conclui com certa ironia Mendoza Potellá:

Aníbal R. Martínez descreve assim a "promessa cumprida": "Em 31 de dezembro de 1943, as empresas haviam convertido 6 milhões de hectares pela nova Lei e apenas haviam renunciado a 2 milhões de hectares. Então, em 21 de abril de 1944, começou a realizar-se a promessa acordada, a qual obviamente não aparecia no texto da Lei. Nesse dia começou um gigantesco programa de outorga de novas concessões". Trata-se de um momento culminante da historia petroleira venezuelana: as concessionárias se consolidam e estendem sua implantação no país. Nas palavras de Pedro Esteban Mejía: "indubitavelmente a outorga de concessões efetuada contribuiu para acentuar o poderio econômico e político das empresas, do mesmo modo que para incrementar a dependência econômica da Venezuela". Uma maneira muito peculiar, diríamos nós, de "aproveitar as condições favoráveis dadas pela Segunda Guerra Mundial" (...) Salvador de la Plaza comenta que, nesses anos (1943 a 55 e com cifras próprias) enquanto a produção de petróleo quadruplicava, a participação da Nação aumentou treze vezes: "(...) mas, em virtude de não se haver operado uma transformação da estrutura feudal do campo nem uma mudança da política econômico-financeira do Estado, essa maior participação traduziu-se em uma acrescida dependência do país em relação aos trustes petroleiros, em uma mais acentuada desfiguração do desenvolvimento econômico, com o consequente enriquecimento dos importadores, de funcionários venais, etc., e a sequela do desperdício e da corrupção." A esta altura podemos resumir o resultado

\footnotetext{
${ }^{242}$ POTTELLÁ, Carlos Mendoza. De las concesiones a los contratos. Visión retrospectiva de la política petrolera venezolana. Trabajo de ascenso (inédito). Caracas: Escuela de Economía, 1985, p. 28-32.
} 
do pacto Medina-companhias: nova vida às velhas concessões e normalização definitiva das boas relações Estado-concessionárias. ${ }^{243}$

De fato, a Lei de Hidrocarbonetos de 1943 constituiu a base de uma reforma cuja significação queda eclipsada quando se leva em conta o progresso social que deveria advir da modernização dos meios oficiais de participação fiscal na exploração da maior riqueza natural do país. Se, por um lado, o desempenho econômico dos anos pós-reforma apresentou incrementos consideráveis no nível da produção e da renda do petróleo por habitante (veja-se o gráfico 10, da nota 159 , p. 101, supra) - desempenho cuja feição foi a de um salto quantitativo, representado pela curva ascendente que, mesmo com oscilações negativas nos anos 50, manteve-se até por volta de 1979 - os efeitos sociais dessa mudança, por outro lado, revelaram-se frustrantes, manifestando, em verdade, o tipo de projeto de sociedade - oligárquico, concentrador e excludente - que as classes dominantes traçaram, desde o início, para a Venezuela petroleira. Se a década de 1940 representou anos de grande instabilidade política (marcada pela ascensão da AD, através de um golpe de Estado em 1945, seguida da deposição de Rómulo Gallegos, por outro golpe em 1948, e pela instalação da ditadura de Pérez Jiménez em $1952^{244}$ ), foi, no entanto, um período em que a economia

\footnotetext{
${ }^{243}$ Idem, ibidem, p. 33-35.

${ }^{244}$ A importante e conturbada conjuntura política dos anos 1940-50 pode ser interpretada da seguinte maneira: a deposição do general Medina Angarita, em 1945, pôs fim ao domínio de quase quatro décadas do gomezismo - décadas caracterizadas pelo extremo autoritarismo político, pela corrupção administrativa e por uma linha econômica escandalosamente submissa aos interesses das petroleiras norte-americanas e anglo-holandesas. López Contreras e Medina Angarita, gomezistas tradicionais, foram, no entanto, adotando, enquanto presidentes (1936-1941 e 1941-1945, respectivamente) uma linha paulatinamente mais progressista, sem nunca, no entanto, ser propriamente democrática. Medina chegou a implementar uma política de laivos autonomistas, que teria descontentado as empresas estrangeiras (vale recordar a Lei de 1943), e a adotar algumas liberdades políticas, como a legalização de partidos e sindicatos antes proibidos. O golpe que o derrubou em 1945 e alçou ao poder Rómulo Betancourt, da Ação Democrática, espelhou profundas transformações sociais e políticas na Venezuela de então, visíveis na emergência dos diversos movimentos sociais - como o crescente proletariado urbano, os camponeses, que iam alcançando maior grau de organização política, bem como os grupos partidários que acediam à legalidade (nacionalistas, comunistas, liberais pequeno-burgueses, social-cristãos, etc.). Paralelamente, fortaleciam-se uma burguesia industrial e uma classe média urbana. $A A D$, em sua origem, representou os interesses de grande número desses setores sociais, alguns dos quais aspiravam a um regime democrático e a uma distribuição mais equitativa das rendas da indústria petroleira, então em ascensão. Quando, em 1948, uma Junta Militar interrompeu, por sua vez, o governo de Rómulo Gallegos, da $A D$, e preparou a instalação da ditadura de M. Pérez Jiménez, o que se planejava era justamente barrar esses movimentos ascendentes de organização político-partidária e de exercício popular democrático. Os anos de ditadura (1952-1958) consolidaram uma economia capitalista dependente-rentista, tendo por sustentação social a grande burguesia financeira e a comercial importadora, os grandes
} 
conheceu anos sucessivos de ampliação das exportações de petróleo (que aproveitou a crise da produção mexicana e a demanda crescente durante e após a guerra mundial), de relativo desenvolvimento tecnológico no setor petroleiro (com crescentes investimentos de empresas estrangeiras), e de forte incremento das receitas fiscais (em grande parte, devido à normatização das tarifas pela Lei de 1943, além do próprio aumento do número de concessões). ${ }^{245}$ Igualmente, foram anos de adoção de medidas para substituição de importações, ocasionadas pelas vicissitudes da guerra e responsáveis por promover, no país, um notável surto manufatureiro e de serviços - setores que, ademais, se valeram ciosamente dos ingentes investimentos externos. Porém, contrastantemente, o descompasso entre o progresso do sistema produtivo - que se assentava em definitivo na renda do petróleo - e o alarmante atraso verificável nas condições materiais em que viviam e continuariam a viver as camadas populares sugeria que o período de prosperidade seguinte à reforma fora próspero apenas em sentido relativo, e que a própria reforma de 1943 consistiu tão-só em uma oportunidade habilmente

latifundiários e as empresas estrangeiras, sobretudo as petroleiras. Ao fim da década, em 1958, um novo golpe de Estado encerraria a ditadura perezjimenista e inauguraria, com eleições diretas para presidente da República, o período democrático conhecido como puntofijismo. Um traço que permaneceu praticamente inalterado, a despeito de todos esses câmbios políticos, foi, como se afirmou, a preponderância, na definição das políticas econômicas, dos interesses dos capitais estrangeiros investidos e das empresas petroleiras instaladas no país.

${ }^{245} \mathrm{O}$ quadro abaixo mostra esse crescimento excepcional das receitas (entre 1945 e 1957). A porcentagem da receita petroleira no total dos ingressos nacionais saltou de 53,5\% em 1945 para 70,7\% em 1957.

Tabela 11: Receitas Fiscais entre 1945 e 1957

\begin{tabular}{lrr} 
ANOS & $\begin{array}{c}\text { INGRESOS } \\
\text { TOTALES }\end{array}$ & $\begin{array}{c}\text { INGRESOS PROCEDENTES } \\
\text { DE LA INDUSTRIA } \\
\text { PETHOLERA }\end{array}$ \\
\hline 1945 & & 353 \\
1946 & 660 & 489 \\
1947 & 856 & 689 \\
1948 & 1.281 & 1.158 \\
1949 & 1.776 & 1.269 \\
1950 & 1.980 & 901 \\
1951 & 1.917 & 1.317 \\
1952 & 2.267 & 1.476 \\
1953 & 2.408 & 1.589 \\
1954 & 2.534 & 1.498 \\
1955 & 2.632 & 1.714 \\
1956 & 2.992 & 3.108 \\
1957 & 4.380 & 3.822 \\
& 5.405 & \\
\hline
\end{tabular}

Fonte: ARANDA, Sergio. La economía venezolana: Una interpretación de su modo de funcionamiento. Bogotá: Siglo Veintiuno Editores, 1977, p. 140 (modificado). 
aproveitada pelos setores da burguesia venezuelana para vorazmente apoderarse do Estado e de suas fontes de riqueza. Ao renunciar a uma potencial autonomização econômica (tornada viável pela legislação e por anos sucessivos de receitas crescentes), os grupos governantes fecharam os olhos à persistência do quadro de estagnação social, no qual não se podiam (ou mal se podiam) suprir as necessidades ordinárias das classes subalternas. Não há nenhuma dificuldade em confirmar essa última asserção: embora sejam relativamente escassos os dados de indicadores das condições gerais de vida disponíveis para a década de 1940, um estudo demográfico (La población de Venezuela, publicado em 1974 ${ }^{246}$ ) apontava, em uma população de aproximadamente cinco milhões de habitantes (exatamente 5.034.838, pelo censo de 1950) - cuja mudança estruturaldemográfica mais significativa fora o início do êxodo populacional para as cidades ao longo dos anos de 1940 -, condições de grande ou extrema miséria dos contingentes majoritários da população venezuelana: por exemplo, 69,8\% das moradias no país não dispunham de água corrente; $58,8 \%$ delas não possuíam nenhum serviço de esgoto; 50,2\% não possuíam nem mesmo banheiros, e 52\% tinham tão-só piso de terra. Todas essas porcentagens, ademais, aumentariam nos anos seguintes, acompanhando a precarização progressiva dos tipos de moradia urbana. Mais: apenas $51,2 \%$ dos homens (de 10 anos ou mais) eram alfabetizados, e $48,8 \%$ das mulheres. A população economicamente ativa, refletindo o desequilíbrio da distribuição populacional, concentrando-se em centros urbanos devido à atração da atividade petroleira, era de apenas 33,9\% da população total; o volume de empregos do setor petroleiro e de minas atingia somente $2,8 \%$ do total nacional; o total de desempregados em 1950 ascendia a $6,3 \%$ da força de trabalho nacional; e - indicativo também eloquente - a expectativa de vida ao nascer, embora crescente e inversa aos níveis decrescentes de mortalidade infantil, alcançava não mais do que 53,9 anos em 1950. ${ }^{247}$ Tais dados, apesar de esparsos, dificilmente levariam a crer que 0

\footnotetext{
${ }^{246}$ CARRUYO, Dionisio et alii (coord.). La población de Venezuela. S/I. CICRED Series, 1974.

${ }^{247}$ Cf. CARRUYO, Dionisio et alii (coord.). La población de Venezuela. S/I. CICRED Series, 1974. De grande interesse para a interpretação que adotamos aqui, duas conclusões desse estudo demográfico afirmavam: "(...) Consecuencia de los hechos anotados, encontramos que el drenaje acumulado para el país a partir de 1950 alcanzó 54.912 millones de bolívares en 1969, cifras estas que equivalen al 72.0 por ciento del capital existente para ese mismo año. Ello significa que de no haber existido ese drenaje acumulado el capital existente hubiese sido mayor casi en un 75.0 por ciento. Nótese pues el tremendo freno que ha tenido el proceso de crecimiento de la
} 
avanço da economia petroleira nos anos pós-reforma tenha-se feito acompanhar de um progresso real aproveitável para toda a sociedade. Ou que tenha verdadeiramente correspondido a algo como a "política nacional para nossos povos" das palavras de Pérez Alfonso, ao defender novamente, anos depois, a soberania venezuelana em matéria de petróleo. Ao contrário disso, e considerando-se dados de entre 1950 e 1957 - os quais podem ser tomados, sem risco de erro, como representativos de uma tendência inalterada dos anos 40 para os 50 -, constatou-se que, à medida que o capitalismo de base rentista ia-se firmando na Venezuela, correlatamente à elevação da participação do capital estrangeiro também na indústria manufatureira e a um quadro de repressão política oficial aos grupos populares e aos movimentos sindicais - configurava-se o paulatino agravamento da concentração social da renda nacional, a despeito de todas as anteriores iniciativas democratizantes do nacionalismo petroleiro não radical:

\begin{abstract}
A força dos setores empresariais, nacionais e estrangeiros, foi capaz de anular qualquer esforço feito em sentido inverso. Nas condições da ditadura de Pérez Jiménez, em que os partidos políticos de raízes populares foram proscritos, reprimidas as organizações sindicais de trabalhadores e reprimidas e perseguidas as pessoas que poderiam liderar movimentos de caráter reivindicativo de qualquer setor dos trabalhadores, a tendência das empresas e organizações empresariais encontrou solo fértil para acelerar o processo concentrador. (...) [a] remuneração do trabalho declinou, no total da renda nacional, em 7,4\% entre 1950 e 1957, enquanto que a remuneração do capital ascendeu na mesma cifra. (...) Assim, [em 1957] 88\% das pessoas recebem a metade da renda nacional, ao passo que os outros $12 \%$ recebem a outra metade. ${ }^{248}$
\end{abstract}

\footnotetext{
economía venezolana a consecuencia de la naturaleza de sus relaciones económicas internacionales y ello, sin entrar a considerar el aspecto concerniente a las importaciones y su incidencia en la economía nacional". (p. 123) (...) Sin embargo, es de señalar que dado el grado de subdesarrollo que ha caracterizado a nuestra economía, con las consiguientes deformaciones de índole estructural nos encontramos con que es el Sector Terciario el que aparece aportando en mayor medida al producto con un $44.1 \%$. Ello se explica porque en virtud del carácter primario de la explotación petrolera en Venezuela, en forma de enclave, y la configuración de una burguesía importadora con una alta participación en la estructura del poder, impidieron, al igual que en el presente, el desarrollo vigoroso de la producción industrial. En consecuencia, ante la inexistencia de un sector dinámico generador de empleo productivo, como la industria, las actividades de servicio se expandieron en respuesta a una población creciente que necesitaba de ocupación". (p. 125-6)

${ }^{248}$ ARANDA, Sergio. La economía venezolana: Una interpretación de su modo de funcionamiento. Bogotá: Siglo Veintiuno Editores, 1977, p. 172-174.
} 
Em 1976, a $1^{\circ}$ de janeiro, entrou em vigor a Lei que declarava a nacionalização completa da indústria petroleira, determinando que as plantas, instalações e equipamentos das empresas estrangeiras no país passassem à propriedade do Estado venezuelano. Com isso, em tese, consolidava-se finalmente o controle estatal sobre o petróleo, sobremodo importante após os impasses provocados pela anterior Lei sobre Bens Sujeitos a Reversão, de 1971, que acarretara desinversões, descapitalização e fraudes contábeis das empresas concessionárias, confrontadas com a reversão inevitável. A nova lei, vimos atrás, enquadrava-se em um cenário internacional de ideais anticolonialistas e discursos desenvolvimentistas (especialmente de formulação cepalina, no caso latinoamericano) e enfatizava progresso e soberania nacional como metas essenciais. Se a Venezuela ocupara, na década anterior, um papel destacado na proposição de políticas internacionais conjuntas de defesa dos preços do petróleo (cf. OPEP), a nacionalização parecia coroar a longa luta nacional contra o oligopólio das petroleiras estrangeiras. Vimos também que, ao princípio da década de 70 , adquirira ascendência a ideia mais ampla de nacionalização como estratégia para a transformação estrutural da economia e, simultaneamente, para a promoção do desenvolvimento social em bases efetivamente mais democráticas. Dessa perspectiva, o controle estatal sobre o conjunto das atividades petroleiras (exploração, prospecção, pesquisa, refino, comercialização) deveria servir a imprimir impulso ao país ao ampliar, incorporar e harmonizar essas atividades com as dos outros setores industriais, de acordo com um projeto de diversificação produtiva que buscaria no petróleo uma fonte tanto de provimento de energia como de investimentos em infraestrutura - via Estado. ${ }^{249}$ Era, logo, quase consensual a urgência de uma alteração incisiva no modelo concessionário, de modo a tornar o Estado o gerenciador único dos crescentes benefícios petroleiros. Consistia nisso, em suma, o projeto do nacionalismo petroleiro não radical, pertinazmente defendido nas propostas de inúmeros intelectuais e políticos nacionais, e repetido quase sem variação pelo próprio discurso oficial. A Comissão Presidencial de Reversão, criada em maio de 1974 pelo recém-

\footnotetext{
${ }^{249}$ Cf. SILVA CALDERON, Álvaro. Trayectoria de la nacionalización petrolera. Revista Venezolana de Economía y Ciencias Sociales, Caracas, v. 12, n. 1, p. 109-123, abr./2006. Disponível em: http://www.scielo.org.ve/scielo.php?script=sci_arttext\&pid=S1315-64112006000100008\&lng=es\& $\mathrm{nrm}=$ iso $>$. Acesso em 25 de março de 2016.
} 
empossado C. Andrés Pérez e composta por representantes de diversos setores e partidos políticos, ao discutir detalhadamente a conveniência de antecipar a reversão das concessões (a vencerem em 1983), pretendia fundamentar em um consenso nacional esse amplo projeto de transformação estrutural. ${ }^{250}$

Contudo, meses depois, ao fim das discussões da Comissão, abriu-se importante ponto de dissenso entre seus membros - ponto que iria revelar-se crucial na definição do alcance histórico da nacionalização pretendida. A bem dizer, nesses tempos iminentes de crise energética mundial, o capital petroleiro internacional não via inteiramente com maus olhos as nacionalizações - que, afinal, podiam livrar as empresas privadas dos crescentes problemas relacionados às movimentações operárias, bem como deixavam aos Estados nacionais os riscos técnicos e comerciais inerentes às etapas de exploração e prospecção, garantindo às transnacionais grande espaço de ação na etapa mais lucrativa, isto é, a comercialização do petróleo. Os liames de dependência econômico-tecnológica e de associação de classes eram assim preservados sem ferir o "espírito nacionalista petroleiro" em voga. Nesse quadro específico, o projeto final oficial de Andrés Pérez trouxe ao projeto de lei da Comissão um acréscimo importante, cujo teor, adequando-se aos reclamos da Fedecámaras e disposto provavelmente após conversações encobertas do governo com as petroleiras estrangeiras ${ }^{251}$, legitimava, muito a propósito, a possibilidade de 0 Estado firmar contratos de associação com entidades privadas, "(...) cujos objetivos - notou criticamente um especialista - não eram compatíveis com o espírito de uma lei que devia reservar ao Estado o domínio e o controle absolutos de todas as instâncias da indústria estatizada (.... ${ }^{252} \mathrm{~A}$ introdução desse artifício

\footnotetext{
${ }^{250}$ Cf. LANDER, Luís. A treinta años de la nacionalización el debate continúa. Presentación. Revista Venezolana de Economía y Ciencias Sociales, 2006, vol. 12, № 1 (ene.-abr.), pp. 103-107. ${ }^{251}$ Cf. POTTELLÁ, C. Mendoza. De las concesiones a los contratos, p. 73-75.

${ }^{252}$ ZAVALA, D. Maza \& MATA, H. Malavé. "Aspectos económicos y políticos de la nacionalización de la industria petrolera en Venezuela" In: KAPLAN, Marcos (coord.). Petróleo y desarrollo en México y Venezuela. México, D.F.: Editorial Nueva Imagen, 1981, p. 176. (Grifo nosso.)

Rezava o acréscimo ao artigo 5o da Lei: "(...) En casos especiales y cuando así convenga al interés público, el Ejecutivo Nacional o los referidos entes podrán, en el ejercicio de cualquiera de las señaladas actividades, celebrar convenios de asociación con entes privados, con una participación tal que garantice el control por parte del Estado y con una duración determinada. Para la celebración de tales convenios se requerirá la previa autorización de las Cámaras en sesión conjunta, dentro de las condiciones que fijen, una vez que hayan sido debidamente informadas por el Ejecutivo Nacional de todas las circunstancias pertinentes." (Ley Orgánica que reserva al Estado la Industria y el Comercio de Hidrocarburos, de 21/08/1975. Disponível em:
} 
legal, que permitia estabelecer convênios de assistência técnica e de comercialização entre a estatal PDVSA e as antigas concessionárias - ou seja, na prática, permitia a constituição de empresas mistas para administrar atividades que se reservavam legalmente ao Estado - não impediu, a princípio, que o país aproveitasse positivamente a conjuntura petroleira internacional seguinte a 1974, e (segundo números que apresentamos no capítulo anterior) exibisse - ao menos entre 1974 e 1980 - índices invejáveis de crescimento da produção nacional, com notável variação interanual, tendo por elemento impulsor os investimentos e as ofertas de crédito oficiais provenientes, em grande medida, das receitas da indústria em vias de ser estatizada. Porém, para os partidos de esquerda, assim como para muitos intelectuais e técnicos envolvidos na Comissão, esse acréscimo legal desfigurava o sentido nacionalista da causa petroleira, e franqueava meios casuísticos para a preservação dos interesses estrangeiros, em óbvio prejuízo dos nacionais. De fato, em essência, a nacionalização do petróleo assim consumada, confirmando os receios de seus críticos, não oferecia recursos efetivos para conter $\mathrm{o}$ anterior apetite das transnacionais, que mantiveram sobre a riqueza venezuelana um domínio agora exercido sob novas formas e mecanismos. Esse desvio foi, já à época, reiteradamente denunciado por um grupo de ilustres estudiosos venezuelanos, cujos subsequentes trabalhos, aliás, assentariam em definitivo as linhas interpretativas centrais desse processo nacionalizador venezuelano - linhas que sublinham a constituição de um enclave transnacional a controlar, desde seus primeiros dias, a indústria petroleira nacional, e a ditar - sob o signo da alienação - o modo de empregá-la socialmente pelas classes governantes do país. ${ }^{253}$ Afirmavam eles a propósito dos convênios, apenas dois anos após a nacionalização:

Os convênios de assistência técnica e de comercialização são complementários. Se, por sua parte, os primeiros propendem a perpetuar a dependência tecnológica da indústria petroleira venezuelana, os segundos tendem a manter a dependência comercial em relação aos monopólios transnacionais, e entre ambos comportam uma enorme sangria de excedente econômico gerado na Venezuela a favor desses monopólios. Ademais, uns e outros se reforçam

http://www.pdvsa.com/index.php?tpl=interface.sp/design/readmenu.tpl.html\&newsid_obj_id=163\&n ewsid_temas $=6$

${ }^{253}$ Cf. ZAVALA, D. F. Maza et alii. Venezuela: contratos de tecnología y comercialización petrolera. Problemas del Desarrollo. México, № 33, Ano IX, Febrero-Abril 1978, pp. 164-182. 
reciprocamente em seus efeitos globalmente antinacionalizadores e antinacionais. Em razão dos convênios tecnológicos, "assessores" dos monopólios transnacionais atuam na direção comercial das empresas operadoras nacionalizadas, que são simplesmente ex-filiais desses consórcios. Assim, [por exemplo] funcionários da Exxon, sob pretexto de "serviços técnicos", velam zelosamente na Lagoven pela aplicação do respectivo contrato de compra e venda de petróleo para aquele monopólio. Como tal convênio estabelece o compromisso da produção exportável da Lagoven quase exclusivamente com a Exxon, ao mesmo tempo que confere a esta o poder de suspender as aquisições de petróleo na medida e conveniência que deseje, a principal operadora venezuelana queda à mercê da Exxon neste aspecto vital, e dá ao consórcio norte-americano uma arma de grande poder para defender seu "contrato tecnológico", que é fonte de dominação e extração de lucros sem causa. Em suma, se o convênio de assistência técnica contribui para manter e reforçar a onerosa atadura comercial da Lagoven com a Exxon, o convênio de comercialização consagra e reafirma a ligação envolvida na suposta assistência técnica, complementando-se ambos os contratos para manter totalmente subordinada a Lagoven à Exxon. ${ }^{254}$

De fato, os contratos de comercialização assinados entre a nova estatal e as antigas concessionárias permitiam que estas reservassem a si próprias - ao contrário do que previra a própria lei de nacionalização (Lei que Reserva ao Estado a Indústria e o Comércio dos Hidrocarbonetos) que estabelecia a preferência de transações regulares diretamente com Estados ou entes estatais dos países consumidores - a maior parte dos volumes produzidos pelo país (em 1980, ainda em torno de $80 \%$ da produção nacional), o que, na prática e dado o volume extraordinário, influía diretamente sobre os valores a serem acordados entre as partes. Através dos contratos, as companhias transnacionais contavam com o benefício de poder ampliar ou reduzir em 10\% (com variação de até $20 \%$ em um período trimestral qualquer, dentro da variação anual de $10 \%$ ) os volumes de compras contratadas - conforme fossem (segundo seus critérios) favoráveis ou desfavoráveis os preços internacionais do barril. ${ }^{255}$ Além disso, tais contratos, de 2 anos, podiam ser renovados por igual período, por simples manifestação de uma das partes. Dadas essas vantagens, os efeitos negativos sobre o lucro total decorrentes das oscilações da demanda mundial recaíam especialmente sobre o vendedor (a PDVSA e suas filiais), já onerado, aliás, pelos riscos exclusivos de

\footnotetext{
${ }^{254}$ ZAVALA, D. F. Maza et alii. Venezuela: contratos de tecnología y comercialización petrolera, pp. 167-168.

${ }^{255}$ Cf. ZAVALA, D. Maza \& MATA, H. Malavé. "Aspectos económicos y políticos de la nacionalización de la industria petrolera en Venezuela". Op. cit., pp. 180-183.
} 
produção. Como agravante, ainda, esses termos assim convencionados tornavam remotas as possibilidades reais de a estatal venezuelana conquistar diretamente mercados próprios, restando enfraquecida ela na concorrência com as grandes transnacionais suas clientes, uma vez que estas, em mercados potenciais, "(...) pod[iam] apresentar suas próprias ofertas em condições mais vantajosas e desalojar a empresa venezuelana, inclusive com petróleo venezuelano comprado desta casa matriz sob contrato." ${ }^{256}$ (!) Os ganhos pouco expressivos verificáveis nos preços de realização do petróleo entre 1975 (ano anterior à nacionalização) e 1978 (ano de demanda crescente) mostram que as grandes petroleiras detinham um intocado controle sobre o mercado mundial, tornando-as capazes de impor à Venezuela preços de contrato inferiores mesmo aos estabelecidos pela OPEP: entre esses anos, o preço de realização variou positivamente apenas $11 \%$ (de 11 dólares em 1975 para 12,24 dólares em 1978). ${ }^{257}$ Cumpre acrescentar que, nesse cenário pós-nacionalização, a significação mais profunda do tipo de negociação assim acordado nos convênios entre a PDVSA e as petroleiras privadas repousava no fato de que o Estado venezuelano renunciava de moto próprio à importante conquista, anteriormente alcançada com a criação da OPEP, de poder unilateralmente fixar os preços de exportação. ${ }^{258}$ Desse ponto de vista, a nacionalização - ao transnacionalizar-se isto é, ao permitir conservar-se sob novas formas a ascendência das petroleiras estrangeiras sobre as decisões políticas estratégicas nacionais - exprimiu um passo atrás nas já parcimoniosas conquistas de autonomia da década anterior.

O mesmo desvio desnacionalizador, que concorria para o retrocesso, pode ser encontrado nos convênios de assistência técnica, considerados ainda mais lesivos que os de comercialização. Tais convênios, cedo acoimados de inconstitucionais, disfarçavam sob linguagem jurídico-comercial a ingerência direta de executivos e funcionários das petroleiras estrangeiras na condução da administração estatal. Através de diversos expedientes, tais executivos e funcionários podiam dispor de informações privilegiadas sobre assuntos de estratégia produtiva e comercial da estatal, além de poderem impor a ela padrões técnicos próprios, influindo diretamente nas decisões gerenciais acerca de

\footnotetext{
${ }^{256}$ Cf. Idem, ibidem, p.182. (Grifo nosso.)

257 Idem, ibidem, p. 184.

${ }^{258}$ Cf. POTTELLA, C. Mendoza. De las concesiones a los contratos, p. 102-107.
} 
questões de pessoal, mercado e tecnologia - o que reforçava, no plano ideológico, o não superado "(...) sentimento de incapacidade ou de impossibilidade de subtrair-se à relação umbilical com as transnacionais" ${ }^{259}$ motivo da resignação de muitos quanto à dependência externa. Realmente, o disposto nesses convênios propiciava meios de intromissão tão espúrios - e sob amparo contratual - que provocaram imediata reação de figuras públicas nacionais. Assim, em maio de 1977, um grupo de vinte e cinco intelectuais venezuelanos apresentou publicamente - dirigido aos líderes dos principais partidos nacionais (inclusive a $A D$, do presidente) - um remitido manifestando preocupação e repúdio pelas distorções presentes nos convênios tecnológicos, inaceitáveis por comprometer a independência do Estado no tocante ao mais importante bem público material da nação. O artigo (Con los convenios tecnológicos las transnacionales siguen controlando la industria petrolera. Remitido del 22 de mayo de 1977) trazia a chancela dos mais eminentes estudiosos de então da questão petroleira e suas implicações nacionais, e constitui hoje um dos mais valiosos documentos históricos do assunto. Desafortunadamente, e não obstante seu valor elucidativo e autoridade dos que o subscreviam, não foram as denúncias suficientemente ouvidas para alterar a postura oficial. O remitido apontava e descrevia três principais mecanismos, estabelecidos pelos contratos de tecnologia, que ensejavam a ingerência das petroleiras - a saber: a assessoria, o trânsito de informação e a continuidade administrativa gerencial e política:

Os convênios garantem a orientação da indústria nacional, por parte das antigas empresas concessionárias, através de sua assessoria em todas as áreas possíveis de gestão da indústria petroleira, desde as operações de produção e refino até a gestão gerencial, passando pelas recomendações para a compra de materiais e equipamentos, seleção e treinamento de pessoal, e assessoramento para a administração de contratos de trabalho. Seria ingênuo esperar que agora, as mesmas antigas concessionárias generosamente aconselhem uma política de desenvolvimento da indústria petroleira que favoreça os interesses do país acima de seus próprios interesses; que favoreça, por exemplo, a gradual eliminação dos laços de dependência tecnológica. (...)

\footnotetext{
${ }^{259}$ ZAVALA, D. Maza \& MATA, H. Malavé. "Aspectos económicos y políticos de la nacionalización de la industria petrolera en Venezuela", p. 189.
} 
Os convênios garantem às empresas transnacionais o acesso aos livros, aos registros e a toda informação das operadoras nacionais, com o que as empresas petroleiras estrangeiras podem ter, a todo o momento, uma informação completa e detalhada da indústria petroleira venezuelana.

(...) O acesso das transnacionais à informação e às decisões da indústria petroleira nacional se vê favorecido, além disso, pela continuidade administrativa da qual tanto se orgulha o Governo Nacional. Na prática, essa continuidade administrativa significa: a) que o pessoal venezuelano de confiança das transnacionais, que ocupava cargos de gerência na concessionárias, permaneça com esses mesmos cargos uma vez nacionalizadas as empresas. Esse pessoal não possui reservas nem segredos para seus antigos patrões das concessionárias, os quais são agora seus "assessores" das empresas de serviço constituídas no país pelas transnacionais para prestar "assistência técnica" à indústria petroleira após a nacionalização; b) que, em nome de uma suposta racionalidade técnica, a gestão da indústria petroleira se organize para que continue nas mãos das mesmas empresas, orientada pelos mesmos critérios e interesses prevalecentes antes da nacionalização; c) que se mantenha uma relação entre a operadora e a antiga empresa matriz que impeça a integração nacional da indústria. ${ }^{260}$

Acresciam-se, ainda, dois outros dispositivos, de conteúdo similar: 1) o referente ao poder de veto das empresas em relação ao pessoal venezuelano a ser selecionado para treinamento - artificio que dava oportunidade às petroleiras estrangeiras de não conceder aperfeiçoamento técnico e acesso a cargos de confiança a funcionários venezuelanos que fossem vistos como inadequados ou infensos aos interesses das petroleiras; e 2) o de vinculação da pesquisa nacional em matéria petroleira às necessidades e estratégias das transnacionais

\footnotetext{
${ }^{260}$ REMITIDO. Con los convenios tecnológicos las transnacionales siguen controlando la industria petrolera. El Nacional, Caracas, domingo 22 de mayo de 1977. Subscreveram esse valioso documento os professores universitários: Luís Lander, D. F. Maza Zavala, Simón Sáez Mérida, Orlando Araujo, Héctor Malavé Mata, Armando Córdova, Gastón Parra, Francisco Mieres, Pedro Duno, Estanislao González, Irene Rodríguez G., Manuel Rodríguez Mena, J. R. Núñez Tenorio, Ramón Losada Aldana, Freddy Balzán, Carlos Mendoza Pottellá, L. A. Lizardi McCallum, Tulio Colmenares, Rafael Haddad, Denzil Romero, Carlos Blanco, José Manuel Hermoso, Edgardo Lander, José León, Judith Valencia.

O documento, também referido por POTTELLÁ, C. Mendoza. De las concesiones a los contratos, p. 87, foi republicado recentemente em: Revista BCV, Vol. XXIII, No 1, Caracas, enero-junio 2009, pp. 153-162, e está disponível em: http://www.bcv.org.ve/upload/ publicaciones/ rbcv012009.pdf.

A propósito do valor histórico das afirmações contidas no remitido, observa o professor Carlos Mendoza Pottellá: "(...) Tales afirmaciones fueron el resultado del análisis de varios contratos de asistencia técnica, cuyas copias llegaron a los medios académicos por intermedio de funcionarios de la industria preocupados ante las graves implicaciones de tales arreglos. Después de siete años, las denuncias hechas en ese documento han sido confirmadas por el desarrollo posterior de la realidad petrolera". (p. 87)
} 
(especialmente a maior delas, a Exxon), de maneira a opor obstáculo à pesquisa nacional independente. Privilegiavam-se por esse modo as pesquisas ligadas às transnacionais, as quais depois venderiam à Venezuela essa mesma tecnologia a título de assistência técnica. Além do mais, os convênios se faziam sobre "(...) técnicas, métodos e processos já incorporados às operações correntes das empresas nacionalizadas e, por isso, amplamente conhecidos pelos técnicos venezuelanos. (...) [Outros] já estavam desenvolvidos e constituíam parte dos ativos pelos quais já tinham sido pagos pela indenização". Com o mesmo significado - concluía o documento - os valores contabilizados sob a rubrica de assistência técnica, ao ascenderem a valores muito acima do cabível, ${ }^{261}$ cumpriam o duplo propósito de "(...) justificar ante o país uma indenização muito maior do que a reconhecida oficialmente, realizando-a sob a forma de pagamentos por assistência técnica", e de "(...) proporcionar às transnacionais petroleiras um mecanismo que Ihes garant[isse], depois da nacionalização, 0 controle e a direção da indústria petroleira venezuelana (...)."262

A análise do impacto desses dois tipos de contratos, inserida na análise geral do desempenho econômico dos anos de boom petroleiro, conduz a um balanço objetivo pouco animador do alcance histórico da nacionalização petroleira e de seus desdobramentos para a sociedade nacional. De acordo com os principais estudiosos, embora se reconheça a importância histórica da nacionalização em si, o caso venezuelano, semelhantemente a outros, não representou senão mais um exemplo de estatização concertada, o qual, em suas linhas essenciais, atendeu sobretudo aos anseios de poder de setores burgueses nacionais então emergentes, animados por um contexto mundial de readequação

\footnotetext{
${ }^{261}$ Cf. os cálculos da "cláusula PAGAMENTOS" feitos em POTTELLÁ, C. Mendoza. De las concesiones a los contratos, p. 92 e seg., os quais permitiram a esse estudioso concluir: "(...) La característica fundamental de los pagos contemplados en estos convenios es el establecimiento de un monto fijo, por barril producido y por barril refinado para el cálculo del pago total, sistema que refuerza (...) la noción de que tales pagos no remuneran ninguna asistencia, (...) de que se trataba simplemente de continuar indemnizando a las petroleras, que ya lo habían sido, en demasía, por una inversión recuperada más de ocho veces en los diez años anteriores a la nacionalización." (p. 92) "(...) Durante esos cuatro años [1976 a 1980] la sangría neta por concepto de asistencia técnica, resultado de la aplicación de las cláusulas de pagos descritas, fue de 3.350 millones de bolívares, según cifras oficiales. Esta sola cantidad, que no incluye (...) otros pagos hechos por el mismo concepto, pero al margen de los contratos, es de una magnitud comparable a la de la indemnización que les fue reconocida a las ex-concesionarias por la nacionalización de sus activos y representa en verdad, la duplicación de esa indemnización. (p. 100) (Grifo nosso.)

${ }^{262}$ REMITIDO. Con los convenios tecnológicos las transnacionales siguen controlando la industria petrolera, pp. 156-159.
} 
das relações de dependência dos países periféricos, mas que jamais estiveram em oposição franca aos meios de exploração e às estratégias de dominação imperialista do grande capital internacional. ${ }^{263}$ Dessa perspectiva, as limitações mais sérias apontadas na nacionalização residiram (como ilustram, igualmente, alguns dados estatísticos do capítulo anterior): a) na persistência do controle transnacional da etapa de comercialização do petróleo (e de seus derivados, com maior valor agregado), o que provocou internamente grandes dificuldades agravadas pelos contratos de comércio - de introduzir o petróleo venezuelano diretamente em mercados internacionais; b) na dependência tecnológica, permanentemente reforçada tanto pela inércia de políticas oficiais em desenvolver pesquisas nacionais autônomas, como pelos empecilhos legais e práticos levantados pelos contratos de tecnologia; c) na opção das classes governantes pelo modelo rentista de desenvolvimento econômico, mantendo uma ligação frágil entre a riqueza proporcionada pelas receitas do petróleo nacionalizado e os outros setores produtivos nacionais; e d) na fugacidade das melhorias sociais condicionadas às rendas petroleiras, sujeitando o progresso social quase todo ao imediatismo de políticas populistas (de "conciliação de classes"). No plano das instituições nacionais, essas circunstâncias se viram refletidas na perpetuação do Estado clientelista venezuelano, estruturado de modo a garantir a consecução do projeto "nacional" burguês, ao passo que promovia o controle das classes subalternas sem, todavia, deixar de permanecer subserviente às grandes corporações internacionais. ${ }^{264}$

Dito em termos equivalentes, - e recordando-se a transcendência histórica que sempre cumpriu atribuir à conquista do domínio nacional dos recursos naturais e atividades econômicas a eles associadas (cabe lembrar, como assinalou L. Trótski, que tal conquista, apesar de limitações concretas, não deixava de ser uma medida "altamente progressista") - as nacionalizações em países capitalistas subdesenvolvidos puderam (e podem) ${ }^{265}$, contraditoriamente, tanto constituir um impulso a transformações democráticas reais, conducentes à elevação de um desenvolvimento social amplo, como representar não mais que

\footnotetext{
${ }^{263}$ Cf. KAPLAN, M. (coord.). Petróleo y desarrollo en México y Venezuela. México, D.F.: Editorial Nueva Imagen, 1981.

${ }^{264}$ Cf. ZAVALA, D. F. Maza et alii. Op. cit., p. 187-8.

${ }^{265}$ Voltamos à discussão de alguns desses pontos na Conclusão, adiante.
} 
um meio de fortalecimento do poder burguês associado. O estudo do tumultuado e variegado processo de nacionalização do petróleo na Venezuela - cuja culminância foi a referida nacionalização transnacionalizada - permite concluir que nenhum projeto de modernização democrática e/ou de autonomização econômica, no país, tornou-se historicamente viável ao ser combinadamente conduzido segundo as exigências das grandes empresas petroleiras estrangeiras e dirigido por um Estado nacional indisfarçavelmente oligárquico. Este, embora tenha podido conservar uma fachada de institucionalidade liberal-democrática, o fez apenas na medida em que essa mesma institucionalidade impediu que o processo extravasasse para fora das fronteiras do nacionalismo não radical. $O$ assim denominado capitalismo de Estado - que, no exemplo venezuelano, tem sido por vezes interpretado como a face econômica daquela institucionalidade política (e que foi por ela impulsionado) - não consistiu senão em um mecanismo extraordinariamente funcional para a consolidação do poder privado das grandes corporações transnacionais em economias dependentes, e apenas reflexamente erigiu-se como instrumento de ascensão das classes dominantes dessas nações subdesenvolvidas. ${ }^{266}$ Nesse quadro, não surpreende que tais classes preteriram toda e qualquer oportunidade real aberta a um ideal maior de democracia e soberania, e resignaram-se a outro, muito menos ousado. No exemplo de luta nacional aqui estudado, a resultante da adoção desse segundo ideal constituiu aquilo que, ironicamente, foi rotulado de uma nacionalización chucuta - isto é, uma simples experiência mutilada.

\footnotetext{
${ }^{266}$ Vejam-se os diversos problemas relacionados à revolução nacional na América Latina e às possibilidades de transformações democráticas e liberação nacional nos Pequenos Escritos Políticos, de Florestan Fernandes (FERNANDES, F. Brasil: em compasso de espera. Pequenos escritos políticos. Rio de Janeiro: Ed. UFRJ, 2011. (Col. Revisitando o Brasil, v. 4).
} 


\section{Cap. 4: A cooptação do movimento operário e a repressão à luta armada}

Do ponto de vista dos conflitos de classes, dois processos históricos concorreram decisivamente para que, durante os anos 1960-70, se consolidasse o puntofijismo como modo oligárquico-autoritário de organização político-social e - o que significa a mesma coisa - como expressão superestrutural do capitalismo dependente venezuelano. Foram eles: a cooptação do movimento operário pelo Estado, cujo efeito principal foi o de desmobilizar uma potencial força social contrária ao modelo de dependência e de sujeição à dominação imperialista; e a supressão violenta dos grupos políticos radicais, que se haviam decidido pela luta armada contra os governos da democracia puntofijista. O primeiro processo uma gradual mas poderosa atração de grupos de trabalhadores e lideranças sindicais para o projeto burguês associado - ganhou maior ímpeto já ao fim da ditadura de Pérez Jiménez, em 1958, e, ao enfraquecer os tradicionais ideais anarquistas e socialistas nos meios operários e sindicais, semeou as condições propícias ao triunfo da "conciliação de classes" ajustada no Pacto de Punto Fijo. O segundo processo, materializado na "pacificação" dos anos 1960, teve por propósito - em grande medida, coroado de êxito - afastar do cenário nacional os possíveis agentes de transformação revolucionária da sociedade, criando-se assim meios efetivos para firmar-se a associação das classes burguesas venezuelanas com os interesses das grandes corporações transnacionais. A cooptação de uns e a repressão a outros abriram caminho à associação conservadora, o que tornaria não casual, por exemplo, o fato de, em um quadro de fragilidade das forças sociais defensoras de autonomia e democracia, ter predominado o caráter especioso que encontramos na nacionalização petroleira de 1976. Nas páginas seguintes, apresentamos sucintamente a descrição desses dois processos, os quais - deve-se sublinhar - foram por vezes obliterados por estudiosos que, mais atentos ao comportamento estrito de variáveis econômicas, destinaram menor atenção às condições sociais conflituosas de cuja solução ou contenção dependeu o desempenho dessas variáveis na medida e forma esperadas pelas elites do país. Igualmente, a análise dos dois processos deve permitir exemplificar um outro elemento histórico relevante, a saber, a atuação 
recorrentemente opressiva e repressiva do Estado burguês associado - atuação que denota, nessas sociedades dependentes fortemente cindidas, o papel primordial do Estado como instrumento político de proteção do capital contra o trabalho (não raro por meios contrários ao próprio direito constituído) revelandose, assim, decisivo naqueles momentos em que a luta de classes ameaça romper os limites da normalidade burguesa. Em tais momentos, salta aos olhos a natureza vazia do discurso democrático oficial, e essa circunstância ideológica exprime, por si só, a incapacidade, já referida, de essas sociedades de classes conservarem-se duradouramente de acordo com seus próprios valores políticos e sociais proclamados.

Em suas origens, o movimento operário venezuelano caracterizou-se por uma frágil combatividade e pouca capacidade de organização, explicáveis todavia em uma formação social com forte predominância de formas pré-capitalistas de trabalho - como era a Venezuela agrária da primeira década do século XX. ${ }^{267}$ Apesar disso, já em 1909 formaram-se as primeiras organizações operárias (como a Associação de Trabalhadores e Artesãos do Distrito Federal), e as primeiras greves foram deflagradas. Em 1914, uma greve de telegrafistas de Caracas atingiria dimensão nacional, fazendo de seus líderes os alvos principais da repressão do governo de Juan Vicente Gómez. Para escapar à perseguição da ditadura gomezista, os grêmios e associações operárias passaram a se organizar em Sociedades de Socorro e Mútuo Auxílio, e recorriam ao artifício formal de pôrse sob o patrocínio de figuras da hagiografia católica. Em 1919, enquanto alguns governos da Europa estremeciam sob o crescendo das agitações proletárias após a I Guerra, surgia na Venezuela a Confederação Geral Operária, a primeira união sindical de trabalhadores venezuelanos - em um ano, aliás, assinalado pela eclosão de diversos movimentos grevistas em vários pontos do país. Ao que parece, essas mobilizações estiveram, em parte ao menos, influenciadas diretamente pela ideologia anarcossindicalista, trazida à Venezuela por trabalhadores espanhóis e italianos, muitos fugidos ou expulsos de seus países de nascimento. ${ }^{268}$ Foi, porém, com a formação do proletariado petroleiro durante os anos de 1920 que o movimento operário venezuelano alcançou maior

${ }^{267}$ Cf. VITALE, Luis. Notas para una historia del movimiento obrero venezolano. UCV, Caracas, 1981.

${ }^{268}$ Cf. VITALE, L. Op. cit., p. 3. 
coesão enquanto força social organizada ${ }^{269}$, embora sofresse cotidianamente com as medidas de policiamento e controle impostas nos campos de exploração das empresas petroleiras. ${ }^{270} \mathrm{Em}$ junho de 1925, os trabalhadores de Mene Grande, após sucessivos protestos contra as arbitrariedades das empresas, realizaram a primeira greve petroleira, que durou nove dias e teve entre suas exigências 0 aumento de salários, a remuneração de horas extras e férias, e o fim das multas por alegadas infrações de trabalho. A respeito disto assinalou-se:

"(...) A greve petroleira de 1925 constituiu um fato relevante na história venezuelana porque os trabalhadores demonstraram pela primeira vez que eram capazes de paralisar a principal indústria extrativa do país, pondo em relevo o poderio da nova classe social emergente. Nestes conflitos começou a forjar-se a nova vanguarda operária venezuelana". ${ }^{271}$

Em maio de 1931, fundou-se o Partido Comunista da Venezuela, responsável por organizar, no mesmo ano, o primeiro sindicato petroleiro do país - a Sociedade de Auxílio Mútuo de Operários Petroleiros (SAMOP), de importante atuação nas companhias da região de Zúlia, e que reunia mais de cinco mil trabalhadores. A organização do partido contou com o apoio do Bureau do Caribe, ligado à Internacional Comunista, e durante toda a década manteve-se atrelado,

\footnotetext{
269 Esse papel histórico fundamental do proletariado petroleiro contrastava com o dos trabalhadores de outros setores da indústria e comércio, que, sob o gomezismo, permaneceram coagidos a uma atuação irremediavelmente restrita: Observa um estudioso: "(...) En otras ramas de actividad, o el tamaño medio de los establecimientos era inferior al mínimo requerido por la ley para la constitución de sindicatos, y/o - lo que era el caso predominante - cuando aquel tamaño lo permitía (teóricamente, como era el caso de los institutos bancarios y muchas empresas industriales o comerciales, y en los servicios públicos), la política gubernamental entorpecía o reprimía abiertamente la labor sindical, reforzando así una extendida oposición de los patronos a la organización y actuación de los sindicatos. Por estas razones, y al margen de los desarrollos (...), durante mucho tiempo el sindicalismo venezolano fue básicamente un "sindicalismo de gremios" (telegrafistas, linotipistas, zapateros, etc.), con mucha mística pero con una débil base organizativa". (TORO, Héctor Valecillos. ¿Retador o garante del sistema? Los 50 años de la Confederación de Trabajadores de Venezuela. Nueva Sociedad, № 85, septiembre-octubre, 1986, $\mathrm{s} / \mathrm{p}$.)

270 "(...) En la década de 1920, ya existían más de 10,000 obreros petroleros, sometidos a una inicua explotación, como lo señala Salvador de la Plaza: "Las empresas imperialistas crearon los campos petroleros, debidamente cercados, y los convirtieron en pequeños estados autónomos dentro del Estado, regidos por reglamentos y cuerpos de policías propios que tenían por finalidad asegurar la más exhaustiva explotación de los trabajadores venezolanos. El libre comercio de esos 'campos' y la entrada de ellos a quienes no portaran la ficha de enrolamiento de la compañía respectiva estaban prohibidos, así como también el tránsito por las carreteras construidas por las compañías para comunicar entre sí a los campos petroleros o con los poblados más cercanos." (VITALE, L. Op. cit., p. 5)

${ }^{271}$ Cf. VITALE, Luís. Op. cit, p. 4.
} 
apesar da clandestinidade, à orientação oficial do comunismo soviético, que preceituava a atuação partidária no âmbito de partidos legais. Importa notar que o aparecimento do comunismo na Venezuela esteve condicionado pelas mudanças estruturais por que atravessava a sociedade nacional, cuja base material vinha deslocando-se da agricultura de exportação para a indústria petrolífera, e cuja estrutura política caudilhesca perdurava como herança da época anterior. Nesse contexto cambiante, tornou-se inevitável a contradição entre o caudilhismo em declínio e os grupos sociais que despontavam. Em fins de 1935, em seguida à morte de Juan Vicente Gómez (em 17 de dezembro), instalou-se no país um quadro de violenta disputa pelo poder central. Enquanto digladiavam entre si grupos de familiares e partidários do ditador, os setores ascendentes de classe média (com destaque para os estudantes) realizavam protestos exigindo liberdades políticas reais e a adoção de novas formas de distribuição das rendas do petróleo. Por sua vez, multidões de populares tomaram as ruas em diversas cidades (Caracas, Maracaibo e outras), e suas ações se dividiram entre saques a estabelecimentos comerciais e ataques às propriedades de familiares e políticos ligados ao caudilho morto. Os distúrbios se prolongaram pelos dois meses seguintes, configurando no país um clima pré-revolucionário, no qual, em algumas regiões, grupos de populares e de trabalhadores chegaram mesmo a organizar guardas cívicas e milícias armadas como formas embrionárias de poder popular em luta contra o gomezismo. Congruentemente, em fevereiro de 1936, ocorreria a primeira grande greve geral da história venezuelana, cujo êxito parcial se viu confirmado, por exemplo, na conquista do Seguro Social Obrigatório e na Lei (de julho de 1936) que regulamentava a jornada de trabalho de oito horas e os sindicatos por empresa. O efeito dessa lei, contudo, que institucionalizava a atividade sindical, foi o de integrá-la ao sistema oficial, fato que, na prática, restringia a livre iniciativa dos trabalhadores. ${ }^{272}$ Nessa onda de agitações, ainda em 1936, também os trabalhadores rurais puseram-se a organizar meios de luta próprios, através do estabelecimento das Ligas Camponesas. Entre dezembro de 1936 e janeiro de 1937, realizou-se o congresso de fundação da Confederação Venezuelana do Trabalho (CVT), na qual predominaram os sindicatos ligados aos comunistas, o que constituiu razão suficiente para que sua liderança fosse logo

$\overline{{ }^{272} \text { Cf. VITALE, Luís. Op. cit, p. } 8 .}$ 
objeto de perseguição oficial (em fevereiro de 1937, vários membros de sua direção foram expulsos do país). A despeito do movimento organizatório simultaneamente urbano e rural nesses anos de 1930, continuavam a inexistir instituições ou canais legais de representação popular e operária ${ }^{273}$ - (deve-se recordar que, até então, não fora constituído nem mesmo um partido burguês oficial) - de maneira que o alcance das transformações sociais que se vinham desenrolando, havia ao mesmo duas décadas, acabou por impor à vaga de levantamento popular e agitações operárias uma saída dramaticamente contingente, ou seja, o amortecimento e absorção de suas lutas e reivindicações por grupos políticos oligárquicos dominantes da fase anterior - nomeadamente 0 liderado pelo general López Contreras, instalado enfim como o sucessor de Gómez. Conquanto algumas mudanças político-institucionais importantes viessem a ser implantadas depois, pode-se dizer que, de uma perspectiva revolucionária, 1936 ressentiu-se da carência de uma mais consistente tradição de organização e de lideranças proletárias autônomas, o que redundaria, nos anos seguintes, na assimilação das organizações e movimentos de trabalhadores (da cidade e do campo) pelos partidos populistas que começavam a surgir. Com efeito:

Ao longo de 1936, o proletariado venezuelano mostrou pela primeira vez na história do país que era a força decisiva na luta pela libertação nacional e social. [Mas,] comprovou-se, igualmente, que sem a aliança com outros setores de explorados, a classe operária isolada não poderia conquistar o poder. Esta tarefa não pôde ser levada adiante devido à ausência de um partido marxista revolucionário. As massas trabalhadoras foram rapidamente canalizadas pelo populismo da Ação Democrática. $^{274}$

Entre os anos de 1936 e 1947 (período que correspondeu aos governos de López Contreras e Medina Angarita, e à maior parte do curto governo de Rómulo Gallego, da $A D^{275}$, deposto pelo golpe militar de Pérez Jiménez em 1948), -

\footnotetext{
${ }^{273}$ Cf. MAYA, Margarita López. Luta hegemônica na Venezuela. 2010, Cap. 3.

${ }^{274}$ VITALE, L. Op. cit., p. 9.

${ }^{275}$ A Acción Democrática foi formalmente lançada como partido político legal em 1941. As organizações anteriores, dos anos de clandestinidade, das quais provieram seus líderes, foram a Agrupación Revolucionaria de Izquierda (ARDI), a Organización Venezolana (ORVE) e, desde 1936, o Partido Democrático Nacional (PDN). A história oficial do partido adeco reivindica, ainda hoje, uma tradição de luta (iniciada nos tempos do PDN) contra a exploração latifundiária da terra, a usurpação estrangeira dos recursos nacionais e, ao mesmo tempo, a luta pela construção de uma sociedade democrática fundada em uma economia de sentido nacionalista - todos valores
} 
assistiu-se, sucessivamente, ao ocaso do gomezismo e à ascensão paulatina da socialdemocracia na Venezuela. Não obstante, durante esses tempos de instabilidade e alterações políticas, o movimento operário e sindical permaneceu sob a influência predominante do PCV e sua orientação ideológica revolucionária (marxista-leninista). ${ }^{276} \mathrm{~A}$ instauração de regimes fascistas na Europa exigiu a radicalização da luta dos trabalhadores em todo o mundo, e isso explica, em parte, a ascendência que então possuíam os comunistas sobre as diversas organizações operárias e sindicais. No caso venezuelano, essa influência não seria, contudo, duradoura, e iria refluir acentuadamente nos anos seguintes à II Guerra. Ainda assim, em 1944, na Convenção Sindical Nacional, reunida em Caracas, dos 150 sindicatos de trabalhadores representados pelos 370 delegados presentes, mais de dois terços eram dirigidos por figuras ligadas ao PCV, enquanto 41 eram dirigidos pela AD. ${ }^{277}$ Mas, esse dinamismo dos comunistas perdeu rapidamente força quando o movimento que depôs o presidente Medina Angarita, em 1945, levou a AD ao proscênio político nacional. A partir daí, implantou-se a política de promover, através do Ministério do Trabalho, a criação de sindicatos operários e camponeses cuja direção estivesse, desde o início, submetida ao domínio do partido adeco: em 1947, mais de 900 sindicatos foram oficialmente criados atendendo a essa injunção. Um ano antes, fora criada a Federação de Trabalhadores Petroleiros (FEDEPETROL), também sujeita à AD.

sistematicamente esquecidos ou ignorados pelo partido durante o exercício do poder político ao longo das quatro décadas de hegemonia na condução do país. Há, pois, certa incongruidade entre a história e a divisa do partido Por una Venezuela libre y de los venezolanos. (Pan terra trabajo). Por sua vez, o Copei é fundado em 1946.

276 "En la escena de las organizaciones sindicales y políticas se perfilan dos grandes tendencias de índole revolucionaria: la comunista, marxista-leninista, liderada por Juan Bautista Fuenmayor, Rodolfo Quintero, Miguel Enrique Otero Silva y los hermanos Machado, que siguen las directrices del "Komintern" (Internacional Comunista); y la Socialista, liderada por Rómulo Betancourt, Valmore Rodríguez, Raúl Leoni y Alejandro Oropeza Castillo. Esta adopta una posición reformista, alejada de los dictados de la Komintern e inspirada también en la doctrina de "La especificidad Latinoamericana", tesis política del Peruano Víctor Raúl Haya de la Torre, que tuvo una influencia decisiva dentro del naciente partido A.D." (DÍAZ, Rolando. Los sindicatos en Venezuela: de la negociación a la confrontación. IDEGES, 2009, pp. 3-4.)

${ }_{277} \mathrm{Um}$ fator agudamente limitante da força das organizações sindicais nos últimos anos do gomezismo devia-se ao fato de que a existência legal dos sindicatos dependia da aceitação do princípio jurídico de que as organizações laborais não desenvolvessem atividades políticas, mas apenas as estritamente relacionadas com os assuntos gremiais e reivindicativos: "(...) el artículo 143 de la Ley del Trabajo castigaba con la disolución a aquellos sindicatos que se inmiscuyeran en política, una muestra de lo cual fue dada por el gobierno con la disolución de 91 sindicatos laborales influidos por los comunistas que participaban en la Convención Nacional Obrera de marzo de 1944". (SALAMANCA, Luis. La incorporación de la Confederación de Trabajadores de Venezuela al sistema político venezolano: 1958-1980. Caracas: Revista de la Facultad de Ciencias Jurídicas y Políticas, no 95, 1995, p. 250) 
Ainda, de significação análoga, no II Congresso Sindical Nacional, realizado em 1947, ao decidirem os delegados recriar a CVT (ilegalizada em março de 1944 e então rebatizada de Confederação de Trabalhadores da Venezuela - CTV), esta restaria - a não ser por um único dirigente comunista - sob completo controle da AD. ${ }^{278}$ A CTV passou a constituir a principal reunião de sindicatos do país e, embora fosse logo dissolvida pelo novo governo ditatorial em 1949 (como consequência da proibição de sindicatos, congressos e movimentos de trabalhadores), retornaria alguns anos depois (1959, ano do III Congresso), para tornar-se então uma peça-chave no funcionamento do sistema político puntofijista. Em pouco tempo, restaria ela definitivamente apartada do influxo dos grupos esquerdistas $\left(\mathrm{PCV}^{279}\right.$ e $\left.\mathrm{MIR}^{280}\right)$. Os comunistas, aliás, que experimentavam agora a perda de espaço representativo no meio sindical, haviam sido duramente golpeados pela repressão desencadeada sobre seus dirigentes e militantes nos anos do governo de Pérez Jiménez.

Esse fato crucial - o drástico encolhimento da influência comunista, acentuado nos três anos seguintes a 1945 e ultimado quando o movimento civilmilitar de janeiro de 1958 pôs termo ao interregno perezjimenista (e trouxe de volta ao primeiro plano a $A D$ ) - iria convergir para definirem-se as linhas fundamentais que marcariam a etapa seguinte do sindicalismo venezuelano, lançando-o de vez no caminho da colaboração de classe. Esta colaboração, concebida nas condições históricas de dependência estrutural e de horror das

\footnotetext{
${ }^{278}$ Cf. SALAMANCA, L. Op. cit., pp. 254-257. De 300 delegados presentes no II Congresso da nova CTV, 257 pertenciam à AD, e dos 7 dirigentes, 6 eram adecos.

${ }^{279}$ Não obstante, no III Congresso da CTV, os delegados comunistas ainda compunham quase um quarto do total (210 em 900), e no Comitê Executivo havia 3 comunistas entre seus 16 membros. No entanto, entre 1959 e 1961, a cisão dentro da CTV entre a maioria adeca - defensora de um sindicalismo de conciliação e de apoio à política econômica do presidente Rómulo Betancourt - e a minoria comunista (a que se juntara o MIR) - decidida a um sindicalismo de mobilização com o recurso às greves - levou a expulsão dessa ala esquerdista no IV Congresso Extraordinário, em 1961. A partir daí, a CTV permaneceria inteiramente sob domínio AD-Copei.

${ }^{280} \mathrm{Em}$ agosto de 1960, formou-se o Movimiento de Izquierda Revolucionaria (MIR) a partir de uma cisão da ala esquerda da AD, ocorrida meses antes. O MIR constituiu a mais importante fissura na hegemonia política adeca. Declarou-se logo um partido de orientação marxista e defensor da luta armada como meio de construir uma sociedade democrática socialista. Seu lema "No somos comunistas, somos la izquierda revolucionaria." não impediu evidentemente a aliança com o PCV na formação dos grupos guerrilheiros. Contudo, juntamente com o PCV, foi posto na ilegalidade em maio de 1962, pelo governo de R. Betancourt. Este, aliás, em mensagem ao Congresso, nesse ano, parabenizaria os dirigentes da CTV "(...) que procedieron a efectuar una operación profiláctica marginándolos de sus cuadros de dirección" (Cf. SALAMANCA, L. Op. cit., p. 311), em referência à expulsão dos comunistas no IV Congresso Extraordinário. Afastados os comunistas e mirristas, selava-se a longa união entre governos AD-Copei e a direção cetevista.
} 
elites ao comunismo (instilado ainda mais pelo alinhamento do país ao bloco das democracias ocidentais pós-guerra), manifestou-se de facto como a cooptação da classe operária através de sua representação sindical, mediante o quê essa classe integrou-se a um sistema político funcionalmente americanófilo e anticomunista, e deu seu assentimento ao pacto das elites, que, em última análise, iria assegurar o modelo econômico dependente-rentista e o tipo populista de desenvolvimento social. Em outras palavras, entre 1958 e 1998, o movimento sindical venezuelano, na medida em que podia considerar-se representativo da organização política dos trabalhadores, vinculou explicitamente seu pensamento e ação à estratégia de aliança com forças não operário-populares, como - além da $A D$ - a socialdemocracia cristã (reunida no COPEI) e os setores mais importantes do empresariado (Fedecámaras). ${ }^{281}$ Objetivamente, o progressivo atrelamento da maioria dos sindicatos à diretriz política da Ação Democrática, cuja hegemonia nacional impôs-se, possuiu o significado histórico transcendente da decisão das lideranças sindicais em defender (e aderir a) o sistema político bipartidarista nascido de 1958. A decisão encontrava justificativa no pressuposto, que adquiriu clareza e consenso nos anos seguintes, de que cumpria à classe trabalhadora oferecer a paz laboral como contribuição ao "pacto social" inscrito no convênio de Punto Fijo. Esta linha de ação, concretizada na medida em que a cooptação contagiava e corrompia diretamente os níveis superiores das lideranças sindicais, transformou o sindicalismo venezuelano desses anos em um típico sindicalismo de livre mercado ${ }^{282}$, e apoiou-se firmemente em duas premissas: a do reconhecimento oficial, pelos líderes sindicais, da legitimidade do sistema político em vigor e de seus protagonistas históricos - do que derivava como condição necessária ao desenvolvimento nacional a imperiosidade de renunciar ao antagonismo de classes; e a da aceitação dos limites do campo das ações reivindicatórias dos sindicatos às esferas decisórias pertencentes ao Estado, o que, por sua vez, minou a representatividade e a autonomia dessas organizações operárias. Ora, ao mesmo tempo que a corrupção alimentava a cupidez da

\footnotetext{
${ }^{281}$ Veja-se o Acuerdo de Avenimiento Obrero-Patronal, de 1958 - firmado entre o Comitê Sindical Unificado Nacional, a Federação de Câmaras e Associações de Comércio e Produção (Fedecámaras) e o Ministério do Trabalho - considerado um documento básico para a compreensão das ideias que nortearam, em grande medida, as relações capital-trabalho e, no plano político, o Pacto de Punto Fijo. (Cf. Anexo 1)

${ }_{282}$ Cf. TORO, Héctor Valecillos. ¿Retador o garante del sistema? Los 50 años de la Confederación de Trabajadores de Venezuela. Nueva Sociedad. № 85, septiembre-octubre, 1986.
} 
crescente aristocracia operária, adrede sindicalizada, fortalecia-se a propensão a burocratizar-se a organização sindical, levando-a a exercer uma função deliberadamente diversiva da representação sindical frente ao movimento político da classe trabalhadora. ${ }^{283} \mathrm{O}$ diversionismo assim adotado patenteou-se sobretudo na anuência que as lideranças sindicais conferiam às sucessivas políticas econômicas (por vezes recessivas) dos governos puntofijistas, bem como na indiferença manifestada diante dos movimentos que tinham efetivamente impulso popular. ${ }^{284}$ Por isso, ao denegar à classe operária a oportunidade de ação e de conscientização sobre sua condição histórica de massa explorada e oprimida, o sindicalismo puntofijista representou - mais do que uma "correia de transmissão"

\footnotetext{
${ }^{283}$ Provavelmente, o mais importante exemplo da união de interesses - muitos deles escusos entre o sindicalismo cooptado e diversionista da CTV, o empresariado e os partidos políticos atuantes no Estado foi a criação, em 1966, do Banco dos Trabalhadores da Venezuela (BTV), cuja fundação deveria servir ao propósito de auxiliar trabalhadores menos favorecidos a satisfazer suas necessidades fundamentais (especialmente moradia própria), mas que, na prática, funcionou como instrumento de crédito a uma miríade de empresas afiliadas que se dedicavam a inúmeras atividades de serviço, e cuja direção era constituída por representantes sindicais dos partidos $A D$, COPEI e MEP, nomeados pelo presidente do Banco segundo negociações dos três partidos no âmbito da CTV. A propósito observa M. L. Maya: "Desde su nacimiento [BTV] fue concebido como un instrumento de fortalecimiento económico para las organizaciones sindicales afines a los partidos de Punto Fijo. Era por una parte una manera de legitimar al Estado frente a los sectores laborales, al abrir un canal para la distribución del ingreso público hacia sectores que por otra vía no tenían acceso al crédito y era a su vez, la forma de asentar la legitimidad del sindicalismo cetevista ante sus bases, toda vez que las prerrogativas del banco eran visualizadas como demandas elevadas por la CTV al Estado y satisfechas por éste. Más allá de esta doble función legitimadora, en la medida en que crecía el BTV se fue constituyendo también en una suerte de espacio exclusivo de la CTV para financiar el enriquecimiento de sus organizaciones y líderes y aun de grupos económicos privados. Los recursos del Estado fluyan sin reservas hacia el BTV y éste repartía a diestra y siniestra utilidades y créditos que fueron comprometiendo a la más variada gama de líderes sindicales y empresarios privados ligados o no a los partidos de Punto Fijo." (MAYA, Margarita López. El BTV: una historia con final feliz. p. 357. Artigo disponível em: http://gumilla.org/biblioteca/php/buscar.php?base=biblo\&cipar=biblo.par\&epilogo=\&Formato=w\&Op cion=detalle\&Expresion=!IBanco+de+los+Trabajadores+de+Venezuela).

Em fins dos anos 1970, o BTV chegaria a ser o maior banco do país, e, em 1982, ano em que sofreria intervenção, $57 \%$ de suas ações estavam nas mãos da CTV.

${ }^{284}$ Referindo-se à CTV, resume Roberto L. Sánchez um aspecto desse diversionismo sindical: "(...) La función de esta central como apagafuegos de las luchas obreras se comprueba en el hecho de que fue sólo en mayo de 1989, luego del levantamiento semi-insurreccional espontáneo del pueblo de Caracas, y luego de tres décadas de predominio de su estrategia de conciliación de clases, que la CTV organizó una huelga nacional en contra de un gobierno puntofijista (paro nacional de 24 horas cumplido el 18 de mayo del 89, [cuando] era presidente Carlos Andrés Pérez del partido Acción Democrática). Antes de esa fecha, durante treinta años, la CTV mantuvo una conducta de permanente conciliación de clases, limitando las luchas reivindicativas de los trabajadores a las migajas que sobraban del festín petrolero. Conducta conciliadora que luego de 1989 se continuó por una década más." (SÁNCHEZ, R. L. El movimiento de trabajadores en la Venezuela bolivariana. Configuración de tendencias: autonomistas contra leninistas. Espacio Abierto, vol. 21, núm. 1, enero-marzo, 2012, p. 151)
} 
entre as decisões do governo e as massas trabalhadoras ${ }^{285}$ - um autêntico freio à formulação efetiva de reivindicações sociais para além dos benefícios imediatos que uma economia de base rentista podia proporcionar. Nesses anos, portanto, aristocratização operária e burocratização sindical conjugaram-se na perpetuação da dependência e do subdesenvolvimento nacional, em um processo que fazia recordar as antigas preocupações de L. Trótski quanto a operários e burocratas desse tipo resignarem-se "a lutar por migalhas do sobrelucro do imperialismo capitalista [e, ao mesmo tempo, a] demonstrar ao estado 'democrático' até que ponto são indispensáveis e dignos de confiança em tempos de paz (...)". ${ }^{286} \mathrm{~A}$ contrapartida dessa "confiança" que a "democracia" podia depositar no trabalhador comum não ia mais longe do que algumas garantias jurídicotrabalhistas, algumas melhorias na subsistência diária e algumas perspectivas vagas de ascensão social ${ }^{287}$ - todas ao preço da sujeição incondicional da classe trabalhadora aos valores da democracia burguesa. Ao cabo, isso significou que a opressão do Estado seria, indiretamente, exercida e reproduzida pelo próprio sindicalismo cooptado. O excerto a seguir reúne com detalhes as características essenciais que adquiriu historicamente o sindicalismo venezuelano nessa sua assim considerada fase luminar, isto é, na de sua consolidação e perfeita integração ao sistema político puntofijista:

(...) a gestão dos sindicatos cobre um vasto campo de atividades que transcendem a área das reivindicações ao nível da empresa, abarcando ações que têm um caráter nitidamente social e político. Neste terreno, a ação do movimento operário enfatizou a "defesa e consolidação do regime democrático" e a ampliação primordialmente através de iniciativas de caráter parlamentário dos direitos econômicos e sociais dos trabalhadores. Ao atuar desse modo, majoritariamente a direção sindical recusou-se a qualquer antagonismo de importância com o sistema de relações capitalistas existentes no país. (...) [A] maioria sindical jamais encarou a possibilidade de limitar significativamente, e menos ainda modificar, os direitos de propriedade, parecendo não ver nesses direitos a base efetiva da dominação de classe. Se cabe ser cético quanto ao êxito alcançado

${ }^{285}$ Cf. DÍAZ, Rolando. Los sindicatos en Venezuela: de la negociación a la confrontación. IDEGES, 2009, pp. 5-6.

${ }^{286}$ Cf. nota 104 , acima.

287 "(...) es justo reconocer que el sindicalismo en este período consiguió ciertos logros importantes para los trabajadores venezolanos, como lo es la creación e institucionalización de la formación profesional de los trabajadores, mediante la creación del Instituto Nacional de Cooperación Educativa (I.N.C.E.), la Ley de Representación Laboral en las Empresas del Estado, la reforma de la Ley del Seguro Social, la Ley contra despidos injustificados, la extensión de la Contratación Colectiva en sector público, entre otros". (DÍAZ, R. Op. cit., p. 4-5. 
pela atividade político-social dos sindicatos venezuelanos, há pouca razão para dúvida sobre a eficácia dessas organizações em conseguir objetivos de caráter específico. Neste sentido, e seguindo uma pauta quase universal, nosso movimento operário tem sido relativamente afortunado em conseguir: a) a manutenção e desenvolvimento da organização sindical. Certamente, os sindicatos chegaram a ser aceitos finalmente como uma instituição característica e permanente do ambiente econômico e social, alcançando vencer a propensão empresarial de enfrentar ou resistir à organização dos trabalhadores; b) convencidos de que a distribuição do trabalho disponível é demasiado importante para deixá-la a critério do empresariado, os sindicatos têm procurado e alcançado um controle e racionamento mais ou menos efetivo das oportunidades de trabalho. Ao fazê-lo, o movimento sindical tratou de dar resposta ao reclamo, insistente e justificado, de uma seguridade nos empregos por parte dos trabalhadores. Aspecto esse de muitíssima importância, sobretudo em um país como o nosso, onde tradicionalmente tem havido escassez de oportunidades ocupacionais remunerativas. Apesar disso, a forma e a intensidade como se tem levado à prática esse objetivo sindical - em especial nas atividades do setor governamental - deram origem a sérios problemas; c) os sindicatos têm facilitado uma melhoria gradual das condições de trabalho, em particular das remunerações, horas de trabalho e outros aspectos do emprego. Em função de uma complexa determinação causal, os sindicatos tendem a transformar essa melhoria em algo mais uniforme entre as diferentes empresas e indústrias. Ao cumprir essa tarefa, os sindicatos têm desempenhado um papel de grande importância, promovendo um movimento mais ou menos constante das normas convencionais de subsistência, isto é, do que se julga comumente como o nível mínimo de vida; d) finalmente, o movimento operário tem cumprido um papel muito importante no desenvolvimento e aperfeiçoamento de um sistema jurídico orientado para decidir as disputas sobre os direitos dos trabalhadores individuais. A conquista desses objetivos tem efetivamente ocorrido, pondo em relevo uma das mais importantes características (e em nenhum sentido exclusiva) do sindicalismo venezuelano: a flexibilidade e o pragmatismo na negociação dos termos dos contratos de trabalho. De fato, é característico da gestão negociadora dos sindicatos o afã, muitas vezes desmedido e oportunista, por ajustar tanto seus objetivos como suas táticas às circunstâncias cambiantes, e deixando de lado questões essenciais de natureza ideológica. Enfoque pragmático e oportunista, cuja presença constitui uma indicação clara da carência de um propósito estratégico em matéria de negociação coletiva. ${ }^{288}$

O reconhecimento que o Estado, AD/Copei, Fedecámaras e os próprios sindicatos de trabalhadores concederam à CTV, como maior e mais importante representante da classe trabalhadora, outorgou a essa confederação um papel central no processo de cooptação do movimento operário nos anos seguintes a 1958. Sua atuação ao longo do período, vista por alguns estudiosos como decisiva à obtenção e manutenção da democracia venezuelana, correspondeu a

\footnotetext{
${ }^{288}$ TORO, Héctor Valecillos. ¿Retador o garante del sistema? Los 50 años de la Confederación de Trabajadores de Venezuela. Nueva Sociedad. № 85, septiembre-octubre, 1986, pp. 3-5.
} 
um tipo de sindicalismo de conciliação estruturado pragmaticamente segundo a concepção de que o essencial, ao lado da própria estabilidade do regime democrático-burguês, estava na conquista do status (análogo ao de que goza o capital) de legitimidade do trabalho como parte concordemente integrante do corpo da sociedade moderna. Para que isso se materializasse, conformou-se entre a CTV e o Estado um conjunto de relações ditas neocorporativistas ${ }^{289}$, as quais atendiam ao triplo propósito 1) - da perspectiva dos dirigentes sindicais de integrá-los aos grupos políticos governantes como membros ativos na tomada de decisões de ordem política e econômica (em princípio, de acordo com os interesses dos trabalhadores) - daí a convivência íntima com os partidos políticos governantes e com as instituições públicas de crédito (ex.: o BTV, recurso valioso para fortalecer o sindicalismo cetevista em detrimento de outras centrais sindicais); 2) - da perspectiva do Estado - de promover a estabilidade política necessária ao jogo bipartidarista, através do controle sobre as massas operárias (e populares) facilitado pela adesão e apoio oficial dos dirigentes sindicais às ações do Estado; e 3) - da perspectiva das classes burguesas associadas - de assegurar a apropriação privada da riqueza nacional (especialmente, é claro, o petróleo) em conformidade com as tradicionais relações de dependência respeitantes às empresas e capital estrangeiros - obtendo, por assim dizer, "a um baixo custo" o compromisso e a conivência das organizações de representação operária. Certamente, a consecução desses objetivos pôde contar com o estímulo das conjunturas econômicas favoráveis de 1961-1965 e, sobretudo, de 19731979, que operaram como fatores positivos na propensão das massas trabalhadoras a aceitar o padrão conciliatório de ação sindical. Significativamente, quando tais conjunturas deram lugar a momentos de recessão - mais prolongada após a segunda - a importância da ação política representativa da CTV decresceu visivelmente. Os quatro itens a seguir sintetizam os traços mais

\footnotetext{
${ }^{289}$ A expressão é empregada, não exatamente com o mesmo sentido daqui, em SALAMANCA, L. Op. cit., Introducción. pp. 193-196.

Durante o período de Punto Fijo, surgiram outras centrais sindicais, como a Central Unitária de Trabalhadores da Venezuela (CUTV), ligada estreitamente ao PCV; a Confederação de Sindicatos Autônomos da Venezuela (CODESA), surgida a partir de grupos ligados à Igreja Católica e ao COPEI; e a Confederação Geral de Trabalhadores (CGT), contrária à influência deste último na direção da CODESA. A pouca expressão que essas centrais sindicais tiveram no meio operário e político, a começar pelo número comparativamente reduzido de trabalhadores afiliados, em nenhum momento pôs em xeque a ampla hegemonia cetevista.
} 
relevantes e o significado da integração da CTV ao sistema puntofijista nos anos de apogeu do sindicalismo de conciliação: 290

a) a orientação fundamental do trabalho sindical, como força política, residia no compromisso de preservar, em combinação com as outras forças sociais, os elementos que garantissem a ordem política existente e alimentassem o funcionamento regular da economia - entendidas a primeira como democracia representativa, e a segunda como produção de bens destinados a promover a acumulação e distribuição social da riqueza segundo a participação de cada um no processo produtivo. O sistema produtivo capitalista não era compreendido como algo pernicioso em si - apenas devia ter controlados e atenuados seus efeitos sociais negativos -, nem os interesses de empresários e trabalhadores eram necessariamente antagônicos ou inconciliáveis com o ideal do bem comum. Desse ponto de vista da conciliação das classes, era preciso pôr de lado o recurso extremo às greves, consideradas como de efeito desestabilizador para a produção industrial. ${ }^{291}$

b) a defesa das reivindicações da classe trabalhadora (operária e camponesa) devia exercer-se por meios institucionais (como os contratos coletivos, a representação operária nas empresas do Estado, as comissões de arbitragem, etc.), de modo que tais meios não ferissem os direitos da propriedade privada nem a capacidade do Estado e empresários de satisfazer a essas demandas operárias/camponesas. Como se notou, tratava-se de um sindicalismo "(...) que reduziu a luta de classes ao mínimo possível, desviando-a para o

\footnotetext{
${ }^{290}$ As características aqui descritas têm por fonte teórica (embora dele se afastem em alguns pontos) o excelente trabalho de Luis Salamanca, La incorporación de la Confederación de Trabajadores de Venezuela al sistema político venezolano, especialmente os capítulos 4 e 5.

${ }^{291} \mathrm{Em}$ um esclarecedor artigo, Francisco Iturraspe aponta como a democracia puntofijista aproveitou-se da subordinação neocorporativista dos sindicatos ao Estado para, sistematicamente, transformar as greves em ações ilegais e, do ponto de vista da cultura política, em ações disfuncionais: "(...) en el campo de la cultura jurídica y de la cultura política, encontramos que la huelga se constituyó en Venezuela como un fenómeno 'maldito', considerado 'disfuncional' por la cultura empresarial, gubernamental y hasta sindical. Esto forma parte de que es mal visto 'reclamar' dentro de una mentalidad generalizada y coherente con el sistema económico rentista. (...) Las huelgas son tratadas en los medios de comunicación como alteraciones del orden público, obscuras maniobras politiqueras, cuando no, como episodios subversivos. Los sindicatos temen que el desarrollo del conflicto y el ejercicio de la huelga provoquen el rebasamiento de los dirigentes por las bases y la pérdida de sus posiciones y control". (ITURRASPE, Francisco. Democracia y conflicto. Deslegitimación del sistema político venezolano (1958-1998). Gaceta Laboral, año/vol. 6, n 3, 2000, p. 372) Nota o pesquisador que, por exemplo, entre 1974 e 1984, as greves consideradas legais não passaram de 18 contra 1.548 consideradas ilegais (em alguns desses anos, nenhuma greve foi considerada legal!).
} 
Estado, e convertendo-a naquilo que Lipset denominou a luta democrática de

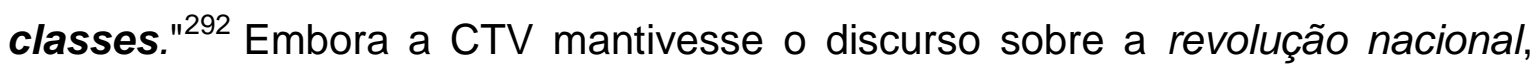
sua concepção do papel histórico da classe trabalhadora definia-a não como uma força revolucionária (em sentido tradicional), mas como uma força modernizadora das estruturas econômica e social vigentes.

c) dominado por dois partidos que, em suas cúpulas, não manifestavam nenhuma real vinculação operário-popular, o Estado ambicionou determinar concretamente o tipo de sindicalismo que mais convinha ao seu projeto de desenvolvimento nacional. Como não se podia ocultar o caráter dependenterentista da economia, nem a grave desigualdade social advinda da administração plutocrática da receita petroleira - e, portanto, era de esperar o enfrentamento com as massas populares e de trabalhadores - a solução residiu, então, na ingerência e controle que o Estado poderia exercer sobre as organizações de representação operária. Com esse sentido, ao eleger a CTV como interlocutor social praticamente único da classe trabalhadora (vale mencionar que, nos anos 60-70 a CTV chegou a dominar $85 \%$ da população ativa sindicalizada), o Estado transformou o movimento sindical em coadjuvante da tarefa de tratar e solucionar os problemas laborais. Em troca, a CTV recebia o "direito oficial" de monopolizar a representação sindical e, por conseguinte, de fixar o alcance das exigências operárias: "(...) apesar da existência de quatro centrais sindicais (CTV, CUTV, CODESA e CGT) no processo de formulação de políticas, o pluralismo sindical se reduz exclusivamente à negociação com a CTV, em virtude do controle dos partidos majoritários e da política restritiva do Estado em relação às outras centrais. Salvo a política de subsídios estatais da qual participavam legalmente todas as centrais sindicais (embora com muita discriminação quanto a algumas delas), o resto das políticas laborais de incorporação sindical está baseado na exclusiva participação e representação da CTV". ${ }^{293} \mathrm{~A}$ ingerência estatal podia realizar-se tanto na seleção das lideranças sindicais (neste caso, indiretamente, através da influência dos partidos que controlavam os sindicatos e da conivência dos órgãos governamentais), como na definição das pautas de reivindicações,

\footnotetext{
${ }^{292}$ SALAMANCA, L. Op. cit., p. 294.

${ }^{293}$ SALAMANCA, L. Op. cit., p. 316.
} 
negociadas com os líderes cetevistas em níveis de moderação aceitáveis para o Estado e os empresários. ${ }^{294}$

d) o fortalecimento do sindicalismo cooptado tornou viável estabelecer, de fato, relações pacíficas da classe trabalhadora com empresas estatais e com industriais privados, seguindo um esquema colaborativo sindicatos-Estadoempresários. A compensação pelo assentimento desse esquema traduziu-se em incremento dos padrões de vida e de trabalho de grande parte da população, favorecida pela implementação de políticas distributivas oficiais. Mas, se isso representou um ganho claramente derivado das exigências de poder dos sindicatos no âmbito do Estado ao qual se integrava, não bastou, todavia, para configurar um verdadeiro avanço democrático - nem mesmo para os próprios padrões oficiais. A transitoriedade dos benefícios (veja-se o Cap. 2, supra) comprova a subordinação do desenvolvimento social às práticas populistas assentadas no clientelismo que o Estado, no papel de principal gerenciador das receitas do petróleo, exercia sobre os diversos setores e classes sociais. $O$ sindicalismo de conciliação cetevista tendeu para esse modelo burguês de democracia, assumindo assim o compromisso de firmar a paz social como condição ao desenvolvimento econômico, e abrindo mão de qualquer perspectiva revolucionária ou radical-popular de construção de uma democracia social consistente. Por consequência, abriu mão também da luta pela autonomização econômica do país e uma possível integração mais efetiva com o restante do continente, como preconizavam, cada um a seu modo, os socialistas revolucionários e os reformadores desenvolvimentistas. Nos anos da hegemonia cetevista, o nacionalismo reformador e o socialismo revolucionário permaneceram como quimeras distantes no meio operário-sindical.

\footnotetext{
294 O formalismo da democracia puntofijista tinha reflexo em formalismo análogo na administração sindical: "(...) Tradicionalmente la renovación de los liderazgos sindicales ha sido un proceso carente de la transparencia que establece la legislación laboral venezolana. Tres factores pueden señalarse para explicar esta deficiente libertad sindical. Un primero radica en el interés empresarial, en el mantenimiento de determinadas estructuras sindicales, con las cuales se ha mantenido un cierto status quo, que ha facilitado a su modo, el desenvolvimiento de las relaciones colectivas de trabajo. Un segundo factor, radica en los propios liderazgos sindicales, cuya perpetuación y permanencia aspiran no sea interrumpida. Y finalmente la Administración del Trabajo, ha carecido de voluntad para demandar el cumplimiento de las normas expresas que sobre elecciones sindicales están establecidas en el ordenamiento laboral venezolano". (LUCENA, Héctor. "La crisis política en Venezuela: repercusiones y respuestas del movimiento sindical", citado por ITURRASPE, Francisco. Democracia y conflicto. Deslegitimación del sistema político venezolano (1958-1998), p. 353.)
} 
Entretanto, ao princípio da década de 1980, quando o país ingressava em um período de prolongada crise econômica, marcada, como vimos, pela queda dos preços internacionais do petróleo e agravada pelo drama do endividamento externo, o movimento sindical cooptado iniciou uma trajetória de rápido declínio em sua importância política - quer quanto à dimensão da representatividade dos sindicatos, quer como ator privilegiado integrado ao Estado. O gráfico abaixo demonstra esse declínio de representatividade:

\section{Gráfico 15: Sindicatos constituídos e taxa de sindicalização $(1973-75=100)$}

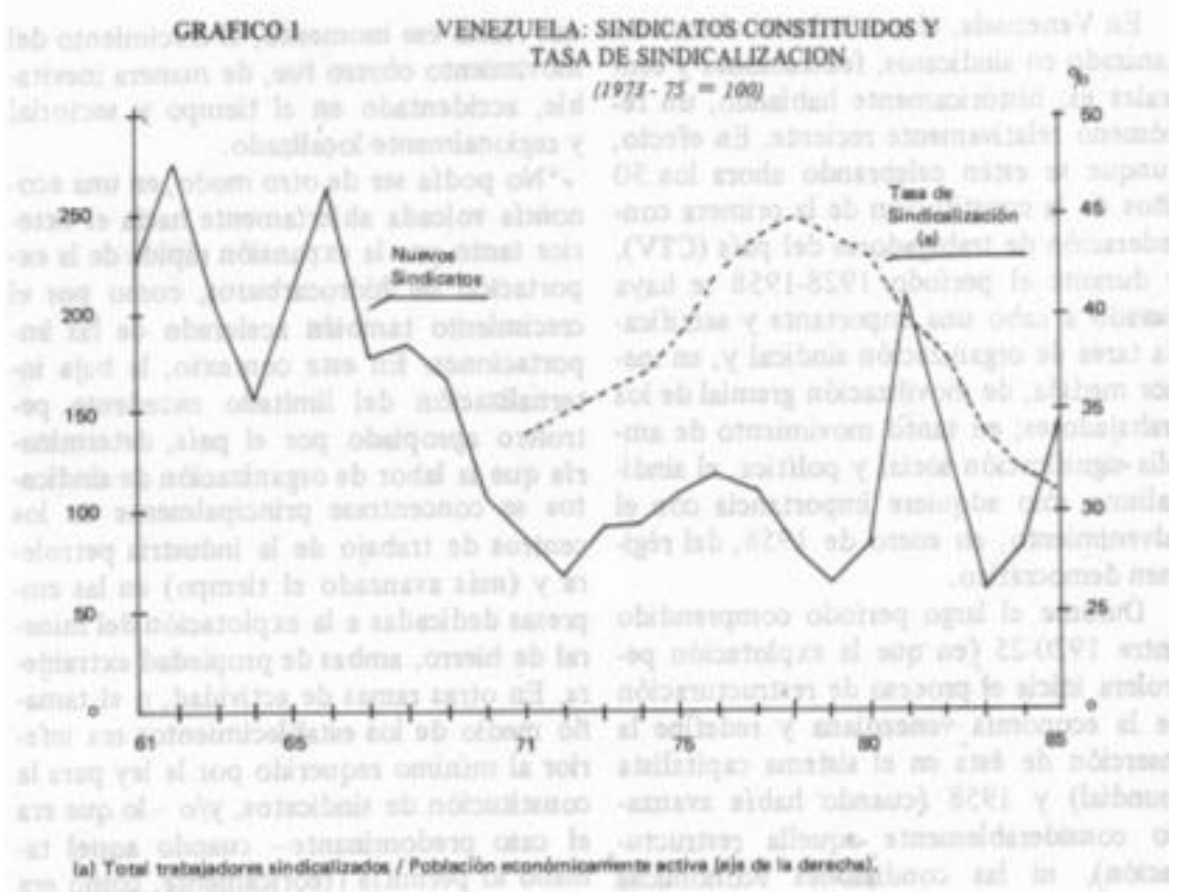

Fonte: TORO, Héctor Valecillos. ¿Retador o garante del sistema?, s/p.(modificado)

A curva da taxa de sindicalização inflete negativamente a partir de 1978 para atingir, em 1985, um valor inferior ao de quinze anos antes (a despeito disso, em 1986, havia ainda um percentual de $30 \%$ de trabalhadores sindicalizados contra $16,6 \%$ em 1961). As causas do descenso são várias e, combinadas, provocaram um situação caracteristicamente de crise do sindicalismo venezuelano: o crescimento do desemprego, sobretudo com a redução da força de trabalho em setores de maior concentração de trabalhadores sindicalizados (indústria manufatureira, construção e serviços públicos); o aumento da ocupação informal, em consequência também da diminuição da oferta de cargos públicos; e a perda 
relativa da capacidade dos sindicatos de reivindicar efetivamente melhorias durante o período de recessão prolongada, o que repercutia no prestígio dos sindicatos e na expectativa dos trabalhadores quanto ao poder de negociação dos representantes sindicais. ${ }^{295}$

O acentuado processo de deslegitimação das instituições venezuelanas ao longo das décadas de 1980/90 (processo relacionado, como aludiremos adiante, aos vários escândalos de corrupção administrativa, casos graves de abuso de poder de autoridades militares e policiais, crise política envolvendo o impedimento do presidente Andrés Pérez e tentativas de golpes de Estado militares), somado à persistente situação de estagnação da economia petroleira, precipitou a significativa mudança do cenário político em 1998, manifestada na ascensão do Movimento V República (integrando a aliança Pólo Patriótico) e na consequente vitória eleitoral de Hugo Chávez. No novo cenário, o bolivarianismo chavista emergiu, em meio à descrença geral quanto à democracia puntofijista, como uma alternativa promissora tanto na esfera política como na sindical, alijando rapidamente os tradicionais partidos $A D$ e Copei e a já decrépita CTV. ${ }^{296} \mathrm{O}$ forte vínculo que unira esta àqueles partidos dificultou a aproximação das antigas lideranças sindicais com o novo grupo político ascendente, e, à medida que os chavistas acentuavam o radicalismo de seu discurso político, menor se mostrava a possibilidade dessa aproximação. O novo governo não demorou a declarar o repúdio ao sindicalismo da CTV, referindo-se a ele como uma "máfia sindical". $\mathrm{O}$

\footnotetext{
${ }^{295}$ Cf. TORO, Héctor Valecillos. ¿Retador o garante del sistema?, p. 4.

${ }^{296}$ Uma nova fase se definiu para o movimento operário e sindical venezuelano ao ascender ao poder Hugo Chávez e encontrar fim a hegemonia dos partidos de Punto Fijo. A reorganização dos sindicatos, contudo, esbarrou (e tem esbarrado ainda, mesmo após a morte de $\mathrm{H}$. Chávez) nas dificuldades de alcançar a necessária autonomia frente ao poder centralizado do regime bolivariano. Em um artigo de 2006, afirmava Héctor Lucena: "(...) Cette phase est donc caractérisée par un renforcement du mouvement des travailleurs, qui a progressivement retrouvé sa capacité de mobilisation. La relation conflictuelle entre le gouvernement et le patronat, avant et après le coup d'État d'avril 2002, a permis au mouvement des travailleurs de se développer sans craindre de voir se former la traditionnelle alliance entre entrepreneurs et institutions publiques pour contrer leur action. Cette configuration a été déterminante pour le redéploiement du mouvement. Les principales mesures politiques et économiques adoptées par le gouvernement Chavez ont été appuyées par le mouvement syndical. Cependant, l'orientation centralisatrice et présidentialiste du pouvoir est telle que l'UNT [Unión Nacional de los Trabajadores, criada em 2003, de orientação bolivariana] est souvent mise devant le fait accompli. La politique salariale, l'élaboration des lois ou encore la gestion des principales entreprises publiques sont appuyées par I'UNT après avoir été décidées dans d'autres sphères". (LUCENA, Héctor. Venezuela: le mouvement ouvrier dans la révolution bolivarienne. Etat des résistances dans le Sud - 2007, Alternatives Sud $n^{\circ} 4 / 2006$. Disponível em: http://www.cetri.be/Venezuela-Le-mouvementouvrier?lang=fr. Grifos nossos.)
} 
completo desprestígio da CTV sobreviria com a participação no fracassado golpe de Estado de abril de 2002 e na igualmente malsucedida paralisação-sabotagem de 2002-2003. Ao optar por ações golpistas, o sindicalismo cetevista afastou-se do legalismo pacífico que constituíra sua marca, e expôs um traço de sua prática que sempre procurara dissimular: o oportunismo político. Restaurado o governo constitucional de Hugo Chávez e vencido em seguida o locaute-sabotagem, a influência da CTV resvalou definitivamente no crepúsculo político. ${ }^{297}$

À democracia venezuelana pode ser creditado o fato de, em meados de 1975, haver o presidente C. Andrés Pérez recusado imiscuir seu governo no plano de criação do que viria a ser, nos anos imediatos, a mais ampla operação de repressão política organizada nos (e entre os) países da América do Sul: a Operação Condor. ${ }^{298}$ Apesar disso, a recusa de Pérez não significava que o Estado venezuelano tivesse por tradição o apego à legalidade e o respeito aos direitos civis e políticos de grupos oponentes ao regime estabelecido. Isto não ocorrera nem mesmo quando, em 1958-9, a institucionalidade democrática substituíra o regime ditatorial. Ao contrário, foi uma tradição de violência o que marcou todo o século XX venezuelano. E, como recordou Orlando Araujo (no eloquente Venezuela violenta, de 1968), se a violência não nasceu com a democracia puntofijista nem foi seu monopólio, floresceu todavia nela como um

\footnotetext{
${ }^{297}$ A propósito do envolvimento da liderança da CTV, em conluio com a Fedecámaras, no intento de depor o presidente Hugo Chávez, observa Steve Ellner: "(...) lo más importante es que, fueran lo que fueran las críticas de miembros del comité ejecutivo, no hubo ningún esfuerzo organizado para moderar el empeño en sacar a Chávez de la Presidencia de la República. Ningún miembro del comité ejecutivo llegó a plantear una "autocrítica" a raíz del fracaso de la huelga general, ni cuestionar la alianza con Fedecámaras. De hecho, esta insistencia en no reconocer sus errores explica en gran parte porqué se permitió que la huelga siguiera hasta agotarse, en lugar de suspenderla después del primer mes, cuando ya era evidente que tenía pocas posibilidades de éxito. Este fracaso no solamente tuvo consecuencias devastadoras para la economía nacional, también contribuyó a desacreditar a la oposición y, en particular, a la CTV". (ELLNER, Steve. Tendencias recientes en el movimiento laboral venezolano: autonomía vs. control. Revista Venezolana de Economía y Ciencias Sociales, vol. 9, núm. 3, septiembre-diciembre, 2003, p. 176) ${ }^{298}$ Cf. DINGES, John. Os anos do condor. Uma década de terrorismo internacional no Cone Sul. São Paulo: Cia das Letras, 2005, p. 162-166. Afirma o autor: " O presidente Carlos Andrés Pérez vetou qualquer participação no plano [de organização da Operação Condor com a participação da venezuelana DISIP]. Pérez, um dos poucos chefes de Estado democraticamente eleitos à época no continente, era um fervoroso anticomunista, mas um opositor igualmente inflexível da destruição da democracia chilena por Pinochet". (p. 165)
} 
elemento imprescindível à consolidação da nova ordem política. De fato, a violência histórica venezuelana, que, em outros momentos, "poderia ter sido revolucionária", acabou por converter-se em poderoso instrumento do governo recém-instalado: desde os primeiros dias de Punto Fijo, a perseguição política e a repressão policial tornaram-se expedientes privilegiados da concepção de democracia posta em execução pelos membros da cúpula AD-Copei agora no poder. Do conteúdo dessa democracia excluíam-se absolutamente as noções de comunismo e revolução:

O 23 de janeiro de 1958 culmina um processo de violência iniciado pela esquerda dez anos antes e apoiado, nas últimas horas, pela burguesia e pelo Exército. Como em 1936 e em 1945, a violência poderia ter frutificado em revolução. Mas não foi assim, e o governo foi controlado pela alta burguesia, que, havendo lucrado nos tempos de Pérez Jiménez, apresentava-se agora como salvadora. O resultado foi Betancourt, que, para neutralizar os grupos reacionários do poder (curas, militares e ianques) começou vociferando um anticomunismo histérico (recordemos o ministro do Interior de Gómez), um intocável "fio constitucional" (recordemos "o lenço no nariz") e finalmente uma pitoresca e desavergonhada condição de súdito ianque que, mesclando o dramático com o ridículo, produziu o estancamento e a castração da Corporação Venezuelana de Petróleo, o endividamento externo, a entrega da exploração do alumínio à Reynolds, do ferro à Koppers, o ódio oficial a Cuba e o hábito muito porto-riquenho de intercalar expressões em inglês dentro da conversação em espanhol. Este personagem pode orgulhar-se de haver sido o primeiro presidente da Venezuela que concluiu seu período com um saldo de 300 mortos políticos (não se contam aqui os saldos de ações armadas: Barcelona, Carúpano e Puerto Cabello) por ação repressiva, mais de dez jornais fechados; um balanço de dez mil presos políticos durante os cinco anos, e dezoito parlamentares inconstitucionalmente detidos e sequestrados. Se o de López Contreras foi chamado de o "quinquênio astuto", bem poderíamos chamar o de Betancourt de o "quinquênio violento". 299

Em um contexto internacional condicionado pela polarização ideológicomilitar da Guerra Fria - e, ao nível regional, pelas primeiras vitórias antiimperialistas da Revolução Cubana - a irrupção de movimentos armados na Venezuela dos anos 1960 inscreveu-se no clima de intenso conflito social que cercou a instauração do regime de Punto Fijo. Este, sob a liderança da AD

\footnotetext{
${ }^{299}$ ARAÚJO, Orlando. Venezuela violenta. Caracas: Banco Central de Venezuela, 2013, p. 113. A edição original desta obra do renomado escritor venezuelano é de 1968. O trecho sobre "o lenço no nariz" é uma referência irônica à lamentação de R. Betancourt quando da morte de Vicente Gómez e da continuidade do regime gomezista sob López Contreras.
} 
(Rómulo Betancourt, 1959-1964), logo identificou no PCV "um foco de agitação subversiva" e, portanto, uma força política a ser combatida e extirpada tanto no plano político-partidário como no operário-sindical. ${ }^{300}$ Neste último, como vimos, as primeiras medidas para afastar os sindicatos da órbita de influência comunista já haviam sido tomadas desde ao menos 1947, e ganhariam força com o gradual atrelamento da CTV à política oficial adeca. Por sua vez, a definição pró-EUA do regime conduziu, em 1962, à ilegalização do PCV e do MIR, ambos, aliás, já anteriormente (1960) expulsos da CTV e de federações e ligas camponesas. A expulsão e a ilegalização se fizeram sob o pretexto de os comunistas sustentarem uma ideologia incompatível com os "ideais da democracia venezuelana" e com a necessidade de garantir a paz social. ${ }^{301}$ Opostamente, os protestos populares, como o realizado durante a visita do vice-presidente norte-americano Richard Nixon a Caracas em maio de 1958, já haviam indicado a fragilidade dessa "paz social", e apontavam a consciência crescente (visível, sobretudo, entre os estudantes e os jovens da ala esquerda da $A D$ ) do perigo de ingerência do imperialismo norte-americano nos países da região - causa sabida de miséria social e de ameaça à democracia, como bem se podia divisar no caso, de anos antes, da invasão norte-americana da Guatemala. Os protestos populares - que estudantes e operários vinham amiudando desde os últimos dias da ditadura e que recrudesceriam com as manifestações de desempregados (em agosto de 1959) - levariam R. Betancourt a revidar com a mesma dureza autoritária dos anos anteriores a 1958. Assim, o terrível saldo de mortes e de prisões não

\footnotetext{
${ }^{300}$ Vale lembrar, contudo, que o PCV em 1958 não adotara (ao menos por sua direção) uma postura autônoma revolucionária que o pusesse também contra os setores considerados progressistas da burguesia venezuelana (ou seja, os que lutavam, como a $A D$, pela derrubada do ditador Pérez Jiménez). Em janeiro de 1959, os dirigentes reunidos do Comitê Central do partido definiram sua posição de luta como sendo de defesa de um "governo de união nacional". Por outro lado, o anticomunismo dos setores burgueses progressistas se mostrou patente antes mesmo da queda de Pérez Jiménez: em 20 de janeiro de 1958, em Nova lorque, os futuros pactuantes de Punto Fijo (R. Betancourt, Rafael Caldera e Jóvito Villalba) juntamente com Fuster Dulles, secretário de Estado norte-americano, firmaram o compromisso (com o Pacto de Nova lorque - esboço do de Punto Fijo) de excluir o PCV de qualquer acordo político oficial pósditadura e de promover $\mathrm{o}$ isolamento dos comunistas nos meios políticos e operários. (Cf. ESPINOZA, Elia Oliveros. La lucha social y la lucha armada en Venezuela. Caracas: Fundación Editorial El perro y la rana, 2012, p. 25.)

${ }^{301}$ Afirmaria R. Betancourt, no momento de assumir a presidência da República, em fevereiro de 1959: "En el transcurso de mi campaña fui muy explícito en el sentido de que no consultaría al Partido Comunista (PCV) para la integración del gobierno... es el hecho que la filosofía política comunista no se compagina con la estructura democrática del Estado venezolano". (Citado por LINÁRES, Pedro Pablo. La lucha armada en Venezuela. Caracas: Universidad Bolivariana de Venezuela, 2006, p. 21.
} 
alimentaria ilusão aos que esperavam mudanças mais profundas: apenas naquele mês, a ação policial contra os manifestantes computou 12 mortes e 130 feridos. ${ }^{302}$ Insertas nesse cenário, a exclusão do acordo de Punto Fijo e depois a ilegalização passaram a ser vistas, da perspectiva comunista, como uma decisão previsível em um governo que, a despeito da histórica luta democrática de seus líderes, não pretendia nem tocar a estrutura econômica nem a história de sujeição à política e ao capital estrangeiros. Por conseguinte, a atuação na clandestinidade a que se viram obrigados o PCV e o MIR ensejou rapidamente sua radicalização - a convicção de que, de fato, deveriam formar a vanguarda política das massas populares - e levou ambos à opção imediata (conquanto não unânime entre os dirigentes comunistas) pela luta armada contra o regime puntofijista.

Os movimentos guerrilheiros atuaram, na Venezuela, durante os anos de 1960, 70 e 80, embora o período de maior expressão histórica tenha-se desenrolado entre 1961 e 1969, quando o país foi agitado pelas guerrilhas das Forças Armadas de Libertação Nacional (FALN), formadas pelo PCV e MIR. Em 1962, um setor da URD, conduzido por Fabricio Ojeda, se uniu à FALN. Também nesse ano, duas sublevações militares exprimiram a insatisfação de alguns segmentos das Forças Armadas, e demonstraram sua vinculação com o PCV e o MIR: em maio, levantou-se em Carúpano o Batalhão de Infantaria da Marinha № 3 - uma insurreição na qual participaram com os militares vários militantes civis de ambos os partidos; em junho, sublevou-se a Base Naval de Puerto Cabello, na qual atuaram 500 militares, que também contaram com a participação de civis. A repressão foi aqui particularmente violenta: ao fim de uma semana, contavam-se duas centenas de mortos e quatro centenas de feridos. Foram os seguintes os grupos guerrilheiros venezuelanos (e seus local e período de ação):

1) Frente Simón Bolívar - Estados de Lara e Portuguesa (1962-1968)

\footnotetext{
302 "(...) El movimiento revolucionario y popular le correspondió librar una lucha en medio de un terrorismo de Estado. Esto se refleja en el dominio militar sobre la autoridad civil, predominio por parte del Gobierno de los valores bélicos en la sociedad. Esto se manifestaba en la suspensión de las garantías constitucionales, represión desproporcionada hacia el movimiento popular y revolucionario, torturas, muertes, detenciones, cercos militares en liceos, universidades y barriadas populares como el caso de los allanamientos masivos en el 23 de Enero, Lomas de Urdaneta, El Guarataro, San Agustín, Cementerio, Propatria. Para ilustrar esta afirmación basta observar cifras donde consta que sólo en el mes de enero de 1962 asesinaron a 35 personas en manifestaciones, hubo 202 heridos y 1.053 detenidos. Para este momento, aún los grupos armados no habían comenzado a actuar". (ESPINOZA, Elia Oliveros. La lucha social y la lucha armada en Venezuela, p. 44.
} 
2) Frente José António Páez - Estados de Portuguesa, Trujillo, Barinas e Apure (1962-1966)

3) Frente Manuel Ponte Rodríguez - Estado Monagas (1964-1968)

4) Frente José Leonardo Chirino - Estados Falcón, Lara e Yaracuy (19621972)

5) Frente Ezequiel Zamora - Estados de Miranda, Guárico e Anzoátegui (1963-1968)

6) Frente Antonio José de Sucre - Estados de Sucre, Monagas e Anzoatégui (1967-1979)

7) Frente Américo Silva - Estados de Sucre, Monagas e Anzoatégui (19771982). ${ }^{303}$

A despeito do valor e heroísmo que animaram as frentes guerrilheiras em sua luta por uma pátria verdadeiramente livre, o movimento armado venezuelano já se encontrava em franco declínio em fins dos anos de 1960. O definhar da luta resultou da combinação de erros estratégicos das frentes e, sobretudo, da violentíssima repressão militar que Ihes moveram os governos de Rómulo Betancourt e Raúl Leoni (este 1964-1968). Além disso, em 1965, o PCV resolvera retornar aos meios políticos pacíficos, o que provocou a primeira grande ruptura nas fileiras da guerrilha. O MIR, por outro lado, decidiu-se pela manutenção das ações armadas, mas não logrou impedir as divergências internas. Assim, em 1969, o quadro era de enfraquecimento geral dos grupos guerrilheiros, havendo sido presos vários líderes, enquanto outros escolhiam entregar-se, procurando aproveitar a anistia proposta pelo presidente Rafael Caldera, que assumira naquele ano com promessas de pacificar o país. Referindo-se a essa situação das FALN, afirma J. B. Berardo: "(...) Ao cabo de alguns anos de lutas, noventa por cento de seus efetivos estavam dizimados pelas forças regulares do exército. Em 1967, a organização ficou reduzida a um grupo de cerca de duzentos guerrilheiros nos Estados (...) de Miranda e Falcón, mas com limitada capacidade de ação, em face do cerco do exército". ${ }^{304}$ Entre os erros de estratégia da

\footnotetext{
${ }^{303}$ Cf. DOSSIER Lucha armada venezolana en los 60. Memorias de Venezuela. Centro Nacional de Historia. Octubre/2010, no 16.

${ }^{304}$ BERARDO, João Batista. Guerrilheiras e guerrilheiros no drama da América Latina. São Paulo: Edições Populares, 1981, p.129.
} 
guerrilha, o mais importante talvez tenha sido o de supor que a luta, inicialmente travada em zonas rurais, pudesse daí expandir-se para as cidades, à medida que, apoiados no campesinato, se ampliasse o número de grupos revolucionários. Esta suposição - uma aplicação da teoria foquista de guerrilha - não pareceu levar em conta o peso desproporcionalmente menor da população rural em uma sociedade rapidamente urbanizada e que dependia quase exclusivamente do petróleo, explorado em áreas distantes das rurais. Também, a concepção das frentes como vanguardas armadas da revolução provocou o distanciamento do movimento guerrilheiro em relação aos movimentos sociais populares (especialmente urbanos), e serviu, frequentemente, de pretexto às ações repressivas do governo, que acusava esses movimentos de vínculos com a guerrilha. ${ }^{305}$ De qualquer modo, e apesar de deficiências e erros, o movimento guerrilheiro venezuelano, como outros do continente, pode reivindicar com justiça a grandeza política de ter sido uma alternativa legítima de resistência ao autoritarismo das elites proprietárias do país e ao compromisso, por vezes abjeto, delas com os grupos econômicos internacionais, representantes do imperialismo euro-americano.

Por fim, cumpre fazer uma breve alusão a dois temas relacionados ao violento processo de supressão da luta armada venezuelana. Ambos exprimem, em boa medida, o formalismo ideológico da democracia puntofijista. Primeiro, a pretensa pacificação promovida pelo regime: em maio de 1969, foi anunciado pelo governo de Rafael Caldera a intenção de conceder indulto a todos que desejassem depor armas e reintegrar-se à vida pública comum. Formou-se para isso um Comitê de Pacificação, encarregado de intermediar os acordos entre os guerrilheiros e o Estado. O presidente anunciou também a disposição de legalizar o MIR, como, aliás, fora feito pouco antes ao PCV. (Este pudera participar das eleições presidenciais de fim de 1968, sob a sigla UPA - União Para Avançar). Para muitos setores da sociedade (e, inclusive, para muitos guerrilheiros),

\footnotetext{
${ }^{305}$ Cf. SÁNCHEZ, Roberto López. 4 de octubre: 32 años de la masacre de Cantaura. Aporrea, 26/09/2014. Disponível em: http://www.aporrea.org/ddhh/a195610.html. Lembra, ainda, este autor que: "(...) [a] separación entre la izquierda y las luchas del pueblo fue la causante de que en posteriores escenarios de exacerbación de la lucha de clases, como el estallido del Caracazo en febrero de 1989, los partidos autodenominados "socialistas" y "comunistas" no jugaran ningún papel, quedaran totalmente por fuera del accionar popular, arrinconados como simples observadores de la majestuosa insurrección espontánea que el pueblo de Caracas y zonas cercanas desarrolló entre el 27 de febrero y el 3 de marzo de 1989".
} 
cansados da violência e sacrifício de vidas, tais propostas tiveram boa acolhida, e o governo empenhou-se em estampar com elas o espírito democrático e conciliador do poder. (Essa imagem pacificadora, ademais, serviria depois para respaldar, como vimos, a idealização da Venezuela como uma democracia excepcional no cenário internacional da época). Contudo, o alcance da pacificação assim oferecida ressentiu-se de sua natureza mais de recurso ideológico que de medida efetivamente democrática. Afinal, o que se propôs foi o apaziguamento de grupos que já não representavam forças rebeldes suficientemente organizadas e que, inclusive, tinham sido duramente atingidas pela própria repressão oficial. A pacificação ocultava o duplo intento de isolar socialmente os grupos guerrilheiros ainda em ação, representando-os como partidários incondicionais da violência ${ }^{306}$; e de anistiar as próprias ações ilícitas dos órgãos de repressão. A par disso, e diante do prosseguimento de manifestações e protestos populares, a reação do governo continuou sendo a desmedida violência policial, que, sem solução de continuidade dos anos anteriores, vitimaria ainda estudantes, camponeses e operários. E, diante dos grupos guerrilheiros que se mantiveram em luta ${ }^{307}$, a resposta foi a repressão militar sistematicamente realizada à margem da legalidade:

Este discurso de pacificação (...) não pôde ser mantido por muito tempo, porque a dinâmica da luta de classe levou o governo a mostrar a outra cara da pacificação. (...) Dois fatos de transcendência permitiram ao governo mostrar sua verdadeira face: a greve dos professores, declarada em 28 de outubro de 1969 (...) [e] a invasão da Universidade Central da Venezuela em 31 de outubro e sua tomada pela Guarda Nacional e Exército. (...) A violência do governo não se deteve nem um

\footnotetext{
${ }^{306}$ Orlando Araújo, escrevendo ainda em dias de violência revolucionária e de violência repressiva, indagava acerca das cogitações (inclusive oficiais) de pacificação da luta guerrilheira: "(...) ¿Aceptarán pacíficamente las clases dominantes el ser sustituidas en la dirección económica y política del país? ¿Aceptará pacíficamente el capitalismo extranjero abandonar un negocio tan productivo como el petrolero? ¿Aceptará el poder imperialista pacífica y cortésmente, que Venezuela prescinda de la tutela de Estados Unidos y explote y venda su petróleo a quien quiera comprarlo en el mercado internacional? ¿Aceptarán pacíficamente los latifundistas la eliminación del latifundio y el reparto de tierra a los campesinos? ¿Aceptará el comercio importador, sin rebelarse, la reducción de las importaciones superfluas y el aumento progresivo de los impuestos? ¿Aceptará, sin chistar, la burguesía estéril la sustitución de las leyes y de otras instituciones que consolidan sus privilegios, por instituciones y leyes que disminuyan sus ingresos y redistribuyan sus riquezas?" (ARAÚJO, Orlando. Venezuela violenta, p. 132.)

${ }^{307}$ Após 1969, de desmembramentos do MIR e do PRV (este, surgido em 1966 do PCV), nasceram outros grupos guerrilheiros: Bandeira Vermelha (1970), Organização de Revolucionários (1970), Grupo Ponto Zero (1972), Liga Socialista (1973) e Comitê de Integração Revolucionária (1973).
} 
só momento na caçada inclemente a toda tentativa de subversão. Nestes casos, a pacificação se convertia em tortura, assassinatos, operações antiguerrilhas, desaparecimentos praticados por corpos policiais (SIFA, Digepol, Polícia Metropolitana). (...) Em 13 de junho de 1972, José Vicente Rangel escreve no diário El Punto um artigo intitulado "A pacificação a nu", no qual denuncia que, naquele ano, foram assassinados 36 estudantes em manifestações, continuam as torturas a camponeses detidos em áreas de guerrilhas, incrementam-se os cercos militares no oriente do país. Foram assassinados dirigentes revolucionários como Jesús Márquez Finol, Américo Silva, Alberto Caricote, Plinio Rodríguez e Argenis Reina. A pacificação se converteu em uma palavra de ordem porque os fatos dizem o contrário. ${ }^{308}$

Segundo, o silêncio oficial lançado sobre os desaparecidos políticos dos anos de repressão: os sucessivos governos de Punto Fijo, a despeito das numerosas e reiteradas denúncias públicas de violações dos direitos humanos, ignoraram e eludiram solenemente o dever de responsabilização legal de órgãos e de agentes policiais e militares suspeitos de praticarem crimes de tortura, assassinato e desaparecimento forçado. ${ }^{309} \mathrm{~A}$ impunidade, como sói ocorrer, estimulava ainda mais as práticas repressivas ilegais, que, lugubremente eficientes, acabaram por institucionalizar-se. Foi o que aconteceu, por exemplo, nas áreas rurais próximas das ações guerrilheiras:

Instalaram-se os Teatros de Operações (TO) e Acampamentos Antiguerrilheiros, que significaram a tortura, o assassinato e o desaparecimento para centenas de humildes camponeses, suspeitos de colaborar com as guerrilhas esquerdistas. Os campos mais famosos (diríamos que tristemente famosos pela quantidade de crimes cometidos neles) foram o TO4, de Cocollar (Estado de Anzoátegui),

\footnotetext{
308 ESPINOZA, Elia Oliveros. La lucha social y la lucha armada en Venezuela, pp. 87-88.

${ }^{309} "$ "....) Los gobiernos de la época recurrieron de manera constante a la tortura, el asesinato y la desaparición de dirigentes y activistas de la izquierda revolucionaria. Entre los crímenes individuales más sonados podemos mencionar el de Fabricio Ojeda, ahorcado en 1966 en las propias oficinas del servicio de inteligencia militar (SIFA); el de Alberto Lovera, lanzado al Mar Caribe en 1965 y reflotado su cadáver en las playas de Lecherías, estado Anzoátegui; el de Jesús Márquez Finol (el "Motilón"), asesinado en una calle de Caracas en 1973; el de Jorge Rodríguez, muerto en salvajes torturas por la Disip (policía política) en 1976; el de Tito González Heredia, también asesinado en una calle caraqueña en 1976. Junto a estos asesinatos, ocurrieron igualmente las desapariciones. Algunos autores señalan que fue en Venezuela durante los años 60 donde se presentó por vez primera la táctica de la desaparición forzada de personas como mecanismo represivo para combatir a la oposición política en América Latina y que se inició con propiedad durante el gobierno de Raúl Leoni (1964-1969). Dirigentes guerrilleros como Víctor Soto Rojas y Trino Barrios fueron capturados con vida y luego asesinados, sin que hasta el presente hayan aparecido sus cadáveres. El estudiante de la UCV Noel Rodríguez, secuestrado por la inteligencia militar en 1973 y cuyo cadáver sólo vino a aparecer este año 2013". (SÁNCHEZ, R. L. \& RODRÍGUEZ, Carmen A. H. La lucha contra la impunidad de los crímenes políticos en Venezuela. História Actual Online. Núm. 33, (Invierno, 2014), pp. 135.
} 
o TO5, de Yumare (Estado de Yaracuy) e o TO3, de Urica (Estado de Monagas), o acampamento antiguerrilheiro de Cachipo. Um dos casos mais emblemáticos foi o de Juan Chacón Lanza, camponês oriental incorporado à frente guerrilheira Antonio José de Sucre, o qual foi capturado em 1969, após uma operação militar, e conduzido ao TO4, de Cocollar, onde foi espancado e torturado, para ser, ao final, queimado vivo em uma fogueira armada dentro do próprio quartel. ${ }^{310}$

A violência assim institucionalizada perdurou por todo o período da democracia puntofijista ${ }^{311}$, e suas vítimas (como também a memória delas) ainda hoje aguardam reparação. A significação mais crua do terror oficial repousa no poder de privar as maiorias populares não só dos direitos cívicos e políticos elementares, mas também dos direitos humanos fundamentais, como o direito à liberdade e à dignidade humanas. Nesses anos da história venezuelana, a violência do Estado se praticou de modo especialmente zeloso em proveito dos interesses de uma minoria, para a qual os órgãos oficiais funcionaram como meios para oprimir e para matar. Nada menos que isso. Por essa razão, há que reconhecer-se que esse tipo de democracia também ajudou a alimentar fogueiras assassinas.

Os processos de cooptação do movimento operário e de repressão à luta armada - embora com ritmos diferentes - revelaram a medida e a forma que o Estado venezuelano assumiu como instrumento fundamental de poder da classe burguesa associada. Ao aparelhar-se para exercer um poderoso controle social quer pela concessão estratégica de espaços nos centros oficiais de decisão política, quer pela execução sistemática da violência institucionalizada - ele obedeceu, acima de tudo, ao intento de assegurar as condições de consolidação

\footnotetext{
${ }^{310}$ SÁNCHEZ, R. L. \& RODRíGUEZ, C. A. H. La lucha contra la impunidad de los crímenes políticos en Venezuela, p. 136.

${ }^{311} \mathrm{Em}$ 1982, por exemplo, sob o governo de Luis Herrera Campins (do Copei), uma ação antiguerrilha dizimou o principal grupo armado venezuelano de então, o Bandeira Vermelha. $O$ episódio é conhecido como o Massacre de Cantaura, no qual 23 guerrilheiros foram sumariamente mortos. Segundo o historiador R. L. Sánchez, quase todos foram executados a queima-roupa, com tiros de misericórdia. Não houve detidos. Apenas em 2013 o Ministério Público, após investigações e exumações, responsabilizou os chefes militares e os diretores dos órgãos de inteligência da época. (Veja-se SÁNCHEZ, R. L. 4 de octubre: 32 años de la masacre de Cantaura. Aporrea, 26/09/2014.)
} 
e funcionamento de um sistema produtivo opulentíssimo mas iníquo, e orientado para explorar a riqueza pública com vistas essencialmente à apropriação privada. O volume, por assim dizer, de manipulação e violência que isso exigiu não desdisse do costumeiro autoritarismo truculento das classes dominantes dos outros países da América Latina. O inusitado, no entanto, do caso venezuelano restaria por conta do contraste entre o terrorismo que o Estado exerceu e a imagem democrática que ele foi capaz de criar. $\mathrm{O}$ inusitado também se revelaria no grau desmesurado - dir-se-ia hediondo - que a violência oficial voltaria a atingir nos últimos anos da democracia puntofijista. Era o ano de 1989, e não ia dirigida contra grupos rebeldes armados, mas contra cidadãos simples dos bairros pobres de Caracas e de outras cidades. 


\section{Parte II: 0 rentismo sob a "ofensiva neoliberal" e 0 aprofundamento do subdesenvolvimento (1984-1998)}

"Em um sistema de livre comércio e de mercados livres, os
países pobres - e as pessoas pobres - não são pobres porque
outros são ricos. De fato, se os outros se tornassem menos
ricos, os pobres se tornariam, com toda a certeza, ainda mais
pobres."

(Margaret Thatcher, Statecraft, 2002)

Assinalou-se de passagem, em capítulo anterior, que o atribuir caráter de receituário ao neoliberalismo exprime a constatação crítica, por muitos, de que esse pensamento econômico, em vez de uma formulação científica de leis que rejam processos produtivos, constitui antes um sistema ideológico poderosamente deformador e manipulador, que tomou por objeto a realidade do capitalismo mundial do fim do século XX. Nas décadas que encerraram o século, as grandes transformações históricas (que incluíam os avanços prodigiosos na tecnologia cibernética e de informação, bem como, no plano político-econômico, o fim das experiências socialistas do mundo soviético e a eclosão de uma fase aguda da crise estrutural do capital) assomaram, todavia - vistas da perspectiva falseadora neoliberal - como um tempo de renovação do capitalismo, no qual se conjugaria o imenso progresso técnico-científico com um vertiginoso movimento de internacionalização industrial e financeira. Como uma benfazeja consequência adicional - declarava-se - abria-se ao mundo um período propício ao encurtamento das distâncias políticas e culturais entre os diversos povos e países. Tratava-se da globalização - um fenômeno considerado impetuoso, onipresente e irreversível, com a faculdade de conduzir todos a um nível superior e final da evolução histórica, que teria por apanágio o triunfo universal da democracia parlamentar e da liberdade individual. Com efeito, calcando-se em um gigantesco trabalho de propaganda através dos meios de comunicação de massa e de parte expressiva da produção acadêmica mundial, essa globalização (que logo receberia o apodo de neoliberal), ao frutificar em um cenário então 
supostamente liberto das inúmeras espécies de totalitarismos, pretendia inculcar, acima de tudo, a crença no renascimento dos princípios naturais da economia isto é, o mercado e sua liberdade, restaurados como valores primordiais de organização e planejamento de toda a vida produtiva, social e política do planeta. ${ }^{312}$ Nesse sentido, os problemas crônicos - sobretudo os de ordem social, como o desemprego, a violência e a miséria - decorreriam da recusa ou da insuficiência das sociedades em materializar verdadeiramente aqueles princípios - e não deles em si mesmos. É algo disso, aliás, que parece ressoar das palavras que encimam esta Parte II, as quais, repetidas sempre com certa solenidade farsesca, professam, nas altas esferas do poder do capital, a fé nesses assim considerados princípios naturais.

Apesar da veemência com que esses valores foram defendidos e difundidos nos meios sociais, políticos e científicos - o que permitia quase nenhum espaço a dissensões - alguns estudiosos logo puseram-se a denunciar 0 sentido anticientífico e historicamente retrógrado das teses neoliberais e, igualmente, o grau inusitado de perversidade que nascia das práticas dos governos suscetivos à globalização. Por exemplo, da experiência chilena dos anos 70-80, notabilizada por ter sido o primeiro ensaio real das receitas neoliberais, anteriores mesmo à reaganomia e ao thatcherismo e implantadas em um país subdesenvolvido sob ferrenha ditadura militar, pôde-se inferir toda a sua irracionalidade pragmática de contrarrevolução ideológica e autoritária: tratava-se, na realidade, de uma política de transnacionalização econômica desapiedada, que comprometia o próprio desenvolvimento nacional e suprimia grande parte dos direitos trabalhistas e sociais das classes trabalhadoras, lançadas em um estado de carência material e opressão política - tudo em nome da ação reguladora da mão invisível smithiana, secundada pela força da mão militar. ${ }^{313}$ Foi esse modelo

\footnotetext{
${ }^{312}$ Cf. uma visão crítica dessa presunção da globalização neoliberal em PAULANI, Leda M. Modernidade e discurso econômico. São Paulo: Boitempo, 2005.

313 "A Contrarrevolução Monetarista - que se apresenta como modelo 'científico' simples e rigoroso da teoria econômica, produto da análise a mais pura possível da economia positiva esconde, na verdade, todo um programa ideológico-político que, baseado no liberalismo econômico clássico do laissez-faire laissez-passer e no liberalismo político espúrio da Escola da Escolha Livre (Public Choice), constitui o ataque mais encarniçado e frontal ao intervencionismo do Estado e a todas as conquistas sociais duramente alcançadas pelo Estado do Bem Estar Social que surge da revolução keynesiana e do Estado planejador e promotor do desenvolvimento (...). $E$ claro que a contrarrevolução monetarista conduz ao fascismo, pois em nenhuma outra coisa pode desembocar 'o objetivo perfeitamente alcançável do capitalismo como tal', sobretudo e de maneira
} 
que vingaria depois em toda a América Latina, sob governos militares e civis. Junto a isso - ou fruto disso - estava a perversidade sistêmica, atestada por duas formas dominantes de tirania nesse "mundo globalizado": a tirania do controle da informação, raiz da vitória de um "discurso único do mundo" e do estado de alienação político-cultural em que acabaram submergidas as classes exploradas e oprimidas; e a do fetichismo do dinheiro, cuja valorização dirige rigidamente as políticas oficiais em todos os níveis, e cujas velocidade de transações e volatilidade de investimentos surgem como uma conquista positiva da tecnologia e um dado natural da realidade econômica atual. ${ }^{314} \mathrm{O}$ mundo assim tiranizado pelas forças da globalização - quer dizer, subjugado por um tipo de modernização na qual a noção de desenvolvimento, esvaziada primeiro de conteúdo social democrático, torna-se apenas um sinônimo do frio conceito de eficiência econômica - tinha prontos diante de si os ingredientes de um receituário que se singularizou, acima de tudo, pelo tom peremptório de suas proposições e pelo absolutamente nenhum apoio empírico a elas. É o caso das seguintes proposições, explícitas ou veladas, formadoras de um "decálogo" políticoeconômico, desprovido, porém, de qualquer comprovação positiva: 1ํo: é questão indisputável a obrigatoriedade da observância dos governos aos movimentos do mercado; 2을 em matéria econômica, a iniciativa privada é sabidamente mais eficiente que o Estado (sempre emperrado pela burocracia e pela corrupção administrativa) tanto na gestão dos serviços públicos como na exploração dos recursos naturais; 3: os gastos sociais devem ser contidos nos limites da austeridade fiscal, necessária à estabilidade financeira; 4: o mercado deve fixar os níveis de salários, em cuja definição o Estado não deve tomar parte e os

particular quando historicamente está provado que tal sistema, sem reformas, sem controle e sem intervenção do Estado, não pode resultar em outra coisa que em regimes de pressão, autoritarismo e suspensão dos mais elementares direitos, duramente conquistados pelas revoluções políticas populares. Esse fato se apresenta com maior clareza na América Latina. (...) Pretendeu-se oferecer [ao Chile] o marco teórico-ideológico à nova 'onda' do militarismo, adicionar a manu militari do totalitarismo à mão invisível do livre mercado". (VILLARREAL, René. $A$ contrarrevolução monetarista. Teoria, política econômica e ideologia do neoliberalismo. Rio de Janeiro: Record, 1984, p. 20 e 492)

314 "Entre os fatores constitutivos da globalização, em seu caráter perverso atual, encontram-se a forma como a informação é oferecida à humanidade e a emergência do dinheiro em estado puro como motor da vida econômica e social. São duas violências centrais, alicerces do sistema ideológico que justifica as ações hegemônicas e leva ao império das fabulações, a percepções fragmentadas e ao discurso único do mundo, base dos novos totalitarismos - isto é, dos globalitarismos - a que estamos assistindo". (SANTOS, Milton. Por uma outra globalização: do pensamento único à consciência universal. $6^{\underline{a}}$ ed. Rio de Janeiro: Record, 2001, p. 44.) 
sindicatos não constituem senão agentes nocivos; 5: as liberdades políticas são uma decorrência das liberdades econômicas - e não o contrário; 6o: a inflação é uma questão técnica, a ser resolvida por medidas igualmente técnicas; 7ㅇ: o Estado deve restringir sua atuação, na esfera econômica, às funções de promover a liberdade e a competitividade dos mercados, de proteger e garantir os contratos privados e defender a integridade da propriedade; 80: também lhe compete eliminar os obstáculos à livre circulação de capitais e mercadorias (estrangeiros), e igualmente, 9o: controlar a circulação de pessoas (trabalhadores); 10: a ingerência estatal é sempre perniciosa e conduz a regimes totalitários, cujo inevitável fracasso a história já demonstrou. ${ }^{315}$ Todas essas regras, ademais, deviam nascer da Economia - ciência que se assenta em modelos matemáticos, que falham apenas quando "a política interfere na economia". Porém, apesar dessa roupagem de discurso rigoroso, e se examinados no vis-à-vis da realidade presente, globalização e neoliberalismo apenas revelam - uma como mascaramento ideológico, outro como teoria de fundamentação dúbia - os elementos históricos que compõem a etapa atual do capitalismo e o estado de agudização extrema de suas contradições intrínsecas: superprodução industrial global, ampliação desmedida das atividades especulativas contra as produtivas, conflitos sociais agravados pelo desemprego permanente (estrutura), pela miséria crescente e pela perda de direitos fundamentais, disputas interimperialistas por recursos e mercados das regiões periféricas, crise do Estado democrático (no centro e na periferia) e dos valores éticos, destruição ambiental... ${ }^{316}$

$\mathrm{Na}$ Venezuela de meados dos anos 1980 - quando já se instalara o período de longo declínio econômico e deterioração das condições gerais de vida - as ideias neoliberais começaram a ganhar acolhida entre os grupos governantes e passaram, paulatinamente, a reorientar a ação do Estado, especialmente em relação à indústria petroleira. Como se procurará apresentar a seguir, essa nova orientação - a despeito de aprofundar as condições de subdesenvolvimento do país, ampliando a miséria e aguilhoando a insatisfação popular ao ponto das

\footnotetext{
${ }^{315}$ Cf. ZÚÑIGA, Simón Andrés. Decálogo del economista neoliberal. ALAI, América Latina en Movimiento, 12/03/2014. Disponível em: http://alainet.org/active/71985.

${ }^{316} \mathrm{Cf}$. as análises desses elementos feitas por vários autores em COGGIOLA, Osvaldo (Org.). Globalização e socialismo. São Paulo: Xamã, 1997. Cf. também ROMERO, Alberto. Globalización y pobreza. Nariño: Ediciones Unariño, 2002.
} 
explosões extremas - cercou-se da expectativa de modernizar o país e de conferir-Ihe a tão sonhada soberania econômica. Com esse espírito, empreendeuse a Abertura petroleira do início dos anos 90 , cujas promessas na economia, no entanto, não foram capazes de esconder os contornos de um cenário de grave crise social e política, ao qual sobreviriam, por fim, os importantes acontecimentos de 1998. 


\section{Cap. 5: Crise econômica e social. A Abertura Petroleira}

Uma descrição da trajetória econômica e social da Venezuela nas duas décadas que se seguiram ao fim do boom dos anos de 1970 conduz a conclusões que corroboram as teses marxistas (especialmente trotskistas) sobre as possibilidades históricas de desenvolvimento em sociedades coloniais e semicoloniais, bem como de ocorrência, nelas, de uma revolução democrática. A experiência de nacionalização do petróleo (e do ferro) e o agigantamento da participação estatal no sistema produtivo, ocorridos em anos de conjuntura internacional favorável, constituíram, na vida contemporânea do país, um exemplo ímpar de oportunidade histórica de autonomização econômica. Contudo, inseridas em um projeto burguês-associado de desenvolvimento dependente, a experiência nacionalizadora e as novas dimensões do Estado sofreram as injunções e limitações impostas pelo modo subordinado de associação das classes burguesas nacionais aos grupos econômicos estrangeiros. Em termos equivalentes, a sujeição da estrutura econômica e da orientação política do país aos interesses do imperialismo norte-americano e europeu ditou os limites do desenvolvimento venezuelano, restringindo severamente os anseios autonomistas dos setores burgueses nacionalistas, que, ao cabo, resignaram-se à modernização nos termos estabelecidos de fora. Quanto a uma revolução democrática, de feitio popular e/ou socialista, esta frustrou-se completamente, quer em razão da consolidação de um regime político-partidário elitista e conservador, que dominou amplamente as instituições políticas, quer em razão da ação de um aparelho estatal de funções repressivas destinadas a coibir e sufocar setores e grupos sociais que buscassem - através da organização das classes trabalhadoras ou através de movimentos insurrecionais armados - uma democracia de facto. Em tal cenário, era de esperar que se perpetuasse o subdesenvolvimento. Decerto, a proposição de um projeto de nacionalização das riquezas de um país semicolonial que, apesar de toda a possível expectativa ufanista, não logre romper efetivamente os vínculos de subordinação com as empresas e os capitais estrangeiros envolvidos em sua exploração está fadada a apenas dar formas novas à dependência estrutural. Não é inútil recordar que o rompimento efetivo de 
vínculos - em outras palavras, a autonomização econômica - tenha de atingir obrigatoriamente os níveis 1) da tecnologia (com o desenvolvimento de um corpo de conhecimento técnico, a criação de empresas nacionais de pesquisa e produção de bens de capital, e programas de especialização de mão de obra); 2) do controle comercial (com a adoção de políticas com que se estabeleça o equilíbrio entre a tradicional orientação primário-exportadora da economia e um projeto de diversificação produtiva, de modo a canalizar para esse projeto determinadas parcelas dos volumes da receita tributária sob controle do Estado, a fim de diminuir gradual e duradouramente o peso daquela orientação em favor dessa diversificação); e 3) das atribuições do Estado (com a transformação deste - ainda que o projeto não assuma imediatamente um sentido socialista de fato em proprietário efetivo das riquezas naturais do país e de sua exploração econômica, impondo-se-Ihe a incumbência de destinar outras tantas parcelas da receita estatal ao provimento de serviços sociais básicos - públicos, exclusivos e gratuitos). Além disso, a superação da condição estrutural de atraso e sujeição política às nações imperialistas precisa resultar, nessas sociedades semicoloniais, da ação independente e revolucionária das classes trabalhadoras, uma vez conscientes da fraqueza e cumplicidade de interesses das classes proprietárias nacionais com os grandes grupos econômicos estrangeiros. A ilusão, portanto, de se construir aí um capitalismo autônomo conduzido pela burguesia "nacional" não queda senão nisso mesmo - uma ilusão, patente na estreiteza dos períodos de prosperidade material que porventura ocorram ao país, sempre condicionados por oscilações de um mercado mundial irremediavelmente controlado por e para as grandes corporações transnacionais. O oposto disso é a conviç̧ão do imperativo das transformações revolucionárias permanentes, cujo valor está em não transigir com "as meias medidas" do projeto burguês-associado. No caso da Venezuela petroleira, muito pouco daquela autonomia foi, a rigor, conquistado, e a insistência teórica nesses pontos cruciais da questão da autonomização/soberania contrasta com o desalento que resultou do fracasso da política de nacionalização dos anos de 1970.

Como uma circunstância claramente derivada dessa oportunidade histórica perdida, consumada no referido fracasso, a democracia possível do projeto burguês-associado venezuelano viu-se obrigada, nas duas décadas seguintes à 
de 1970, a abandonar a ideia de desenvolvimento nacional como fator de integração e paz social, que, como vimos, pretendeu legitimar todo o sistema político (partidário e sindical) de Punto Fijo. Daí em diante, em um ritmo que se agravaria conforme se passava à década de 90, os fortes desequilíbrios registrados nos indicadores macroeconômicos, as perdas reais dos salários, o endividamento externo e interno, a degradação dos serviços públicos, a corrupção administrativa, etc., sublinhariam a exaustão, igualmente irreversível, tanto do modelo rentista de desenvolvimento econômico como do arranjo populista conciliatório de organização político-social. Tornou-se, pois, forçoso ao governo reconhecer o inevitável da adoção de políticas recessivas, e o pacote econômico de medidas neoliberais anunciado em fevereiro de 1989 por Andrés Pérez assinalou o momento decisivo das mudanças: empreendiam-se a política de liberalização econômica e a de redução das funções sociais do Estado. Ambas, aplicadas pelo governo por toda a década seguinte, correspondiam às diretrizes sugeridas pelo $\mathrm{FMI}$, com o qual o novo presidente tivera conversações pouco antes. Condizente com o ideário neoliberal, que realizava então sua formidável ofensiva ideológica no continente, a abertura ao capital privado (especialmente notável, evidentemente, no setor petroleiro) em detrimento dos investimentos estatais correspondeu à nova crença oficial de que a ação reguladora do Estado na economia (petroleira) era a principal responsável pelo quadro de estagnação e crise da Venezuela - econômica e socialmente falando. No plano social, os cortes em gastos com serviços públicos repercutiriam diretamente na qualidade de vida do grosso da população, e iriam destruir bruscamente grande parte do consenso popular sobre a democracia venezuelana e a legitimidade de suas instituições algo que vinha sendo erodido desde os primeiros anos da década de 1980. De fato, quanto à política de conciliação de classes - sustentada na redistribuição clientelista da renda petroleira -, debilitava-se sua eficácia à medida que se iam esgotando os meios que a alimentavam e reaflorava o descontentamento popular. Era o fim do populismo de conciliação. Quanto à estrutura econômica, a assim chamada Abertura Petroleira, inaugurada no início da década seguinte, consistiu justamente em implementar um conjunto de mudanças - conduzido pelo governo e pela direção da estatal PDVSA - com o propósito de ampliar a participação de empresas privadas (de capital nacional e estrangeiro) nas diversas fases da 
exploração petrolífera (da prospecção à comercialização), através principalmente da assinatura de convênios específicos. $O$ argumento neoliberal admitido pelo governo (e entusiasticamente brandido pela direção da estatal) era o de que, em uma economia nacional que permitia ao capital privado o livre acesso ao conjunto das atividades produtivas, os investimentos aí porventura feitos, igualmente livres da interferência estatal, tenderiam a estimular a eficiência e a competitividade da indústria em questão, inserindo-a com vantagens em um mercado mundial único - globalizado. Os ganhos sociais disso, por sua vez, decorreriam naturalmente de um infalível crescimento econômico assim conduzido. (Após 1983, ano marcado pela debacle da Sexta-Feira Negra, ideias como essas começaram a penetrar com maior força em setores empresariais e intelectuais. O denominado Grupo Roraima, formado por empresários e acadêmicos, ganhou notoriedade com as propostas de redução do papel econômico do Estado e de consequente ampliação das atividades empresariais privadas. ${ }^{317}$ ) Embora essas ideias fossem apresentadas com grande energia e eloquência, não alcançaram consenso entre os especialistas da economia petroleira. Afinal, para muitos deles, se desde os anos da nacionalização e dos contratos de comércio e de tecnologia, a ingerência (direta ou indireta) das grandes petroleiras estrangeiras revelara as deficiências do processo de controle efetivo do petróleo pelo Estado venezuelano, agora parecia tratar-se claramente de uma estratégia ainda mais incisiva de desnacionalização da indústria petroleira. Segundo alguns, divisava-se um verdadeiro plano "(...) para tornar mais elitista e antinacional o já por si injusto aproveitamento privado do mais valioso bem público [venezuelano]". ${ }^{318}$ Mas, as mudanças de orientação na política petroleira tinham, naquele momento, a vantagem de contar com a descrença geral (sobretudo popular) na democracia e na eficiência do Estado venezuelano - descrença alimentada, entre outras coisas,

317 Cf. DIJOHN, Jonathan. The Political Economy of Economic Liberalisation in Venezuela. Development Research Centre, LSE, 2004, p. 5.

${ }^{318}$ POTELLÁ, Carlos Mendoza. Apertura petrolera: nombre de estreno para un viejo proyecto antinacional. Soberanía.org. 06/04/03. Fecha de publicación: 1 de abril de 1996. Disponível em http://www.soberania.org/Articulos/articulo_073.htm. Acrescenta este importante estudioso da questão petroleira sobre a Abertura dos anos 1990: "(..) Se trata de la revancha definitiva del poder petrolero, que ha visto llegada la hora de acabar de una vez por todas con los sueños populistas y socialistoides que todavía obstaculizan la integración del país en el escenario mundial unipolar, donde se impone a los pequeños el "libre mercado" de las transnacionales y las grandes naciones que fundamentan su poderío económico y político precisamente en la disposición de mercados externos irrestrictamente abiertos y el resguardo proteccionista de sus economías domésticas". 
pelos fatos sucedidos nos dias do Caracaço, em 1989, pelas tentativas de golpe de 1992 e, enfim, pelo próprio impeachment do presidente em 1993. Nas páginas seguintes, procuramos apresentar o comportamento de alguns indicadores econômicos e sociais dos anos 1980-90, que ilustram a grave situação de crise instalada desde os primeiros anos da década, bem como os posteriores impactos dessa nova etapa da política petroleira, de liberalização econômica. Deve-se reter de antemão que essa etapa corresponde a um momento de reinserção do país na nova reordenação do mercado mundial, cujas principais transformações foram condicionadas, em grande medida, pelo início de uma fase de declínio das taxas mundiais de lucro nos países centrais a partir de fins dos anos de 1960. A globalização que emergiu desse contexto mundial do sistema capitalista tem o significado essencial de uma nova ofensiva das economias imperialistas sobre 0 excedente econômico produzido nos países da periferia, o que explica, em contrapartida, que as políticas econômicas aí implantadas tenham tido imediato impacto negativo no nível de progresso material e de bem-estar das populações desses países. Com efeito, como se verá no caso da Venezuela, ao fim de um decênio de Abertura Petroleira, as estatísticas já mostravam ao menos três evidências de novo recuo do desenvolvimento geral do país: a queda do valor tributável da produção petroleira, o aumento da dependência em relação ao petróleo e, digno de maior nota, o aprofundamento do subdesenvolvimento social.

Compreendendo-se, pois, a globalização econômica como uma nova etapa de internacionalização das finanças e dos próprios processos produtivos em escala mundial (como resposta à crise estrutural de acumulação no centro), as economias periféricas por ela afetadas tenderam, entre si, a uma diferenciação da importância de suas participações na divisão internacional do trabalho. Dessa diferenciação, e como fruto de um nítido crescimento desigual, surgiu uma semiperiferia destacando-se do conjunto, composta por países (quase todos da Ásia e Oceania) com rendas per capita bem superiores (duas vezes e meia) à da média periférica. $O$ impulso para tal crescimento nesses países emergentes veio da absorção de expressivos volumes de investimentos externos e da adoção de políticas oficiais de industrialização. Mas, exceto esses, a maioria dos países periféricos rumou no caminho de acentuar as deficiências de desenvolvimento: visto que se revelaram incapazes, por exemplo, de diversificar a composição de 
suas exportações, propenderam a aumentar sua dependência em relação à produção primária, em geral de avanço lento e sujeita às variações bruscas do mercado externo. De acordo com um estudo de Enrique Arcero ${ }^{319}$ (no qual as afirmações anteriores, em parte, se baseiam), a economia mundial experimentou entre 1970 e 2000 um ritmo de crescimento mais lento que nas duas décadas posteriores à II Guerra. Nesse cenário, merece ser notado que, como demonstra a tabela abaixo, a parcela do conjunto da periferia no total do PIB mundial, durante as três décadas, subiu quase 11 pontos (de $27,8 \%$ a $38,6 \%$ ), com a predominância da participação da produção da China e dos Tigres asiáticos. No entanto, a porcentagem que cabia às outras regiões apontou um decréscimo de sua participação - especialmente após 1980 para a América andina, Cone Sul e África subsaariana. Adicionalmente, a tabela 13 apresenta a relação das produções per capita da periferia e do centro como porcentagem da primeira no total da segunda. Nela se vê o gradual afastamento entre regiões da periferia, configurando-se uma distinção entre áreas atrasadas e as assim chamadas áreas semiperiféricas:

Tabela 12: Participação no PIB mundial (dólares constantes e taxa de paridade de poder de compra de 1995)

\begin{tabular}{lrrrr}
\hline & 1975 & 1950 & 1990 & 2000 \\
\hline Mundo & 100 & 100 & 100 & 100 \\
Centro & 72,2 & 70,7 & 67,9 & 61,4 \\
Periferia & 27,8 & 29,3 & 32,1 & 38,6 \\
América periférica & 9,5 & 10,3 & 8,4 & 8,3 \\
América andina & 1,9 & 1,9 & 1,6 & 1,4 \\
Carbe & 0,1 & 0,1 & 0,1 & 0,1 \\
Cono Sur & 5,1 & 5,6 & 4,4 & 4,4 \\
México y Centroamérica & 2,4 & 2,8 & 2,4 & 2,4 \\
Asia y Oceania & 11,0 & 11,9 & 17,0 & 24,0 \\
Asia del Este y Paófico & 2,4 & 2,8 & 3,4 & 3,7 \\
Sur de Asia & 4,4 & 4,4 & 5,6 & 6,6 \\
China & 3,2 & 3,5 & 6,1 & 11,3 \\
Tigres & 1,0 & 1,2 & 1,9 & 2,5 \\
Eurdfrica & 7,3 & 7,1 & 6,7 & 6,3 \\
Africa subsahariana & 2,6 & 2,5 & 2,1 & 1,9 \\
Asia y Europa Central & 1,5 & 1,4 & 1,6 & 1,5 \\
Oriente Medio y Norte de África & 3,2 & 3,2 & 3,0 & 3,0
\end{tabular}

Fonte: ARCERO, E. El impacto de la globalización en la periferia...., p. 33.

A acentuada diminuição relativa PIB-periferia/PIB-centro nos casos específicos da América andina, periférica e Cone Sul contrasta com o ligeiro

\footnotetext{
${ }^{319}$ Cf. ARCERO, Enrique. El impacto de la globalización en la periferia y las nuevas y viejas formas de la dependencia en América Latina. Cuadernos del CENDES, vol. 22, núm. 60, septiembre-diciembre, 2005, pp. 31-37.
} 
crescimento do conjunto geral da periferia e, mais nitidamente, com o forte aumento da China e dos Tigres. Os desdobramentos dessa assimetria no âmago da própria periferia capitalista demonstram, comparativamente, a persistência - a médio prazo - do ritmo lento ou estagnado do desenvolvimento da região latinoamericana. Outra contribuição do estudo encontra-se na afirmação de que desindustrialização, desemprego, aumento da pobreza e concentração social de renda são os efeitos mais característicos a traduzir essas cifras contrastantes na vida do continente, ademais submetido a partir dos anos 1980 ao impacto da globalização neoliberal. Encerrando-se o século, esses números permitiriam ainda concluir, com especial ênfase para a América Latina, que "(...) apesar da predição das correntes econômicas dominantes, não houve convergência entre os países periféricos e os centrais (o índice de Gini das rendas per capita dessas nações se elevou) e a causa fundamental da desigualdade de rendas no mundo continua sendo a disparidade de renda entre as nações." ${ }^{320}$

\begin{tabular}{|c|c|c|c|c|}
\hline & 1975 & 1980 & 1990 & 2000 \\
\hline Mundo & 29,6 & 28,6 & 26,5 & 27,1 \\
\hline Centro & 100,0 & 100,0 & 100,0 & 100,0 \\
\hline Periferia & 10,5 & 10,5 & 10,4 & 12,5 \\
\hline Améñca periférica & 31,5 & 32,1 & 23,6 & 23,2 \\
\hline Aménica andina & 29,3 & 26,9 & 19,8 & 17,7 \\
\hline Caibe & 25,5 & 22,5 & 18,7 & 17,4 \\
\hline Cono Sur & 33,8 & 35,0 & 25,3 & 25,7 \\
\hline México y Centrosmérica & 29,2 & 31,2 & 23,7 & 23,6 \\
\hline Asia y Oceanla & 5,6 & 5,8 & 7,6 & 11,0 \\
\hline Asia del este y Paclifico & 10,3 & 11,4 & 12,6 & 13,6 \\
\hline Sur de Asia & 5,7 & 5,3 & 5,9 & 6,9 \\
\hline China & 3,5 & 3,8 & 6,3 & 12,4 \\
\hline Tigres & 24,2 & 28,8 & 44,0 & 58,5 \\
\hline Euräfrica & 18,5 & 16,6 & 13,0 & 11,7 \\
\hline Africa subsahariana & 12,1 & 10,6 & 7,5 & 6,1 \\
\hline Asia y Europa central & 30,3 & 28,0 & 27,5 & 27,1 \\
\hline Oriente Nedia y Norte de Africa & 24,6 & 22,4 & 17,4 & 16,8 \\
\hline Periferia, excep. China & 14,1 & 13,9 & 12,2 & 12,6 \\
\hline
\end{tabular}

Fonte: ARCERO, E. El impacto de la globalización en la periferia...., p. 34.

No que tange à Venezuela, como se mencionou, o período de anos imediatamente anteriores à decisão de implantar políticas amplas de liberalização econômica (1989) representa, para a grande maioria dos estudiosos, o início da

${ }^{320}$ Idem, p. 35. 
trajetória descendente do desenvolvimento baseado na renda petroleira. (Já vimos, em capítulo anterior, as razões e a dimensão da desindustrialização, que começava a se tornar aguda por volta de meados da década (cf. Tabelas 9 e 10)). Interessa destacar aqui, dentre essa quase unanimidade teórica sobre a falência do modelo rentista, uma explicação que, da perspectiva liberal, procura identificar as determinações históricas do fracasso. ${ }^{321}$ Segundo essa explicação, as antigas expectativas positivas no rentismo petroleiro como motor de progresso esbarraram no fato de que o tipo de sistema produtivo por ele determinado - o capitalismo rentístico - padece o mal congênito da incapacidade de manter estável a relação fundamental entre a produtividade do trabalho e os níveis correspondentes de salário real. O descompasso entre produtividade e salário, como visto no gráfico seguinte, é, no caso venezuelano, parte de um conjunto de desvios em relação a um padrão esperado em sociedades capitalistas desenvolvidas e/ou em desenvolvimento.

\section{Gráfico 16: Produtividade e salários reais $(1950-2002) 1950=100$}

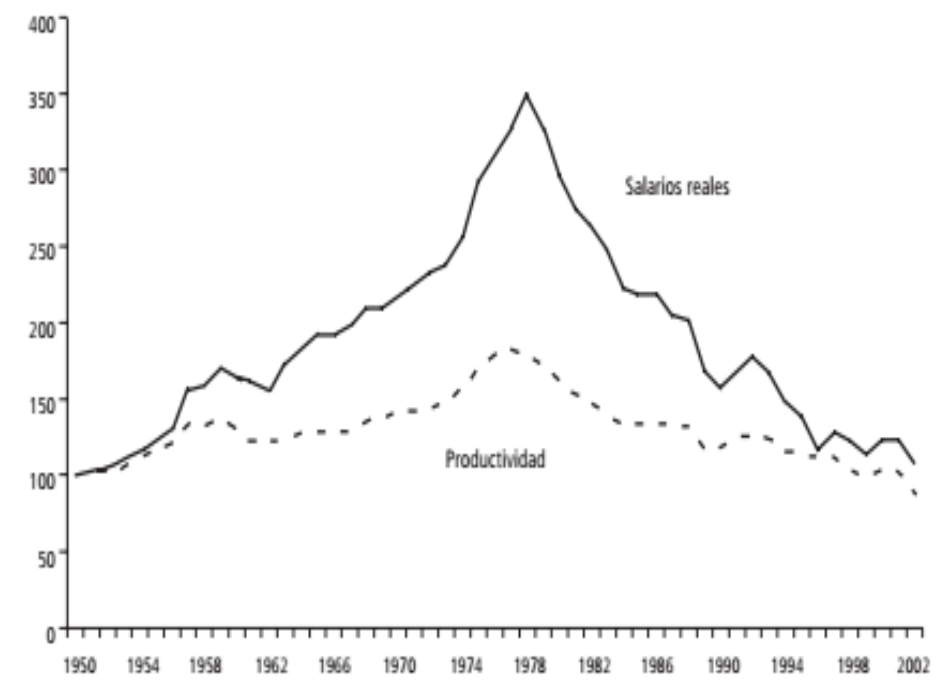

Fonte: BAPTISTA, Asdrúbal. El capitalismo rentístico, p. 105.

Em primeiro lugar, a renda dos salários, ao não vincular-se diretamente aos ganhos de eficiência produtiva, ascendem e descendem abruptamente em contraste com o comportamento regular da produtividade. A razão disso está na

${ }^{321}$ Trata-se de algumas proposições do renomado economista venezuelano Asdrúbal Baptista, que participou por alguns meses, em 1994, do governo de Rafael Caldera. O texto aqui empregado é BAPTISTA, A. El capitalismo rentístico. Elementos cuantitativos de la economía venezolana. Cuadernos del Cendes, Año 22, № 60, septiembre-diciembre 2005, pp. 95-111. 
intervenção anômala do Estado no que deveria ser o equilíbrio dos fatores de produção. Como no capitalismo rentístico venezuelano o Estado é o grande perceptor da renda (e o crescimento desta não é fruto do aprimoramento das forças produtivas, mas simplesmente da variação da demanda externa), as políticas populistas redistributivas adotadas - necessárias à estabilidade política do modelo - ampliam artificialmente a renda dos trabalhadores (veja-se o capítulo anterior sobre a política de cooptação da classe operária) e a canalizam para o consumo, em grande parte, de gêneros importados. (Vimos no cap. 2, que a falta de impulso à produção industrial nacional e à sua diversificação, somada à abundância de crédito ao consumo, constituía um sintoma da enfermidade holandesa. É de notar, pois, certa proximidade teórica entre o capitalismo rentístico em questão e essa enfermidade). A ascensão contínua do salário real, de 1962 até o pico de 1978, preparou a brusca queda que ocorreria até 1991 momentaneamente interrompida nesse ano, mas não mais realmente revertida daí em diante. A fórmula equivocada do sistema era jungir os salários exclusivamente à renda petroleira, acabando por estimular um nível de consumo que somente artigos de fora podiam abastecer. Assim: "Tome-se o período 19501978. Durante essas quase quatro décadas [sic], a produtividade cresceu a uma taxa anual de $1,5 \%$ enquanto os salários reais aumentaram 3,8\%. Não são necessários maiores comentários. Salvo pela presença de um excedente rentístico, cujo caráter internacional implica que nada custa à economia produzi-

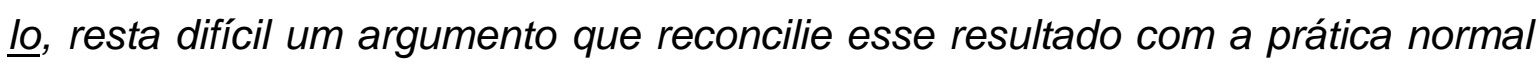
da economia contemporânea (...)". ${ }^{322}$ Em segundo lugar, o volume de empregos oferecidos pelo Estado venezuelano também constituiu, no período, um desvio da "norma" econômica ao manter um imenso contingente de trabalhadores excedentários: de acordo com cálculos do autor, a diferença entre o volume de emprego efetivo e o de emprego normal (categoria que, segundo ele, exprime a relação entre o grau de desenvolvimento esperado de um país e o volume de seu emprego público), atingia sua culminância em 1980-85, quando a taxa chegou próximo de $65 \%$ de trabalhadores excedentes (em valores absolutos, quase 700 mil trabalhadores em um total de 1,1 milhão efetivos, enquanto o emprego público normal deveria ser de 378 mil) - novamente uma anormalidade apenas explicável

${ }^{322}$ BAPTISTA, Asdrúbal. El capitalismo rentístico, p. 105-106. Grifo nosso. 
pela existência de um excedente de renda de origem externa, e não pela exigência da produção nacional. Em suma, um traço valioso desse tipo de argumentação, que gostaríamos de ressaltar, consiste em comprovar que, também do ponto de vista do liberalismo, o modelo petroleiro-rentista venezuelano encerrava em si contradições insolúveis de existência. ${ }^{323}$ Por isso, não foi casual que esses argumentos estivessem malgré soi na raiz das formulações que ganhariam aceitação ao aproximar-se o fim da década, e postulassem então os "ajustes" neoliberais da economia, em especial quanto ao valor do trabalho e às dimensões e funções do Estado. ${ }^{324}$

Ao longo dos anos 1990, as variações na estrutura ocupacional refletem, como seria previsível, o clima geral de instabilidade e descenso econômico, 0 qual - se aparentara ser de alguma melhora nos primeiros anos após as medidas do pacote de ajustes (em 1992 e $1993^{325}$ ) - logo mostrou o pouco sucesso delas para conter a queda nos níveis de emprego (recordem-se também as curvas descendentes de produtividade e de salário real do gráfico anterior): tanto o setor público como o privado formal sofreram reduções entre 1990 e 1998 . O emprego informal, índice muitas vezes negligenciado nas análises econômico-sociais cresceu quase $8 \%$ no período, e ficou acima inclusive da variação correspondente da taxa de desemprego. Esta taxa atingiria em 1999 o auge de 15,6\% da população ativa, enquanto a taxa de emprego informal chegava a $52 \%$ da PEA,

\footnotetext{
323 "El capitalismo rentístico es una estructura inviable, en el estricto sentido de que carece de mecanismos de autorregulación, valga decir, y en los términos convencionales de la teoría económica, carece de un equilibrio estable (...). Ello significa, además, su imposibilidad de autorreproducirse, y por lo tanto de garantizar un crecimiento sostenido de su actividad económica." (Idem, p. 109)

${ }^{324} \mathrm{Em}$ um artigo coetâneo que avaliava a importância do pacote de medidas neoliberais recémanunciado em fevereiro de 1989, por C. A. Pérez sob a sonora denominação de El Gran Viraje, afirmava um economista: "Estamos transitando hacia una economía, que debe generar sus propios excedentes dentro de sí misma. Eso quiere decir que la acumulación de capital (el beneficio) debe generarse dentro de las propias empresas. Debido a que la productividad sólo crece lentamente a largo plazo, la única forma inmediata de sustituir la ausencia de la renta petrolera como motor de acumulación es manteniendo deprimidos los niveles salariales reales. Ello se está consiguiendo actualmente a través de la devaluación del bolívar, que por la vía de la inflación de los precios de consumo, permite elevar la tasa de beneficio interna de las empresas. De esta forma, así como antes la sobrevaluación era el mecanismo fundamental de apropiación del excedente, ahora la subvaluación se ha convertido en el nuevo mecanismo de dinamismo económico." (PURROY, M. Ignacio. Evaluación del Programa Económico. Revista SIC 1989 oㅡ 52 (513) pp. 122-130. Disponível em http://www.gumilla.org/?p=page\&id=13867005923472)

${ }^{325}$ Deve-se lembrar que, nos anos imediatos a 1990, as receitas petroleiras venezuelanas foram momentaneamente incrementadas em razão das perturbações no mercado petroleiro mundial provocadas pelo conflito armado envolvendo a invasão iraquiana do Kuwait e a consequente guerra com o Ocidente.
} 
em 1999 (dado que não consta na tabela 16, mas é informado por um relatório da Cepal Panorama Social de América Latina - 2000-2001). Acrescentamos à tabela seguinte os números da inflação desses anos, que, por sua importância na definição do nível de consumo básico dos trabalhadores formais, têm, é claro, efeito ponderável e imediato sobre as condições de vida da população informal e desempregada. Sabe-se, ademais, que o nível de pobreza entre trabalhadores informais é sensivelmente superior aos dos trabalhadores formais, como o é também o acesso aos serviços básicos de saúde e de educação. (Obs.: nenhum desses indicadores apresentaria melhorias substanciais até pelo menos 20022003, já sob o governo de Hugo Chávez).

Tabela 14: Estrutura Ocupacional (em \% da PEA) e Inflação

\begin{tabular}{|c|c|c|c|c|c|}
\hline \multirow[b]{2}{*}{ Años } & \multirow{2}{*}{$\begin{array}{l}\text { Sector } \\
\text { público }\end{array}$} & \multicolumn{2}{|c|}{ Sector privado } & \multirow[b]{2}{*}{ Desempleo } & \multirow[b]{2}{*}{ Inflación } \\
\hline & & Formal & Informal & & \\
\hline 1990 & 17,7 & 36,2 & 36,2 & 9,9 & 36,5 \\
\hline 1991 & 17,4 & 36,9 & 37,0 & 8,7 & 31,0 \\
\hline 1992 & 16,8 & 39,3 & 36,8 & 7,1 & 31,9 \\
\hline 1993 & 15,8 & 39,9 & 38,1 & 6,3 & 47,3 \\
\hline 1994 & 15,0 & 31,4 & 44,8 & 8,5 & 70,8 \\
\hline 1995 & 15,8 & 30,5 & 43,1 & 10,2 & 56,6 \\
\hline 1996 & 15,0 & 29,8 & 42,6 & 12,4 & 103,2 \\
\hline 1997 & 15,2 & 31,3 & 42,4 & 10,6 & 37,6 \\
\hline 1998 & 14,1 & 30,4 & 44,1 & 11,0 & 29,9 \\
\hline 1999 & n.d. & n.d. & n.d. & 15,6 & 20,0 \\
\hline
\end{tabular}

Fonte: BCV, Apud VELÁSQUEZ, E. La política económica en Venezuela, p. 86 (modificado)

O programa de ajustes de 1989, ao fixar uma nova orientação à economia e às funções sociais do Estado - de acordo, presumivelmente, com conceitos inovadores como competitividade, eficiência e qualidade - incidiu diretamente sobre o sentido tradicional das políticas públicas vigentes, que eram tanto mais enraizadas na vida venezuelana quanto maior a rede clientelista que o Estado podia sustentar. A principal mudança se deveu a que o campo de ação dessas políticas passou a confinar-se aos limites financeiros determinados pela política geral de contenção de gastos públicos. As políticas sociais, a partir de 1989, perdiam seu significado de promoção da integração social ao desenvolvimento, vital ao discurso populista, e conformavam-se à concepção de que deviam visar estritamente a dar lenitivo às situações prementes de carência provocadas pelo 
próprio reajuste econômico. Passavam, por isso, a ser políticas focadas, dirigidas a grupos que se encontravam em situações de maior vulnerabilidade. ${ }^{326}$ Assim redefinidas, portanto, seriam implementadas através de subsídios diretos e adquiriam caráter rigorosamente transitório. Essa concepção neoliberal de assistência obedecia à fria lógica segundo a qual a pobreza consistia em um problema de insuficiência de meios dos pobres em satisfazer suas necessidades básicas, explicável pela condizente incapacidade desses indivíduos de se inserir produtivamente no mercado. O funcionamento livre do sistema econômico os manteria à margem enquanto eles não desenvolvessem as habilidades necessárias à sua inserção produtiva. ${ }^{327} \mathrm{O}$ Estado agiria contra a racionalidade do mercado se interviesse provendo meios que manteriam a pobreza, e não a eliminariam. Demais disso, os próprios serviços necessários à sociedade (como educação e saúde) constituíam áreas mais bem supridas pelo mercado do que pelo Estado. A realidade concreta, contudo, logo desacreditou essas prescrições, e a contínua subida dos níveis de pobreza (na Venezuela e, parcialmente, em toda a América Latina), durante os anos 1980 e 1990, obrigou ao Estado aumentar seus gastos em serviços básicos. A despeito disso, as metas prometidas jamais se cumpriram, e a pobreza permaneceu como o maior estigma dos anos finais da democracia de Punto Fijo. Dois estudos oficiais, do BCV e da Cepal, dão a medida estatística disso. O primeiro (La evolución de la pobreza en Venezuela, de 1998), empregando a metodologia de Amartya Sen (que identifica os pobres como os que não conseguem renda para aquisição da cesta básica normativa, e os pobres em situação extrema os que não o conseguem para a cesta básica alimentar), quantifica o fenômeno entre 1976 e 1996, descrevendo a trajetória desde a condição privilegiada do país nos anos 1970 de um dos menos atingidos pelo problema da pobreza social à alarmante condição de um dos mais pobres do continente nos últimos anos do século. Entre as conclusões do estudo está a que, ao avançar a última década, a pobreza extrema se acentuou mais do

${ }^{326}$ Cf. SILVA, José I. \& SCHLIESSER, R. La evolución de la pobreza en Venezuela. Caracas: BCV, 1998.

327 "(...) El fundamento sobre el que se levanta una política social con tales características no es otro que la hipótesis de que el crecimiento económico sostenido impulsado por el adecuado funcionamiento del mercado incorpora paulatinamente a la economía moderna a los sectores menos privilegiados, logrando en el largo plazo una reducción significativa de la pobreza (...), no justificándose, más allá de un periodo inicial relativamente corto, el establecimiento de política social alguna". (Idem, p. 15-16) 
que a pobreza geral. ${ }^{328}$ (Recorde-se que, no ano de 1976, fora publicado o estudo de Michel Chossudovsky - La miseria en Venezuela - (cf. cap. 2) que denunciava os significativos níveis de pobreza e marginalização, mesmo quando as estatísticas apontavam um quadro geral de situação de menor pobreza.) Entre o $1^{\circ}$ semestre de 1990 e o $2^{\circ}$ de 1996 , a taxa de incidência de pobreza extrema variou $35,87 \%$, e a de pobreza geral variou $15,42 \%$.

Tabela 15: Taxas de incidência: pobreza geral e pobreza extrema

\begin{tabular}{|c|c|c|c|c|c|}
\hline \multicolumn{4}{|c|}{ Tasa de Incidencia (\%) } & \multicolumn{2}{|c|}{ Tasa de Incidencia $(\%)$} \\
\hline Semestres & $\begin{array}{l}\text { Pobreza } \\
\text { Extrema }\end{array}$ & $\begin{array}{l}\text { Pobreza } \\
\text { General }\end{array}$ & Semestres & $\begin{array}{l}\text { Pobreza } \\
\text { Extrema }\end{array}$ & $\begin{array}{l}\text { Pobreza } \\
\text { General }\end{array}$ \\
\hline 176 & 4,81 & 14,36 & 1186 & 8,52 & 31,77 \\
\hline 1176 & 3,77 & 13,42 & 187 & 8,56 & 34,23 \\
\hline 177 & 3,29 & 12,66 & 1187 & 12,72 & 42,70 \\
\hline 1177 & 2,42 & 11,30 & I88 & 9,69 & 37,90 \\
\hline 178 & 2,33 & 10,66 & II88 & 18,12 & 50,06 \\
\hline 1178 & 2,30 & 10,30 & 189 & 30,12 & 62,93 \\
\hline 179 & 2,21 & 9,53 & 1189 & 29,16 & 70,56 \\
\hline II79 & 2,40 & 11,20 & 190 & 29,45 & 70,36 \\
\hline 180 & 2,55 & 11,85 & 1190 & 34,12 & 72,60 \\
\hline II80 & 2,43 & 12,09 & I91 & 37,09 & 75,40 \\
\hline 181 & 2,71 & 13,06 & II9 1 & 39,50 & 74,29 \\
\hline II8 1 & 2,60 & 13,36 & 192 & 36,07 & 70,81 \\
\hline 182 & 2,83 & 14,19 & 1192 & 36,31 & 71,40 \\
\hline 1182 & 2,58 & 13,71 & 193 & 36,30 & 70,44 \\
\hline 183 & 2,87 & 15,33 & 1193 & 40,95 & 74,40 \\
\hline 1183 & 3,30 & 16,69 & 194 & 46,30 & 78,31 \\
\hline 184 & 4,05 & 17,42 & II94 & 55,13 & 83,49 \\
\hline II84 & 5,49 & 21,59 & I95 & 55,69 & 83,95 \\
\hline 185 & 6,83 & 26,37 & II9S & 55,68 & 82,09 \\
\hline II85 & 7,09 & 29,00 & 196 & Nd & Nd \\
\hline 186 & 7,26 & 29,58 & 1196 & 65,32 & 85,78 \\
\hline
\end{tabular}

Fonte: SILVA, J. I. \& SCHLIESSER, R. La evolución de la pobreza...p. 28

O segundo estudo - o relatório Cepal - Panorama Social de América Latina 19902000) - demonstra a evolução de três variáveis correlatas principais: pobreza, gastos públicos e distribuição de renda. Da primeira apresentamos sucintamente a conclusão geral relativa a todos os países latino-americanos para servir de

\footnotetext{
${ }^{328}$ Nota o estudo: "Tal aumento [da pobreza a partir sobretudo de 1983] se expresa a través de una creciente proporción de familias cuyos ingresos no cubren las necesidades básicas, así como en un incremento en el déficit porcentual medio del ingreso de los pobres respecto a la línea de pobreza. Esto es, además de haber aumentado el número de pobres, el ingreso de estas personas se ha alejado cada vez más del costo de la canasta de consumo que cubre tales necesidades básicas. (...) El problema se agudiza al observarse que el número de familias cuyos ingresos no satisfacen, tan sólo, el costo de la canasta alimentaria básica (pobreza extrema)(...). Lo anterior, evidencia un constante empeoramiento en el patrón de pobreza que se expresa en secuelas irreversibles sobre los que la padecen (desnutrición, incapacidad laboral, descomposición social, etc.). (SILVA, J. I. \& SCHLIESSER, R. La evolución de la pobreza en Venezuela. p. 69)
} 
cotejo ao que se disse acima sobre o caso específico da Venezuela. Das outras duas, retiramos do estudo geral os dados pertinentes apenas à Venezuela, de modo a ilustrar, primeiro, como os gastos sociais tiveram variações diferentes de setores quando se compara o fim da década ao seu início; segundo, como a distribuição social de renda, a exemplo de praticamente todos os países do continente, tendeu a concentrar-se nos segmentos mais ricos da população, segundo uma marcha que levou toda a região a ostentar, como foi aludido no início, o desolador status de a região mais socialmente desigual do planeta. Conforme o relatório, os anos 1990 se destacaram por uma tendência significativa apenas em termos relativos - à redução do número de lares pobres: ao final da década, os 11 países de maior contingente de pobres diminuíram a pobreza se comparada ao ano de $1990 .^{329}$ Contudo, o registro da pobreza em termos absolutos e sua caracterização material deixavam pouca razão para comemoração: nos lares pobres, a maioria não possui água potável e reúne mais de três pessoas por cômodo; além disso, predominam neles baixos níveis de instrução e de ocupação, em que o chefe de família possui em média apenas três anos de estudos e encontra-se desempregado. Predomina também o quadro de crianças e jovens sem instrução e/ou afastados da escola, e que ingressam cedo no mercado informal de trabalho. Em números absolutos para o continente: quase 77 milhões habitam moradias superocupadas. Também 165 milhões de pessoas (das quais mais de 109 milhões são pobres) não têm acesso a água potável. Quanto a outra variável, os números da tabela abaixo mostram que, no cenário latino-americano dos anos 1990, a Venezuela apresentou, em evolução de gasto social, uma melhoria percentual apenas em educação e seguridade social, porém bem abaixo da média simples da região. Em sentido oposto, os gastos nos setores de saúde e nutrição, moradia, água e saneamento experimentaram um

\footnotetext{
${ }^{329} \mathrm{O}$ relatório conclui, não obstante os números que indicam a redução de lares pobres e os incrementos com gasto social, em vários países da América Latina, que: "(...) aunque la mayoría de los países han incrementado el gasto social durante los años noventa, ninguno ha logrado aún el acceso universal a servicios de calidad en educación básica, salud básica y agua potable, ni cumplido las metas de esta iniciativa: el gasto en servicios sociales básicos sólo representa $12.4 \%$ del gasto público total (algo más de la tercera parte del gasto público social), y $10 \%$ de la asistencia oficial para el desarrollo destinada a estos servicios. (Cepal. Panorama Social de América Latina, p. 138). Cf. também as observações feitas ao gráfico 1: América Latina: evolução da pobreza e da indigência - 1980-2012, que apresentamos na Introdução, p. 28 supra.
} 
recuo - particularmente notável nos últimos três - em relação aos valores do começo da década (variação de $-31 \%$ ).

Tabela 16: Nível e evolução do gasto social por setores nos anos 1990 - Venezuela

\begin{tabular}{|c|c|c|c|c|c|c|c|c|}
\hline \multicolumn{9}{|c|}{$\begin{array}{l}\text { AMÉRICA LATINA (15 PAISES): NIVEL Y EVOLUCION DEL GASTO SOCIAL POR SECTORES EN LOS AÑOS NOVENTA al } \\
\text { (En dólares de 1997) }\end{array}$} \\
\hline \multirow[b]{2}{*}{ Pais } & \multicolumn{2}{|c|}{ Educación } & \multicolumn{2}{|c|}{ Salud y nutrición } & \multicolumn{2}{|c|}{ Seguridad social } & \multicolumn{2}{|c|}{ Vivienda, agua, saneamiento y otros } \\
\hline & $\begin{array}{c}\text { Gasto social } \\
\text { per cápita } \\
\text { en 1998-1999 }\end{array}$ & $\begin{array}{l}\text { Variación } \\
\text { absoluta } \\
\text { respecto de } \\
1990-1991\end{array}$ & $\begin{array}{c}\text { Gasto social } \\
\text { per cápita } \\
\text { en 1998-1999 }\end{array}$ & $\begin{array}{l}\text { Variación } \\
\text { absoluta } \\
\text { respecto de } \\
1990-1991\end{array}$ & $\begin{array}{c}\text { Gasto social } \\
\text { per cápita } \\
\text { en 1998-1999 }\end{array}$ & $\begin{array}{c}\text { Variación } \\
\text { absoluta } \\
\text { respecto de } \\
1990-1991\end{array}$ & $\begin{array}{c}\text { Gasto social } \\
\text { per capita } \\
\text { en 1998-1999 }\end{array}$ & $\begin{array}{c}\text { Variación } \\
\text { absoluta } \\
\text { respecto de } \\
1990-1991\end{array}$ \\
\hline Promedio simple & 137 & 51 & 111 & 28 & 243 & 91 & 49 & 10 \\
\hline Venezuela & 140 & 11 & 49 & .8 & 94 & 5 & 31 & .31 \\
\hline
\end{tabular}

Fonte: Cepal Panorama Social de América Latina, p. 144 (modificado)

Tabela 17: Distribuição de renda por lares 1990-1999 - Venezuela

\begin{tabular}{|c|c|c|c|c|c|c|c|c|}
\hline \multicolumn{9}{|c|}{$\begin{array}{l}\text { AMÉRICA LATINA (17 PAISES): DISTRIBUCION DEL INGRESO DE LOS HOGARES, a/ 1990-1999 } \\
\text { (En porcentajes) }\end{array}$} \\
\hline \multirow[b]{2}{*}{ Pais } & \multirow[b]{2}{*}{ Año } & \multirow{2}{*}{$\begin{array}{c}\text { Ingreso } \\
\text { promedio bl }\end{array}$} & \multicolumn{4}{|c|}{ Participación en el ingreso total del: } & \multicolumn{2}{|c|}{ Relación del ingreso medio per cápita c } \\
\hline & & & $\begin{array}{c}40 \% \\
\text { más pobre }\end{array}$ & $\begin{array}{c}30 \% \\
\text { siguiente }\end{array}$ & $\begin{array}{l}20 \% \text { anterior } \\
\text { al } 10 \% \text { más rico }\end{array}$ & $\begin{array}{c}10 \% \\
\text { más rico }\end{array}$ & $D^{10 / D^{(144)}}$ & $Q^{5} / Q^{1}$ \\
\hline \multirow[t]{3}{*}{ Venezuela } & 1900 & 8.9 & 167 & 25.7 & 28.9 & 28.7 & 121 & 13.4 \\
\hline & 1907 & 18 & 14.7 & 24.0 & 286 & 328 & 14.9 & 16.1 \\
\hline & 1999 & 12 & 14.6 & 25.1 & 29.0 & 31.4 & 150 & 18.0 \\
\hline
\end{tabular}

Fonte: Cepal Panorama Social de América Latina, p. 69 (modificado)

Índice igualmente representativo, a maioria dos países latino-americanos continuava a exibir, em fins dos anos 1990, altos níveis de desigualdade social. Por exemplo, a renda total percebida pelos $10 \%$ de lares mais ricos era superior a 19 vezes a renda dos $40 \%$ mais pobres. Do mesmo modo, entre $2 / 3$ e $3 / 4$ da população (conforme o país considerado) possuem renda per capita inferior à media geral da região. Na Venezuela, o fenômeno da concentração de renda, ao longo da década de 1990, é particularmente visível na participação da renda total dos $40 \%$ mais pobres, que declinou (de $16,7 \%$ a $14,6 \%$ ), ao passo que a participação dos $10 \%$ mais ricos ampliou-se (de $28,7 \%$ a $31,4 \%$ ). Portanto, aos que viam com ceticismo a declaração dos governos latino-americanos (como o venezuelano, que, ao lado do chileno, esteve entre os primeiros a abraçar o 
neoliberalismo) de que as políticas neoliberais propiciariam solução ao problema da pobreza ao promover o desenvolvimento econômico pela livre ação das "leis de mercado" encontrariam na crescente desigualdade que caracterizou a distribuição da renda ao fim da década um bom motivo para a descrença.

Em acréscimo a esse cenário social, os indicadores econômicos mostram também que o rentismo petroleiro sob a condução do neoliberalismo desaguou em um grave retrocesso produtivo, de consequências negativas para o conjunto da sociedade venezuelana. As três tabelas seguintes descrevem o retrocesso em termos, primeiro, do desempenho dos principais fatores de produção (trabalho e capital) ao longo das décadas de 1950 a 1990, demonstrando o desequilíbrio crescente entre eles - declinam salários e ordenados e crescem lucros e dividendos, sem que tenha havido algum avanço importante de produtividade nos anos 1990 (tabela 18); segundo, da redução de investimentos privados e públicos, denotando que a política de liberalização dos anos 1980-90 nem atraiu volumes

Tabela 18: Distribuição líquida da renda nacional por fator de produção (1950-1998)

\begin{tabular}{|l|r|r|}
\hline & $\begin{array}{c}\text { Share of wages and } \\
\text { salaries in national } \\
\text { income (annual average, } \\
\text { percent) }\end{array}$ & $\begin{array}{c}\text { Share of corporate } \\
\text { profits, dividends, rents } \\
\text { and interest payments in } \\
\text { national income (annual } \\
\text { average percent) }\end{array}$ \\
\hline $1950-1960$ & $47 \%$ & $53 \%$ \\
$1960-1970$ & $46 \%$ & $54 \%$ \\
$1970-1980$ & $49 \%$ & $51 \%$ \\
$1980-1988$ & $46 \%$ & $54 \%$ \\
$1989-1998$ & $36 \%$ & $64 \%$ \\
\hline
\end{tabular}

Fonte: DIJOHN, Jonathan. The Political Economy of Economic Liberalisation in Venezuela, p. 9

Tabela 19: Taxas de Investimentos em capital fixo 1950-1998

\begin{tabular}{|r|rrr|rrr|}
\hline & \multicolumn{3}{|c|}{$\begin{array}{c}\text { All investment } \\
\text { (as \% GDP) }\end{array}$} & \multicolumn{3}{c|}{$\begin{array}{c}\text { Non-0il investment } \\
\text { (as \% non-oil GDP) }\end{array}$} \\
\hline & \multicolumn{1}{|c|}{ Total } & Public & Private & \multicolumn{1}{c|}{ Total } & Public & Private \\
\hline $1950-60$ & 27.7 & 10.5 & 17.2 & 34.8 & 16.9 & 17.8 \\
$1960-70$ & 24.2 & 8.4 & 15.8 & 26.1 & 9.1 & 17.0 \\
$1970-80$ & 34.4 & 10.8 & 23.6 & 36.8 & 9.6 & 27.2 \\
$1980-90$ & 21.3 & 10.6 & 10.7 & 22.5 & 8.7 & 13.8 \\
$1990-98^{*}$ & 15.8 & 9.9 & 6.9 & 13.7 & 5.6 & 8.1
\end{tabular}

Fonte: DIJOHN, Jonathan. The Political Economy of Economic Liberalisation in Venezuela, p. 8 
Tabela 20: Taxas de crescimento de setores industriais (1988-1998) (crescimento médio anual em \% da produção bruta)

\begin{tabular}{|lr|}
\hline All manufacturing & $-1.8 \%$ \\
\hline 362 glass products & $6.4 \%$ \\
361 pottery, ceramics & $5.7 \%$ \\
351 industrial chemicals & $3.2 \%$ \\
311 food products & $2.8 \%$ \\
384 transport equipment & $2.4 \%$ \\
372 non-ferrous products & $1.8 \%$ \\
356 plastic products & $1.5 \%$ \\
324 footwear & $0.3 \%$ \\
321 textiles & $-0.4 \%$ \\
313 beverages & $-1.2 \%$ \\
342 printing \& publishing & $-2.5 \%$ \\
354 petroleum derivatives & $-3.2 \%$ \\
369 non-metallic minerals & $-3.7 \%$ \\
382 non-electric machinery & $-4.1 \%$ \\
371 iron and steel & $-4.6 \%$ \\
383 electrical machinery & $-5.4 \%$ \\
332 wood fumiture & $-6.0 \%$ \\
341 Pulp, paper & $-6.1 \%$ \\
355 rubber products & $-6.5 \%$ \\
352 Other chemical products & $-6.6 \%$ \\
381 fabricated metal products & $-7.6 \%$ \\
323 leather products & $-7.7 \%$ \\
322 Apparel & $-8.4 \%$ \\
390 other manufacturing & $-9.0 \%$ \\
314 tobacco & $-9.3 \%$ \\
\hline
\end{tabular}

Fonte: DIJOHN, Jonathan. The Political Economy of Economic Liberalisation in Venezuela, p. 11

massivos de investimentos produtivos, como se prometia, nem ampliou a capacidade do Estado de financiar a produção nacional (tabela 19); e terceiro, da já referida desindustrialização, contrariando as declarações de que a liberalização de mercados e a maior integração comercial representariam impulso à modernização tecnológica e, por conseguinte, ao crescimento industrial (a grande maioria dos 25 setores da indústria venezuelana relacionados na tabela 20 apresentou crescimento negativo ao longo do decênio, ao passo que alguns dos que apresentaram crescimento positivo são setores com emprego de níveis mais baixos de tecnologia (como produtos alimentícios e produtos não ferrosos). ${ }^{330}$

${ }^{330}$ Cf. DIJOHN, Jonathan. The Political Economy of Economic Liberalisation in Venezuela, pp. 811. Uma importante conclusão deste estudo sobre a adoção do neoliberalismo na Venezuela, especialmente preocupado em reduzir o papel do Estado no controle da economia, é a seguinte: "The logic of the state abdication model is to reduce the discretionary control by the state over rent creation through economic liberalisation and advocate greater democracy, which is supposed to make state action more accountable, transparent and predictable. Firstly, there is no evidence that state abdication, by reducing some type of state-created rents, reduces rent-seeking and corruption. The regulatory structure of the state is still open to influencing under any type of 
A ética e a racionalidade do capitalismo dependente, com as quais as elites governantes das nações periféricas manifestam sem acanhamento seu egoísmo de classe, regem não só o modo da associação subordinada, mas também o alcance concreto das transformações históricas internas, impondo-Ihes um padrão de mudanças que, a despeito da aura de modernização, não constituem senão alterações estratégicas destinadas a readequar a estrutura econômica nacional às mudanças externas. Por conseguinte, essas alterações estão fadadas a perpetuar a dependência estrutural, que, em todo o caso, é funcional a essas elites, e corresponde em essência ao seu "modo de vida". Por isso, para elas a dependência não é um problema, mas um cálculo, que fazem ao se combinarem à força dos interesses hegemônicos. Desse cálculo resulta a parcela interna da apropriação dualizada do excedente econômico nacional. Afirma um estudioso:

\begin{abstract}
(...) A articulação estrutural de dinamismos econômicos externos e internos requer uma permanente vantagem estratégica do polo econômico hegemônico, aceita como compensadora, útil e criadora pelo outro polo. Ainda aqui, são os momentos de crise e de transição que revelam melhor a natureza do processo. Quando se dá a eclosão do mercado moderno, a revolução comercial ou a revolução industrial, os parceiros internos se empenham em garantir as condições desejadas pelos parceiros externos, pois veem em seus fins um meio para atingir os seus próprios fins. Não que se considerem incapazes de "montar o jogo": pensam que usando tal método tornam o processo mais "lucrativo", "rápido" e "seguro". Privilegiam, assim, as vantagens relativas do polo dinâmico mais forte porque "jogam nelas" e pretendem realizar-se através delas. ${ }^{331}$
\end{abstract}

Dado o peso excepcional do petróleo na vida econômica venezuelana, era de esperar que a política de liberalização da economia dos anos finais de 1980 atingisse profundamente o setor petroleiro. De fato, essa política, explicitamente defendida como necessária a uma "mais eficiente integração do país ao mercado mundial globalizado" - mas veladamente consentida como uma exigência de fora

economic regime. Secondly, democratic reforms, and in particular, decentralisation, have not made the regulatory environment more secure. If anything, the institutional environment has become more uncertain with the decline in the legitimacy of political parties and government ministries in this period". (p. 19)

${ }^{331}$ FERNANDES, Florestan. Capitalismo dependente e classes sociais na América Latina, p. 60. 
imposta pelo capitalismo central (debatendo-se em meio à crise de acumulação que 0 atingiu) -, definiu os rumos do petróleo venezuelano por toda a década de 1990. As limitações que, como estudamos, cercaram a nacionalização de 1976, permitindo expedientes que mantiveram, ao longo dos anos, a interferência das petroleiras internacionais na atividade nacionalizada, somadas à crescente autonomia que foi alcançando a direção executiva da estatal PDVSA após 1989 em relação ao próprio Estado (especificamente em relação ao MEM - Ministério de Energia e Minas), ${ }^{332}$ tornaram mais fácil essa nova investida das empresas estrangeiras sobre as etapas da produção petroleira nacional. Sob a ofensiva neoliberal, elas contavam ainda com o suposto consenso, que então adquiria força, do benefício social das privatizações. Nesse sentido, a Política Petroleira de Abertura consistiu na orientação oficial voltada a reprivatizar a indústria petroleira venezuelana e, correlatamente, a restringir o poder do Estado de fixar legalmente o montante da tributação sobre o petróleo e de controlar os volumes de oferta e os preços do produto.

O quadro conjuntural da Abertura estava relacionado, primeiro, à queda contínua e acentuada dos preços internacionais do petróleo nos anos 1980, o que reflexamente representou uma redução do volume de receita auferida pelo Estado. Diante da falta de recursos internos no final dessa década, uma medida oficial de efeito imediato foi facilitar a entrada de capitais estrangeiros em quantidades expressivas, o que o governo procurou justificar alegando a necessidade de investimentos em agricultura, indústria manufatureira e serviços públicos básicos, tanto mais prementes quanto declinavam as condições de vida da população e cresciam as taxas anuais de desemprego. ${ }^{333}$ (Vimos, porém, que, por toda a década de 1990, os investimentos produtivos não vieram na proporção esperada). Segundo, a instabilidade financeira (que se instalara após a desvalorização do bolívar em 1983), a instabilidade política (fruto de críticas oriundas do Copei e de grupos dentro da própria $A D$, contrários ao pacote de medidas liberalizantes adotado por Andrés Pérez sem consulta prévia aos aliados políticos $^{334}$ ) e a instabilidade social (agravada pelos distúrbios populares de

\footnotetext{
332 Cf. MOMMER, Bernard. Subversive Oil. SDS-Website. Disponível em: http://www.isioma.net/sds00703.html. s/d. ${ }^{333} \mathrm{Idem}$.

${ }^{334}$ Cf. DIJOHN, J. The Political Economy of Economic Liberalisation in Venezuela, p. 15.
} 
fevereiro de 1989) tornaram o país um lugar de grande risco para investimentos do exterior, exigindo, por isso, condições mais flexíveis para a atração de capitais. Tudo isso, evidentemente, repercutiu de modo negativo na indústria nacional. No entanto, para o setor petroleiro - e sobretudo para a direção da petroleira estatal - esse quadro adverso representava o motivo e a oportunidade de ampliar a importância econômica da empresa, tanto nacional como internacionalmente, sob a condição, porém, de desatrelá-la do controle estatal e, o que era mais importante, de desvencilhá-la das políticas distributivas populistas, em conformidade com o preceito de que um Estado economicamente hipertrofiado quer como empresário quer como arrecadador de impostos - era um campo aberto à ineficiência técnica e à corrupção administrativa. Da perspectiva liberalizante, o Estado devia restringir seu papel ao de promover a liberdade e a competitividade dos mercados, o que também pressupunha, nessa conjuntura, o afrouxamento dos laços da política petroleira nacional com as tradicionais cotas internacionais fixadas pela OPEP, às quais a Venezuela desastrosamente estava obrigada a ater-se como país-membro. ${ }^{335}$ Demais disso, a racionalidade econômica ditava a necessidade de a planificação da produção petroleira ser traçada segundo critérios técnicos, formulados por profissionais especialistas em matéria petroleira descomprometidos de interesses político-partidários imediatistas. Esses os fundamentos doutrinais do programa de Abertura, que Bernard Mommer, um estudioso agudo do assunto, descreve e resume nos seguintes termos:

Pérez começou a permitir o retorno dos investidores privados à indústria petroleira venezuelana. Como parte da abertura da economia venezuelana ao mundo exterior em geral, a estatal PDVSA foi encarregada da Abertura Petroleira. O papel do MEM, que anteriormente à nacionalização havia sido de responsável pelas relações legais, contratuais e fiscais com as companhias estrangeiras foi reduzido à condição de organismo referendário. A estatal PDVSA invocou o evangelho da competitividade ao governo, alegando que os royalties e impostos teriam de ser reduzidos para atrair os investidores estrangeiros. O governo acolheu esse conselho. Além das associações para operações com óleos crus extrapesados (...), a empresa abriu a investimentos privados os campos "marginais" produtores de crus convencionais (acordos conhecidos como "Contratos de Serviços Operativos'), os quais, em 2001, chegaram a produzir em torno de 500

\footnotetext{
${ }^{335}$ Reiteradamente os executivos da PDVSA propuseram a renúncia do país a membro do cartel petroleiro internacional, em cuja fundação, recorde-se, a Venezuela tivera papel central.
} 
mil barris/dia. A maior parte desta produção não está sujeita à cota da OPEP - isto é, supõe-se que a PDVSA realize os ajustes do caso, além de estar submetida a baixos níveis de impostos. Neste processo, novamente, reduziu-se a produção da estatal sujeita a níveis altos de impostos. Além disso, nestes contratos, a PDVSA atua como um "guarda-chuva", protegendo o capital privado contra o Estado, garantindo que a companhia estatal pague uma indenização a seus "sócios" no caso de ocorrer alguma mudança legislativa em detrimento deles. Estes contratos, por outro lado, incluíram a arbitragem internacional, um artifício que a Venezuela jamais havia aceitado até então. Por último, mas não menos importante, no caso de disputas, as exportações da estatal PDVSA - renunciando a companhia nacional contratualmente a seus privilégios de empresa pública - estão sujeitas a embargo. Não obstante, o Congresso aprovou todos esses contratos. Tendo atuado em favor dos investidores estrangeiros privados, a PDVSA, do mesmo modo, insistiu em uma baixa tributação também para si própria. Sua melhor oportunidade chegou no caótico ano de 1993. O presidente Pérez foi destituído de seu cargo, principalmente em consequência das duas tentativas de golpe de Estado em 1992. Um governo provisório [presidido pelo escritor Ramón José Velásquez] muito débil assumiu o poder e aceitou uma nova Lei de Imposto sobre a Renda com generosas isenções por inflação. Ademais, o poder discricionário do governo sobre o imposto para as exportações, que havia sido criado em 1970 para permitir a arrecadação de lucros extraordinários em períodos de altos preços foi suprimido progressivamente, para desaparecer por completo em 1996. Estas medidas contribuíram para uma significativa queda da receita petroleira. $^{336}$

De fato, foi rapidamente alcançado o objetivo de reduzir a arrecadação fiscal do Estado na produção petroleira. Segundo dados oficiais da estatal, a receita bruta da empresa foi, em 1981, de 19,7 bilhões de dólares, pagando ao Estado o montante fiscal de 13,9 bilhões de dólares. Em 2000, a receita bruta chegou a 29,3 bilhões de dólares, cabendo ao Estado o montante de 11,3 bilhões. Ou seja, "(...) por cada dólar de receita bruta, a PDVSA pagou ao Estado em 1981 o correspondente a 71 centavos em rendas, royalties e impostos, e em 2000 somente 39 centavos." (Cf. sítio eletrônico oficial PDVSA - Petróleos de Venezuela, S.A. - www.pdvsa.com) A tabela abaixo, ainda de acordo com informações oficiais da empresa, apresenta a evolução da relação contribuição (fiscal)/gastos (internos) da estatal petroleira, destacando a brusca inversão dos valores relativos a partir de 1990 (de uma média aproximada de 80/20 entre 1976 e 1989, a relação decairia a 20/80 em 2000). Conclui-se: "Em 2000, as receitas

\footnotetext{
336 MOMMER, Bernard. Subversive Oil. SDS-Website. Disponível em: http://www.isioma.net/sds00703.html. s/d.
} 
petroleiras foram de 50 bilhões de dólares, dos quais o Estado venezuelano recebeu 10 bilhões (20\%), e os restantes 40 bilhões foram gastos nos denominados custos operativos PDVSA e na transferência da renda petroleira ao capital petroleiro internacional ou ao capital privado nacional. Transferir lucros ao exterior foi o verdadeiro resultado da internacionalização. De 1995 a 2000, a empresa esteve transferindo, de suas contas domésticas para suas filiais estrangeiras, uma média de 500 milhões de dólares anuais em lucros". (PDVSA)

Tabela 21: Relação contribuição/gastos PDVSA (1976-2000)

\begin{tabular}{|rrrr|}
\hline \multicolumn{1}{|c|}{ Periodos } & $\begin{array}{c}\text { Aportes a la } \\
\text { Nación }(\mathbf{A})^{*}\end{array}$ & $\begin{array}{c}\text { Gastos de PDVSA } \\
(\mathbf{B})^{*}\end{array}$ & Relación A/B \\
\hline $1976-1979$ & 120.092 & 30.267 & $80 / 20$ \\
$1980-1984$ & 271.089 & 62.354 & $81 / 19$ \\
$1985-1989$ & 563.181 & 127.977 & $81 / 19$ \\
$1990-1996$ & 7.735 .982 & 3.795 .966 & $67 / 33$ \\
2000 & 10.000 .000 & 40.000 .000 & $20 / 80$ \\
\hline
\end{tabular}

*Millones de bolívares (PDVSA 1976 al 2002)

Fonte: PDVSA - Petróleos de Venezuela, S.A. (www.pdvsa.com)

A Abertura petroleira encerrou malfadadamente o século XX venezuelano um século assinalado pelas lutas da sociedade por conquistar a soberania econômica em relação a suas riquezas naturais. Contudo, ainda que a política de reprivatização (ou reinternacionalização) ${ }^{337}$ do petróleo não tenha nunca destoado

\footnotetext{
${ }^{337} \mathrm{O}$ artifício legal que permitia à direção executiva da PDVSA reprivatizar a exploração petroleira era o mesmo que, duas décadas antes, havia ensejado mutilações drásticas ao projeto de nacionalização do petróleo. Trata-se do art. 5 da Lei Orgânica que Reserva ao Estado a Indústria e o Comércio de Hidrocarbonetos, de janeiro de 1976, que facultava as formas de associação como os convênios de assistência técnica e os de comercialização (veja-se nota 252, supra). Com a Abertura dos anos 1990, recorre-se aos convênios operativos, aos convênios de associação e às associações estratégicas. Segundo o valiosíssimo trabalho de Parra Luzardo: "Durante el lapso de 1994-1998, realmente la apertura petrolera, diseñada por la tecnoestructura de Pdvsa, cobró exagerada fuerza. En efecto, se han puesto en ejecución diversas modalidades de apertura, tales como los convenios operativos, las asociaciones estratégicas, los convenios de asociación para la exploración a riesgo de nuevas áreas y la producción de hidrocarburos, bajo el esquema de ganancias compartidas. De igual forma, mediante ley se autorizó la venta del 49 por ciento del capital social de la Petroquímica (Pequiven), así como la apertura del mercado interno de la gasolina y otros combustibles derivados de los hidrocarburos. También se ha avanzado en propiciar la participación del capital transnacional en las actividades correspondientes de la industria del gas natural, que por leyes está reservada al Estado venezolano. Para garantizar todo ese proceso de apertura ilimitada se puso en vigencia, a partir de 1998, la nueva organización de Petróleos de Venezuela, S.A. (LUZARDO, Gastón Parra. Análisis de la actividad petrolera en el
} 
da tradicional ideologia e da prática comum das elites governantes venezuelanas, sempre dispostas a "privilegiar as vantagens relativas do polo dinâmico mais forte" para nelas "jogar e realizar-se", seu impacto negativo sobre o desenvolvimento do país foi grande quando comparado a épocas anteriores. Por isso, a Abertura e seus desdobramentos têm merecido a atenção crítica de estudiosos da questão, sobretudo daqueles mais ciosos das possibilidades de desenvolvimento nacional e democrático através do petróleo. É, pois, já ampla e profunda a reflexão de acadêmicos e publicistas sobre o assunto. Aqui, neste brevíssimo escorço da Abertura, interessa-nos apenas destacar sua significação essencial como política de transnacionalização globalizadora ${ }^{338}$, importante para a demonstração da proposição da perpetuidade da dependência estrutural venezuelana sob o influxo da associação subordinada dos setores sociais dominantes. Importante também para explicar a ruína final do puntofijismo, incapaz de preservar o poder quando escassearam os meios de manter 0 populismo de conciliação e as políticas redistributivas. Mas, se a Abertura encerrou o século, não encerrou todavia a luta. E esta continua sendo vigorosa, e exposta com clareza quanto ao significado da política que a deve fundamentar:

(...) essa velha política que reaparece a cada manhã com um novo nome ou moda. Agora é a vez da Abertura, e em pouco tempo - já estamos a caminho, será a da privatização da PDVSA. É esse o meio pelo qual chegamos a ter, supostamente, a segunda empresa petroleira a nível mundial e, ao mesmo tempo, cinco sextas partes da população venezuelana postas entre os estratos de necessidades básicas insatisfeitas, pobreza crítica e miséria extrema. (...) A política petroleira venezuelana deve ser formulada claramente a nível estatal, isto é, deve ser estabelecida com a participação de todos os poderes públicos. A justificativa é dúplice: a primeira refere-se a que, quaisquer que sejam os titulares da propriedade sobre os recursos do subsolo e os ativos dessa indústria, o Estado está na obrigação, claramente estabelecida pela Constituição e pelas leis, de controlar, regular e fiscalizar qualquer atividade produtiva que se desenvolva em seu território. A segunda refere-se a essa condição atual, que pode ser revertida no tempo, mas enquanto existir deve ser exercida plenamente e sem complexos: o Estado é o proprietário dos recursos e da indústria erigida para sua exploração. (...) Acima de tudo, essa política petroleira, enquanto política reivindicadora dos lesados direitos dos proprietários coletivos, deve ser também o produto de uma ampla consulta em todos os estamentos da sociedade. Para isso, é preciso conceder participação

lapso 1994-1998. Soberania.info.. Abril/1999. Disponível em http://www.soberania.org/ Articulos/ articulo_289.htm.)

${ }^{338}$ Cf. LUZARDO, Gastón Parra. Análisis de la actividad petrolera en el lapso 1994-1998. 
real a todas as organizações representativas que não a exercem diretamente nos poderes públicos centrais, como a CTV, Fedecámaras, grêmios profissionais, universidades, corporações de desenvolvimento regional, estados e municípios, sem esquecer, desde já, esse poder público não deliberante que são as Forças Armadas. ${ }^{339}$

Em dezembro de 1998, a eleição do antigo militar rebelde Hugo Chávez representou a vitória de um novo discurso sobre o significado do petróleo para o destino do país, bem como o triunfo de um novo conteúdo nas relações internacionais, cuidadosamente redefinidas doravante como de defesa contra a avidez e a beligerância imperialistas, especialmente norte-americanas. A vitória eleitoral foi também, ao menos em parte, uma resposta popular, por meios institucionais, à usurpação neoliberal da riqueza pública venezuelana. Dez anos antes, entretanto, o Caracaço já representara uma tentativa semelhante, porém espontânea e não organizada, de reação popular às iniquidades sociais, que o petróleo podia haver minimizado e que a política neoliberal certamente agravou. O capítulo seguinte procura narrar e explicar esse episódio - de longe, o mais confrangedor da história contemporânea venezuelana.

${ }^{339}$ POTELLÁ, Carlos Mendoza. Apertura petrolera: nombre de estreno para un viejo proyecto antinacional. Soberanía.org. 06/04/03, pp. 25-26 


\section{Cap. 6: O Caracaço e os levantes militares de 1992}

Mal acabara de se instalar o governo de $\mathrm{C}$. Andrés Pérez em meio à expectativa geral por ele mesmo construída sobre certa "nostalgia" do primeiro mandato, a sociedade venezuelana foi sacudida, durante os últimos dias de fevereiro e primeiros dias de março de 1989, pela irrupção de uma brutal revolta popular, que, de início, tomou Caracas e algumas áreas adjacentes, espalhandose em seguida para várias outras cidades importantes do país. Por cinco dias aproximadamente (cinco em Caracas, um pouco menos nas outras cidades), a Venezuela se encontrou mergulhada em gravíssima convulsão social, que explodira súbita e impremeditadamente, sem liderança política, com a atuação quase exclusiva de indivíduos dos setores populares pobres, e que, contudo, desdizia da imagem internacional de relativa tranquilidade que o país desfrutava após a "pacificação" definitiva da guerrilha. Ainda que distúrbios populares tenham sido sempre fenômenos mais ou menos corriqueiros no cenário latinoamericano, imerso em pobreza, criminalidade e instabilidade política, o aspecto mais surpreendente dessa revolta venezuelana (denominada de El Sacudón ou de El Caracazo, apesar de não haver-se restringido apenas à capital) reside, antes de tudo, no grau superlativo que alcançou a violência desencadeada primeiro, das ações dos revoltosos, que, no calor dos protestos, atearam fogo a coletivos e automóveis, organizaram barricadas e bloqueios de ruas, promoveram depredações e saques de estabelecimentos comerciais, como também reagiram, em uns poucos casos, enfrentando armados as forças de segurança; segundo, e sobretudo - das ações repressivas dos corpos policiais e militares (Guarda Nacional, Polícia Metropolitana e Exército), convocados incontinenti pelo governo para debelar os distúrbios e "restabelecer a ordem". Sobrepujando os dias mais cruentos do combate às frentes guerrilheiras, a intensidade da repressão oficial para a qual chegou-se a suspender as garantias constitucionais e a convocar, para Caracas, 10.500 efetivos militares - atingiu níveis tais de truculência que, ao 
final dessa Semana Trágica ${ }^{340}$, reconhecia-se publicamente um total de mais de 300 mortos e 1.500 feridos, além de um sem-número de detidos, quase todos pessoas comuns moradoras dos bairros populares. O governo admitiu, a princípio, a suma gravidade dos acontecimentos, os quais o próprio presidente descreveria à imprensa estrangeira como sendo produto da "ação dos pobres contra os ricos", mas procurou negar os excessos e a ilegitimidade das ações da polícia e do exército contra a população. Porém, as investigações que se seguiram - iniciadas ainda em 1989 por tribunais penais ordinários e militares a partir de denúncias apresentadas por familiares de vítimas e por grupos não governamentais - confirmaram o que a imprensa diária viera noticiando alarmada naqueles dias de furor repressivo, ou seja, a ocorrência, entre outras ações, de invasões arbitrárias de domicílios por policiais e soldados, muitas delas seguidas de execuções sumárias de "suspeitos"; disparos indiscriminados com armas de guerra (os FAL) contra residências e civis inermes, especialmente durante as horas do toque de recolher; prisões ilegais e torturas; desaparecimentos forçados e inumações coletivas clandestinas feitas pelas forças de segurança para ocultamento e destruição de evidências dos atos criminosos. ${ }^{341}$ Imediatamente, inúmeras declarações públicas de jornalistas, intelectuais e políticos contestaram os números oficiais de mortos e feridos. ${ }^{342}$ Uma década depois, essas investigações - que por longos anos haviam esbarrado na "(...) negligência dolosa com ânimo de dificultar o estabelecimento dos fatos" ${ }^{343}$ por parte dos órgãos

\footnotetext{
${ }^{340}$ Cf. IZARD, Miquel. El poder, la mentira y la muerte: De El Amparo al Caracazo. Caracas: Fondo Editorial Tropykos, 1991, p. 69-74.

${ }^{341}$ A gravidade desses fatos levou a que, em 1999, a Corte Interamericana de Direitos Humanos julgasse e condenasse o Estado venezuelano pelas ações de fevereiro/março de 1989. Cf. CORTE INTERAMERICANA DE DERECHOS HUMANOS. Caso del Caracazo Vs. Venezuela. Sentencia de 11 de noviembre de 1999; e Idem. Sentencia de 29 de agosto de 2002. (Especialmente: V - Hechos probados). Disponíveis em www.corteidh.or.cr. Nesta última sentença, a Corte estabeleceu as reparações e custos a serem feitos pelo Estado venezuelano a vitimas sobreviventes e a familiares de vítimas fatais do Caracaço. ${ }_{342}$ Cf. IZARD, M. Op. cit. p. 75-94.

${ }^{343}$ REPÚBLICA BOLIVARIANA DE VENEZUELA. Poder Ciudadano. Defensoría del Pueblo. A 18 años de "El Caracazo": Sed de justicia. Caracas: febrero/ 2007, p. 5. Este informe oficial do governo venezuelano, acatando as decisões da Corte Interamericana, reconheceu: "Durante los sucesos de El Caracazo, se violó toda la normativa internacional de derechos humanos relativo al uso de las armas por parte de los funcionarios encargados de hacer cumplir la ley, ya que las fuerzas policiales y armadas venezolanas atacaron desproporcionada e indiscriminadamente a la población civil, conforme a un plan de guerra antisubversiva [conhecido como Plano Ávila]. Con base en el anteriormente expuesto, la Defensoría del Pueblo ha podido determinar además el estado de cumplimiento de las decisiones de la Corte Interamericana de Derechos Humanos, y ha procedido a valorar el cumplimiento de éstas, considerando que el mismo ha sido insuficiente, no
} 
oficiais - ainda encontravam dificuldade para esclarecer as circunstâncias de várias mortes e desaparecimentos. Embora, por isso, o número de vítimas jamais pudesse ser estabelecido com exatidão, algumas organizações de direitos humanos do país estimam que a cifra deveu alcançar, provavelmente, os 2 ou 3 mil mortos ${ }^{344}$, o que torna o Caracaço o mais dramático fato da vida social venezuelana e o de mais profunda e penosa memória em sua história recente.

Justificadamente, o grau assombroso de violência e as trágicas consequências da ação estatal fizeram dessa revolta um tema que tem recebido grande consideração dos estudiosos da sociedade venezuelana. Estes, em geral e a despeito de ressaltarem o traço inopinado da explosão popular, apontam algumas causas próximas e imediatas para o seu desencadeamento - causas que, concorda-se, eram bastante visíveis naquela conjuntura nacional. Entre as primeiras estava a queda contínua, ao longo de toda a década de 80, dos padrões de vida das classes populares e da qualidade dos serviços públicos (queda provocada, como vimos, pela diminuição das receitas do Estado em virtude do descenso dos preços internacionais do petróleo, e agravada pela desvalorização do bolívar e o aumento da dívida externa) ${ }^{345}$; também, o crescente descrédito das instituições oficiais, particularmente do Poder Executivo, marcado por sucessivas denúncias de corrupção administrativa - como, por exemplo, as que envolveram o governo de Jaime Lusinchi (1984-1989), sua amante Blanca Ibáñez e as fabulosas fraudes com dólares praticadas por funcionários do RECADI denúncias vindas a público poucos dias apenas antes da revolta. ${ }^{346} \mathrm{~A}$ isso

obstante a ello, se han dado algunos avances." (p. 152). Em fevereiro de 2007, o Ministério Público da Venezuela declarou publicamente que deveria ser julgado todo o Alto Comando policial, militar e político da época dos crimes, e que solicitaria a extradição do antigo presidente Carlos Andrés Pérez, àquela altura no exílio. Não obstante isso, ainda hoje, 27 anos depois dos terríveis acontecimentos, nenhum responsável pelos crimes de fevereiro/março de 1989 foi sequer preso ou julgado. Resta, pois, advertir que, para o juízo da História, se a nódoa dos crimes recai diretamente em seus perpetradores, não inquina menos àqueles que, ontem ou hoje, sendo obrigados moral e legalmente a investigar e a punir, furtam-se a fazê-lo.

${ }^{344} \mathrm{Cf}$. Comité de Familiares de las Víctimas de los sucesos ocurridos entre el 27 de febrero y los primeros días de marzo de 1989 (COFAVIC), em http://www.cofavic.org; e Programa Venezolano de Educación-Acción en Derechos Humanos (Provea), em http://www.derechos.org.ve/provea.

${ }^{345}$ Veja-se o Cap. 5, supra.

${ }^{346} \mathrm{O}$ escândalo do RECADI (Regime de Câmbios Diferenciais), do Ministério da Fazenda, envolveu, entre outras coisas, tráfico de influência e concessões irregulares de divisas preferenciais a empresas importadoras, com o consequente superfaturamento de importações (em alguns casos, por empresas fantasmas). Estima-se que esse esquema - "(...) un instrumento utilizado por funcionarios públicos, empresarios, políticos y particulares para traficar influencias, otorgar y recibir privilegios y ventajas económicas, evadir leyes y lucrarse en grupo e individualmente, en detrimento de los intereses nacionales" - tenha permitido a apropriação ilícita 
somaram-se alguns episódios de grave violência oficial que provocaram forte indignação pública, como os casos da Revolta de Mérida, em março de 1987 (na qual ocorreram violentos distúrbios por toda a cidade, durante cinco dias precipitados pelo incidente do assassinato impune de um estudante - e que, estendendo-se a outras cidades, foram brutalmente reprimidos pelo governo) e o Massacre de El Amparo, em outubro de 1988 (no qual 14 pescadores dessa aldeia na fronteira com a Colômbia foram mortos pelo Comando Especial de Contrainsurgência José Antonio Páez - CEJAP - o qual, contudo, apresentou a falsa versão de serem aqueles homens um grupo de guerrilheiros colombianos em emboscada. A revelação das circunstâncias verídicas, graças ao testemunho de dois pescadores que haviam milagrosamente escapado ao massacre, desatou uma série de protestos violentos e de saques, motivados também, em grande medida, pela obstinação do governo em não reconhecer as evidências de assassínios e não punir os culpados). ${ }^{347}$ As razões imediatas do Caracaço, por sua vez, ligam-se ao repúdio e à frustração geral ante o anúncio, feito por Andrés Pérez em 16 de fevereiro, da adoção de um programa de ajuste econômico ("el paquete") que, acordado junto ao FMI, entre suas medidas estabelecia a liberação de preços de gêneros básicos (como a gasolina) e de tarifas dos serviços públicos, a par do corte de subsídios para alguns desses gêneros. Tais medidas contrariavam abertamente as promessas feitas pelo presidente, havia poucos dias, de não sacrificar o país a exigências impopulares de programas neoliberais. (De fato, como se verá adiante, foi justamente a elevação do preço das passagens do transporte urbano o estopim da revolta). Além disso, o ambiente de repulsa popular fora ainda alimentado, dias antes, pelas circunstâncias da "coroação de Pérez" - como acabou sendo jocosamente chamada a posse do novo presidente, celebrada em meio a grande pompa - e cujos gastos imoderados contrastariam, naqueles dias, com a situação de carestia e escassez

de um montante próximo a 15 bilhões de dólares (!) por indivíduos e empresas privadas. (Cf. BEROES, Agustín. RECADI: La gran estafa. Planeta, 1990. Edição digital disponível em: http://www.angelfire.com $/ \mathrm{nb} / 17 \mathrm{~m} /$ noolvidar.html; veja-se também: MAYA, Margarita López. Luta hegemônica na Venezuela, 2010, p. 40.)

${ }^{347}$ Estes dois importantes episódios (a Revolta de Mérida e o Massacre de El Amparo) estão descritos e analisados detalhadamente, entre outras obras, em IZARD, Miquel. Op. cit., pp. 15-59, e em MAYA, Margarita López. Op. cit., pp. 48-52. Para a narrativa que se lerá em seguida, dos sucessos do Caracaço, valemo-nos amplamente das informações desses dois trabalhos, que reconstruíram os acontecimentos a partir de fontes jornalísticas daqueles dias (sobretudo os diários El Nacional e El Universal, de Caracas). 
de mercadorias de primeira necessidade, as quais todos sabiam estarem açambarcadas por comerciantes temerosos quanto ao alcance do pacote de medidas prestes a ser anunciado. ${ }^{348}$ Às vésperas do Caracaço, portanto, problemas acumulados durante uma década concorriam com motivos circunstanciais para transformar o sentimento de insatisfação popular, longamente represado, em uma verdadeira "(...) mistura explosiva [que] precisava apenas de uma faísca para incendiar-se. O 27 de fevereiro de 1989 aproximou da mistura a centelha necessária". 349

É quase unânime entre os estudiosos o reconhecimento de que o Caracaço constitui uma linha divisória na história contemporânea do país, inserida entre uma época de suposta prosperidade e liberdade e outra, de estagnação e crise político-social. Considerada assim em uma perspectiva ampla, a eclosão da revolta assinalaria, no plano externo, um ponto de virada dos movimentos sociais em todo o continente latino-americano, ao inaugurar um tempo de sucessivas revoltas populares que sobreviriam ao agravamento da miséria social dos anos 1980-1990 ${ }^{350}$ No plano interno, indicaria a debilidade institucional que se ia revelando no país, e cuja expressão mais nítida se encontraria na crise de representatividade dos partidos hegemônicos, suplantados afinal, em 1998, por novas forças políticas ascendentes. ${ }^{351}$ As interpretações teóricas do Caracaço condicionadas, em grande medida, por seus traços mais chocantes, isto é, o inesperado da revolta, suas funestas dimensões e a crueza da repressão - têmse detido em algumas questões cruciais. Por exemplo: por que ocorreu uma revolta popular tão grave durante um regime considerado democrático?; ou, por que, diante do protesto popular, a resposta pronta e incisiva dada pelo Estado venezuelano - o qual era historicamente visto, até aquele momento pelo menos, como produto da luta pela legalidade democrática e o fator central da "conciliação de classes" - incorreu em tamanha atrocidade, comparável somente aos desmandos das mais cruéis ditaduras militares da época?; ou, ainda, por que a

\footnotetext{
${ }^{348}$ Acrescenta-se, nesse ambiente de indignação popular, um outro episódio: "(...) En los últimos días de febrero, la familia Cisneros, tan vinculada a CAP [Pérez], celebró con lujo de boato y derroche, la boda de uno de los vástagos a través de una fiesta de Canaá que la prensa del corazón se apresuró a calificar de 'boda del siglo'". (IZARD, M. Op. cit. p. 70).

${ }^{349}$ MAYA, Margarita López. Op. cit., p. 48.

${ }^{350} \mathrm{Cf}$, acima, nota 3.

${ }^{351}$ Cf, por exemplo, MARTínEZ, José Honorio. Causas e interpretaciones del Caracazo. Revista Historia Actual Online, № 16, Primavera, 2008, pp. 85-92.
} 
multidão insurgida não se voltou contra figuras e partidos políticos, mas se dirigiu principalmente contra serviços públicos e estabelecimentos comerciais, sob a forma de depredações e saques? ${ }^{352}$ Tendo em mente essas e outras questões, apresentamos a seguir uma narrativa concisa dos fatos mais importantes da revolta de 1989, para, à continuação, expor algumas de suas principais interpretações teóricas. Ao fim, aduzimos uma breve consideração sobre a realidade do Estado democrático em sociedades subdesenvolvidas.

Os fatos: Na manhã de 27 de fevereiro, uma segunda-feira, principiaram tumultos em algumas áreas dos subúrbios de Caracas em razão dos primeiros protestos contra os novos preços de tarifas cobrados no transporte coletivo urbano. Com efeito, no fim de semana anterior (25 e 26), haviam sido decretados o aumento de $100 \%$ dos preços da gasolina e, por conseguinte, o aumento das tarifas do transporte público. Apesar de o índice estabelecido entre o governo e as empresas de transporte ter sido de $30 \%$ de reajuste das passagens, os valores de fato cobrados dos usuários estavam muito acima disso, o que motivou as primeiras queixas e altercações com funcionários das empresas: no terminal do Novo Circo de Caracas e nas cidades-dormitório de La Guaira, Cátia La Mar e Guarenas, estudantes e populares exigiam a observância dos valores oficiais divulgados, e puseram-se então a impedir a saída e circulação dos ônibus dos terminais. Protestos semelhantes precipitaram-se também nas cidades de Barquisimeto, San Cristóbal, Mérida, Maracay, Barcelona e Porto La Cruz, como também em Maiquetía e Naiguatá, Los Teques, Porto Ordaz e Maracaibo - todos provocados pelas novas tarifas e pelo abuso das empresas, que, em alguns casos, pretenderam aplicar um aumento de 100\%. Em Valência, Carora, Acarigua e Cidade Guayana, os protestos começariam à tarde. No dia seguinte (28), Guanare, San Felipe, Cumaná, Calabozo, Barinas, Maturín, Ciudad Bolivar e Porlamar registrariam também manifestações e distúrbios. Para muitas pessoas, de já exígua renda, a circunstância desastrosa de o aumento das tarifas ocorrer no final do mês, antes do recebimento dos salários, acirrou ainda mais o agastamento geral. ${ }^{353}$

\footnotetext{
${ }^{352}$ Cf. MAYA, Margarita López. Op. cit., p. 53.

${ }^{353}$ Cf. MAYA, Margarita López. Op. cit., p. 57 et seq.
} 
Nas primeiras horas da manhã de 27, em Guarenas, a uns $40 \mathrm{~km}$ a leste de Caracas, a exaltação popular já estalara para além das simples reclamações verbais contra as tarifas: dois veículos haviam sido incendiados e o Centro Comercial Miranda foi alvo de saques, sem que a polícia pudesse intervir (por falta de efetivos e armas). Houve em seguida, nessa cidade, depredações a estabelecimentos comerciais, a postos da polícia e ao terminal de transporte público. ${ }^{354}$ Enquanto isso, em Caracas, a multidão insatisfeita do Novo Circo, engrossada por camelôs e outros populares, dirigiu-se para as avenidas do centro da cidade, onde levantaram as primeiras barricadas. O trânsito de veículos começou a congestionar-se à medida que ganhava volume a revolta, cujas palavras de ordem voltavam-se agora contra todas as novas medidas do governo. Ao começo da tarde, estudantes da Universidade Central da Venezuela (UCV) somaram-se ao grupo inicial, e participaram também da obstrução de vias públicas do centro. Com o correr do dia, crescia a animosidade dos manifestantes: no centro da cidade e adjacências, veículos de transporte de alimentos eram parados e saqueados (como ocorreu na importante via Francisco Fajardo, que cruza Caracas, e cujas pistas foram interrompidas pelos populares); vários coletivos foram incendiados (sendo, inclusive, os bombeiros impedidos pela multidão de chegar ao local); carros e caminhões, uma vez retidos ou destruídos, eram usados para interromper outras ruas e avenidas; colunas de fumaça indicavam incêndio em diversos pontos da cidade. Por essa altura, a Polícia Militar interveio, embora, inicialmente, de modo hesitante. Contudo, ao final da tarde, já se contavam as primeiras vítimas fatais, como a jovem Yulimar Reyes, estudante da UCV, alvejada por um tiro. Não obstante, até esse momento, o governo federal, por desinformação ou negligência, dera pouca atenção à situação das ruas. $O$ presidente, àquelas horas fora de Caracas, não se pronunciou nem adotou alguma medida. A movimentação popular prosseguia e, próximo do anoitecer, o estado caótico da circulação pública agravou-se ainda mais quando, já sem transitarem os ônibus, interrompeu-se o serviço de metrô de Caracas: multidões de funcionários e trabalhadores se viram obrigadas a

354 "(...) Entre os jornalistas e cinegrafistas que faziam a cobertura, afirmou-se que existia em Guarenas, desde o fim de semana anterior, uma grande tensão, pois os moradores previam o desacato dos condutores ao aumento oficial da tarifa". (MAYA, M. López. Op. cit., p. 58) A cidade de Guarenas parece ter sido o foco inicial da revolta, embora informações dos diários indiquem que os distúrbios foram mais ou menos simultâneos a outros lugares. 
regressar a pé para casa - um contratempo que não seria sem implicações, pois as pessoas, "(...) [p]elo caminho, iam adquirindo concretamente consciência da magnitude do protesto que se desenrolava; depois disso, muitos populares se incorporariam ao movimento". 355

Esse primeiro dia de tumultos transcorreu com incidentes semelhantes, de igual gravidade, nas outras grandes cidades do país (Maracaibo, Barcelona, Porto la Cruz etc.). E, tal como em Caracas, todas elas registrariam saques também durante a noite, especialmente nas áreas comerciais, onde a população aproveitou para invadir mercados, padarias e lojas de eletrodomésticos. Ao amanhecer de 28, terça, a revolta cobrou maior ânimo, talvez estimulada pelo silêncio dos representantes do governo diante do acontecido na véspera. A partir daí, em Caracas, a população levantada transformou a capital em cenário de novos e mais graves distúrbios, que, embora vistos (talvez um pouco irrealisticamente) como uma "espécie de catarse coletiva" ${ }^{356}$, exprimiam, sem dúvida, o paroxismo de um transbordante inconformismo popular. Fosse sob a forma de um "saque festivo" a bens de consumo (inalcançáveis, aliás, por outro modo), fosse sob a forma de protestos contra a injustiça cotidiana e a autoridade negligente, o certo é que o sentimento de revolta popular nada tinha da natureza de simples "(...) atos de vandalismo contra a segurança pessoal e familiar dos venezuelanos" $^{\prime 357}$, como o julgou, enfim pronunciando-se, o governo federal. É o que confirmam os trechos da descrição seguinte, referentes ao segundo dia da sedição:

(...) Em Caracas, as principais avenidas foram tomadas por centenas de manifestantes, que destruíam portas e vitrinas e se apoderavam de tudo. Entre as palavras de ordem que eram ouvidas ou ficaram pichadas nas paredes e muros das ruas, exclamava-se: "O povo tem fome!", "O povo está furioso!", "Basta de mentiras!". Em alguns casos, empunhavam-se bandeiras e cantava-se o hino nacional, ao irromper nos estabelecimentos. As multidões impediram o trânsito, levantando grandes fogueiras no meio das principais avenidas, e interromperam com elas todas as entradas da cidade. Foram relatados casos de especial enfurecimento contra estabelecimentos de imigrantes chineses, libaneses e portugueses, em razão do fato de serem eles considerados os responsáveis pela escassez (por açambarcamento de mantimentos)

\footnotetext{
${ }^{355}$ MAYA, M. López. Op. cit., p. 60.

${ }^{356}$ IZARD, M. Op. cit. p. 70.

357 "Decreto de Suspensão de Garantias", de 28 de fevereiro de 1989. Citado em: RBV. A 18 años de "El Caracazo", p. 27.
} 
que havia ocorrido nas semanas anteriores. Algumas reportagens assinalam também que foram vistos grupos armados (alguns, inclusive, com uniformes de polícia e rostos ocultos por lenços) que chegavam com caminhões para levar mercadorias das lojas. Além dos estabelecimentos de comércio de alimentos, foram saqueadas lojas de eletrodomésticos, roupas, ferramentas e outros produtos. Na Avenida Andrés Bello não restou sequer um único estabelecimento intacto. Tampouco algum na Avenida Nova Granada. Nas avenidas San Martín e Lecuna, as portas metálicas ficaram destroçadas e o chão coberto de paus e pedras. (...) Além disso, verificou-se também o amotinamento dos reclusos de El Junquito e Los Flores de Cátia, que queimaram colchões e provocaram tumulto. Os doentes mentais do hospício de Cátia, em número de aproximadamente sessenta, foram liberados na tarde desse dia, e apenas cinco deles regressariam nos dias seguintes. (...) As reportagens tendem a indicar que em boa parte desse dia a polícia foi menos severa ao reprimir e, por vezes, solidarizou-se com a população, participando das ações. Em Antímano, por exemplo, a PM, diante da incapacidade de controlar a situação, chegou a um acordo com os moradores, deixando entrar as mulheres e crianças nos estabelecimentos comerciais para saquear, enquanto os homens permaneciam no morro (onde ficam suas residências), nas barricadas, esperando as mercadorias. ${ }^{358}$

Nesse e nos dias seguintes, fatos similares continuaram a se repetir por quase todo o pais, misturando em um mesmo ato pilhagem, destruição e protesto, e envolvendo numa única onda de revolta pessoas pobres, pequenos criminosos, domésticas, desempregados, estudantes e trabalhadores. Era a resposta instintiva do povo ao "beijo mortal do FMr" (segundo diria, logo depois, o presidente da AD, Gonzalo Barrios), resposta com a qual o próprio governo, por sua inércia, parecia transigir. Mas, a repressão oficial desatou-se enfim. E, uma vez efetivamente iniciada, realizou-se pronta e feroz (advertida talvez por alguma lembrança longínqua da lição de O. Barrot, "La légalité nous tue."): ao início da noite de 28, o presidente Andrés Pérez anunciou, pela televisão, a suspensão de garantias constitucionais fundamentais (a inviolabilidade dos domicílios e o direito à liberdade de trânsito, reunião, expressão e manifestação pacífica), estabeleceu o estado de sítio e impôs o toque de recolher, proibindo-se a circulação de pessoas entre as seis horas da tarde e as seis da manhã. ${ }^{359}$. Daí em diante, as forças policiais e do Exército, em ação desde a madrugada anterior, obedeceriam às diretrizes de um secreto plano militar (Plano Ávila), de restabelecimento imediato da ordem social. Com essas medidas, deu-se aos corpos de segurança

\footnotetext{
${ }^{358}$ MAYA, M. López. Op. cit., p. 61-62.

359 Veja-se o Decreto de Suspensão de Garantias, de 28 de fevereiro de 1989. Citado em: RBV. A 18 años de "El Caracazo", p. 27-28.
} 
livre curso à violência repressiva: como se fossem operações de guerra, soldados e policiais atacaram as áreas tomadas pela revolta com disparos aleatórios contra a multidão, vitimando desconsideradamente trabalhadores e transeuntes ${ }^{360}$; em bairros populares, nos quais alguns grupos de delinquentes reagiram a tiros contra os soldados, ocorreu o ametralhamento indiscriminado das residências, acompanhado nas horas seguintes por invasões das casas, prisões (ilegais e seguidas de tortura ${ }^{361}$ ) e mesmo execuções ${ }^{362}$; durante a noite, corpos de vítimas foram enterrados em valas comuns e clandestinas. Nas horas do toque de recolher, destacamentos de soldados, ansiosos por reprimir qualquer transgressão, excederam-se em extremos de brutalidade inconsequente. ${ }^{363}$ Os

${ }^{360}$ Um episódio tragicamente célebre desses dias deu-se nas escadarias de Mesuca, em Petare, quando um grupo de soldados do Exército disparou contra as pessoas que transitavam pela área ou procuravam aí se abrigar dos tumultos das ruas vizinhas. Narra um padre dessa paróquia, Matías Camuñas, testemunha dos fatos: "(...) Allí le di la unción a dos muertos: uno, con un disparo de FAL en el pecho; $y$ otro que parecía que tenía tiempo en el lugar. También pude ver a una muchacha herida y a quien posteriormente le cortaron la pierna en el Hospital Pérez de León. (...) En la noche hicimos una misa al pie de la escalera, en conmemoración de los fallecidos y durante el recorrido que hicimos por la zona pudimos encontrar algunos cadáveres perdidos entre los matorrales. (...) No sabría determinar cuántas muertes se habrán dado en ese lugar, pero estoy seguro de que fueron muchas, ya que las escaleras de Mesuca eran muy transitadas por personas durante esos días y permitían un blanco fácil desde diferentes puntos del sector de Palo Verde". (Depoimento colhido em CORREO DEL ORINOCO, 27 de Febrero de 1989. Edición Especial. 24/ 02/2013, p.17. Disponível em: http://alainet.org/images/COE-27F.pdf). Supõe-se, segundo diferentes fontes, que nesse episódio morreram entre vinte e sessenta pessoas, todas civis.

${ }^{361} \mathrm{Cf}$. as declarações feitas por vítimas à delegação da Anistia Internacional em visita ao país no mês de maio seguinte. Segundo seu informe, os exames médicos de pessoas que haviam sido detidas confirmaram as alegações de maus tratos por agentes de segurança. (Veja-se: AMNISTíA INTERNACIONAL. Venezuela: denuncias de homicidios arbitrarios y torturas: febrero y marzo de 1989. Informe de Marzo de 1990.

${ }^{362} \mathrm{Em}$ um desses bairros, o 23 de Janeiro, a reação militar foi especialmente letal. Conta, em entrevista 20 anos depois dos fatos, um morador do 23 de Janeiro, José Nazareth Fuentes: "(...) En muchos apartamentos encontré amigos tirados en el piso, con un orificio pequeñito en la espalda, y cuando los volteaba, tenían un tremendo boquete (agujero grande) en el pecho. Daba mucha rabia encontrar a la gente muerta bajo su propio techo. (...) La tormenta de proyectiles del 23 de enero parecía no tener fin. [Fuentes no regatea al decir que "muchos" en la zona le respondían a los militares con disparos de 9 milímetros]. "Eso puso la cosa peor, porque ellos (los militares) estaban lejos en Catia y esos disparos no le hacían nada, pero cuando a los militares les tocó responder, lo hacían con más intensidad, y sin ningún tipo de clemencia. jEntonces esto aquí era el infierno en vivo y directo, mi hermano!". (PANORAMA DIGITAL. "El caracazo" contado desde el 23 de enero: "Ésto era el infierno en vivo y directo". Edição digital de 27/02/2009. Disponível em: http://www.aporrea.org/ddhh/n129737.htm.

${ }^{363}$ Relata o mesmo pároco de Petare: "(...) Se da un toque de queda. En Venezuela no se sabía qué era un toque de queda, los soldados, la Guardia Nacional, no sabían qué era un toque de queda, así que cuando comenzó el toque de queda, los militares siguieron la orden de disparar a todo lo que se moviera. El día miércoles 1 de marzo, por la mañana, llegó a la puerta de la lglesia un Comando del Ejército, con la orden de 'disparen a discreción'. Hoy en día en la torre todavía se ven once disparos. El cura jesuita Arturo Sosa narra que, en un momento por el ruido y desorden, salen huyendo de un psiquiátrico los enfermos mentales, a la calle, y los militares los acribillaron a plomo ".(Testimonio ofrecido por el párroco Matías Camuñas a la DP. Citado em: RBV. A 18 años de "El Caracazo", p. 26.) 
dias 1ํ, 2 e 3 foram, assim, de intensa e terrível repressão. Por conseguinte, o número de vítimas fatais cresceu assustadoramente, e se somou ao de feridos, de detidos arbitrariamente e de desaparecidos. Os jornais da capital, que praticamente não haviam circulado nos dias 28 e 1ํㅡㄹ relataram, a 2, quinta-feira:

A morgue foi declarada em emergência, pois seus espaços eram já insuficientes para atender os casos e praticar as autópsias de lei e identificação. Os hospitais estão declarados em emergência diante do número de feridos que ingressaram nas últimas 72 horas. $A$ polícia e a GN efetuaram numerosas invasões de domicílios, onde localizou mercadorias roubadas nos saques. Os culpados foram levados às autoridades de Caracas, para serem julgados conforme a lei de vagabundos e meliantes. ${ }^{364}$

Esse dia 2, auge provavelmente das operações de repressão, traria ainda alguns rasgos pavorosos, segundo noticiaria a imprensa dos dias seguintes:

Tudo parecia verdadeiramente haver degenerado em matança na quinta-feira pela manhã, quando foi morto um comandante. Efetuava ele uma invasão em um conjunto de moradias populares; encostouse a uma porta e um disparo de dentro o matou na hora. Seus homens o vingaram. Mas, afirma um médico do Hospital Pérez Carreño, por culpa de um franco-atirador isolado, o exército matou 20 ou 30 inocentes dentro do edifício. Na sexta-feira, sentindo que a carnificina poderia pôr em perigo seu regime, o presidente Pérez dá ordem ao exército para acalmarem-se. ${ }^{365}$

De fato, a 3, já se relatava uma lenta normalização das atividades cotidianas nas cidades do interior. Em Caracas, no entanto, persistiam ainda invasões, tiroteios e prisões (agora também de "subversivos" ${ }^{366}$ ), embora em número rapidamente decrescente como resultado instantâneo das operações policial-militares da véspera. Por fim, aquietou-se também a capital. No sábado, 4 , exaurida em definitivo a revolta a força de balas, os jornais denunciavam - ao

${ }^{364}$ Citado por IZARD, M. Op. cit. p. 71. A "Lei de vagabundos e meliantes" será discutida logo adiante.

${ }_{365}^{36}$ El Nacional de 08/03/1989. Citado por IZARD, M. Op. cit. p. 82.

${ }^{366}$ Relata o informe da Anistia Internacional: "(...) Entre los detenidos también hubo un grupo de sacerdotes jesuitas de la barriada obrera de La Vega, a quienes, el 4 de marzo, más de 40 guardias nacionales sacaron de su casa sin explicaciones en mitad de la noche y que estuvieron varias horas detenidos. Posteriormente se supo que se les consideraba sospechosos de estar en posesión de armas y de propaganda subversiva. A la mañana siguiente, el ejército allanó violentamente la casa de un catequista vecino, Francisco Pérez García, en ausencia de su morador, causando daños y llevándose objetos de valor y documentos, como una biblia y un informe de Amnistía Internacional. Otros activistas comunitarios y ex presos políticos también sufrieron registros en sus viviendas o fueron buscados por la policía, aunque no llegaron a ser detenidos.) 
lado da declaração de Andrés Pérez de que a Venezuela suspenderia os pagamentos da dívida externa pública e privada - diversos episódios entre lúgubres e disparatados, como o caso das fossas comuns em que jaziam centenas de cadáveres, retirados do necrotério na madrugada anterior e lançados no setor A Peste, do Cemitério Geral do Sul; o dos relatos de transeuntes, que se deparavam com corpos crivados jazendo a céu aberto em ruas e calçadas; o do colapso dos serviços funerários populares, congestionados pela multidão de pessoas inconsoladas que procuravam enterrar condignamente seus entes; e o da intempestiva exigência do presidente da Fedecámaras de que fossem punidos e expulsos do país "os delinquentes estrangeiros que participaram dos atos de vandalismos" dos dias anteriores. ${ }^{367} \mathrm{~A}$ semana encerrava-se, assim, transfeita na maior tragédia social que o país jamais conhecera. E, sobretudo na capital, haveria ainda de ao drama humano acrescentar-se o grande saldo de destruição material, cujo cômputo também se começava a fazer. ${ }^{368}$

As interpretações teóricas: Padece pouca dúvida que o Caracaço assinala um momento de grande importância na trajetória dos movimentos sociais da América Latina em geral, e da vida político-social da Venezuela em particular. Inconformismo e inquietação popular levados ao extremo da disrupção social violenta; desmascaramento da pretensa identidade entre Estado democrático burguês e os valores básicos de uma verdadeira democracia social; despertar da consciência popular quanto aos efeitos desastrosos do neoliberalismo; e, especificamente na Venezuela, definhamento do arranjo político de Punto Fijo e a falência do modelo petroleiro-rentista - todos esses elementos estão invariavelmente presentes, em maior ou menor grau, nas interpretações teóricas

\footnotetext{
${ }^{367}$ Cf. IZARD, M. Op. cit. p. $72-73$.

${ }^{368}$ Cf. MAYA, M. López. Op. cit., p. 65-67. Há nesta obra da historiadora venezuelana um balanço, tão preciso quanto possível, das perdas humanas (com a caracterização dos tipos de mortes e de ferimentos) e dos prejuízos materiais resultantes dos dias da revolta. Quanto às primeiras, estimase: "(...) $87 \%$ dos mortos eram homens, com idade média de 27 anos; 95\% eram venezuelanos e $83 \%$ não tinham antecedentes criminais; $85,8 \%$ das mortes foram provocadas por armas de fogo, e 11,9\% por causas não registradas. De acordo com a análise do Centro de Estudos para a Paz, da UCV, de 266 cadáveres que mostravam feridas por armas de fogo, mais de $60 \%$ tinham recebido disparos localizados ou no tórax $(35,71 \%)$ ou na cabeça (29,32\%). Desses cadáveres, 211 haviam recebido um único disparo (79,2\%), enquanto 39 haviam recebido dois (14,66\%). Tratava-se, portanto, de execuções sumárias de uma população civil indefesa, cujo delito principal fora o de estar nas ruas depois do toque de recolher." (p. 66). Quanto aos prejuízos materiais, estes alçaram-se, em números redondos, aos 6 bilhões de bolívares. (Ver p. 66-67)
} 
que se elaboraram sobre a revolta de 1989 e suas consequências históricas. Com efeito, a virtude de certos acontecimentos gravíssimos, como o Caracaço, está, muitas vezes, em expor com inesperada clareza a precariedade das forças que sustentam uma dada ordem político-social nos seus momentos de crise aguda, bem como em revelar a artificialidade do discurso ideológico que defende tal ordem, mesmo em seu declínio final. Compreende-se, desse ponto de vista, que o Caracaço seja considerado uma suma dos limites surpreendentemente estreitos do desenvolvimento histórico venezuelano, e que, igualmente, tenha fixado o termo de existência dessa experiência burguesa e de sua ideologia. É significativo que as interpretações do Caracaço descrevam com grande consenso esses limites e esse termo.

Uma das primeiras interpretações do Caracaço é o trabalho de Miquel Izard (El Poder, la Mentira y la Muerte, de 1991), surgido em livro dois anos após os acontecimentos de fevereiro/março. Baseado em ampla pesquisa de fontes jornalísticas, esse opúsculo constitui um contundente libelo dos crimes do Estado venezuelano perpetrados naqueles cinco dias terríveis. Entretanto, a força principal da argumentação está, propriamente, em comprovar a recorrência desse tipo de crimes na vida social do país. Para M. Izard, a democracia venezuelana que "no lo es ni de sombra" - sustenta-se, antes e acima de tudo, em uma violência estatal sistemática e regular, oculta sob a capa da democracia, mas exercida cotidianamente através de inúmeros aparelhos repressivos oficiais, como a DISIP ${ }^{369}$, aliados a outros, privados, como as milícias e os grupos paramilitares contratados por grupos de empresários e formados para agirem na cidade e no campo. A eficácia das ações desses aparelhos repressivos encontrava seu maior impulso na impunidade que o Estado invariavelmente Ihes garantia, o que tornava a omissão uma das principais formas da ação oficial. A par disso, - acrescenta o estudioso - combinavam-se à violência direta o controle da informação e o alheamento da consciência social por meio da imposição do silêncio da História Oficial:

\footnotetext{
${ }^{369}$ A DISIP (Dirección de los Servicios de Inteligencia y Prevención) foi criada pelo presidente Rafael Caldera em março de 1969, e tinha por função expressa o combate ao terrorismo e ao tráfico de drogas no país. O emprego elástico do conceito de subversão permitiu, todavia, transformar a instituição em polícia política, não raro atuando à margem da lei. (Cf. o que ficou discutido a propósito da repressão à luta armada, no cap. 4, supra)
} 
Um poder sustentado na violência deve, necessariamente, violentar o passado. Apresentar e inculcar como história, não o que ocorreu, mas uma interpretação do ocorrido que interessa ao poder que seja interiorizada como ideologia. Dessa maneira, enfrentamos uma dicotomia entre essa história - a História Oficial - e o que muitos denominam memória popular - aquela que conservam os membros das classes subalternas, os marginalizados e os que não são nunca levados em conta. ${ }^{370}$

Em um país vitrina - como define M. Izard a Venezuela desses anos - cuja democracia era motivo da jactância internacional de suas elites governantes, concorriam, no entanto, duas forças que se alimentavam mutuamente: a Mentira e a Morte. Quer dizer: de um lado, um aparatoso mecanismo de ocultamento da realidade, agindo através, ao mesmo tempo, do encobrimento dos fatos e da manipulação e sujeição ideológica dos meios de comunicação ao Estado; e, de outro, uma brutal política de controle, confinamento e eliminação física de grupos de indivíduos indesejados, reputados "perigosamente antissociais" - quer fossem os politicamente subversivos, quer fossem os socialmente delinquentes. Segundo M. Izard, da primeira condicionante - a Mentira - nascia esse "traço social" impingido aos venezuelanos, isto é, a memória curta e o olvido fácil das tragédias sociais da nação, que tinha no esquecimento do episódio trágico de El Amparo, atrás citado, um exemplo categórico. Da segunda - a Morte - provinha um meio de controle social pelo qual munia-se o Estado de recursos legais e ilegais para a perseguição sistemática aos elementos perniciosos da sociedade. Entre esses recursos, de atuação silenciosa mas notavelmente eficiente, estava a longeva Lei sobre vagabundos e meliantes. ${ }^{371}$ Esta lei - uma lei administrativa (portanto não

\footnotetext{
370 IZARD, M. Op. cit. p. 11.

${ }^{371}$ A Ley sobre Vagos y Maleantes foi publicada em 16 de agosto de 1956, no governo do ditador M. Pérez Jiménez, e substituiu a lei (de mesmo nome) de 14 de agosto de 1939, inspirada esta última na legislação franquista. Em seu artigo 1ำ lia-se: "Los vagos y maleantes, para su corrección y como medida de defensa social, serán sometidos al régimen de seguridad pautada en la presente Ley." Esse regime de segurança previa a internação em Casa de Reeducação e Trabalho (art. $4^{\circ} \mathrm{c}$ ), em Colônia Agrícola Correcional fixa ou móvel (art. $4^{\circ}$ e) ou em Colônia de Trabalho fixa ou móvel (art. 4ํํ). A mera condição (real ou suspeita) de desocupado, mendigo ou erradio bastava para que os indivíduos devessem ser presos, sob alegação de que "constituyen una amenaza para la sociedad" (art. $\left.2^{\circ}\right)$, sendo o confinamento por um período de até cinco anos, prorrogável por outros cinco. A detenção era aplicável também automaticamente aos casos em que os indivíduos possuíssem antecedentes criminais ou que já tivessem sido condenados pela própria Lei de Vagabundos e Meliantes (!) - uma aberração jurídica que permitia ao Estado, na prática, punir indefinidamente um mesmo ato delituoso. Demais, além da clara incidência que tinha sobre indivíduos pertencentes aos setores pobres da sociedade, a Lei oferecia azo a que se perseguissem também opositores políticos do governo ou grupos de trabalhadores urbanos e rurais em luta - como o denunciou em documento a Anistia Internacional em 1995 (cf. AMNISTíA
} 
integrando o sistema jurídico penal, e que era posta em execução diretamente pelo Poder Executivo, através dos Chefes Civis, Governadores e o Ministro da Justiça) - ao subordinar as concepções mais comuns de controle legal das classes populares ao princípio preventivo e punitivo da delinquência sem a necessidade de provas para caracterização de delitos sancionáveis - era exercida com ampla eficácia repressiva na medida em que era aplicável "antes da comissão do delito" $^{372}$, baseava-se para a detenção apenas na alegação imprecisa de periculosidade social, e recaía sobre sujeitos facilmente identificáveis por sua condição marginal (biscateiros, desocupados, pedintes, meliantes etc.). Em complemento, admitia-se tacitamente que, por esse princípio, as causas sociais da pobreza não eram matéria jurídica. Nos dias turbulentos do Caracaço, essa lei - que, desde havia muito, vinha justificando ações arbitrárias e ilegais do Executivo contra cidadãos comuns pobres (segundo a consideração jurídica da pobreza como delito) - prestou-se a dar fundamento legal à desmedida repressão policial e militar. Assim, quando inexistiu a alegação, por exemplo, de subversão política, o Estado pôde lançar mão, diante do levantamento de uma multidão de miseráveis, do argumento da urgência de combater os que, efetivamente ou potencialmente, "constituíam uma ameaça à sociedade". Explicase por esse modo o sentido principal da repressão oficial: punição e extirpação do crime de pobreza, aplicadas sumariamente contra sujeitos cujas condições de vida por si só tipificavam o criminoso. Por essa razão e em um cenário tal, provavelmente persuadiu a poucos a resposta indignada que deu Jaime Lusinchi às denúncias que fez um minucioso relatório da Anistia Internacional, poucos dias

INTERNACIONAL. Venezuela: La Ley sobre Vagos y Maleantes: Supresión de la disidencia y castigo de los indigentes. Disponível em: http://www.amnesty.org/es/library/asset/AMR53 /001/1995/es/ab6cb95aeb6b-11dd-b8d6-03683db9c805/amr530011995es.html.) O óbvio conteúdo discricionário da Lei foi motivo de grande polêmica nas décadas de 1970 a 90, e suscitou, por sua derrogação, inúmeros esforços dos defensores dos direitos humanos. Apenas em 14 de outubro de 1997, a Corte Suprema de Justiça da Venezuela declarou-a inconstitucional. (Para o texto da Lei de Vagabundos e Meliantes, cf. Gaceta Oficial de la República de Venezuela, de 16 de agosto de 1956. Disponível em: www.pgr.gob.ve/dmdocuments/ 1956/25129.pdf. Acesso em 16/05/2014.) ${ }^{372}$ Cf. HERNÁNDEZ, Tosca. La ley sobre Vagos y Maleantes y el sistema jurídico venezolano. Una ideologización del delito y la pena. Disponível em: http://gumilla.org, p. 460. Sobre a eficácia desta lei administrativa, mais expedita que os processos penais, diz a autora: "(...) Concretamente se observa que la Ley sobre Vagos y Maleantes permite un mayor y más eficaz control represivo, porque siendo dos años el promedio de duración de los procesos penales ordinarios, ésta puede aplicarse en un máximo de cincuenta días, previendo apenas tres días para la evacuación de testigos, y esto con el indiciado detenido. En muy corto tiempo los sujetos pueden ser detenidos, juzgados y sentenciados de forma que esta 'rapidez' crea la impresión de que los problemas delictivos están siendo resueltos eficazmente". (p. 461. Grifo nosso.) 
antes de ele retirar-se da presidência e menos de dois meses do Caracaço: "Na Venezuela, não se tortura nem se mata por sistema; hoje, quem disser isso está mentindo deliberadamente". ${ }^{373}$

Em um outro estudo (Dismembering and Remembering the Nation, também de 1991), Fernando Coronil e Julie Skurkie interpretam os acontecimentos de 1989 ("o mais feroz massacre de uma revolta popular na história contemporânea da América Latina" ${ }^{374}$ ) como uma culminância das contradições suscitadas pela irrupção de ideias e práticas neoliberais de livre-mercado na vida social venezuelana - ou seja, justamente em uma sociedade que, até então, preservara alguma coesão de classes graças aos vínculos de proteção estabelecidos entre o Estado e o povo, consoante os valores ideológicos populistas de concórdia social e unidade nacional. Essas contradições, segundo os autores, evidenciaram-se sobretudo em dois planos. A princípio, no plano do discurso político, ao mudar-se drasticamente o sentido da ação civilizadora do Estado. Durante a campanha eleitoral e nos primeiros dias de governo, Andrés Pérez, enfatizando o problema da dívida externa, proclamara o papel de liderança da Venezuela entre os países devedores na luta contra as grandes finanças internacionais, responsáveis por grave ameaça à independência das nações e ao bem-estar dos povos. De acordo com o presidente, uma luta moral devia travar-se entre a comunidade dos países latino-americanos e os financistas internacionais. Com esse espírito, Pérez multiplicou os ataques verbais ao FMI e aos grandes bancos, e insistiu em reformas sociais democráticas. No âmbito interno, Pérez declarara também a necessidade de combater as políticas protecionistas, que minavam a economia nacional e impediam-na de desenvolver-se. El Gran Viraje, o plano econômico de 16 de fevereiro, deveria ser um programa de austeridade capaz de impelir o país de um capitalismo artificial para um capitalismo real, sem falsas esperanças e conforme a racionalidade de mercado. Eram esses os pontos "de consenso" nos quais se apoiava a retórica da modernização nacionalista do presidente recémempossado, que, não obstante, diante da crise econômica e necessitando de recursos financeiros do exterior, assinaria, ao final do mês, uma Carta de Intenção

\footnotetext{
${ }^{373}$ Citado em IZARD, p. 67.

${ }^{374}$ Cf. CORONIL, Fernando \& SKURSKI, Julie. "Dismembering and Remembering the Nation. The Semantics of Political Violence in Venezuela". In: Comparative Studies in Society and History, vol. 33, $N^{\circ} 2$, Abril 1991, pp. 288-337.
} 
com o FMI. Reconhecia-se pela primeira vez a sujeição das diretrizes econômicas nacionais às prescrições e exigências do neoliberalismo. Esses vaivéns das decisões oficiais encontraram expressão nas mudanças do discurso político, cujo conteúdo protecionista e coletivista foi sendo substituído por outro, de caráter manifestamente excludente e individualista. Afirmam os autores:

Com a entrada em cena dessa variante populista do discurso de livremercado de Pérez, o povo passou a ser apresentado como um produto indisciplinado e indolente de uma economia improdutiva, um sintoma da enfermidade causada pelos longos anos de dinheiro fácil obtido através da abundante renda petroleira. O esforço oficial de explicar a crise sem envolver efetivamente a elite governante do país apresentava agora os venezuelanos como consumidores irresponsáveis. Concebia-se que, se as estruturas protecionistas estatais fossem desmanteladas, o povo se voltaria para o trabalho produtivo, pois as pessoas precisavam da disciplina e da diretriz que o mercado podia fornecer. O novo governo introduziu seu programa de ajustes empregando uma linguagem moral de reforma. Embora insistisse na necessidade de reformar o comportamento individual, ele não mencionava a reforma social, que tinha sido o elemento central do discurso protecionista. Este prometera corrigir as desigualdades sociais intervindo na organização do mercado. $O$ discurso de livre-mercado, ao contrário, prometia corrigir as distorções econômicas reorientando o comportamento e as percepções individuais. ${ }^{375}$

Para o povo, essas novas concepções representavam uma flagrante traição da economia moral protecionista cometida pela moralidade fria do capital, e indigna o bastante para romper os liames entre as massas e seus líderes, entre o povo e o Estado. Quando, no plano da prática política, a apregoada austeridade foi implantada por meio das medidas de reajuste - levando ao fim do controle de preços de alimentos, aos cortes de subsídios, à liberação de câmbio - era inevitável que todo o ônus recaísse, mais uma vez, sobre as massas populares, havia muito amargando um empobrecimento desesperador. Foi então que "(...) a angústia tornou-se pânico" ${ }^{376}$, e explodiu a revolta. A partir daí, esse mesmo povo viu-se transformado "(...) de virtuoso fundamento da democracia em uma ameaça selvagem à existência dela - uma presença bárbara". ${ }^{377}$ Os vínculos de proteção oficial aos pobres não se ajustavam mais ao novo pensamento do livre-mercado,

\footnotetext{
${ }^{375}$ Idem, p. 313.

${ }^{376}$ Idem, p. 314.

377 Idem, p. 330.
} 
o qual desejava ver reduzidas as atribuições do Estado, especialmente se implicassem gastos sociais. Abandonando assim o protecionismo, o Estado empurrou definitivamente os pobres para fora do corpo político, ao passo que os limites entre as classes sociais "(...) mudaram-se em barreiras que separam os civilizados dos bárbaros" ${ }^{\prime 378}$, justificando-se assim toda violência estatal. A fratura social se revelou afinal no distanciamento inconciliável de uma elite civilizada em relação ao populacho bárbaro. $\mathrm{E}$, entre ambos, um Estado empenhado em uma luta civilizatória contra a barbárie. A nação perdia então seu caráter unitário, desmembrada enfim em partes antagônicas e posta em perigo pela ação desagregadora daqueles que não podiam ser incluídos no espaço globalizado dos mercados. Os desamparados de outrora eram agora, a bem dizer, uma horda inassimilável. Por isso, ao cabo, sufocada a amotinação dos pobres, o saldo trágico de mortos e desaparecidos bem pôde ser visto impassivelmente pela elite governante, como uma simples contingência, embora odiosa, da vida em sociedade. E se tudo isso, na verdade, não deixava de ser mais "um crime no meio da Pátria", como lastimava Pablo Neruda ao pensar na triste história do continente, era, no entanto, para essa elite, apenas e somente mais uma morte do povo: "E a morte do povo foi como sempre tem sido:/ como se não morresse ninguém, nada,/ como se fossem pedras as que caem/ sobre a terra, ou água sobre a água." ${ }^{379}$

Guardando certa proximidade teórica com essa interpretação, Margarita López Maya (El Caracazo, cap. 3 de Del viernes negro al referendo revocatorio) assinala a pertinência de se compreender a extensão e gravidade do Caracaço (bem como a notável ascensão dos protestos populares, que se prolongariam por

\footnotetext{
${ }^{378}$ Idem, p. 330.

379 ("Y la muerte del pueblo fue como siempre ha sido:/ como si no muriera nadie, nada,/ como si fueran piedras las que caen/ sobre la tierra, o agua sobre el agua.") Estes versos de Las masacres foram escolhidos por Coronil e Skurski para epígrafe de seu texto, e traduzem com argúcia poética esse traço deplorável dos momentos trágicos (como o Caracaço) das relações de classes nas sociedades subdesenvolvidas, sufocadas agora sob o jugo das políticas neoliberais. Em conclusão, afirmam os autores: "(...) At a moment in history when the globalization of space is being achieved through simultaneous integration and fracture, inclusion and exclusion, transmuted colonial relations remain dynamic forces within processes of global change. The events we analyze (...) are moments in this worldwide reordering of body politics. Through them we may glimpse the movement from a world organized by what Tom Nairn calls the uniformed imperialism of direct political control and territorially fixed markets to one shaped by what we call the multiform imperial controls of fluid finance capital, a world of increasingly deterritorialized markets and shifting political, economic, and cultural boundaries. The Venezuelan riots and massacres, as people who lived through them know, are inseparable from the hidden violence of postmodern empires". ( $\mathrm{p}$. 334)
} 
toda a década de 1990 e entrariam vigorosos pelo novo século) a partir de uma combinação de fatores político-institucionais e fatores subjetivos, aos quais se somariam ainda episódios críticos de confronto com uma autoridade injusta. ${ }^{380}$ Ao acentuado descenso econômico do modelo de desenvolvimento por substituição de importações nos anos 1970-80 seguiu-se um contínuo empobrecimento das classes médias venezuelanas. Concomitante a isso, e em íntima relação, a sociedade venezuelana se defrontou com a perda de prestígio político de atores e instituições públicas, que paulatinamente entraram em um irreversível processo de deslegitimação. Ao longo da década de 1980, foram-se desgastando os elementos fundamentais que até então haviam conferido estabilidade ao sistema inaugurado em 1958: primeiro, a centralização política - que dera preeminência quase absoluta aos dois partidos ( $A D$ e Copei) e seus líderes nacionais em detrimento de outras formas de representação da sociedade civil, mas que passara agora a representar um impedimento ao ingresso de novos atores sociais, como os grupos políticos de vocação popular; e, segundo, a mediação política desses dois partidos e dos sindicatos a eles atrelados (reunidos na Confederação de Trabalhadores da Venezuela, CTV) - mediação que se foi tornando claramente ineficiente, uma vez que partidos e organizações de representação operária se viram progressivamente tomados pela corrupção, assaz facilitada no quadro de abundância de dinheiro do petro-Estado dos anos 1970. Os anos do governo de Jaime Lusinchi, caracteristicamente, notabilizaramse pelo descrédito dos poderes Executivo e Judiciário, por escândalos pessoais do presidente, por ampla corrupção administrativa e - coroando o descalabro dos meios de representação - por atos de extremo autoritarismo, como durante a Revolta de Mérida e a de El Amparo. Nesse ambiente, o sentimento de revolta da população diante de uma autoridade injusta exprimia uma mudança na consciência coletiva, que passava a reconhecer como intolerável a contradição entre, de um lado, a propalada democracia e a riqueza petroleira, e, de outro, a generalizada pobreza real e a injustiça do Estado. Os sucessos de Mérida e de EI

380 Cf. MAYA, Margarita López. Del viernes negro al referendo revocatorio. Caracas: Alfadil Ediciones, 2005. (Tradução para o português: Luta hegemônica na Venezuela. A crise do puntofijismo e a ascensão de Hugo Chávez. 2010. Disponível em www.iela.ufsc.br.) O capítulo 3 tem por base um texto de 1999. Veja-se, ainda, da autora: Protesta y cultura en Venezuela: los marcos de acción colectiva en 1999. Buenos Aires: Clacso, 2002, especialmente Cap. 1: La protesta de los '90). 
Amparo serviram para fazer colidir de vez esses elementos inconciliáveis, desnudando a face moral da crise, porquanto "(...) a justiça não estava sendo ministrada para os setores subordinados e, além disso, o poder estava sendo exercido de maneira arbitrária e sem freios contra os mais humildes, violando cláusulas vitais da relação entre um Estado que se pretendia democrático e os setores populares". ${ }^{381}$ O Caracaço não representou senão o momento do desbordar violento dessas contradições, inaugurando então o processo de esvaziamento das mediações político-sociais erigidas desde 1958 (e que seriam aluídas definitivamente pelas tentativas de golpes de Estado de 1992 e pela crise presidencial de 1993). É sobremodo significativo que, a partir de fevereiro de 1989, as manifestações populares de protesto assumissem a particularidade de serem conduzidas por atores distintos e desvinculados dos tradicionais partidos, reavivando por esse modo uma política de la calle, na qual a conduta sociopolítica do venezuelano comum enveredava por tipos de ações menos convencionais, marcadas dai em diante pela maior frequência e por um grau mais intenso de confrontação e violência. ${ }^{382}$ Decorrendo da dissolução dos vínculos clientelistas e corporativos tecidos entre os dois partidos e os diversos setores da sociedade, o sistema bipartidário puntofijista derivou, assim, para um vazio de mediações, rapidamente aproveitado por grupos de orientação popular e/ou populista, cujos discursos proclamavam uma nova liderança e a mobilização das massas. Neste sentido, portanto, os acontecimentos de fevereiro-março de 1989 trouxeram ao proscênio político um povo que, não obstante, "(...) até os anos oitenta era considerado dentro da região latino-americana entre os menos propensos à

\footnotetext{
${ }^{381}$ MAYA, M. López. Luta hegemônica na Venezuela, p. 52.

382 Lembra ainda a Autora: "As primeiras eleições regionais e locais, que ocorreram em dezembro de 1989, a escassos dez meses do Caracaço, refletiram em seus resultados o fato de que uma parte do eleitorado foi às urnas para expressar seu repúdio ao governo nacional e às políticas econômicas que este vinha implementando. O presidente Pérez, respaldado por seu partido (AD), havia sido eleito um ano antes com o voto majoritário em 19 dos 20 estados do país. Mas, nessas primeiras eleições para governadores, os candidatos da $A D$ perderam em 9 estados, a maioria deles estratégicos - ficando sem os governos de Miranda, Carabobo e Arágua no centro (junto com o Distrito Federal, principais sedes das indústrias manufatureiras), o de Zúlia (onde se localiza o grosso da indústria petroleira) e o do Estado de Bolívar (sede da Corporação Venezuelana de Guayana e das indústrias de ferro, hidroeletricidade e alumínio). Tanto o voto de oposição quanto a abstenção eleitoral, que alcançou a cifra de 54,85\%, atuaram como mecanismo de desafogo do descontentamento político e do mal-estar social reinante, enviando uma mensagem clara, conquanto não ouvida naquele momento pelos atores hegemônicos." (MAYA, M. López. Luta hegemônica na Venezuela, p. 106-7)
} 
mobilização" 383 , e abriram um tempo novo de protestos, um tempo que principiara "cuando la gente salió a la calle y ya no regresó":

A extrema disrupção da vida cotidiana nas urbes venezuelanas durante os dias do Caracaço pôde certamente ser motivada por um complexo de fatores, entre os quais se inclui como um dos componentes-chave a traição a uma economia moral. No entanto, foi a debilidade das instituições, projetadas no passado para conter e regular a ordem política e a vida cotidiana, o motivo que explica a extensão, a duração e a violência do protesto. Se os atores políticos e os sindicatos estivessem em sintonia com suas bases, decerto teriam podido prever as dificuldades que sobreviriam ao anúncio do pacote. Conquanto fosse altamente improvável que alguém pudesse predizer a magnitude da ira popular que se vinha represando, partidos e sindicatos íntegros necessariamente deveriam ter elaborado estratégias para opor-se e/ou negociar com o governo o modo como se aplicariam as medidas do pacote. Isto, por seu turno, teria dado às pessoas alguns canais de vazão de seu mal-estar, ou então alguma esperança de alterar os dramáticos efeitos que elas esperavam. Mas, ao contrário disso, as instituições de mediação estavam demasiado erodidas para serem capazes de atuar. (...) A democracia venezuelana revelou-se tão carente de traços democráticos efetivos, e as instituições que regulam a vida diária tão faltas de consistência, que somente uma ação firme, rápida e profunda de mudanças político-institucionais poderia ter evitado o processo de deslegitimação política que se desencadeou a partir de então, e que alguns anos mais tarde levaria a sociedade à crise e à transformação política. ${ }^{384}$

Durante os anos de 1980, ainda perdurava na visão internacional (mesmo nos meios acadêmicos) sobre a Venezuela a ideia de que a abundância petroleira permitira a construção - incaracterística na América Latina - de um Estado de Bem-estar social, apoiado em um sistema político democrático, estável e representativo. A revolta popular de 1989, ao eclodir, teria provocado grande surpresa e consternação, levando os estudiosos a procurar reavaliar os fundamentos reais daquela construção. Em Violence and the welfare state, de Luis Pedro España, publicado em $1994^{385}$, a revolta venezuelana é interpretada da óptica de uma sociedade na qual a violência exercida por atores sociais privados havia desaparecido como fenômeno social de larga escala, desde que o

\footnotetext{
${ }^{383}$ MAYA, M. L. Protesta y cultura en Venezuela: los marcos de acción colectiva en 1999. Buenos Aires: Clacso, 2002, p. 14. A expressão seguinte, referente ao Caracaço, é do historiador Ramón $\mathrm{J}$. Velásquez, citada à p. 16. 384 MAYA, M. López. Op. cit., p. 72-73.

${ }^{385} \mathrm{Cf}$. ESPAÑA N., Luis Pedro. "Violence and the welfare state: the case of Venezuela as an oil country". In: RUPESINGHE, K. \& RUBIO C., M. (ed.). The culture of violence. Tokyo: United Nations University Press, 1994, cap. 7, pp. 178-197.
} 
país alcançara em fins do século XIX a unidade política nacional (com o fim das revoltas armadas, dos exércitos de caudilhos e dos golpes palacianos que marcaram a sucessão dos governos de então) e desenvolvera, nas primeiras décadas do XX, uma economia igualmente única para toda a nação. A partir daí, a violência institucionalizara-se sob a forma de um direito exclusivo do Estado. Após 1958, a democracia assentada em um acordo das principais forças sociais teria propiciado um estado de coisas em que as divergências entre classes encontravam em canais institucionais os meios suficientes de solução. A coincidência dessa articulação de forças sociais com a prosperidade material garantida por exportações crescentes de petróleo tornou possível a constituição de um Estado planejador e provedor de serviços básicos satisfatórios ao conjunto da sociedade. A Venezuela, nos anos posteriores ao acordo de 1958, realizara, em grande medida, o ideal da "democracia feliz" ("happy democracy"), segundo o qual esta consistia na "(...) criação de um conjunto de procedimentos $e$ instituições cujo fim último era solucionar conflitos, diferenças e dissensões através de meios pacíficos. Democracia, assim, pode ser interpretada como a entidade política que garante a menor violência possível nas relações sociais". ${ }^{386}$ O Pacto de Punto Fijo, ao excluir as forças sociais radicais, e incluir as Forças Armadas, a Igreja Católica, as organizações sindicais patronais e operárias e outras associações civis, alcançou um "(...) consenso entre as partes, [o qual se] conseguia através de negociação. Qualquer conflito entre elas era resolvido desse modo e a preservação da democracia tornou-se um desiderato de todos os interessados." ${ }^{387}$ Nesse sentido, a crise econômica dos anos 1980 somente liquidaria a estabilidade da democracia venezuelana se houvesse condições políticas favoráveis à desestabilização - condições que fossem aproveitáveis por uma oposição desleal ao regime. Essa oposição desleal, contudo, segundo o estudioso, não parecia existir naquele momento (L. España escrevia o texto em meados de 1991), ao menos não existia com força suficiente para alcançar o objetivo. Por essas razões, em fins dos anos 1980, a violência política não reaparecera na Venezuela, mas tão-somente a violência social. Essa particularidade da vida venezuelana de então explicaria a natureza da revolta

\footnotetext{
${ }^{386}$ ESPAÑA N., L. P. Op. cit., p. 186.

${ }^{387}$ Idem.
} 
popular de fevereiro como um fenômeno socialmente desarticulado, em que predominaram reações de tipo individual e instintivo. Daí a surpresa que tomou a muitos quando ela estourou.

A expressão em larga escala da violência social não organizada (que não tem objetivos coletivos - ao contrário da violência política, religiosa ou nacionalista) ficou evidente na explosão social de 27-28 de fevereiro de 1989. Hoje em dia, dados os poderosos métodos de represália utilizados para restaurar a ordem, essa violência não organizada apresenta-se no instinto criminoso individual não contido. Assim, ao analisarem-se as causas que levaram a essa manifestação social violenta, encontramos que a motivação imediata é a resposta pessoal e individual; aspectos estruturais da ordem política e social podem ser identificados como causas somente em um nível mais profundo, abaixo da superfície. Visto que o alarmante aumento na violência diária na Venezuela - como um fenômeno envolvendo crime comum, repressão e outros tipos de violência menos definidos, tais como a procura por lucro e a corrupção - origina-se da globalidade da crise econômica no país e da relativa mudança da prosperidade para a depressão, a redução da violência a níveis "normais" provavelmente requer a resolução de problemas macrossociais que dão origem a ela. Nesse sentido, a proteção policial ou a repressão estatal de algum modo determina o limite, ou a ação privilegiada, do novo processo de construção da paz na Venezuela. ${ }^{388}$

Constituiriam fatores em um nível mais profundo da violência social a perda de credibilidade da capacidade do Estado de manter os meios pacíficos de negociação entre as classes, como também a conviç̧ão crescente, nos vários segmentos da sociedade, de que certos setores ou classes sociais tornavam-se, à medida que se agravava a crise, inaceitavelmente mais privilegiados pelo Estado no gozo de direitos fundamentais. Uma hipótese otimista para o desfecho desse drama social na Venezuela dos anos 1980-90 achava-se na expectativa de que a violência faria parte de um processo de ajuste da sociedade desde o momento em que principiara o declínio da economia petroleira. $O$ ajuste esperado deveria significar, acima de tudo, uma mudança do paradigma de desenvolvimento venezuelano na direção de um projeto social viável, no qual a violência fosse novamente controlada. A hipótese pessimista, por sua vez, previa o caos social sobrevindo ao fracasso desse projeto, um quadro no qual o governo seria incapaz de administrar a violência e contê-la no interior de um sistema democrático, o que traria por resultado inevitável o exacerbar-se da própria violência. A exacerbação

${ }^{388}$ Idem, p. 193. 
seria ocasionada pelo acréscimo de violência política do Estado à violência social reinante. Àquela altura (1991), ambas as hipóteses eram igualmente prováveis. ${ }^{389}$

Com efeito, um novo projeto de sociedade (se viável ou não, ainda há que se definir) viria, de fato, a substituir o projeto malogrado estabelecido na metade do século passado. O advento do regime bolivariano chavista, em 1998, fez-se sob o signo maior da mudança, galvanizando esperanças e anseios de quase toda a sociedade venezuelana, e progressivamente cingindo-se a um ideal renovador revolucionário. No plano histórico concreto, a instauração do novo regime encontra explicação no desagravo que sobretudo as camadas populares e médias exigiam diante do cenário de abandono e miséria em que se encontrava o país, mergulhado em uma crise econômica e social que contrastava terrivelmente com as décadas de prosperidade. O movimento bolivariano ascendente pretendia materializar o desagravo popular, e inicialmente identificou na globalização e na política neoliberal adotada pelos governos anteriores o alvo de uma luta nacional. O Caracaço - um movimento puramente popular - iniciou essa luta, tivessem ou não os insurgidos consciência clara disso. Para a maioria dos estudiosos, a revolta de fevereiro de 1989 assinala o início de uma longa batalha popular, que nos anos sucessivos iria espalhar-se por todo o continente, voltada contra o neoliberalismo e o processo de globalização econômica - ambos identificados como expressões renovadas do imperialismo das nações capitalistas avançadas. Ora, para alguns desses estudiosos, o Caracaço estaria - não apenas cronologicamente - na origem da vitória política de Hugo Chávez e, por extensão, na raiz do projeto de construção do socialismo do século XXI. Essa ilação redefiniria significativamente a maneira de explicar a revolta de 1989:

Aos olhos de grande parte do mundo, o ano de 1989 está representado na queda do Muro de Berlim, no fim das sociedades de regime soviético e na derrota do socialismo do século XX. Contudo, 1989 para muitos outros, particularmente de países de língua espanhola, está também associado com o começo da revolta na América Latina contra as terapias de choque neoliberais e a emergência, nos anos seguintes, de um "socialismo do século XXI". Este ponto de mudança revolucionária na história da América Latina (e do mundo) é conhecido como o Caracaço (ou Sacudón), que irrompeu em Caracas, na Venezuela, em 27 de fevereiro de 1989 e rapidamente se tornou "a mais ampla e mais severamente reprimida revolta na história da América Latina". (...) Apenas

${ }^{389}$ Idem, p. 196. 
vinte anos depois do Caracaço, o socialismo latino-americano se expande rapidamente e vem provocando uma renovação do socialismo em todo o mundo. Por isso, os Estados Unidos, como a principal força imperialista, tem procurado insistentemente intervir, não só participando do fracassado golpe militar contra Chávez, mas também no bem sucedido golpe de 2009, contra o presidente democraticamente eleito de Honduras, Manuel Zelaya, que havia ingressado na ALBA. ${ }^{390}$

De fato, diversos cientistas sociais, dentro e fora da Venezuela, tendem hoje a estabelecer uma relação mais ou menos direta entre esses três elementos históricos: a explosão social do Caracaço (como inauguração da luta popular contra a globalização e o neoliberalismo e, em consequência, fator do ocaso do regime que os instaurou na Venezuela - a democracia puntofijista); a ascensão do movimento bolivariano (inicialmente nos meios militares, e logo fortalecido pela crescente simpatia popular, que era clara o suficiente para respaldar o movimento militar de fevereiro de 1992 e para conduzir ao triunfo eleitoral de 1998); e a construção de um novo projeto histórico socialista (fundado na soberania econômica e no protagonismo popular, a serem exercidos ambos em uma democracia de tipo participativo). São inúmeros os autores que (evidentemente, com nuanças relativas e próprias) propõem ou apoiam esse juízo de uma nova fase da história venezuelana, oficialmente batizada de $\mathrm{V}$ República, concebida nos dias trágicos do Caracaço e vista como ponto de partida de uma época progressista a se plasmar em praticamente todo o continente latino-americano.

Servem de exemplo os excertos de dois reconhecidos estudiosos:

Richard Gott:

(...) o Caracaço marcou o início do fim do ancien régime na Venezuela. Trinta anos antes, em janeiro de 1958, o povo tomou as ruas e abriu caminho, sob a direção da Junta Patriótica, para a derrubada da ditadura do general Pérez Jiménez. Agora esse povo estava fazendo a mesma coisa, quase por acidente, para mostrar seu desejo de livrar-se de um governo corrupto e burocrático, mas de fachada democrática. Contudo, enquanto o levantamento de 1958 havia sido organizado, direcionado e politicamente inspirado, o Caracaço de 1989 foi anárquico, caótico e sem liderança. (...) O permanente receio da população branca de Caracas tem sido o de os cidadãos pobres e escuros dos morros descerem um dia sobre suas alegres áreas de lazer e tomar vingança. O Caracaço de 1989 deixou uma crua lembrança do que podia acontecer quando os velhos sistemas de controle social falhavam. Algo similar, embora sem a mesma violência, ocorreria em abril de 2002, quando os moradores das favelas, silenciosa e espontaneamente, desceram dos morros e bloquearam ruas

${ }^{390}$ FOSTER, J. Bellamy. Foreword. Monthly Review, Volume 62, Number 3. 
e estradas para restaurar o poder de seu presidente - após ter ele sido derrubado em um golpe de Estado de opereta. Uma nova era começou na Venezuela em 1999, após uma década de crise econômica e social e do colapso dos velhos e corruptos partidos políticos. Hugo Chávez apelou para os pobres dos morros para ajudar a organizar a revolução, e eles já haviam começado a responder no momento da (efêmera) derrubada do presidente em abril de 2002. ${ }^{391}$

\section{Gregory Wilpert:}

A primeira verdadeira fissura no sistema e, dessa maneira, o primeiro impulso para Chávez desafiá-lo veio em fevereiro de 1989, quando o tratamento de choque neoliberal de Andrés Pérez resultou em distúrbios por todo o país. Pérez reagiu aos protestos não só lançando a polícia e o exército para reprimi-los mas também agindo em retaliação à população pobre, por vários dias, mesmo depois de os distúrbios terem terminado. (...)

A tentativa de golpe [de 1992] e o apoio popular que [Chávez] recebeu dos pobres do país e da esquerda foram resultado direto do brutal Caracaço de 1989, de 12 anos de declínio econômico e de 25 anos de repressão política à esquerda do país. (...)

Paralelo ao declínio econômico e político, um movimento de resistência foi crescendo, tanto na sociedade civil quanto nos meios militares venezuelanos. A primeira explosão espontânea da resistência civil foi o Caracaço, de 27 de fevereiro de 1989. A brutal repressão à revolta acabou por radicalizar e mobilizar um setor progressista no interior do exército da Venezuela, que se pôs a organizar um golpe (junto com civis de esquerda) que fosse capaz de trazer uma "verdadeira" democracia ao país. Esse golpe, embora tenha falhado, projetou seu líder Hugo Chávez na cena nacional. Desse modo, o golpe, junto com o Caracaço, conferiu um novo ímpeto de organização para os movimentos sociais. No momento em que Chávez se preparava para lançar sua candidatura à presidência, em 1998, o sistema político e a economia neoliberal se encontravam tão gravemente desacreditados e os mecanismos para manter os oponentes tão ineficazes, que Chávez pôde aproveitar a oportunidade e vencer a eleição de modo arrasador. ${ }^{392}$

É intrínseco à natureza do pensamento social que as interpretações da realidade histórica carreguem em si parte da carga ideológica inerente à condição social e ao momento político em que atuam os sujeitos que as elaboram. Esse peso da ideologia, que é produto da realidade concreta dos conflitos sociais, se não vicia ou distorce obrigatoriamente a interpretação da realidade, por vezes é inevitável que lhe imprima o cunho dos desejos e dos objetivos da classe a que pertence seu formulador. Também é inevitável que nessa interpretação distintiva

\footnotetext{
391 GOTT, Richard. Hugo Chávez and the bolivarian revolution. London: Verso, 2005, p. 44 e 218.

392 WILPERT, Gregory. Changing Venezuela by Taking Power. The History and Policies of the Chávez Government. London: Verso, 2007. pp. 16-17 e 184.
} 
do passado e do presente, os grupos políticos em luta busquem, cada qual, encontrar legitimação para seus próprios projetos históricos. Por isso, as épocas de mudança na hegemonia de classes fazem-se acompanhar de reapropriações ideológicas do passado histórico pelos grupos ascendentes, de maneira a servirem essas reapropriações como validação dos atos que imporão a nova hegemonia. No que diz respeito ao Caracaço - caracteristicamente um acontecimento situado no centro de uma luta hegemônica - as maneiras de compreendê-lo não fogem a essas imposições histórico-ideológicas. Estando mais ou menos positivamente assentados os fatos objetivos da revolta em si, a adesão ou a oposição ao atual projeto chavista define, em boa parte, o caráter do debate presente sobre a revolta de 1989, em particular quanto à questão da continuidade (ou não) do processo político-social que vincularia diretamente Caracaço/Revolução Bolivariana. É nesta vinculação que, conforme a perspectiva que se adote, residiria ou a motivação popular da Revolução (e, portanto, o significado histórico desta como produto da luta do povo) ou, diversamente, a redução do papel e da ação popular ao quadro traçado pelo discurso retórico populista da Revolução (e, portanto, a distorção histórica por este provocada). Em termos objetivos (para empregar as palavras de um crítico da ideologia chavista): "Chávez foi engendrado pelo Caracaço? ou o Caracaço foi recuperado ideologicamente pelo chavismo ${ }^{\prime \prime 393}$ Parece claro que essa dissensão teórica possui uma motivação ideológica.

No plano histórico simbólico, naquilo que alguns chamam de imaginário coletivo, o regime inaugurado por Hugo Chávez reivindica ainda hoje os dias do Caracaço como o seu momento fundador, como o primeiro e fundamental elo de uma cadeia de eventos que suscitou e deu forma e conteúdo à Revolução Bolivariana. Nesta cadeia se sucederiam ao Caracaço, como fatos lógicos e de mesma significação, a tentativa de derrubada do governo de Andrés Pérez em 4 de fevereiro de 1992 (comemorado, não oficialmente, o Dia Nacional da Dignidade), a vitória nas eleições presidenciais de dezembro de 1998, a promulgação da Constituição da República Bolivariana da Venezuela em 1999 (ato formal fundador da $\mathrm{V}$ República) e a reação e restauração imediata, pela

${ }^{393}$ Cf. PEÑAFIEL, Ricardo. "Venezuela: L'interpellation du peuple". In: CORTEN, André et alii. L'interpellation plébéienne en Amérique latine. Violence, actions directes et virage à gauche. Québec: Éditions Karthala, 2012, p. 97. 
força da ação popular, do presidente deposto pelo golpe de 11 de abril de 2002. Nas imagens oficiais, o Caracaço passa a constituir, não uma simples explosão irracional e desorganizada de multidões aflitas e famintas, mas um movimento politicamente coerente, de bases populares, consistente com a tradição das lutas do povo venezuelano. A Revolução Bolivariana seria sua culminância; e Hugo Chávez, seu instrumento. Uma expressão sintética (e muitíssimo reiterada) disso está nos dois trechos seguintes - o primeiro, um artigo publicado pelo PSUV, comemorativo do aniversário do Caracaço; o segundo, parte de um discurso do próprio presidente Hugo Chávez:

(...) o 27 de fevereiro de 1989, (...) quando os marginalizados baixaram aos centros, quando as invisibilidades de sempre se fizeram protagonistas, quando se rompeu a bolha de passividade na qual havia mergulhado todo um aguerrido povo e quando nossa história se partiu em dois; para nunca mais voltarmos a ser os mesmos. (...) O Caracaço constitui o ponto de ruptura da democracia representativa, o despertar coletivo da consciência de um povo que se elege a si mesmo como o sujeito protagônico de sua própria história; o Caracaço também constitui um parto doloroso de uma nova etapa em nossa luta pela emancipação pátria; (...) nunca mais seremos os mesmos desde aqueles dias; e neles abrimos as grandes alamedas da história e nos pusemos a andar. ${ }^{394}$

Vinte anos depois de O Caracaço que me engendrou, dezessete anos depois da Rebelião Militar Bolivariana que me pariu e dez anos depois da tomada de posse que aqui me trouxe, ponho novamente minha vida e todo meu futuro nas mãos do povo e sua soberana decisão. Este soldado revolucionário fará o que o povo mande.

À luz dos autores que vimos enumerando na interpretação da revolta popular de 1989, é razoável afirmar que a reapropriação ideológica do Caracaço pelo chavismo, essencial à legitimação do novo processo político sobre a base ideal do protagonismo popular, não chega, a rigor, a romper a necessária objetividade da análise dos fatos. Há uma grande concordância nos trabalhos

\footnotetext{
394 27F: 24 años de El Caracazo, un pueblo masacrado por rebelarse contra medidas neoliberales del FMI. 23/02/2013. Disponível em: http://www.psuv.org.ve/portada/27-febrero-24-anos-caracazo /\#.V499ARLCrX0

${ }^{395}$ CHÁVEZ, Hugo. "Las líneas de Chávez". 22/01/2099. Citado por PEÑAFIEL, Ricardo. "Venezuela: L'interpellation du peuple", Op. cit., p.98.

A representação social do Caracaço possui tamanho apelo emocional na sociedade venezuelana que, em sentido contrário à reapropriação ideológica que a Revolução Bolivariana tem feito dele, os atuais grupos de oposição ao governo de Nicolás Maduro também o empregam como bandeira da "luta popular" contra o alegado autoritarismo bolivarianista. "Um outro Caracaço" foi o mote de grande parte dos protestos estudantis e "populares" de fevereiro de 2014, segundo a imagem veiculada pela grande mídia privada venezuelana.
} 
políticos e historiográficos ${ }^{396}$ sobre a extrema relevância da revolta tanto em, por um lado, precipitar o fim da democracia puntofijista (não obstante tivesse de transcorrer ainda toda uma década) e a quebra de confiança geral da sociedade em suas instituições, como em, por outro, expor inequivocamente aos grupos políticos de esquerda, não integrados ao esquema puntofijista, a necessidade de transformações radicais como base para qualquer solução que se pretendesse efetiva dos problemas sociais do país. Não haver dado a necessária atenção ao efeito socialmente dissolutivo da revolta sobre a estrutura política montada na conciliação constituiu um erro pelo qual a elite governante venezuelana pagaria, em seguida, alto preço. Negar, entretanto, a vinculação original e o compromisso do movimento bolivariano e, especialmente, da liderança individual de Hugo Chávez (e sua convicção pessoal forjada pela experiência dos dias da revolta) com as lutas dos movimentos populares e, sobretudo, com a construção de um regime democrático - sob a alegação de que "(...) o protagonismo popular [nos anos do chavismo] revela-se um fetiche tendente a reduzir o campo da ação coletiva e a neutralizar seu valor político ("protagônico" ou soberano) sobredeterminando-a, obrigando-a a manter-se no quadro imposto pela lei e pela retórica da Revolução bolivariana" ${ }^{397}$ - é, porventura, subestimar o valor progressista do novo regime. Um regime que, na história da Venezuela (e do continente), tem representado um momento inusitado e privilegiado de inclusão política e social das camadas pobres populares, de valorização de ideais socialistas (em uma época de domínio quase absoluto da irracionalidade

\footnotetext{
${ }^{396}$ Não obstante, o estudo de Ricardo Peñafiel identifica nessa reapropriação do chavismo um ocultamento e uma distorção deliberada da realidade objetiva do Caracaço, expressos incisivamente em um dos subtítulos Chávez et la trahison du Caracazo. Para Peñafiel, o Caracaço foi um movimento violento e desarticulado, de saques e desordens (e assim visto por seus protagonistas), que, contudo, a versão chavista procurou tornar asséptico, sob a denominação de uma rebelião popular. Ao dar à revolta um caráter orgânico e coletivo, o chavismo procurou controlar o poder "indomável" da explosão popular e canalizá-lo para um propósito diverso do original. A partir disso, e referindo-se às posteriores iniciativas oficiais de organização popular (círculos bolivarianos, conselhos comunais, cooperativas agrícolas etc.) criadas por Hugo Chávez, indaga o autor: "(...) en lui donnant (imposant) une voie (...), le chavisme n'est-il pas en train de chercher à 'domestiquer' cette force 'indomptable' qui s'est exprimée lors du Caracazo (ainsi que dans une série d'autres actions colletives contestataires antérieures et ultérieures? N'est-il pas en train de neutraliser la valeur politique d'actions collectives qui, en cessant d'être spontanées, ne sont plus en mesure de montrer d'autres 'limites' que celles déjà établies par le discours politique institué? En 'aidant' les personnes engagées dans des luttes (pour l'eau, le logement, les terres agricoles, etc.) en leur offrant reconnaissance, ressources, structures et pouvoir, Chávez n'est-il pas en train de désamorcer les espaces d'expression des conflits pour les contraindre à ne servir que sa cause?" (Op. cit., p 107)

${ }^{397}$ PEÑAFIEL, Ricardo. "Venezuela: L'interpellation du peuple", p. 95.
} 
neoliberal) e de democratização da riqueza material - embora seja indiscutivelmente claro que esse projeto histórico progressista encontra-se ainda muitíssimo longe de concretizar os objetivos e as condições históricas que ele próprio traçou como necessários à sua viabilidade e legitimidade, e cujo possível fracasso ele próprio reconhece ser o resultado de fragilidade em suas convicções originais e de incapacidade em impedir que os ideais e as práticas democráticas (socialistas ou não) se corrompam em contato com o despotismo político e a ganância material que reinaram na história pregressa do país e que o chavismo considera seu propósito combater e destruir. ${ }^{398} \mathrm{O}$ protagonismo popular, nestes anos, está a meio caminho entre a idealização e a concretização. Não se compreenderia, porém, a importância atual da presença popular nos momentos difíceis da política recente do país, nem a sucessão de vitórias dos candidatos bolivarianos nas disputas eleitorais desde 1998, sem conceder algum grau de efetividade a esse protagonismo do povo venezuelano. Encarar deste modo a realidade presente da Venezuela é, talvez, mais consentâneo com os fatos hoje observáveis, com os avanços democráticos inegáveis do movimento bolivariano e, em especial, com o legado histórico que se deve reconhecer e conservar da história do Caracaço.

Uma das consequências dos acontecimentos de fevereiro/março de 1989 foi acentuar a instabilidade da ordem política nacional. ${ }^{399}$ A repressão violentíssima, como foi dito, provocou o amplo repúdio de personalidades e grupos políticos, e convenceu alguns deles - como os militares - de que era necessária uma mudança mais profunda na vida institucional do país. Assim, em fevereiro de 1992, oficiais de média e baixa patentes (de tenentes a coronéis) do Exército tentaram depor o presidente Andrés Pérez, quando este voltava de uma viagem ao exterior. Ao total, eram cerca de 300 oficiais e pouco mais de 2000 soldados. Insurgiram-se tropas de Maracay, Maracaibo e Valência, cabendo ao

\footnotetext{
${ }^{398}$ Cf., por exemplo, HARNECKER, Marta. Venezuela: una revolución sui géneris. Ponencia Seminario de LAC (Foro Social Mundial III). 24 enero 2003. Disponível em: http:// www.rebelion.org/docs/97071.pdf; e, também, LANDER, Edgardo. Venezuela: a busca de um projeto contra-hegemônico. CLACSO, Consejo Latinoamericano de Ciencias Sociales. Julho 2005. Disponível em http://bibliotecavirtual.clacso.org.ar/ar/libros/grupos/cece2PT/10_lander.pdf ${ }^{399}$ Cf. MAYA, Margarita López. Luta hegemônica na Venezuela, pp. 96-116.
} 
tenente-coronel Hugo Chávez Frías a liderança do movimento. Provavelmente por erros do comando na operação de prisão do presidente e, igualmente, pela rápida ação de militares leais ao governo, Caracas rapidamente ficou sob controle das tropas legais. ${ }^{400}$ Logo ao dia seguinte, o comandante Hugo Chávez rendeu-se e, pela televisão, anunciou que os objetivos não haviam sido, àquele momento, alcançados, pediu aos companheiros que depusessem armas e assumiu toda a responsabilidade pelo movimento.

Em 27 de novembro do mesmo ano, militares de alta patente das Forças Armadas tentaram uma nova insurreição. O movimento partiu de Arágua, com aviões que bombardeariam Caracas (o palácio presidencial, o prédio do Congresso e uma sede da DISIP). O movimento contou com civis, que conseguiram invadir e controlar uma estação de televisão, e a usaram para lançar mensagens de convocação à sublevação. Mas, como a revolta de fevereiro, o movimento foi rapidamente dominado e presos seus líderes. Apesar disso, o governo de Pérez não logrou recuperar força: "O que o Caracaço não conseguiu alcançar em 1989, conseguiram-no os golpes de 1992, especialmente o primeiro: desatar um incontível processo de desmoronamento da sustentação política do governo e propiciar a emergência de atores e ações que depois impulsionariam mudanças drásticas no sistema político venezuelano". ${ }^{401}$

Em maio do ano seguinte, após decisão da Corte Suprema de Justiça, o Congresso autorizaria o início do processo de impeachment do presidente Pérez. No final desse ano, nas eleições presidenciais, elegeu-se Rafael Caldera, que, embora tivesse sido fundador e líder histórico do Copei, retirara-se do partido e fundara outro, o Convergência. Teve nas eleições o apoio de partidos de esquerda, como o MAS (Movimento ao Socialismo) e o PCV. Ocorria assim a primeira vitória, desde 1958, de um candidato não pertencente ao esquema ADCopei, embora sua figura não representasse a oportunidade de uma verdadeira mudança de fundo.

\footnotetext{
400 Idem, p. 97.

401 Idem, p. 98.
} 
A concepção marxista do Estado descreve o moderno Estado burguês como "(...) um corpo secretado pela sociedade para vigiar o funcionamento cotidiano da vida social e que está a serviço da classe dominante para manter a dominação que tal classe exerce. Existe uma necessidade objetiva de existir esse corpo de vigilância - necessidade estreitamente vinculada ao grau de pobreza e ao volume de conflitos sociais que sobejam no seio da sociedade". ${ }^{402}$ De acordo com essa concepção, somente à medida que se abrande a pobreza social e se concretize algum grau aceitável de integração dos trabalhadores, como cidadãos, à sociedade capitalista - e não unicamente sua conscrição forçada ao sistema produtivo - é que as funções mais violentamente coercitivas do Estado-vigia podem atenuar-se, ao mesmo tempo que certa representação política efetiva seja concedida às classes trabalhadoras no âmago do Estado como forma necessária de expressão daquilo que a própria burguesia postula como a democracia - um de seus valores ideológicos capitais. Porém, o Estado de direito que daí emerge não constitui garantia nem de um nível satisfatório e duradouro de bem-estar dos trabalhadores e das classes populares nem, por extensão, da continuidade do funcionamento da sociedade burguesa e suas estruturas de poder em quadros democráticos. Diante disso, o sucesso da luta socialista pela supressão do Estado burguês estaria condicionado pela capacidade de organização e de combate das classes trabalhadoras, que, ao insurgirem-se e apoderarem-se das instituições estatais, as dirigiriam às necessidades proletárias - entre elas, a de aproveitar a própria máquina administrativa existente (os técnicos e funcionários burgueses, por exemplo) para reorganizar em proveito próprio as funções sociais do Estado. O objetivo primeiro do novo Estado proletário residiria, portanto, na destruição dos mecanismos capitalistas de exploração de classe e das estruturas políticas de dominação burguesa. Mas, também neste caso da vitória proletária, o Estado enquanto tal perduraria, e só desapareceria historicamente quando fosse dada solução à situação que o justifica, ou seja, a de carência social de bens essenciais (motivação primordial das revoltas populares, provocadas afinal pela consciência mais ou menos clara de que a riqueza que a sociedade produz sofre uma partilha desigual e excludente). Esse estágio superior de desenvolvimento

\footnotetext{
${ }^{402}$ MANDEL, Ernest. La conception marxiste de l'Etat. Bruxelles, Documents Socialistes, 1965. Disponível em http://www.ernestmandel.org/fr/ecrits/txt/1965/la_conception_marxiste_de_etat.htm.
} 
social permaneceu e permanece ainda inalcançado concretamente, mesmo em sociedades socialistas, do passado e do presente.

Ora, nas nações subdesenvolvidas da América Latina, as parcelas grandemente majoritárias de suas sociedades estão sujeitas a condições permanentes de miséria social e de exclusão política. Nelas, nem a integração nem a democracia burguesas "clássicas" são, a rigor, possíveis. Nesses países dependentes, de evolução lenta e presa aos limites estreitos estabelecidos pelo capitalismo monopolista, a transnacionalização de suas economias não só vem significando a imposição de obstáculos intransponíveis ao desenvolvimento econômico pleno como entidades nacionais autônomas, mas também tem engendrado - em função dos agudos e constantes conflitos de classes - formas extremamente autocráticas de poder político, tornadas responsáveis por destruir qualquer espaço de manifestação da contestação popular ao estado de carência material ocasionado pela exploração econômica interna e externa. Como nessas sociedades periféricas os setores dominantes das burguesias renunciaram peremptoriamente à revolução nacional, permitiram que o próprio Estado se transnacionalizasse. ${ }^{403}$ A lógica da dominação interna de classe acabou por imprimir a esse mesmo Estado o papel de executor da violência política institucionalizada, que se exerce sobretudo sob a forma de repressão armada às manifestações mais contundentes de sedição, quer nascidas das camadas populares quer dos setores médios radicais. De fato, ainda que se alegue que a vinculação das elites nacionais ao capital internacional acarrete uma "debilidade nacional" dos grupos dominantes, essa fraqueza inexiste quando o que está em jogo é, internamente, a defesa dos privilégios proporcionados pela associação burguesia nacional/capital estrangeiro. Em tais circunstâncias, transparece com toda a crueza o traço truculento do Estado "nacional", que, erguido como baluarte da ordem burguesa - de proteção da propriedade, dos interesses materiais e das

\footnotetext{
403 "Cada vez mais o Estado transnacionalizado se vê impotente frente aos centros de decisão econômicos e políticos que dirigem o sistema transnacionalizado. Na medida em que os Estados transnacionalizados não têm condições de determinar que tipo de industrialização, de desenvolvimento, que convém às necessidades e às potencialidades de cada país em particular, eles se veem frente à única condição que Ihes sobra: promover as condições para que a transnacionalização se dê e administrar suas crises. Os sonhos de desenvolvimento, de afirmação de soberania nacional, são substituídos pela retórica dos grandes projetos que não pertencem nem beneficiam fundamentalmente aos países 'hóspedes' dos projetos transnacionalizados". (SOUZA, Herbert José de. O capital transnacional e o Estado. Petrópolis: Vozes, 1985, p. 16.)
} 
prerrogativas políticas de classe - permite avaliar quão tênue tem sido, na América Latina, a diferença entre os regimes de direito e os regimes de força. Nessas sociedades subdesenvolvidas, em momentos de turbulência social, a democracia ambivalente reserva às classes populares - marginalizadas e exploradas - o mesmo tratamento que Ihes concederiam as ditaduras militares, traindo nessas ações o latente despotismo e a permanente exclusão do modelo de democracia e de desenvolvimento que o capitalismo dependente é capaz de construir. Nesses momentos, o ordenamento democrático constitucional dá lugar às ações pretorianas do Estado repressor - deixando às claras, assim, a essência despótica de todas essas variações do Estado burguês, bem como sua incompatibilidade, ao menos no capitalismo periférico, com os universais direitos do homem e do cidadão, que estão na origem desse mesmo ordenamento. É desse ponto de vista que, presumimos, deve-se compreender a explosão social de fevereiro de 1989 e a reação oficial a ela, quando o Estado venezuelano, revestido até então da aura democrática de distribuidor da riqueza nacional diante da crise profunda de seu sistema produtivo - assumiu, frente à revolta popular eclodida, a face indisfarçada de uma ditadura burguesa cruel e homicida, supostamente contrária a sua própria tradição democrática. A bem dizer, essa tradição ocultou, quanto pôde, seu funcionamento juridicamente baseado em recursos repressivos dirigidos às camadas pobres e marginalizadas da sociedade, como foi o caso da soturna Lei de vagabundos e meliantes. A explosão de 1989 expôs cruamente as deficiências da democracia burguesa venezuelana. $O$ Caracaço ergueu-se, ao fim, como um daqueles monumentos de miséria burgueses a que se referiu, certa vez, Graciliano Ramos. 


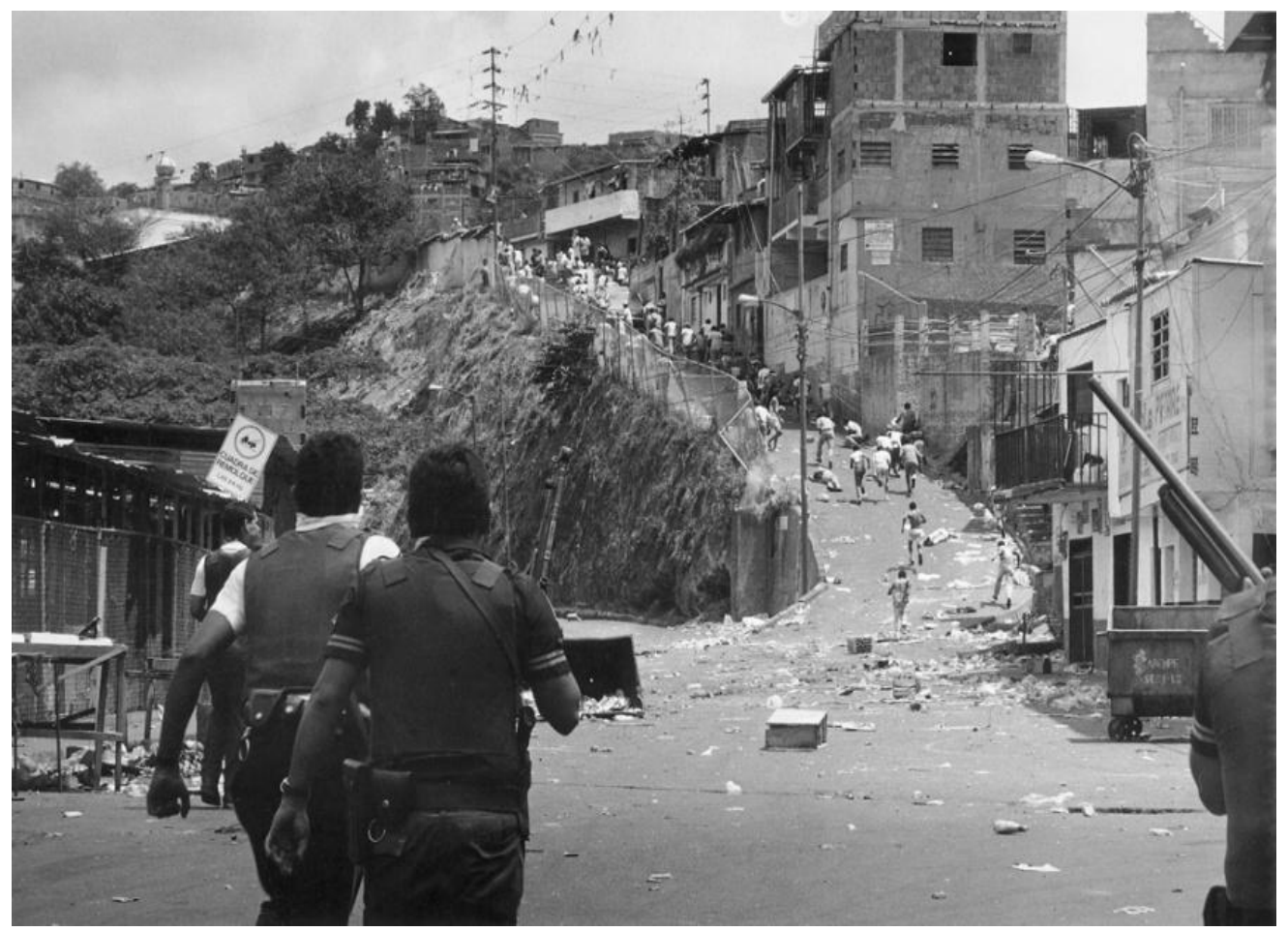

Fig. 1: Pessoas feridas no Bairro 19 de Abril, Petare. (Francisco "Frasso" Solórzano). Noticias 24 e $A V N^{404}$

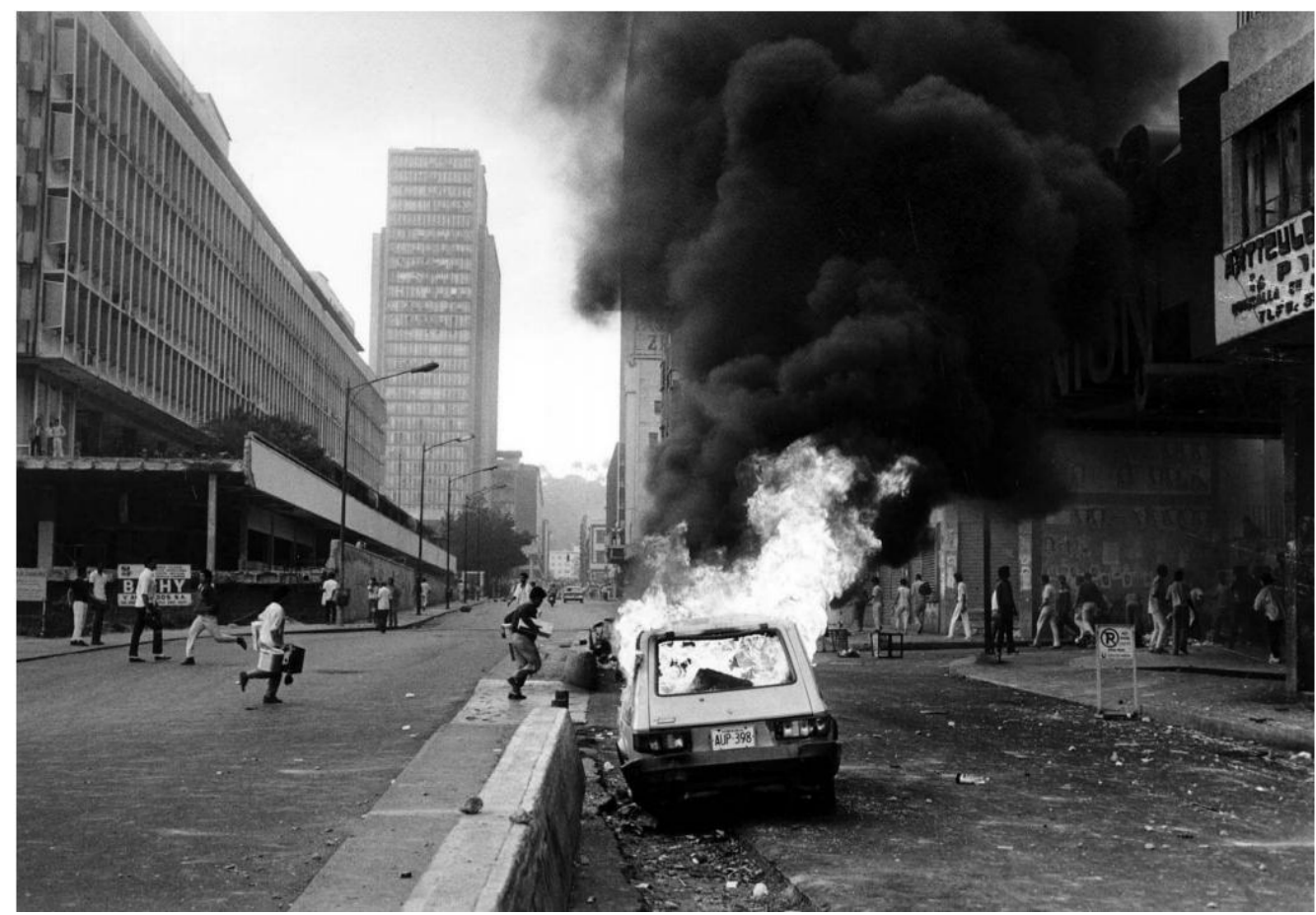

Fig. 2: Caracaço. (Tomás "Tom" Grillo). ABN

\footnotetext{
${ }^{404}$ As 9 fotografias seguintes, da revolta de fevereiro-março de 1989, foram feitas por Francisco "Frasso" Solórzano e Tomás "Tom" Grillo. (Coligidas por Noticias 24, Agencia Venezolana de Noticias e Agencia Bolivariana de Noticias. Disponíveis em: http://venezuelanalysis.com /images/7946; e em: www.embavenez-us.org/pdfs/elcaracazoinpictures .pdf. A foto da fig. 11 é de autoria de José Cohén, e foi extraída de CORONIL, Fernando \& SKURSKI, Julie. Op. cit., p. 306.
} 


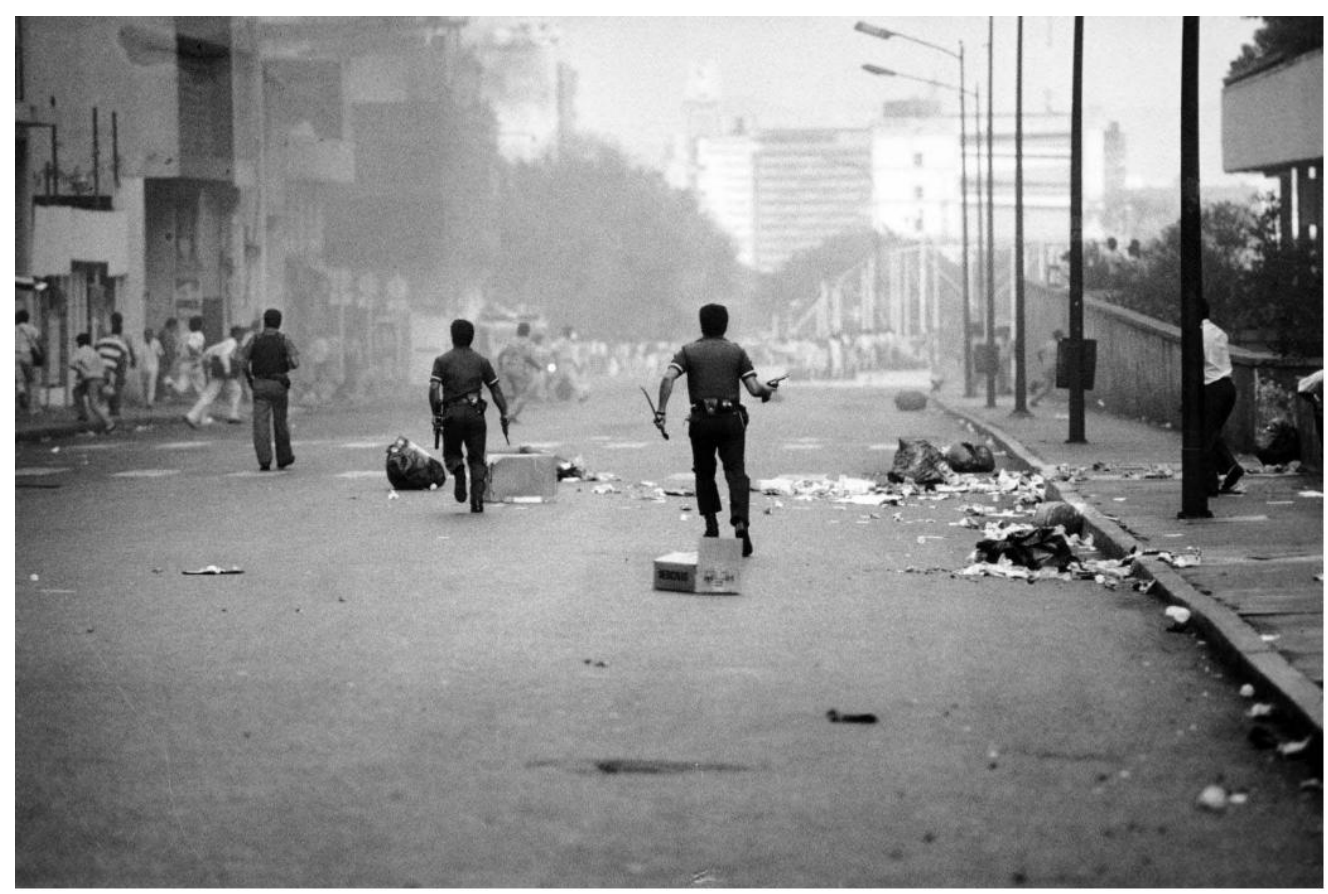

Fig. 3: Caracaço (Tomás "Tom" Grillo). ABN

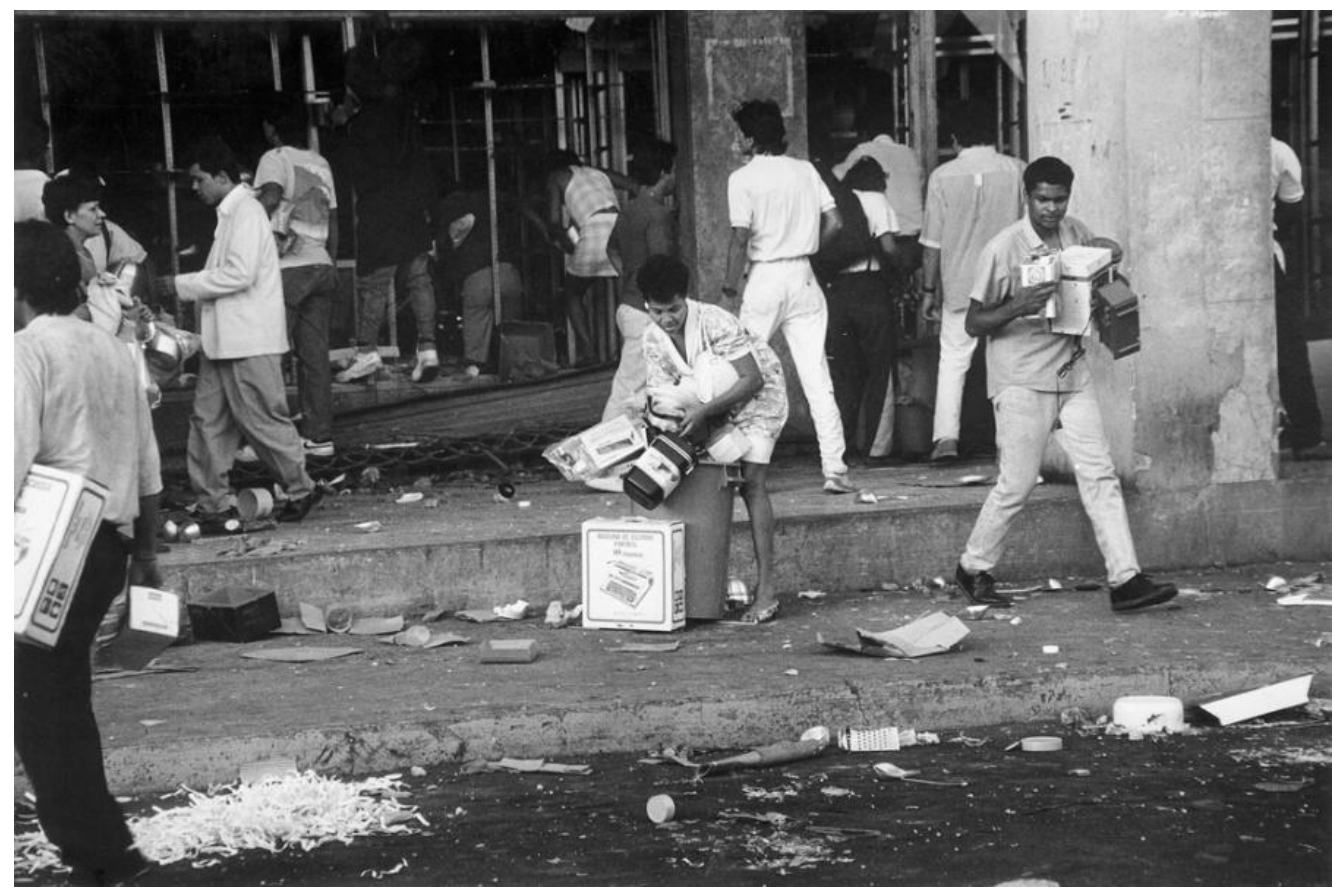

Fig. 4: Saques no centro de Caracas (Francisco "Frasso" Solórzano). Noticias 24 e AVN 


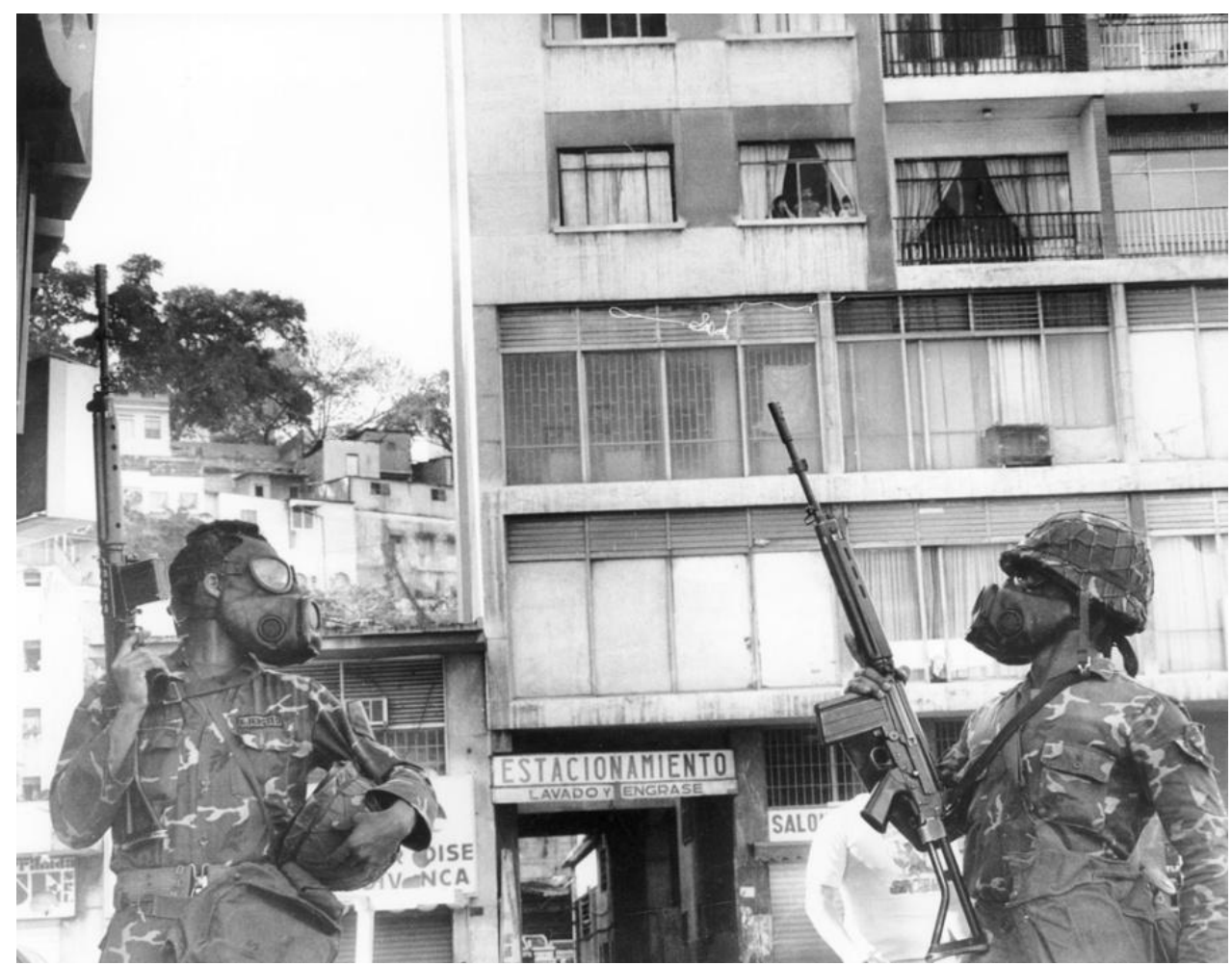

Fig. 5: El Caracazo (Francisco "Frasso" Solórzano). Noticias 24 e AVN

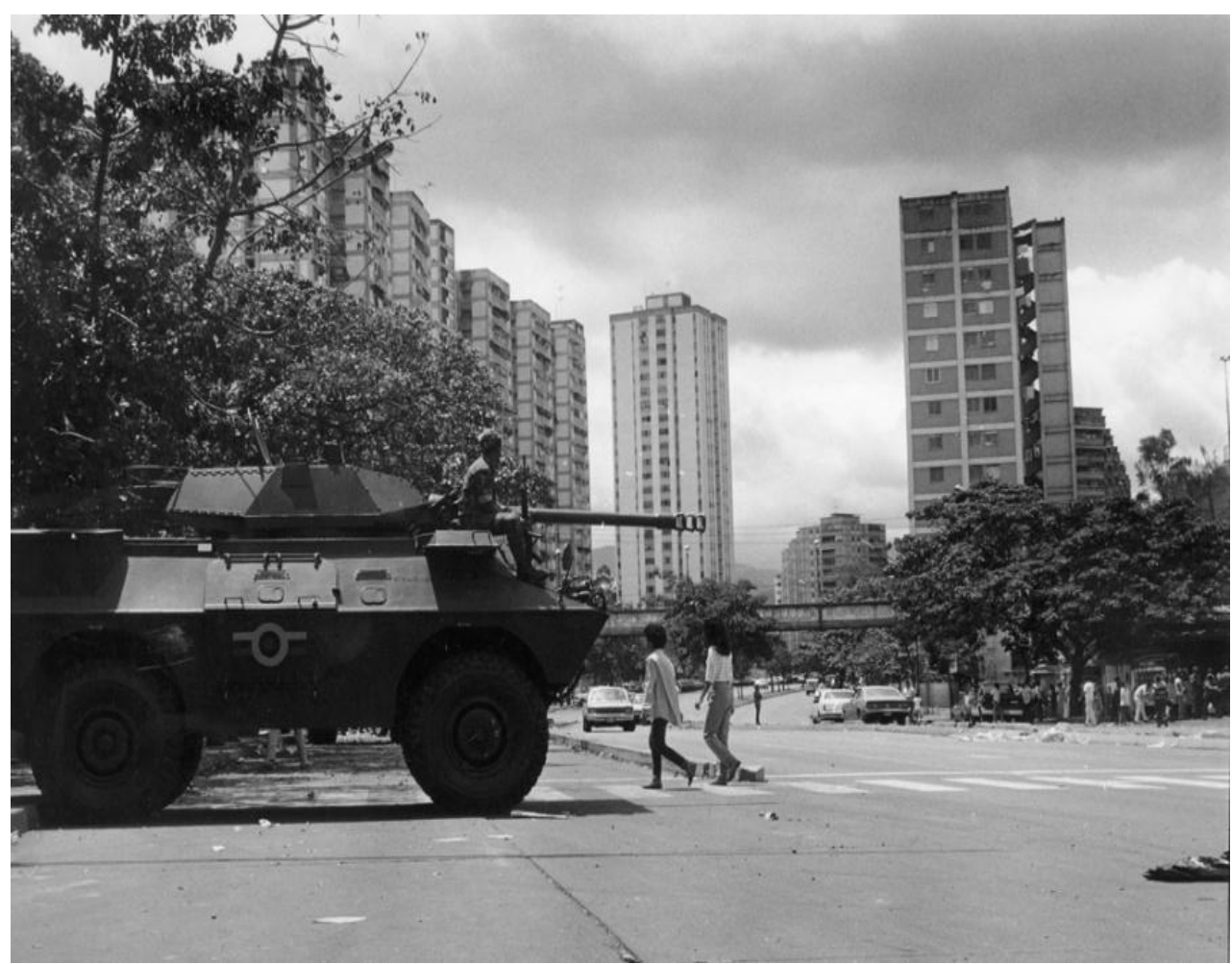

Fig. 6: Av. Intercomunal EI Valle (Francisco "Frasso" Solórzano). Noticias 24 e AVN 


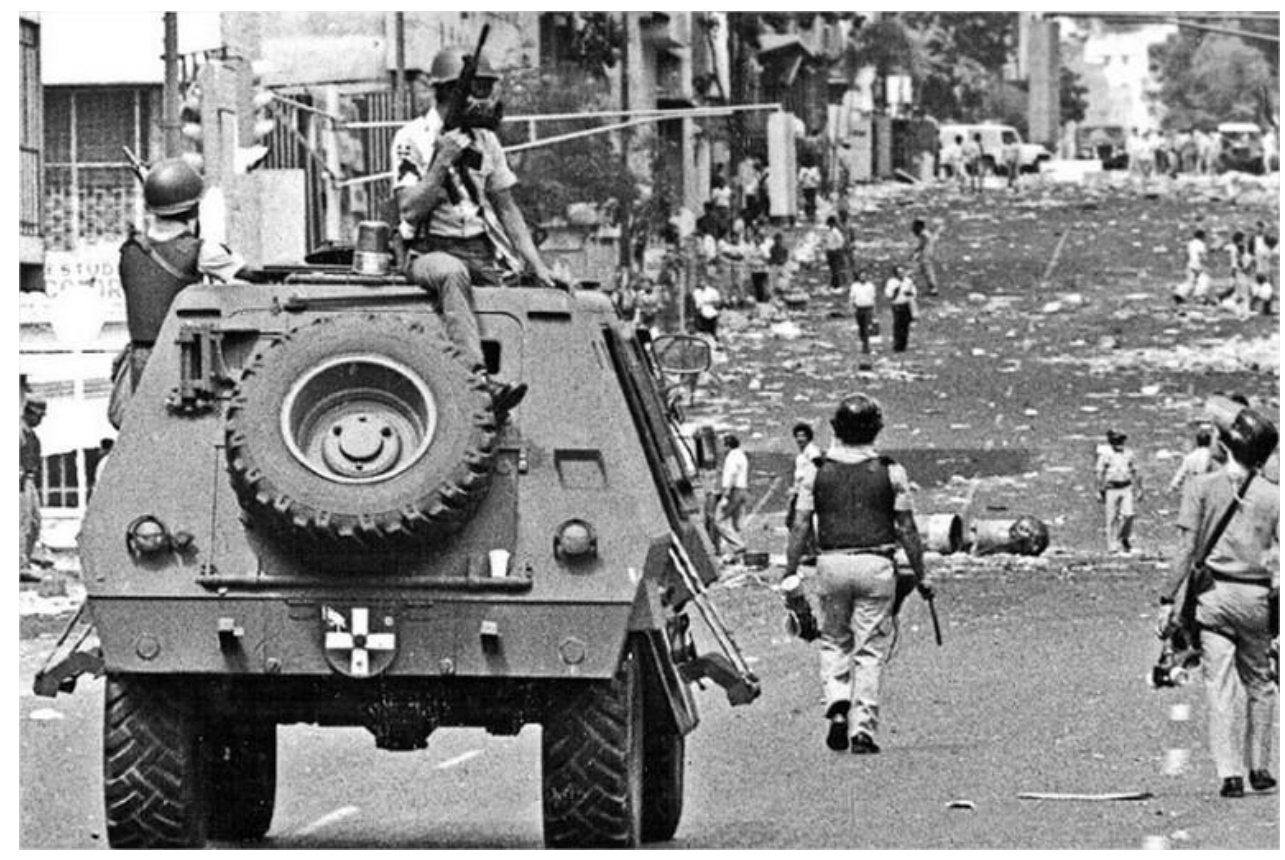

Fig. 7: Armamentos de guerra contra civis inermes (Arquivo de venezuelanalisys.com)

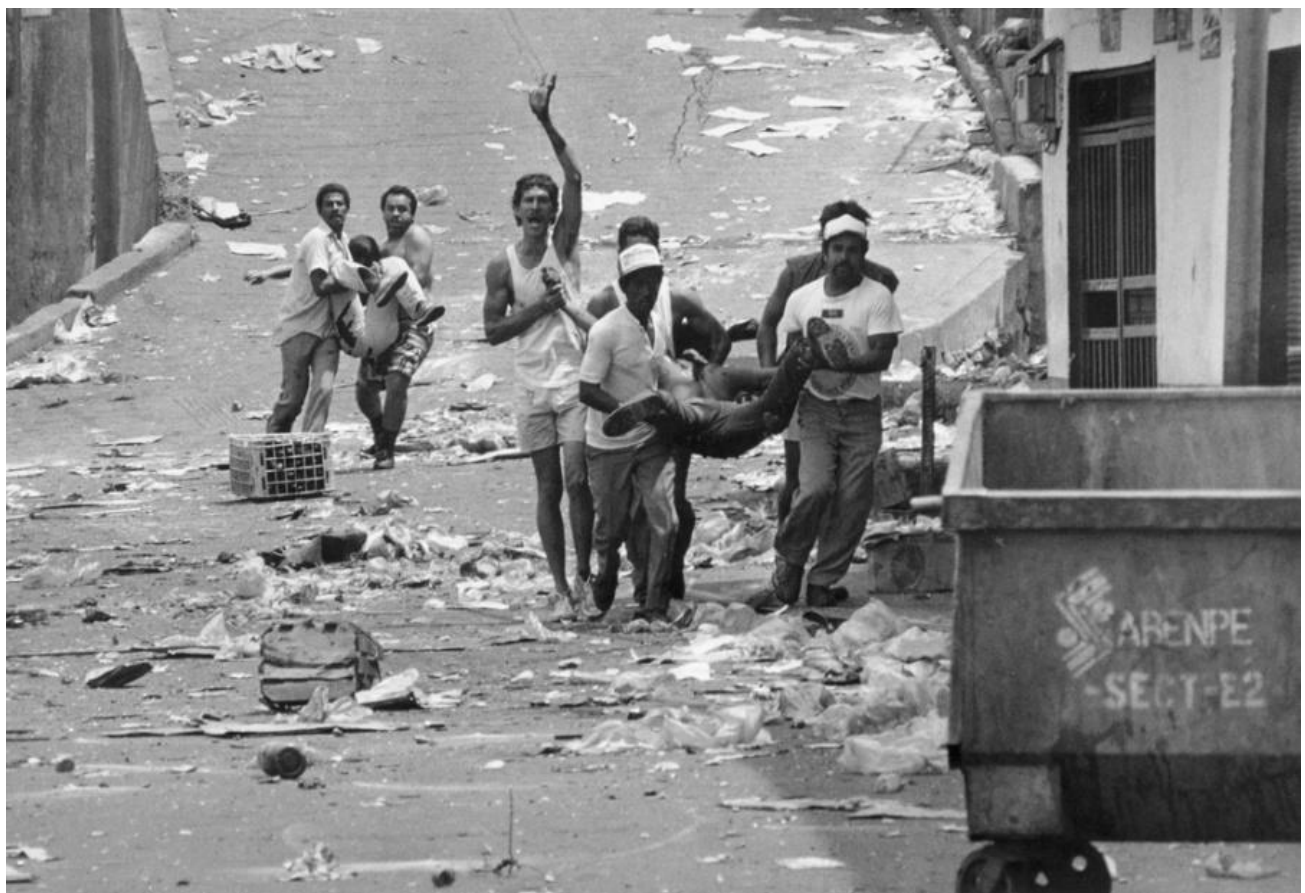

Fig. 8: Bairro 19 de Abril, Petare. (Francisco "Frasso" Solórzano). Noticias 24 e AVN 


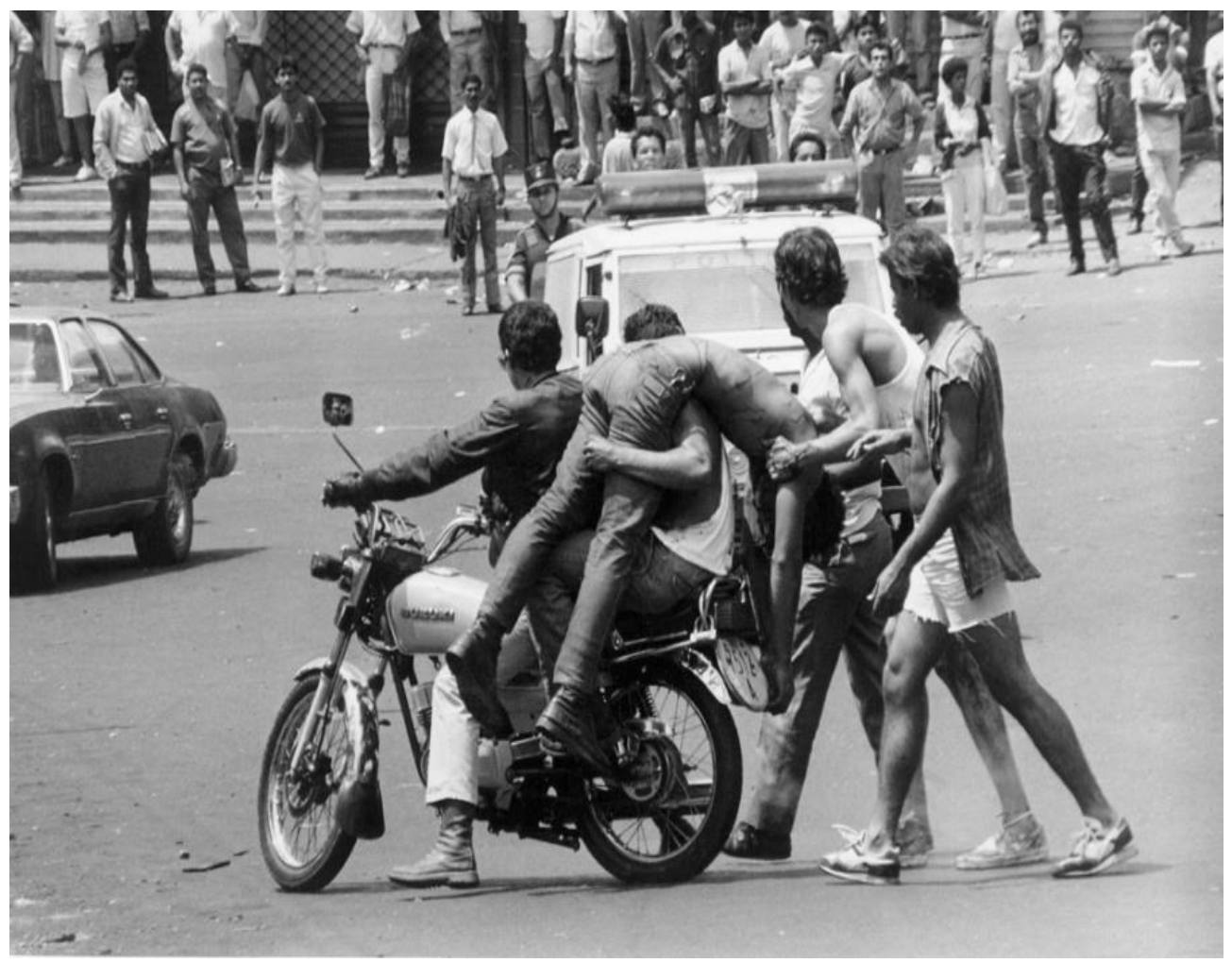

Fig. 9: Bairro 19 de Abril, Petare. (Francisco "Frasso" Solórzano). Noticias 24 e AVN

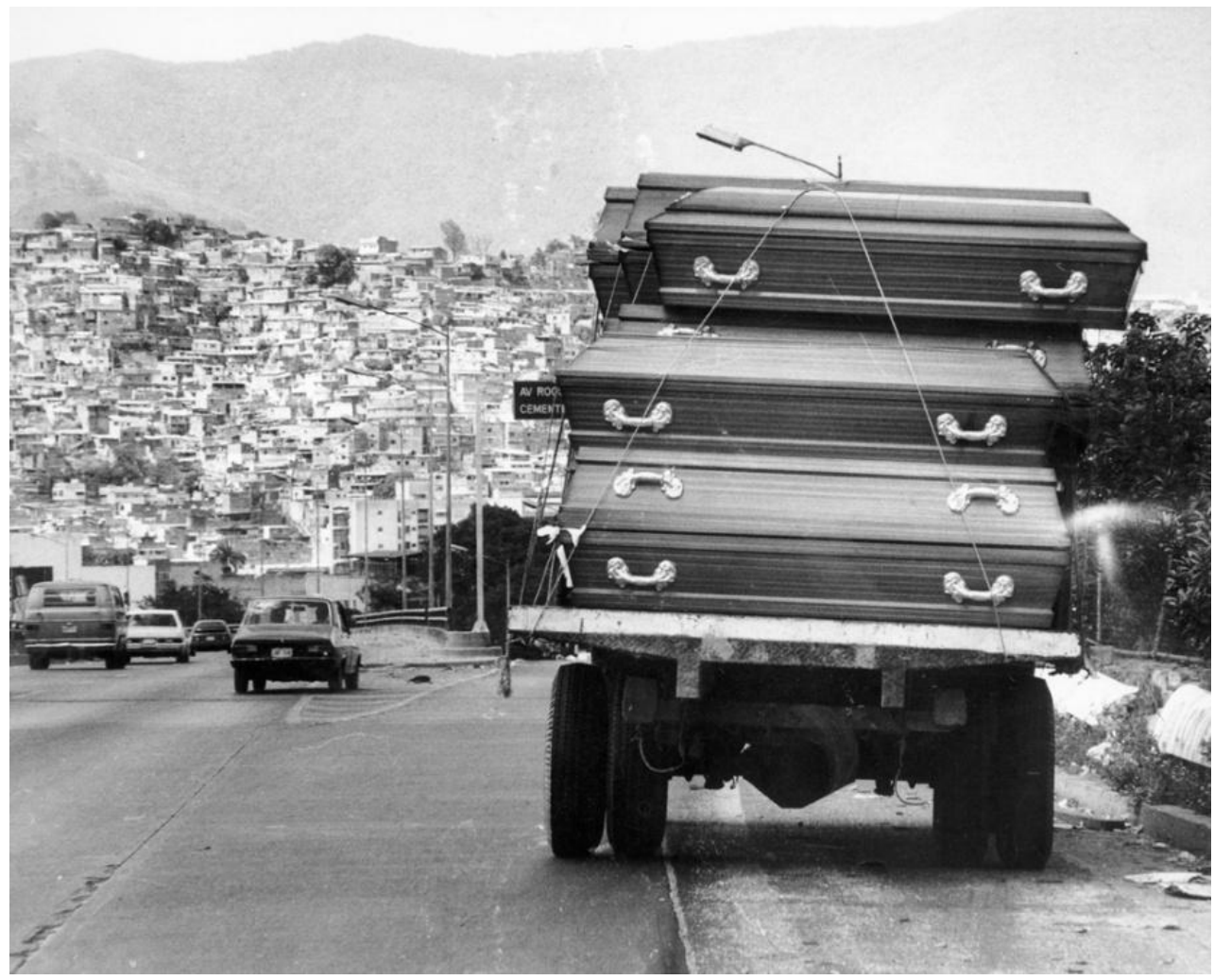

Fig. 10: Esquifes para Caracas. (Francisco "Frasso" Solórzano). Noticias 24 e AVN 


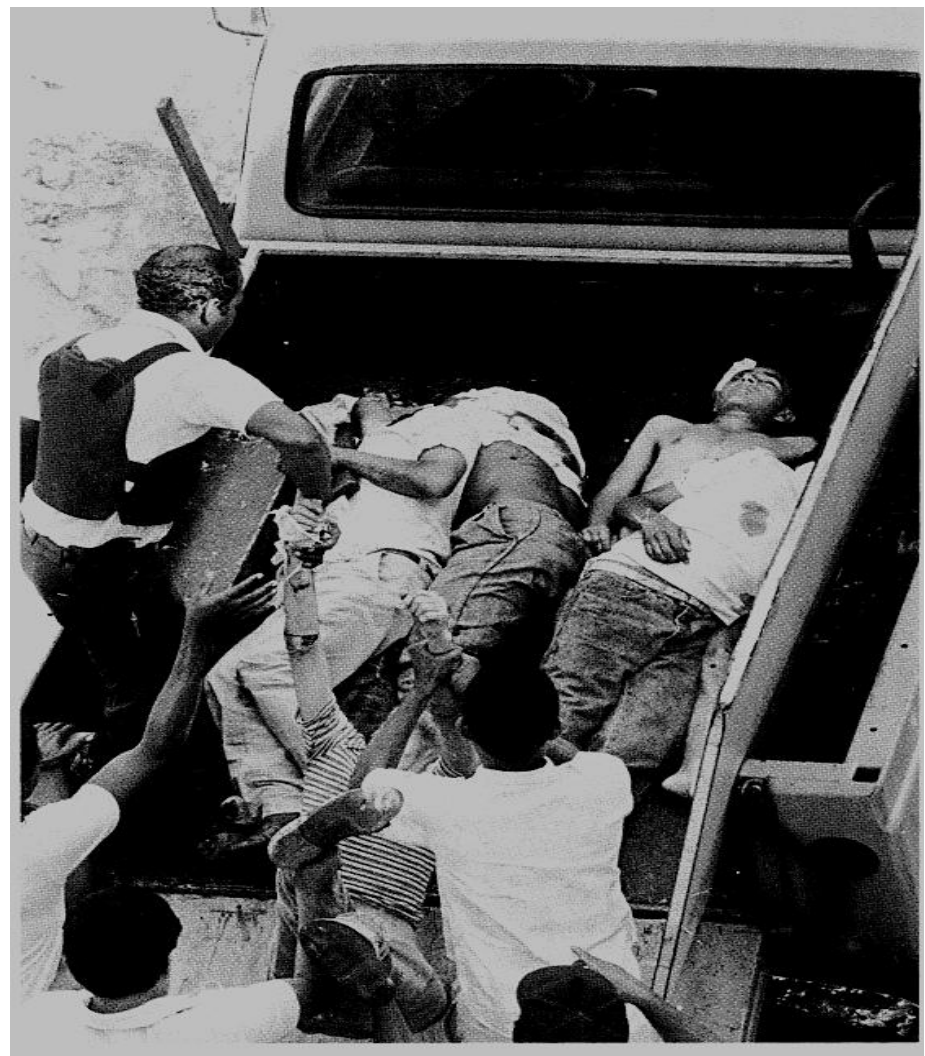

Fig. 11: Agentes amontoando corpos em um veículo (Foto: José Cohén)

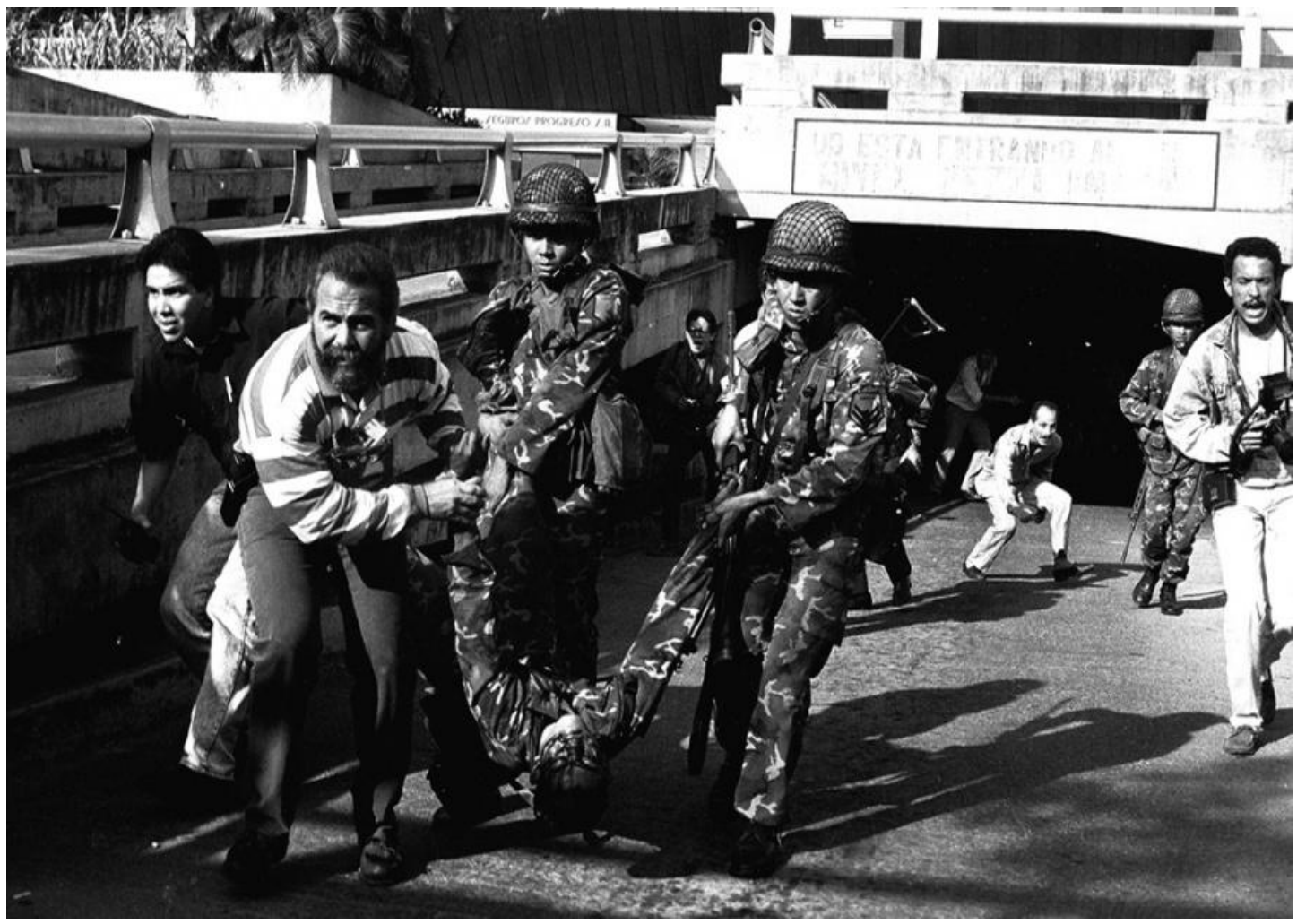

Fig. 12: Civis e militares rebeldes carregam soldado ferido durante a rebelião de 4 de fevereiro de 1992. (Notícias 24). 


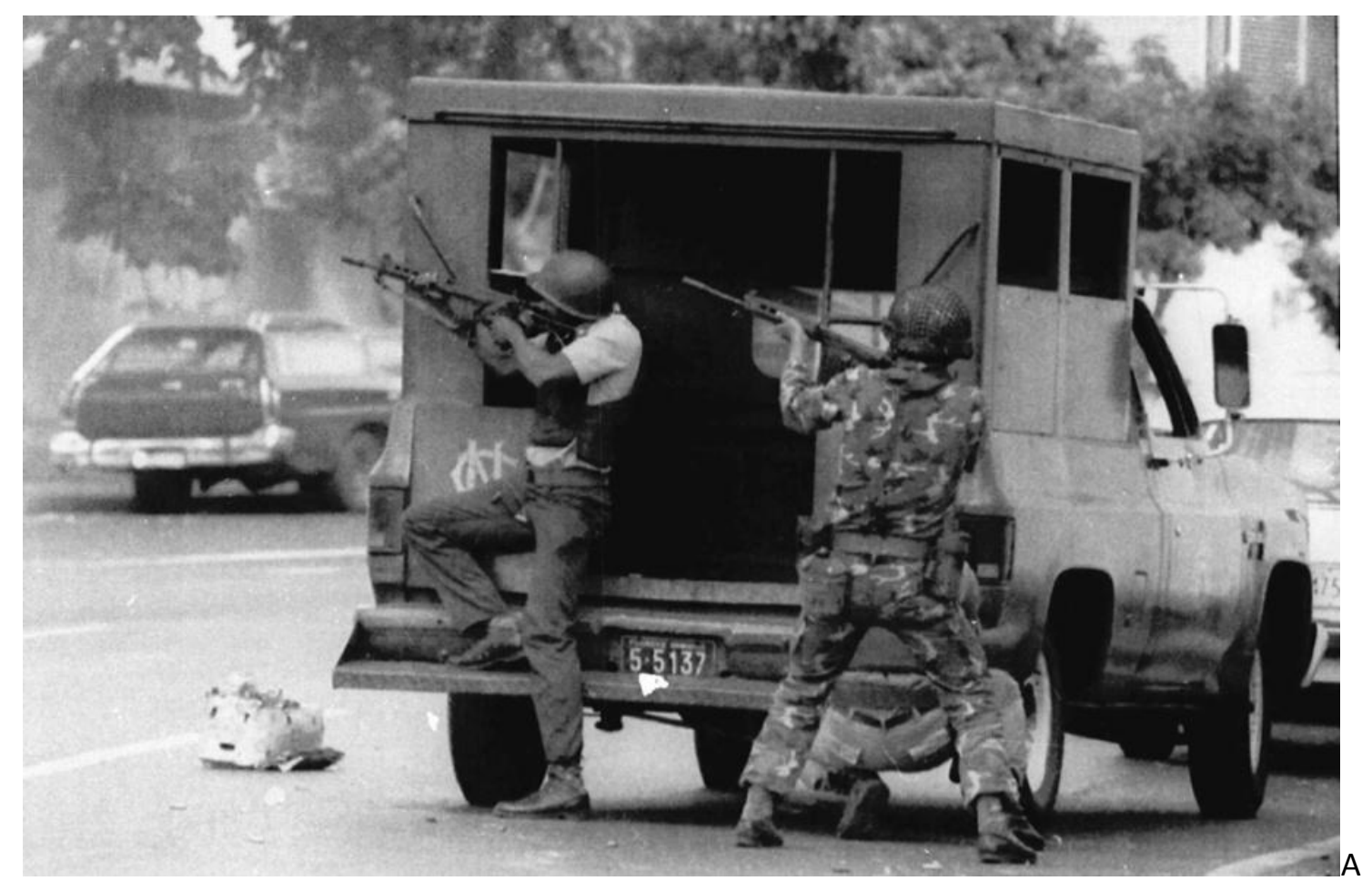

Fig. 13: Policial e soldado combatem rebeldes em fevereiro de $1992(A P)$

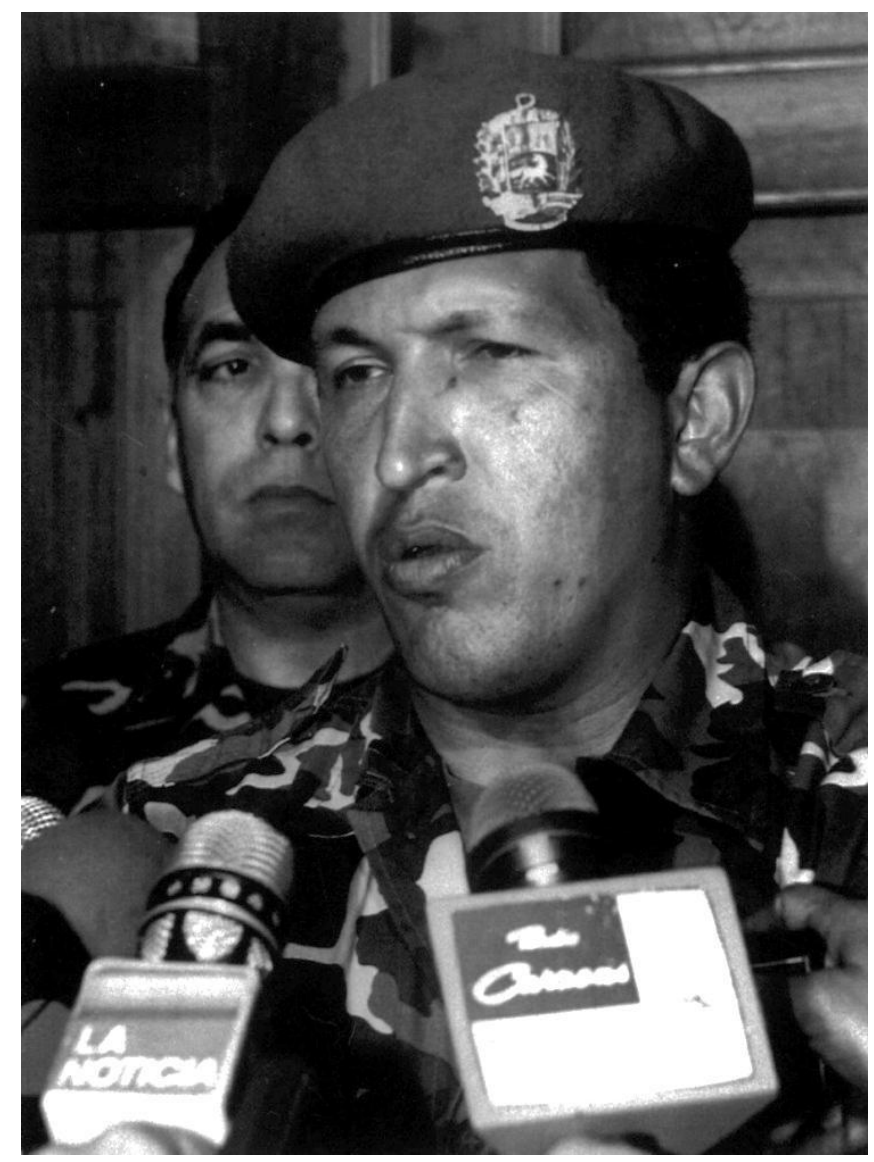

Fig. 14: Hugo Chávez exorta os companheiros a depor as armas e declara que os objetivos do movimento não foram alcançados "por enquanto". (AP) 


\section{Cap. 7: A crise final da democracia de Punto Fijo}

Uns poucos meses apenas antes da explosão popular de fevereiro de 1989, era ainda possível encontrar análises afirmando, com seriedade, que "(...) 0 traço de maior relevância no sistema político venezuelano é, sem dúvida, sua estabilidade, em uma região de 'democracias condicionais' que devem ser permanentemente avaliadas para julgar suas possibilidades de sobrevivência". ${ }^{405}$ Tal afirmação, embora possa representar um acidental erro de observação se considerarmos a grave convulsão social e a crise institucional que se instalariam imediatamente depois na Venezuela, denotava antes a considerável força, em parte ainda atuante, dos elementos que sustentaram a democracia puntofijista durante as três décadas anteriores e o fariam ainda por mais um decênio. Eram eles, como vimos, a relativa abundância de recursos públicos, que, apesar de em forte declínio havia anos, alimentava ainda a rede de clientelismo em torno do qual se organizava o "(...) complexo de pactos que estabeleceram as regras do jogo entre os atores políticos mais importantes" ${ }^{406}$; o sistema de alternância dos dois partidos políticos hegemônicos, que, por um lado, garantia aos setores sociais abastados a desejada representatividade democrática e, por outro, dificultava a ascensão de outros partidos ao primeiro plano do cenário nacional; e o fracasso das alternativas político-ideológicas à direita (o militarismo) e à esquerda (o socialismo revolucionário), estando a primeira submetida aos princípios e práticas da democracia representativa, e a segunda eliminada à força de violência pelo aparato repressivo estatal. Esse ambiente político e social mudaria drasticamente depois do Caracaço, e a década de 1990, conquanto se iniciasse com expectativas de recuperação econômica, rápido revelou a ilusão das promessas de reajustes da economia. Neste último e breve capítulo, nos limitamos a sumariar as causas que explicam a crise final do regime de Punto Fijo, aceitas por grande parte da literatura do assunto, e cujas condições históricas de formação e evolução procuramos expor e discutir nos capítulos anteriores.

\footnotetext{
${ }^{405}$ CALCAÑO, Luis Gómez. La democracia venezolana entre la renovación y el estancamiento. Revista Pensamiento Iberoamericano, no. 14, 1988, jul.- dic., pp. 181-195.

${ }^{406}$ Idem, p. 181.
} 
Em termos concisos, a crise final do regime puntofijista foi fruto da lenta desagregação da combinação rentismo petroleiro/ populismo de conciliação/ desenvolvimento nacional, completada quando cada um dos elementos da relação esgotou-se inteiramente. Primeiramente, a base material da crise revelouse na falência da organização do sistema produtivo nacional segundo um modelo que tinha por alicerce as receitas petroleiras, progressivamente ampliadas e controladas pelo Estado. A nacionalização do petróleo, a despeito das brechas abertas para anular ou reduzir a capacidade perceptiva fiscal do Estado, criou condições concretas para se lançarem as bases de uma verdadeira industrialização do país. A oportunidade histórica, contudo, não foi aproveitada, e os anos de prosperidade (entre 1973 e 1983, aproximadamente) encontraram o obstáculo da incapacidade de a economia absorver produtivamente os grandes volumes de capital disponíveis sob a forma de investimentos públicos e privados estrangeiros. A industrialização não alcançou a necessária diversificação produtiva, embora o Estado tenha promovido o desenvolvimento dos setores de base. A herança do petróleo - "a riqueza fácil" - predominou com seu peso negativo sobre os projetos de modernização industrial, e nesses anos de crédito abundante, o mercado consumidor - que aumentara significativamente e podia constituir a garantia da produção nacional - foi, em grande medida, abastecido pela importação de produtos manufaturados. O resultado, já por volta de meados dos anos 1980, foi a queda acentuada da produção industrial, manifestada nos números do comércio exterior do período (por ex.: saldo importações menos exportações. Cf. tabela 9, cap. 2). Em contrapartida, o fracasso em diversificar o sistema produtivo fortaleceu a condição de enclave econômico do país, aumentando a dependência do petróleo. Isso significou, evidentemente, a sujeição maior da economia às oscilações do mercado externo, que, por infortúnio, tendeu a retrair-se durante toda a década de 1980. Os preços do petróleo em queda reduziram a capacidade de o Estado arcar com os custos das despesas internas. A partir de 1983, o volume crescente da dívida externa passou a representar um dos mais preocupantes limitadores do desenvolvimento do país, forçado à depleção de grande parte da riqueza nacional produzida (cf. gráfico 13, cap. 2). Paralelamente, após 1985, o setor não petroleiro reduziu drasticamente sua participação nos níveis de remuneração dos trabalhadores e no volume de 
empregos oferecidos, o que tinha um particular efeito negativo, se se recorda que, em complemento, o setor petroleiro foi sempre de pouco poder de absorção de mão de obra. Os efeitos sociais da crise eram visíveis na queda contínua do nível de vida material da população.

No início da década de 1990, fatores circunstanciais externos (conflitos armados nas áreas petrolíferas do Oriente Médio) e a adoção de políticas de abertura comercial e financeira (ao final da década anterior) prometeram o começo da recuperação econômica para a Venezuela, e mais uma vez o petróleo teria papel central nessa nova fase, agora em um mercado mundial supostamente globalizado. Condizente com isso, a estatal petroleira - que, para alguns, tornarase "um Estado dentro do Estado" - empreendeu a política de internacionalização de suas estruturas - produtiva, fiscal e legal. Assim, contra uma exploração estatal "ineficiente", ganhou força um movimento subversivo entre os executivos da empresa nacional, desejosos de salvar a produção petroleira das mãos do país $^{407}$ - isto é, das mãos "populistamente" pródigas do Estado. A Abertura Petroleira dos anos 1990 reabilitou a crença nos efeitos benéficos da liberdade de comércio, e pôs em execução o plano de suprimir por inteiro o estatismo econômico. Não obstante, no quadro do regime político que controlava o país, a Abertura acabou por conduzir à ruína tanto o regime quanto a si própria: ao final da década, os preços internacionais voltaram a cair (em grande parte, por causa da própria Abertura, que permitira inundar o mercado mundial com volumes excessivos de petróleo venezuelano) e o cenário político interno sofreu uma alteração substancial de rumo, com a eleição de um novo presidente, crítico acerbo do regime anterior:

Quando o velho regime político aceitou essa estrutura [a Abertura], que pressupunha não somente que a empresa nacional se alinhasse com as companhias petroleiras estrangeiras contra o Estado, mas também que o próprio Estado concedesse a arbitragem internacional contra si mesmo e pusesse em dúvida a mais elementar manifestação de seu direito soberano - o de exercer os direitos sobre os recursos naturais e de regulamentá-los - não há dúvida de que o regime assinou seu próprio atestado de óbito. O petróleo como fonte rentística internacional e a posterior distribuição da receita petroleira haviam sido os dois elementos fundamentais do dito regime. Por outro lado, o novo regime político promovido a partir da PDVSA, baseado nos investimentos

407 Cf. MOMMER, Bernard. Subversive Oil. SDS-Website. Disponível em: http://www.isioma.net/sds00703.html. s/d. 
estrangeiros, pressupunha a globalização do recurso natural e a minimização da renda petroleira internacional. Em outras palavras, era um projeto essencialmente antinacional e, como tal, também estava destinado ao fracasso. Com o colapso dos preços internacionais do petróleo em 1998, o novo regime idealizado pela PDVSA não sobreviveu ao regime político antigo. As eleições gerais de dezembro de 1998 terminaram com a impetuosa vitória de Hugo Chávez e seu Movimento Quinta República. ${ }^{408}$

Acompanhando o declínio das receitas petroleiras, agravado pela internacionalização da indústria, as políticas oficiais de caráter redistributivo foram sendo paulatinamente abandonadas. Se já não tinham o mesmo efeito democratizante dos anos de bonança fiscal, agora, com as reformas neoliberais preconizando o corte de gastos públicos, elas eram claramente insuficientes para conter o agravamento do quadro de carência social. Assim, nesses anos, acentuaram-se entre as camadas sociais majoritárias as desigualdades e a exclusão, especialmente em relação aos serviços sociais básicos (educação, saúde e segurança). Entre os setores sociais dominantes, por sua vez, a ideologia neoliberal ia persuadindo a muitos sobre o caráter nocivo do estatismo, da "política na economia" e das práticas populistas contrárias às "leis de mercado". Essas circunstâncias conduziram ao rompimento progressivo do consenso das elites e da expectativa popular quanto às políticas de conciliação de classes. Os conflitos sociais que essa "conciliação" conseguira atenuar durante as décadas anteriores - conjugando os programas assistencialistas, a cooptação das classes trabalhadoras (principalmente através de sua representação sindical) e, em um plano oculto, a repressão violenta a grupos antagônicos radicais - já não eram mais contidos nos limites da negociação por meios pacíficos e institucionais. Adquiriam cada vez mais as formas de protestos populares, de manifestação crescentemente violenta e desatrelados dos partidos políticos tradicionais. ${ }^{409}$ Entre as elites, o consenso político perdeu força com a retirada de apoio a figuras históricas do puntofijismo - Andrés Pérez na $A D$, e Rafael Caldera no Copei. $O$ primeiro, cassado por corrupção; o segundo, disputando (e vencendo) a eleição presidencial de 1994 com o apoio de partidos de esquerda em ascensão. Estes,

\footnotetext{
${ }^{408}$ MOMMER, Bernard. Venezuela: El petróleo como fuente rentística internacional y soberanía. ALAI 480-48, noviembre-diciembre de 2012, año XXXVI, pp. 33.

${ }^{409}$ Cf. MAYA, Margarita López (coord.). Protesta y cultura en Venezuela: los marcos de acción colectiva en 1999. Buenos Aires: Clacso, 2002.
} 
aliás, cuja capital importância mereceria um estudo à parte de história política, foram pouco a pouco ocupando o espaço que os partidos hegemônicos perderam na representação popular. A reforma do Estado, de 1984, surtira pouco efeito em termos de combate à corrupção e de democratização das instituições, tragicamente evidente na reação do governo nos dias do Caracaço. ${ }^{410}$ As tentativas militares de depor Andrés Pérez em 1992 demonstravam que a insatisfação provinha também de setores das Forças Armadas, no interior das quais cresciam o movimento bolivariano e seu líder, Hugo Chávez. As contradições que se acumulavam entre os efeitos sociais das políticas desnacionalizantes e o imperativo que os partidos de esquerda convincentemente proclamavam de recuperar, em algum grau mínimo satisfatório, a independência econômica nacional levaram, enfim, à perda absoluta da crença popular na democracia venezuelana. Como bem observou E. Lander:

\begin{abstract}
As políticas de ajuste estrutural implantadas [deram] particular evidência a duas características inter-relacionadas que a democracia venezuelana compartilha com a dos outros países do continente, e que uma renda petroleira expansiva havia parcialmente ocultado e/ou atenuado. Em primeiro lugar, o caráter de elite - profundamente excludente e insensível às demandas da maioria da população - que esse regime político possui. Em segundo lugar, o caráter severamente estreito das margens de decisão autônoma do sistema político por condicionamentos econômicos e geopolíticos internacionais. Precisamente esses dois assuntos constituem o eixo em torno do qual se articula o conteúdo fundamental do discurso de Chávez: o popular e a autonomia nacional. Quiçá aí resida a explicação para o imenso apoio popular e para as fortes resistências que sua figura e seu governo geram em outros setores sociais. ${ }^{411}$
\end{abstract}

\footnotetext{
${ }^{410}$ Não obstante isso, observa Daniel Hellinger: "During the Lusinchi administration, the Presidential Commission on State Reform (COPRE) had made various proposals to decentralize state administration and democratize the internal workings of the parties. President Pérez accelerated some of these reforms after the Caracazo, implementing in 1989 the first direct elections of governors and mayors. The resulting decentralization of political and administrative power opened the way for new actors to emerge and enhanced the influence of personal factors in voting." (HELLINGER, Daniel. "Political Overview: The Breakdown of Puntofijismo and the Rise of Chavismo", in: ELLNER, Steve \& HELLINGER, Daniel (Ed.). Venezuelan Politics in the Chávez Era: Class, Polarization, and Conflict. London: Lynne Rienner Publishers, 2003, p. 33) Entre esses novos atores, merece destaque o partido $A$ Causa $R$, que experimentou grande ascensão nos anos de 1990. Aristóbulo Istúriz, candidato do partido, elegeu-se em 1992 para a prefeitura da cidade de Caracas. Nas eleições nacionais de 1993, o partido se converteu na terceira força política do país, superando o partido Movimento ao Socialismo (MAS). (Cf. MAYA, Margarita López. Luta hegemônica na Venezuela. A crise do puntofijismo e a ascensão de Hugo Chávez, especialmente capítulo 6.)

${ }_{411}$ LANDER, Edgardo. Izquierda y populismo: alternativas al neoliberalismo en Venezuela. Transnational Institute - Octubre 2004, p. 7.
} 
A influência crescente do pensamento e das práticas políticas neoliberais na vida venezuelana a partir de fins da década de 1980 não foi, a rigor, a causa do fracasso do desenvolvimento nacional, francamente reconhecível no fim da década seguinte. Certamente o precipitou, ao internacionalizar ainda mais os benefícios que a produção petroleira podia trazer à sociedade venezuelana. Mas foi a decisão política - reiterada sucessivamente ao longo de todo o período pelos governos de Punto Fijo - de renunciar à soberania econômica em prol de uma associação subordinada com as grandes empresas petroleiras internacionais atuantes no país a razão que condenou a sociedade a assistir o lento fracasso de seu desenvolvimento nacional. Com efeito, uma autêntica modernização, capaz de alicerçar solidamente o desenvolvimento de uma nação, ocorre apenas quando se some a um progresso técnico-científico de base nacional e autônoma a democratização social dos benefícios que o sistema produtivo assim impulsionado gera. ${ }^{412} \mathrm{Na}$ história venezuelana do século $\mathrm{XX}$, se é inegável que o petróleo significou um grandioso progresso das condições materiais de vida da sociedade, é também verdade que ele jamais pôde romper o quadro de dependência estrutural do país em relação às economias avançadas. O progresso histórico venezuelano graças ao petróleo continua sendo um progresso relativo, verdadeiro quando se compara uma época de atraso com outra, de atraso menor. Dito objetivamente, a economia petroleira sempre frustrou as esperanças de autonomia e autossuficiência da sociedade venezuelana - e no interior dela as esperanças dos setores burgueses nacionalistas. Contudo, a autonomia e a autossuficiência poderiam ter sido alcançadas em épocas econômicas favoráveis, se, por exemplo, a experiência da nacionalização dos anos 1970, e mesmo a da Abertura dos 90 (se possuísse o propósito efetivo de captar tecnologia e capitais internacionais para o aperfeiçoamento produtivo) fossem orientadas por um ideal de desenvolvimento nacional. Em última análise, pois, a crise final de Punto Fijo é produto do fracasso desse ideal. A polarização social que irrompeu nos anos seguintes ao Caracaço e que ainda não encontrou solução nos dias de hoje também possui raízes naquela decisão política e nesse fracasso. $O$ atual projeto histórico bolivariano, ainda em curso (e hoje também sob forte risco de malogro)

$\overline{412}$ Cf. FERNANDES, Florestan. Capitalismo dependente e classes sociais na América Latina. $4^{\underline{a}}$ ed. São Paulo: Global, 2000. 
possui a missão, conferida a princípio pelas massas populares e por setores sociais médios, de tornar real um novo ideal de desenvolvimento nacional, bem como de promover a integração dele ao conjunto do continente latino-americano. 


\section{Conclusão}

"Não se produz demasiada riqueza. Mas periodicamente se produz demasiada riqueza em suas formas capitalistas, antitéticas."

(Karl Marx, O Capital, Livro III, Cap. XV)

"Vendo a realidade presente, especialmente a realidade da América Latina, (...) não sou pessimista nem em relação às perspectivas de evolução do socialismo e, através dele, da ciência e da tecnologia, nem com referência ao futuro da América Latina. A transição difícil é muito mais contraditória e violenta, quando o que se desagrega é a forma assumida pela 'civilização ocidental moderna' sob uma organização tão complexa e poderosa quanto o capitalismo. De outro lado, o 'socialismo nascente' vem contaminado pelo capitalismo, não só porque tem de recorrer a recursos simétricos para combatê-lo, vencê-lo e destruí-lo, mas muito mais porque as fases iniciais de concentração de poder envolvem uma corrupção inevitável dos ideais democráticos do socialismo."

(Florestan Fernandes, Capitalismo dependente e classes sociais na América Latina, 1973)

Vimos, ao início, que a história não reservou à Venezuela das últimas décadas do século XX (ou de qualquer outra época) nada da excepcionalidade que Ihe quiseram atribuir alguns políticos e intelectuais; nada que a singularizasse no cenário regional ou mundial que fosse além da habitual especificidade histórica intrínseca a qualquer formação econômico-social quando considerada em dado espaço e momento históricos. Ao contrário, se bem analisada, sua trajetória desses anos se enquadrou perfeitamente nas grandes linhas principais da história da América Latina - definidas, por um lado, pelo processo já antigo de inserção dependente no mercado mundial, especialmente sob a hegemonia econômicomilitar norte-americana; e, por outro, pelo despontar sempre renovado das lutas sociais democráticas e anticolonialistas, em geral travadas em torno da contraposição entre a dependência (que se tem perpetuado desde os tempos da formação dos Estados nacionais) e a soberania econômica (que constitui necessariamente o alicerce da democracia social) - em um cenário dominado pela deplorável condição geral de subdesenvolvimento. No período aqui estudado, um dos traços mais salientes dessa trajetória foi, como procuramos demonstrar, a incapacidade de romper o círculo de ferro da exploração 
imperialista, de realizar em grau apreciável a integração econômica e social interna e regional, e de propiciar enfim níveis aceitáveis e duradouros de participação das classes populares na distribuição da riqueza nacional e na condução política democrática do país. Em que pese à sua "inspiração modernizadora", as experiências históricas da nacionalização do petróleo nos anos 70 e da Abertura petroleira nos 90 desaguaram, de igual maneira, na continuidade da dependência externa e no imobilismo de uma economia que persiste sendo essencialmente rentista e de desenvolvimento exógeno. Outrossim, os terríveis acontecimentos do Caracaço - que dilaceraram a sociedade e a fé popular na democracia oficial - seguidos da crise políticoinstitucional dos primeiros anos da década de 90 e a crescente miséria social que os acompanhou patentearam os outros aspectos críticos decorrentes daquela incapacidade. Segue-se daí a convicção de que a história da Venezuela, afim à de todo o continente, tem sido, desafortunadamente, a de produzir riquezas em meio à miséria, prosperidade em meio à revolta, e arremedos de democracia em meio ao mais cruento autoritarismo. Ineludível, pois, que suas antinomias estejam estruturalmente condicionadas pelas formas capitalistas antitéticas da produção material, sob as quais a sociedade venezuelana tem existido e que são tão mais acerbas nessas nações periféricas. Reconhecido isso, portanto, e considerandose a resultante do processo político-social venezuelano que, em 1998, precipitou o fim da democracia puntofijista - processo cujo móvel principal, reiteremos, foi e tem sido a reemergência e fortalecimento dos movimentos contestatórios populares $^{413}$, o desafio histórico atual de vencer a dependência e o subdesenvolvimento passa forçosamente pelo confronto com seus elementos antitéticos de caráter condicionante fundamental - ou seja, o capitalismo dependente.

Reatando-se o fio de algumas considerações apresentadas na Introdução, recordemos que uma valiosa contribuição da teoria do desenvolvimento desigual e combinado ao estudo da história das nações periféricas reside na demonstração de quão infundada é a crença - cara, no entanto, aos desenvolvimentistas e aos neoliberais - de que as diversas formas de influxos recíprocos entre as nações

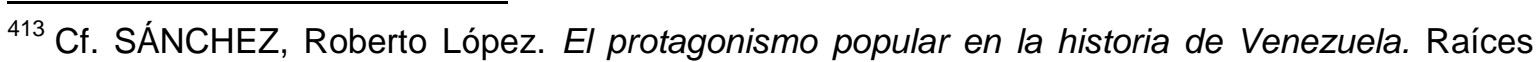
históricas del proceso de cambios. Disponível em: http://encontrarte.aporrea.org/media/56/ elprotaginismol.pdf. 
capitalistas avançadas e as nações atrasadas são aptas para, por si só, gradual e progressivamente, homogeneizar os níveis de desenvolvimento econômico e de equidade social de ambos os grupos de países. Já se insistiu suficientemente que não só a perspectiva desse nivelamento espontâneo é historicamente improvável (e nunca de facto constatado na América Latina, senão de forma muito pontual e inconstante), como também sua preconização pelas grandes instituições financeiras internacionais e pelos governos das potências imperialistas constitui um expediente ideológico mistificador de certa realidade hoje já insofismável: a de que, na atual divisão internacional do trabalho, as desigualdades de desenvolvimento entre os países vêm-se acentuando, acompanhadas na periferia pelo consequente agravamento da insuficiência das condições de vida materiais e socioculturais da imensa maioria de suas populações. Esse comprometimento danoso dos países atrasados com as economias centrais, inscrito em um cenário mundial de saturação dos mecanismos da acumulação capitalista, mas de permanência do grande poderio bélico das nações imperialistas, sempre à mão para uso imediato, não oferece alternativa democraticamente viável dentro dos limites do sistema produtivo do capital. A differentia specifica desse sistema, como apontou K. Marx ${ }^{414}$ - ou seja, a valorização e reprodução, incessantemente buscadas, do valor-capital através da apropriação de trabalho não pago como sua lei absoluta e incondicional - o torna incompatível com as necessidades materiais básicas e os valores morais fundamentais dos povos, sobretudo entre os que se configuraram historicamente como dependentes. Nesses povos, a dependência externa só é aproveitável para suas respectivas elites, com cuja conivência e aceitação a própria dependência se preserva. Cumpre insistir, pois, que, para as sociedades periféricas, não é de esperar outro quadro senão o agravar-se do estado de fraturamento social e de elitização do poder político, bem como, para suas economias, o fragmentar-se da região em áreas econômicas desarticuladas e mesmo antagônicas, estando umas ainda presas à rígida orientação primárioexportadora, e outras, menos débeis, empurradas para a forma regressiva de um novo padrão exportador de especialização produtiva. É, aliás, por tais razões que, no cenário venezuelano atual, em que a força dos movimentos populares tem impelido o país para uma atmosfera de revolução social, reacendeu-se a questão

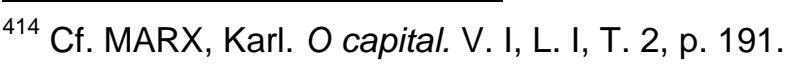


duplamente crucial da imperiosidade da integração latino-americana como meio de enfrentar esse desafio e do socialismo como sua via única. Afinal, à luz dos exemplos do passado, ambos - integração e socialismo - são, rigorosamente falando, os princípios-chave sem os quais é impensável que a oportunidade histórica progressista de hoje - a assim chamada Quinta República bolivariana de atingirem-se a soberania e a democracia possa ser efetivamente aproveitada. $^{415}$

Se se admite o momento atual como de relativo enfraquecimento do poderio hegemônico continental dos EUA (poderio deslocado, em parte, pela ampliação das relações da América Latina com outras regiões do planeta - como a China, hoje grande investidora e parceira comercial), a formação de uma consciência integracionista pelos governos progressistas da região representa, de qualquer perspectiva nacional democrática séria, um passo fundamental para um salto civilizatório e para uma nova configuração da economia mundial. Assim o julga Theotônio dos Santos: "[A] integração sul-americana [etapa primeira da integração latino-americana] é mais que uma questão econômica; a integração é um fenômeno de larga duração, expressão de um destino histórico. (...) Este é o momento em que as forças progressistas da região precisam unir-se para promover um novo estilo de desenvolvimento socioeconômico, ecologicamente sustentável e com um profundo sentido social e humano." ${ }^{416}$ Vistas em conjunto,

\footnotetext{
${ }^{415}$ No âmbito do movimento chavista, essa questão integração/socialismo vem sendo formulada sob a rubrica do Socialismo do século XXI, empunhado por Hugo Chávez a partir de 2005. Haiman El Troudi, hoje ministro do governo de Nicolás Maduro, estabeleceu a questão nos seguintes termos: "Socialismo del Siglo XXI como sistema: - En lo Político: El Poder popular: transferencia del poder al pueblo, autogobiernos populares, propiedad y recursos comunales, democracia socialista - En lo Territorial: La Geometría del poder: ecosocialista, endógeno, desconcentración, corresponsabilidad para el desarrollo local - En lo Internacional: El internacionalismo integrador: mundo pluripolar, complementación y unidad latinoamericana caribeña, ALBA y ALMA para Nuestra América - En la Autodeterminación: La defensa y soberanía nacional: guerra popular de resistencia, alianza cívico-militar con un carácter patriótico, popular y antiimperialista, ejército popular y defensa popular como garantías de la revolución del pueblo En lo Social: El Desarrollo Humano Integral: dignificación de la vida, satisfacción de necesidades materiales y culturales, plena inclusión social, humanización del trabajo, igualdad de las culturas En lo Económico: La Economía Socialista: régimen de propiedad mixta pero con condiciones, nuevas relaciones sociales de producción, combate a la concentración y centralización de la propiedad, preponderancia del interés colectivo sobre el individual - En lo Estratégico: La Planificación Democrática: centralizada y participativa ... Estado fuerte, pueblo empoderado". (TROUDI, Haiman El. Socialismo del Siglo XXI a la venezolana. Octubre 2007. Disponível em: www.haiman.com.ve)

416 SANTOS, Theotônio dos. "Integración: fenómeno de larga duración. In: Integración Suramericana: temas estratégicos. Revista América Latina en movimiento. ALAl, noviembredeciembre de 2012, año XXXVI, no $480-481$, pp. 12-15. Afirma esse estudioso que "(...) el gobierno
} 
as atuais iniciativas integracionistas de países como Brasil, Argentina, Venezuela, Bolívia e Equador - cujos instrumentos têm sido, junto a outros mais antigos, a criação da ALBA, CELAC, Petrocaribe, UNASUL (e Banco do Sul) - conquanto evidentemente ainda não possuam uma estratégia nem socialista nem anticapitalista, revelam-se como avanços na integração regional de importância tal que vêm constituindo, em associação com outras áreas econômicas (China, Irã, Rússia, África etc.), uma barreira aos interesses imperialistas sobretudo norteamericanos - barreira cuja solidez, todavia, ainda é incerta e que precisa consolidar-se atendendo às novas concepções de integração. No caso da América Latina - com economias em que as exportações de produtos primários minerais, petrolíferos e agropecuários têm imenso peso e cujas sociedades, por sua vez, permanecem fortemente cindidas - essas novas ideias de integração definem-se imprescindivelmente pelas disposições do que se tem denominado de gestão soberana dos recursos naturais, e que podem ser resumidas nas seguintes prescrições: ${ }^{417}$

* 1ํ) o aproveitamento do potencial de exploração e exportação de matérias primas deve ser combinado à adoção de políticas de industrialização nacional, especialmente nos setores que utilizem essas matérias primas, de modo tanto a ampliar o valor agregado das exportações primárias como de suprir eficientemente o mercado nacional e regional. Ademais, ampliam-se, por conseguinte, as oportunidades de autonomização econômica da região ao dirigirem-se investimentos (especialmente públicos) aos setores de infraestrutura

Lula da Silva consiguió concretar esta meta histórica con la creación de la Unión de Naciones Suramericanas (UNASUR), el apoyo al Banco del Sur y el asumir posiciones políticas siempre favorables a los intereses regionales. (...) Caminamos así hacia una política de Estado a favor de la integración regional así como fortalecemos nuestra [do Brasil] decisión histórica de ejercer un papel unificador de las dos orillas del Atlántico Sur." Haja ou não algum exagero nesse juízo, o certo é que, de fato, as mudanças no cenário político da região na última década e meia têm favorecido a intensificação das interações regionais, nas quais Brasil e Venezuela possuem papeis importantíssimos. É certo também tratar-se de valiosa oportunidade histórica para "(...) finalmente elaborar projetos de desenvolvimento econômico, tecnológico, financeiro, física e energética, de infraestrutura, de cadeias produtivas, de formas político-institucionais de integração, de meio ambiente, culturais, de integração social e laboral, educacional, de saúde publica, entre tantas outras esferas de integração". (SADER, Emir. A integração latino-americana na hora decisiva. ALAl, América Latina en Movimiento, 28/11/2013. Disponível em: http://alainet.org/active/69369.)

${ }^{417}$ Valemo-nos amplamente, neste assunto, das ponderadas proposições sobre a integração sulamericana desenvolvidas em BRUCKMANN, Mônica. Recursos naturales y la geopolítica de la integración sudamericana. Disponível em: http://www.reggen.org.br/reggen. Também, da mesma autora, em UNASUR: Una estrategia regional para la gestión soberana de los recursos naturales. ALAI - América Latina en movimiento. 12/11/2012. Disponível em: http://alainet.org/active/60230. 
de transporte e de comunicação entre as diversas áreas - em nível nacional e regional - de extração, produção, consumo e exportação, segundo o melhor aproveitamento das complementaridades econômicas dos diversos países.

* 2) No que toca a setores estratégicos da economia - fontes energéticas, recursos hídricos, produção alimentar, bem como tecnologia eletrônica avançada e biotecnologia - é preciso ampliar e desenvolver conjugadamente centros de pesquisa avançada que produzam conhecimentos técnico-científicos próprios às características e necessidades da região, e, por consequência, mitiguem a dependência tecnológica em relação aos países avançados. O progresso tecnológico autóctone é a pedra de toque da autonomização econômica e, se submetido ao controle dos interesses sociais fundamentais, representa o recurso mais rápido e promissor de superação da situação de embaraço das forças produtivas da região.

* 3) Considerando-se os graves conflitos sociais decorrentes da tradicional estrutura autoritária e privatista das atividades extrativas e agropecuárias em toda a América Latina ${ }^{418}$, é necessário que se submetam essas atividades a uma política oficial de proteção dos grupos e comunidades (especialmente camponeses e povos indígenas) cujo modo de vida e sustento dependem diretamente da conservação dessas áreas e reservas em que os recursos devam ser explorados. A expulsão desses grupos de seu habitat não só os priva dos meios de subsistência como agrava os problemas correlatos dos centros urbanos adjacentes, para os quais são eles forçados a se deslocar em condições geralmente precárias. O aspecto socioambiental da integração social interna, em cada país, impõe-se como um passo decisivo no processo de integração regional - aspecto sem o qual, aliás, perde irremediavelmente conteúdo e sentido o esperado salto civilizatório.

* 4) Todo o projeto de integração socioeconômica tem de regular-se pelo princípio básico da preservação ambiental, o qual, ao não impedir a exploração racional dos recursos naturais, o faz todavia por meio de mecanismos que incluam a compensação e a recuperação do impacto ambiental acumulado. A

\footnotetext{
418 "Según datos de la CEPAL, el 35\% de los conflictos en América Latina y el Caribe durante los últimos cinco años están relacionados a la minería de oro, $23 \%$ a la minería de cobre y $15 \%$ a la de plata." (BRUCKMANN, M. UNASUR: Una estrategia regional para la gestión soberana de los recursos naturales. ALAI - América Latina en movimiento.)
} 
consecução efetiva desse princípio em escala regional (e mundial) distingue uma exploração judiciosa da natureza daquela que se tem realizado em prejuízo irreparável das delicadas condições mesológicas, e que tem sido própria à irracionalidade da exploração capitalista. ${ }^{419}$

Mas, apesar da óbvia pertinência de tais preceitos para um programa factível de integração que vá mais longe do que uma mera associação comercial e aduaneira regional, as condições ainda imperantes de dependência estrutural nas economias latino-americanas propendem a refrear os projetos progressistas e sua declarada tenção integracionista, e, em sentido contrário a esta, mantêm ou agravam antigos desequilíbrios e divergências domésticas do continente. $O$ entrave no caminho presente da integração se deve a, ao menos, três motivos principais (que se podem combinar conforme as particularidades nacionais): ou porque os novos grupos políticos governantes, no anseio de preservarem-se no poder, esbarram no pragmatismo político que os obriga a alianças e concessões aos grupos conservadores, renunciando assim, em grande medida, à defesa das transformações mais radicais de conteúdo democrático-popular que Ihes serviram

\footnotetext{
${ }^{419}$ Importa ainda enfatizar, entre as questões fundamentais atinentes à gestão soberana dos recursos naturais, a observação acerca do problema da financeirização desses recursos. A partir de um estudo de Claude Serfati (La mundialización bajo la dominación de la finanza), aponta a mesma autora: "(...) Durante las últimas décadas, las materias primas y recursos alimenticios llamados commodities - se han convertido en un tipo de activos financieros. Este proceso de conversión está compuesto de tres elementos: 1. Los mercados de las commodities se convirtieron en una esfera de inversión para el sector financiero en búsqueda de lucros elevados después de la desaparición de la burbuja de internet, atraídos por la promesa de lucros elevados y rápidos así como por la diversificación de las carteras. Para las instituciones financieras no bancarias, las commodities cumplieron un rol similar al del sector inmobiliario para los bancos; 2. La integración de los mercados de commodities, como componente de los mercados financieros, facilitada por la creación de vehículos de inversión destinados a la especulación, como los llamados "mercados futuros". Éstos reforzaron el pasaje entre los mercados de commodities y los mercados bursátiles; 3. La fuerte atracción ejercida por los mercados de commodities sobre los inversores financieros estuvo estimulada por la desregulación de este sector. En relación a la gestión económica de los commodities, Serfati define tres categorías de actores económicos: los arbitrageurs y hedgers, directamente interesados en la adquisición o la venta de productos físicos; los especuladores "tradicionales" que toman, por lo general, una posición de riesgo que los arbitrageurs rechazan; y los "especuladores de índice" (fondos de pensión, fondos especulativos, compañías de seguros, bancos, etc.) que no tienen ningún interés por el producto físico, sino exclusivamente por los beneficios potenciales. Razón por la cual estos últimos adoptan, generalmente, posición de comprador y especulan sobre un alza en curso, alimentando de esta manera un alza permanente. La participación de estos "especuladores de índice" en el mercado de futuros no ha dejado de crecer: pasó de 7\% en 1998 a 40\% en 2008. Mientras que en el mismo periodo, los arbitrageurs pasaron de 79\% a 34\% [sic] y los "especuladores tradicionales" pasaron de $14 \%$ para $26 \%$. Es decir, $66 \%$ del mercado de futuros de commodities está en manos de especuladores tradicionales y financieros. El autor sostiene que la lógica especulativa que se impuso en el mercado de commodities fue responsable del aumento de los precios de los bienes de alimentos y de materias primas que se produjo entre 2005 y julio de 2008." (Idem)
} 
de impulso junto aos segmentos explorados e excluídos da sociedade - o que significa dizer que o progressismo, neste caso, dilui-se em simples veleidade política e desarticula a perspectiva supranacional da democracia; ou porque o planejamento estatal, especialmente nas economias de enclave, tende à acomodação ao modelo de rentismo econômico tradicional, conduzindo esses países à situação em que o processo de modernização e de progresso social, conquanto avance em algum grau, permanece enleado no ingresso fiscal (minerador/petroleiro) como a praticamente única fonte de recursos - o que explica as tendências a não alterar-se o caráter primário-exportador da produção, a não empreender-se a diversificação produtiva e a manter-se sujeitado o comércio às oscilações da demanda do mercado extrarregional ${ }^{420}$; ou porque em uma outra dimensão do problema - revigora-se ou reatualiza-se o fenômeno, descrito outrora como de cooperação antagônica, da expansão de formas de subimperialismo na região - trata-se especificamente do caso brasileiro ${ }^{421}$ _ através da internacionalização de empresas do país e da consequente exploração dos recursos naturais e humanos dos países vizinhos - o que, se não eclipsa absolutamente a hegemonia norte-americana, traz de novo à tona a antiga aspiração de dominação e expansão regional das classes dominantes brasileiras, tornando assim ingênua, como inexequível, a proposta de uma autêntica integração regional. ${ }^{422}$ (De fato, a "integração regional solidária" do discurso oficial

\footnotetext{
420 Segundo alguns estudiosos, as diferenças conjunturais no progresso socioeconômico de países como Venezuela e Bolívia - esta em pujante desenvolvimento, aquela lamentavelmente paralisada - devem-se ao grau diverso de resolução com que os governos de Maduro e Morales têm implementado as políticas de socialização do ingresso fiscal e vencido as ameaças dos grupos burgueses opositores nacionais e internacionais. Poucos estudiosos, no entanto, discutem o problema da continuidade - e mesmo ampliação - dessa base primário-exportadora e seu efeito desintegrador no processo de construção do socialismo em ambos os países. Curiosamente, ainda no caso venezuelano, faz parte dos planos de governo apresentados pelos partidos de oposição ao tempo das eleições a ampliação da produção petroleira como o recurso principal para o desenvolvimento do país! (Vejam-se os artigos NUÑEZ, Hermán L. Torres. Paralysed Venezuela vs Thriving Bolivia: Two Faces of Socialism. October 14th 2014. Disponível em http://venezuelanalysis.com/analysis/10961; e EMERSBERGER, Joel. Bolivia-Venezuela Comparisons Should be Very Helpful to Radical Chavistas. October 20th 2014. Disponível em: http://venezuelanalysis.com/analysis/10970.)

${ }^{421}$ Cf. LUCE, Mathias S. O subimperialismo brasileiro revisitado: a política de integração regional do governo Lula (2003-2007). Dissertação de mestrado. Universidade Federal do Rio Grande do Sul, 2007.

${ }^{422}$ Vale lembrar que essa cooperação antagônica da formação econômico-social subimperialista "(...) expressa a busca por uma autonomia relativa na política internacional e pelo controle de uma parcela da massa de valor, de modo a ser uma economia que não apenas transfere valor [para o centro imperialista], mas se apropria de valor." (LUCE, Mathias S. O subimperialismo, etapa superior do capitalismo dependente. Tensões mundiais, Fortaleza, v. 10, n. 18, 19, 2014, p. 60.
} 
brasileiro oculta, na realidade das relações internacionais, a contradição atual entre, de um lado, o apoio mais do apenas formal à ampliação da autonomia política conjunta latino-americana frente às potências centrais, e, de outro, a empenhada defesa oficial dos interesses particulares das empresas brasileiras na região, nem sempre em concerto com as necessidades dos países que as sediam. ${ }^{423}$ ) $A$ isso tudo acresce-se a força fragmentadora - ainda vigorosa, a despeito da derrota do plano de implantação da ALCA - com que os EUA (através, entre outros meios, de instituições como o BID, OEA, BM e FMI) mantêm sob sua influência as economias da região, especialmente o grupo de países nos quais, segundo se pode reconhecer, o progressismo não vingou ou o fez de modo mais débil: é o caso do bloco que se organizou recentemente na Aliança do Pacífico - México, Colômbia, Peru e Chile. Nesses países, todos signatários de Tratados de Livre Comércio com os EUA, os princípios do neoliberalismo ainda definem integração a partir do modelo tecnicista de promoção do comércio livre e da cooperação econômico-financeira, sem implicações políticas, sociais ou culturais, como referem documentos oficiais de fundação dessa aliança comercial. Em síntese, portanto, resta verdadeiro que os diversos graus de dependência do quadro latino-americano, hoje tão matizado ao nível dos regimes políticos, bem como o maior ou menor "nacionalismo" de suas lideranças políticas, engendram uma multiplicidade de padrões de integração regional que mostram-se, infelizmente, de difícil conciliação, e que, por conseguinte, parecem indicar a imensa dificuldade, ou mesmo a inviabilidade, do esforço integracionista nas condições históricas presentes do continente. ${ }^{424}$

(Grifo nosso). No plano militar, esse anseio (sub)imperialista brasileiro esteve, desde os anos 1970, na origem do programa de produção de energia nuclear através da importação de tecnologia alemã (Acordo Nuclear Brasil-Alemanha). Cf. ARNT, Ricardo (org.). O armamentismo e o Brasil. A guerra deles. São Paulo: Brasiliense, 1985.

${ }^{423}$ De fato, "(...) [e]ssas empresas, concentradas em setores como hidrocarbonetos, minérios, agropecuária e construção civil, operam com o horizonte capitalista da maximização dos lucros, sem levar em conta as necessidades do desenvolvimento econômico e social dos países onde se instalam. Isso implica possibilidade de conflitos entre os interesses dos investidores brasileiros e os de governos e/ou outros atores locais" (FUSER, Igor. O mito da "generosidade" no contencioso Brasil-Bolívia do gás natural. Revista Tensões mundiais, Fortaleza, v. 10, n. 18, 19, 2014, p. 232. Disponível em: www.tensoesmundiais.net/index. php/tm/article/viewFile/350/386.

${ }_{424}$ Cf. KARG, Juan Manuel. Alianza del Pacífico: ¿Integración o dependencia? ALAI, América Latina en Movimiento, 06/01/2014; e LARSEN, Federico. Proyectos y tensiones en la integración de América Latina. ALAI, América Latina en Movimiento, 07/10/2014. Segundo F. Larsen: "(...) Mientras gobiernos como Venezuela o Bolivia basan su desarrollo en la transición a nuevas formas de convivencia y producción en la sociedad - cristalizadas en sus respectivas reformas constitucionales - otorgando a la construcción desde las bases de poder popular real y concreto, 
Dadas todas as contrariedades, é da ordem dos fatos previsíveis o perigo que correm as iniciativas progressistas de desembocar em uma, por assim dizer, integração conservadora - ou seja, em uma rearticulação das relações regionais através da qual, sem alterar-se a essência da condição de economias periféricas sob a hegemonia do Norte, acabem por ser amplamente favorecidos apenas alguns setores empresariais nativos mais poderosos, e se faça desacompanhada da contrapartida necessária de uma distribuição menos excludente da riqueza produzida por essas sociedades. Ou, então, de desembocar em uma integração simplesmente natimorta, na qual, por exemplo, as economias regionais, estimuladas por aumentos da demanda de matérias primas indispensáveis às economias industrializadas - como ocorreu nesta última década - vejam reforçada a tendência de reprimarização produtiva e se deixem atrair, "em nome do bem coletivo", pelas ilusões do assim chamado neoextrativismo - do qual o modelo venezuelano é apenas uma variante. Essas ilusões (que, em um excelente artigo recente, M. Moncada resume em cinco falácias principais ${ }^{425}$ ) prometem aos incautos, hoje como no passado, que as receitas provenientes da produção extrativista irão permitir aos países superar seu estado crônico de pobreza e promover o crescimento econômico em moldes próximos aos das nações industrializadas; que, ao ampliarem-se as atividades extrativas, gerar-se-á um volume expressivo e sustentado de novos empregos; que os impactos ambientais decorrentes da ação extrativa em larga escala serão suscetíveis de reversão; que não há, presentemente, alternativas viáveis ao extrativismo nesses países, e seria tolice abrir mão dele em detrimento dos "interesses do bem coletivo" - isto é, das camadas pobres que os regimes progressistas pretendem representar. E que - suprema quimera - a perspectiva

otros como Brasil o Argentina continúan sosteniendo los mismos principios de acumulación capitalista buscando corregir ciertas desigualdades dadas por una desigual distribución de la renta. Son todas estas variables las que protagonizan la discusión política latinoamericana en los últimos años. (...) El neoliberalismo encarnado en los gobiernos de la Alianza del Pacifico, siguen sumando espacio a partir de la pronta incorporación de nuevos gobiernos centroamericanos, como Panamá y Costa Rica, una reedición fragmentada del ALCA que hoy intenta penetrar en Brasil de la mano del nuevo conservadurismo. Un escenario que, en el plano regional, podría demorar las ya débiles aspiraciones de un nuevo rumbo para el continente".

425 Cf. MONCADA. Martha. Las falacias del neoextractivismo. ALAI - América Latina en Movimiento, 13/07/2012. Disponível em: http://alainet.org/active/56494. As considerações feitas nesse artigo se referem diretamente ao caso do Equador atual, mas são amplamente válidas em seus aspectos mais importantes também para as outras economias extrativistas da região, que, igualmente, possuem regimes progressistas. 
de longo prazo será, seguramente, a superação do próprio extrativismo e a consecução de um estágio superior e autônomo de desenvolvimento econômico e social. A lógica dos fatos econômicos parece indicar a esses países dependentes que quanto mais próxima a reprimarização, mais distante a integração. Além disso, despida de ilusões, a realidade revela que, nas condições antitéticas do capitalismo dependente, a demasiada riqueza porventura produzida por esses meios extrativistas (ou similares) não só tem conduzido à gritante injustiça nos modos de sua socialização, como também tem justificado e dado rédeas soltas ao egoísmo de classe, com seus meios despóticos de defesa dos interesses privados contra o bem-estar da maioria e contra, inclusive, o próprio equilíbrio do meio natural em que se vive. Por isso, aduz-se com razão:

A obtenção de maiores receitas como sinônimo de riqueza outorga a esta última uma acepção unicamente crematística, ao não considerar que riqueza é também o patrimônio natural e cultural que possuímos, quase sempre sem valor econômico no mercado. Tal acepção "naturaliza" o processo de desenvolvimento adotado pelas economias industriais e desconhece que existem outras vias e formas de vida para nos relacionarmos com nosso entorno. Por outro lado, desconhece ou minimiza o fato de que os setores extrativos intensificam as pressões ambientais e aprofundam as iniquidades [sociais], pois as perspectivas de crescimento econômico são limitadas pela capacidade de sobrecarga do ecossistema. Esta perspectiva parcial - isto é, mais receitas como condição para superar as dificuldades atuais - ofusca, finalmente, uma análise mais rigorosa sobre o estilo de desenvolvimento e o alcance e conteúdo do "bem viver". ${ }^{426}$

As proclamações do socialismo em construção hoje na Venezuela - pelo menos ao nível formal das declarações - sublinham o anelo de superar essa concepção crematística da riqueza e de transformar a atividade petroleira do país em alavanca para um modelo produtivo socialista ${ }^{427}$, através do qual se alcance a suprema felicidade social mencionada por Simon Bolívar. Porém, e apesar dos

\footnotetext{
${ }^{426}$ MONCADA, Martha. Op. cit., 13/07/2012.

427 Cf. o documento oficial: REPÚBLICA BOLIVARIANA DE VENEZUELA. Líneas Generales del Plan de Desarrollo Económico y Social de la Nación 2007-2013. Caracas: setiembre de 2007. Disponível em http://www.cenditel.gob.ve/node/343. Veja-se, especialmente, o papel que é conferido ao petróleo no futuro da Venezuela, na parte VI. Venezuela: Potencia Energética Mundial: "Debido al creciente aumento de la demanda de energía fósil en el mundo y a la magnitud de las reservas de esas materias primas que posee, el petróleo continuará teniendo una influencia significativa en el futuro de Venezuela. El petróleo será decisivo más allá del horizonte del programa para la captación de recursos del exterior, la generación de inversiones productivas internas, la satisfacción de las propias necesidades de energía y para el apoyo al surgimiento y consolidación del nuevo modelo productivo. " (p. 39)
} 
avanços reais que a Revolução Bolivariana tem logrado no plano social ${ }^{428} \mathrm{e}$ político (como a organização e fortalecimento dos conselhos comunais e o ativismo das camadas populares presente em momentos de crise institucional) avanços esses que potencialmente criam as condições necessárias ao erigir de uma sociedade socialista - a análise do comportamento da economia venezuelana ao longo dos últimos quinze anos, comparado ao das décadas anteriores aqui estudadas, vem reforçando a tese da persistência do modelo de Estado rentista, agora sob a rubrica socialista. Esse rentismo "perpetuado" confronta-se hoje com os mesmos velhos problemas para os quais tantas vezes se alertou no passado; ou seja, a crescente dependência em relação às receitas das exportações de petróleo, o aumento compulsivo do volume de exportação do produto para tentar sanar desequilíbrios de balanço, e a vulnerabilidade do planejamento econômico oficial diante das graves oscilações da demanda mundial. ${ }^{429}$ É forçoso, porém, reconhecer que esse punctum saliens da história venezuelana (caudal instável de rendas versus desenvolvimento autônomo efetivo) traz em si, hoje, o ganho da reorientação democrática da distribuição das receitas petroleiras - especialmente por meio dos programas sociais básicos (las

\footnotetext{
${ }^{428} \mathrm{Um}$ dado isolado mas expressivo desse avanço, no plano social, está representado no gráfico
} seguinte:

\section{Gráfico 17: Taxa de crescimento interanual do IDH 1980-2013 - Venezuela}

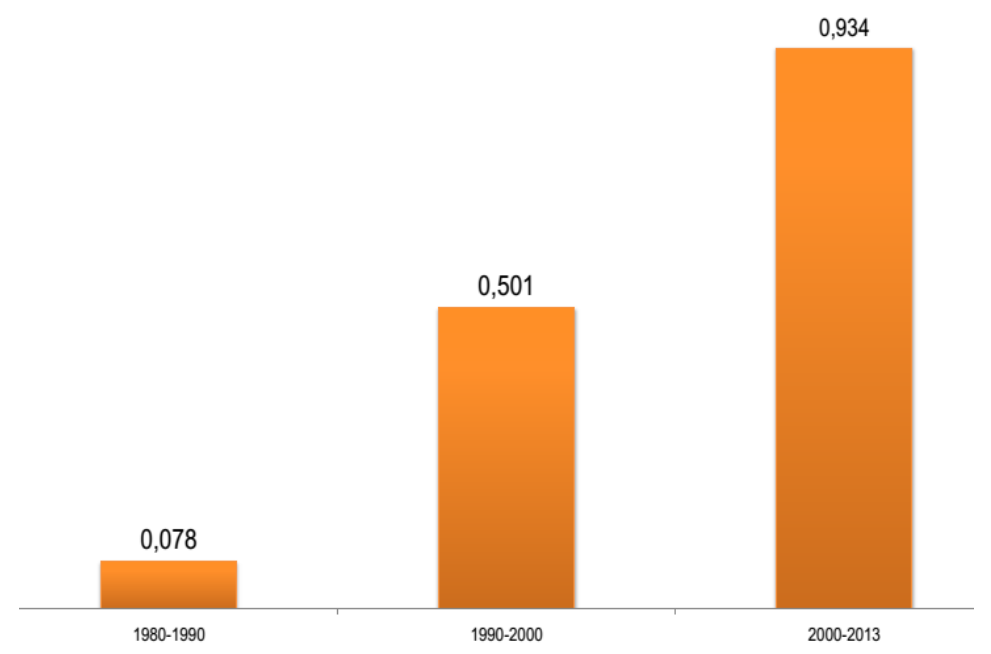

Fonte: PNUD - Informe sobre Desarrollo Humano. Apud: Índice de Desarrollo Humano en Venezuela, 1980-2013 (INE)

429 A esses problemas alguns estudiosos apontam um adicional, de natureza conjuntural recorrente: o da sobrevalorização do câmbio venezuelano, que se faz acompanhar de altos índices de inflação e de desestímulo contínuo à produção industrial nacional. Certamente, a sobrevalorização do bolívar torna mais fácil a importação de produtos industrializados, engendrando uma concorrência na qual os artigos nacionais, quando existem, têm pouca chance de vencer. Como vimos, Celso Furtado já apontara o mesmo problema em meados dos anos 70. 
Misiones, que promoveram melhorias substanciais nos indicadores sociais dos últimos anos); mas, isso mesmo que dá forças ao processo de mudanças põe em risco o próprio ganho e as próprias melhorias:

O socialismo rentista venezuelano até o presente compartilha traços essenciais do modelo capitalista rentista que o precedeu. (...) Os abundantes petrodólares, hoje tal como ontem, têm propiciado inúmeros programas e projetos, que, contudo, logo se interrompem ou não se realizam em coordenação com outros programas, cujos objetivos poderiam ser distintos ou mesmo contraditórios. A importação massiva de veículos automotores, por exemplo, satisfaz o apetite tributário do SENIAT, instituição encarregada de recolher os impostos na Venezuela, mas debilita a capacidade de sustentar e desenvolver uma sólida indústria automotora. Por outro lado, a possibilidade de estabelecer e consolidar um modelo econômico pós-capitalista passa não só pela capacidade regulatória e financeira do Estado. Faz falta também a participação ativa de outros fatores produtivos: pequenos e médios empresários, profissionais e técnicos, camponeses e trabalhadores, aos quais o governo, em muitas ocasiões, tem fechado os espaços de ação. Do mesmo modo, têm sido frágeis os esforços realizados até agora para alcançar modificações importantes nos valores dos venezuelanos: uma sociedade rentista, com uma forte cultura política paternalista e clientelar, necessita de práticas habituais distintas se pretende interiorizar valores como a solidariedade e o respeito à natureza. Os processos sociais participativos que pressupõem a aquisição de novos valores e sejam capazes de superar o consumismo típico de toda sociedade rentista requerem algum tempo para o seu amadurecimento. ${ }^{430}$

Em termos objetivos, a Revolução Bolivariana enfrenta hoje os percalços da transição difícil ao socialismo, na qual os avanços e os recuos guardam correspondência tanto com as estratégias da luta socialista quanto com as contaminações pelo capitalismo e a corrupção dos ideais democráticos. ${ }^{431}$ Saber

\footnotetext{
${ }^{430}$ MAYA, M. López \& LANDER, Luis E. El socialismo rentista de Venezuela ante la caída de los precios petroleros internacionales. Cuadernos del CENDES, vol. 26, núm. 71, mayo-agosto 2009, p. 21-22. Disponível em: http:// www.redalyc.org/articulo.oa?id=40311835004 (Negrito nosso); Veja-se também: LANDER, Edgardo. Venezuela: terminal crisis of the rentier petro-state model? Disponível em: http://internationalviewpoint.org/spip.php?article3679. Outubro de 2014.

${ }_{431} \mathrm{Um}$ exemplo categórico dessas contaminações, no caso em questão, é apontado por Manuel Sutherland, em um artigo no qual demonstra, com dados para até 2011, como a burguesia venezuelana é ainda senhora de $71 \%$ do PIB do país, em contraste com o discurso estatizante socialista da cúpula do PSUV. Daí sua advertência: "(...) La crítica revolucionaria es el camino de la inmensa base honesta del PSUV y de los trabajadores estatales que trabajan con denuedo y se esfuerzan por mejorar la situación del país. El chavismo honesto debe confrontar a las direcciones reformistas y alzar la voz contra los atropellos preñados de peculado. La única forma de que las cosas avancen y sean realmente revolucionarias, es que haya una profunda revisión crítica de lo que sucede y a partir de allí plantear un cambio drástico en la situación actual. Para grandes problemas, grandes soluciones. Debatir, criticar, organizar y actuar en pro de solucionar los desmanes propios del capitalismo es la labor principal a impulsar". (SUTHERLAND, Manuel. La economía venezolana o cómo la burguesía hurta la renta petrolera y es dueña del $71 \%$
} 
concretizar umas e resguardar-se das outras compõem a ingente tarefa das classes trabalhadoras e populares e daqueles que pretendem formar sua liderança revolucionária. Nesse sentido, a primeira implicação importante do processo bolivariano é o das fases da transição. V. Lênin chamou de doença infantil de esquerdismo o anseio por saltar imediatamente da situação de atraso e apatia das massas populares sob o Estado burguês para uma situação com um Estado plenamente democrático, socialista e popular. ${ }^{432}$ Contra essa perniciosa ilusão, é preciso que se criem espaços políticos efetivos nos quais as classes trabalhadoras e as maiorias populares participem diretamente das estruturas de poder, e ao mesmo tempo, desenvolvam uma consciência política que lhes permita conduzir por si mesmas, a partir de certo ponto, o processo de transição socialista. Portanto, cabe à vanguarda política chavista aproveitar a experiência das massas populares e promover o engajamento e a conscientização política delas. Cabe-lhe também reconhecer que ela, vanguarda, não pode triunfar sozinha, e que o Estado de transição deve, ao fim, submeter-se às decisões da vontade popular. Para o exercício eficiente dessa vontade, porém, urge indefectivelmente a tarefa - mais do que todas fundamental para o propósito de emancipação - de associar a conscientização das classes sociais aos princípios e conquistas da ciência (em suas diversas disciplinas), como remédio para a irracionalidade (sob suas inúmeras formas, como a irracionalidade econômica), para o dogmatismo doutrinário (que sacraliza os "fins socialistas" e com eles justifica toda arbitrariedade da liderança revolucionária) e para o sempre renitente mal do culto à personalidade (não ausente na Venezuela bolivariana). Esta é sua máxima obrigação, se se deseja uma vanguarda revolucionária de fato. Há certamente hoje, na Venezuela, uma democracia possível, que a Revolução Bolivariana possui meios de transformar em democracia plena, e sem a qual crescerá o perigo de permitir-se a reação dos grupos de oposição ligados às grandes corporações nacionais e estrangeiras. Esses grupos não se pouparão ao

del PIB. 09/09/2011. Disponível em: http://www.argenpress.info.) Veja-se também o artigo de R. Galíndez, em que se apontam as debilidades da tese do desenvolvimento e socialismo com empresários e petróleo, cujos efeitos têm ameaçado o futuro da Revolução Bolivariana e sua meta de autonomia econômico-social. Cf. GALÍNDEZ, Ricardo. Dos grandes tesis económicas se debaten en el seno del campo revolucionario bolivariano. 25/08/2008. Disponível em: http://www.aporrea.org/actualidad/a62259.html.

${ }_{432}$ LENINE, V. I. Esquerdismo: doença infantil do comunismo. Primeira edição: como panfleto, Junho 1920. Disponível em: http://www.marxists.org/archive/lenin/index.htm 
esforço de tentar conter pela violência o processo de mudanças, sobretudo porque estão animados pelo respaldo com que contam, velada ou abertamente, do governo norte-americano. ${ }^{433} \mathrm{O}$ assunto tem merecido a atenção de investigadores nacionais e internacionais idôneos, e espera-se que as denúncias de golpismo e ingerência externa surtam o efeito de provocar o repúdio internacional. A segunda implicação importante diz respeito ao tempo da transição - ou seja, a do radicalismo maior ou menor - súbito ou gradual - das transformações impostas aos pilares que sustentam a economia capitalista dependente. Três, ao menos, são os pontos mais sensíveis: a propriedade da terra, a da indústria e serviços, e do capital bancário. A comparação aqui com o processo revolucionário cubano dos anos 60 é inevitável: em dez anos de revolução, a nacionalização das terras, em Cuba, já atingia mais de 70\% delas (e se completaria nos anos seguintes). Nesse mesmo lapso de tempo, 100\% da indústria, do comércio de atacado e varejo, do transporte, da educação e do sistema bancário estavam já nacionalizados. Esse ritmo rápido, por assim dizer, da Revolução Cubana foi, sem dúvida, o que garantiu à liderança revolucionária o apoio das massas de operários e camponeses - apoio que, combinado à inserção da produção cubana no então mercado socialista, permitiu enfrentar com bom êxito o cerco imperialista norte-americano. Na Venezuela, a reforma agrária nos anos de Hugo Chávez transferiu mais de 7 milhões de hectares para próximo de 200 mil famílias. Isso correspondeu a menos de 10\% das terras cultiváveis do país, e muito distante do necessário para garantir a autossuficiência alimentar nacional. Em consequência disso, a maior parcela da produção de alimentos continua em mãos de empresas privadas nacionais e estrangeiras, e o governo é ainda obrigado a importar algo em torno de $60 \%$ a $70 \%$ de alimentos. A rede MERCAL, o mecanismo de distribuição alimentar do Estado, atinge, segundo alguns estudos, apenas 30\% da demanda popular. Quanto à indústria, a transição para o socialismo choca-se com obstáculos estruturais. Embora, por exemplo, o governo, tenha nacionalizado, em 2012, 1168 empresas e o Estado detenha o controle majoritário ou de parcela significativa dos setores de petróleo, energia

\footnotetext{
${ }^{433}$ É sabido que grupos de oposição (venezuelanos e estrangeiros) recebem ajuda financeira do governo norte-americano através de doações feitas pela USAID. Do mesmo modo, líderes da oposição, como María Corina, Leopoldo López e Henrique Capriles, vêm promovendo abertamente as tentativas violentas de deposição do governo chavista ("la salida" de Nicolás Maduro), com apoio dos EUA.
} 
elétrica, cimento, siderurgia, a produção industrial (afora o petróleo) continua concentrada em poucos grandes grupos privados: 571 empresas corresponderam a $80 \%$ da produção nacional em 2007, com uma baixa parcela da produção nacional de bens de capital. Assim, a economia venezuelana parece ir tornandose mais e mais dependente do capital privado, cuja fração no total do PIB aumentou em relação ao setor público. Apesar disso, outros dados demonstram que, entre 1999 e 2010, 62\% das receitas públicas foram dirigidas para gastos com serviços sociais, sobretudo educação, saúde e alimentação. A pobreza social caiu de mais de 60\% em 2003 para 25,4\% em 2012, e a distribuição social de renda, entre 1998 e 2011 , dos $20 \%$ mais ricos desceu de $53 \%$ do total nacional para $44,8 \%$, enquanto a dos $60 \%$ mais pobres subiu de $25,6 \%$ para $32,3 \%$. Muitos outros números, como esses, apontariam tanto os progressos como as deficiências no processo bolivariano de construção do socialismo, de modo que seus defensores podem citar fartamente os primeiros, enquanto os opositores 0 fazem sobejamente com as segundas. ${ }^{434}$

Sem embargo disso, para todo aquele que se dispuser a uma atitude ao mesmo tempo racional, objetiva e comprometida com o processo venezuelano, talvez a melhor conclusão a apresentar-se seja esta, inspirada em A. Gramsci ${ }^{435}$ : que o pessimismo da consciência crítica obriga a advertir os riscos de estagnação ou retrocesso da transição atual, cujos aspectos progressistas, aliás, alguns céticos rotulam hoje com a denominação algo irônica de populismo socialista; $\underline{0}$ otimismo da vontade transformadora, por sua vez, nos lembra que, para as nações dependentes, como as latino-americanas, os primeiros passos no processo de descolonização equivalem justamente a essas formas incipientes, mas concretas, de socialização da riqueza e de autonomização no emprego dos meios materiais de sua produção. Não há dúvida de que contra elas os grupos sociais outrora privilegiados oporão a mais tenaz resistência, procurando obstar a

\footnotetext{
${ }^{434}$ Cf. REPÚBLICA BOLIVARIANA DE VENEZUELA. INSTITUTO NACIONAL DE ESTADÍSTICA. Resumen de indicadores socioeconómicos. BOLETINES ELECTRÓNICOS. Disponível em: http://www.ine.gov.ve; CARLSON, Chris. What the Statistics Tell Us about Venezuela in the Chavez Era. Nov 30th 2012. Disponível em: Venezuelanalysis.com. WEISBROT, Mark y RAY, Rebecca. Evolución reciente de la economía venezolana. Center for Economic and Policy Research, Septiembre de 2010. Disponível em: www.cepr.net.

${ }^{435}$ Cf. a carta 139, de 19 de dezembro de 1929, in: GRAMSCI, Antonio. Lettere dal carcere. Nuova ed. riveduta e integrata sugli autografi, con centodiciannove lettere inedite. Torino: Einaudi, 1965, 1a.edizione elettronica del 17 marzo 2008. Disponível em: http://www.e-text.it, p. 180.
} 
qualquer preço o caminho ao socialismo. ${ }^{436} \mathrm{E}$ o farão tão mais renhidamente quanto mais próximo estiver seu colapso como classe proprietária e expropriadora - mesmo sendo sabedora de que é nesse terreno da propriedade privada e da exploração do trabalho o lugar onde vicejam as causas da alienação social. Daí ser conveniente lembrar, em razão dos riscos do "socialismo nascente" venezuelano, que, ao lado da superação da dependência externa, a descolonização também deve significar a superação das diversas formas de alienação que persistem durante a fase de transição socialista, e de cuja eliminação dependem as conquistas autenticamente socialistas, próprias de um estádio evolutivo ainda inexistente, mas tão factível quanto necessário. Essas diversas formas persistentes de alienação encontram-se 1) nas relações sociais, pelas quais os produtores diretos continuam a se ver privados do produto de seu trabalho e obrigados a vender sua força de trabalho em condições extorsivas; 2) na vida política, provocada pela contingente ausência de democracia sob o Estado de transição; e 3) na própria realização individual dos sujeitos sociais, mutilada pela sobrevivência da divisão do trabalho em que sobretudo se opõem trabalho manual e trabalho intelectual. ${ }^{437}$ Visto que, nas sociedades em transição

\footnotetext{
${ }^{436}$ Afirmava Roberto López Sánchez, historiador da Universidade de Zúlia, em um texto escrito antes da morte do presidente Hugo Chávez, sobre o processo bolivariano: "(...) A mediano plazo, la perspectiva del movimiento popular y del propio Chávez sigue siendo favorable. Aún con la eventual salida de Chávez del poder, ya sea electoralmente o con un golpe de estado, la burguesía no tiene condiciones favorables para crear un consenso social que facilite la gobernabilidad. Todo lo contrario. Un gobierno de la derecha significaría con toda seguridad el exacerbamiento de todas las contradicciones y luchas sociales, incluso dentro de las fuerzas armadas y los cuerpos policiales. La única manera de detener este proceso es con un genocidio como el cometido en los países del cono sur, pero (...) la burguesía no tiene capacidad actualmente, en términos históricos, para ejecutar algo así. Chávez podría regresar nuevamente al poder en cualquier escenario político futuro. De eso no debe haber dudas. La certeza que tenemos es que cada día se generan y profundizan las condiciones para que en Venezuela ocurra una verdadera revolución social. Ese proceso implicaría la derrota definitiva de la burguesía criolla que por 170 años mantuvo al país como furgón de cola del imperialismo de turno, y la apertura a un verdadero poder popular, a una sociedad de democracia participativa y protagónica, que surgiría ante el mundo como la alternativa ante la incapacidad del modelo liberal parlamentario y del neoliberalismo económico para resolver las grandes necesidades de los pueblos. Implicaría también, y como condición necesaria, el desplazamiento de toda la burocracia que hasta ahora se plegó a Chávez en forma oportunista, sin compartir en absoluto los fundamentos nacionalistas y populares de los cambios que el presidente ha propuesto, y que ha venido siendo una traba tanto para el cumplimiento de los planes socioeconómicos gubernamentales como para la participación popular efectiva en la conducción de dichos planes". (SÁNCHEZ, R. López. El protagonismo popular en la historia de Venezuela. Segunda parte, p. 17.)

${ }^{437} \mathrm{Cf}$. a fecunda reflexão sobre o processo de desalienação sob o socialismo em transição em MANDEL, E. A formação do pensamento econômico de Karl Marx. Rio de Janeiro: Zahar Editores, 1968 (Cap. 11: Desalienação progressiva pela construção da sociedade socialista, ou então, Alienação inevitável na "sociedade industrial"?, pp. 188-211). Tratando dos países de socialismo realmente existente (considerados como em transição) indagava esse cientista: "(...) É manifesto
} 
ao socialismo, os motivos fundamentais da alienação continuam a residir na permanência do caráter mercantil da produção, da distribuição e da organização do trabalho - ainda, a rigor, submetidas às "leis de mercado" e à valorização do capital - a chave do processo de desalienação está tanto em enfraquecer rápida e progressivamente essa orientação mercantil da economia, substituindo-a pela planificação socialista ${ }^{438}$, como em impedir a burocratização das esferas estatais, tornando-as tão dependentes quanto possível do controle popular. Na Venezuela, o fortalecimento dos conselhos comunais, o aprimoramento do controle operário das fábricas e o recurso aos vários tipos de referendos (consultivo, revogatório, aprobatório e ob-rogatório, presentes na Constituição Bolivariana ${ }^{439}$ ) são realizações iniciais, mas palpáveis, para efetivar esse controle popular sobre as instâncias governamentais. (Ademais, a premissa a não ser esquecida é a seguinte: "(...) Não sendo o Estado mais do que uma instituição transitória, da qual alguém se serve na luta, na revolução, para submeter violentamente seus adversários, então é puro absurdo falar de um Estado popular livre: enquanto o proletariado ainda faz uso do Estado, ele o usa não no interesse da liberdade, mas para submeter seus adversários e, a partir do momento em que se pode falar em liberdade, o Estado deixa de existir como tal." ${ }^{440}$ )

que as necessidades de consumo dos trabalhadores não estão aí inteiramente satisfeitas; isso não implica uma alienação do trabalhador em relação aos produtos de seu trabalho, sobretudo quando esses produtos são bens que ele deseja adquirir e que o desenvolvimento insuficiente das forças produtivas (sem falar das deformações burocráticas do sistema de distribuição!) o impede de se apropriar deles? É manifesto também que a divisão do trabalho (cujos prejuízos são reforçados pela organização burocrática) aliena frequentemente o trabalhador e o cidadão da atividade produtiva. O número de candidatos aos estudos universitários que não são admitidos na Universidade e que são pois obrigados a prosseguir uma atividade com a finalidade única de subsistência são outros tantos testemunhos dessa alienação". Cap. 11, pp. 190-191.)

${ }_{438}$ O célebre trecho da Crítica do Programa de Gotha, no qual K. Marx sintetizou tanto o vigor utópico como o sentido histórico do socialismo, continua a servir inescusavelmente de horizonte programático para os projetos que pretendam, efetivamente, superar as formas de alienação humana: "Numa fase superior da sociedade comunista, quando tiver sido eliminada a subordinação escravizadora dos indivíduos à divisão do trabalho e, com ela, a oposição entre trabalho intelectual e manual; quando o trabalho tiver deixado de ser mero meio de vida e tiver se tornado a primeira necessidade vital; quando, juntamente com o desenvolvimento multifacetado dos indivíduos, suas forças produtivas também tiverem crescido e todas as fontes da riqueza coletiva jorrarem em abundância, apenas então o estreito horizonte jurídico burguês poderá ser plenamente superado e a sociedade poderá escrever em sua bandeira: "De cada um segundo suas capacidades, a cada um segundo suas necessidades!". (MARX, Karl. Crítica do Programa de Gotha. São Paulo: Boitempo, 2012, p. 33)

${ }^{439}$ Cf. o artigo Expertos debatieron en ÚN logros y retos de la Constitución. Abogados y ex constituyentes expusieron sus puntos de vista a 15 años de la aprobación de la Carta Magna. (Últimas Notícias). Disponível em: http://www.elmundo.com.ve/noticias/actualidad/noticias/ expertos-debatieron-en-un-logros-y-retos-de-la-con.aspxsobre referendos

${ }^{440}$ ENGELS, F. "Carta a August Bebel". In: MARX, Karl. Crítica do Programa de Gotha, p. 55. 
Por fim, há que se referir ainda a uma última questão (que aqui apenas citaremos, mas à qual não se deve conceder importância menor), ou seja, a da necessidade de se superar, tão breve quanto possível, o próprio paradigma energético mundial (o de hidrocarbonetos), para cuja existência - é preciso não esquecer - tem contribuído diretamente o sistema de produção venezuelano. Isso implica dizer: uma sociedade racionalmente organizada, que seja capaz uma vez de abolir os mecanismos de exploração de classes, deverá ser também capaz de reorganizar sua produção material dentro dos limites de preservação das condições naturais à vida no planeta. As informações científicas hoje disponíveis alertam, com evidências empíricas e dados estatísticos, para os efeitos terrivelmente deletérios de um modelo produtivo baseado nos combustíveis fósseis, os quais, ademais de estarem geograficamente "mal distribuídos" (o que acirra os conflitos armados imperialistas pelo controle das reservas mundiais das regiões periféricas), são os principais responsáveis pelo grave desequilíbrio do efeito estufa, causa principal do fenômeno do aquecimento global, e que está relacionado às emissões excessivas de gases na atmosfera (especialmente dióxido de carbono) provenientes de atividades industriais e urbanas. ${ }^{441}$ Ora, possuidora das maiores jazidas petrolíferas do mundo e, além disso, tendo em

\footnotetext{
${ }^{441}$ Segundo cientistas, a concentração de dióxido de carbono na atmosfera atingiu em maio de 2013 o nível de 400 ppm (partes por milhão), "(...) uma concentração que, estima-se, a Terra não vê há 3 milhões de anos. Os pesquisadores apontavam este limiar como o pico máximo antes que os efeitos do aquecimento global se tornassem perigosos". (Aquecimento global: ultrapassado limiar crítico de carbono. Reportagem de Rafael Ferreira, 18/05/2013. Disponível em: www.oeco.org.br/biblioteca/27193-aquecimento-global-ultrapassado-limiar-critico-de-carbono)
}

Gráfico 18: Concentração de dióxido de carbono na atmosfera, medida no

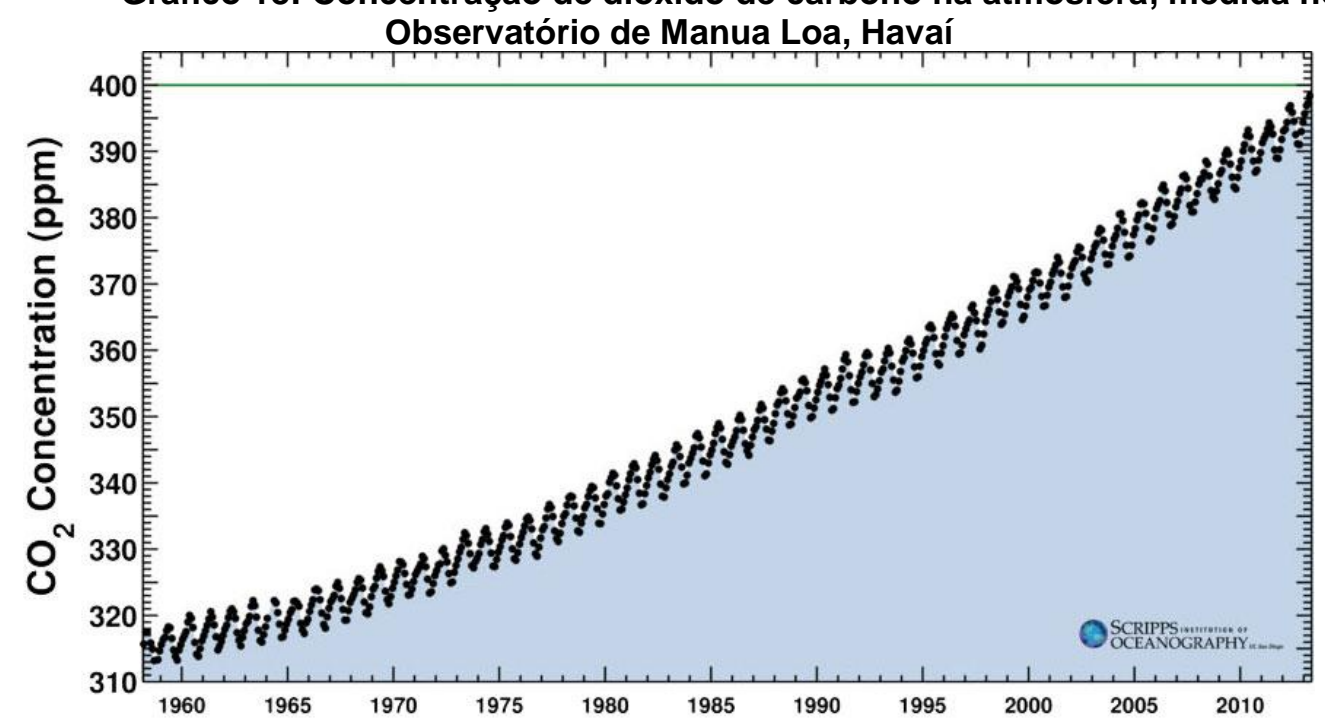

Fonte: Scripps Institute of Oceanography/Divulgação. 
seu território áreas amplíssimas que abrigam grande parte da biodiversidade do planeta, a Venezuela tem papel destacado no trato e solução mundial da questão ambiental. Esse desafio hoje lançado à Revolução Bolivariana (como a todas que se lhe seguirem neste novo século) envolve mais do que "distribuir riqueza ao povo"; envolve engendrar uma nova concepção de existência e realização humana, na qual a coexistência multiétnica e cultural - pacífica e tolerante - se some a formulações e regras da produção da vida material que atendam às reais necessidades humanas ao mesmo tempo que respeitem o frágil equilíbrio biosférico. ${ }^{442}$ (Certamente haverá os que alegarão, com certa indulgência altiva, que tais proposições habitam apenas o mundo da utopia. Pode-se replicar, contudo, que fora dessa "utopia" pouca ou nenhuma discussão tem efetivamente valor - nem ético nem científico.) O problema econômico da Venezuela, como de toda a América Latina, não é simplesmente aumentar o nível de desenvolvimento de suas forças sociais de produção, mas eliminar a incompatibilidade entre esse nível e o seu emprego nas condições de injustiça social e de degradação ecológica, que negam as verdades científicas e os valores morais tão arduamente construídos por nossa evolução cultural. O capitalismo, central ou periférico, alimenta com desfaçatez essa incompatibilidade. Por isso é preciso insistir ainda uma vez na necessidade de se recuperar hoje, em sua plenitude, um pensamento crítico que concilie a reflexão ético-filosófica de conteúdo humanista, a investigação científica rigorosa e a ação política radical, reunindo-as todas em um conjunto harmônico capaz de identificar-se efetivamente com os interesses e os anseios vitais das maiorias populares em geral, e das classes trabalhadoras em particular. Já afirmamos atrás, também, que o pensamento materialista-dialético de matriz marxista é dotado das ferramentas teóricas e práticas para a construção do socialismo neste século XXI. Afinal, o que está em jogo é a própria vida social

\footnotetext{
${ }^{442 "}$ Como nota ponderadamente E. Lander: "(...) Nobody is suggesting that the shift to a post-oil society means that all the oil wells can be shut down from one day to the next. Nevertheless, there is an urgent need to take steps and define the route for this essential transition. This imperative is absent from the public policies of practically every government in the world. Instead, they continue to give priority to economic growth over and above what is required to preserve life. Similarly, Venezuelan government's policies fail to contemplate the need for this transition; on the contrary, they are taking the country's long-term future in the opposite direction". (LANDER, Edgardo. Venezuela: terminal crisis of the rentier petro-state model?, p. 15.) Importa acrescentar que, ao deixar de ser uma questão marginal para tornar-se central nas discussões sobre a construção do socialismo no século XXI, a preocupação com a preservação ambiental não deve obliterar aquela que, durante os anos 70 e 80, pairou como o grande espectro da humanidade - a questão nuclear - que hoje continua longe de haver sido solucionada com segurança.
} 
e biológica do planeta: a própria habitabilidade humana da Terra. E, como bem notou E. Mandel, apenas o marxismo pode prover coerentemente a unidade dialética entre teoria e prática, e combiná-las em força material de transformação e de emancipação humana. ${ }^{443}$ Ademais, no que respeita ao nosso objeto de estudo - uma economia dependente e subdesenvolvida - essa mesma tradição marxista, nomeadamente a inspirada nas reflexões sobre a revolução permanente, fixou em um modelo teórico consistente tanto os passos como a meta histórica dos países atrasados e semicoloniais em sua luta de emancipação. É expressivo que, sob o enfoque de suas proposições, a questão que vínhamos discutindo sobre integração regional ganhe um sentido mais profundo ao se falar igualmente em integração dos movimentos e lutas sociais da América Latina, conferindo-Ihe uma dimensão internacionalista que ressalte a imperiosidade da conjugação e ampliação à escala mundial das lutas de todas as classes exploradas e excluídas sob o modo de produção do capital. Não se deve esquecer que o capitalismo (e seu rebento, o imperialismo) a ser combatido configura também um sistema mundial. Dessa perspectiva, a adaptação da tradição marxista (e, especialmente, a concepção de revolução permanente) à realidade latino-americana - na qual se deve sopesar também o papel dos movimentos camponês, indígena, estudantil e ambientalista, ao lado do clássico papel do movimento operário, especificamente nas condições traçadas pelo

\footnotetext{
443 É de sublinhar-se a atualidade do axioma do jovem Marx: "As armas da crítica não podem, de fato, substituir a crítica das armas; a força material tem de ser deposta por força material, mas a teoria também se converte em força material uma vez que se apossa dos homens. A teoria é capaz de prender os homens desde que demonstre sua verdade face ao homem, desde que se torne radical. Ser radical é atacar o problema em suas raízes. Para o homem, porém, a raiz é o próprio homem." (MARX, Karl. Introdução à Crítica da Filosofia do Direito de Hegel). Da verdade dessa proposição segue-se que as ideias, sob a forma de conhecimento objetivo de uma realidade material que ademais as engendra, passam dialeticamente a ocupar a função revolucionária de esclarecer e orientar essa reorganização, a qual só pode ocorrer como destruição da realidade existente. Esse o aspecto mais valioso da dialética, e assim o refere o próprio K. Marx: "(...) Em sua configuração racional, [a dialética] é um incômodo e um horror para a burguesia e para os seus porta-vozes doutrinários, porque no entendimento positivo do existente, ela inclui ao mesmo tempo, o entendimento de sua negação, da sua desaparição inevitável, porque apreende cada forma existente no fluxo do movimento, portanto também com seu lado transitório; porque não se deixa impressionar por nada e é, em sua essência, crítica e revolucionária. O movimento, repleno de contradições, da sociedade capitalista faz-se sentir ao burguês prático de modo mais contundente nos vaivéns do clico periódico que a indústria moderna percorre e em seu ponto culminante - a crise geral." (MARX, K. O capital. São Paulo: Nova Cultural, 1985, p. 21. Grifo nosso.
} 
capitalismo dependente - deriva apenas de uma natural interpretação e atualização autóctone desse valioso legado histórico-científico universal. ${ }^{444}$

Os capítulos anteriores pretenderam demonstrar que, nas duas décadas e meia da história venezuelana aqui descritas, ao não dar uma solução positiva ao dilema dependência/soberania, as classes dominantes venezuelanas admitiram a contingência de enfrentar a conformação de uma sociedade desmembrada, agudamente polarizada entre os que gozam egoisticamente as vantagens da opulência e os que amargam as privações mais elementares da vida cotidiana. Afinal, não propuseram elas um projeto nacional concreto socialmente integrador e, por essa razão, aceitaram o risco de que as classes exploradas e excluídas se insurgissem contra o precário tipo de cidadania oferecido e contra o modo iníquo de distribuir a grande riqueza do país. Disso, certamente, não podia resultar outra coisa senão a desintegração social. Semelhantemente, o Estado venezuelano, diante do mesmo dilema e da mesma sociedade pobre levantada, preferiu a Morte como aliada - ou seja, o emprego dos mais violentos meios de repressão, cujas feridas infligidas inclementemente às classes oprimidas, como em 1989, ainda não se fecharam, e cobraram um alto custo às elites e ao Estado quando se entreabriu àquelas a oportunidade, uma década depois, de subverter o status quo, ou ao menos modificá-lo em proveito próprio, usando os recursos que a própria institucionalidade burguesa provia através do jogo eleitoral. A Revolução Bolivariana só pôde nascer da decisão das camadas exploradas e excluídas de reordenar a vida social e política do país. Foi esse o principal resultado do dilema da dependência/soberania, mantido irresoluto por tanto tempo. A tarefa entregue à liderança bolivariana - primeiramente a Hugo Chávez, agora a Nicolás Maduro e ao PSUV - começa pela transformação fundamental que é a superação do capitalismo dependente, e termina pela obra hercúlea de implantar o socialismo. A história dos próximos anos ainda dirá se essa liderança está à altura do que lhe foi delegado. Cumpre apontar que, nessas fases iniciais, notam-se contaminações e corrupção de ideais democráticos nos sinais evidentes de concentração

\footnotetext{
${ }^{444}$ Nesse sentido, vale recordar aqui a conhecida sentença de J. C. Mariátegui, em Ideología y política: "No queremos, ciertamente, que el socialismo sea en América calco y copia. Debe ser creación heroica. Tenemos que dar vida, con nuestra propia realidad, en nuestro propio lenguaje, al socialismo indo-americano. He aquí una misión digna de una generación nueva". (MARIÁTEGUI, J. C. Ideología y política. Caracas: Ministerio de Comunicación e Información, 2006, p. 232. Disponível em: http://www.minci.gob.ve/2006/01/ideologia-y-politica/
} 
burocrática e plutocrática do poder estatal. Por esse motivo, compete aos movimentos sociais venezuelanos - os dos trabalhadores assalariados acima de todos - integrados de algum modo ao conjunto dos movimentos sociais de esquerda latino-americanos - o empenho em dirimir esses desvios. Repetindo: é preciso que a Revolução Bolivariana, que tem criado condições favoráveis ao exercício de uma democracia bem mais efetiva que as simples formalizações da representação liberal-burguesa, seja ela própria engolfada (juntamente com o Estado que ela vem constituindo) pelos movimentos sociais populares, o que tornaria por fim realidade uma declaração do próprio Hugo Chávez, que certa vez comparou o governo bolivariano a uma simples "folha ao vento", e "o vento" o povo venezuelano. Se esse protagonismo popular alcançar um nível de concretude histórica muito maior do que o atual, que obvie o caráter de simples abstração teórico-ideológica, e lograr, assim, atingir no processo revolucionário um ponto de irreversibilidade das mudanças - e se, além disso, a ele se juntarem os movimentos sociais e as conquistas democráticas do restante do continente, abandonando-se paulatinamente a "credulidade servil no Estado" ${ }^{445}$, tão mais comum em sociedades de forte tradição clientelista - será plausível abrigar a esperança de que este início de século possa ter, para a América Latina, uma significação tão promissora quanto teve o início do século passado para outra região semelhante, tão socialmente injusta, atrasada e cindida como era a Rússia dos czares. Afinal - como assinalou argutamente um estudioso do capitalismo dependente - a história encerra, e encerrará sempre, um algo de incontível todas as vezes que o que se contrapuser a ela forem a injustiça e a ânsia irracional de mutilar a liberdade dos homens. De fato:

"Se o poder autocrático, a violência organizada e o egoísmo cego pudessem conter a evolução das sociedades humanas, a humanidade não teria tido história". ${ }^{446}$

\footnotetext{
${ }^{445}$ Essa expressão, bem conhecida (e referida por seu autor como uma "superstição distante do socialismo"), está em MARX, K. Crítica do Programa de Gotha, p. 46.

${ }^{446}$ FERNANDES, Florestan. Capitalismo dependente e classes sociais na América Latina, p. 111.
} 


\section{Índice de tabelas e gráficos}

Tabela 1: PIB/Orçamentos destinados à educação, à saúde e ao serviço da dívida

Tabela 2: Número de pessoas (por milhões) vivendo com menos de 1 dólar/dia

Tabela 3: América Latina: as 500 maiores empresas locais e transnacionais por vendas e setores de atividade econômica

Tabela 4: América Latina e Caribe: tendências e projeções do mercado de trabalho

Tabela 5: Indicadores econômicos 1972-1975 (em milhões de bolívares)

Tabela 6: Matrícula escolar 1973-1974 e 1974-1975, em milhares de alunos

Tabela 7: Venezuela - Produto Territorial Bruto - milhões de bolívares a preços de 1968

Tabela 8: Gastos do Governo/ Investimentos/ Dívida Pública - 1970-1984 - em milhões de bolívares

Tabela 9: Comércio exterior de produtos manufaturados - milhões de dólares

Tabela 10: Participação do setor manufatureiro no PIB não petroleiro, emprego e remunerações

Tabela 11: Receitas Fiscais entre 1945 e 1957

Tabela 12: Participação no PIB mundial

Tabela 13: PIB per capita em porcentagem do PIB do centro

Tabela 14: Estrutura Ocupacional (em \% da PEA) e Inflação

Tabela 15: Taxas de incidência: pobreza geral e pobreza extrema

Tabela 16: Nível e evolução do gasto social por setores nos anos 1990 Venezuela

Tabela 17: Distribuição de renda por lares 1990-1999 - Venezuela

Tabela 18: Distribuição líquida da renda nacional por fator de produção (19501998)

Tabela 19: Taxas de Investimentos em capital fixo (1950-1998)

Tabela 20: Taxas de crescimento de setores industriais (1988-1998)

Tabela 21: Relação contribuição/ gastos PDVSA (1976-2000) 
Gráfico 1: América Latina: evolução da pobreza e da indigência - 1980-2012

Gráfico 2: América Latina: Participação na renda por grupos de decis

Gráfico 3: Coeficiente de GINI (por grupo de países)

Gráfico 4: América Latina: emprego informal total (por sexo) - 2010

Gráfico 5: Taxa de Analfabetismo da população com mais de 15 anos, por país. 2000-2008

Gráfico 6 : Concentração dos fluxos tecnológicos por grupos de países

Gráfico 7 : IED por grupos de países (1967-1989)

Gráfico 8: Evolução do mercado financeiro mundial - 1985-1999

Gráfico 9: AL: Variação anual do PIB e da demanda agregada 1990-2009 (em \%)

Gráfico 10: Desenvolvimento Econômico da Venezuela 1830-2006

Gráfico 11: Capital não residencial público e privado 1922-2002

Gráfico 12: PTB e Taxa de inflação

Gráfico 13: Transferências externas vinculadas ao endividamento

Grupo de gráficos (14): Evolução de indicadores sociais - anos 1970-80

Gráfico 15: Sindicatos constituídos e taxa de sindicalização $(1973-75=100)$

Gráfico 16: Produtividade e salários reais (1950-2002) $1950=100$

Gráfico 17: Taxa de crescimento interanual do IDH 1980-2013 - Venezuela

Gráfico 18: Concentração de dióxido de carbono na atmosfera, medida no Observatório de Manua Loa, Havaí 


\section{Índice de figuras}

Fig. 1: Pessoas feridas no Bairro 19 de Abril, Petare (Foto: Francisco "Frasso" Solórzano). Noticias 24 e AVN p. 261

Fig. 2: Caracaço (Foto: Tomás "Tom" Grillo). ABN. p. 261

Fig. 3: Caracaço (Foto: Tomás "Tom" Grillo). ABN. p. 262

Fig. 4: Saques no centro de Caracas (Foto: Francisco "Frasso" Solórzano). Noticias 24 e AVN. p. 262

Fig. 5: El Caracazo (Foto: Francisco "Frasso" Solórzano). Noticias 24 e AVN ...p. 263

Fig. 6: Av. Intercomunal El Valle (Foto: Francisco "Frasso" Solórzano). Noticias 24 e $A V N$ p. 263

Fig. 7: Armamentos de guerra contra civis inermes. Arquivo venezuelanalisys.com p. 264

Fig. 8: Bairro 19 de Abril, Petare (Foto: Francisco "Frasso" Solórzano). Noticias 24 e $A V N$. p. 264

Fig. 9: Bairro 19 de Abril, Petare. (Foto: Francisco "Frasso" Solórzano). Noticias 24 e $A V N$. p. 265

Fig. 10: Esquifes para Caracas. (Foto: Francisco "Frasso" Solórzano). Noticias 24 e $A V N$. p. 265

Fig. 11: Agentes amontoando corpos em um veículo (Foto: José Cohén). p. 266

Fig. 12: Civis e militares rebeldes carregam soldado ferido durante a rebelião de 4 de fevereiro de 1992. (Notícias 24). ..p. 266

Fig. 13: Policial e soldado combatem rebeldes em fevereiro de 1992 (AP)...p.267

Fig. 14: Hugo Chávez exorta os companheiros a depor armas e declara que os objetivos do movimento não foram alcançados "por enquanto".(AP) p.267 
Anexos

Anexo 1

\section{Pacto de Avenimiento Obrero-Patronal de 1958}

La Federación de Cámaras y Asociaciones de Comercio y Producción, como entidad representativa de sectores patronales y el Comité Sindical Unificado, en su carácteride representante de la Clase Obrera, estiman conveniente llevar a conocimiento de patronos y trabajadores la siguiente declaración:

Se han venido sosteniendo conversaciones en torno a la necesidad de fortalecer una paz social permanente, que garantice el normal desenvolvimiento de las actividades productoras y permita una armoniosa colaboración èn la que tanto los trabajadores como los patronos asuman su responsabilidad dentro de los limites juntos de sus deberes y derechos, mediante el respeto mutuo y la comprensión serena hacia el progresivo aumento de la riqueza nacional y la participación y retribución de su labor en los términos de una verdadera justicia social. Con vistas al deseo anteriormente expresado y teniendo como norma que el momento que vive el pais exige de todos los sectores que integran la vida nacional el mayor esfuerzo para lograr la consolidación de un sistema institucional donde prevalezcan el respeto y los valores morales, la jerarquización de la dignidad humana y el libre ejercicio democrático de las instituciones, recomendamos los siguientes puntos básicos para que sirva de norma en sus relaciones a empresarios $y$ trabajadores:

$I^{\circ}$ ) La creación de comisiones de avenimiento en las empresas, formadas por representantes patronales $y$ sindicales, con el propósito de discutir en dichas comisiones los problemas que pueden ser motivo de conflicto y que surjan en ocasión del trabajo, a fin de buscarle soluciones adecuadas a cada uno de ellos, mediante los buenos oficios de dichas comisiones. Esas Comisiones de avenimiento estarán formadas por partes iguales de representantes sindicales $y$ de representantes patronales. Dicho procedimiento será un paso adicional a cualquier sistema de conciliación vigente entre los trabajadores y las empresas y 
no afectará los derechos de los trabajadores ni de las empresas bajo la Ley o los acuerdos obrero-patronales.

2) Reconocimiento y respeto a la libertad de organización sindical sin interferencia de ninguna clase.

$\left.3^{\circ}\right)$ la conveniencia de mantener la mayor estabilidad posible de los trabajadores, colaborando las empresas en no hacer despidos a menos que tengan razones que asi lo ameriten.

$4^{\circ}$ ) Estricto cumplimiento de los Contratos Colectivos y de la Ley del Trabajo tanto por parte de los patronos como por parte de los trabajadores.

$\left.5^{\circ}\right)$ La conveniencia de celebrar Contratos Colectivos por actividad económica que tiendan a uniformar las condiciones de trabajo y estabilizar las relaciones obreropatronales.

$\left.6^{\circ}\right)$ La necesidad de que tanto patronos como trabajadores, sin renunciar a las acciones legales que les competen, agoten las medidas conciliatorias antes del planteamiento de cualquier conflicto, valiéndose para ello de los procedimientos que existan en los Contratos Colectivos vigentes, de las gestiones de los funcionarios del Trabajo y de las Comisiones de Avenimiento que nazcan como fruto de la presente declaración.

Las organizaciones gremiales tanto patronales como obreras velarán porque estos puntos tengan la mayor aplicación y deberian participar activamente en los estudios $y$ discusiones de los acuerdos que interesen a la vida obreropatronal, ratificando su voluntad de continuar en las relaciones que faciliten su adopciön ${ }^{152}$.

Pacto firmado entre Gustavo Lárez Ruíz (presidente do Comitê Sindical Unificado Nacional), Ángel Cervini (presidente da Federação de Câmaras e Associações de Comércio e Produção) e Raúl Valera (ministro do Trabalho), em 24 de abril de 1958. (Fonte: Revista sobre Relaciones Industriales e Laborales, 44/2008, pp. 8384) 


\section{Anexo 2}

\section{Pacto de Punto Fijo (31 de octubre 1958)}

Los partidos Acción Democrática, Social Cristiano Copei y Unión Republicana Democrática, previa detenida y ponderada consideración de todos los elementos que integran la realidad histórica nacional y la problemática electoral del país, y ante la responsabilidad de orientar la opinión pública para la consolidación de los principios democráticos, han llegado a un pleno acuerdo de unidad y cooperación sobre las bases y mediante las consideraciones siguientes:

1a Como es del conocimiento público, durante varios meses las distintas fuerzas políticas que han participado en las acciones unitarias para la defensa del régimen democrático han mantenido conversaciones destinadas a asegurar la inteligencia, mutuo respeto y cooperación entre ellas, interesadas por igual en la consolidación de la unidad y la garantía de la tregua política, sin perjuicio de la autonomía organizativa y caracterización ideológica de cada uno, conforme se declaró expresamente en el acta de ampliación de la Junta Patriótica firmada el 25 de enero de 1958 por los partidos políticos que la integraban inicialmente. El resultado obtenido es favorable, toda vez que las naturales divergencias entre los partidos, tan distintas de unanimismo impuesto por el despotismo, se han canalizado dentro de pautas de convivencia que hoy más que nunca es menester ampliar y garantizar. El análisis cabal de los antecedentes, de las características actuales y de las perspectivas de nuestro movimiento democrático, la ponderación comprensiva de los intereses legítimamente representados por los partidos a nombre de los centenares de miles de sus militantes; el reconocimiento de la existencia de amplios sectores independientes que constituyen factor importante de la vida nacional; el respaldo de las Fuerzas Armadas al proceso de afirmación de la República como elemento institucional del Estado sometido al control de las autoridades constitucionales, y el firme propósito de auspiciar la unión de todas las fuerzas ciudadanas en el esfuerzo de lograr la organización de la Nación venezolana, han estado presentes en el estudio de las diferentes fórmulas propuestas. La sincera definición y defensa de los derechos que asisten a los partidos como representantes de grandes núcleos nacionales y la preocupación común de atender en conjunto a los intereses perdurables de la Nación, si bien han podido en forma ocasional provocar la generosa impaciencia de calificados valores de la opinión, son la garantía de que las deliberaciones han respondido a un serio y responsable enfoque de las urgencias del país.

2a Las minuciosas y largas conversaciones han servido para comprometer a las organizaciones unitarias en una política nacional de largo alcance, cuyos dos polos podemos definir así: a) seguridad de que el proceso electoral y los Poderes Públicos que de él van a surgir respondan a las pautas democráticas de la libertad efectiva del sufragio; $y$ b) garantía de que el proceso electoral no solamente evite la ruptura del frente unitario, sino que lo fortalezca mediante la prolongación de la tregua política, la despersonalización del debate, la erradicación de la violencia interpartidista y la definición de normas que faciliten la formación del Gobierno y de los cuerpos deliberantes de modo que ambos agrupen equitativamente a todos los sectores de la sociedad venezolana interesados en la estabilidad de la República como sistema popular de Gobierno. 
3a Establecidos esos principios de carácter general, COPEI, AD y URD comprometen su acción y responsabilidad en los términos siguientes: a. Defensa de la constitucionalidad y del derecho a gobernar conforme al resultado electoral. Las elecciones determinarán la responsabilidad en el ejercicio de los Poderes Públicos, durante el periodo constitucional 1959-1964; intervención de la Fuerza contra las autoridades surgidas de las votaciones es delito contra la Patria. Todas las organizaciones políticas están obligadas a actuar en defensa de las autoridades constitucionales en caso de intentarse o producirse un golpe de Estado, aun cuando durante el transcurso de los cinco años las circunstancias de la autonomía que se reservan dichas organizaciones hayan podido colocar a cualquiera de ellas en la oposición legal y democrática al Gobierno. Se declara el cumplimiento de un deber patriótico la resistencia permanente contra cualquier situación de fuerza que pudiese surgir de un hecho subversivo y su colaboración con ella también como delito de lesa patria. b. Gobierno de Unidad Nacional. Si bien el ejercicio del Poder por un partido es consecuencia legítima de una mayoría electoral, la suerte de la democracia venezolana y la estabilidad del Estado de derecho entre nosotros imponen convertir la unidad popular defensiva en gobierno unitario cuando menos por tanto tiempo como perduren los factores que amenazan el ensayo republicano iniciado el 23 de enero; el gobierno de Unidad Nacional es el camino para canalizar las energías partidistas y evitar una oposición sistemática que debilitaría el movimiento democrático. Se deja claramente sentado que ninguna de las organizaciones signatarias aspira ni acepta hegemonía en el Gabinete Ejecutivo, en el cual deben estar representadas las corrientes políticas nacionales y los sectores independientes del país, mediante una leal selección de capacidades. c. Programa mínimo común. Para facilitar la cooperación entre las organizaciones políticas durante el proceso electoral y su colaboración en el Gobierno Constitucional los partidos signatarios acuerdan concurrir a dicho proceso sosteniendo un programa mínimo común, cuya ejecución sea el punto de partida de una administración nacional patriótica y del afianzamiento de la democracia como sistema. Dicho programa se redactará por separado, sobre las bases generales, ya convenidas, y se considerará un anexo del presente acuerdo. Como este programa no excluye el derecho de las organizaciones políticas a defender otros puntos no comprendidos en él, se acuerda para estos casos la norma siguiente: ningún partido unitario incluirá en su programa particular puntos contrarios a los comunes del programa mínimo y, en todo caso, la discusión pública en los puntos no comunes se mantendrá dentro de los límites de la tolerancia y del mutuo respeto a que obligan los intereses superiores de la unidad popular y de la tregua política.

4a El ideal de la unidad como instrumento de lucha contra la tiranía y contra las fuerzas en aptitud de reagruparse para auspiciar otra aventura despótica, sería la selección de un candidato presidencial democrático único, la formación de planchas únicas para los cuerpos colegiados y la formación de un frente único a base de un solo programa integral de Gobierno. En la práctica se ha evidenciado que diversos factores reales contradicen esa perspectiva histórica, mas, afortunadamente, hay otros medios idóneos de preservar la Unidad Nacional. Por consiguiente, lejos de considerar comprometida la unidad por la comprobación de naturales contradicciones interpartidistas que se corresponden con la esencia de la actividad democrática, las organizaciones signatarias después de confrontar sus distintas opiniones entre sí y con las emitidas por voceros independientes autorizados, de la prensa y de otros factores nacionales define: 
1. Los requerimientos de la unidad son compatibles con la eventualidad de diversas candidaturas y planchas legislativas.

2. Para que la presentación de varias candidaturas presidenciales y diversas planchas legislativas pueda verificarse sin menoscabo de la unidad y sin ruptura de la tregua interpartidista, es indispensable fortalecer el sentimiento de común interés patriótico y la tolerancia y mutuo respeto entre las fuerzas unitarias, base de lo cual debe ser la sincera y solemne adhesión de todas las fuerzas democráticas a los puntos contenidos en esta declaración y al espíritu que la anima, tal como hoy se consagra con la firma de este documento.

3. Para garantizar la tregua política y la convivencia unitaria de las organizaciones democráticas, se crea una Comisión Interpartidista de Unidad encargada de vigilar el cumplimiento de este acuerdo. Dicha Comisión estará encargada de orientar la convivencia interpartidista, de conocer las quejas que se produzcan contra las desviaciones personalistas o sectarias en la campana electoral y de diligenciar ante cualquiera de los signatarios, y a nombre de todos, la morigeración y control en lo que pudiera comprometer la convivencia democrática.

5a Para garantizar que varias postulaciones presidenciales y varias planchas legislativas sean en todo momento expresiones de la voluntad nacional de celebrar elecciones que en definitiva se traduzcan en fortalecimiento de la democracia, se proclama:

I. Cada organización queda en libertad de sustentar su propio candidato presidencial y sus propias planchas para los cuerpos colegiados dentro del concepto de unidad aquí consagrado y en el sentido de que garanticen la tolerancia mutua durante la campaña y el cumplimiento de los compromisos generales convenidos en esta declaración cualquiera que sea la candidatura o plancha que obtuviera mayor número de votos.

II. Todos los votos emitidos a favor de las diversas candidaturas democráticas, serán considerados como votos unitarios y la suma de los votos por los distintos colores como una afirmación de la voluntad popular a favor del régimen constitucional y de la consolidación del Estado de derecho.

III. La postulación de los candidatos presidenciales y de las planchas legislativas es de la responsabilidad de cada partido o coalición. Será el pueblo elector a quien le corresponda calificar con el voto cualquier postulación.

IV. Los partidos que suscriben este documento garantizan la adhesión de los principios y normas aquí consagrados de sus respectivos candidatos a la Presidencia de la República.

$V$. Los partidos signatarios se comprometen a realizar una campaña positiva de afirmación de sus candidatos y programas dentro del espíritu de la unidad, evitando planteamientos y discusiones que pueden precipitar la pugna interpartidista, la desviación personalista del debate $y$ divisiones profundas que luego pudieran comprometer la formación del Gobierno de Unidad Nacional.

VI. Después de publicado el resultado oficial de las elecciones, tendrá lugar en Caracas un gran acto popular encargado de ratificar los siguientes principios: a. Pública adhesión de todas las organizaciones y candidatos participantes al resultado de las elecciones, como expresión de la soberana voluntad popular. b. Ratificación por parte de las organizaciones signatarias de su sincero propósito de respaldar al Gobierno de Unidad Nacional, al cual prestarán leal y democrática 
colaboración. Consideran las organizaciones signatarias que la adhesión de todas las fuerzas políticas a los principios y puntos fijados en esta declaración es una garantía eficaz para el ejercicio del derecho electoral democrático dentro de un clima de unidad. La cooperación de los organismos profesionales gremiales, cívicos y culturales, de la prensa y de personalidades independientes, con los fines así precisados, consolidarán la convivencia nacional y permitirán el desarrollo de una constitucionalidad estable que tenga en sus bases la sinceridad política, el equilibrio democrático, la honestidad administrativa y la norma institucional que son la esencia de la voluntad patriótica del pueblo venezolano. Como este acuerdo no fija principio o condición contrarios al derecho de las otras organizaciones existentes en el país, y su leal cumplimiento no limita ni condiciona el natural ejercicio por ellas de cuantas facultades pueden y quieren poner al servicio de las altas finalidades perseguidas, se invita a todos los organismos democráticos a respaldar, sin perjuicio de sus concepciones específicas, el esfuerzo comprometido en pro de la celebración del proceso electoral en un clima que demuestre la aptitud de Venezuela para la práctica ordenada y pacífica de la democracia.

Caracas, 31 de octubre de 1958.

(Firmado)

Por Unión Republicana Democrática,

Jóvito Villalba.

Ignacio Luis Arcaya.

Manuel López Rivas.

(Firmado)

Por el Partido Social Cristiano Copei,

Rafael Caldera.

Pedro del Corral.

Lorenzo Fernández.

(Firmado)

Por Acción Democrática,

Rómulo Betancourt.

Raúl Leoni.

Gonzalo Barrios. 


\section{Bibliografia}

ALCÂNTARA, Manuel \& FREIDENBERG, Flavia (coords.). Partidos políticos de América Latina. Países andinos. México: FCE, IFE, 2003.

ALFONSO, Juan Pablo Pérez. Petróleo y dependencia. Caracas: Síntesis dos mil, 1971.

ALMEIDA, Zoraida. Efectos del crecimiento y de las políticas de desarrollo en la pobreza y en la distribución del ingreso : el caso de Venezuela. Caracas: $\mathrm{BCV}, \mathrm{s} / \mathrm{d}$.

ÁLVAREZ, R. Regalado. América Latina entre siglos. Cuba: Ocean Sur, 2006.

AMÉRICA LATINA EN MOVIMIENTO.¿Fin del ciclo progresista? no 510, deciembre 2015, Año 39, 2ª época.

AMNISTÍA INTERNACIONAL. Venezuela: denuncias de homicidios arbitrarios y torturas: febrero y marzo de 1989. Informe de Marzo de 1990. Disponível em: https://www.amnesty.org/es/library/asset/AMR53 /002/1990/es/2b23f18f-ee6b-11dd96f1-9fdd7e6f4873/amr530021990es.html.

AMNISTÍA INTERNACIONAL. Documento - Venezeula: La Ley sobre Vagos y Maleantes: Supresion de la disidencia y castigo de los indigentes. Disponível em: http://www.amnesty.org/es/library/asset/AMR53/001/1995/es/ab6cb95ae b6b-11dd-b8d6-03683db9c805/amr530011995es.html.

APONTE, Miguel. Venezuela: el socialismo del siglo XXI y la enfermedad holandesa como estrategia económica. (Material de discusión). Disponível em: http://economiapoliticaehucv. wordpress.com/.

ARAUJO, Orlando. Venezuela violenta. Presentación de Carlos Mendoza Potellá. Caracas: Banco Central de Venezuela, 2013.

ARANDA, Sergio. La economía venezolana: Una interpretación de su modo de funcionamiento. Bogotá: Siglo Veintiuno Editores, 1977.

ARCERO, Enrique. El impacto de la globalización en la periferia y las nuevas y viejas formas de la dependencia en América Latina. Cuadernos del CENDES, vol. 22, núm. 60, septiembre-diciembre, 2005, pp. 25-61. Disponível em: http://www.redalyc.org/articulo.oa?id=40306003 
ARENAS, Nelly \& HENRÍQUEZ, Haydée Ochoa. Venezuela: ¿más democracia o más populismo? Los consejos comunales y las disputas sobre la hegemonía democrática. Buenos Aires: Teseo, 2010.

ARNT, Ricardo (org.). O armamentismo e o Brasil. A guerra deles. São Paulo: Brasiliense, 1985.

ARRIGHI, Giovanni. O longo século XX: Dinheiro, poder e as origens de nosso tempo. Trad. de Vera Ribeiro. Rio de Janeiro: Contraponto; São Paulo: Unesp, 1996.

ARRIGHI, Giovanni \& SILVER, Beverly J. Caos e governabilidade no moderno sistema mundial. Rio de Janeiro: Contraponto; Editora UFRJ, 2001

BAMBIRRA, Vânia. O capitalismo dependente latino-americano. Florianópolis: Insular, 2012 (1ํㅡㄹ., em espanhol: México: Siglo XXI, 1974).

BANCO MUNDIAL. Desarrollo y cambio climático. Informe sobre desarrollo mundial 2010. Disponível em: http://www.worldbank.org.

BANKO, Catalina. Industrialización y políticas económicas en Venezuela. São Paulo: Cadernos PROLAM/USP, ano 6, vol. 1, 2007, p. 129-147.

BAPTISTA, Asdrúbal. La economía venezolana entre siglos. Revista Nueva Economía. Vol. 28, Oct. 2008, pp. 59-80.

- El capitalismo rentístico. Elementos cuantitativos de la economía venezolana. Cuadernos del Cendes, Año 22, $\mathrm{N}^{\circ}$ 60, septiembre-diciembre 2005, pp. 95-111.

BARBOSA, Nelson Prato. Rebelión militar y golpe de Estado en Venezuela. Revista Ciencias Sociales 76: 173-185, junio 1997.

BARROS, Pedro Silva. Chávez e petróleo: uma análise da nova política econômica venezuelana. São Paulo: Cadernos PROLAM/USP, ano 5, vol.2, 2006, p. 209-237.

BEINSTEIN, Jorge. Capitalismo senil. A grande crise da economia global. Trad. de Ryta Vinagre. Rio de Janeiro: Record, 2001.

BENAYON, Adriano. Globalização versus desenvolvimento. São Paulo: Escrituras, 2005.

BENEDITO, Flávio. (org.). Venezuela: Temas contemporâneos, São Paulo, 2011. Disponível em: http://pt.scribd.com/doc/65432081/VENEZUELA-TEMASCONTEMPORANEOS. 
BERARDO, João Batista. Guerrilheiras e guerrilheiros no drama da América Latina. São Paulo: Edições Populares, 1981.

BEROES, Agustín. RECADI: La gran estafa. Planeta, 1990. Versão digital. Disponível em: http://www.angelfire.com $/ \mathrm{nb} / 17 \mathrm{~m} /$ noolvidar.html

BETHELL, Leslie (Org.). A América Latina após 1930: Economia e sociedade. Trad. de Geraldo Gerson de Souza. São Paulo: Editora da Universidade de São Paulo; Brasília, DF: Fundação Alexandre de Gusmão, 2005. (série História da América Latina, v. 6).

BETHELL, Leslie (ed.). História de América Latina. Los países andinos desde 1930. Trad. castellana de Jordi Beltrán. Barcelona: Editorial Crítica, 2002, v.16.

BHAGWATI, Jagdish. Em defesa da globalização: como a globalização está ajudando ricos e pobres. Trad. Regina Lyra. Rio de Janeiro: Elsevier, 2004.

BORÓN, Atilio A. (org.). Nova hegemonia mundial. Buenos Aires: CLACSO, 2004.

BORÓN, Atilio. Socialismo siglo XXI: ¿Hay vida después del neoliberalismo? 1a ed. Buenos Aires: Luxemburg, 2008.

BRESSER-PEREIRA, Luiz Carlos. "Do ISEB e da CEPAL à teoria da dependência". In: TOLEDO, Caio Navarro de. (org.) Intelectuais e política no Brasil: A experiência do ISEB. Rio de Janeiro: Revan, 2005, pp. 201-232.

BROWN, Michael B. A economia política do imperialismo. Trad. de Ney Kruel. Rio de Janeiro: Zahar Editores, 1978.

BRUCKMANN, Mônica. Recursos naturales y la geopolítica de la integración sudamericana. s/d. Disponível em: http://www.reggen.org.br/reggen. UNASUR: Una estrategia regional para la gestión soberana de los recursos naturales. ALAI - América Latina en movimiento. 12/11/2012. Disponível em: http://alainet.org/active/60230

BUHL, Kathrin \& KOROL, Claudia (orgs.). Criminalización de la protesta y de los movimientos sociales. São Paulo: Instituto Rosa Luxembourg Stiftung, 2008.

BUKHARIN, Nikolai I. A economia mundial e o imperialismo. Esboço econômico. Trad. de Raul de Carvalho. São Paulo: Abril Cultural, 1984.

CALCAÑO, Luis Gómez. La democracia venezolana entre la renovacion y el estancamiento. Revista Pensamiento Iberoamericano, no. 14, 1988, jul.dic., pp. 181-195.

CALCAÑO, Luís Gómez \& ARENAS, Nelly. ¿Modernización autoritaria o actualización del populismo? La transición política en Venezuela. Cuestiones Políticas, no 26, enero-junio de 2001, pp. 61-89. 
CALELLO, Osvaldo. Trotsky y la revolución en América Latina. Ediciones de la Izquierda Nacional, 2009. Disponível em www.izquierdanacional.org.

CARDOSO, F. H. \& FALETTO, Enzo. Dependência e desenvolvimento na América Latina. Ensaio de interpretação sociológica. $8^{\mathrm{a}}$ ed. Rio de Janeiro: Civilização Brasileira, 2004. (1ª ed.: Zahar Editores, 1970).

CARLSON, Chris. Venezuela continues to search for solutions to high crime rate. Venezuelanalysis.com, 2/02/2013. Disponível em: http:// venezuelanalysis.com/news/7668.

CARRUYO, Dionisio et alii (coord.). La población de Venezuela. S/I. CICRED Series, 1974.

CASANOVA, Pablo González (Org.). América Latina: História de meio século. Brasília: Editora UnB, 1977.

. (Coord.) Historia política de los campesinos latinoamericanos. México, D.F.: Siglo Veintiuno Editores, 1985, v. 3.

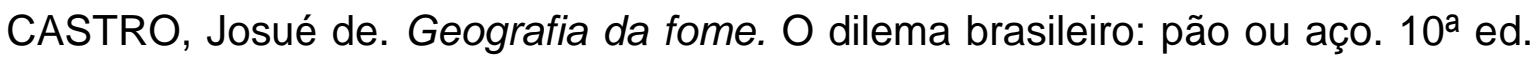
RJ: Edições Antares, 1984.

CECEÑA, Ana E. \& SADER, Emir. (coords.). La guerra infinita: Hegemonía y terror mundial. Buenos Aires: CLACSO, 2002.

CEPAL. Estudio Económico de América Latina y el Caribe. Vários anos. Disponível em: http://www.eclac.cl.

. El ahorro en Venezuela. (1970-1988). Trabajo preparado por Cristina Rodríguez. Distribución interna. 13/11/1989. Disponível em: http://repositorio.cepal.org/handle/11362/33324.

Globalização e desenvolvimento. Brasília, 2002. Disponível em http://www.eclac.org/cgibin/getProd.asp?xml=/publicaciones/xml/9/10029/P1 0029.xml\&xsl=/ tpl/p9f.xsl\&base=/tpl/top- bottom.xsl.

- Boletín demográfico América Latina e Caribe. Estimaciones y proyecciones de población. 1950-2050. CELADE, 2004.

CHESNAIS, François. A mundialização do capital. Trad. de Silvana Finzi Foá. São Paulo: Xamã, 1996.

CHOSSUDOVSKY, Michel. La miseria en Venezuela. $2^{\mathrm{a}}$ ed. Caracas: Vadell Hermanos Edit., 1977. Obra reeditada digitalmente por Motorspade, em agosto de 2008. Disponível em: http://pt.scribd.com/doc/5036864/Lamiseria-en-venezuela-Michel-Chossudovsky. Acesso em 05/2010. 
A globalização da pobreza. Impactos das reformas do FMI e do Banco Mundial. Trad. de Marylene P. Michael. São Paulo: Moderna, 1999.

COGGIOLA, Osvaldo (Org.). Globalização e socialismo. São Paulo: Xamã, 1997.

COGGIOLA, Osvaldo. América Latina siglo XXI: ¿una revolución en marcha?, 2006.

A crise (2007-2012). Lineamentos para uma abordagem global. 2012 (texto digital, disponível em www.apufpr.org.br/greve2012/images/stories/oc a crise 2007-2012.pdf.

COGGIOLA, O. \& MARTINS, J. Dinâmica da globalização. Mercado mundial e ciclos econômicos (1970-2005). Santa Catarina: UFSC, 2006.

COLISTETE, Renato Perim. O desenvolvimentismo cepalino. Revista de Estudos Avançados. vol.15, № 41, São Paulo, Jan./Apr. 2001.

CONTRERAS, Miguel Angel. Ciudadanía, Estado y democracia en la era neoliberal: dilemas y desafíos para la sociedad venezolana. Caracas: FACES, Universidad Central de Venezuela, 2004. pp. 111-132. Disponível em: http://www.insumisos.com/lecturasinsumisas/Ciudadania_estado\%20 y\%20democracia.pdf

CORONIL, Fernando \& SKURSKI, Julie. "Dismembering and Remembering the Nation. The Semantics of Political Violence in Venezuela". In: Comparative Studies in Society and History, vol. 33, № 2, April 1991, pp. 288-337. Disponível em: http://www.jstor.org/stable/178904. Acesso em 03/2010.

CORREO DEL ORINOCO, 27 de Febrero de 1989. Edición Especial. 24/ 02/2013, p.17. Disponível em: http://alainet.org/images/COE-27F.pdf)

CORTE INTERAMERICANA DE DERECHOS HUMANOS. Caso del Caracazo Vs. Venezuela. Sentencia de 11 de noviembre de 1999; e Sentencia de 29 de agosto de 2002. Disponíveis em www.corteidh.or.cr.

CORTEN, André et alii. L'interpellation plébéienne en Amérique latine. Violence, actions directes et virage à gauche. Québec: Éditions Karthala, 2012.

DAMAS, Germán Carrera. Historia contemporánea de Venezuela: bases metodológicas. 2. ed. Caracas: Universidad Central de Venezuela, Ediciones de la Biblioteca, 1979.

(Coord.). Formación histórico-social de Venezuela. Caracas: Centro de Estudios del Desarrollo, Universidad Central de Venezuela, Ediciones de la Biblioteca, 2002. 
DECARLI, Humberto. El mito democrático de las Fuerzas Armadas Venezolanas. Caracas: Ediciones Comisión de Relaciones Anarquistas, 2006. Disponível em: http://www.nodo50.org/ellibertario.

DEMIER, Felipe. A natureza do governo Chávez: uma contribuição teórica para o debate. (10/04/2007). Disponível em: www.soberania.org.

DíAZ, Rolando. Los sindicatos en Venezuela: de la negociación a la confrontación. IDEGES, 2009. Disponível em: http:// revistasenlinea.saber.ucab.edu.ve/temas/index.php/educab/article/view/844

DíAZ, G. \& CORREDOR, C. "Evolución de la economía informal en Venezuela", in: Observatorio de la Economía Latinoamericana, № 105, noviembre 2008. Disponível em http://www.eumed.net/cursecon/ecolat/ve/.

DIJOHN, Jonathan. The Political Economy of Economic Liberalisation in Venezuela. Development Research Centre, LSE, 2004.

DINGES, John. Os anos do condor. Uma década de terrorismo internacional no Cone Sul. (Trad. de Rosaura Eichenberg). São Paulo: Cia das Letras, 2005.

DOSSIER Lucha armada venezolana en los 60. Memorias de Venezuela. Centro Nacional de Historia. Octubre/2010, no 16.

ECHEVARRÍA, Oscar A. Deuda... Crisis cambiaria: causas y correctivos. Caracas: Universidad Católica Andrés Bello, 1986.

EDWARDS, Sebastián. Crisis y reforma en América Latina. Del desconsuelo a la esperanza. Buenos Aires: Emecé Editores, 1995.

ELÍAS, Antonio. (comp.). Los gobiernos progresistas en debate. Argentina, Brasil, Chile, Venezuela y Uruguay. Buenos Aires: CLACSO; Montevideo: PIT-CNT. Instituto Costa Duarte, 2006.

ELLNER, Steve. Um chavismo sem Chávez é possível? Le monde diplomatique Brasil. 02/09/2012. Disponível em: http://www.diplomatique.org.br /artigo. php?id=1258.

Tendencias recientes en el movimiento laboral venezolano: autonomía vs. control. Revista Venezolana de Economía y Ciencias Sociales, vol. 9, núm. 3, septiembre-diciembre, 2003, pp. 157-178. Disponível em: http://www.redalyc.org/articulo.oa?id=17709308.

. Rethinking Venezuelan Politics. Venezuelanalysis.com, February 11th 2008. Disponível em: www.venezuelanalysis.com.

ELLNER, Steve \& HELLINGER, Daniel (Ed.). Venezuelan Politics in the Chávez Era: Class, Polarization, and Conflict. London: Lynne Rienner Publishers, 2003. 
ELLNER, Steve \& SALAS, Miguel T. Venezuela: Hugo Chávez and the decline of an "exceptional democracy". Lanham: Rowman \& Littlefield Pub., 2007.

EMERSBERGER, Joel. Bolivia-Venezuela Comparisons Should be Very Helpful to Radical Chavistas. October 20th 2014. Disponível em: http://venezuelanalysis.com/analysis/10970.

ESPAÑA N., Luis Pedro. "Violence and the welfare state: the case of Venezuela as an oil country". In: RUPESINGHE, K. \& RUBIO C., M. (ed.). The culture of violence. Tokyo: United Nations University Press, 1994, cap. 7, pp. 178-197.

ESPINOSA, Elia Oliveros. La lucha social y la lucha armada en Venezuela. Caracas: Fundación Editorial El perro y la rana, 2012.

ESTAY, Jaime \& SÁNCHEZ, Germán (coord.). El ALCA y sus peligros para América Latina. Buenos Aires: CLACSO, 2005.

ESTENSSORO, Luís. Capitalismo, desigualdade e pobreza na América Latina. Tese de doutorado, FFLCH-USP, 2003.

FERNANDES, Bernardo Mançano (org.). Campesinato e agronegócio na América Latina: a questão agrária atual. São Paulo: Expressão Popular, 2008.

FERNANDES, Florestan. A sociologia numa era de revolução social. $2^{\underline{a}}$ ed. Rio de Janeiro: Zahar Editores, 1976.

. Sociedade de classes e subdesenvolvimento. $4^{\underline{a}}$ ed. Rio de Janeiro: Zahar Editores, 1981.

. Capitalismo dependente e classes sociais na América Latina. $4^{\mathrm{a}}$ ed. São Paulo: Global, 2000.

. Em busca do socialismo: últimos escritos e outros textos. São Paulo: Xamã, 1995.

- Da guerrilha ao socialismo: a revolução cubana. São Paulo: Ed. Expressão Popular, 2007.

Brasil: em compasso de espera. Pequenos escritos políticos. Rio de Janeiro: Ed. UFRJ, 2011. (Col. Revisitando o Brasil, v. 4).

FERREIRA, Carla et alii (org.). Padrão de reprodução do capital. Contribuições da teoria marxista da dependência. São Paulo: Boitempo, 2012.

FIGUEROA, Federico Brito. Historia económica y social de Venezuela: Una estructura para su estudio. Caracas: Universidad Central de Venezuela, Ediciones de la Biblioteca, 1996, tomo III. 
. 30 ensayos de comprensión histórica. Caracas: Universidad Central de Venezuela, Ediciones de la Biblioteca, 1997.

FIORI, José L. et alii. O mito do colapso do poder americano. RJ-SP: Record, 2008.

FLORES, Consuelo S. \& CORTÉS, Claudio Lara (coords.). La crisis global y el capital ficticio. Editorial Arcis- Clacso, s/d.

FOSTER, J. Bellamy. Foreword. Monthly Review, Volume 62, Number 3.

FRANK, Andre Gunder. Capitalismo y subdesarrollo en América Latina. Trad. de Elpidio Pacios. Buenos Aires: Ediciones Signos, 1970.

FREIRE, Paulo. Pedagogia do oprimido. 17ª ed. RJ: Paz e Terra, 1987.

FRONJOSA L., Ernesto. La ley de hidrocarburos de Venezuela del año 1943: Un complejo proceso de negociación en el ámbito global. Academia Nacional de la Ingeniería y el Hábitat. Boletín No 25. Mayo de 2013. pp. 176- 210.

FUKUYAMA, Francis. The End of History and the last Man. London: Penguin Books, 1992.

FURTADO, Celso. A economia latino-americana: formação histórica e problemas contemporâneos. $2^{\mathrm{a}}$ ed. São Paulo: Companhia Editora Nacional, 1978.

Ensaios sobre a Venezuela. Subdesenvolvimento com abundância de divisas. Rio de Janeiro: Contraponto: Centro internacional Celso Furtado, 2008.

FUSER, Igor. O mito da "generosidade" no contencioso Brasil-Bolívia do gás natural. Revista Tensões mundiais, Fortaleza, v. 10, n. 18, 19, p. 231-255, 2014. Disponível em: www.tensoesmundiais.net/index.php/tm/article/viewFile /350/386.

GALÍNDEZ, Ricardo. Dos grandes tesis económicas se debaten en el seno del campo revolucionario bolivariano. 25/08/2008. Disponível em: http://www.aporrea.org/actualidad/a62259.html.

GANDÁSEGUI, Marco A. América Latina y las inversiones extranjeras. 30/05/2013. Artigo disponível em http://alainet.org/active/64327.

GARRETÓN, Manuel Antonio. Neoliberalismo corregido y progresismo limitado: los gobiernos de la Concertación en Chile. 1990-2010. Santiago: CLACSO, 2012. Disponível em: http://bibliotecavirtual.clacso.org.ar/clacso/coediciones/ 20121121122525/NeoliberalismoCorregido.pdf" 
GENTILI, Pablo A. A. \& SILVA, Tomaz T. da. Neoliberalismo, qualidade total e educação. Visões críticas. Petrópolis: Editora Vozes, 2002.

GENTILI, Pablo. (org.) Universidades na penumbra. Neoliberalismo e reestruturação universitária. São Paulo: Cortez, 2001.

GÓMEZ, Luis \& SONNTAG, Heinz. "A Venezuela como exportadora de petróleo". In: SORJ, Bernardo et alii. Economia e movimentos sociais na América Latina. São Paulo: Brasiliense, 1985.

GONÇALVES, Reinaldo. Venezuela: rupturas e macrocenários. Rio de Janeiro: Revista OIKOS, 2009, vol. 8, ํㅡㄴ 2., pp. 201-222. Disponível em: www.revistaoikos.org.

GOTT, Richard. Hugo Chávez and the bolivarian revolution. London: Verso, 2005.

GRAMSCI, Antonio. Gli intellettuali e l'organizzazione della cultura. 3. ed. Roma: Editori reuniti, 1996. Texto digital disponível em http://www.liberliber.it/biblioteca/licenze/.

. Lettere dal carcere. Nuova ed. riveduta e integrata sugli autografi, con centodiciannove lettere inedite. Torino: Einaudi, 1965, 1a.edizione elettronica del 17 marzo 2008. Disponível em: http://www.e-text.it.

GUDYNAS, Eduardo. Estado compensador y nuevos extractivismos. Las ambivalencias del progresismo sudamericano. Nueva Sociedad, no 237, enero-febrero de 2012. Disponível em: www.nuso.org.

GUEVARA, Ernesto Che. El socialismo y el hombre nuevo. Prólogo de José Aricó. $8^{\underline{a}}$ ed. México: Siglo Veintiuno, 1988.

HARDY, José Toro. Venezuela: 55 años de política económica, 1936-1991. Caracas: Editorial Panapo, 1992.

HARNECKER, Marta. Venezuela: una revolución sui géneris. Ponencia Seminario de LAC (Foro Social Mundial III). 24 enero 2003. Disponível em: http:// www.rebelion.org/docs/97071.pdf

HARVEY, David. O novo imperialismo. Trad. de Adail Sobral e Maria S. Gonçalves. São Paulo; Edições Loyola, 2004.

HERNÁNDEZ, Rossana. Aspectos problemáticos del excepcionalismo en Venezuela (1958-1989). Revista Venezolana de Ciencia Política, N. 9 / enero-junio de 2006, pp. 153-167.

. Ideas y creencias en la política económica (1989-1993): Un enfoque teórico y epistemológico. Revista Economía, XXXII, 24, julio-diciembre, 2007, pp. 67-93. 
HERNÁNDEZ, Tosca. La ley sobre Vagos y maleantes y el sistema jurídico venezolano. Una ideologización del delito y la pena. Disponível em: http://gumilla.org/biblioteca/bases/biblo/ texto/SIC1978410_460-462.pdf.

HILFERDING, Rudolf. O capital financeiro. Trad. de Reinaldo Mestrinel. São Paulo: Nova Cultural, 1985 (série Os economistas).

HOBBES, Thomas. Leviatã, ou matéria, forma e poder de um estado eclesiástico e civil. Trad. de João P. Monteiro e Maria B. N. Silva. 4를. ed. São Paulo: Nova Cultural, 1988 (Coleção Os pensadores).

HOBSBAWM, Eric. Era dos extremos: O breve século XX (1914-1991). 2ª . ed. São Paulo: Companhia das Letras, 2003.

HONTY, Gerardo. Cambio Climático: negociaciones y consecuencias para América Latina. Montevideo: CLAES (Centro Latino Americano de Ecología Social), 2011.

IASI, Mauro Luís. As metamorfoses da consciência de classe. O PT entre a negação e o consentimento. São Paulo: Expressão popular, 2006.

IEA (International Energy Agency). World Energy Outlook 2009. Disponível em: http://www.worldenergyoutlook.org/publications/weo-2009/.

ITURRASPE, Francisco. "El movimiento sindical venezolano en la época de la mundialización: la transición del "puntofijismo" al "bolivarianismo". In: Los sindicatos frente a los procesos de transición política. Enrique de La Garza Toledo. CLACSO. 2001. Disponível em : http://bibliotecavirtual.clacso.org.ar/ ar/libros/garza3/iturraspe.pdf. Acesso em 022012.

. Democracia y conflicto. Deslegitimación del sistema político venezolano (1958-1998). Gaceta Laboral, año/vol. 6, no 3, 2000, pp. 347-380.

IZARD, Miquel. El poder, la mentira y la muerte: De El Amparo al Caracazo. Caracas: Fondo Editorial Tropykos, 1991.

KAPLAN, Marcos (coord.). Petróleo y desarrollo en México y Venezuela. México, D.F.: Editorial Nueva Imagen, 1981.

KARL, Terry Lynn. The Paradox of Plenty. Oil Booms and Petro-States. California: University of California Press, 1997.

KATZ, Claudio. Socialismo o neodesarrollismo. 2006. Disponível em http://katz.lahaine.org. Acesso em jun 2010.

- Las encrucijadas del nacionalismo radical. 2007. Disponível em http://katz.lahaine.org. Acesso em jun 2010. 
El imperialismo contemporáneo, 2011. Disponível em www.lahaine.org/katz. Acesso em dez 2012.

. Desenlaces del ciclo progresista. 25.ene.2016. Disponível em: http://katz.lahaine.org/?cat=1

KATZ, Claudio \& COGGIOLA, Osvaldo. Neoliberalismo ou crise do capital? São Paulo: Xamã, 1996.

LANDER, Edgardo \& NAVARRETE, Pablo. La política económica de la izquierda latinoamericana en el gobierno. Amsterdam: Havens Center - Rosa Luxemburg Stiftung - Transnational Institute, 2007.

LANDER, E. Izquierda y populismo: alternativas al neoliberalismo en Venezuela. Disponível em: http:/www.tni.org/sites/www.tni.org/files//zquierdaypopulismo. Alternativas al neoliberalismo en Venezuela.pdf. (Transnational Institute Octubre 2004). Acesso em maio de 2010.

- Venezuela: a busca de um projeto contra-hegemônico. CLACSO, Consejo Latinoamericano de Ciencias Sociales. Disponível em http://bibliotecavirtual.clacso.org.ar/ar/libros/grupos/cece2PT/10_lander.pdf

. Venezuela: terminal crisis of the rentier petro-state model? Disponível em: http://internationalviewpoint.org/spip.php?article3679. Outubro de 2014.

LANDER, Luis E. Petróleo y democracia en Venezuela: del fortalecimiento del Estado a la subversión soterrada y la insurrección abierta. Revista Galega de Economía, vol. 14, núm. 1-2 (2005), pp. 1-14. Disponível em: https://www.usc.es/econo/RGE/Vol14_1_2/Castelan/art9c.pdf.

A treinta años de la nacionalización el debate continúa. Presentación. Revista Venezolana de Economía y Ciencias Sociales, 2006, vol. 12, no 1 (ene.-abr.), pp. 103-107.

LEMOINE, Maurice. Venezuela's press power. How hate media incited de coup against the president. Le monde diplomatique. August 2002. Disponível em http://mondediplo.com/2002/08/10venezuela.

LENIN, V. I. O imperialismo, etapa superior do capitalismo. Lisboa/Moscovo: Editorial Avante - Edições Progresso, 1984.

LENINE, V. I. Esquerdismo: doença infantil do comunismo. Primeira edição: como panfleto, Junho 1920. Disponível em: http://www.marxists.org/ archive/lenin/index.htm

LINÁRES, Pedro Pablo. La lucha armada en Venezuela. Apuntes sobre guerra de guerrillas venezolanas en el contexto de la Guerra Fría (1959-1979) y el rescate de los desaparecidos. Caracas: Universidad Bolivariana de Venezuela, 2006. 
LOPES, J. Leite. Ciência e libertação. $2^{\underline{a}}$ ed. Rio de Janeiro, Editora Paz e Terra, 1978.

LUCE, Mathias Seibel. O subimperialismo brasileiro revisitado: a política de integração regional do governo Lula (2003-2007). Dissertação de mestrado. Universidade Federal do Rio Grande do Sul, 2007.

O subimperialismo, etapa superior do capitalismo dependente. Tensões mundiais, Fortaleza, v. 10, n. 18, 19, p. 43-65, 2014.

LUCENA, Héctor. Venezuela: le mouvement ouvrier dans la révolution bolivarienne. Etat des résistances dans le Sud - 2007, Alternatives Sud n4/2006. Disponível em: http://www.cetri.be/Venezuela-Le-mouvementouvrier?lang=fr

LUZARDO, Gastón Parra. De la nacionalización a la apertura petrolera. Derrumbe de una esperanza. 4ª ed. Caracas: BCV, 2009.

Análisis de la actividad petrolera en el lapso 1994-1998. Soberania.info.. Abril/1999. Disponível em http://www.soberania.org/ Articulos/ articulo_289.htm. Acesso em janeiro de 2011.

. El combate por la soberanía petrolera. Suplemento de la Revista BCV. vol. XXIII, no 2, Caracas, julio-diciembre, 2009. Disponível em: www.bcv.org.ve. Acesso em janeiro de 2011.

MACHADO, Luiz Toledo. A teoria da dependência na América Latina. São Paulo: Estudos Avançados, 13 (35), 1999, p. 200.

MAGDOFF, Harry. A era do imperialismo. A economia da política externa dos Estados Unidos. Trad. de Yolanda Toledo. São Paulo: HUCITEC, 1978.

MANDEL, Ernest. A crise do capital. Os fatos e sua interpretação marxista. São Paulo: Ensaio; Campinas, SP: Editora da Universidade Estadual de Campinas, 1990.

Actualité du trotskysme. (1978). Disponível em: www.marxists.org /francais/mandel/works/1978/11/em10781100_pdf.zip.

. La conception marxiste de l'Etat. Bruxelles, Documents Socialistes, 1965. (Documents socialistes: Numero special). Disponível em: http:// www.ernestmandel.org/fr/ecrits/txt/1965/la_conception_marxiste_de_etat.htm

. El pensamiento de Leon Trotsky. Edição digital. Disponível em www.revoltaglobal.net. 
. "Emancipation, science et politique chez Karl Marx" In: WORONOFF, Denis \& BROHM, Jean-Marie. Marx ... ou pas?: Reflexions sur un centenaire. Paris : Etudes et Documentation Internationale, 1986.

A formação do pensamento econômico de Karl Marx. De 1843 até a redação de O Capital. Rio de Janeiro: Zahar Editores, 1968.

MANNHEIM, Karl. Idéologie et utopie. Une introduction à la sociologie de la connaissance. Paris: Librairie Marcel Rivière et Cie, 1956. Collection Petite bibliothèque sociologique internationale. Édition électronique. Disponível em: http://www.uqac.uquebec.ca/zone30/Classiques_des_sciences_sociales/inde x.html.

MANTEGA, Guido. Teoria da dependência revisitada. EAESP/FGV/NPP - Núcleo de Pesquisas e Publicações, № 27/1997.

MÁO Jr., José R. A revolução cubana e a questão nacional (1868-1963). São Paulo: Ed. do Autor, 2007.

MARIÁTEGUI, J. C. Ideología y política. Caracas: Ministerio de Comunicación e Información, 2006. Disponível em: http://www.minci.gob.ve/2006/01/ ideologia-y-politica/

MARINI, Ruy M. La acumulación capitalista mundial y el subimperialismo. México: Ediciones Era, Cuadernos Políticos, № 12, abril-junio de 1977. Disponível em: www.marini-escritos.unam.mx.

Dialéctica de la dependencia. 11르 reimpresión. México: Ediciones Era, 1991. Disponível em: www.marini-escritos.unam.mx/004_dialectica_es. htm .

MARTÍNEZ, José Honorio. Causas e interpretaciones del Caracazo. Revista Historia Actual Online, № 16, Primavera, 2008, pp. 85-92 Disponível em http://www.historia-actual.org/Publicaciones/index.php/haol/article/viewArticle $/ 253$

MARX, Karl. O capital: Crítica da economia política. Trad. de Regis Barbosa e Flávio R. Kothe. $2^{\underline{a}}$ ed. São Paulo: Nova Cultural, 1985, 3 v.

Crítica do Programa de Gotha. Trad. de Rubens Enderle. São Paulo: Boitempo, 2012.

MARX, K. \& ENGELS, F. Manifesto do Partido Comunista. Trad. de Víctor Hugo Klagsbrunn. Rio de Janeiro: Contraponto; São Paulo: Fund. Perseu Abramo, 1998.

MARX, K. \& ENGELS, F. "Mensagem do Comitê Central à Liga de março de 1850". In: História. São Paulo: Ática, 1984. 
MATA, Héctor Malavé. Venezuela: la economía en el período 1974-1980. México: Comercio Exterior, vol. 32, núm. 1, enero de 1982, pp. 99-104. Disponível em: http://revistas.bancomext.gob.mx/rce/magazines/655/10/RCE10.pdf.

MAYA, Margarita López (coord.). Protesta y cultura en Venezuela: los marcos de acción colectiva en 1999. Buenos Aires: Clacso, 2002.

MAYA, Margarita López. Del viernes negro al referendo revocatorio. Caracas: Alfadil Ediciones, 2005.

. Luta hegemônica na Venezuela. A crise do puntofijismo e a ascensão de Hugo Chávez. Trad. de Flávio Benedito. 2010. Disponível em www.iela.ufsc.br.

MAYA, M. López \& LANDER, Luis E. El socialismo rentista de Venezuela ante la caída de los precios petroleros internacionales. Cuadernos del CENDES, vol. 26, núm. 71, mayo-agosto 2009, pp. 67-87, Universidad Central de Venezuela. Disponível em: http:// www.redalyc.org/articulo. oa?id= 40311835004.

MÉNDEZ V., Sofía (Org.). La crisis internacional y la América Latina. México: Centro de investigación y docencia económicas - Fondo de cultura económica (Serie Lecturas, v. 55), 1986.

MÉSZÁROS, István. A crise estrutural do capital. São Paulo: Boitempo, 2009.

MIERES, Francisco. El petróleo y la problemática estructural venezolana. Caracas: Instituto de Investigaciones, Universidad Central de Venezuela, 1969.

. "Evolución socioeconómica de Venezuela". In: Problemas del Desarrollo. Revista Latinoamericana de Economía, Vol. 20, oㅡ 76, 1989, pp. 167-186. Disponível em: http://www.probdes.iiec.unam.mx.

MILLET, Damien; MUNEVAR, Daniel \& TOUSSAINT, Éric. Les chiffres de la dette 2011 (CADTM). Artigo disponível em: http://www.cadtm.org/lMG/pdf/ Les_chiffres_de_la_dette_2011_DEf.pdf.

MOGUILLANSKY, G. \& BIELSCHOWSKY, R. Inversión y reformas económicas en América Latina. Santiago: Fondo de Cultura Económica - CEPAL, 2000.

MOMMER, Bernard. Petróleo global y Estado Nacional. Abril de 2003. Edição digital disponível em: https://pt.scribd.com/doc/80004891/2003-Petroleoglobal-y-Estado-nacional-Bernard-Mommer\#scribd

—. La cuestión petrolera. 1988. Edição digital disponível em: https://pt.scribd.com/doc/216844901/La-Cuestion-Petrolera-Bernard-Mommer -1988-Corregida-050111 
The Political Role of National Oil Companies in Exporting Countries: The Venezuelan Case. Oxford Institute for Energy Studies. September 1994. Disponível em: http://citeseerx.ist.psu.edu/ viewdoc/download?doi=10.1.1.392.8448\&rep=rep1\&type=pdf

Subversive Oil. Disponível em: http://www.isioma.net/sds00703.html.

. Venezuela: El petróleo como fuente rentística internacional y soberanía. ALAI 480-48, noviembre-diciembre de 2012, año XXXVI, pp. 30-34.

MONCADA, Martha. Las falacias del neoextractivismo. ALAI - América Latina en movimiento, 13/07/2012. Disponível em: http://alainet.org/active/56494.

NOVACK, George. Uneven and combined Development in History. Edição digital disponível em www.marxists.org/archive/novack/works/history/ch05.htm.

NUÑEZ, Hermán L. Torres. Paralysed Venezuela vs Thriving Bolivia: Two Faces of Socialism. October 14th 2014. Disponível em: http:// venezuelanalysis.com/analysis/ 10961.

OIT. Panorama Laboral 2011. América Latina y el Caribe. Oficina Regional para América Latina y el Caribe, 2011.

PALMA, Pedro A. Riesgos y consecuencias de las economías rentistas: El caso de Venezuela. Revista Problemas del Desarrollo, 165 (42), abril-junio 2011. Disponível em: http://www.revistas.unam.mx/index.php/pde/article/view/ 24971

PAULANI, Leda. Modernidade e discurso econômico. São Paulo: Boitempo, 2005.

PERDOMO, Rogelio Pérez. Venezuela 1958-1999: el derecho en una democracia renqueante. Disponível em: http://biblio.juridicas.unam.mx/libros/3/1078/ 14.pdf. Acesso em janeiro de 2012.

PETRAS, James F. \& MORLEY, Morris H. "El 'modelo' venezolano de desarrollo y la política norteamericana". In: Problemas del Desarrollo. Revista Latinoamericana de Economía, no 27, Ano VII, 1976, pp. 66-92. Disponível em: http://www.probdes.iiec.unam.mx.

PETRAS, James \& VELTMEYER, Henry. What's left in Latin America?: Regime change in new times. Farham: Ashgate, 2009.

PETRAS, James. América Latina: cuatro bloques de poder. La Jornada, 10/03/2007. Disponível em: http://www.jornada.unam.mx/2007/03/10/ index.php? section=politica\&article=030a1 pol.

. Obama's War in the Western Hemisphere and Venezuela's National Liberation Struggle. Global Research, March 16th 2015. Disponível em: http://venezuelanalysis.com/analysis/11274. 
PIA, Alberto J. et alii. Clase obrera: Partidos y sindicatos en Venezuela 19361950. Caracas: Ediciones Centauro, 1982.

PIETRI, Arturo Úslar. Sembrar el petróleo. Ahora, 14/07/1936. Disponível em http://www.analitica.com/bitblioteca/ uslar/sembrar_el_petroleo.asp.

POTTELLÁ, Carlos Mendoza. De las concesiones a los contratos. Visión retrospectiva de la política petrolera venezolana. Trabajo de ascenso (inédito). Caracas: Escuela de Economía, 1985. Disponível em http://petroleovenezolano.blogspot.com/ 2009/12/de-las-concesiones-loscontratos-vision.html. Acesso em 01/2011.

. El poder petrolero y la economía venezolana. Caracas: Universidad Central de Venezuela - Consejo de Desarrollo Científico y Humanístico, 1995.

. Nacionalismo petrolero venezolano en cuatro décadas. Maracaibo: Ediciones Astro Data, 2010.

. La Economía Política del Petróleo en Venezuela. (Versión de marzo de 2010, actualizada, sobre un texto de 1983). Disponível em: http:// petroleovenezolano.blogspot.com/2010/03/la-economia-politica-del-petroleoen_17.html. Acesso em 03/2011.

Apertura petrolera: nombre de estreno para un viejo proyecto antinacional. Soberanía.org. 06/04/03. Fecha de publicación: 1 de abril de 1996. Disponível em http://www.soberania.org/Articulos/articulo_073.htm.

PREBISCH, Raúl. El desarrollo económico de la América Latina y algunos de sus principales problemas. (originalmente mimeografado: Santiago, CEPAL, 1949). Reedição em Desarrollo Económico, Vol. 26, No. 103. (Oct. - Dec., 1986), pp. 479-502. Disponível em: http://links.jstor.org/sici?sici=0046001X\%28198610\%2F12\%2926\%3A103\%3C479\%3AEDEDLA \%3E2.0.CO\%3B2-P. (http://www.jstor.org; Thu Dec 28 10:23:33 2006).

PROVEA (Programa Venezolano de Educación-Acción en Derechos Humanos). Informe Anual 2001. Disponível em http://www.derechos.org.ve/informesanuales/informe-anual-2001/.

RABILOTTA, Alberto. Esencia del imperio neoliberal. Destrucción social y caos mundial (I). ALAl, América Latina en Movimiento, 07/03/2014. Disponível em: http://alainet.org/active/75106.

RAMÍREZ, Ruperto R. Izquierda y modernidad en América Latina: Venezuela, Cuba y México. México: Universidad Autónoma del Estado de México, 1996.

REGALADO, Roberto. La izquierda latinoamerciana en el gobierno. 11/06/2008. Disponível em http://www.rebelion.org/noticia.php?id=68635. 
REPÚBLICA BOLIVARIANA DE VENEZUELA. Líneas Generales del Plan de Desarrollo Económico y Social de la Nación 2007-2013. Caracas: setiembre de 2007. Disponível em http://www.cenditel.gob.ve /node/343.

REPÚBLICA BOLIVARIANA DE VENEZUELA. Poder Ciudadano. Defensoría del Pueblo. A 18 años de "El Caracazo": Sed de justicia. Caracas: febrero/ 2007.

REVISTA BCV. Juan Pablo Pérez Alfonso, ¿profecías cumplidas?. (Suplemento de la Revista BCV). Vol. XXII, № 1. Caracas, enero-junio 2008.

REVISTA BCV. La política económica de Venezuela en el contexto de Latinoamérica. FOROS 5/ 2005.

REVISTA NUEVA ECONOMÍA. Caracas: Academía Nacional de Ciencias Económicas, Año XVI, no28, Octubre 2008.

REVKIN, Andrew. Poverty and Lack of Research Block Path to a Well-Fed World. The New York Times. August 5, 2010.

REY, Juan Carlos et alii. El financiamiento de los partidos políticos y la democracia en Venezuela. Caracas: Editorial Ateneo de Caracas/ Editorial Jurídica Venezolana, 1981.

. Caracas: Academía Nacional de Ciencias Económicas, Año XVIII, № 31, Julio 2010.

ROMERO, Alberto. Globalización y pobreza. Nariño: Ediciones Unariño, 2002.

RUIZ-CARO, Ariela. El papel de la OPEP en el comportamiento del mercado petroleiro internacional. Santiago de Chile: CEPAL-ECLAC, abril de 2001 (Serie Recursos naturales e infraestructura).

SACHS, Jeffrey D. \& WARNER, Andrew. Economic Reform and the Process of Global Integration. Brooking Papers in Economic Activity; 1995. Disponível em: http://earth.columbia.edu/sitefiles/file/about/director/pubs/brookings -q195.pdf.

SADER, Emir. "Posneoliberalismo en Brasil". In: ALAI (Agencia Latinoamericana de Información). América Latina: Las izquierdas en las transiciones políticas. Quito: ALAI, mayo de 2012.

A integração latino-americana na hora decisiva. ALAI, América Latina en Movimiento, 28/11/2013. Disponível em: http://alainet.org/active/69369.

SALAS, Miguel Tinker. The Enduring Legacy. Oil, Culture and Society in Venezuela. Durham and London: Duke University Press, 2009. 
SALAMANCA, Luis. La incorporación de la Confederación de Trabajadores de Venezuela al sistema político venezolano: 1958-1980. Caracas: Revista de la Facultad de Ciencias Jurídicas y Políticas, № 95, 1995.

- La democracia venezolana desde 1989: De la explosión a la descentralización. Nueva Sociedad Nro. 150 Julio-Agosto 1997, pp. 106-111.

SALAZAR-CARRILLO, Jorge \& WEST, Bernadette. Oil and Development in Venezuela during the 20th Century. Westport, Connecticut: Praeger, 2004.

SAMPAIO JR., Plínio de Arruda. "Globalização e reversão neocolonial: o impasse brasileiro. In: HOYOS VÁSQUEZ, Guillermo. Filosofía y teorías políticas entre la crítica y la utopía. Buenos Aires: CLACSO (Consejo Latinoamericano de Ciencias Sociales), 2007. Disponível em: http: //bibliotecavirtual.clacso.org.ar/ar/libros/grupos/hoyos/11Sampaio.pdf.

SÁNCHEZ, R. López. El protagonismo popular en la historia de Venezuela. Raíces históricas del proceso de cambios. Segunda parte. Disponível em: http://encontrarte.aporrea.org/media/56/elprotaginismol.pdf. Acesso em agosto de 2011.

. 4 de octubre: 32 años de la masacre de Cantaura. Aporrea, 26/09/2014. Disponível em: http://www.aporrea.org/ddhh/a195610.html.

- El movimiento de trabajadores en la Venezuela bolivariana. Configuración de tendencias: autonomistas contra leninistas. Espacio Abierto, vol. 21, núm. 1, enero-marzo, 2012, pp. 145-181. Disponível em: http://www.redalyc.org/articulo.oa?id=12221805007

SÁNCHEZ, R.L. \& RODRÍGUEZ, Carmen A. H. La lucha contra la impunidad de los crímenes políticos en Venezuela. História Actual Online. Núm. 33, (Invierno, 2014), pp. 133-142. Disponível em: http://historiaactual.org/Publicaciones/index.php/haol/article/viewArticle/974

SANTOS, Boaventura de Souza (org.). Democratizar a democracia. Os caminhos da democracia participativa. Rio de Janeiro: Civilização Brasileira, 2002.

SANTOS, Milton. Por uma outra globalização: do pensamento único à consciência universal. 6르 ed. Rio de Janeiro: Record, 2001.

SANTOS, Theotônio dos. Imperialismo y dependencia. Caracas: Fund. Biblioteca Ayacucho, 2011. Disponível em: http://www.bibliotecayacucho.gob.ve/ fba/index.php?id=97\&backPID=2\&tt_products $=368$ 1977.

Imperialismo e corporações multinacionais. Rio de Janeiro: Paz e Terra,

. Democracia e socialismo no capitalismo dependente. Petrópolis: Vozes, 1991. 
. Do terror à esperança: auge e declínio do neoliberalismo. São Paulo: Ideias \& Letras, 2004.

. "Integración: fenómeno de larga duración. In: Integración Suramericana: temas estratégicos. Revista América Latina en movimiento. ALAI, noviembredeciembre de 2012, año XXXVI, no 480-481, pp. 12-15.

SAWAYA, Rubens R. Subordinação consentida. Capital multinacional no processo de acumulação da América Latina e Brasil. São Paulo: Annablume; Fapesp, 2006.

SCHORR, Martin (et alii). Más allá del pensamiento único. Hacia una renovación de las ideas económicas en América Latina y el Caribe. Buenos Aires: Clacso, 2002.

SCHULDT, Jürgen. Somos pobres porque somos ricos. 28/07/2004. Disponível em: www.rebelion.org/noticia_pdf.php?id=2579.

SCHULDT, Jürgen \& ACOSTA. Alberto. Petróleo, rentismo y subdesarrollo. ¿una maldición sin solución? Revista Nueva Sociedad, no 204, pp. 71-89. Disponível em: http://nuso.org/articulo/petroleo-rentismo-y-subdesarrollo-unamaldicion-sin-solucion/

SECCO, Lincoln. História do PT 1978-2010. Cotia, SP: Ateliê Editorial, 2011.

SEOANE, José (comp.). Movimientos sociales y conflicto en América Latina. Buenos Aires: CLACSO, 2004.

SILVA CALDERON, Álvaro. Trayectoria de la nacionalización petrolera. Revista Venezolana de Economía y Ciencias Sociales, Caracas, v. 12, n. 1, p. 109123, abr./2006. Disponível em: http://www.scielo.org.ve/scielo.php?script $=$ sci $\_$arttext $\&$ pid $=\$ 1315-64112006000100008 \& \operatorname{lng}=e s \& \mathrm{nrm}=\mathrm{iso}>$. Acesso em 25 de março de 2016.

SILVA, José I. \& SCHLIESSER, R. La evolución de la pobreza en Venezuela. Caracas: BCV, 1998.

SITEAL. El analfabetismo en América Latina, una deuda social. Dato destacado 18, 11/2010. Disponível em: http://www.siteal.iipe-oei.org/datos_destacados/ 258/analfabetismo-en-america-latina.

SOCIALIST ECONOMIC BULLETIN. (A Bulletin of Socialist Economic Analysis published by Ken Livingstone). Venezuela's trade confronted with the international financial crisis. 27 December 2008. (Disponível em www.socialisteconomicbulletin.blogspot.com).

SOLANA, Fernando. (coord.) América Latina XXI: ¿Avanzará o retrocederá la pobreza? Parlamento Latinoamericano: Fondo de Cultura Económica, 2002. 
SOUZA, Herbert José de. O capital transnacional e o Estado. Petrópolis: Vozes, 1985.

STIGLITZ, Joseph E. O mundo em queda livre. Os Estados Unidos, o mercado livre e o naufrágio da economia mundial. São Paulo: Companhia das Letras, 2010.

SUNKEL, Oswaldo. O marco histórico do processo desenvolvimento/ subdesenvolvimento. 5를 ed. Rio de Janeiro: Unilivros, 1980.

SUTHERLAND, Manuel. La economía venezolana o cómo la burguesía hurta la renta petrolera y es dueña del 71\% del PIB. 09/09/2011. Disponível em: http://www.argenpress.info.

- Nacionalización de SIDOR, éxitos de la clase trabajadora, retos, y deberes fundamentales para el desarrollo socialista venezolano. 01/05/2008. Disponível em: http://www.nodo50.org/ceprid/spip.php?article102\&id _document=1\#documents_portfolio.

TORO, Héctor Valecillos \& RODRíGUEZ, Omar Bello (comps.). La economía contemporánea de Venezuela. 1990-1999. Ensayos escogidos. Tomo I e II. Caracas: Departamento de Publicaciones BCV, 2001, Disponível em: http:/www.bcv.org.ve.

TORO, Héctor Valecillos. ¿Retador o garante del sistema? Los 50 años de la Confederación de Trabajadores de Venezuela. Nueva Sociedad. № 85, septiembre-octubre, 1986, pp. 14-29. Disponível em: http://nuso.org/articulo/ retador-o-garante-del-sistema-los-50-anos-de-la-confederacion-detrabajadores-de-venezuela/

TORRES, Ana T. Memorias de una venezolana de la democracia. Conferencia inaugural de la Cátedra Venezuela. Caracas: Universidad Metropolitana, 28/02/2008. Disponível em: www.analitica.com/ mujeranalitica/1171569.doc.

TROTSKY, Leon. 1905. (edição francesa). Disponível em: http://www.marxists.org/francais/trotsky/livres/1905/1905_0.htm.

. Escritos Latinoamericanos (compilación). Buenos Aires: CEIP León Trotsky, 2007. . A revolução permanente. São Paulo: Expressão Popular, 2007.

TROUDI, Haiman El. Socialismo del Siglo XXI a la venezolana. Octubre 2007. Disponível em: www.haiman.com.ve.

VALENCIA, Adrián Sotelo. Teoria da dependência e desenvolvimento do capitalismo na América Latina. Londrina: Praxis; Bauru: Canal 6, 2008. 
VELÁSQUEZ, Ramón J. et alii. Venezuela moderna: Medio siglo de historia. $2^{\underline{a}}$ ed. Barcelona: Editorial Ariel, 1979.

VILLARREAL, René. A contrarrevolução monetarista. Teoria, política econômica e ideologia do neoliberalismo. Rio de Janeiro: Record, 1984.

VITALE, Luis. Estado y estructura de clases en la Venezuela contemporánea. Universidad Central de Venezuela (Escuela de Trabajo Social). Caracas, 1984. Disponível em www.archivochile.com/ldeas_Autores/vitale.

Modos de producción y formaciones sociales en América Latina. Cuadernos Marxistas Latinoamericanos de Educación Política. Disponível em www.archivochile.com/ldeas_Autores/vitale.

. Notas para una historia del movimiento obrero venezolano. UCV, Caracas, 1981.

WEISBROT, Mark y RAY, Rebecca. Evolución reciente de la economía venezolana. Center for Economic and Policy Research, Septiembre de 2010. Disponível em: www.cepr.net.

WILPERT, Gregory. Changing Venezuela by Taking Power. The History and Policies of the Chávez Government. London: Verso, 2007.

WOODS, Alan. La revolución bolivariana. Un análisis marxista. Madrid: Fundación Federico Engels, 2005.

YERGIN, Daniel. La história del petróleo. Traducción de María Elena Aparicio Aldazabal. Buenos Aires: Javier Vergara Editor S.A., 1992.

ZAVALA, D. F Maza. Venezuela: una economía dependiente. Caracas: UCV, 1964.

ZAVALA, D. F. Maza et alii. Venezuela: contratos de tecnología y comercialización petrolera. Problemas del Desarrollo. México, № 33, Ano IX, Febrero-Abril 1978, pp. 164-182.

ZAVALA, D. F Maza et alii. Venezuela: crecimiento sin desarrollo. $8^{a}$ ed. México, D.F.: Editorial Nuestro Tiempo, 1982.

ZIEGLER, Jean. Destruição massiva. Geopolítica da fome. Trad. de José Paulo Netto. São Paulo: Cortez, 2012.

ZÚÑIGA, Simón Andrés. Decálogo del economista neoliberal. ALAI, América Latina en Movimiento, 12/03/2014. Disponível em: http://alainet.org/active/ 71985. 